\author{
UNIVERSIDADE DE SÃO PAULO \\ ESCOLA DE COMUNICAÇÕES E ARTES
}

PEDRO ULSEN

\title{
Comunicação para a Sustentabilidade em Organizações do Terceiro Setor
}

SÃO PAULO 


\section{PEDRO ULSEN}

\section{Comunicação para a Sustentabilidade em Organizações do Terceiro Setor}

Tese apresentada ao Programa de Pós-Graduação em Ciências da Comunicação da Escola de Comunicações e Artes da Universidade de São Paulo para a obtenção do título de Doutor em Ciências da Comunicação.

Área de Concentração: Interfaces Sociais da Comunicação.

Linha de Pesquisa: Políticas e Estratégias da Comunicação.

Orientadora: Profa. Dra. Margarida M. Krohling Kunsch.

\section{SÃO PAULO}


Autorizo a reprodução e divulgação total ou parcial deste trabalho, por qualquer meio, convencional ou eletrônico, para fins de estudo e pesquisa desde que citada a fonte.

Catalogação na Publicação

Serviço de Biblioteca e Documentação

Escola de Comunicações e Artes da Universidade de São Paulo

Dados inseridos pelo(a) autor(a)

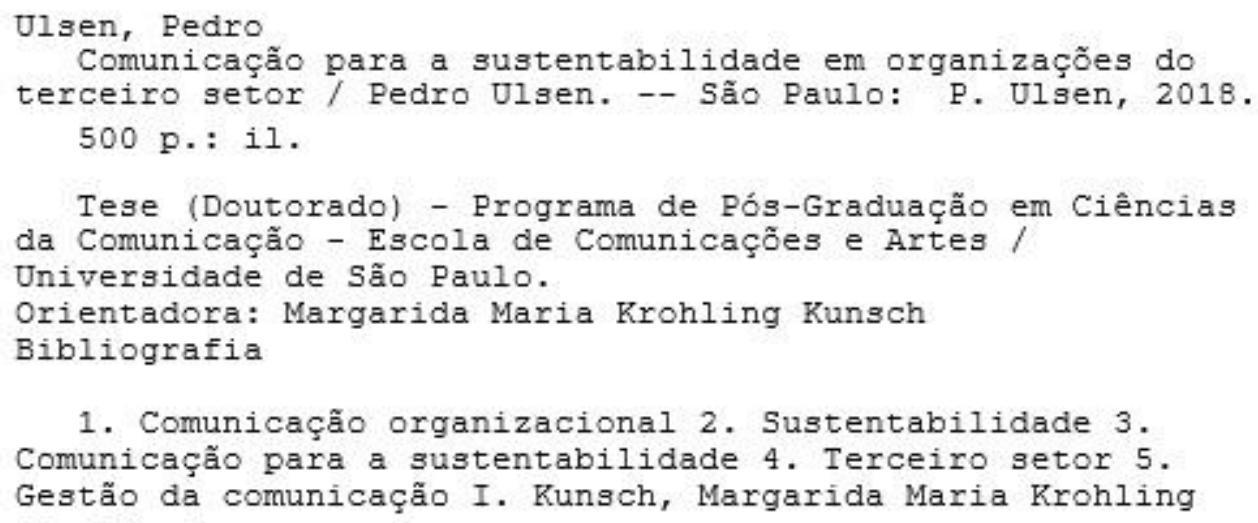

CDD 21.ed. -302.2 
ULSEN, Pedro. Comunicação para a sustentabilidade em organizações do terceiro setor. Tese apresentada ao Programa de Pós-Graduação em Ciências da Comunicação (PPGCOM) da Escola de Comunicações e Artes da Universidade de São Paulo (ECA-USP) para obtenção do título de Doutor em Ciências da Comunicação.

Aprovado em

1

Banca Examinadora

$\operatorname{Prof}(\mathrm{a})$. $\operatorname{Dr}(\mathrm{a})$. Instituição:

Julgamento: Assinatura:

Prof (a). Dr (a). Instituição: Julgamento: Assinatura:

Prof (a). Dr (a). Instituição:

Julgamento: Assinatura:

Prof (a). Dr (a). Instituição:

Julgamento: Assinatura:

Prof (a). Dr (a). Instituição:

Julgamento: Assinatura:

Prof (a). Dr (a). Instituição:

Julgamento: Assinatura: 


\section{AGRADECIMENTOS}

À Shirlei Escobar Tudissaki, eterna companheira, luz da minha vida.

À minha mãe, Tânia Mantovani, pela presença marcante em minha história.

Ao meu pai, Carlos Ulsen, de quem herdei a coragem para enfrentar desafios.

Aos meus irmãos, André e Carina, parceiros desta vida agora e para sempre.

À querida família que me acompanha, eterno porto seguro em diversas situações.

Aos amigos desta jornada e de outras tantas, pelos momentos de alegria e felicidade.

À querida Professora Margarida Kunsch, verdadeira mestra, exemplo de ser humano.

Aos entrevistados, absolutamente generosos em compartilhar seus conhecimentos. 
Mar Português

"Ó mar salgado, quanto do teu sal São lágrimas de Portugal!

Por te cruzarmos, quantas mães choraram, Quantos filhos em vão rezaram!

Quantas noivas ficaram por casar Para que fosses nosso, ó mar!

Valeu a pena? Tudo vale a pena Se a alma não é pequena.

Quem quer passar além do Bojador Tem que passar além da dor.

Deus ao mar o perigo e o abismo deu, Mas nele é que espelhou o céu". 


\section{RESUMO}

O objeto desta tese é o mapeamento das variáveis no processo da comunicação para a sustentabilidade em organizações do terceiro setor. O ponto de partida são os estudos que defendem o potencial da comunicação para conscientizar, engajar e empoderar os públicos sobre a necessidade de criação de uma sociedade mais justa e equilibrada. A justificativa está na proposta de reforçar as pesquisas sobre comunicação em uma perspectiva transformadora, resgatando a função social da área. Outra justificativa é a necessidade de pesquisas que estabeleçam convergências entre comunicação e sustentabilidade para ampliar a qualidade de vida das pessoas e preservar a natureza. $\mathrm{O}$ objetivo geral é pesquisar e analisar como a comunicação organizacional é desenvolvida no terceiro setor e quais seriam os impactos das ações dessas organizações direcionadas à sustentabilidade para o benefício da sociedade. Os procedimentos metodológicos reúnem processos cientificamente desenvolvidos que fundamentam o percurso do processo de pesquisa com base em recursos quantitativos e qualitativos de aplicação de questionários e entrevistas em profundidade. A tese de doutorado está fundamentada nos seguintes eixos temáticos: comunicação organizacional, sustentabilidade e terceiro setor. $O$ trabalho foi iniciado com a pesquisa quantitativa, sendo um questionário utilizado como instrumento de coleta. O universo foi composto com a montagem de um banco de dados com base nas organizações que atuam com sustentabilidade listadas no portal da Abong e no site ONGs Brasil. De forma complementar, a pesquisa qualitativa foi feita com entrevistas em profundidade com especialistas e gestores de organizações de referência envolvidas diretamente com a temática. Acredita-se em uma formatação planejada para que o discurso seja assertivo, sendo possível ampliar resultados mapeando públicos e analisando os efeitos da comunicação, o que envolve um trabalho responsável de comunicação com a elaboração de materiais de conteúdos bem fundamentados e produtos acessíveis aos públicos, desenhados em uma linguagem própria para gerar significado às pessoas envolvidas. Com um modelo sistematizado de comunicação para a sustentabilidade, será possível ampliar o conhecimento dos cidadãos sobre como manter condições sustentáveis para o futuro.

Palavras-chave: Comunicação organizacional; Sustentabilidade; Comunicação para a sustentabilidade; Terceiro setor; Gestão da comunicação. 


\begin{abstract}
The subject of this thesis is the mapping of variables in the communication process for sustainability in third sector organizations. The starting point are the studies that defend the potential of communication to raise awareness, engage and empower the public about the need to create a fairer and more balanced society. The justification lies on the proposal to strengthen research on communication in a transformative perspective, rescuing the social function of the area. Another justification is the need for research that establishes convergences between communication and sustainability to increase people's quality of life and preserve nature. The general objective is to research and analyze how organizational communication is developed in the third sector and what would be the impacts of their actions aiming sustainability for the benefit of society. The methodological procedures bring together scientifically developed processes that base the course of the research process based on quantitative and qualitative resources of application of questionnaires and in-depth interviews. This thesis is based on the following thematic axes: organizational communication, sustainability and third sector. The research started with the quantitative aproach by applying a questionnaire used as a collection instrument. The universe was composed by the assembly of a database based on the organizations that act with sustainability listed in the Abong's portal and the ONGs Brazil website. In a complementary way, the qualitative research was carried out with in-depth interviews with specialists and reference managers from relevant organizations directly involved with the theme. It is believed in a format designed to assert the discourse, and it is possible to expand results by mapping audiences and analyzing the effects of communication, which involves responsible communication work with the elaboration of well-informed content materials and products accessible to the public, designed in a language of their own to generate meaning for the people involved. With a systematized model of communication for sustainability, it will be possible to increase citizens' knowledge about how to maintain sustainable conditions for the future.
\end{abstract}

Keywords: Organizational communication; Sustainability; Communication for sustainability; Third sector; Communication management. 


\section{RESUMEN}

El objeto de esta tesis es el mapeo de las variables en el proceso de la comunicación para la sostenibilidad en organizaciones del tercer sector. El punto de partida son los estudios que defienden el potencial de la comunicación para concientizar, comprometer y empoderar a los públicos sobre la necesidad de crear una sociedad más justa y equilibrada. La justificación está en la propuesta de reforzar las investigaciones sobre comunicación desde una perspectiva transformadora, rescatando la función social del área. Otra justificación es la necesidad de investigaciones que establezcan convergencias entre comunicación y sostenibilidad para ampliar la calidad de vida de las personas y preservar la naturaleza. El objetivo general es investigar y analizar cómo la comunicación organizacional se desarrolla en el tercer sector y cuáles serían los impactos de las acciones de esas organizaciones dirigidas a la sostenibilidad para el beneficio de la sociedad. Los procedimientos metodológicos reúnen procesos científicamente desarrollados que fundamentan el recorrido de la investigación con base en recursos cuantitativos y cualitativos de aplicación de cuestionarios y entrevistas en profundidad. La tesis de doctorado está fundamentada en los siguientes ejes temáticos: comunicación organizacional, sostenibilidad y tercer sector. El trabajo se inició con la investigación cuantitativa, empleando como instrumento de recolección un cuestionario. El universo fue compuesto con el montaje de un banco de datos basado en las organizaciones que actúan con sustentabilidad listadas en el portal web de Abong y ONGs Brasil. De forma complementaria, la investigación cualitativa fue hecha con entrevistas en profundidad con especialistas y gestores de organizaciones de referencia involucradas directamente con la temática. Se cree en un formato planificado para que el discurso sea asertivo, siendo posible ampliar resultados mapeando públicos y analizando los efectos de la comunicación, lo que implica un trabajo responsable de comunicación con la elaboración de materiales de contenidos bien fundamentados y productos accesibles a los públicos, diseñados en un lenguaje propio para generar un significado en las personas involucradas. Con un modelo sistematizado de comunicación para la sostenibilidad, será posible ampliar el conocimiento de los ciudadanos sobre cómo mantener condiciones sostenibles para el futuro.

Palabras clave: Comunicación organizacional; Sostenibilidad; Comunicación para la sostenibilidad; Tercer sector; Gestión de la comunicación. 


\section{LISTA DE QUADROS}

Quadro 1: Categorias das organizações disponibilizadas no portal da Abong........163

Quadro 2: Categorias de organizações selecionadas no portal da Abong ...............164

Quadro 3: Categorias de organizações disponibilizadas no site ONGs Brasil .........165

Quadro 4: Categorias de organizações selecionadas no site ONGs Brasil.............167

Quadro 6: Definição de sustentabilidade .........................................................182

Quadro 7: Formato das entrevistas com gestores de comunicação........................205

Quadro 8: Formato das entrevistas com especialistas em sustentabilidade ...........243 


\section{LISTA DE FIGURAS}

Figura 1: Comunicação organizacional integrada

Figura 2: Comunicação para a sustentabilidade em organizações do terceiro setor 82

Figura 3: Níveis da comunicação e perenidade das ações .83

Figura 4: Tipos de abordagem da comunicação para a sustentabilidade .................90

Figura 5: Transdisciplinaridade da comunicação organizacional ............................97

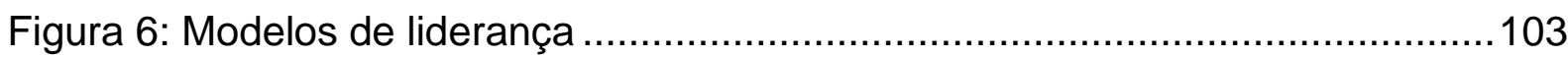

Figura 7: Estilos de linguagem na comunicação para a sustentabilidade ...............116

Figura 8: Sentidos humanos na comunicação para a sustentabilidade ....................121

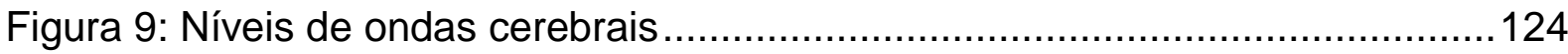

Figura 10: Repertórios envolvidos para interpretação das mensagens...................129

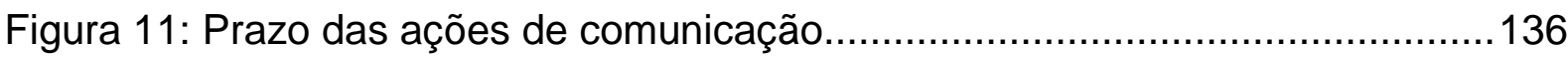

Figura 12: Escala de mudança dos interlocutores...........................................140

Figura 13: Recursos envolvidos na comunicação organizacional .........................145

Figura 14: Percurso da comunicação para a sustentabilidade no terceiro setor .....148

Figura 15: Abrangência das ações de comunicação para a sustentabilidade ..........151

Figura 16: Frequência das ações da comunicação para a sustentabilidade ............156

Figura 17: Nuvem de palavras comunicação e engajamento .................................212

Figura 18: Nuvem de palavras sobre potenciais e limites da comunicação ............218

Figura 19: Nuvem de palavras de integração de comunicação e sustentabilidade.224

Figura 20: Nuvem de palavras de recursos necessários e ações de planejamento 229

Figura 21: Nuvem de palavras d avaliação da comunicação no terceiro setor .......235

Figura 22: Nuvem de palavras de todas respostas dos gestores de comunicação. 239

Figura 23: Nuvem de palavras com respostas de Afra Balazina ...........................239

Figura 24: Nuvem de palavras com respostas de Bruno Weis..............................240

Figura 25: Nuvem de palavras com respostas de Mariana Moraes ........................240

Figura 26: Nuvem de palavras com respostas de Maurício Bianco........................241

Figura 27: Nuvem de palavras com respostas de Rejane Romano .......................241

Figura 28: Nuvem de palavras com respostas de Renato Guimarães ....................242

Figura 29: Nuvem de palavras governos e grupos intergovernamentais ...............249

Figura 30: Nuvem de palavras sobre potenciais do terceiro setor.........................255

Figura 31: Nuvem de palavras sobre comunicação para a sustentabilidade ..........264

Figura 32: Nuvem de palavras sobre liderança do terceiro setor ..........................270

Figura 33: Nuvem de palavras sobre recursos para uma nova consciência social .276

Figura 34: Nuvem de palavras todas respostas especialistas em sustentabilidade 279

Figura 35: Nuvem de palavras com respostas de Denise Hamú.............................280

Figura 36: Nuvem de palavras com respostas de Enrique Leff ............................280

Figura 37: Nuvem de palavras com respostas de Leonardo Boff...........................281

Figura 38: Nuvem de palavras com respostas de Fernando Almeida ....................281 
Figura 39: Nuvem de palavras com respostas de Pedro Jacobi .282

Figura 40: Nuvem de palavras com respostas de Oded Grajew .282 


\section{LISTA DE GRÁFICOS}

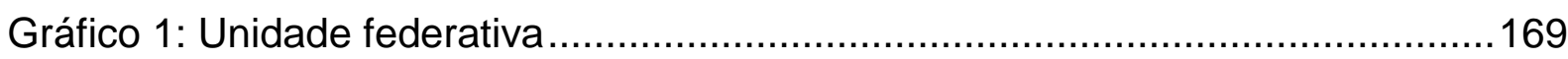

Gráfico 2: Ano de criação ...................................................................... 171

Gráfico 3: Cargo do respondente .............................................................. 173

Gráfico 4: Escolaridade do respondente ...................................................... 174

Gráfico 5: Principal área de formação do respondente .................................... 175

Gráfico 6: Principal foco de atuação....................................................... 177

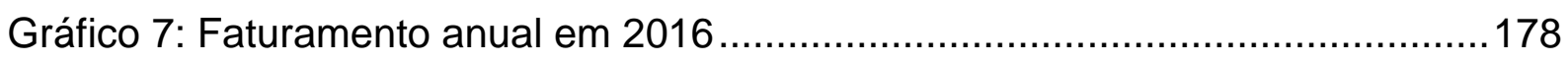

Gráfico 8: Quantidade de funcionários, colaboradores e voluntários .....................179

Gráfico 9: Liderança da sustentabilidade .................................................... 180

Gráfico 10: Melhor definição de sustentabilidade ...........................................183

Gráfico 11: Relevância estratégica da comunicação......................................184

Gráfico 12: Investimento em comunicação em 2016 .......................................185

Gráfico 13: Estrutura da área de comunicação .............................................. 186

Gráfico 14: Colaboração entre comunicação e sustentabilidade..........................187

Gráfico 15: Atividades desenvolvidas pela comunicação ................................... 189

Gráfico 16: Públicos estratégicos ................................................................. 191

Gráfico 17: Principais meios de comunicação ............................................... 193

Gráfico 18: Linguagem preferencialmente utilizada ......................................... 194

Gráfico 19: Objetivos estratégicos da sustentabilidade ....................................... 195

Gráfico 20: Frequência do envolvimento da comunicação nas decisões ................196

Gráfico 21 Desafios da comunicação .......................................................... 198

Gráfico 22: Principais impactos das ações de comunicação para sustentabilidade 200

Gráfico 23: Avaliação da área de comunicação ............................................202 


\section{SUMÁRIO}

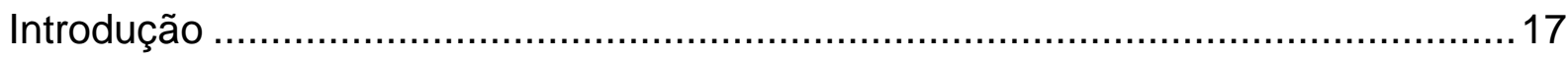

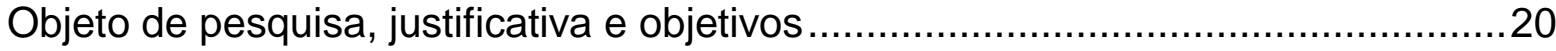

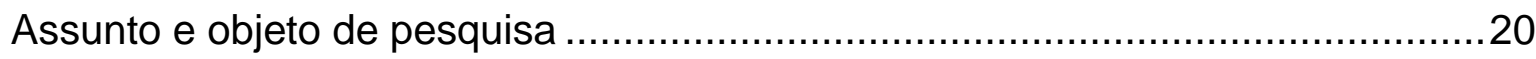

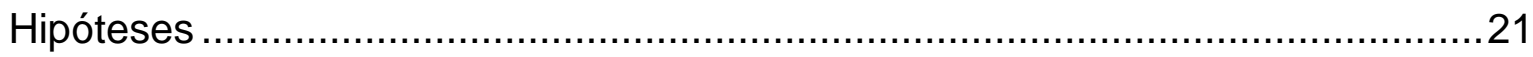

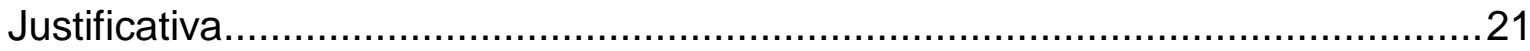

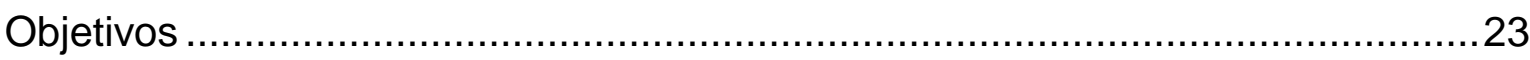

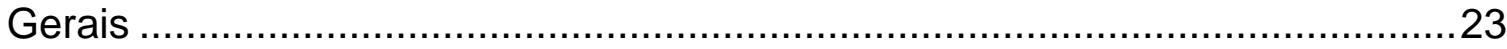

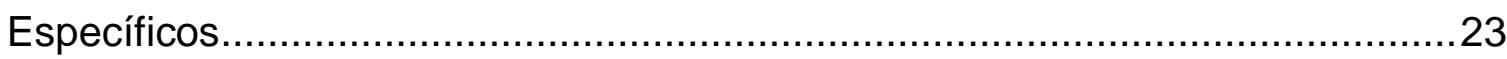

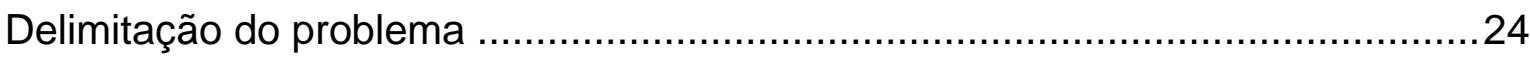

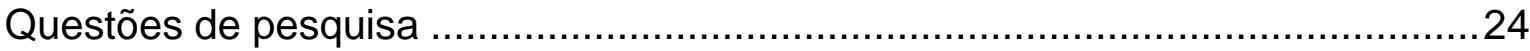

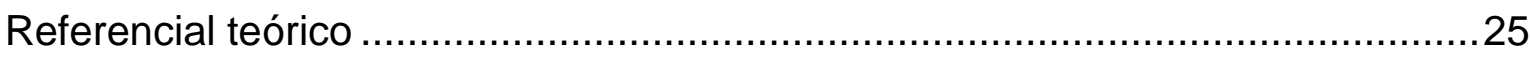

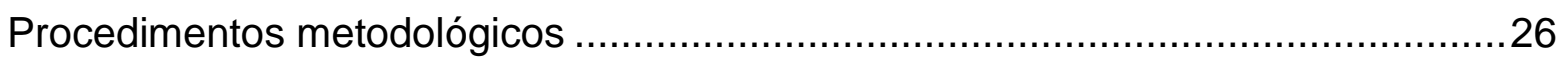

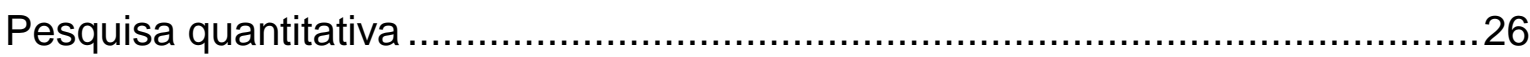

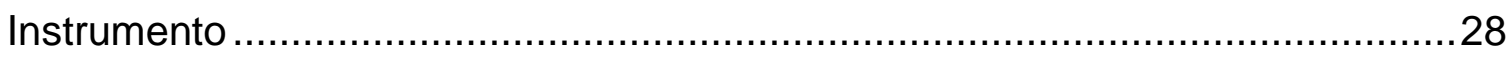

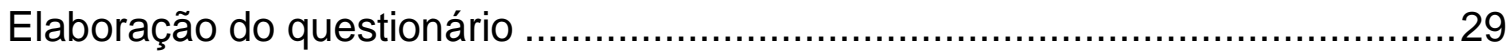

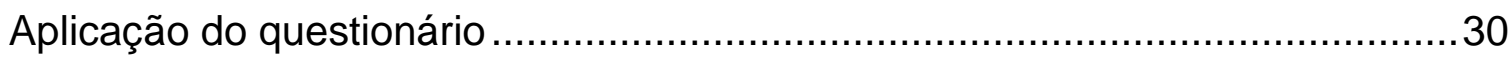

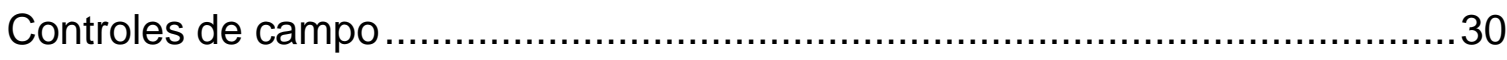

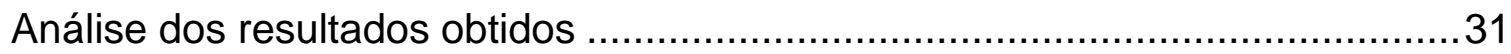

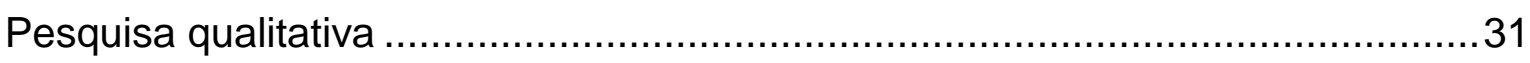

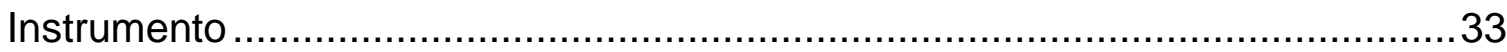

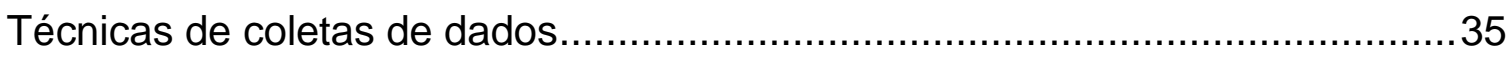

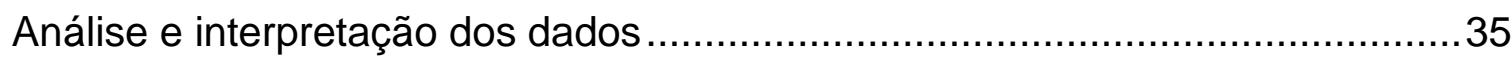

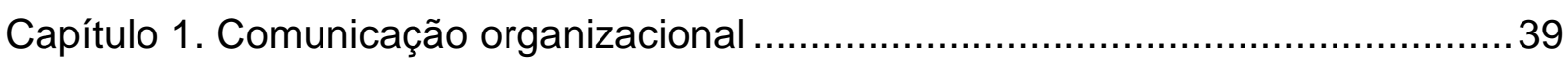

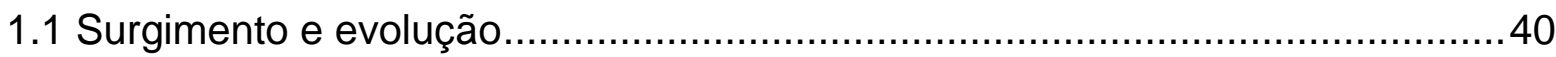

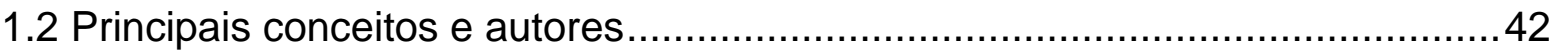

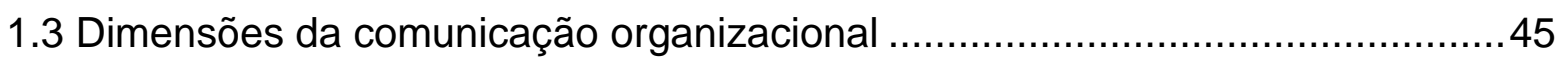

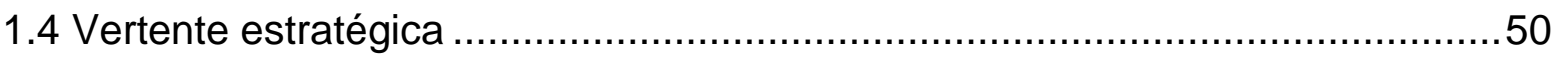

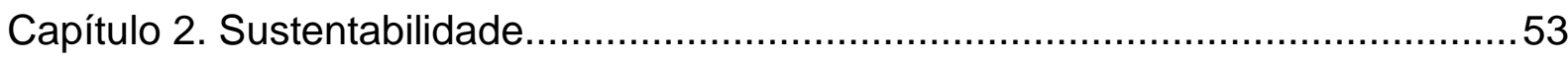

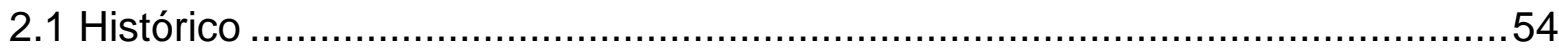

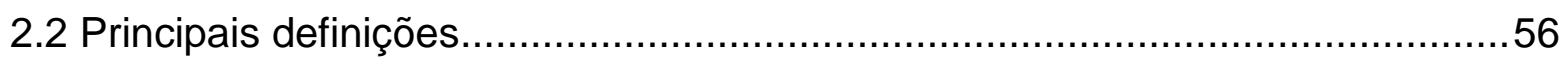

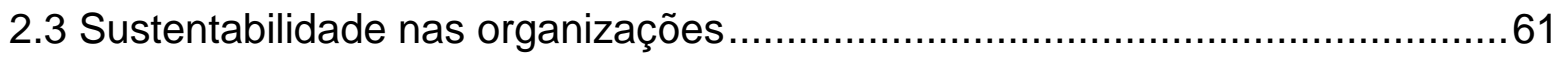

2.4 Sustentabilidade como tendência..........................................................

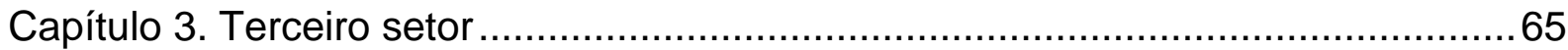

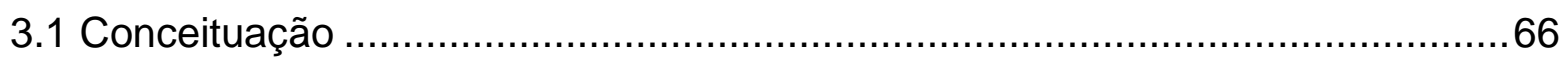


3.2 Histórico .68

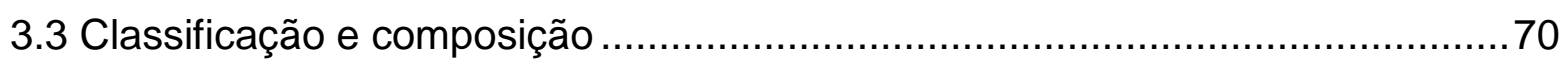

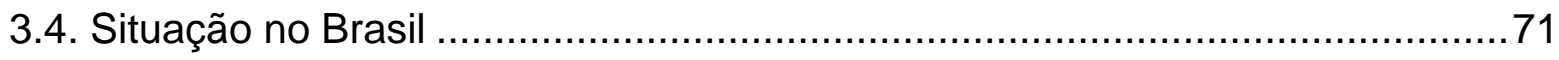

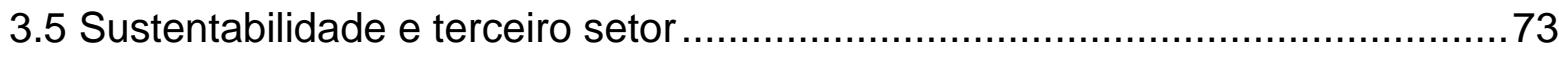

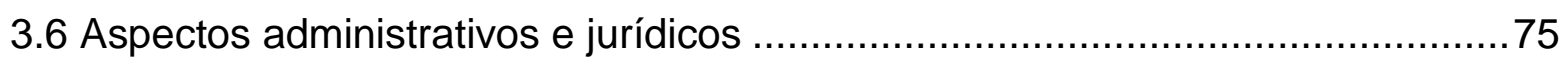

Capítulo 4. Comunicação para sustentabilidade em organizações do terceiro setor 79

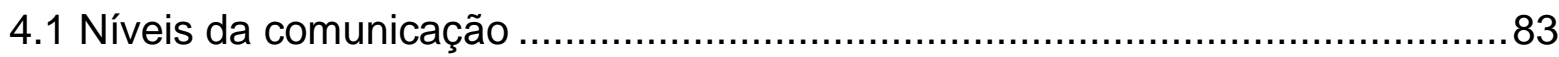

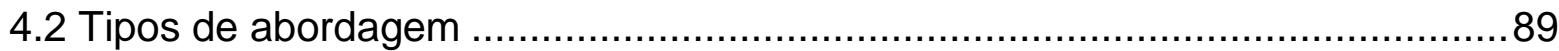

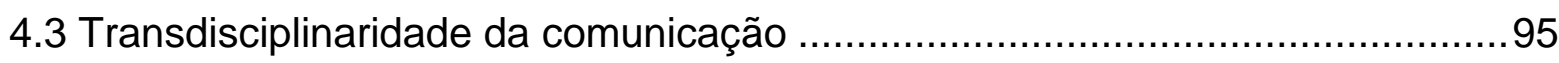

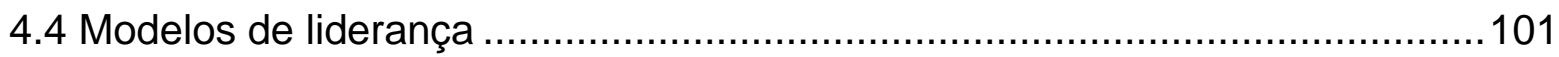

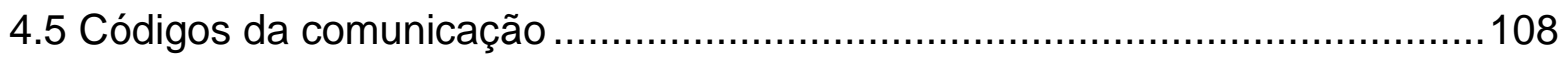

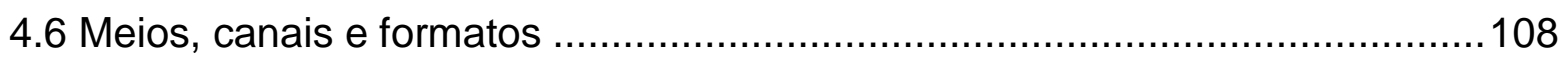

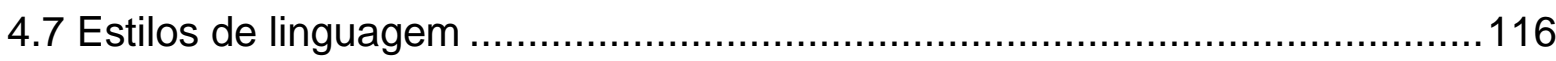

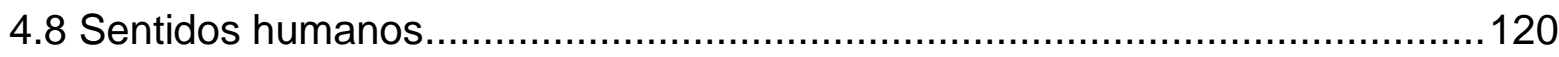

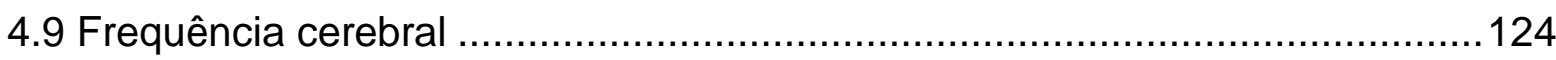

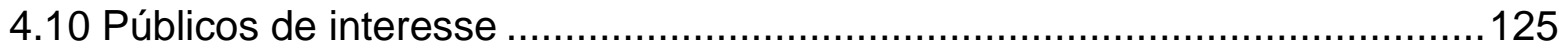

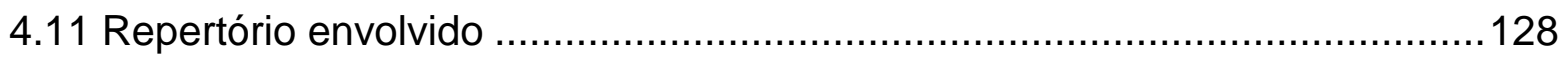

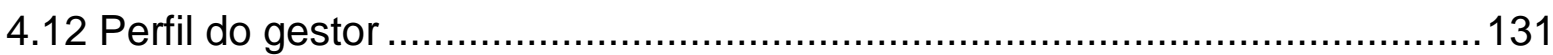

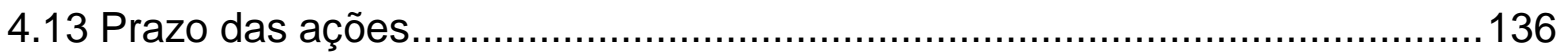

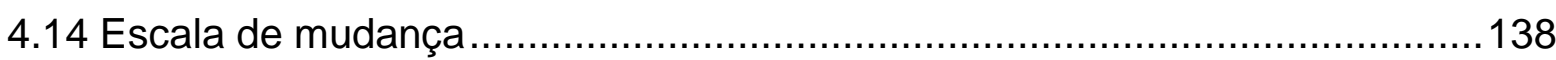

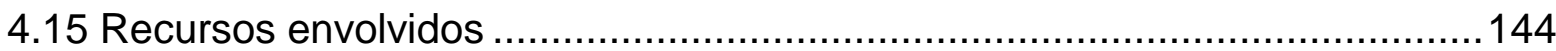

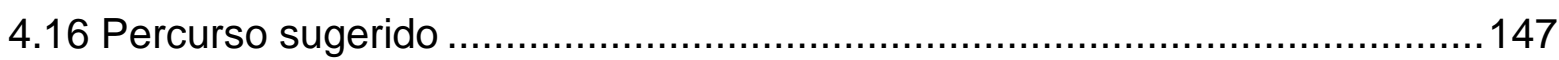

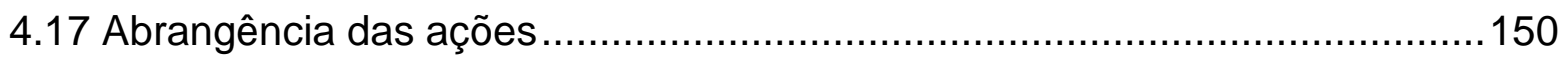

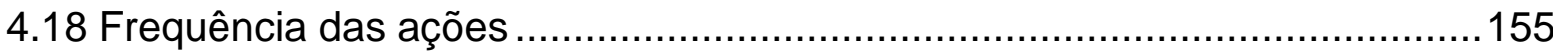

4.19 Considerações e desafios ................................................................158

Capítulo 5. A visão das organizações do terceiro setor ........................................163

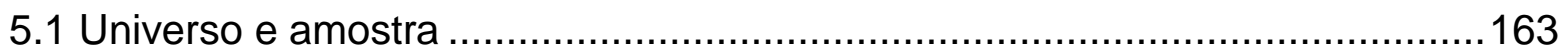

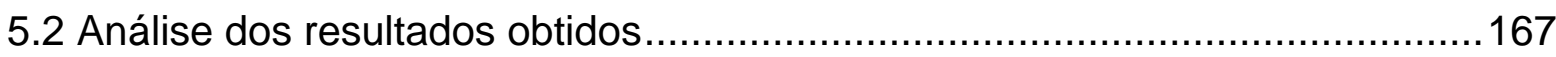

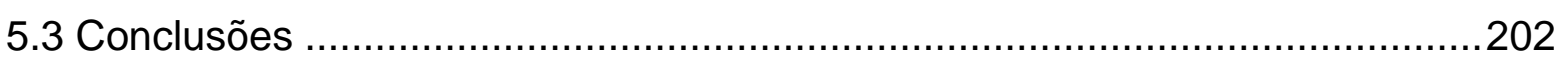

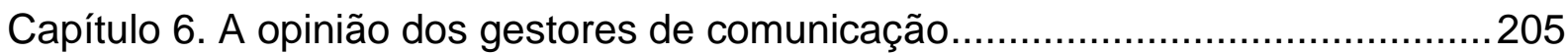

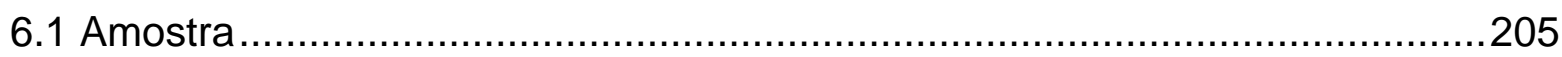

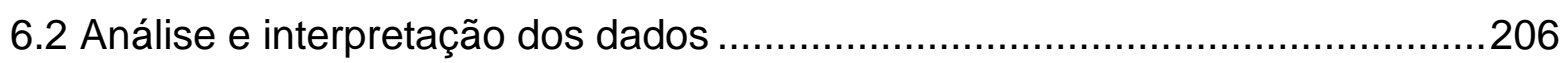

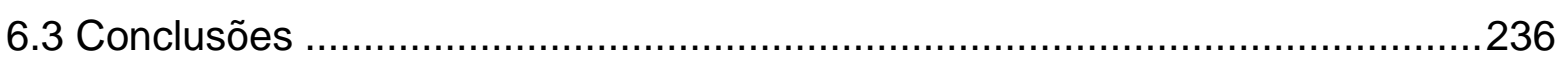

Capítulo 7. A opinião dos especialistas em sustentabilidade ….............................243

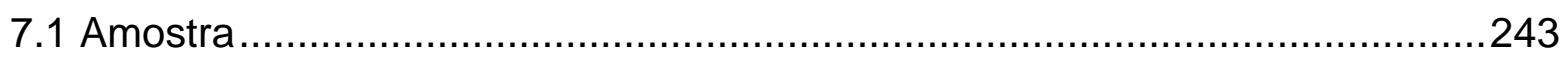


7.2 Análise e interpretação dos dados

7.3 Conclusões

Considerações finais

Referências

Sumário de apêndices 307

Apêndice 1. Questionário enviado para organizações do terceiro setor 309

Apêndice 2. Organizações da Abong acionadas na pesquisa 317

Apêndice 3. Organizações do site ONGs Brasil acionadas na pesquisa 323

Apêndice 4. Nomes das organizações participantes. 405

Apêndice 5. Endereços das organizações participantes 411

Apêndice 6. Nomes dos respondentes das organizações participantes 417

Apêndice 7. E-mails das organizações participantes 423

Apêndice 8. Telefones das organizações participantes 429

Apêndice 9. Entrevistas com gestores de comunicação 435

Apêndice 10. Entrevistas com especialistas em sustentabilidade. 469 


\section{Introdução}

Há séculos iniciativas de desenvolvimento para um mundo mais justo e equilibrado têm sido criadas, inicialmente como tentativas mais isoladas que, com o passar do tempo, têm ganhado consistência e respaldo conceitual. Pouco a pouco, na história da humanidade, com o agravamento das condições climáticas, ambientais e conflitos sociais, muitos pesquisadores têm se dedicado a tentar equacionar a questão.

Mas, como? Por um lado, de forma geral, os que tentam reconstruir o mundo sugerindo refundar o sistema socioeconômico predominante. Do outro lado, aqueles que tentam melhorar o que já existe, com práticas menos destrutivas de desenvolvimento. Entre esses extremos, apenas um consenso: o mundo precisa ser diferente. O homem precisa mudar.

Desde então, a sustentabilidade tem unificado sonhos e expectativas diversas, alimentando o desejo muitas vezes sincero daquelas pessoas preocupadas em criar condições para um ambiente melhor no presente e para o futuro. Embora a trajetória não seja fácil, nem linear, pouco a pouco os diferentes anseios vêm se encontrando e se identificando em valores comuns, como a necessidade de preservação da vida e do planeta, o respeito às condições humanas em termos sociais e o entendimento de que deve haver um modelo de desenvolvimento mais justo entre as diferentes organizações.

Já em meados do século XX, inclusive com a criação de importantes iniciativas, como a Organização das Nações Unidas (ONU), a sustentabilidade entra em uma curva de crescimento com debates que passaram a sustentar um discurso para a estruturação desse conceito de forma mais consistente, criando espaço para embasar essa trajetória na sociedade civil e sendo, aos poucos, também incorporada pelas organizações.

Nesse movimento, uma parte da sociedade que se beneficiou foi o terceiro setor, ao reunir iniciativas civis de pessoas também interessadas em contribuir voluntariamente para criar e implementar meios de atingir objetivos coletivos. Nessa trajetória, o terceiro setor tem se envolvido, em escala mundial, e também, no Brasil, com as mais diferentes questões sociais, econômicas, políticas, ambientais, culturais, entre outras, em múltiplos formatos. 
Em um outro movimento, às vezes convergente, e outras vezes não, a comunicação tem se destacado como um fenômeno inicialmente espontâneo e, pouco a pouco, cada vez mais profissionalizado, sendo pesquisado como uma ciência e incorporado como suporte, instrumental e estratégico, para a consecução das metas organizacionais.

Enquanto fenômeno pragmático, a comunicação tem servido aos interesses aos quais é aplicada; enquanto ciência, a comunicação tem sido objeto de estudo, muitas vezes em uma perspectiva crítica, que lhe confere uma reflexão própria para o resgate de atribuições de cunho mais social e coletivo. Então, por que não envolver essas duas vertentes em um estudo? E entender como a comunicação pode ser efetiva para a prática organizacional, mas, também, estratégica quando vista como ciência? E somar a isso os demais movimentos descritos, como a sustentabilidade e o terceiro setor?

Nasce assim esta pesquisa inédita: "Comunicação para a sustentabilidade em organizações do terceiro setor". Uma abordagem única, desenvolvida com o objetivo de pesquisar e analisar como a comunicação organizacional é desenvolvida no terceiro setor e quais seriam os impactos das ações dessas organizações direcionadas à sustentabilidade para o benefício da sociedade.

Partindo para os objetivos específicos, estão: analisar as práticas de comunicação e sustentabilidade adotadas pelas organizações no terceiro setor; verificar se a comunicação no terceiro setor tem contribuído para aumentar a consciência sobre a importância da sustentabilidade; buscar aportes teóricos para uma base conceitual da comunicação para a sustentabilidade e fundamentos para ampliar a sustentação da conceituação desse processo; apurar a incorporação do conceito de sustentabilidade nas organizações pesquisadas e contribuir para gerar mais consciência social com uma comunicação estratégica.

Para tanto, os procedimentos metodológicos envolveram processos científicos que fundamentam o percurso do processo de pesquisa com diferentes métodos de coletas de dados em realidades distintas e envolvendo uma abordagem quantitativa e qualitativa. $O$ trabalho foi iniciado com a pesquisa quantitativa com aplicação de um questionário online disponibilizado para todas as organizações do terceiro setor que atuam com sustentabilidade cadastradas em dois bancos de dados de âmbito nacional. 
Sendo assim, o questionário foi estruturado em quatro partes: (1) Identificação, (2) Composição, (3) Gestão, (4) Mensuração. Como a pesquisa quis entregar uma visão nacional sobre estas práticas, o questionário foi enviado para organizações de todo o Brasil. A aplicação do questionário foi feita entre 12/3/2017 e 28/6/2017, somando uma amostra de 218 organizações (13,65\% das 1.597 que receberam o questionário). Para aumentar a quantidade e qualidade das respostas, foram desenvolvidos controles de campo detalhados posteriormente.

Para complementar a pesquisa quantitativa, a pesquisa qualitativa foi realizada por meio de entrevistas em profundidade com especialistas e gestores de organizações de referência envolvidos diretamente com a temática. Esta opção decorreu do fato de a entrevista em profundidade ser oportuna para que uma realidade seja compreendida a partir da fonte selecionada. Assim, um roteiro básico foi criado para direcionar as entrevistas. Em termos de técnica de coleta, a gravação foi realizada em todas as nas entrevistas presencias e por telefone. Em alguns casos, as respostas foram enviadas por e-mail a pedido dos entrevistados.

Para responder às questões como foco em comunicação, os entrevistados foram os seguintes: Afra Balazina (SOS Mata Atlântica), Bruno Weis (Instituto Socioambiental), Mariana Moraes (Grupo de Institutos Fundações e Empresas), Mauricio Bianco (Conservação Internacional), Rejane Romano (Instituto Ethos) e Renato de Paiva Guimarães (Greenpeace).

Já as questões como foco em sustentabilidade foram respondidas pelos seguintes entrevistados: Denise Hamú (ONU), Enrique Leff (palestrante, escritor, pesquisador e professor universitário), Fernando Almeida (engenheiro, escritor, consultor, conferencista e pesquisador), Leonardo Boff (teólogo, escritor, ativista ambiental e dos direitos humanos), Oded Grajew (Instituto Ethos e Oxfam Brasil) e Pedro Jacobi (USP).

Com o desenvolvimento da pesquisa, foi possível mapear as diferentes variáveis envolvidas nesse movimento de comunicação para a sustentabilidade no terceiro setor, com as particularidades de cada área. As variáveis indicadas nesta tese foram organizadas da forma mais didática possível para esclarecer que a comunicação, quando analisada em fluxo, está sujeita a diferentes interferências. Quando se trata de comunicação para a sustentabilidade, as especificidades 
aumentam, tornando-se mais complexas ao envolvermos nesse processo as organizações do terceiro setor.

Deste modo, a proposta é que a comunicação para a sustentabilidade em organizações do terceiro setor seja compreendida a partir de um processo que envolve os seguintes elementos: níveis; abordagem; transdisciplinaridade; liderança; códigos; meios, canais e formatos; linguagem; sentidos; frequência cerebral; públicos de interesse; repertório; perfil do gestor; prazo; escala de mudança; recursos envolvidos; percurso; abrangência; e frequência.

\section{Objeto de pesquisa, justificativa e objetivos}

\section{Assunto e objeto de pesquisa}

O objeto desta pesquisa é o mapeamento das variáveis no processo da comunicação para a sustentabilidade em organizações do terceiro setor. Dessa forma, a perspectiva foi trabalhar os potenciais da comunicação para gerar mudanças, principalmente em organizações que envolvam seus públicos em campanhas bemsucedidas direcionadas para a sustentabilidade.

A proposição deste conteúdo parte do entendimento de que a sociedade tem condições para se tornar mais justa e causar menos impacto ao meio ambiente com a prática da sustentabilidade, destacando que a comunicação oferece recursos essenciais para que isso ocorra.

O ponto de partida é a observação feita por Kunsch (2009a), que discute 0 potencial da comunicação diante da assimilação do conceito de sustentabilidade e da sua importância.

Somente com a comunicação será possível conscientizar a população em geral, os governos, a iniciativa privada e os segmentos representativos da sociedade civil de que 0 atendimento às necessidades e aspirações do presente sem comprometer a possibilidade de atendê-las no futuro é uma tarefa de todo a sociedade mundial e não só de uma pessoa, de uma organização e de um só país (KUNSCH, 2009a, p. 70).

Com um modelo sistematizado de comunicação para a sustentabilidade, tornase possível ampliar o conhecimento dos profissionais da área e demais cidadãos 
sobre como atender às aspirações do presente e manter condições sustentáveis para o futuro. Essa afirmação está alinhada com o propósito do terceiro setor, que reúne entidades ou associações que atuam na execução de atividades de utilidade pública. Estas organizações apresentam gerenciamento próprio e buscam promover, em diferentes áreas, a melhoria na qualidade da vida das pessoas. São exemplos as Organizações Não Governamentais (ONGs) e as Organizações da Sociedade Civil de Interesse Público (OSCIPs).

Considera-se ainda a existência de uma lacuna entre as organizações do terceiro setor envolvidas com a temática e o entendimento de que mudanças de comportamento e atitude podem ser ampliadas com o engajamento dos envolvidos. A proposta é apresentar um olhar transdisciplinar por meio da compreensão das convergências entre comunicação organizacional, sustentabilidade e terceiro setor, apresentando um quadro teórico de referência fundamentado em recentes e relevantes pesquisas sobre os temas.

\section{Hipóteses}

- A comunicação organizacional pode ser estratégica para fomentar o desenvolvimento de práticas sustentáveis na sociedade;

- A comunicação organizacional reúne técnicas que podem engajar públicos em ações sociais e ambientais;

- As organizações do terceiro setor desenvolvem ações de comunicação mais direcionadas para a divulgação das suas atividades e pouco para o desenvolvimento da sustentabilidade;

- O terceiro setor reúne organizações que possuem recursos limitados e uma estrutura pouco desenvolvida de comunicação organizacional.

\section{Justificativa}

Esta pesquisa dá continuidade aos estudos apresentados na dissertação de mestrado "O perfil do gestor de comunicação para a sustentabilidade nas organizações", defendida nesta mesma Escola em 2012. Naquele momento, a pesquisa foi desenvolvida com o objetivo de identificar o perfil do gestor de comunicação que contribui para o desenvolvimento da sustentabilidade nas organizações e analisar a formação recebida pelos egressos dos cursos de 
Comunicação Social com habilitação em Relações Públicas das instituições de ensino superior localizadas no Estado de São Paulo.

Além disso, o trabalho justifica-se para reforçar as pesquisas brasileiras sobre comunicação organizacional em uma perspectiva transformadora. Diante da necessidade de se atender aos apelos sustentáveis, e do posicionamento estratégico dado aos comunicadores nesta tarefa, a relevância de pesquisas que estabeleçam convergências entre comunicação e sustentabilidade é essencial para a qualidade de vida das pessoas e preservação da natureza.

No ambiente organizacional, a adoção de uma filosofia sustentável tem sido justificada diante dos impactos ambientais que estas causam e do relacionamento entre sociedade e os públicos envolvidos. O terceiro setor tem contribuído e apresenta potencial para aperfeiçoar sua atuação a partir de pesquisas criteriosas sobre a sua área de atuação. Nesse sentido, o relacionamento entre comunicação e sustentabilidade, sobretudo em ambientes organizacionais, tem recebido merecida atenção. Assim, a necessidade de desenvolver mais pesquisas relacionadas ao tema é mais uma motivação para a proposição deste estudo em nível de doutorado.

Acredita-se, ainda, na importância do resgate da função social da comunicação, ciência essencial para criar mecanismos de interação entre públicos para fins coletivos. Nessa perspectiva, que deve avançar em seu alcance e amadurecimento, o comunicador deve ser envolvido na tarefa estratégica de contribuir para a construção de uma sociedade mais digna e justa.

É relevante ainda destacar que esta pesquisa está atenta à necessidade de sistematizar de forma científica mais contribuições da comunicação no ambiente do terceiro setor, que apresenta ainda espaço extenso de desenvolvimento, direcionado à criação de mecanismos de engajamento de públicos em causas sustentáveis.

[...] as organizações precisam se conscientizar de que a sustentabilidade no seu real significado não é um modismo a ser adotado ou algo que vai se traduzir apenas em ganhos de negócios e de imagem positiva. Trata-se de algo bem mais complexo, envolvendo uma filosofia de gestão e um compromisso público dos mais relevantes (KUNSCH, 2009a, p. 68).

Cabe destacar que este pesquisador teve a oportunidade de atuar em projetos de comunicação e sustentabilidade. Uma das experiências ocorreu como consultor 
associado da Ideia Sustentável, consultoria em sustentabilidade empresarial que realiza palestras, workshops e produz conteúdo para diversas organizações, tendo como missão desenvolver uma nova geração de líderes e inserir a sustentabilidade no core business das organizações para que sejam mais éticos, transparentes, íntegros, responsáveis e respeitosos em relação às pessoas e ao meio ambiente.

Experiência complementar ocorreu quando este pesquisador atuou como editor de publicações na Lead, agência de comunicação fundada há vinte anos e reconhecida por sua atuação na comunicação de empresas e organizações sustentáveis. Na ocasião, este profissional foi responsável, em 2014, pela redação do Relatório de Sustentabilidade da Allianz Brasil, do Relatório de Atividades da Fundação Cásper Líbero e do Relatório de Atividades da Fundação Espaço Eco.

Diante da complexidade dos desafios, decisões embasadas cientificamente podem contribuir para a transformação das organizações. É neste cenário que o comunicador deve saber como atuar, pois, este é o profissional que tem a oportunidade de assumir o desenvolvimento da sustentabilidade nas organizações, contribuindo para este avanço também na sociedade.

\section{Objetivos}

\section{Gerais}

Pesquisar e analisar como a comunicação organizacional é desenvolvida no terceiro setor e quais seriam os impactos das ações dessas organizações direcionadas à sustentabilidade para o benefício da sociedade.

\section{Específicos}

- Analisar as práticas de comunicação e sustentabilidade adotadas pelas organizações no terceiro setor.

- Verificar se a comunicação no terceiro setor tem contribuído para aumentar a consciência sobre a importância da sustentabilidade.

- Buscar aportes teóricos para uma base conceitual da comunicação para a sustentabilidade e fundamentos para ampliar a sustentação da conceituação desse processo. 
- Apurar a incorporação do conceito de sustentabilidade nas organizações pesquisadas e contribuir para gerar mais consciência social com uma comunicação estratégica.

\section{Delimitação do problema}

Nesta pesquisa a perspectiva foi utilizar os potenciais da comunicação para a geração de mudanças, o que deve ser conseguido por organizações que engajem seus públicos em campanhas bem-sucedidas para a sustentabilidade. Essas atribuições têm origem no resgate da função social da área, o que ocorre a partir do conhecimento sobre o tema e uma ampla visão dos canais de divulgação e dos públicos participantes em uma perspectiva unificada de teoria e prática.

O problema inicial é a percepção de que as organizações do terceiro setor no Brasil, apesar de todos os avanços, carecem de equipes profissionais de comunicação. Este cenário é mais evidente em estruturas de pequeno e médio porte, o que impede que as próprias organizações atuem de forma mais estratégica para a manutenção das suas operações e a consecução das metas organizacionais.

De forma complementar, a própria comunicação também precisava de uma pesquisa mais aprofundada sobre como conceituar e operacionalizar sua atuação para a sustentabilidade. Finalmente, também foi identificado como problema inicial a ausência de clareza sobre as variáveis envolvidas em um processo efetivo de comunicação para a sustentabilidade no terceiro setor, o que impedia os pesquisadores e os profissionais da área de ter um olhar ao mesmo tempo científico e pragmático sobre todos os elementos envolvidos nesse fluxo para a criação de mensagens que ampliem os resultados planejados.

\section{Questões de pesquisa}

(1) A comunicação organizacional pode ser estratégica para fomentar o desenvolvimento de práticas sustentáveis na sociedade?

(2) As organizações do terceiro setor desenvolvem ações de comunicação muito mais de divulgação do que na promoção para a sustentabilidade?

(3) As organizações do terceiro setor possuem uma estrutura limitada de comunicação para a sustentabilidade? 
(4) Por que envolver a comunicação para desenvolver ações direcionadas para práticas sustentáveis?

(5) Como direcionar a comunicação para o engajamento do público em ações sustentáveis?

(6) Quem é o profissional responsável por desenvolver ações e campanhas de comunicação para práticas sustentáveis?

(7) Quais recursos profissionais devem ser utilizados para desenvolver as ações de comunicação para a sustentabilidade?

(8) Quais benefícios sociais e ambientais as ações de comunicação e sustentabilidade podem gerar para a sociedade e como mensurar os resultados?

\section{Referencial teórico}

Esta tese de doutorado está fundamentada nos seguintes eixos temáticos: comunicação organizacional, sustentabilidade e terceiro setor. O ponto de partida é a comunicação organizacional, seguida de um capítulo focado exclusivamente na questão da sustentabilidade e de uma revisão dos estudos sobre comunicação para a sustentabilidade. Na sequência, o último eixo temático é sobre o terceiro setor para completar a fundamentação teórica desta pesquisa.

Em termos de comunicação organizacional optou-se, para fins deste trabalho, por apresentar um retrato panorâmico sobre a área. Muitos outros recortes já foram feitos, cada um para ocasiões específicas sendo que, neste caso, entende-se que o recorte mais amplo atende à necessidade de embasar a pesquisa e situar o leitor na realidade brasileira da comunicação organizacional.

Diante da contextualização, este eixo temático foi fundamentado em Margarida M. Krohling Kunsch (2016, 2010, 2014, 2009a, 2009b, 2009c, 2007a, 2007b, 2003), Gaudêncio Torquato (2011, 2009), Wilson da Costa Bueno (2015, 2009), Rudimar Baldissera (2009a, 2009b, 2001) e Cicilia M. Krohling Peruzzo (2011, 2002).

Sobre a sustentabilidade destaca-se uma ampla pluralidade conceitual e vertentes diversas de compreensão sobre o tema. Para esta pesquisa, foram utilizados estudiosos brasileiros e estrangeiros com estudos consolidados na área e compreendem a interface necessária que ela estabelece tanto com a comunicação quanto com o terceiro setor. É o caso de Fernando Almeida (2007), Leonardo Boff 
(2013, 2012), Moacir Gadotti (2002), John Elkington (2001), Ignacy Sachs (2007, 2004) e Enrique Leff (2009).

Sobre o terceiro setor identificou-se também avanços em termos de estudos nos últimos anos. Para tanto os autores indicados a seguir embasaram o referencial teórico desta pesquisa. São os seguintes autores e obras: Rosa Maria Fischer (2002), Simone de Castro Tavares Coelho (2000), Andrés Pablo Falconer e Rosa Maria Fischer (1998), Rubem César Fernandes (1995), Andrés Pablo Falconer (1999), Lester M. Salamon e Helmut K. Anheier (1997), Antônio Carlos Carneiro de Albuquerque (2006), Maria Izilda Santos de Matos (2005), Maiso Dias Alves Júnior (2008), Débora Nacif de Carvalho (2006) e Oded Grajew (2017).

\section{Procedimentos metodológicos}

Os procedimentos metodológicos detalhados a seguir reúnem processos, cientificamente desenvolvidos, que fundamentam o percurso do processo de pesquisa. A linha de raciocínio congrega diferentes métodos de coletas de dados em realidades distintas, contemplando as questões de pesquisas e os objetivos gerais e específicos. Nesse sentido, a pesquisa será desenvolvida com base em recursos da abordagem qualitativa e quantitativa.

\footnotetext{
Os métodos de investigação se classificam como quantitativos e qualitativos por apresentarem características contrastantes quanto à forma e ênfase, entretanto não são excludentes. Esta classificação não significa que se deva optar por um ou outro. O pesquisador pode, ao desenvolver o seu estudo, utilizar os dois, usufruindo, por um lado, da vantagem de poder explicitar todos os passos da pesquisa e, por outro, da oportunidade de prevenir a interferência de sua subjetividade nas conclusões obtidas (NEVES, 1996, p. 101).
}

\section{Pesquisa quantitativa}

O trabalho foi iniciado com a pesquisa quantitativa para fornecer uma visão mais ampla sobre ações de comunicação desenvolvidas por organizações de diferentes portes, estruturas e áreas de atuação. Da mesma forma, foi utilizada para apurar mais informações sobre os impactos gerados no público pelas ações de comunicação das organizações do terceiro setor. Este tipo de pesquisa considera possibilidades de quantificações, o que significa traduzir em números opiniões e 
informações para classificá-las e analisá-las com o uso de recursos e de técnicas estatísticas.

\begin{abstract}
Está relacionada aos postulados teóricos da matriz positivista, cujo paradigma analisa a realidade e o processo de conhecimento com 0 uso de técnicas que buscam a objetividade através de uma lógica formal com neutralidade no processo de investigação: a realidade é exterior ao indivíduo e a apreensão dos fenômenos é feita de forma fragmentada (BAPTISTA, 2013, p. 32).
\end{abstract}

A pesquisa quantitativa mede, conta e estabelecer relações. Neste estudo adotou-se a pesquisa de levantamento. As técnicas na pesquisa empírica quantitativa podem ser definidas em duas vertentes: aquela em que a pesquisa é aplicada por meio de um entrevistador, e aquela em que o próprio entrevistado responde à pesquisa.

A elaboração de uma pesquisa quantitativa revela quantas pessoas de uma determinada população compartilham de uma característica ou um grupo de características, sendo especialmente planejada para gerar medidas precisas e confiáveis. A pesquisa quantitativa é apropriada para medir opiniões, atitudes e preferências. Também deve ser usado para determinar o perfil de um grupo de pessoas, baseando-se em características em comum. Por meio de técnicas estatísticas, ela pode criar modelos capazes de identificar opiniões ou comportamentos.

Seguindo ensinamentos de Richardson (1989), este tipo de pesquisa envolve o emprego da quantificação das mais simples às mais complexas, para o tratamento estatístico. O diferencial é garantir a precisão dos trabalhos realizados, conduzindo a um resultado com poucas chances de distorções.

De forma geral, os estudos de campo quantitativos são conduzidos por um modelo de pesquisa em que o pesquisador parte de quadros conceituais de referência estruturados, a partir dos quais formula hipóteses sobre os fenômenos e situações que quer estudar. A coleta de dados enfatizou números (ou informações conversíveis em números) que permitiram verificar a ocorrência ou não das questões iniciais e, então, a aceitação, ou não, das hipóteses.

Richardson (1989) revela ainda que este método é, frequentemente, aplicado em estudos descritivos, que se propõem investigar e descobrir 
características de um determinado fenômeno.

No planejamento deste tipo de estudo, o primeiro passo foi a identificação das variáveis específicas mais importantes para, assim, explicar as complexas características de um problema. Embora muitos experimentos em Ciências Sociais estejam limitados pelas características dos sujeitos, pelo instrumento de avaliação empregado e outros elementos, como disposição de pessoas e tempo para responder, o que poderia implicar grave incorreção é a eventual tendência dos profissionais em fazer generalizações, com base nos resultados dos experimentos.

Os dados foram analisados com apoio da estatística ou de outras técnicas matemáticas. Também, os tradicionais levantamentos de dados são o exemplo clássico do estudo de campo quantitativo (Popper, 1972).

Ainda, entre os tipos de estudos quantitativos, segundo Diehl (2004) podese citar os de correlação de variáveis ou descritivos (os quais, por meio de técnicas estatísticas, procuram explicar seu grau de relação e o modo como estão operando), os estudos comparativos causais (em que o pesquisador parte dos efeitos observados para descobrir seus antecedentes) e os estudos experimentais (que proporcionam meios para testar hipóteses).

A coleta de dados foi realizada com questionários que revelaram variáveis distintas e relevantes para a pesquisa, geralmente apresentado em quadros e gráficos.

\section{Instrumento}

O questionário foi o instrumento escolhido para a coleta de dados da pesquisa quantitativa, tendo como base fundamental o referencial teórico-metodológico decorrente da pesquisa bibliográfica apresentada e, como parâmetros centrais, os objetivos previamente apresentados. O questionário, com a maioria das perguntas fechadas, foi disponibilizado no formato online e desenvolvido com a utilização da versão paga do SurveyMonkey, especializado na elaboração de pesquisas pela internet e utilizado por diversas instituições de pesquisa científica, com sigilo dos resultados e privacidade dos respondentes. Para o encaminhamento do questionário à amostra adotada, foi elaborada carta com envio por e-mail e apresentação dos objetivos de pesquisa. Todos os contatados foram convidados a responder ao questionário, indicado em link específico do sistema SurveyMonkey. Além da carta e 
do acesso ao questionário, também foram disponibilizados os contatos do pesquisador para que os respondentes pudessem entrar em contato no caso de dúvidas.

\section{Elaboração do questionário}

Para a elaboração do questionário e posterior discussão dos resultados, foram realizadas reuniões de orientação embasadas no referencial teórico adotado e na proposição do conteúdo e do formato das questões. Como resultado, o questionário foi estruturado em quatro partes: (1) Identificação, (2) Composição, (3) Gestão, (4) Mensuração, conforme Apêndice 1.

A aplicação de um questionário para organizações do terceiro setor que atuam com sustentabilidade teve o objetivo de apurar as práticas mais recentes e inovadoras de comunicação para a sustentabilidade. Como a pesquisa pretendeu ter uma visão nacional sobre estas práticas, aliando elementos de pesquisa qualitativa e quantitativa, o questionário foi enviado para organizações de todo o País.

Do ponto de vista metodológico, o questionário é o instrumento perfeitamente adequado às Ciências da Comunicação e essencial para obter do público consultado os melhores dados de análise. A aplicação do questionário foi realizada mediante um planejamento com estratégias e objetivos previamente estabelecidos. Junto com o questionário, a pessoa recebeu um e-mail explicando a natureza da pesquisa e sua relevância.

Como método quantitativo, a pesquisa de opinião ou survey, como também é conhecida, possibilita a coleta de vasta quantidade de dados originados de grande número de entrevistados. Dentre seus aspectos positivos, podem-se destacar [...] a viabilidade de realização de análises estatísticas de variáveis como dados sociodemográficos, de atitude, dentre outras (NOVELLI, 2006, p. 164).

A aplicação dos roteiros foi realizada mediante um planejamento com estratégias e objetivos previamente estabelecidos.

É importante que seja definido um plano detalhado das etapas que envolverão a realização da pesquisa de opinião. Nesse planejamento são identificadas as estratégias a serem adotadas, a fim de que os objetivos sejam alcançados. O planejamento visa assegurar níveis de consistência interna ao processo, a fim de possibilitar o alcance dos 
objetivos pretendidos e evitar incoerências que possam comprometer os resultados obtidos (NOVELLI, 2006, p. 165).

O questionário escolhido para a coleta de dados teve como base o referencial teórico e metodológico decorrente da pesquisa bibliográfica realizada e esteve alinhado com os objetivos do projeto de pesquisa. Neste caso, foi utilizada a técnica de entrevistas estruturadas de autopreenchimento, por meio de questionário online do sistema SurveyMonkey, via internet. O conteúdo foi enviado aos respondentes por email. O objetivo foi, diante da multiplicidade de definições sobre sustentabilidade, reunir organizações do terceiro setor que atuam em diferentes áreas.

\section{Aplicação do questionário}

A aplicação do questionário foi feita entre 12/3/2017 e 28/6/2017, somando uma amostra total de 218 organizações (13,65\% das 1.597 que receberam o questionário), sendo que 149 das respostas foram completadas após estímulo dos controles de campo e 69 a partir do contato feito por e-mail. Detalhadamente, os totais de respostas em cada mês estão indicados a seguir: 37 em março, 44 em abril, 84 em maio e 53 em junho.

\section{Controles de campo}

Para aumentar a quantidade e qualidade das respostas, foram desenvolvidos controles de campo com base nas seguintes etapas: (1) envio e recebimento, com o controle de eventuais devoluções; (2) controle das respostas recebidas; (3) novo envio (repique) para estimular a participação na pesquisa para aqueles que não responderam; (4) considerando que não havia sido obtida a amostra desejada, começou a ser feito contato telefônico com os não participantes, sugerindo sua participação no estudo.

Destaca-se a imensa dificuldade para a obtenção do retorno dos questionários preenchidos. Houve um esforço concentrado para se conseguir o maior número possível de respostas, o que foi possibilidade pela contratação da prestação de serviços de duas profissionais treinadas para realizar o Follow Up. Neste caso, contatos diários realizados e todas as organizações consideradas válidas para a pesquisa foram acionadas por e-mail e por telefone. Considera-se que o número 
obtido seja representativo da amostra trabalhada com base em um universo já mencionado.

\section{Análise dos resultados obtidos}

A análise foi realizada a partir dos dados obtidos com as 218 organizações que responderam ao questionário. Trata-se de uma análise descritiva centrada nos resultados obtidos com as questões levantadas nas quatro partes que compuseram o questionário: (1) Identificação; (2) Composição; (3) Gestão; (4) Mensuração.

\section{Pesquisa qualitativa}

Para complementar a pesquisa quantitativa, foi realizada uma pesquisa qualitativa sobre o tema por meio de entrevistas em profundidade com especialistas e gestores de organizações de referência envolvidos diretamente com a temática. Neste sentido Silva e Menezes (2005) definem o que é pesquisa qualitativa da maneira indicada a seguir.

A pesquisa qualitativa considera que há uma relação dinâmica entre o mundo real e o sujeito, isto é, um vínculo indissociável entre o mundo objetivo e a subjetividade do sujeito que não pode ser traduzido em números. A interpretação dos fenômenos e atribuição de significados são básicos no processo qualitativo. Não requer o uso de métodos e técnicas estatísticas. O ambiente natural é a fonte direta para coleta de dados e o pesquisador é o instrumento-chave. O processo e seu significado são os focos principais de abordagem (SILVA; MENEZES, 2005, p. 20).

A pesquisa qualitativa deve ser usada para entender as ações e opiniões de determinadas pessoas. Esse tipo de pesquisa fornece um processo a partir do qual as principais questões são identificadas e perguntas são formuladas, descobrindo o que importa para os entrevistados e porquê. Com esse objetivo, foi importante trabalhar com uma amostra heterogênea de pessoas, pois ela revelou áreas de consenso e contrariedades nos padrões de respostas.

Esta pesquisa qualitativa não foi projetada para coletar resultados quantificáveis, sendo que os dados qualitativos consistem em descrições detalhadas de situações, eventos, pessoas, interações e comportamento com citações diretas das pessoas sobre experiências, atitudes, crenças e pensamentos.

Este método não emprega um instrumental estatístico como base na análise 
de um problema, não pretendendo medir ou numerar categorias (Richardson, 1989). Para alguns, todos os estudos de campo são necessariamente qualitativos e, mais ainda, identificam-se com a observação participante.

Nesse sentido, podemos considerar que a pesquisa qualitativa trabalha, predominantemente, com informações não numéricas coletadas pelo pesquisador. Ou, então, que os números e as conclusões neles baseadas representam menor importância na análise. Dentro de tal conceito amplo, os dados qualitativos incluem também informações não expressas em palavras, tais como pinturas, fotografias, desenhos, filmes, vídeo tapes e até mesmo trilhas sonoras (Tesch, 1990).

$\mathrm{Na}$ pesquisa qualitativa existem alguns métodos mais apropriados para a coleta e a análise de dados, como entrevistas, observação participante, análise documental, estudos de caso, história de vida, entre outros. Mais do destacar diversas técnicas, metodologias e instrumentos, é importante destacar as características básicas da pesquisa qualitativa. Sem pretender esgotá-las, podese dizer que incluem:

a) foco na interpretação ao invés de na quantificação: geralmente, o pesquisador qualitativo está interessado na interpretação que os próprios participantes têm da situação sob estudo;

b) ênfase na subjetividade ao invés de na objetividade: aceita-se que a busca de objetividade é um tanto quanto inadequada, já que o foco de interesse é justamente a perspectiva dos participantes;

c) flexibilidade no processo de conduzir a pesquisa: o pesquisador trabalha com situações complexas que não permite a definição exata e a priori dos caminhos que a pesquisa irá seguir;

d) orientação para o processo e não para o resultado: a ênfase está no entendimento e não num objetivo pré-determinado, como na pesquisa quantitativa;

e) preocupação com o contexto, no sentido de que o comportamento das pessoas e a situação ligam-se intimamente na formação da experiência;

f) reconhecimento do impacto do processo de pesquisa sobre a situação de pesquisa: admite-se que o pesquisador exerce influência sobre a situação de pesquisa e é por ela também influenciado (CASSEL; SYMON, 1994, p. 127).

Apesar da importância crescente, a pesquisa qualitativa ainda pode alcançar mais destaque. Existem ainda pesquisadores que a evitam em nome de uma pretensa neutralidade científica e de um rigor metodológico mais associado 
com as ciências exatas. Suas principais vantagens estão alinhadas com as características indicadas a seguir: dados coletados preferencialmente nos contextos em que os fenômenos são construídos; a análise de dados desenvolvida, de preferência, no decorrer do processo de levantamento destes; estudos apresentados de forma descritiva, à luz dos significados dos próprios sujeitos e de outras referências; teoria construída por meio da análise dos dados empíricos; interação entre pesquisador e pesquisado é fundamental, razão pela qual o pesquisador precisa estar preparado, principalmente em técnicas comunicacionais; integração de dados qualitativos com dados quantitativos deve ser estimulada.

\section{Instrumento}

O enriquecimento do trabalho foi possível com a realização de entrevistas em profundidade com gestores de comunicação de organizações de referência e especialistas em sustentabilidade. A vantagem deste tipo de entrevista é que ela foi conduzida pelo entrevistado e ajustada pelo roteiro do pesquisador. A entrevista em profundidade é dinâmica e flexível, muito oportuna para que uma realidade seja compreendida a partir da fonte selecionada.

A lista de questões desse modelo tem origem no problema de
pesquisa e busca tratar da amplitude do tema, apresentando cada
pergunta da forma mais aberta possível. Ela conjuga a flexibilidade da
questão não estruturada com um roteiro de controle. As questões, sua
ordem, profundidade, forma de apresentação, dependem do
entrevistador, mas a partir do conhecimento e disposição do
entrevistado, da qualidade das respostas, das circunstâncias da
entrevista (DUARTE, 2011, p. 62).

Tal opção decorreu do fato de que a entrevista em profundidade, além de dinâmica e flexível, é oportuna para que uma realidade seja compreendida a partir da fonte selecionada. Sobre o tipo de entrevista, a opção preferível foi a semiaberta, realizada por telefone, iniciando com algumas questões essenciais que podem ser aprofundadas a partir das respostas recebidas. No caso das entrevistas por e-mail, o tipo foi a entrevista em profundidade fechada pela impossibilidade de pedir complementação sobre determinado ponto específico. 
Mais do que uma coleta de informações interativa baseada na consulta direta a informantes, a entrevista em profundidade pode ser um rico processo de aprendizagem, em que a experiência, visão de mundo e perspicácia do entrevistador afloram e colocam-se à disposição das reflexões, conhecimento e percepções do entrevistado (DUARTE, 2011, p. 81).

Uma visão próxima e complementar é apresentada por Augusto Triviños (1987), que define este tipo de entrevista como entrevista semiestruturada, a qual

[...] parte de certos questionamentos básicos, apoiados em teorias e hipóteses que interessam à pesquisa, e que, em seguida, oferecem amplo campo de interrogativas, fruto de novas hipóteses que vão surgindo à medida que se recebem as respostas do informante. Desta maneira, o informante, seguindo espontaneamente a linha de seu pensamento e de suas experiências dentro do foco principal colocado pelo investigador, começa a participar na elaboração do conteúdo da pesquisa (TRIVIÑOS, 1987, p. 146).

Um roteiro básico foi criado para direcionar as entrevistas, considerada a abordagem mais adequada para revelar o conhecimento dos especialistas e gestores selecionados.

\begin{abstract}
Esse texto, limitado pelo espaço disponível e objetivo, trata da entrevista em profundidade, técnica qualitativa que explora um assunto a partir da busca de informações, percepções e experiências de informantes para analisá-las e apresentá-las de forma estruturada. Entre as principais qualidades dessa abordagem está a flexibilidade de permitir ao informante definir os termos da resposta e ao entrevistador ajustar livremente as perguntas. Esse tipo de entrevista procura intensidade nas respostas, não-quantificação ou representação estatística (DUARTE, 2011, p. 62).
\end{abstract}

Do ponto de vista do tipo de entrevista, a opção implementada foi a semiaberta, que tem início com algumas questões essenciais que puderam ser aprofundadas a partir das respostas recebidas.

A lista de questões desse modelo tem origem no problema de pesquisa e busca tratar da amplitude do tema, apresentando cada pergunta da forma mais aberta possível. Ela conjuga a flexibilidade da questão não estruturada com um roteiro de controle. As questões, sua ordem, profundidade, forma de apresentação, dependem do entrevistador, mas a partir do conhecimento e disposição do entrevistado, da qualidade das respostas, das circunstâncias da entrevista (DUARTE, 2011, p. 66). 


\section{$\underline{\text { Técnicas de coletas de dados }}$}

Como técnica de coleta, a gravação foi realizada nas entrevistas presencias e por telefone pela facilidade que oferece de registrar todo o diálogo, sendo que a transcrição foi produzida na sequência. Em alguns casos, as respostas foram enviadas por e-mail a pedido dos entrevistados. A meta de revelar práticas e modos de atuação que colaborassem para dar maior clareza à proposta desta tese foi atingida. De modo geral pode-se dizer que as questões abordaram todo o conteúdo proposto. Para concluir, as informações foram transpostas e analisadas.

\section{Análise e interpretação dos dados}

A análise e a interpretação dos dados estiveram apoiadas na metodologia da hermenêutica de profundidade proposta por Thompson (1995). Ele defende a interpretação como método e talvez o único modo de produzir conhecimento sobre a realidade social. Para tanto, foi necessário garantir um aspecto central à interpretação, sendo a hermenêutica da profundidade é uma orientação metodológica que direciona o uso das diversas técnicas de apreensão da realidade. Além disso, ela sugere uma série sistematizada de procedimentos que possibilitam a análise cultural pela interpretação do pesquisador, por meio das inter-relações de perspectivas que compõem os fenômenos sociais "combinados dentro de um movimento de pensamento coerente, que iluminará diferentes aspectos desses fenômenos multifacetados" (Thompson, 1995, p. 356).

A hermenêutica está alinhada com as premissas defendidas no referencial teórico, pois ela inscreve suas análises no âmbito da vida cotidiana e se preocupa com os modos pelos quais as formas simbólicas são interpretadas pelas pessoas que as produzem, cabendo ao pesquisador interpretar a interação dos sujeitos.

Um dos principais cuidados, indicado pelo autor, é a não limitação da análise das formas simbólicas, sempre as contextualizando às conjunturas social e histórica. Na comunicação organizacional, é necessário que haja uma atenção especial à análise de materiais institucionais. Thompson, neste sentido, defende que "muitas vezes as formas simbólicas são analisadas separadamente dos contextos em que elas são produzidas e recebidas pelas pessoas que rotineiramente dão sentido a essas formas e as integram a outros aspectos de suas 
vidas" (Thompson, 1995, p. 364).

Para responder a esses desafios, o autor propõe a hermenêutica de profundidade constituída em um referencial metodológico amplo, abrangendo três fases principais: análise sócio-histórica, uma análise formal ou discursiva, e interpretação/reinterpretação. Assim, interpretar a partir da hermenêutica compreende partir do campo simbólico, expresso no discurso, para revelar as disputas incorporadas, em uma interpretação crítica do discurso.

As informações recolhidas nas entrevistas em profundidade foram articuladas para desenvolver uma narrativa. Para evitar acúmulo de informações, os resultados foram selecionados e sistematizados a partir de uma análise qualitativa, destacando os trechos mais relevantes das entrevistas.

Analisar implica separar o todo em partes e examinar a natureza, funções e relações de cada uma. Geralmente, a opção mais fácil e menos útil para a redação do relatório é organizar os resultados pela apresentação de cada unidade (...). O pesquisador, sem perder de vista os objetivos do trabalho, classifica as informações a partir de determinado critério, estabelecendo e organizando grupos de temas comuns, como que as agrupando em "caixas" separadas para se dedicar individual e profundamente a cada uma. Esta estrutura geral assume a forma de esquema de análise e cada conjunto (caixa) é chamado categoria, uma unidade de análise completa e única em si mesma (DUARTE, 2011, p. 78).

Para tornar a metodologia mais completa, categorias foram construídas e consolidadas no roteiro de perguntas.

Categorias são estruturas analíticas construídas pelo pesquisador que
reúnem e organizam o conjunto de informações obtidas a partir do
fracionamento e da classificação em temas autônomos, mas inter-
relacionados. Em cada categoria, o pesquisador aborda determinado
conjunto de respostas dos entrevistados, descrevendo, analisando,
referindo à teoria, citando frases colhidas durante as entrevistas e a
tornando um conjunto ao mesmo tempo autônomo e articulado
(DUARTE, 2011, p. 79).

Duarte (2011) sugere que, para auxiliar na redação, haja uma introdução em cada categoria, para que seja definido e explicado o que será tratado, tendo ao fim um texto conclusivo. Entende-se assim que, além dos resultados obtidos e analisados, a pesquisa qualitativa encontra-se alinhada com a relevância do tema. 
Para que a pesquisa estivesse integrada com a vertente quantitativa, as respostas dos questionários enviados para as organizações do terceiro setor foram analisadas. Isso foi feito com a visualização de um resumo dos seus dados, seguido pela exploração das respostas individuais, criação de gráficos dinâmicos, utilização de regras de filtros, comparação e exibição para segmentos específicos, além da apresentação e categorização de respostas. 


\section{Capítulo 1. Comunicação organizacional}

Primeiro eixo temático desta tese, este capítulo trata da comunicação organizacional, compreendendo que esta temática no Brasil apresenta estrutura evoluída como resultado da dedicação de muitos pesquisadores, principalmente oriundos das universidades, com uma pluralidade de conceitos.

A comunicação organizacional é um campo de conhecimento consolidado no Brasil. Para além de uma visão fragmentada nas especializações, Margarida Kunsch (2003) propõe a comunicação organizacional integrada com uma sistematização ampla e pragmática que beneficia qualquer organização com uma comunicação instrumental, estratégica e humana.

Em abordagem complementar, o pesquisador Wilson Bueno (2009) incorpora o conceito de comunicação empresarial associado a uma conciliação entre os aspectos mercadológico e institucional. Segundo ele, a comunicação empresarial ou organizacional é compreendida como conjunto de ações, estratégias, planos, políticas e produtos planejados por uma organização para estabelecer relações com seus públicos de interesse (Bueno, 2009).

Este mesmo autor destaca a importância da vertente estratégica da comunicação organizacional, o que demonstra o cenário da comunicação organizacional a respeito do estágio de desenvolvimento em que este campo profissional se encontra, facilitando o próprio planejamento para uma melhora nesse sentido. Gaudêncio Torquato (2011) relaciona o tema com as subáreas de jornalismo, relações públicas, publicidade e editoração, além de outros segmentos, como assessoria de imprensa, jornalismo empresarial, marketing cultural, entre outros.

Seguindo uma construção a partir da reflexão sobre a complexidade, Rudimar Baldissera (2009b) acredita que é equivocada a compreensão dos públicos como passivos e defende que a ideia de linearidade e unidade não dá conta de estruturas sociais e organizacionais complexas. $\mathrm{O}$ autor defende ainda que a organização seja vista como espaço de fluxos multidirecionais e heterogêneos. $O$ autor indicado parte do paradigma da complexidade de Edgar Morin (2001) para explicar a comunicação organizacional como um processo de disputa de sentidos no âmbito das relações.

Sobre os desafios da área, alguns podem ser considerados diante dos atuais cenários social, ambiental e econômico: mensuração de resultados, customização de conteúdos e profissionalização da equipe. Esta compreensão assegura a criação de 
condições mais favoráveis para o desenvolvimento da sustentabilidade nas organizações.

\subsection{Surgimento e evolução}

Com uma abordagem voltada ao desenvolvimento histórico, o texto de Margarida M. Krohling Kunsch (2009a, p. 64) revela os principais momentos de evolução da comunicação organizacional. A autora defende que o surgimento decorre dos primeiros estudos de diferentes campos do conhecimento, como administração, teoria das organizações, sociologia, psicologia, antropologia, linguística e teoria da comunicação.

Os primeiros estudos de comunicação organizacional foram realizados na década de 1940, nos Estados Unidos, período em que estiveram mais associados à comunicação de negócios e ao desenvolvimento industrial, como extensão do discurso corporativo.

Uma década depois (1950), a comunicação já assumia contornos mais precisos, ainda que unidirecional e hierarquizada, porém contemplando mais elementos, como habilidades comunicativas, eficácia dos meios de comunicação utilizados e estudos sobre as relações humanas.

De 1960 a 1980, a comunicação organizacional já passava a ser mais estudada. A visão instrumental era predominante (o que ocorre ainda hoje em vários casos), mas já havia a preocupação de pesquisadores com a sistematização do conhecimento e das práticas que vinham sendo desenvolvidas. A partir de então, mais precisamente na década de 1980, a comunicação organizacional tornou-se mais evidente e sofreu questionamentos, momento em que a convergência das pesquisas já realizadas e a capacidade de garantir soluções para os relacionamentos das organizações com seus públicos apresentaram à área um espaço maior de atuação, mais oportuno e importante às organizações.

Desde a década 2000, a comunicação organizacional passou a assumir uma configuração mais interdisciplinar, com maior foco nas teorias da comunicação e nas estratégias. Na primeira década do século XXI, passou a ser considerada um campo de perspectivas múltiplas e universal em sua abordagem, por seus métodos, suas teorias, seus âmbitos de pesquisa e seus postulados filosóficos (Kunsch, 2009a, p. 71). 
Ainda do ponto de vista histórico, Gaudêncio Torquato (2009) enxerga um processo extenso. De acordo com o autor, os primórdios da comunicação organizacional contemplavam a produção de jornais empresariais na década de 1960, propondo a compreensão desta evolução histórica a partir de quatro conceitos.

O primeiro deles é o do jornalismo empresarial, presente nas décadas de 1970 e 1980 no Brasil, como um nicho especializado, no momento em que o mercado brasileiro começava a oferecer boas perspectivas (Torquato, 2009). O segundo conceito, seguindo a linha do pesquisador citado, é o da comunicação empresarial, estratégica e política. Foi a partir de então que houve uma evolução para uma vertente mais estratégica.

O posicionamento mais elevado do profissional caracterizou a década
de 1990. Na verdade, ele tem sido um eficaz intérprete dos efeitos da
globalização, principalmente no que se refere ao foco do discurso e à
estratégia para conferir nitidez à identidade e à imagem
organizacionais. O comunicador passou a ser um leitor agudo da
necessidade de a empresa interagir estrategicamente com o meio
ambiente e competir em um mercado aberto a novos conceitos e
novas demandas (TORQUATO, 2009, p. 14).

Terceiro conceito na evolução histórica da comunicação organizacional, a comunicação governamental e política surgiu na década de 1980, em um momento de abertura política do Brasil com redemocratização e força no marketing político.

Quarto e último conceito, o da própria comunicação organizacional, demonstra a amplitude de atuação deste campo, adequado a todos os setores da sociedade. $O$ momento foi de consolidação de seu espaço estratégico e de novos desafios. As mais recentes evidências demonstram que a comunicação é um processo de interação e de relacionamento, e não apenas uma ferramenta. Trata-se de uma mudança importante na visão organizacional, que altera a estrutura organizacional, para a qual a Comunicação pode oferecer estratégias, e não somente instrumentos - um dos grandes desafios atuais para os profissionais de comunicação.

Se considerada uma atuação estratégica por parte da Comunicação, é de se supor que inúmeras demandas e possibilidades são apresentadas à área.

A comunicação, agora assumida como estratégica, tem exigido das organizações uma nova postura e ela inclui, obrigatoriamente, 0 planejamento e, em decorrência, a construção de cenários, a 
consolidação e o refinamento de conceitos e, portanto, a realização de pesquisas (BUENO, 2009, p. 251).

Há uma consolidação das estruturas de comunicação organizacional, que tem demonstrado cotidianamente suas atribuições e responsabilidades, por vezes instrumentais, por vezes estratégicas. No contexto do pós-modernismo, no entanto, novos desafios surgem e serão discutidos a seguir. Há muito espaço de atuação ainda para a comunicação organizacional, desde que esta seja praticada com proatividade e responsabilidade.

\subsection{Principais conceitos e autores}

Para além das atribuições de cada uma das habilitações da Comunicação Social, a comunicação organizacional integrada proposta por Kunsch (2003) propõe uma sistematização ampla para que qualquer organização possa ter uma comunicação completa. Segundo a autora, a visão integrada compreende a participação da Comunicação na gestão estratégica, no desenvolvimento econômico, social e ambiental da organização. As ações comunicativas em todos os níveis da organização devem ser utilizadas como incentivo ao diálogo, à participação e à interatividade.

Entendemos por comunicação integrada uma filosofia que direciona a
convergência de diversas áreas, permitindo uma atuação sinérgica.
Pressupõe uma junção da comunicação institucional, da comunicação
mercadológica, da comunicação interna e da comunicação
administrativa, que formam o mix, o composto da comunicação
organizacional (KUNSCH, 2003, p. 150).

A proposta de comunicação organizacional integrada da pesquisadora é a referência principal a partir do qual este estudo se desenvolve. 
Figura 1: Comunicação organizacional integrada

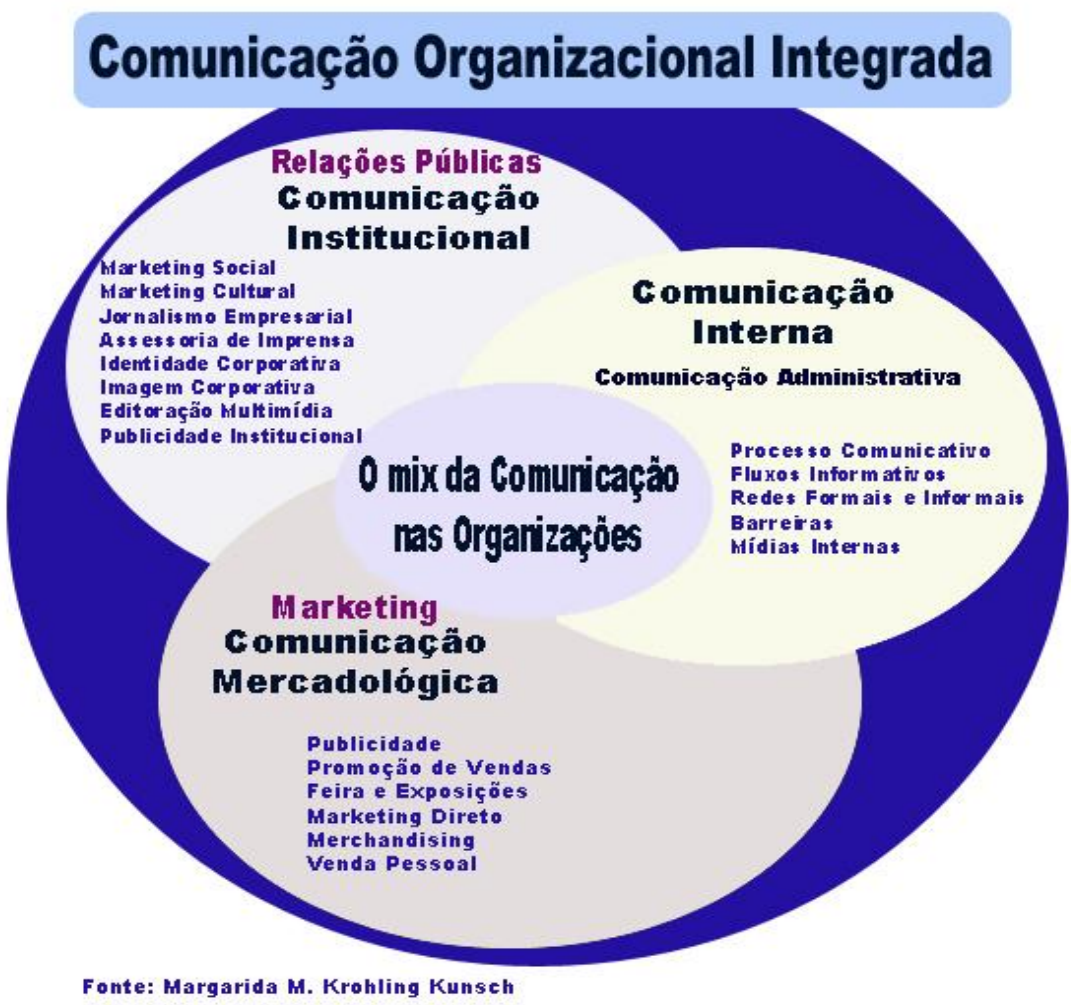

Fonte: Kunsch (2009c)

Desta perspectiva, a comunicação administrativa está associada ao fluxo de informações dentro de uma organização e apresenta uma configuração mais voltada à transmissão de informações. Não tem a mesmas características ou o mesmo alcance da comunicação interna, mas é importante para expressar de modo direto e ágil decisões e novos posicionamentos da organização aos funcionários.

Com a comunicação interna já é diferente, e pode ser muito oportuna para a convergência com a sustentabilidade. A visão associada a este desempenho que se pretende destacar é a comunicação vista como relacionamento. Trata-se de uma abordagem mais ampla. A proposta é que esta visão paute o planejamento da comunicação interna, o que converge com a responsabilidade das organizações frente aos seus funcionários de um tratamento mais humano e responsável.

Ainda, segundo Kunsch (2003), é oportuno destacar os "sete cês" associados ao verdadeiro papel da comunicação:

(...) estabelecer confiança; possibilitar a cocriação, por meio da participação do público receptor; contribuir para um clima favorável e propício no ambiente de trabalho; fazer as conexões com todas as 
modalidades comunicacionais; envolver as pessoas para buscar um comprometimento consciente; celebrar e fazer as correções e os ajustes necessários; e comunicar sempre as ações e os programas que serão levados a efeito (KUNSCH, 2003, p. 162).

O terceiro composto da comunicação integrada é a comunicação institucional, mais relacionada à projeção que a organização planeja ter de si mesma. Suas ações requerem um discurso alinhado e atualizado com as expectativas de seus públicos e é muitas vezes utilizada em momentos de crise para que a identidade organizacional seja reforçada.

Sua função justifica-se na medida em que a organização pretende ser vista de determinado modo (preferencialmente planejado), e tais características é o que compõem a essência do conteúdo das ações institucionais da organização. São exemplos da comunicação institucional: as relações públicas, o jornalismo empresarial, a assessoria de imprensa, a publicidade institucional, a identidade, o marketing social, o marketing cultural e a editoração multimídia (KUNSCH, 2003, p. 166).

Já a comunicação mercadológica, quarta vertente da comunicação organizacional integrada, tem um objetivo voltado à divulgação publicitária de produtos ou serviços. Sua função prioritária é a de servir aos planos de desenvolvimento financeiro do marketing.

A comunicação mercadológica ou de marketing se encarrega, portanto, de todas as manifestações simbólicas de um mix integrado de instrumentos de comunicação persuasiva para conquistar o consumidor e os públicos-alvos estabelecidos pela área de marketing (KUNSCH, 2003, p. 164).

Além destes, outras abordagens também se destacam no Brasil. Podemos retomar Gaudêncio Torquato, que relaciona a comunicação organizacional com as habilitações da Comunicação Social (jornalismo, relações públicas, publicidade e editoração), além de outros elementos, como assessoria de imprensa, jornalismo empresarial, marketing cultural, entre outros.

Nas organizações, a comunicação é usada de diversas formas. Desenvolve-se, de um lado, um conjunto de comunicações técnicas, instrumentais, burocráticas e normativas. E, em paralelo, ocorrem situações de comunicação expressiva, centrada nas capacidades, 
habilidades, comportamentos e posturas das fontes. Esta humaniza, suaviza, coopta, agrada, diverte, converte, impacta, sensibiliza (TORQUATO, 2011, p. 7).

Wilson Bueno adota o conceito de comunicação empresarial associado a uma conciliação entre os aspectos mercadológico e institucional. Isso ocorre, pois, em muitos casos, a múltipla capacidade de atuação da comunicação organizacional pode, muitas vezes, não ser visualizada em todo o seu potencial, e o desenvolvimento de atividades corriqueiras e instrumentais pode predominar em algumas organizações.

\begin{abstract}
Assim, entendemos Comunicação Empresarial ou Comunicação Organizacional como: Conjunto integrado de ações, estratégias, planos, políticas e produtos planejados e desenvolvidos por uma organização para estabelecer a relações permanente e sistemática com todos os seus públicos de interesse (BUENO, 2009, p. 4).
\end{abstract}

Em uma perspectiva criada a partir da compreensão da complexidade, Rudimar Baldissera (2009b) defende que é equivocada a compreensão dos públicos como passivos, lembrando que a ideia de linearidade e unidade não dá conta de estruturas sociais e organizacionais complexas. O autor lembra ainda que é preciso que a organização seja vista como espaço de fluxos multidirecionais e heterogêneos.

Tem-se, então, que a comunicação organizacional se configura como - lugar e o meio para que a dispersão e a desordem simbólica se realizem como força que gera/regera a organização. Trata-se da arena para a manifestação das resistências, dos embates, dos confrontos que, no momento seguinte, em transações, negociações e disputas, se misturam, se associam para se constituírem em nova força que, agora, pode ser (re) organizadora (BALDISSERA, 2009b, p. 160).

Conforme descrito, são várias as abordagens conceituais sobre comunicação organizacional no Brasil. Todas são complementares e destacam determinados aspectos que consideram mais importantes. Para esta pesquisa, entende-se que as definições apresentadas acima contribuam para a compreensão deste conceito tão amplo quanto complexo.

\title{
1.3 Dimensões da comunicação organizacional
}

Em suas pesquisas mais recentes, Margarida Kunsch tem se dedicado a situar as organizações em um contexto mais amplo da sociedade, destacando a sua 
relevância como elementos de estruturas globais e locais que influenciam o desenvolvimento socioeconômico, estando integradas à história e sendo parte da dinâmica da política e econômica.

Nesse sentido, entre toda a produção científica da pesquisadora citada, cabe destacar as atuais dinâmicas nas práticas organizacionais. Para tanto, Kunsch (2014) propõe uma análise fundamentada em quatro dimensões: instrumental, humana, cultural e estratégica. Essa compreensão oferece aos pesquisadores a clareza de observar o quanto a comunicação de cada organização tem sido requisitada, e com qual capacidade de atuação, estando detalhada a seguir, pois também se adequa à realidade estudada nesta pesquisa.

\section{Instrumental}

A dimensão instrumental está relacionada com tarefas mais rotineiras da comunicação, o que ocorre, ainda hoje, na maior parte das organizações, apesar de todo o avanço histórico da relevância da área observado.

Quando é instrumental, a comunicação organizacional é simplesmente utilizada pela administração para tarefas menos complexas e mais específicas. Não há, nessa dimensão, o desenvolvimento de muitas possibilidades e atribuições, sendo que uma equipe obediente e acrítica costuma ser suficiente para a execução das tarefas sem maior envolvimento ou proatividade.

A evolução histórica da comunicação organizacional revela que a tendência é de progresso da área, inclusive no terceiro setor, e que, em muitas organizações, a comunicação é ainda instrumental em decorrência do seu próprio período de evolução e desenvolvimento - o que pode mudar a partir de atuação qualificada e assertiva dos profissionais de comunicação.

\section{Estratégica}

Partindo para a dimensão estratégica, percebe-se que a comunicação neste patamar é uma das grandes possibilidades e um dos principais desafios da comunicação organizacional contemporânea, pois esse estágio também precisa envolver uma organização que compartilhe desta visão ou que esteja receptiva a aceitar investimentos necessários. Em grande parte das organizações, a estratégia da 
comunicação ainda não está sendo abordada como necessária e o termo, muitas vezes, é usado sem a correta fundamentação teórica.

A atuação estratégica, do ponto de vista da comunicação, também significa o alinhamento com a identidade da organização e, de forma pragmática e exequível, agir de modo oportuno e essencial para o desenvolvimento dos objetivos e das metas organizacionais. Significa, na prática, que a comunicação demonstre que o investimento em seus profissionais e em suas ações é relevante e gera mais retorno que gasto, ainda que não sejam necessariamente só financeiro.

Ao estrategista não cabe uma função passiva, isto é, aceitar a configuração adotada pela estrutura do setor, como também as regras impostas e, sim, influenciar tal estrutura. Basta observar que, atualmente, uma das principais características das grandes organizações é o fato de se constituírem e instituírem em referências que lideram as decisões e mudanças em sua atividade, fixando as normas de conduta do setor, culminando por assumir o importante papel de agentes de transformações sociais. Sob esse prisma, o estrategista deve prever e articular os recursos comunicacionais necessários para garantir a circulação de informações selecionadas e fazer com que os públicos reconheçam sua empresa, instituindo-a identitariamente, como referência. Dessa maneira, consegue-se agregar valor à marca que, atualmente, é o principal diferencial mercadológico (BALDISSERA, 2001, p. 4).

Não é, naturalmente, uma tarefa fácil, inclusive é por isso que avaliar e mensurar os resultados da comunicação tem se tornado imperativo aos profissionais que desejam se diferenciar no mercado, em todos os setores. A comprovação dos resultados, de preferência com indicadores numéricos, é o que elimina dúvidas e desfaz contradições no momento em que a meta passa pelo estabelecimento de uma comunicação estratégica nas organizações.

\section{Cultural}

Seguindo a proposta de Margarida Kunsch (2014), outra dimensão da comunicação organizacional é a cultural, embasada na compreensão de que as organizações são formadas por pessoas com diferentes culturas. Esses indivíduos, quando se integram em grupos profissionais, se adaptam à cultura organizacional vigente e aos valores e princípios filosóficos predominantes. 
Além disso, as organizações, por sua vez, estão localizadas em um determinado país, que tem uma cultura nacional, e também sofrem, ainda, interferências de uma cultura global da sociedade internacional. Dessa forma, a comunicação não opera isolada da cultura organizacional, nem está isenta da influência multicultural global.

\begin{abstract}
Neste sentido defendo a necessidade de as organizações e, particularmente, os seus gestores da comunicação considerarem a dimensão cultural como parte integrante do planejamento, das ações comunicativas e dos processos de gestão participativa. Portanto, há que se considerar a dimensão cultural em sinergia com as demais dimensões da comunicação organizacional (KUNSCH, 2014, p. 55).
\end{abstract}

Cabe indicar ainda que o ambiente organizacional é vivenciado por pessoas que precisam ser valorizadas na prática comunicativa cotidiana, sem que sejam exploradas com o excesso de comunicação instrumental, tampouco cobradas em excesso por resultados financeiros. A disponibilização de canais de diálogo entre a diretoria e os demais profissionais de todas as organizações pode valorizar os repertórios de todos aqueles que atuam nas organizações e favorecer o engajamento para a criação de um ambiente mais justo e criativo.

\title{
Humana
}

Finalmente, a dimensão humana da comunicação é muito pouco desenvolvida nas organizações, porém diretamente responsável pela satisfação e o engajamento profissional. Aperfeiçoar a dimensão humana nas organizações é uma forma de criar condições para um ambiente mais solidário, o que também exige a ampliação dos diálogos e de mecanismos de participação coletiva.

Essa abordagem decorre da compreensão de que a troca de informações e o estabelecimento de relações afetivas, emotivas e até de cumplicidade é natural ao ser humano, o que pode ocorrer também de forma saudável nas organizações. Muitos conflitos associados à falta de engajamento dos funcionários podem estar na dificuldade de a organização motivar sua equipe, o que é reforçado quando não se estabelecem relações transparentes de diálogo. 
no âmbito organizacional, para melhoria da qualidade de vida dos trabalhadores, em um ambiente cada vez mais complexo, competitivo, e com cenários conflitantes e paradoxais diante das incertezas que caracterizam a sociedade global na era digital (KUNSCH, 2010, p. 49).

Uma compreensão sofisticada das perspectivas associadas à comunicação organizacional é a de Rudimar Baldissera (2009b), que parte do paradigma da complexidade de Edgar Morin para explicar como a comunicação organizacional insere-se no processo de disputa de sentidos das relações.

Isso vem evidenciar a necessidade de a organização, pelo prisma da complexidade, qualificar os processos de comunicação, para: escutar a alteridade, reconhecendo-a como valor; criar e/ou potencializar os espaços de fala/interação, manifestação livre; dar fluxo amplo e verdadeiro à comunicação; refletir sobre a própria identidade e realizar a autocrítica; possibilitar e estimular a participação da diversidade e dialogar, particularmente, com as manifestações de crítica; compreender os comportamentos como informações que precisam ser interpretadas simbolicamente; e interpretar as demais informações para retroalimentar o sistema organizacional, entre outros aspectos (BALDISSERA, 2009b, p. 163).

A compreensão da comunicação organizacional a partir da complexidade permite que uma perspectiva ainda mais diversa seja trabalhada, com a necessidade de uma atuação profissional atenta aos detalhes e constante capacidade de criação de condições para a humanização dos relacionamentos.

Ao destacar e priorizar a dimensão humana, quis ressaltar que as organizações, os gestores e os responsáveis pela comunicação não podem ficar presos apenas àquela visão pragmática e instrumental da comunicação. É preciso pensar nas pessoas com as quais lidamos, no dia a dia, nos ambientes interno e externo. Não é possível desconsiderar a comunicação humana e as múltiplas perspectivas que permeiam o ato comunicativo no interior das organizações. Acredito que se trata de uma exigência dos novos tempos. A questão da subjetividade dos interlocutores sociais no ambiente organizacional precisa ser levada em conta. A produção comunicativa não deve ficar restrita à questão da técnica e das mídias. Uma meta constante deve ser a busca de uma maior coerência entre o discurso institucional e a prática cotidiana.

Redimensionar a visão da comunicação estratégica conservadora, vendo-a de uma forma mais holística, capaz de interpretar hermeneuticamente o mundo contemporâneo, foi também um dos propósitos, assim como incorporar a dimensão cultural como algo essencial nos processos comunicativos e nas inter-relações entre as pessoas (KUNSCH, 2016, p. 56). 
Nesse sentido, os canais de comunicação organizacionais podem ser utilizados de modo para favorecer a troca de informações e experiências, mas, ainda assim, a relação interpessoal é a mais qualificada para aproximar as pessoas e criar espaço para o estabelecimento de relacionamentos mais produtivos e humanos.

\subsection{Vertente estratégica}

No momento histórico mais recente, na década de 1960, por exemplo, o planejamento esteve muito centralizado na alta administração. A década de 1980 já apresentou o uso do planejamento com outros instrumentos. A evolução gradativa possibilitou que a Comunicação se tornasse parte das tomadas de decisões, ligada também à gestão de relacionamentos e trabalhada como um processo planejado, integrado e monitorado.

Em momentos de mudanças recentes, com a revolução tecnológica nos meios de comunicação, com impacto na alteração nas formas de relacionamento entre as pessoas, a Comunicação tem assumido uma importância mais estratégica. A necessidade de pensar e administrar a comunicação organizacional com todos os públicos e a opinião pública faz parte do planejamento estratégico, direcionado para a excelência e eficácia da comunicação nas organizações. No âmbito público, no privado e no terceiro setor, os objetivos finais são diferentes, no entanto o planejamento e as ferramentas de comunicação são essenciais para direcionar cada organização para as suas finalidades.

Agora, para observar a estratégia, em seu conceito, é importante resgatar os estudos de Bueno (2009, p. 55), segundo quem estratégia é "a forma (arte?) de definir e aplicar recursos com o intuito de atingir objetivos previamente estabelecidos".

Pode-se perceber que, ressalvadas honrosas exceções, a comunicação empresarial brasileira não atingiu ainda esse patamar. 0 planejamento em comunicação raramente é respaldado em cenários previamente desenhados; frequentemente vislumbra a organização individualmente, sem considerar a presença dos concorrentes; e apenas recentemente busca desenvolver metodologias que permitem avaliar, de modo consistente, os resultados de suas atividades (BUENO, 2009, p. 376). 
Ainda assim, há razões para acreditar que essa situação deverá ser revertida nos próximos anos, não apenas porque está em curso um processo crescente e acelerado de capacitação dos gestores em Comunicação Empresarial, mas, em especial, porque, em um mercado competitivo e globalizado, não há mesmo espaço para improvisação (Bueno, 2009, p. 64).

Esse posicionamento mais estratégico também é observado por Torquato (2011), segundo quem, a partir da década de 1990, a sociedade passou a estar mais aparelhada e as organizações se fortaleceram, configurando um contexto mais propício para o desenvolvimento de uma comunicação mais eficiente e sofisticada.

O posicionamento mais elevado do profissional caracterizou a década de 90. Na verdade, ele tem sido um eficaz intérprete dos efeitos da globalização, principalmente no que se refere ao foco do discurso e à estratégia para conferir nitidez à identidade e à imagem organizacional. O comunicador passou a ser um leitor agudo da necessidade de a empresa interagir estrategicamente com o meio ambiente e competir em um mercado aberto a novos conceitos e demandas (TORQUATO, 2011, p. 8).

Reconfigurar a comunicação organizacional as partir do seu potencial transformador na contemporaneidade é um novo desafio para pesquisadores e gestores, com maior conscientização dos atores envolvidos, como governos, iniciativa privada e sociedade civil. Nesse sentido, esse argumento reforça a necessidade de um trabalho integrado alinhado com a nova conjuntura em que a comunicação para a ser estratégica, agregando valor às organizações e contribuindo para a divulgação das iniciativas de sustentabilidade das organizações. 


\section{Capítulo 2. Sustentabilidade}

A discussão da sustentabilidade encontra-se presente em todos os setores da sociedade e apresenta-se como uma tendência contemporânea. Para fins desta tese, optou-se por discutir a princípio duas premissas. A primeira diz respeito à pluralidade de conceitos existentes, uma vez que as discussões sobre o tema são crescentes e têm ocorrido de forma ampla.

A segunda premissa é a das diferentes interfaces da sustentabilidade, sendo que a contextualização que será apresentada a seguir revela que a sustentabilidade carrega, historicamente, uma associação com diferentes áreas, como, por exemplo, agricultura, geografia, sociologia, engenharia, arquitetura, biologia, administração, entre tantas outras, e, também, com a comunicação. Este recorte é necessário para compreender a relação sistêmica que há quando a proposta é a de pensar na convergência desta pesquisa.

A compreensão deste conceito passa pela pluralidade conceitual que engloba propostas integradas e, por outro lado, fundamentos associados à lógica financeira. A multiplicidade de definições muitas vezes se apresenta de forma complementar ou contrastante. A proposta é encontrar pontos de convergência entre os pesquisadores da área e resgatar pesquisas e práticas mais evoluídas no desenvolvimento da comunicação para a sustentabilidade.

Outra característica é que a sustentabilidade estabelece interfaces com diversas áreas, como, por exemplo, agricultura, engenharia, arquitetura, biologia, administração, entre outras tantas e, também, com a comunicação. Uma das definições mais aceitas é proveniente do Relatório Brundtland, de 1987: "Desenvolvimento sustentável é aquele que atende as necessidades das gerações atuais sem comprometer a capacidade das gerações futuras de atenderem às suas necessidades e aspirações". Sustentabilidade e desenvolvimento sustentável são conceitos próximos, o que aponta a necessidade de abordar ambos.

Para esta pesquisa, a proposta é resgatar os autores que têm se destacado em termos de formulação conceitual, para que os significados mais adequados e relevantes sejam vistos como referência na área.

John Elkington é autor de uma das definições mais conhecidas. Com foco maior em organizações, publicou 16 livros e foi um dos primeiros a debater a responsabilidade social e ambiental em grandes organizações. 
Outro autor importante é Ignacy Sachs, que acredita em uma combinação de crescimento econômico, aumento igualitário do bem-estar social e preservação ambiental. Sachs pesquisa a sustentabilidade há mais de trinta anos, e sua visão extrapola as definições comuns do conceito ao propor uma definição fundamentada na convergência entre economia, ecologia, antropologia cultural e ciência política.

É essencial indicar também a contribuição de Enrique Leff, ex-coordenador da Rede de Formação Ambiental para a América Latina e Caribe do Programa da ONU para o Meio Ambiente, que faz uma forte crítica ao atual sistema socioeconômico, responsável pelos males da humanidade, devido ao paradigma de consumo.

Nesta temática, um autor brasileiro bastante citado é Fernando Almeida, expresidente do Conselho Empresarial Brasileiro para o Desenvolvimento Sustentável, para quem a sobrevivência da sociedade depende de uma mudança do modelo de desenvolvimento. Em termos de soluções, o referido autor defende que a formulação de políticas deve envolver os três atores principais da sociedade (governo, empresas e sociedade civil). Nas organizações públicas, privadas ou do terceiro setor, observase um aumento da cobrança da sociedade por uma atuação mais responsável. Considerando a sustentabilidade como uma tendência, há uma ampla possibilidade para a incorporação de práticas organizacionais mais justas.

Uma visão mais holística é apresentada por Leonardo Boff (2012), para quem a definição do Relatório Brundtland é correta, porém limitada, visto que considera apenas o contexto do homem e não aborda as necessidades dos demais seres.

Deste modo existem atualmente três pontos de convergência entre a comunicação e a sustentabilidade: (1) a comunicação da sustentabilidade, (2) a sustentabilidade da comunicação, e (3) a comunicação para a sustentabilidade instância mais complexa e transformadora, e tema desta pesquisa.

\subsection{Histórico}

Do ponto de vista do histórico da sustentabilidade, é oportuno dizer que, nas décadas de 1960 e 1970, insatisfações ligadas às questões ambientais se tornaram mais evidentes. Trata-se de um período repleto de contradições e permeado pela efervescência social de contestação das instituições estabelecidas para a busca de mais liberdade. As causas ambientais eram muito debatidas em determinados grupos, mas tratava-se de uma vertente mais específica em um momento em que causas 
sociais, trabalhistas e econômicas também eram consideradas relevantes e urgentes. No entanto, Leonardo Boff revela que o conceito possui uma história de mais de 400 anos, que poucos conhecem.

Foi na Alemanha, em 1560, na Província da Saxônia, que irrompeu, pela primeira vez, a preocupação pelo uso racional das florestas, de forma que elas pudessem se regenerar e se manter permanentemente. Nesse contexto surgiu a palavra alemã Nachhaltigkeit, que significa "sustentabilidade" (BOFF, 2013, p. 32).

Segundo o autor, esse conceito se manteve ativo na Silvicultura (ciência dedicada ao estudo dos métodos naturais e artificiais de regenerar e melhorar os povoamentos florestais) até a década de 1970, quando o tema passou a ser mais amplamente debatido. Em 1972 foi realizado um evento que é considerado um marco deste histórico, ao contribuir para a expansão da ideia de desenvolvimento sustentável pelo mundo. Trata-se da "Conferência da ONU sobre Meio Ambiente Humano", realizada em Estocolmo, na Suécia.

As discussões que começaram naquela época seguiram pela década de 1980, quando retomaram os ideais de proteção à natureza, quando o embate da Guerra Fria entrava em declínio. Nesse período, muitas expressões eram utilizadas na tentativa de definir a busca por mais equilíbrio com a natureza e condições sociais mais justas. Assim foi sendo reforçado o termo sustentabilidade, retomado por Lester Brown, fundador do Earth Policy Institute, e muitos outros termos continuaram a ser usados, e ainda hoje são, como desenvolvimento sustentável, por exemplo.

No percurso histórico, mais um importante marco ocorreu, em 1987, com a publicação do Relatório "Nosso Futuro Comum", conhecido como Relatório Brundtland, pela Comissão Mundial para Meio Ambiente e Desenvolvimento. O documento sistematizou a essência do que muitos acreditavam, a de um desenvolvimento "capaz de permitir a satisfação das necessidades da geração presente sem comprometer a satisfação das necessidades e a sobrevivência das gerações futuras". Presidida por Gro Brundtland, então primeira-ministra da Noruega, a Comissão Brundtland, tinha como objetivo estudar a relação entre 0 desenvolvimento econômico e a conservação do meio ambiente.

A partir de então, a discussão começou a adquirir contornos mais nítidos e pensadores passaram a assumir esta nova e promissora área de estudo. Foi em 
decorrência desse movimento que foi realizada a Conferência das Nações Unidas sobre Meio Ambiente e Desenvolvimento (Eco 92), que culminou com a elaboração de documentos importantes, como a Declaração do Rio de Janeiro.

Desse momento em diante, a sustentabilidade e seus termos correlatos foram sendo apurados e Organizações Não Governamentais (ONGs) passaram a ser criadas para promover um modelo de desenvolvimento mais equilibrado. Em 1995 foi fundado o Grupo de Institutos, Fundações e Empresas (Gife), reunindo aqueles que fazem investimento social privado. E, em 1997, foi assinado o Protocolo de Kyoto, com o estabelecimento de metas de redução de gases de efeito estufa.

$\mathrm{Na}$ virada do milênio, no ano de 2000, foi realizada a Cúpula do Milênio da ONU, em Nova York, tendo como resultado a Declaração do Milênio, definindo oito objetivos a serem atingidos pelos 191 estados-membros da ONU (Guia CEBDS, 2010, p. 19). A partir de então, muitos eventos com apelos sustentáveis, ambientais e/ou sociais foram realizados pelo mundo, como é o caso da Rio+20 e a 21 $1^{\text {a }}$ Conferência do Clima (COP 21) realizada em dezembro de 2015 em Paris.

Como já adiantado, a conceituação de sustentabilidade é diversa e ainda não há consenso, mas diferentes definições para vários movimentos que interagem constantemente. A convergência desse movimento com as organizações também faz parte da história, e será discutida a seguir.

\subsection{Principais definições}

Há uma série de conceituações associadas à sustentabilidade e assuntos correlatos. John Elkington é um dos nomes mais conhecidos em organizações que trabalham com sustentabilidade. Com origem na sociologia, Elkington hoje faz consultoria na área com a SustainAbility, fundada em 1987. Publicou 16 livros e foi um dos primeiros a debater a responsabilidade social e ambiental em grandes organizações. O autor é o criador da expressão amplamente aceita:

(...) o desenvolvimento sustentável envolve a busca simultânea da prosperidade econômica, da qualidade ambiental e da igualdade social. As empresas que buscam a sustentabilidade precisam empenhar-se não somente na direção de uma única linha de resultados, a financeira, mas sim na linha dos três pilares (ELKINGTON, 2001, p. 429). 
Elkington (2001, p. 46) tem uma visão muito associada à sustentabilidade e ao desenvolvimento sustentável praticado em empresas e defende que estas organizações passaram por etapas. Ele crê que em um primeiro momento ocorre a imposição de limites, com controle de poluição e início da regulamentação. $\mathrm{Na}$ sequência, ele indica que existe a prática de ações projetos pontuais de adequação, para que depois possam atingir uma visão mais sistêmica em busca mais qualidade.

Com essa visão processual, o autor defende que existe um desenvolvimento dos sistemas, o que amplia a capacidade de atuação das empresas, que passam a observar os ciclos de vida de produtos, as cadeias produtivas, os serviços e as funções. Isso leva a uma perspectiva mais atual, que aborda a participação da empresa em economias sustentáveis, com a revisão de padrões de produção e de consumo.

Outro autor de destaque na área é Ignacy Sachs, economista polonês, também conhecido como ecoeconomista por sua concepção de desenvolvimento como uma combinação de crescimento econômico, aumento igualitário do bem-estar social e preservação ambiental. Sachs é um dos teóricos mais densos sobre o assunto e extrapola as definições mais comuns e simples relacionadas com a sustentabilidade. Para ele, que há mais de trinta anos vem se dedicando ao tema, é necessário um debate contemporâneo para que se repense um novo paradigma de desenvolvimento, baseado na convergência entre economia, ecologia, antropologia cultural e ciência política.

O autor trabalhou na organização da Primeira Conferência de Meio Ambiente e Desenvolvimento da ONU, realizada na Suécia, em 1972, e já nesta época formulou o conceito de ecodesenvolvimento. Posteriormente, Sachs foi conselheiro da Conferência das Nações Unidas sobre Meio Ambiente e Desenvolvimento, realizada no Rio de Janeiro, em 1992, e é autor de mais de 20 livros sobre desenvolvimento e meio ambiente. Sua obra de referência foi publicada no Brasil em 2007 e intitula-se "Rumo à ecossocioeconomia: teoria e prática do desenvolvimento", na qual defende que

Para a implantação do projeto do ecodesenvolvimento são necessárias reflexões acerca do atual modelo de produção, que gasta mais energia para produzir determinados alimentos em relação à energia resultante no final do processo, e aos efeitos residuais no ambiente. Imaginação, vontade política, o [...] reaparelhamento da 
economia com tecnologias poupadoras de recursos ou a promoção de sistemas que exigem tempo e investimentos consideráveis também são requisitos (SACHS, 2007, p. 106).

O autor adota um tom crítico com relação ao atual modelo de produção, sendo a partir da necessidade de se repensar tal modelo que o autor desenvolve seus conceitos. A concepção é bastante ampla e envolve a necessidade de repensar as relações humanas para a criação de melhores condições para o desenvolvimento da justiça social.

[...] estratégias de transição precisam, simultaneamente, modular a demanda por meio de mudanças nos estilos de vida, nos padrões de consumo e nas funções produtivas, mediante a incorporação de técnicas ambientalmente adequadas e fazendo as escolhas locacionais corretas. Devem rejeitar as políticas e as concepções de gestores públicos que defendem a ideia de acumular para depois dividir, ou do efeito de percolação (SACHS, 2007, p. 189).

Dando continuidade aos pesquisadores de referência sobre a sustentabilidade, é necessário destacar a contribuição de Enrique Leff, economista mexicano, doutor em Economia do Desenvolvimento pela Sorbonne, atualmente professor de Ecologia Política e Políticas Ambientais na Pós-Graduação da Universidade Nacional Autônoma do México (Unam) e ex-coordenador da Rede de Formação Ambiental para a América Latina e Caribe do Programa das Nações Unidas para o Meio Ambiente (Pnuma). Sua obra de referência é "Ecologia, capital e cultura - a territorialização da racionalidade ambiental", de 2009, e em seus textos também é possível observar a crítica ao atual sistema socioeconômico como criador de males da humanidade principalmente o agravamento das desigualdades. O pesquisador defende um desenvolvimento alternativo pensado no sentido de democratização dos saberes para melhorar a utilização dos recursos naturais. O objetivo não é o de homogeneizar os modelos produtivos, mas o de sugerir uma adaptação a outro paradigma de consumo.

E, para que o novo paradigma produtivo sustentável se realize, faz-se necessária a concentração da integração dos três princípios fundantes de tal modelo, quais sejam: o princípio da diversidade cultural, o princípio da sustentabilidade ecológica e o princípio da racionalidade ambiental, os quais, juntos e articulados, proporcionarão as bases para a construção e aplicação de um novo modelo de desenvolvimento sustentável, integrador das perspectivas de conservação e desenvolvimento, partindo do resgate e da afirmação de diversos 
estilos de etnoecodesenvolvimento que possibilitem a integração da economia de autossubsistência às economias nacionais e ao mercado mundial (LEFF, 2009, p. 141).

A proposta é a de uma produtividade sustentável que considere as especificidades de cada território e esteja articulada com as realidades ecológica, tecnológica e cultural de cada local, orientada para o que ele chama de um novo projeto de civilização.

A efetivação de um modelo de desenvolvimento ecotecnológico, bem
como de uma racionalidade ambiental que o fundamente, deve fazer
parte de um projeto histórico mais amplo, conduzido pela sociedade
civil, através da conscientização, reivindicação e atuação dos
movimentos sociais, sejam de caráter ambiental, étnico, cultural,
"consumerista" ou simplesmente cívico (LEFF, 2009, p. 184).

Outra referência sobre sustentabilidade é o brasileiro Fernando Almeida, expresidente do Conselho Empresarial Brasileiro para o Desenvolvimento Sustentável (CEBDS) e autor de diversos livros sobre o tema. Na obra "Os desafios da sustentabilidade - uma ruptura urgente" (2007), ele condiciona a sobrevivência da sociedade à mudança urgente do modelo de desenvolvimento atual. Sua obra é estruturada em três partes, de modo (1) a descrever o comportamento dos sistemas naturais, (2) como fazer a ruptura estruturada, e (3) como a formação dos líderes é importante para a operação dessa mudança. Sua obra também traz situações de empresas líderes e Organizações Não Governamentais que estão neste caminho de mudança com o objetivo de demonstrar a importância do envolvimento de diferentes setores sociais.

Chama à atenção o conteúdo da segunda parte do livro em que os oito instrumentos mais importantes para a inserção da sustentabilidade no cotidiano empresarial são abordados: ISO 14000, Índice Dow Jones de Sustentabilidade (IDJS), diretrizes da OCDE, Global Compact, Global Reporting Initiative (GRI), norma AA1000 com comitês de garantia independentes, norma AS 8000 da Social Accountability International (SAI) e a lei americana Sarbannes-Oxley.

A terceira parte da obra questiona a exequibilidade do desenvolvimento sustentável. Para Almeida (2007), isso ocorre devido ao seu pouco tempo de existência. Trata-se de uma leitura recomendável aos profissionais que têm diante de 
si a sustentabilidade como um novo tema e um desafio de investir em maior qualidade de vida, tanto para o ambiente quanto para as pessoas.

As megamudanças nos ecossistemas que são a base da nossa
sobrevivência estão induzindo crescentes alterações no
comportamento de diversos atores no setor público, no setor privado
e na sociedade civil. Aumentaram a regulamentação por parte dos
governos e a pressão exercida sobre as empresas pelos grupos de
interesse, sejam eles acionistas, organizações não-governamentais
ou clientes. A tendência é que esse quadro se torne cada vez mais
complexo, à medida que os diversos grupos de interesse vão aferindo
a gravidade da situação (ALMEIDA, 2007, p. 52).

Do ponto de vista da composição de soluções viáveis, tal ponto de vista encontra aderência com o que o autor classifica como "a responsabilidade no mundo tripolar". Segundo sua visão, a formulação de políticas deve envolver os três atores principais da sociedade: governo, empresas e sociedade civil. Esta é a conclusão da Cúpula de Johanesburgo, a Reunião Mundial sobre o Desenvolvimento Sustentável (a Rio+10), promovida pela ONU na África do Sul, em 2002. O principal legado do encontro, em Johanesburgo, foi justamente a recomendação das chamadas parcerias tipo II, as parcerias público-privadas (PPPs) (Almeida, 2007, p. 54).

O brasileiro Leonardo Boff tem estudado o tema há décadas. A visão do autor de "Sustentabilidade: O que é - O que não é" (2013) tem como base uma visão sistêmica fundada em uma nova cosmologia, nas ciências da vida e da Terra, um conceito integrador, que se aplica ao universo, à sociedade, à educação e à vida de todos os seres.

Sustentabilidade é toda ação destinada a manter as condições energéticas, informacionais, físico-químicas que sustentam todos os seres, especialmente a Terra viva, a comunidade de vida e a vida humana, visando a sua continuidade e ainda a atender as necessidades da geração presente e das futuras de tal forma que o capital natural seja mantido e enriquecido em sua capacidade de regeneração, reprodução, e coevolução (BOFF, 2013, p. 107).

Conforme destacado anteriormente, a sustentabilidade tem assumido a condição de uma tendência irreversível que estabelece convergência com diferentes áreas, inclusive com a comunicação. O desenvolvimento da comunicação para a sustentabilidade requer uma sintonia mais aguçada, porém é a mais sofisticada na 
medida que tem a oportunidade de oferecer às gerações futuras melhores condições de vida. Isso faz com que, do ponto de vista organizacional, as iniciativas dessa área tendem a ser mais desenvolvidas quando são sistematizadas de modo planejado.

\subsection{Sustentabilidade nas organizações}

Diante da transversalidade do conceito de sustentabilidade, e diante dos questionamentos ao atual modelo de desenvolvimento socioeconômico, a sustentabilidade é um conceito contemporâneo e um desafio às organizações. Ela alcança um espaço de destaque no século XXI, estabelecendo interfaces com diferentes setores da sociedade, inclusive com as organizações. Sejam estas públicas, privadas ou mistas, têm sido cada vez mais cobradas pela sociedade por uma atuação mais responsável, social ou ambientalmente. Rever modelos de produção é relevante diante da importância que as organizações desempenham e diante dos impactos que causam em geral sem maiores comprometimentos.

É por esta razão que há, no momento, iniciativas direcionadas à demonstração de ações para a prestação de contas à sociedade de ações e projetos que visam à sustentabilidade organizacional. No âmbito empresarial, de modo ainda inicial, a sustentabilidade passa a fazer parte do cotidiano das empresas, tornando-se parte do planejamento e soma-se às ações de responsabilidade corporativa. Este movimento ocorre por vários fatores, sendo o primeiro deles a cobrança por parte da sociedade, que tende a exigir maior participação das organizações em atitudes mais responsáveis.

\footnotetext{
Pesquisa realizada pelo Instituto Globescan e pela Market Analysis Brasil em 2005 revelou que o consumidor deseja que as empresas se envolvam diretamente na solução dos problemas da sociedade. De 2002 a 2005, o número de respondentes que "concordam totalmente ou em parte" com essa questão subiu de $65 \%$ para $88 \%$, e o percentual dos que discordam totalmente ou em parte caiu de $33 \%$ para 11\% (Guia CEBDS, 2010, p. 28).
}

Corroborando as ideias apresentadas pelo Guia do CEBDS, Fernando Almeida refere-se às empresas, ao abordar esta associação, não necessariamente a todas as organizações. 
A sociedade vem demandando mais das empresas uma atitude de maior responsabilidade e transparência. Pesquisas de opinião no Brasil e no mundo têm atribuído à classe empresarial baixas taxas de credibilidade em comparação com outros atores sociais (ALMEIDA, 2007, p. 93).

O segundo fator diz respeito ao momento, quando este é favorável à mudança. Considerando que a sustentabilidade é uma tendência, vive-se atualmente um período de ampla possibilidade para que a incorporação de práticas mais justas seja feita o quanto antes.

A constatação de que as organizações têm um papel a cumprir diante de toda esta realidade socioeconômica e política em que vivemos hoje na sociedade global está induzindo a novos comportamentos e novas atitudes no mercado empresarial. As organizações começam a ver a sustentabilidade como uma forma de se buscar um desenvolvimento mais integral e equilibrado entre o progresso econômico e o social e procuram implantar novas diretrizes nas suas formas de gestão, de produção e de administração de recursos (KUNSCH, 2010, p. 64).

É importante ainda destacar que investir em sustentabilidade pode ocorrer pela oportunidade que as organizações identificam para agregar valor à suas marcas e à sua identidade, estabelecendo normas mais voltadas ao sustentável e demonstrando publicamente que o fazem.

\subsection{Sustentabilidade como tendência}

Entende-se que tendência é um movimento com determinado início histórico que carrega valores, aspirações e expectativas articuladas com poder de influência sob outros grupos. Pelo histórico que a sustentabilidade apresenta e pela consonância em relação às expectativas dos grupos sociais mais engajados, acredita-se que esta é uma das tendências contemporâneas.

Isso ocorre, pois, embora existam inúmeras definições de sustentabilidade, sua proposta tende a reunir esperanças e aspirações daqueles que desejam um mundo mais justo e ações que causem menos impacto à natureza. Há vertentes que ainda são mais complexas e consideram a sustentabilidade como parte de uma visão que atue pela cultura, pelo território e pela educação, entre outros. Considerando a visão de Elkington (2001), o desenvolvimento econômico aliado ao ambiental e ao social 
resume o que incontáveis grupos sociais desejam quando protestam por causas diversas que, na essência, estão contempladas na sustentabilidade.

Quem referência tal perspectiva, do ponto de vista da sustentabilidade como tendência, inclusive no âmbito das organizações, é Rodolfo Guttilla, ex-diretor de assuntos corporativos da Natura. Referindo-se às exigências da sociedade à demanda por certificações, ele diz que

Esses movimentos indicam que está em curso uma verdadeira
revolução no campo da gestão empresarial. Com o acirramento da
competição e a busca de novos mercados pela indústria brasileira, que
inicia uma promissora agenda de internacionalização, novos
patamares de qualidade são perseguidos, em especial no campo dos
relacionamentos com as chamadas partes interessadas: acionistas,
consumidores, trabalhadores, fornecedores, governo e sociedade,
entre outras (GUTILLA, 2005, p. 140).

A crise financeira de 2008 , os desastres naturais recentes e a explicitação de imensas faixas de pobreza extrema, tão graves quanto inegáveis, fornecem recursos para uma mudança e uma atuação mais responsável por parte de todas as organizações. Isso ocorre também uma vez que o paradigma de desenvolvimento atual é diferente de todos os anteriores, quando se considera, por exemplo, o modelo industrial. A preservação e a responsabilidade socioeconômica das organizações são temas muito recentes do ponto de vista histórico, mas certamente vem ganhando espaço de modo crescente e gradual. 


\section{Capítulo 3. Terceiro setor}

O terceiro setor está associado com entidades sem fins lucrativos que atuam na execução de atividades de utilidade pública. Estas organizações têm gerenciamento próprio e o principal objetivo de promover a melhoria na qualidade de vida das pessoas, em várias áreas, caso das Organizações Não Governamentais (ONGs) e das Organizações da Sociedade Civil de Interesse Público (OSCIPs). Do ponto de vista da manutenção financeira, o terceiro setor costuma ser mantido com doações de empresas e pessoas físicas e com repasse de verbas públicas.

As discussões recentes sobre o tema indicam pluralidade conceitual que exige uma compreensão mais precisa sobre as definições. A proposta mais aceita no momento discute o terceiro setor como inserido nas esferas pública, privada e a da sociedade civil, responsável pela integração de indivíduos e organizações voltados para a cidadania. "Essa multiplicidade de denominações apenas demonstra a falta de precisão conceitual, o que, por sua vez, revela a dificuldade de enquadrar toda a diversidade de organizações em parâmetros comuns" (Coelho, 2000).

De acordo com Falconer e Fischer (1998), essa dificuldade de conceituação não impediu que organizações fossem criadas. Os autores entendem que o terceiro setor, historicamente, ampliou sua atuação sem que o conceito conseguisse explicar a diversidade da sua abrangência. O que se percebe é que o terceiro setor é considerado uma união dos objetivos do primeiro setor com a metodologia do segundo setor, resultando em organizações voltadas para benefícios coletivos sob uma administração privada que não visa fins lucrativos. Os benefícios coletivos não são, necessariamente, públicos, mas já há organizações do terceiro setor criadas para promover benefícios coletivos privados.

A mensuração deste alcance é tarefa difícil, visto que muitas vezes esses grupos podem ter um significativo destaque. A abordagem mais aceita diferencia as organizações do terceiro setor em estrutural e operacional, desenvolvida por Salamon e Anheier (1997), indicando que as organizações do terceiro setor costumam apresentar cinco características: estruturadas, privadas, não distribuidoras de lucros, autônomas e voluntárias. Do ponto de vista dos desafios do terceiro setor, um deles é a dificuldade de observação da sua própria condição. A definição das atribuições representa o início da compreensão das transformações pelas quais passam as sociedades globais. 
O terceiro setor carece de mais pesquisas sobre sua atuação no cenário brasileiro. Cientificamente, é necessário contribuir com a construção de um conceito mais sólido, reduzindo diferenças e interpretações equivocadas sobre a área por parte da sociedade, do mercado e dos governos.

\subsection{Conceituação}

Encontrar uma conceituação para o terceiro setor que reúna as diversas organizações que o compõem, baseada em pontos convergentes, é essencial para a determinação dos limites entre terceiro setor, iniciativa privada e Estado.

O terceiro setor está associado com entidades sem fins lucrativos que atuam na execução de atividades de utilidade pública, apresentam gerenciamento próprio e buscam promover a melhoria na qualidade da vida das pessoas, em várias áreas. São exemplos as Organizações Não Governamentais (ONGs) e as Organizações da Sociedade Civil de Interesse Público (OSCIPs). Do ponto de vista da manutenção financeira, o terceiro setor costuma ser mantido com doações de empresas e pessoas físicas e com repasse de verbas públicas.

Para Rosa Maria Fischer (2002), o terceiro setor é formado por organizações sociais direcionadas ao atendimento de interesses públicos, com características próprias e independência para determinar suas ações.

Terceiro setor é a denominação adotada para o espaço composto por organizações privadas, sem fins lucrativos, cuja atuação é dirigida a finalidades coletivas ou públicas. Sua presença no cenário brasileiro é ampla e diversificada, constituída por organizações não governamentais, fundações de direito privado, entidades religiosas, associações culturais, educacionais, as quais desempenham papéis que não diferem significativamente do padrão conhecido de atuação de organizações análogas em países desenvolvidos. Essas organizações variam de tamanho, grau de formalização, volume de recursos, objetivo institucional e forma de atuação (FISCHER, 2002, p. 45).

Simultaneamente ao surgimento de certas organizações da sociedade civil, caracterizadas pela promoção de ações de natureza privada com fins públicos, diferentes denominações passaram a ser dadas às mesmas. Entre os exemplos, estão organizações voluntárias, Organizações Não Governamentais (ONGs), organizações sem fins lucrativos, setor independente e terceiro setor. 
As discussões recentes sobre o tema indicam uma pluralidade conceitual que exige uma compreensão mais precisa sobre as definições. A proposta mais aceita, no momento, discute o terceiro setor como inserido nas esferas pública, privada e da sociedade civil, responsável pela integração de indivíduos e organizações voltados para a cidadania.

Essa multiplicidade de denominações apenas demonstra a falta de precisão conceitual, o que, por sua vez, revela a dificuldade de enquadrar toda a diversidade de organizações em parâmetros comuns. Os contornos deste espaço muitas vezes não estão bem definidos sequer para os diversos agentes que o compõem (COELHO, 2000, p. 42).

Os estudos, de acordo com Falconer e Fischer (1998), indicam que essa dificuldade de conceituação não impediu que organizações fossem criadas. As pesquisas mais recentes revelam que, historicamente, o terceiro setor tem ampliado sua atuação, porém sem que o conceito conseguisse explicar a diversidade da sua abrangência. Detalhando mais, percebe-se que o terceiro setor é considerado uma união dos objetivos do primeiro setor com a metodologia do segundo setor, resultando em organizações voltadas para benefícios coletivos sob uma administração privada que não visa fins lucrativos. Os benefícios coletivos não são, necessariamente, públicos, já que muitas organizações do terceiro setor têm como objetivo promover benefícios coletivos privados.

A mensuração deste alcance é complexa, visto que, muitas vezes, estes grupos podem ter significativo destaque. A tentativa mais utilizada diferencia as organizações do terceiro setor em estrutural e operacional e foi desenvolvida por Salamon e Anheier (1997), a qual indica que as organizações do terceiro setor costumam apresentar cinco características: estruturadas, privadas, não distribuidoras de lucros, autônomas e voluntárias. Do ponto de vista dos desafios do terceiro setor, um deles é a dificuldade de observação da sua própria condição. A definição das atribuições representa o início da compreensão das transformações pelas quais passam as sociedades globais.

Entender o que são, de onde vem, o que querem, como cresceram e se multiplicaram, como atuam as organizações de cidadãos implica retomar os fios de uma história que combina valores e práticas 
ancestrais com fenômenos contemporâneos e, em boa medida, anunciadores de profundas mudanças no perfil das sociedades e da ordem internacional (OLIVEIRA, 2001).

Fernandes (1995) atesta esta indefinição: "A própria ideia de um terceiro setor está longe de ser clara na maioria dos contextos. Torná-la clara é tanto uma tarefa intelectual quanto prática, já que não fará sentido a menos que um número expressivo daqueles envolvidos venha a considerá-la uma ideia significativa" (Fernandes, 1995, online).

O terceiro setor merece mais pesquisas que sejam responsáveis por definições precisas sobre a atuação no cenário brasileiro. As organizações do terceiro setor no Brasil são inúmeras e voltadas para múltiplos objetivos. Do ponto de vista científico, faz-se necessário avançar em pesquisas sobre tais organizações e contribuir com a construção de um conceito mais consistente. A contribuição acadêmica pode tornar mais legítimo o campo de estudos e reduzir as diferenças e interpretações equivocadas sobre a área por parte da sociedade, do mercado e dos governos.

\subsection{Histórico}

Compreender as origens históricas do que é considerado, atualmente, o terceiro setor, é essencial para o desenvolvimento de uma pesquisa científica direcionada para a área. As organizações sociais consideradas como do terceiro setor não foram criadas recentemente. A origem remonta aos séculos XVI e XVII, quando surgiram movimentos da sociedade civil, inicialmente com caráter religioso ou político, na Europa e nas Américas do Norte e do Sul. Nessa época, as organizações estiveram associadas com ações de grupos católicos e protestantes e também ligadas aos sistemas de governo vigentes.

Essa configuração foi alterada nos séculos seguintes. A partir de 1800 surgiam as primeiras associações patronais e os sindicatos de trabalhadores, alterando e diversificando a relação da sociedade com o setor privado e o Estado. Nesse período os vínculos entre Igreja e Estado eram diretos, porém com métodos de atuação que já revelavam a diferenças que se acentuaram nos próximos séculos.

No Brasil, a expressão organizações da sociedade civil é bastante utilizada e decorre de um conceito originado no século XVIII que agora vem sendo utilizado como 
um conjunto de instituições distintas do Estado com foco no desenvolvimento de direitos coletivos.

Assim, do ponto de vista histórico, todas as mudanças ocorridas na estrutura do Estado, nos séculos XIX e XX, influenciaram diretamente a configuração das organizações sociais. No período seguinte à Primeira Guerra Mundial, por exemplo, em que muitos países se enfraqueceram e enfrentaram dificuldades de natureza social, política e econômica, novas tentativas de criação de organizações ocorreram, fortalecendo o desenvolvimento de iniciativas que viriam a se configurar como do terceiro setor.

Ainda em âmbito mundial, a partir da Segunda Guerra Mundial, mudanças profundas em todas as instâncias culminariam no fenômeno da globalização, que, em muitos casos, acentuou a pobreza, a violência, a poluição ambiental e conflitos religiosos, étnicos, sociais e políticos. Pela primeira vez, a maioria dos países foi envolvida em problemas de ordem local, regional, nacional e global.

Na segunda metade do século XX, principalmente na América Latina, inclusive em resposta à ditadura militar, organizações da sociedade civil foram criadas com expressiva carga política e ações de desenvolvimento comunitário e atividades de assistência na saúde, no saneamento básico, economia e educação.

Nas décadas de 1960 e 1970, em decorrência da formulação de programas de cooperação internacional para o desenvolvimento, estipulados pela própria ONU, houve um crescimento de organizações europeias direcionadas a promover projetos em países em desenvolvimento.

A expressão terceiro setor é uma tradução do third sector, utilizado nos Estados Unidos juntamente com outras expressões, como "organizações sem fins lucrativos" (nonprofit organizations) ou "setor voluntário" (voluntary sector). Em outros países da Europa Continental, como Espanha, França e Alemanha, predominam as expressões "Organizações Não Governamentais" (ONGs), "caridade" e "filantropia”, uma origem associada ao sistema de representações da Organização das Nações Unidas (ONU), que assim denominava organizações internacionais que, mesmo sem representarem países, participavam de reuniões na ONU.

Atualmente, um dos principais problemas do terceiro setor é a falta de consciência sobre a sua própria condição, pois as organizações que o integram ainda não se percebem como um conjunto integrado. A obtenção dessa consciência e a 
construção de uma identidade são fundamentais para que suas ações políticas ampliem ainda mais a sua força e notoriedade, permitindo que o setor possa se consolidar mais.

\subsection{Classificação e composição}

O espaço criado pelo terceiro setor é uma extensão das ações não executadas pelo Estado e inviáveis para serem geridas pela iniciativa privada. Tem início o papel do cidadão que, agente ativo da sociedade civil, organiza grupos para envolver pessoas em trabalhos muitas vezes voluntários em substituição aos serviços oferecidos pelo Estado.

É importante explicar que benefícios coletivos que compõem a caracterização do setor não correspondem, necessariamente, a benefícios públicos. Muitas organizações do terceiro setor visam promover benefícios coletivos privados. Este é o caso de organizações de ajuda mútua que defendem interesses de um grupo restrito de pessoas, sem considerável alcance social. As organizações de caráter público, por outro lado, estão voltadas ao atendimento de interesses mais gerais da sociedade, produzindo bens ou serviços que tragam benefícios para a sociedade como um todo.

Possível que essa seja uma primeira importante divisão do setor, quando considerado como aquilo que não é público tampouco privado: não governamental e sem fins lucrativos. Aquelas organizações que atuam efetivamente em ações sociais, na busca de benefícios coletivos públicos, e que podem ser consideradas como de utilidade pública, são capazes de auxiliar o Estado no cumprimento de seus deveres, atentando para as desigualdades vigentes no país e incapacidade do Estado em desempenhar com eficiência as atividades que lhe são atribuídas.

Por outro lado, é difícil definir em que medida as organizações de benefícios mútuos ou privados não exercem uma ação relevante à sociedade, uma vez que os grupos que as compõem e a maneira como atuam podem ser de significativo destaque social. A dificuldade de conceituação do terceiro setor não impediu que as organizações do terceiro setor se proliferassem no Brasil. De acordo com Falconer e Fischer (1998), houve um aumento quantitativo e de tipos dessas organizações nas últimas décadas.

Conforme já destacado, de acordo com a visão estrutural dos autores Salamon 
e Anheier (1997), as organizações que fazem parte deste setor se diferenciam da seguinte maneira:

- Estruturadas: possuem certo nível de formalização de regras ou algum grau de organização permanente.

- Privadas: não têm nenhuma relação institucional com governos, embora possam dele receber recursos.

- Não distribuidoras de lucros: nenhum lucro gerado pode ser distribuído entre seus proprietários ou dirigentes. O que distingue essas organizações não é o fato de não possuírem "fins lucrativos", e sim o destino dado às verbas, que devem ser dirigidas à realização da missão da instituição.

- Autônomas: possuem os meios para controlar sua própria gestão, não sendo controladas por entidades externas.

- Voluntárias: envolvem um grau significativo de participação voluntária não remunerada, que pode variar entre organizações e de acordo com a natureza da atividade por ela desenvolvida.

\subsection{Situação no Brasil}

De acordo com Andrés Falconer (1999), as organizações do terceiro setor no Brasil podem ser classificadas da seguinte forma:

- Igrejas e instituições religiosas - Santas Casas, por exemplo;

- Organizações não governamentais - com foco predominante na defesa de direitos civis por meio da capacitação de pessoas, assessoria social, articulação política e disseminação de informações;

- Empreendimentos sem fins lucrativos - serviços pagos para utilização de alguns serviços, como clubes, instituições culturais, entidades educacionais e recreativas;

- Fundações empresariais - financiadas por grupos privados com foco em ações de cidadania e filantropia com foco de atuação abrangente.

No Brasil, o surgimento de organizações sem fins lucrativos é antigo, sendo a inauguração da Santa Casa de Misericórdia de Santos, em 1543, a primeira instituição do terceiro setor conhecida com registro no País.

Desde então, as organizações têm evoluído junto com a sociedade 
brasileira. Do período colonial, até meados do século $X X$, há predominância de ações de assistência social, saúde e educação realizadas, principalmente, pela Igreja Católica. Tais ações eram desenvolvidas na forma de asilos, orfanatos, Santas Casas de Misericórdia e colégios religiosos. Chamadas de "associações voluntárias", estas iniciativas promoviam ações sociais com base em valores católicos.

Já no século XX, mais precisamente em 28 de agosto de 1935, foi promulgada a Lei № 91, declarando utilidade pública as organizações sem fins lucrativos. Em 1938, foi criado o Conselho Nacional de Serviço Social (CNSS), que estabeleceu que as instituições nele inscritas pudessem passar a receber subsídios governamentais. Neste período, mesmo com esses avanços, a Igreja continuou tendo papel importante na prestação de serviços sociais e passou a receber, em alguns casos, financiamentos do Estado para as suas obras.

No período do regime militar, que reduziu direitos dos cidadãos, mas provocou uma intensa mobilização da sociedade, muitas organizações filantrópicas e assistenciais se uniram aos movimentos sociais para promoverem atendimento às pessoas mais necessitadas. Foi quando surgiram organizações sem fins lucrativos ligados à mobilização social e à contestação política.

Finalmente, a partir da década de 1980, com a redemocratização do País, a cidadania e os direitos fundamentais passaram a ser o foco das organizações sem fins lucrativos. A articulação do terceiro setor começou a se ampliar com grupos consolidados que vêm alcançando mais relevância social, especialmente em virtude da atuação ineficiente do Estado em diferentes áreas, principalmente a social. Da década de 1990 até hoje, houve uma ampliação significativa da criação de ONGs, com as mais variadas finalidades e tamanhos, atuando em diversos setores, como, por exemplo, entidades ambientalistas, grupos de apoio à organização popular e associações de defesa dos consumidores crianças e adolescentes.

Em termos estatísticos, a "Pesquisa sobre Organizações da Sociedade Civil e suas Parcerias com o Governo Federal", divulgada pela Secretaria Geral da Presidência da República no final de 2014, revelou que o Brasil tem 303 mil Organizações da Sociedade Civil (OSCs). Destas, 2\% são fundações, 8\% são 
organizações religiosas e 90\% estão constituídas como associações civis sem fins lucrativos.

Um aspecto central na caracterização do universo das OSCs, no Brasil, está relacionado com a sua distribuição territorial. Segundo os dados coletados, aproximadamente $45 \%$ delas estão sediadas na região Sudeste do país, seguidas do Sul e Nordeste (presença de mais de $20 \%$ em cada região). As Regiões Norte e Centro-Oeste não chegam a 6\% em concentração de OSCs. Em relação às Unidades da Federação, o Estado de São Paulo mantém a maior porcentagem de organizações (22,5\%), seguido por Minas Gerais $(11,1 \%)$.

Os dados ainda revelam que aproximadamente 2,1 milhões de pessoas têm vínculos de trabalho nas OSCs, embora mais de $70 \%$ dessas organizações não apresentem nenhum vínculo de trabalho formal.

\subsection{Sustentabilidade e terceiro setor}

As mudanças globais que vêm gerando uma permanente evolução no modo de pensar da população têm sido discutidas de forma mais intensa atualmente em encontros e conferências. Com isso, a construção do conceito de desenvolvimento sustentável está em evolução. O debate gerado pela responsabilidade social se intensificou, pois a atuação das empresas e o impacto de suas atividades estão afetando a qualidade de vida das pessoas, reforçando a relevância do estudo da responsabilidade social adaptado à realidade do terceiro setor. Apesar das semelhanças entre empresas e organizações da sociedade civil, é necessário considerar que são distintas na missão institucional e, por vezes, apresentam-se como antagônicas em seus objetivos, revelando a necessidade de tratar a sustentabilidade organizacional de forma específica para organizações do terceiro setor.

Os desafios das organizações do terceiro setor, especialmente as ONGs, para manterem suas operações, exigem que novas posturas sejam adotadas, principalmente em termos de ferramentas de gestão, que devem proporcionam transparência, avaliação do impacto das atividades e agilidade na captação de recursos, entre outras vantagens.

A sobrevivência das ONGs extrapola a gestão dos aspectos econômicos, pois a sua essência está na elaboração e execução de ações para a sociedade e/ou o meio 
ambiente, sendo imprescindível que conceitos de sustentabilidade sejam compreendidos e incorporados às práticas de gestão dessas organizações.

A evolução nas discussões sobre a sustentabilidade vem apresentando uma ampla variedade conceitual, mas é importante, ao menos, que as discussões considerem o equilíbrio entre as suas dimensões (ambiental, econômica, social). Como a conceituação da sustentabilidade aborda um desenvolvimento contínuo e duradouro, considerando a disponibilidade dos atuais recursos deve buscar atender aos anseios das futuras gerações, é necessário o desenvolvimento de estudos que ratifiquem a busca pela sua compreensão.

A partir desta perspectiva sustentável, existe uma dificuldade de se operacionalizar o equilíbrio entre as partes. Corroborando este pensamento, Liu (2006) afirma que a harmonia não deve ser entendida de forma isolada, mas deve-se levar em consideração o contexto sociocultural no qual se está inserido, para que haja a busca de um ponto de equilíbrio universal em conformidade entre as partes interessadas. Ignacy Sachs (2007), por exemplo, propõe atividades e economias que proporcionem tal harmonia e identifiquem articulações existentes no desenvolvimento das ações organizacionais que vêm permeando a ideia de atuação socialmente responsável para todos os tipos de organização.

Porém, até que ponto uma ONG harmoniza os conceitos básicos da sustentabilidade na melhoria de sua governança institucional? Essa problemática sugere que todas as organizações, inclusive as não governamentais, devem promover a complementaridade entre os recursos organizacionais para alcançar melhor uma estrutura gerencial que assuma características sustentáveis, argumento a partir do qual se busca compreender como a sustentabilidade está incorporada à gestão e às ações das organizações estudadas.

Nas ONGs, a sustentabilidade é evidenciada pela conformidade de aspectos que facilitam o desenvolvimento dessas organizações diante da dinâmica do mercado. Embora a responsabilidade social possa ser interpretada como uma contribuição social voluntária das organizações, é importante reconhecer que a operacionalização ocorre necessariamente pela gestão efetiva de suas atividades.

A sustentabilidade surge como aspecto estratégico ao buscar o equilíbrio nas questões atuais para que as próximas gerações possam usufruir dos mesmos recursos. O alcance da sustentabilidade nas organizações está associado a quatro 
pilares básicos, segundo Alves Junior (2008): (a) tomar decisões sobre investimentos para a preservação ambiental; (b) envolver-se com o desenvolvimento da comunidade onde atua; (c) realizar o planejamento estratégico de suas atividades, papel esse de seus gestores; e (d) ampliar e diversificar as fontes de recursos na implantação de suas estratégias.

Como algumas das características indicadas estão alinhadas com a identidade e a missão de algumas organizações, isso facilita a busca pela sustentabilidade. Então, questões pontuais podem ser destacadas, como aspectos que favorecem as organizações rumo a essa nova perspectiva, como a qualificação do trabalho na organização, o aperfeiçoamento da gestão, e a criação de uma cultura estratégica de monitoramento e avaliação das atividades. Para Débora Nacif de Carvalho (2006, p. 30), "a sustentabilidade funciona como um plano de fundo, direcionando o estudo da gestão das organizações do terceiro setor para aspectos internos e aspectos do relacionamento das entidades com seu ambiente".

Além disso, em se tratando de uma pesquisa de comunicação organizacional, é essencial destacar que as decisões e os resultados das atividades das organizações devam envolver, alcançar e transformar a realidade dos principais públicos envolvidos. Assim, com o objetivo de melhorar o desempenho das organizações em relação aos objetivos estabelecidos, é necessário discutir como a gestão é praticada em organizações do terceiro setor, tema debatido a seguir.

\subsection{Aspectos administrativos e jurídicos}

Assim como as organizações criadas com finalidade lucrativa, as Organizações Não Governamentais precisam desenvolver práticas de gestão direcionadas para o alcance de seus objetivos. Este é um desafio para o fortalecimento institucional das organizações do terceiro setor e um aspecto condicionante para a continuidade no desenvolvimento de suas atividades organizacionais.

Para dar continuidade às suas atividades com soluções efetivas, as organizações precisam aperfeiçoar mecanismos de gestão para otimizar recursos e ampliar o impacto das suas ações. Para a busca pela sustentabilidade em organizações, é necessária a análise sobre dois enfoques: o gerencial e o sistêmico. O primeiro enfoque envolve o papel operacional na organização da sociedade civil. Já o segundo tende a dar relevância às questões relacionadas com processos 
duradouros de mudança social. Essa análise deve ser realizada para que os dois enfoques direcionem as ações de gestão e comunicação para a sustentabilidade.

As organizações da sociedade civil, mesmo que caracterizadas por um campo de ação composto por forças heterogêneas, têm em comum a defesa por interesses relativos à cidadania e aos interesses e valores públicos. O exercício das ações de defesa desses interesses deve ocorrer, de forma organizada, para formar organizações juridicamente representadas, do associativismo local, passando pelas articulações interorganizacionais até a mobilização na esfera pública nos âmbitos locais, regionais, nacionais e internacionais. As variações nas formas pelas quais a sociedade civil se organiza reflete a origem que os vários tipos de organizações podem assumir.

Associações, cooperativas, Organizações Não Governamentais, ou Organizações da Sociedade Civil de Interesse Público, mesmo com formações jurídicas diferenciadas, apresentam em sua origem e missão as dimensões caracterizadas como definidoras de um movimento social: uma identidade, um adversário e um projeto (Scherer-Warren, 2005). No Brasil, especialmente na década de 1990, como resultado do crescimento do setor econômico informal, o Estado tem se ausentado da esfera social, ampliando o espaço das ações dessas organizações da sociedade civil para a defesa de direitos dos cidadãos. Diante da perspectiva de uma política de desenvolvimento coletivo, essas organizações podem surgir com estratégias e mecanismos criados para ampliar, qualificar e replicar boas práticas para o desenvolvimento sustentável do país. Assim, são instituições essenciais para atuar nas reduções das desigualdades sociais, na medida em que envolvem os demais setores em busca de desenvolver suas áreas de atuação.

Com a formalização crescente de atividades, o terceiro setor é composto por vários tipos de organizações, dentre os quais: associações comunitárias, organizações filantrópicas, beneficentes ou de caridade, Organização Não Governamental, fundação privada, organizações religiosas, sindicato, cooperativa (Alves Junior, 2008). Em meio a esses tipos de organizações, destacam-se as ONGs, que se caracterizam, segundo Tenório (2007), por sua autonomia: "sem vínculo com o governo, voltada para o atendimento das necessidades de organizações de base popular complementando a ação do Estado" (Tenório, 2007, p. 11). Casimiro e Freitas (2008, p. 3) defendem que essas organizações "são conhecidas historicamente, pela 
trajetória de atuação em defesa da democracia, dos direitos humanos, da cidadania, da assistência social e da participação popular local, enfrentando situações próprias de cada região".

Apesar de possuir finalidade diferente de organizações lucrativas, as ONGs possuem estrutura organizacional semelhante a uma empresa e precisam de instrumentos de gestão institucional para atingir os objetivos pretendidos. Essa atividade gerencial é corroborada diante da busca da sua própria sustentabilidade.

Nos últimos anos houve também uma transformação importante no papel do Estado brasileiro diante da sociedade. Entre as transformações importantes, podemos indicar a promulgação de uma legislação regulatória do terceiro setor, como as Leis Federais 9.608/98 e 9.790/99. No entanto, se comparado com outros países, o Brasil ainda precisa de uma legislação mais moderna, que incentive a participação dos diferentes atores sociais envolvidos na busca de uma sociedade mais justa, livre e solidária, que almeje a redução das desigualdades sociais.

Antônio Carlos Carneiro de Albuquerque (2006) indica as formas jurídicas e os títulos para organizações do terceiro setor:

- Associação

- Fundação

- Organizações religiosas

- Organização de utilidade pública federal

- Organização da Sociedade Civil de Interesse Público

- Registro no Conselho Nacional de Assistência Social

- Certificado de Entidade Beneficente de Assistência Social

A Associação é uma pessoa jurídica criada com a integração de ideias e esforços para um propósito. De acordo com o Código Civil Brasileiro, as organizações do terceiro setor, constituídas como associações, são entidades sem finalidade econômica. No entanto, a elas é permitida a atividade econômica para que haja a circulação de bens ou direitos, desde que este não gere lucro e seja distribuído. Os recursos gerados devem ser aplicados na organização.

Já a fundação pode ser criada pela vontade de uma única pessoa, sendo constituída pela união de bens com uma finalidade determinada pelo instituidor. As fundações podem ser criadas por governos, indivíduos ou empresas. 
As organizações religiosas eram enquadradas na figura jurídica de associação, mas, de acordo com a Lei Federal 10.825/03, passarem a configurar uma nova categoria jurídica.

A Organização da Sociedade Civil de Interesse Público (OSCIP) tem finalidade pública e, para obter a qualificação, deve ser uma pessoa jurídica de direito privado sem fins lucrativos e atender aos objetivos sociais e às normas estatutárias previstas em lei. Com a dificuldade de definir o que é interesse público, alguns critérios foram estabelecidos para oferecer sentido à expressão, como critérios de finalidade (sem fins lucrativos) e adoção de um funcionamento específico, com estatutos que contenham fins públicos e instrumentos de transparência e responsabilização dos atos.

As sociedades civis, associações e fundações podem solicitar ao Ministério da Justiça a declaração de Utilidade Pública Federal, se cumprir os requisitos da Lei Federal 91-35, regulamentada pelo Decreto 50.517/61. Quando é declarada de Utilidade Pública Federal, a organização tem que apresentar relatórios anuais e demonstrativos de receitas e despesas, tendo como vantagens a possibilidade de obter dedução fiscal no imposto de renda no caos de doações de pessoas jurídicas, além de acesso a auxílios da União e de autarquias.

Já o registro no Conselho Nacional de Assistência Social (CNAS) pode ser solicitado por organizações sem fins lucrativos que promovam a integração de trabalhadores ao mercado, assistência educacional e de saúde, entre outras atividades da Resolução 31/1999. As organizações devem seguir algumas diretrizes, como aplicar os recursos integralmente no Brasil, não remunerar diretores, sócios ou conselheiros, prestar serviços permanentes sem discriminação de pessoas interessadas.

Para conseguir o Certificado de Entidade Beneficente de Assistência Social, a organização deve demonstrar que esteve inscrita, nos últimos três anos, no Conselho Municipal de Assistência Social de sua cidade. Quando o pedido é aprovado, o certificado de entidade de fins filantrópicos é emitido, sendo que a principal vantagem é a isenção da cota patronal de contribuição da previdência sobre a folha de pagamento da entidade. 


\section{Capítulo 4. Comunicação para a sustentabilidade em organizações do terceiro setor}

Entende-se que o mapeamento das variáveis no processo da comunicação para a sustentabilidade no terceiro setor, objeto desta tese, reúne elementos técnicos e científicos necessários para a geração de mudanças. A perspectiva é que as organizações sejam agentes de transformação, repassando a seus públicos resultados e campanhas bem-sucedidas da sustentabilidade. Esta é uma instância mais complexa da comunicação, que começa pela retomada da função social da qual ela se origina, demandando um profundo conhecimento sobre a causa em que atua, alinhada com uma visão realista dos canais de divulgação e dos públicos envolvidos.

Com a mudança constante de cenário por qual a sociedade contemporânea atravessa e do aumento expressivo da conectividade entre pessoas e dispositivos tecnológicos, fazer comunicação requer cada vez mais a atuação de um profissional multidisciplinar e hábil na condução dessas mensagens, considerando as variáveis existentes, sempre avançando para a entrega do conteúdo da forma mais precisa e transformadora possível.

É necessário que tal perspectiva esteja respaldada em uma compreensão sofisticada da relação dos sujeitos com a noção de sustentabilidade. Tal avaliação vem de Rudimar Baldissera, em artigo intitulado "A comunicação (re) tecendo a cultura da sustentabilidade em sociedades complexas" (Baldissera, 2009). Refletindo sobre a comunicação direcionada para a sustentabilidade, o autor atenta para o fato de o sujeito não necessariamente estar envolvido ou simpático à ideia de tal conceito. "Então, não basta dizer a um sujeito que ele deve fazer algo ou adotar um comportamento específico; é necessário que esse algo ou esse comportamento faça algum sentido para ele" (Baldissera, 2009a, p. 47).

O autor defende que há categorias em que se encontram o "lugar/significação" da sustentabilidade para os diferentes sujeitos, a saber: (1) sustentabilidade como valor central; (2) sustentabilidade como valor periférico e/ou estratégico de mercado; (3) sustentabilidade como não valor, valor negativo e/ou modismo; (4) sustentabilidade como extrassistema. Tal sistematização demonstra que a sustentabilidade tem significação diversificada para os diferentes sujeitos. 
Na perspectiva de a comunicação ser empregada para que a noção de sustentabilidade seja positivamente semiotizada - deslocada para ser valor central -, parece necessário mais esforço/investimento para melhor conhecer os códigos culturais (valores, padrões, estruturas, crenças) dos diferentes grupos/sujeitos e, a partir disso, atualizar processos de comunicação que sejam férteis para que o outro em relação comunicacional possa identificar-se com as ideias que se apresentam (BALDISSERA, 2009a, p. 52).

Adiante com esta discussão, a contribuição de Wilson Bueno (2009) está relacionada com o resgate do papel da comunicação. Sua proposta tem respaldo na recomendação do Código de Melhores Práticas de Governança Corporativa do Instituto Brasileiro de Governança Corporativa (IBGC) às organizações de "cultivarem o desejo de informar".

Percival Caropreso (2011), presidente da agência Setor 2 1/2, especializada em integrar a sustentabilidade na estratégia das empresas, defende a necessidade de que as mensagens sejam revistas, principalmente as publicitárias, já que são muito baseadas na lógica do consumo. O autor pontua que a comunicação deve motivar e ser sedutora, sendo ideal a criação de uma linguagem que estimule e não apenas sensibilize.

Otto Scharmer, do Instituto de Tecnologia de Massachusetts (MIT), é atualmente um nome expoente nas pesquisas de inovação, liderança e sustentabilidade. Segundo o pesquisador, a educação para a sustentabilidade passa, necessariamente, pelo engajamento das pessoas, com envolvimento de todos em assuntos estratégicos, nos processos de inovação, decisões e criação de valor. "Nesse sentido, o que necessitamos para educar melhor as pessoas para a sustentabilidade é um conjunto de ferramentas que nos auxiliem a apreender do futuro na medida em que este emerge" (Scharmer, 2013, online).

Em dissertação de mestrado defendida na ECA-USP, Ulsen (2012) delineou uma compreensão sobre o perfil do gestor de comunicação para a sustentabilidade nas organizações, que entenda como fazer as organizações incorporarem a sustentabilidade em sua gestão e qual o papel da comunicação neste processo.

Muitos resultados podem ser conseguidos se a discussão estiver fundamentada em um trabalho responsável de comunicação, o que significa na prática a elaboração de materiais com conteúdo preciso e muito bem fundamentado a respeito da sustentabilidade, formatados por sua vez em produtos acessíveis aos públicos, desenhados em 
uma linguagem própria e que, finalmente, gerem significado para o interlocutor (ULSEN, 2012, p.194).

Segundo o autor, o gestor de comunicação é estratégico, pois é ele quem lida com as narrativas, produz os materiais de comunicação, é o responsável por discernir o conteúdo da sustentabilidade e oferecê-lo de modo customizado para que tenha significado aos públicos. Trata-se de um processo amplo e sistematizado de planejamento e execução que deve ser desenvolvido de modo estratégico, customizado e contínuo.

Dessa forma, as variáveis indicadas na Figura 2, criadas por este autor para esta tese, foram organizadas da forma mais didática possível para esclarecer que a comunicação, quando analisada em seu fluxo, está sujeita a diferentes interferências. Em se tratando de comunicação para a sustentabilidade, as especificidades aumentam e se tornam ainda mais complexas ao tratarmos desse processo em organizações do terceiro setor. A figura ilustra o processo sugerido. Entende-se que mensagens planejadas com base no mapeamento e na delimitação das diferentes variáveis têm maior chance de serem bem-sucedidas e gerarem os resultados planejados.

Deste modo, a proposta é que a comunicação para a sustentabilidade em organizações do terceiro setor seja compreendida a partir do mapeamento das seguintes variáveis: níveis; abordagem; transdisciplinaridade; liderança; códigos; meios, canais e formatos; linguagem; sentidos; frequência cerebral; públicos de interesse; repertório; perfil do gestor; prazo; escala de mudança; recursos envolvidos; percurso; abrangência; e frequência. 
Figura 2: Comunicação para a sustentabilidade em organizações do terceiro setor

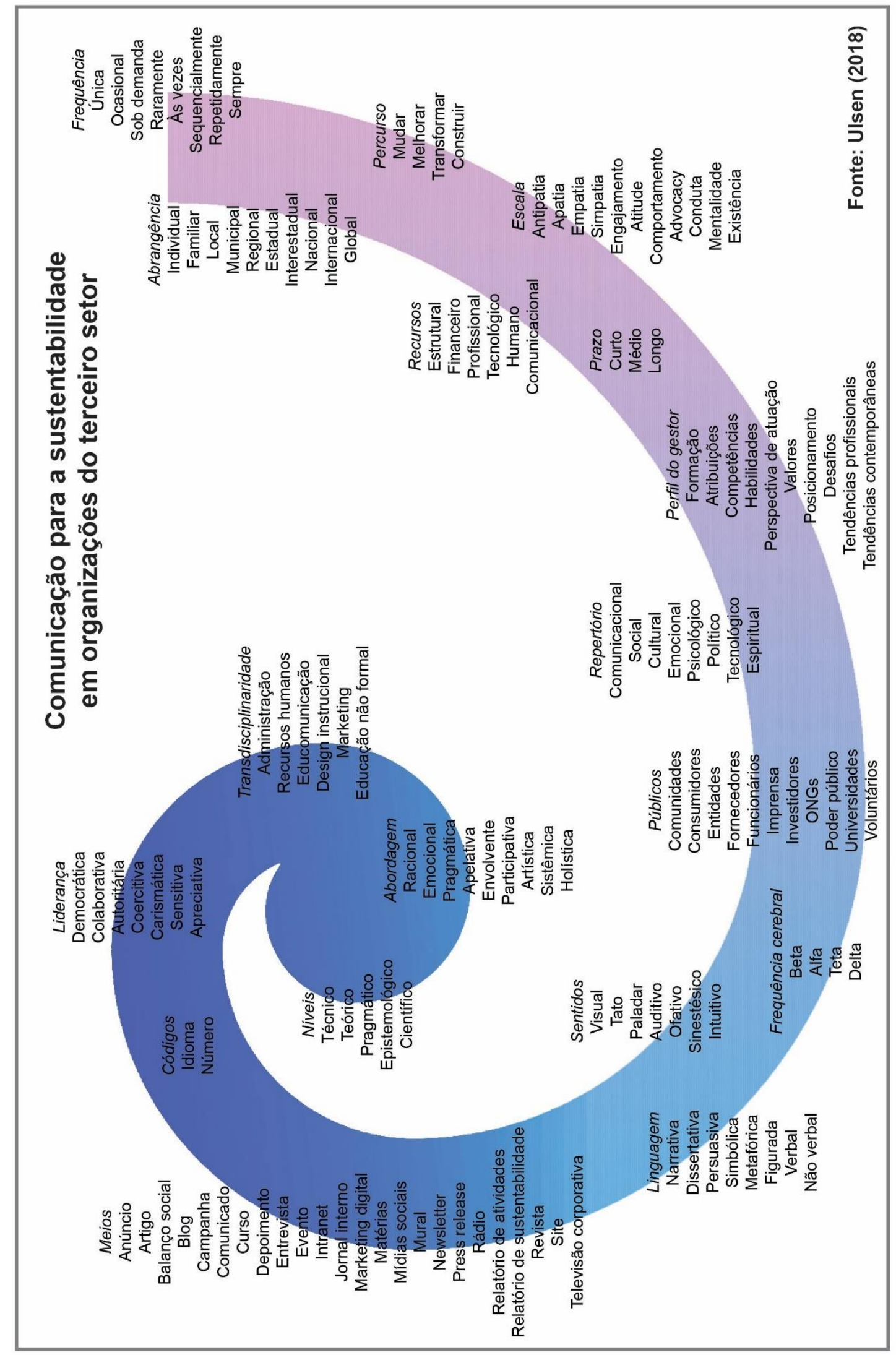

Fonte: Ulsen (2018) 


\subsection{Níveis da comunicação}

Os níveis da comunicação determinam a evolução das ações desenvolvidas nas organizações. Como níveis, pressupõem diferentes recursos e uma escala por meio da qual o trabalho é desenvolvido, podendo variar do mais simples (técnico) ao mais complexo (científico). Importante dizer que o nível de qualificação e profissionalização da comunicação organizacional está diretamente relacionado à perenidade do impacto das ações desenvolvidas, conforme ilustrado na Figura 3.

Figura 3: Níveis da comunicação e perenidade das ações

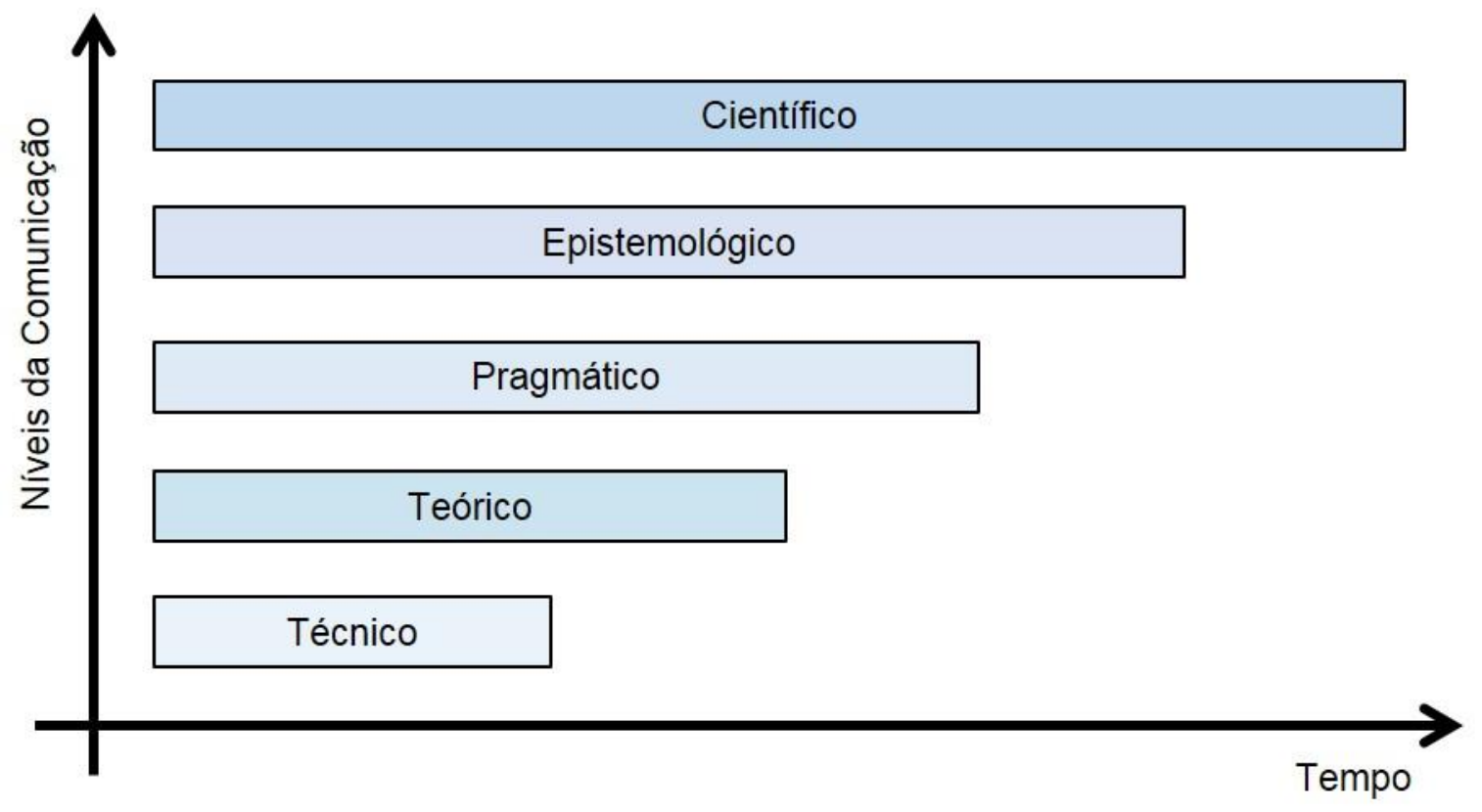

Fonte: Ulsen (2018)

\section{Técnico}

Nível mais básico, está relacionado à comunicação vista e utilizada como um mero instrumento que operacionaliza ações previamente decididas. Nesse caso, o conhecimento comunicacional dos envolvidos é baixo e a qualificação profissional também. A realização técnica da comunicação envolve aspectos mais operacionais e práticos para a implementação de determinada ação sem a reflexão a respeito do tema ou a fundamentação teórica. Como nível inicial, é importante pela execução prática, porém o impacto das suas ações tende a ser menor em decorrência da sobreposição de outras atividades complementares mais complexas e profundas. 


\title{
Teórico
}

Enquanto teoria, a comunicação reúne estudos acadêmicos e pesquisas científicas que consideram os efeitos, origens e o fenômeno da Comunicação Social em seus aspectos tecnológicos, sociais, econômicos, políticos e cognitivos. Além disso, do ponto de vista teórico, a comunicação também estabelece interface com psicologia, filosofia e sociologia, dependendo do tipo de abordagem e dos objetivos da pesquisa.

Os estudos desta área avançaram a partir da popularização das tecnologias midiáticas e sua utilização durante os regimes ditatoriais. No início, as pesquisas concentraram suas atenções sobre as mensagens da mídia e seus efeitos sobre as pessoas. Depois, as pesquisas passaram a analisar o processo de seleção, produção e divulgação das informações por meio da mídia.

As teorias de comunicação reúnem um conjunto de pesquisas desenvolvidas a partir dos estudos sociológicos, antropológicos, psicológicos, linguísticos e filosóficos relacionados com a comunicação humana. A linguagem é um dos itens do estudo, sendo a comunicação um ato essencial de desenvolvimento da sociedade. Muitos teóricos vêm tentando, cada vez mais, compreender seus usos e sua importância.

A comunicação é objeto de estudo de diversas áreas e, portanto, abrange abordagens distintas. Os estudos sobre as Teorias da Comunicação começaram a ser mais explorados a partir do século XX, com a expansão dos meios de comunicação.

\begin{abstract}
Situados na encruzilhada de várias disciplinas, os processos de comunicação suscitaram o interesse de ciências tão diversas quanto à filosofia, a história, a geografia, a psicologia, a sociologia, a etnologia, a economia, as ciências políticas, a biologia, a cibernética ou as ciências cognitivas. Ao longo de sua construção, esse campo particular das ciências sociais esteve, por outro lado, continuamente às voltas com a questão de sua legitimidade científica. Isso o conduziu a buscar modelos de cientificidade, a adotar esquemas pertencentes às ciências da natureza, adaptando-os por meio de analogias (MATTELART; MATTELART, 2012, p. 9).
\end{abstract}

Entre as diferentes escolas de comunicação, a brasileira se destaca pela corrente de estudos intitulada folkcomunicação, introduzida no Brasil, na década de 1960, por Luiz Beltrão de Andrade Lima. A principal característica desse movimento foi os estudos sobre o folclore e a comunicação popular por meio dos meios de 
comunicação de massa, sendo a folkcomunicação o processo de intercâmbio de informações e manifestações de opiniões, ideias e atitudes de massa por meio de agentes e meios ligados, direta ou indiretamente, ao folclore.

As teorias atribuem diferentes medidas para cada um dos componentes da comunicação, sendo que as primeiras delas afirmavam que tudo o que o emissor dissesse seria aceito pelo receptor, o que embasou o surgimento da teoria crítica, que analisa profundamente a dominação ideológica na comunicação de massa.

O nível teórico da pesquisa trata sobre modelo metodológico e os níveis de pesquisa. Na associação da teoria com o paradigma, a proposta é que seja visto como um sistema teórico global, enquanto a teoria é parcial e limitada à interpretação de um fenômeno. As teorias globais são parâmetros em que toda teoria parcial se adequa. Já a explicitação conceitual decorre da teoria entendida como corpo de conceitos, que por sua vez contém elementos explicativos para efetuar e preparar testes de hipóteses. Na medida em que ocorrem as definições dos conceitos, estes são desdobrados em um processo de operacionalização, momento em que a teoria interage com os demais níveis metodológicos e a prática da comunicação nas organizações.

\section{Pragmático}

Diz respeito à utilização dos recursos disponíveis de comunicação com foco em seus desdobramentos práticos. O pragmatismo, em uma concepção popular, é associado ao profissional de qualquer área que tem o hábito de direcionar seus esforços considerando seus aspectos úteis, necessários, sobretudo em termos de efeitos materiais e utilitários.

Essa concepção costuma ser priorizada nas empresas pela importância que oferece para a resolução de problemas, modelo que está alinhado com a criação de formas de execução de tarefas e de planejamento que evidenciem as qualidades organizacionais e as destaquem dos concorrentes. Uma decorrência dessa abordagem é o foco no desenvolvimento dos diferenciais competitivos.

Comparo o diferencial competitivo a um diamante. Em tese, trata-se de uma pedra bruta, sem atrativo e suja, escondida abaixo da superfície terrestre, em locais de difícil acesso e às vezes perigosos. Geólogos e mineradores se empenham em encontrar diamantes, pois, após a lapidação, seu valor é inestimável (NESHEIM, 2007, p. 15). 
A citação acima, de John Nesheim, escritor norte-americano, professor de empreendedorismo na Universidade de Cornell, é um bom exemplo de como a comunicação pragmática pode atuar a serviço de empresários, investidores e corporações para ampliar a produtividade empresarial. Mas, além disso, o autor também esclarece que o diferencial competitivo pode ser importante para outras organizações, inclusive as do terceiro setor.

O diferencial competitivo é o Santo Graal. Os modismos empresariais vêm e vão, mas ele chegou para ficar. Sempre foi e sempre será assim. Todos precisam de diferencial competitivo. Grandes empresas, universidades e organizações sem fins lucrativos, nações, governos, partidos políticos e militares precisam dele, assim como empreendedores e empresas de capital de risco. Repórteres, estudantes e até mesmo você precisa dele. Nosso mundo é intensamente competitivo (NESHEIM, 2007, p. 9).

Importante salientar que a comunicação pragmática, embora muito explorada por empresas, também é importante no terceiro setor para objetivar as ações e tornar as atividades profissionais mais fundamentadas em termos realistas. Ainda assim, como esse nível da comunicação privilegia a vertente prática, também é importante que ela não domine o planejamento da área sob pena da comunicação se tornar um recurso de legitimação de discursos antiéticos e inconsistentes.

\section{Epistemológico}

A epistemologia é um conjunto de conhecimentos teórico-metodológicos ligados simbioticamente que permitem elaborar uma forma de investigar um objeto. Sendo assim a epistemologia da comunicação foi criada com o objetivo de compreender melhor o que é a comunicação. Considerando a comunicação como um processo de transmissão de informação e compreensão de determinado assunto.

De acordo com Maria Immacolata Vassallo de Lopes (2012), o nível epistemológico tem por função exercer uma função de vigilância crítica à pesquisa, pois se traduz em operações criadas para a explicitação de obstáculos e correção da construção do objeto científico. Os paradigmas são responsáveis por alinhar sujeito e objeto. A reflexão epistemológica renova-se permanentemente a partir de duas operações. A primeira é a ruptura epistemológica que ocorre entre objeto científico e objeto real, operacionalizada a partir de um princípio de Gaston Bachelard. A segunda 
operação epistemológica é a da construção do objeto científico. Aspectos da realidade são obtidos através de técnicas de investigação, e não são simplesmente dados e a crítica epistemológica das técnicas precisa ser feita desde a elaboração da problemática da pesquisa.

\section{Científico}

A comunicação é um campo de conhecimento científico consolidado que estuda os meios e processos da transmissão de informações. Entre os objetos de estudo, estão teoria da informação, comunicação intrapessoal, comunicação interpessoal, comunicação organizacional, publicidade, propaganda, relações públicas, análise do discurso, telecomunicações e jornalismo, entre outros.

O campo científico é sempre o lugar de uma luta, mais ou menos
desigual, entre agentes desigualmente dotados de capital específico
e, portanto, desigualmente capazes de se apropriarem do produto do
trabalho científico que o conjunto dos concorrentes produz pela sua
colaboração objetiva ao colocarem em ação o conjunto dos meios de
produção científica disponíveis. Em todo campo se põem, com forças
mais ou menos desiguais segundo a estrutura da distribuição do
capital no campo (grau de homogeneidade), os dominantes,
ocupando as posições mais altas na estrutura de distribuição de
capital científico, e os dominados, isto é, os novatos, que possuem
um capital científico tanto mais importante quanto maior a
importância dos recursos científicos acumulados no campo
(BOURDIEU, 1983, p. 136-137).

Do ponto de vista humano, a comunicação é um processo que envolve a troca de informações e a utilização de sistemas simbólicos como suporte para este objetivo. Os envolvidos neste processo têm incontáveis maneiras de se comunicar, seja por meio de uma conversa, com a utilização de gestos, mensagens enviadas por dispositivos móveis ou a utilização da escrita.

O estudo da Comunicação é amplo e sua aplicação é ainda maior. Para a semiótica, o ato de comunicar é a materialização do pensamento e do sentimento em signos conhecidos pelas partes envolvidas. Estes símbolos são transmitidos e reinterpretados pelo receptor. Hoje, é interessante pensar também em novos processos de comunicação, que englobam as redes colaborativas e os sistemas híbridos, combinando comunicação de massa e comunicação pessoal e comunicação horizontal. 
O campo científico, enquanto sistema de relações objetivas entre posições adquiridas (em lutas anteriores), é o lugar, o espaço de jogo de uma luta concorrencial. O que está em jogo especificamente nessa luta é o monopólio da autoridade científica definida, de maneira inseparável, como capacidade técnica e poder social; ou, se quisermos, o monopólio da competência científica, compreendida enquanto capacidade de falar e de agir legitimamente (isto é, de maneira autorizada e com autoridade), que é socialmente outorgada a um agente determinado.

Dizer que o campo é um lugar de lutas não é simplesmente romper com a imagem irenista da "comunidade científica" tal como a hagiografia científica a descreve - e, muitas vezes, depois dela, a própria sociologia da ciência. Não é simplesmente romper com a ideia de uma espécie de "reino dos fins" que não conheceria senão as leis da concorrência pura e perfeita das ideias, infalivelmente recortada pela força intrínseca da ideia verdadeira. É também recordar que o próprio funcionamento do campo científico produz e supõe uma forma específica de interesse (as práticas científicas não aparecendo como "desinteressadas" senão quando referidas a interesses diferentes, produzidos e exigidos por outros campos) (BOURDIEU, 1983, p. 122123).

Nesta discussão é importante envolver a contribuição de Jesús Martín-Barbero, que relaciona a pesquisa científica com as Ciências da Comunicação, a metodologia da pesquisa e os paradigmas científicos. Em texto estruturado como o prefácio para a segunda edição da obra "Dos meios às mediações: comunicação, cultura e hegemonia", Jesús Martín-Barbero (2003) parte de um dos questionamentos colocados de como assumir o espessor social e perceptivo, presente nas tecnologias de comunicação sem, por outro lado, tornar-se cúmplice discursivo da modernização neoliberal. $\mathrm{O}$ autor citado constata que as mudanças tecnológicas, por rápida que são, não necessariamente permitem que as pessoas assimilem as imagens da modernização, pois seus valores, normas e virtudes têm outro tempo de maturação e velocidade de compreensão.

Ele considera que tentativas de reflexão sobre a hegemonia comunicacional e o mercado na sociedade significa na comunicação convertida no desengate da inserção de culturas e, ao mesmo tempo, em que é necessária uma reflexão a respeito da capacidade estratégia que passou a ocupar a comunicação. Para esboçar esta proposta, o autor desenha o mapa das mediações que dê conta da complexidade existente nas relações constitutivas da comunicação na cultura. 
O que busco com esse mapa é reconhecer que os meios constituem hoje espaços-chave de condensação e intersecção de múltiplas redes de poder e de produção cultural, mas também alertar, ao mesmo tempo, contra o pensamento único que legitima a ideia de que a tecnologia é hoje o "grande mediador" entre as pessoas e o mundo, quando a tecnologia media hoje, de modo mais acelerado, é a transformação da sociedade em mercado, e deste em principal agenciador de mundialização (em seus muitos e contrapostos sentidos) (MARTÍN-BARBERO, 2003, p. 11).

O autor enxerga dentro deste cenário sinais de esperança na presença cada vez mais efetiva das mulheres, nas mobilizações dos jovens e nas reconfigurações coletivas, que recriam a cidadania e reconstituem a sociedade em espaços locais e iniciativas de rádio e televisão comunitários.

Quando é praticada com respaldo científico, a comunicação opera em seu formato mais qualificado, pois tem a favor a integração de pesquisas acadêmicas e a possibilidade de aplicação de novos métodos de trabalho no cotidiano das organizações. A perenidade do impacto das suas ações tende, dessa forma, tende a ser mais qualificado e profissionalizado.

\subsection{Tipos de abordagem}

A abordagem é uma condição da comunicação que se caracteriza por ter foco no sentido, no significado e na interação entre pessoas envolvidas na transmissão e no recebimento de determinadas informações. Todo processo comunicativo está embasado em uma forma de abordagem do interlocutor que pode ser, conforme detalhado a seguir, racional, emocional, pragmática, artística, envolvente, participativa, sistêmica ou holística. 
Figura 4: Tipos de abordagem da comunicação para a sustentabilidade

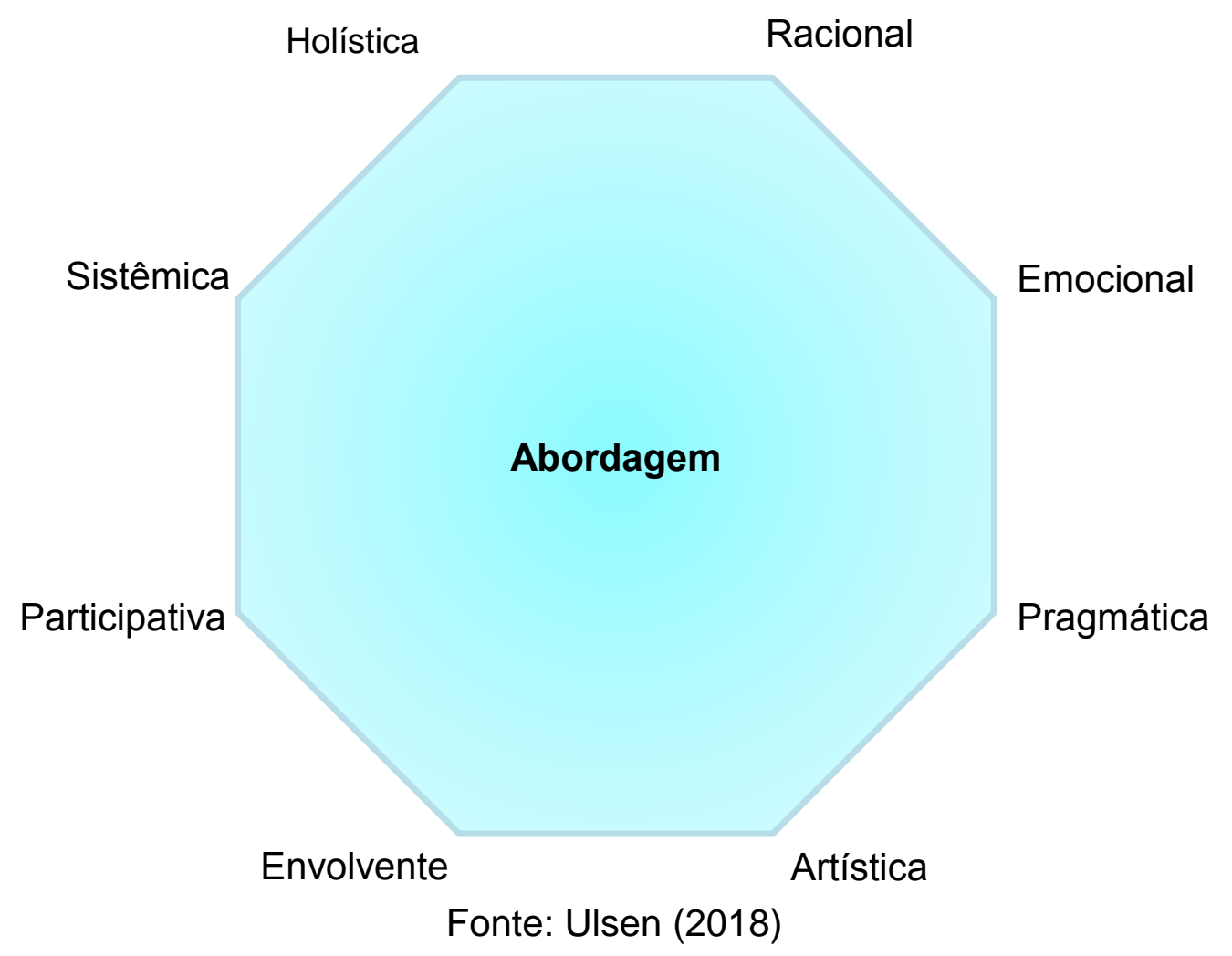

\section{Racional}

A perspectiva racional está fundamentada na utilização da razão para a identificação de respostas que busquem se aproximar o mais possível da realidade. Quando bem utilizada, ela emprega argumentos objetivos que destacam os benefícios de determinada situação ou campanha social. O apelo, mais argumentativo, utiliza uma narrativa que busca construir significados para convencer o interlocutor sobre determinado assunto.

O raciocínio pode ser definido como uma operação intelectual que nos faz refletir sobre algo com a utilização de proposições que criam premissas, válidas ou falsas, para gerar uma conclusão. O raciocínio também pode ser classificado como pensamento, deliberação ou dedução. A citação a seguir do consultor Michael Neill está alinhada com essa abordagem.

O pensamento está ao nosso redor, em toda a parte, e isto de alguma forma o torna amplamente invisível para nós. Sem o pensamento, não haveria delineamento em nosso mundo - não haveria percepção, distinção nem variedade de experiências. O pensamento é tanto o 
criador como a substância de nossas crenças e valores, é a matériaprima para nossas esperanças e sonhos (NEILL, 2014, p. 37).

No contexto da lógica, o raciocínio se inicia com premissas já conhecidas para alcançar um fundamento. A lógica, por sua vez, está baseada na harmonia do raciocínio e na proporcionalidade dos argumentos. Uma abordagem ou um discurso lógico examina formas de argumentação, distinguindo as válidas daquelas falsas.

\title{
Emocional
}

Esta abordagem é mais direcionada para o despertar de emoções, positivas ou negativas, com a utilização de diferentes apelos, como humor, amor, orgulho, alegria, medo, culpa ou vergonha. Quando a abordagem é emocional, ela estimula uma decisão passional em do interlocutor a respeito de determinado assunto.

$O$ foco nas emoções traz sensações ao interlocutor e exploram mais a sensação que ele tem diante de determinada ação e pode, eventualmente, estar integrada também a uma abordagem racional.

\section{Pragmática}

Abordagem que utiliza os recursos de comunicação com foco em resultados práticos. Tal direcionamento é, muitas vezes priorizado nas empresas diante da possibilidade que oferece para a resolução rápida de problemas. Uma decorrência dessa abordagem é o foco nas argumentações, tema dos estudos do pesquisador britânico Madsen Pirie, fundador e presidente do Instituto Adam Smith.

\begin{abstract}
Este livro foi idealizado como um guia prático para aqueles que desejam vencer as argumentações. Ele ensina também como perpetrar falácias com maldade e intenção dolosa. Descrevi cada uma das falácias, ofereci exemplos dela e mostrei por que é falaciosa. Após informações de interesse geral referentes à história ou à ocorrência da falácia, forneci ao leitor recomendações de como e onde a falácia pode ser usada para enganar com eficácia máxima (PIRIE, 2013, p. 10).
\end{abstract}

Além disso, a abordagem pragmática da comunicação, ainda que seja muito utilizada nas empresas, às vezes com métodos e fins pouco transparentes, também pode ser relevante no terceiro setor para tornar determinadas ações profissionais mais objetivas. 


\section{Apelativa}

A abordagem apelativa é usada para dar conselhos, avisos, ordens ou pedidos. Em forma de ordem, apelo ou súplica, ela está centrada no destinatário e ocorre quando a intenção do emissor é exercer uma influência direta nas escolhas do destinatário. Um dos usos mais frequentes dessa abordagem está nos anúncios publicitários e nos comícios políticos, quando o emissor da mensagem explora a suposta urgência de determinado tema para o envolvimento do seu interlocutor.

No âmbito das organizações do terceiro setor que atuam pela sustentabilidade, é comum que muitas organizações, envolvidas frequentemente de forma passional com causas de preservação ambiental, por exemplo, sejam apelativas em suas mensagens para forçar a identificação do interlocutor com a necessidade de adesão imediata ao tema.

\section{Envolvente}

Geralmente criada a partir de uma narrativa envolvente e cativante, conduz o leitor em uma história repleta de significados. Nessa abordagem, o interlocutor é envolvido em um conteúdo construído para cercá-lo de argumentos racionais e sensações emocionais para que tome determinada decisão.

A publicidade, frequentemente, utiliza essa abordagem para ofertar produtos e serviços. Já as organizações do terceiro setor também podem fazê-lo com mais qualidade e eficiência, desde que mantenham a ética na criação de peças direcionadas para causas socioambientais.

\section{Participativa}

Conforme o próprio nome já indica, a abordagem participativa está fundamentada nos princípios da participação, troca de saberes, reflexão, diálogo, planejamento coletivo e gestão social. Nessa perspectiva, as pessoas envolvidas com as causas da organização constroem, juntas, as soluções para os problemas identificados.

Além disso, as técnicas participativas buscam o empoderamento e a emancipação dos públicos para que haja melhor combate às desigualdades sociais e problemas ambientais. Na prática, o empoderamento consiste na coletivização do poder para o uso de todos. Como recurso possível para essa abordagem, a 
comunicação comunitária e educação para a cidadania defendidas por Peruzzo (2002) podem ser utilizadas para o estímulo de ações coletivas.

\title{
Artística
}

A arte pode ser entendida como a atividade humana ligada às manifestações estéticas ou comunicativas realizadas com variedade de linguagens, como arquitetura, desenho, escultura, pintura, escrita, música, dança, teatro e cinema. $\mathrm{O}$ processo criativo artístico se desenvolve a partir da percepção individual ou coletiva com expressão de emoções e ideias com significados exclusivos em cada produção.

No livro intitulado “O que é arte?”, publicado originalmente em 1898, depois de quinze anos de reflexões, o escritor russo Leon Tolstói refutou a ideia de arte como entretenimento e defendeu que ela deve promover o bem-estar coletivo, favorecendo a paz, o progresso e a fraternidade.

\begin{abstract}
A arte, juntamente com a fala, é um meio de comunicação e, portanto, também de progresso - isto é, da caminhada da humanidade rumo à perfeição. A fala permite que as gerações posteriores saibam tudo o que as gerações precedentes sabiam e o que os melhores entre seus contemporâneos sabem por experiência e reflexão. A arte permite que as gerações posteriores experimentem todos os sentimentos vivenciados por outros antes deles e que as pessoas mais avançadas vivenciam agora. E, tal como na evolução do conhecimento - isto é, a suplantação de conhecimento errôneo e desnecessário por conhecimento mais verdadeiro e necessário - assim, também a evolução dos sentimentos se dá por meio da arte, substituindo sentimentos mais baixos, menos generosos e menos necessários para esse bem. Esse é o propósito da arte. E, portanto, o seu conteúdo é melhor quando mais atende a esse propósito, e é pior na medida em que o atende menos (TOLSTÓI, 2016, p. 161).
\end{abstract}

O principal problema na definição da arte encontra-se na variação da compreensão deste conceito, de acordo com o tempo as diferentes culturas humanas, o que faz da arte uma construção cultural dinâmica. Essa abordagem expressa atitudes e emoções, refletindo o estado de ânimo do emissor e seus sentimentos. Quando alguém utilizada esse modelo, expressa suas percepções de um ponto de vista subjetivo.

Ainda assim, a possibilidade artística certamente é mais uma abordagem possível em ações de comunicação para a sustentabilidade, seja para atingir os 
objetivos propostos por Leon Tolstói, seja para quebrar paradigmas e estimular a renovação de modelos mentais na sociedade contemporânea.

\section{Sistêmica}

A abordagem sistêmica deve estar fundamentada em um trabalho responsável por parte dos profissionais envolvidos com a comunicação. O pensamento sistêmico é uma forma de abordagem da realidade que se opõe ao pensamento mecanicista dos filósofos da Revolução Científica, como René Descartes, Francis Bacon e Isaac Newton.

Embora ele não negue a racionalidade científica, o pensamento sistêmico acredita na importância da subjetividade das artes e da interpretação humana. Nesse sentido, destacando a citação do antropólogo, sociólogo e filósofo francês Edgar Morin, o autor defende que haja uma reforma do pensamento relacionado com a organização do conhecimento.

Hoje em dia, admite-se cada vez mais que, como indica a já citada frase de Pascal, o conhecimento das partes depende do conhecimento do todo, como o conhecimento do todo depende do conhecimento das partes. Por isso, em várias frentes do conhecimento, nasce uma concepção sistêmica, onde o todo não é redutível às partes (MORIN, 2010, p. 88).

Trazendo esta discussão para o campo da comunicação, a visão sistêmica também é defendida por pesquisadores que compreendem a complexidade das ações de comunicação e a necessidade de ações mais relacionais. A abordagem sistêmica sugere uma visão de cenário da comunicação, o que cria a possibilidade de observação do contexto de determinada ação de comunicação desde o objetivo inicial até a previsão dos seus resultados finais.

\section{Holística}

A abordagem holística procura compreender fenômenos em sua totalidade e globalidade, sendo que a palavra tem origem no termo grego holos, que significa todo ou inteiro. O conceito de holismo foi criado pelo ex-primeiro-ministro da África do Sul Jan Christiaan Smuts que, 1926, o defendeu como uma tendência de compreensão de um todo maior que a soma das suas partes. 
Este entendimento pode ser aplicado em várias áreas do conhecimento, como medicina, psicologia, física, administração, ecologia e comunicação. No ambiente empresarial, a perspectiva holística é a visão global de uma empresa, com todos os seus elementos, suas estratégias e atividades para a representação única da organização. Ela se opõe à lógica mecanicista, que costuma compartimentar a empresa em vários blocos, com potencial de perda da visão global. Finalmente, a postura holística envolve um processo de aprendizagem contínuo a partir da noção de totalidade, com integração de influências sociais, ambientais, culturais políticas e econômicas.

\subsection{Transdisciplinaridade da comunicação}

Transdisciplinaridade é uma abordagem científica que objetiva a unidade do conhecimento, procurando estimular uma nova compreensão da realidade a partir da articulação de elementos que passam entre, além e através das disciplinas. Este termo foi criado por Jean Piaget, biólogo, psicólogo e epistemólogo, considerado um dos mais importantes pensadores do século XX.

Durante o I seminário Internacional sobre pluri e interdisciplinaridade, realizado na Universidade de Nice (França), em 1970, o pesquisador suíço divulgou pela primeira vez o termo. Além disso, o conceito está fundamentado na Carta da Transdisciplinaridade, produzida no I Congresso Mundial de Transdisciplinaridade realizado em Arrábida, Portugal, em 1994.

\footnotetext{
A transdisciplinaridade, portanto, leva a refletir sobre a educação atual focada na especialização, em que as pessoas buscam instrumental para aplicação imediata de como resolver algo, de forma muitas vezes fragmentada. Remete a uma educação para a compreensão do todo interligado que também inclua novas maneiras de aprender, em que a pessoa possa refletir e extrair suas conclusões para evolução num novo patamar de consciência.

$E$ as novas ciências, num breve panorama, evidenciam que, se as ações das pessoas forem centradas em avaliações, decisões e atitudes colaborativas, integrativas, sistêmicas e mais conscientes, a harmonia nos relacionamentos será um processo mais tranquilo, dinâmico e enriquecedor, e contribuirá para a existência de um Planeta mais sustentável (GARBIN, 2011, p. 51).
} 
Uma abordagem semelhante foi apresentada por André Trigueiro, um dos nomes mais qualificados atualmente no Brasil em termos de jornalismo ambiental. $\mathrm{Na}$ citação a seguir, embora não trate especificamente de transdiciplinaridade, Trigueiro aborda conceitos correlatos e, principalmente, os associa com o desenvolvimento sustentável e a sustentabilidade.

Entender a vida na sua expressão mais holística, sistêmica e interrelacional não constitui o único desafio do nosso tempo. É preciso comunicar esse saber, traduzi-lo sem o peso do jargão ecológicocientífico, torná-lo inteligível ao maior número possível de pessoas, a fim de que uma nova cultura se manifeste na direção da sustentabilidade. Viver de forma sustentável - em equilíbrio com o meio ambiente - não é uma questão de estilo, mas de sobrevivência. Sustentabilidade é, portanto, uma palavra-chave na busca de um novo sistema de valores, um novo paradigma civilizatório. $\mathrm{O}$ desenvolvimento sustentável, conceito consagrado pela ONU pouco antes da Rio-92, através do Relatório Brundtland, é aquele que atende às necessidades do presente sem comprometer a capacidade das futuras gerações de atender às próprias necessidades. Trata-se de um conceito em construção, que precisa ser testado e aprovado (TRIGUEIRO, 2005, p. 164).

Para atuar em um cenário contemporâneo cada vez mais complexo, o profissional de comunicação organizacional precisa integrar disciplinas, sendo que a fundamentação de cada área do conhecimento importante para isso está indicada após a Figura 5. 
Figura 5: Transdisciplinaridade da comunicação organizacional

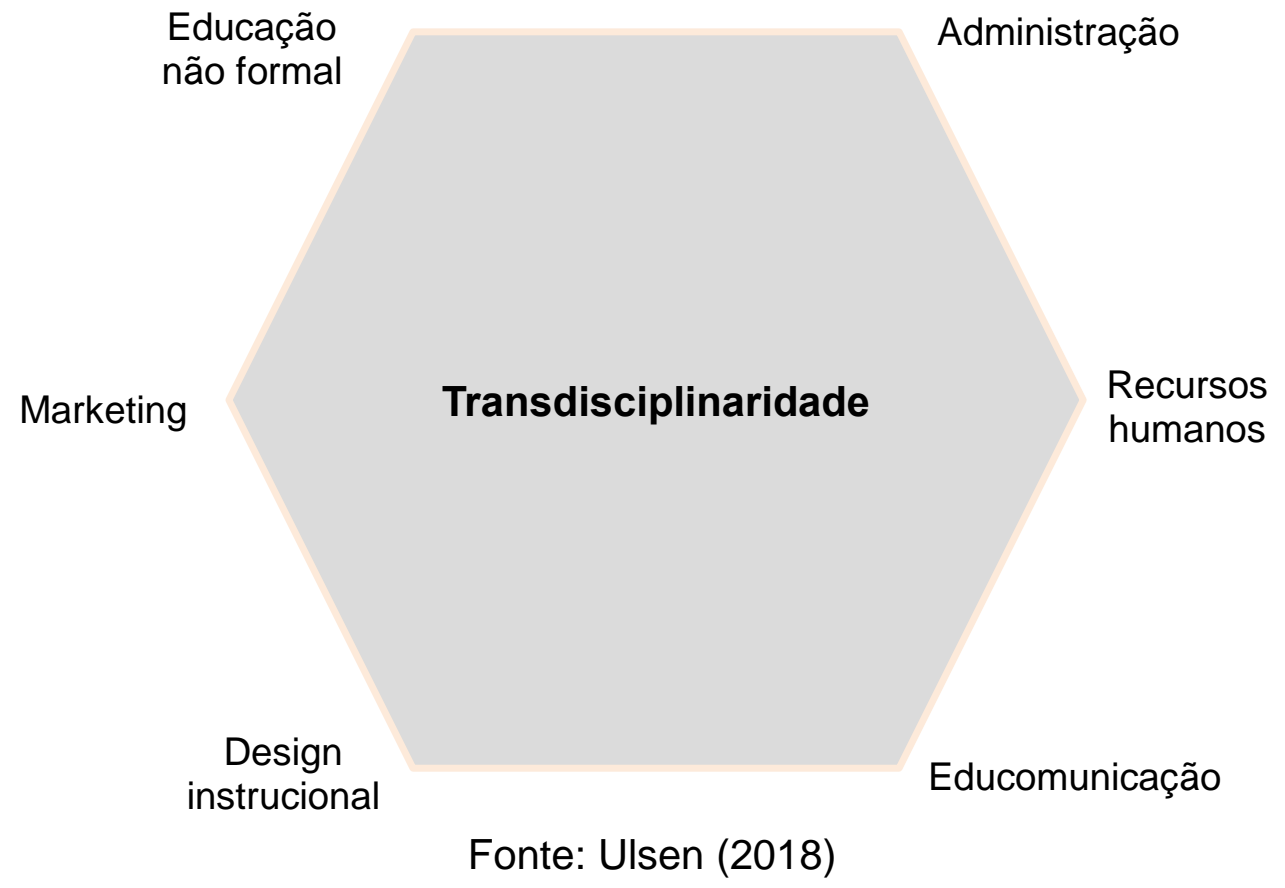

\section{Administração}

Ato de administrar ou gerenciar negócios, pessoas ou recursos com o objetivo de alcançar metas definidas. Trata-se de um ramo das ciências humanas que se caracteriza pela implementação prática de princípios, normas e atribuições em uma determinada organização. Os profissionais formados nessa área atuam com a gestão dos recursos financeiros, materiais e humanos e, também, com o desenvolvimento de mercado.

A administração é essencial dentro de uma organização e assume um espaço estratégico quando é orientada para a entrega de resultados, sejam eles financeiros, ambientais, sociais ou outros. Uma das áreas de atuação do administrador é o setor financeiro, o que reforça o seu papel sobre o desempenho das organizações.

\section{Recursos Humanos}

Conjunto de princípios estratégicos e técnicas orientadas para atrair, manter, motivar e treinar os profissionais de qualquer organização, sendo praticada em geral por administradores e psicólogos para orientar as pessoas em termos de comportamentos e condutas profissionais e direcioná-las para a adequação a este sistema e ao aumento de sua produtividade. 
A área de Recursos Humanos também está diretamente relacionada com a melhoria do bem-estar dos funcionários e o gerenciamento dos perfis de cada um. Dessa forma, tem se tornado crescente a importância de criação de mecanismos bemsucedidos de recrutamento e seleção de pessoas com foco na estruturação de equipes integradas e motivadas.

\section{Educomunicação}

A educomunicação é um campo teórico-prático que se propõe a atuar como uma metodologia pedagógica para a construção de ecossistemas comunicativos, abertos e criativos com relação horizontalizada entre os participantes e produção colaborativa de conteúdos utilizando diversas linguagens e instrumentos de expressão, arte e comunicação. Na prática, ela ocorre com a integração de educação com a comunicação, e pode ser desenvolvida em qualquer ambiente de formação, não estando reduzida ao âmbito formal.

Como exemplos da utilização da educomunicação, estão a rádio escola, a web rádio virtual, o jornal comunitário, os videogames, softwares de aprendizagem online, podcasts, blogs, fotografia e produção de notícias para veiculação em mídias livres. No Brasil, diferentes organizações do terceiro setor desenvolvem programas de educomunicação para fins sociais.

Para Ismar de Oliveira Soares, coordenador do Núcleo de Comunicação e Educação da Escola de Comunicações e Artes da Universidade de São Paulo, a educomunicação é, além de uma tendência, uma necessidade que surgiu dos movimentos sociais e na sociedade civil para a construção da cidadania, convergindo com todas as áreas das ciências humanas.

Trata-se de um conceito novo, originário de experiências como as de Paulo Freire junto às ligas camponesas de educação popular com forte interface na comunicação. A educomunicação pressupõe a utilização de práticas comunicativas em estruturas formais ou informais, visando a integração comunitária e o reconhecimento de direitos com maior acesso à gestão da comunicação.

Para o pesquisador, a educomunicação define-se como um conjunto das ações destinadas a integrar às práticas educativas o estudo sistemático dos sistemas de comunicação, criar e fortalecer ecossistemas comunicativos em espaços educativos, e melhorar o coeficiente expressivo e comunicativo das ações educativas. 
Para Moacir Gadotti, professor titular da Faculdade de Educação da Universidade de São Paulo (USP) e diretor do Instituto Paulo Freire, a integração entre educomunicação e sustentabilidade é determinante para um mundo mais equilibrado.

A educação para o desenvolvimento sustentável é mais do que uma
base de conhecimentos relacionados com o meio ambiente, a
economia e a sociedade. A EDS deve ocupar-se da aprendizagem de
atitudes, perspectivas e valores que orientam e impulsionam as
pessoas a viverem mais sustentavelmente suas vidas. As crises
criadas pelos seres humanos no planeta estão mostrando, todos os
dias, que somos seres irresponsáveis. Educar para o desenvolvimento
sustentável é educar para tomar consciência dessa irresponsabilidade
e superá-la (GADOTTI, 2012, p. 68).

O pesquisador também defende, conforme indicado a seguir, a necessidade de atuação em rede, considerando o ambiente de diversidade em que vivemos atualmente e outros elementos contemporâneos que se configuram como um desafio para os profissionais da área.

Educar para um outro mundo possível é educar para viver em rede;
ser capaz de comunicar e de agir em comum, é educar para produzir
formas cooperativas de produção e reprodução da existência humana,
educar para a autodeterminação. A diversidade é a característica
fundamental da humanidade. Por isso, não pode haver um único modo
de produzir e de reproduzir nossa existência no planeta. O que há de
comum é a diversidade humana. A diversidade humana impõe a
necessidade de construir a diversidade de mundos. A um pensamento
único não devemos opor outro pensamento único. Educar para um
outro mundo possível não é educar para um único mundo possível,
mas educar para outros mundos possíveis.
É educar para a paz, para os direitos humanos, para a justiça social e
para a diversidade cultural, contra o sexismo e o racismo. É educar
para a consciência planetária. É educar para que cada um de nós
encontre o seu lugar no mundo, educar para pertencer a uma
comunidade humana planetária, para sentir profundamente o universo
(GADOTTI, 2012, p. 106-107).

Finalmente, é importante destacar que a educomunicação, embora seja um campo de estudo novo, tem potencial para ampliar as pesquisas que tem realizado e servir, de maneira determinante, para atuar de forma transversal a qualquer ação planejada de comunicação para a sustentabilidade. 


\section{Design instrucional}

Design instrucional é a expressão que se refere à engenharia pedagógica, um conjunto de métodos, técnicas e recursos utilizados em processos de ensinoaprendizagem, desde o ensino clássico até a utilização dos recursos mais atuais, como é o caso do uso das Tecnologias da Informação e Comunicação (TICs). O design instrucional pode ser utilizado como apoio aos processos de comunicação para a sustentabilidade na elaboração de cursos, aulas individuais e criação de materiais didáticos, como impressos, vídeos ou softwares de aprendizagem.

\section{Marketing}

Marketing é uma palavra proveniente da língua inglesa amplamente difundida em termos mundiais, podendo ser entendida como mercadologia, ou o estudo das causas, objetivos e resultados gerados a partir de diferentes formas como nós lidamos com o mercado. Além disso, marketing é a ciência de explorar, criar e entregar valor para satisfazer necessidades previamente criadas em um determinado público para atingir o objetivo primário do lucro. Para tanto, seus recursos estão direcionados para a identificação de necessidades e desejos não realizados para, na sequência, definir, e quantificar o tamanho do mercado identificado e o potencial de lucro.

O marketing também envolve estratégias, técnicas e práticas para agregar valor a determinadas marcas ou produtos para lhes atribuir maior importância. Desse modo, passam a se tornar relevantes aspectos complementares à venda, como o envolvimento dos processos de produção, logística, comercialização e pós-venda do produto ou do serviço em questão.

\section{Educação não formal}

Os projetos de educação não formal são importantes ao possibilitarem mudanças em sistemas consolidados de conhecimento e valores das pessoas e das organizações, favorecendo a criação de novos formatos que permitam extrapolar os limites já conhecidos de formação e gerar a valorização dos aprendizados, promovendo a inovação a partir de novas experiências.

As propostas de educação não formal, por sua própria condição de não formalidade ou menos formalidade, estão numa situação privilegiada para romper com os padrões educativos tradicionais e se transformar em propostas inovadoras que deem contribuições 
significativas para a educação em geral. Mas isso não surge espontaneamente: é resultado do esforço de muitos (CENDALES; MARIÑO, 2006, p. 16).

Além disso, sua importância encontra-se na possibilidade de simplificar os métodos já conhecidos de interpretação da realidade e enquadrar o aprendizado em contextos mais amplos e inovadores.

\begin{abstract}
Uma educação não formal de qualidade, comprometida com os interesses dos meios populares, implica desafios. Um deles é a formação de educadores com capacidade para levar adiante as mudanças que esse tipo de educação requer; outro, a construção de espaços de reflexão e pesquisa pedagógica que permitam recuperar a riqueza das distintas experiências; e, por último, a contribuição para a construção de pedagogias nas diferentes áreas de trabalho como uma maneira de potencializá-las num nível mais amplo. No caso de projetos educativos, a reflexão pedagógica torna-se condição de qualidade, requisito para que o trabalho se enquadre no horizonte desejado e alcance os objetivos esperados (CENDALES; MARIÑO, 2006, p. 16-17).
\end{abstract}

As propostas de educação não formal devem gerar espaços de inclusão e serem compreendidas como um convite para a construção de algo diferente. Em se tratando de sustentabilidade, é a chance de impedir qualquer tipo de desigualdade para construção de novos projetos de desenvolvimento e convivência equilibrada de interesses diversos.

\title{
4.4 Modelos de liderança
}

O conceito de liderança passa constantemente por transformações de acordo com as novas tecnologias, os contextos econômicos e as condições sociais. Ainda assim, o líder nunca deixará de existir, embora tenha que estar atento às novas formas de liderar. Para Mário Sergio Cortella, filósofo, escritor, educador, palestrante e professor universitário, os líderes devem estar atentos aos sentimentos dos integrantes da equipe e, sobretudo, serem capazes de envolver cada um de forma diferente.

No meu modo de ver, o mundo ocidental capitalista produtivo material altamente eficaz caiu numa armadilha: especializou-se nos "comos" e 
deixou de lado os "porquês". E aí temos um adensamento da insatisfação, do incômodo e, especialmente, do desespero.

Essa é uma questão que os líderes não podem perder de vista. Mostrar para as pessoas qual é o resultado da obra e identificar essa obra como magnífica. Se assim não fosse, não haveria quem tocasse címbalo em orquestra. Na Abertura 1812, de Tchaikovsky, por exemplo, o instrumento do címbalo toca pouco durante a peça inteira. E ele vai para casa e fala o quê para a esposa? Que durante a execução do concerto ele fez "pim" três vezes? Claro que não. Ele fala que participou de um concerto. Agora se ele perceber que as pessoas acham que ele só toca címbalo e que, aliás, é altamente substituível, se ele perceber que o spalla (primeiro violino) da orquestra o despreza, ele ficará propenso a ter dois tipos de comportamento: não ter lealdade à orquestra ou atravessar durante a execução, tocar na hora errada. O tocador de címbalos precisa ter clareza de que não foi lá bater o prato três vezes, mas, sim, de que estava compondo uma obra coletiva (CORTELLA, 2007, p. 66).

Todas as organizações precisam de pessoas que não se conformem com a situação atual e que busquem soluções diferentes para novos desafios. Diante disso, a seguir estão apresentados estilos de liderança contemporâneos que foram sistematizados para facilitar a compreensão dos principais modelos de liderança existentes em organizações de todos os setores. Os estilos não são estanques, mas podem conviver dentro da mesma organização ou até serem adaptados pelo líder, que, muitas vezes, transita nesses formatos de acordo com o público com quem se relaciona. 
Figura 6: Modelos de liderança

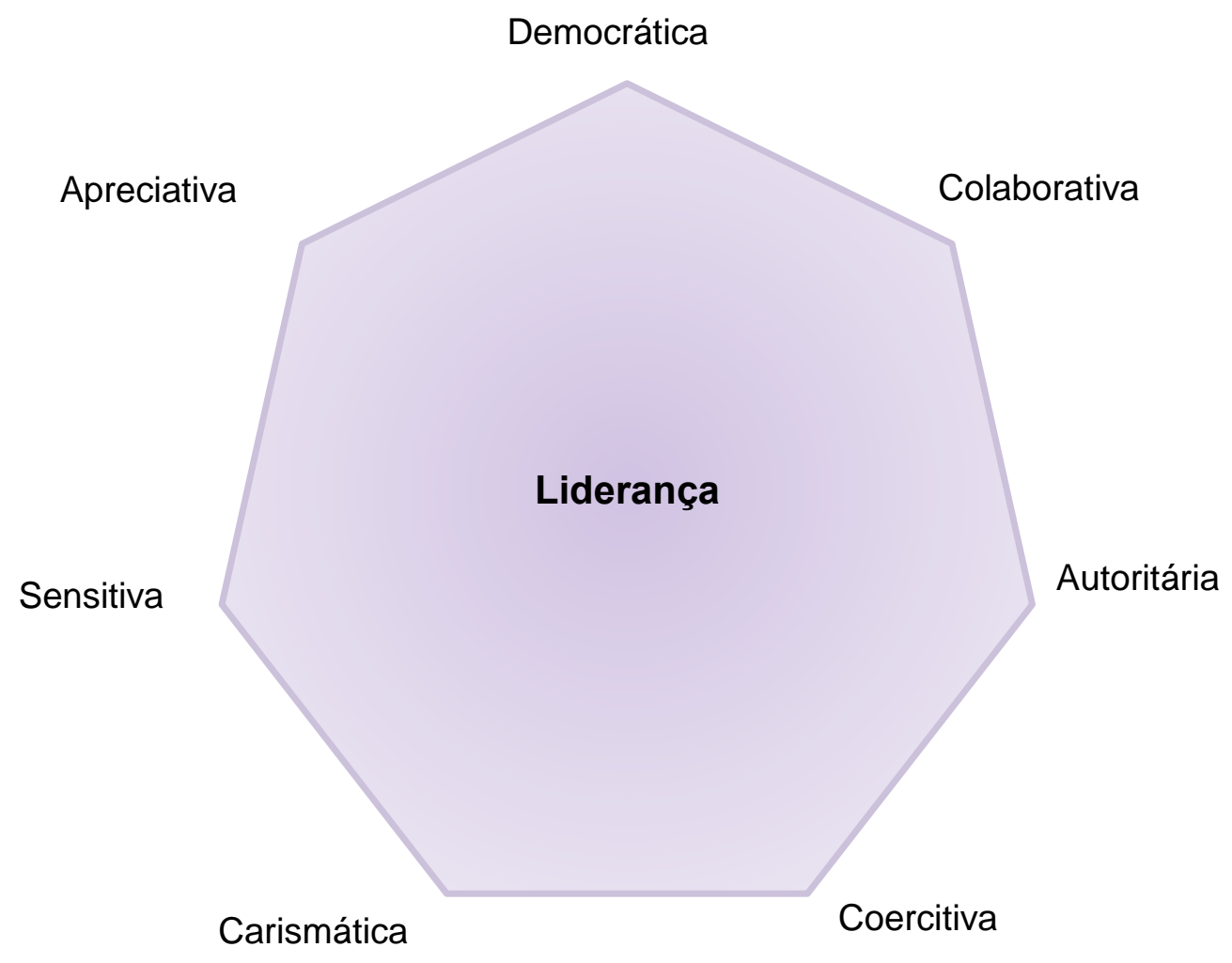

Fonte: Ulsen (2018)

\section{Democrática}

Considerando que a palavra democracia tem origem no grego (demos, que significa povo e, kratos, autoridade), a democracia nada mais é que autoridade do povo. O líder que atua com essa inspiração tem como objetivo criar condições para o estabelecimento de um espírito de grupo na equipe que promova os seus integrantes e os estimule a entregar mais resultados que o esperado.

De forma geral, os líderes democráticos encorajam o grupo a tomar decisões coletivas, coordenam as entregas para atingir a realização geral dos planos, permitem que escolhas importantes sejam tomadas pelo grupo de forma participativa e costumam otimizar a diversidade de opiniões e estilos profissionais para a superação de desafios. Os líderes democráticos podem ser encontrados em qualquer grupo de pessoas como, por exemplo, equipes de estudos, famílias, negócios, religiosas e políticas.

A liderança democrática pode ser inadequada e desvantajosa em determinados ambientes, pois as decisões, em geral, exigem mais tempo para serem tomadas. 
Ainda assim, são várias as vantagens, entre elas a legitimação das decisões feitas diante da qualidade do tratamento dispensado às pessoas nesse caso e à construção de uma sensação de pertencimento ao grupo.

\section{Colaborativa}

O líder com esse perfil tem um senso equilibrado de responsabilidade pública para com o desenvolvimento harmonioso da comunidade e entende a necessidade de evolução do potencial de todas as pessoas direta ou indiretamente envolvidas com a equipe. Para tanto, ele estimula a colaboração, a inovação e o fortalecimento da inteligência coletiva. O profissional com essas características em geral não tem sentimentos e pensamentos egoístas e consegue colocar-se no lugar do outro, demonstrando empatia e criando mecanismos de relacionamento fundamentados no respeito e no diálogo.

O líder colaborativo procura evoluir na espiritualidade, contribuindo para a evolução na espiritualidade das pessoas, com grande ênfase em valores elevados compartilhados, que as mobilize para aspirações e propósitos também elevados, em prol do bem comum.

Procura elevar o nível de sua consciência e contribui para a expansão dos limites da consciência das pessoas, reforçando a importância da evolução do ser, em vez de simplesmente o acúmulo do ser (GARBIN, 2011, p. 216).

Esse formato merece especial atenção em se tratando de organizações do terceiro setor que atuam com sustentabilidade, sobretudo pela vantagem de que, escutando pessoas de comunidades diretamente envolvidas com questões socioambientais, o líder precisa ser mais coordenador de processos e menos determinador de ações pré-concebidas.

\section{Autoritária}

Esse estilo de profissional costuma ser muito focado apenas na execução e no cumprimento de tarefas, regras e normas regidas pela empresa. Seu desempenho leva em consideração apenas as entregas alinhadas com as opiniões do chefe, o que reforça o individualismo das pessoas em que os profissionais são mais executores de tarefas delegadas e pouco ouvidos a respeito de possíveis adequações ou opiniões divergentes. 
Na prática, o gestor determina o que, como, quem fará as atividades, sem perguntar nada a ninguém. Trata-se de uma atitude que acaba sendo ineficiente, conforme já observado em diversos casos, pois gera insatisfação nos colaboradores, que rapidamente perdem engajamento e motivação.

Entre as características da liderança autoritária, estão o comando com base no poder, a extrema preocupação com processos, a crença de que os fins justificam os meios, a pouca habilidade para gerar retorno à equipe, a incapacidade de ouvir e a baixa competência para lidar com pessoas.

Esse tipo de gestor autoritário pode ser comparado a um ditador, considerando que, estando ou não presente no ambiente organizacional, sua figura remete à cobrança e punição severa em caso de erros ou divergências. O líder com esse perfil toma decisões de forma pessoal, desconsiderando em suas análises diversos fatores profissionais que devem predominar nas relações de trabalho.

Uma consequência imediata que esse modelo de liderança gera é a falta de mobilização das equipes, pois o sentimento de insatisfação predomina e os profissionais acabam se sentindo apenas uma máquina de execução de tarefas. No caso mais específico de comunicação, sustentabilidade e terceiro setor, esse comportamento é ainda mais inoperante, considerando a disposição da maior parte das pessoas em atuar em prol de uma causa mais coletiva, como o desenvolvimento social e o equilíbrio do meio ambiente.

\section{Coercitiva}

O líder coercitivo exige obediência imediata, assume um estilo de poder e determina à equipe o que deve ser feito e de que forma a atividade deve ser feita. Essa pessoa é controladora, critica o que acha que está errado e muito dificilmente elogia quando algum membro da equipe se destaca. Esse perfil é aquele que está sempre vigilante, nunca satisfeito e não elogia as iniciativas corretas e bem-sucedidas.

Em geral, essa prática não funciona, pois é raro encontrar alguém que aprecie um ambiente carregado com essa atmosfera. As novas gerações de profissionais que estão chegando ao mercado também estão sendo criadas com outro perfil, e oferecem ainda mais resistência a pessoas assim. No entanto, esse estilo pode funcionar em determinadas situações específicas, como em momentos de crise, por exemplo, que 
demandam um controle mais próximo de todas as atividades em que decisões rápidas e assertivas precisam ser tomadas para evitar o agravamento de alguma situação.

\section{Carismática}

Esse perfil de líder atua de forma mais afetiva e entende que a qualidade do relacionamento deve ser prioridade para a satisfação pessoal e, também, como motivador para a qualidade profissional. O líder carismático cria um ambiente de harmonia no time, pois acredita que o desempenho é consequência de um bom clima de trabalho.

Esse estilo é mais adequado em organizações que costumam lidar com situações de estresse, quando a equipe está sofrendo por alguma razão ou precisa recuperar a confiança. Cabe destacar que esse modelo, no entanto, precisa ser combinado com outros estilos pois, sozinho, pode gerar a falta de direcionamento e tolerância a desempenhos medíocres.

Característica imprescindível nesse caso é a capacidade de criar e manter relacionamentos sinceros e saudáveis. O líder carismático é autoconfiante e também sabe que as pessoas não querem ser controladas, mas sim orientadas. Porém, para se tornar um bom líder, o começo deve ser por si próprio. O profissional precisa se perguntar como se comporta quando as coisas não saem do jeito que gostaria e como costuma se sentir quando tem que agir sob pressão.

Assim, é importante ainda ser ponderado, saber dimensionar o potencial da equipe e ser um hábil comunicador para direcionar da forma mais criativa possível a solução de problemas e a otimização de oportunidades. Dessa forma, o líder, no ambiente organizacional, estabelece o conceito e delega a execução, permanecendo responsável por colocar as pessoas certas na hora certa e no lugar certo.

\section{Sensitiva}

Historicamente, a liderança tem sido associada à rigidez, disciplina e respeito à hierarquia, o que respaldava líderes incisivos, distantes, agressivos e implacáveis com seus subordinados.

No entanto, diante das inúmeras mudanças na sociedade e no ambiente organizacional, cada vez mais é perceptível uma mudança na forma de preparação das lideranças. Engana-se aquele quem acredita que sensibilidade e liderança não 
combina e que isso poderia enfraquecer a gestão. Em muitos casos, um líder sensível compreende que sua equipe é formada por seres humanos que também possuem expectativas diversas que precisam ser respeitadas.

Trata-se de uma mudança de percepção que tem criado novos caminhos e possibilitado mais proximidade entre os membros de uma mesma equipe. Essa configuração tem sido, cada vez mais, essencial, inclusive para organizações do terceiro setor que atuam com sustentabilidade para criar um ambiente seguro em que prevaleça confiança, comprometimento, produtividade, engajamento e dedicação.

Esta sensibilidade é fundamental para gerar colaboradores comprometidos e mais preparados para superar novos desafios. O líder com sensibilidade tem mais opções para reverter problemas iminentes e uma oportunidade para que sua equipe possa se desenvolver profissionalmente, mas, também, pessoalmente.

\section{Apreciativa}

Estilo que vem ganhando cada vez mais espaço nas organizações contemporâneas, está baseado na premissa de que, em vez de se concentrar no que está dando errado no local de trabalho, o líder deve conhecer e desenvolver o que funciona bem.

A liderança apreciativa defende o envolvimento total do líder com a equipe por meio de uma investigação positiva e do diálogo aberto para que todos se sintam incluídos e valorizados, inspirados e motivados. O objetivo é ter profissionais devidamente respaldados e preparados para vencerem juntos. A citação a seguir é de Diana Whitney, escritora norte-americana, consultora e educadora especialista nesse tema.

Liderança apreciativa é a capacidade relacional de mobilizar potencial criativo e transformá-lo em poder positivo - pôr em movimento ondas positivas de confiança, energia, entusiasmo e desempenho - para fazer uma diferença positiva no mundo (WHITNEY, 2011, p. 3).

Embora a sua implementação dependa, sobretudo, de um líder inclinado a adotar esse estilo, algumas técnicas também podem ser utilizadas para iniciar discussões, trocar ideias e desenvolver um plano de ação. Algumas ações simples podem manter a equipe engajada e disposta a trabalhar coletivamente para o mesmo objetivo. 
O ambiente em que predomina essa liderança tende a ser mais harmônico e criativo, pois os profissionais se sentem parte de um time que está aprendendo e se desenvolvendo junto, sem conflitos nem competitividade.

\subsection{Códigos da comunicação}

No processo comunicativo, a codificação consiste na transformação na elaboração de um sistema de signos ou significado em um determinado código conhecido. Uma vez codificada, a mensagem que chega ao receptor precisa ser decodificar, ou seja, decifrada a partir do repertório de cada pessoa.

\section{Idioma}

O idioma é um dos códigos mais conhecidos e utilizados pelo ser humano. Entre os exemplos, estão as línguas faladas e as línguas de sinais.

\section{Número}

Objeto da matemática usado para descrever quantidade, ordem ou medida. Este foi provavelmente foi um dos primeiros conceitos da matemática assimilados pela humanidade no processo de contagem.

\subsection{Meios, canais e formatos}

Os canais de comunicação e os formatos dizem respeito ao modelo sobre o qual a comunicação está estruturada. Adrian Furnham, professor de psicologia da University College London, membro da Sociedade Britânica de Psicologia, expresidente da Sociedade Internacional para o Estudo de Diferenças Individuais, autor de mais de 650 artigos científicos e 55 livros, defende a necessidade de determinação clara dos canais de comunicação.

As pesquisas mostraram que a escolha de um canal de comunicação pode afetar em muito o nível de clareza ou ambiguidade da mensagem que está sendo transmitida. O canal oral (conversas pelo telefone ou reuniões pessoais, por exemplo) são preferíveis ao canal por escrito, como anotações e memorandos, quando as mensagens forem ambíguas (e exigirem bastante assistência para serem interpretadas) 
ao passo que o canal por escrito é preferível quando a mensagem é clara (FURHAM, 2001, p. 43).

Como uma área em constante transformação, pode assumir diversas finalidades, estando os principais indicados a seguir.

\section{Anúncio publicitário}

O anúncio publicitário promove um conceito ou uma ideia em determinado meio de comunicação. Geralmente é financiado por empresas interessadas em aumentar a venda de produtos e serviços, mas também pode ser criado por organizações do terceiro setor interessadas em disseminar causas de seu interesse.

\section{Artigo}

Texto opinativo em que o autor defende seu posicionamento diante de algum tema atual e de interesse coletivo. Trata-se de um conteúdo dissertativo que apresenta argumentos sobre o assunto abordado e o sustenta, apresentando informações coerentes e dados consistentes. As ideias defendidas em um artigo de opinião são de responsabilidade do autor, e, por este motivo, é importante que haja um cuidado especial com a veracidade do material apresentado.

É muito comum que porta-vozes de organizações de todos os setores publiquem artigos em jornais, revistas e sites. Uma característica deste formato é a utilização da persuasão, com a tentativa clara do emissor convencer o seu leitor a incorporar a opinião apresentada. A linguagem, em geral, é objetiva e utiliza frases no modo imperativo para conferir maior clareza às ideias.

\section{Balanço social}

Conjunto de informações com apresentação das atividades de uma organização para a sociedade civil com objetivo de divulgar sua gestão econômicosocial e seu relacionamento com a comunidade como forma de prestação de contas e detalhamento das suas ações de responsabilidade social.

Cada vez mais, as empresas brasileiras têm sido mais cobradas da sociedade para serem mais comprometidas com o meio social em que atuam em um movimento em que ética, transparência e responsabilidade socioambiental têm tido relevância crescente. Com base nos indicadores de desempenho apresentados no Balanço 
Social, a organização planeja e executa um conjunto de atividades que resultem em benefícios aos empregados, à comunidade e ao meio ambiente.

\section{Blog}

Página de internet regularmente atualizada com textos organizados de forma cronológica e conteúdos diversos geralmente com hiperligações para outras páginas. Os leitores costumam ter a possibilidade de realizar comentários sobre o conteúdo publicado, despertando a possibilidade de interações. Na prática, o blog pode servir como evolução do diário pessoal, mas também como um espaço profissional para a disponibilização de conteúdos aos públicos de interesse de pessoas ou organizações.

\section{Campanha publicitária}

Termo utilizado pelos profissionais da área de publicidade para definir o conjunto de anúncios criados a partir de um determinado anunciante com uma duração específica. A campanha publicitária pode ser constituída por peças veiculadas em diferentes meios de comunicação, como rádio, televisão, jornais, revistas, mala direta, telemarketing, e e-mail marketing. O conteúdo, em geral, costuma ser respaldado em pesquisa de mercado.

A principal característica de uma campanha publicitária é que, independentemente do meio ou da ação explorada, as peças devem manter uma identidade entre si em termos editoriais e visuais para aumentar o impacto da campanha. Os avanços recentes da tecnologia estão mudando substancialmente a forma de criação de campanhas publicitárias pois o consumidor tem demonstrado mais interesse em receber conteúdos customizados, frequentemente via dispositivos móveis.

\section{Comunicado interno}

Embora possa parecer um meio de comunicação ultrapassado, o comunicado interno continua sendo importante por várias razões. Trata-se de um dos documentos oficiais mais comuns dentro das organizações, sendo responsável por informar e tornar público informações atualizadas e relevantes sobre qualquer procedimento ou acontecimento. 
É este recurso que mantém os colaboradores alinhados com o que está ocorrendo na organização, servindo como a versão oficial dos líderes da mesma e contribuindo para gerar um ambiente de trabalho mais transparente. Para que seja eficaz, o comunicado interno precisa ser claro, objetivo e escrito em uma linguagem simples.

\section{Curso e treinamento}

Processo de transmissão e aquisição de conhecimento e competências como resultado da formação individual ou do ensino de habilidades práticas relacionadas à determinadas competências. Modalidade frequentemente preparada pelas organizações de diferentes setores para atualização da equipe sobre novas práticas e procedimentos.

\section{Depoimento ou testemunhal}

Relatos elaborados, em geral, por clientes para referendar a qualidade ou a confiança em determinado profissional ou organização. Tem como base a demonstração de confiança e caráter de recomendação do serviço ou produto utilizado. O depoimento tem sido cada vez utilizado pelas organizações pois aproxima o interlocutor da organização que o utiliza ao praticar uma comunicação mais próxima e humana.

\section{Entrevista}

Conversa entre duas ou mais pessoas em que perguntas são realizadas pelo entrevistador para apurar as informações necessárias por parte do entrevistado. No caso do jornalismo, por exemplo, os repórteres entrevistam suas fontes para obter declarações que validem o que foi apurado ou que relatem situações vividas. Os entrevistados podem ser testemunhas ou pessoas com autoridade em determinado assunto que conhecem profundamente esse tema em particular ou que tenha uma trajetória ligada a ele.

\section{Evento}

Os eventos têm se profissionalizado cada vez mais como parte da estratégia organizacional de se relacionar com diferentes públicos. Há alguns formatos mais 
conhecidos de eventos, com características próprias e que atendem melhor a objetivos diferentes. Entre as opções, estão as seguintes: congresso, conferência, convenção, fórum, mesa redonda, painel, palestra, simpósio e seminário.

\section{Intranet}

Rede fechada de computadores, de uso exclusivo de uma determinada organização, como, por exemplo, a rede de uma empresa. O acesso ao seu conteúdo é restrito ao grupo de colaboradores internos previamente selecionados. Trata-se de um recurso de comunicação interna importante para disseminar informações de forma rápida e segura, sobretudo em organizações de grande porte que precisam transmitir informações para milhares de pessoas.

\section{Jornal interno}

Meio de comunicação, geralmente impresso, também utilizado com fins de comunicação interna. Costuma ser produzido a partir da concepção de um projeto editorial e gráfico alinhado com a identidade visual e reúne temas de interesse da organização. Além de ser um mecanismo importante de transmissão de informações, pode ser útil também como recurso de engajamento do público interno e seus familiares.

\section{Marketing digital}

Trata-se do conjunto de estratégias direcionadas para a promoção de marcas na Internet, diferenciando-se do marketing tradicional por envolver diferentes canais online e métodos que permitem a análise dos resultados em tempo real. Suas ações são produzidas com mensagens de apelo promocional ou informativo com o objetivo de vender, divulgar, prospectar ou fidelizar um público previamente selecionada com potencial de interesse no assunto tratado.

\section{Matérias da imprensa}

Conteúdo jornalístico criado com base na apuração de fatos e no testemunho dos personagens envolvidos em determinadas situações, explicadas por sua vez em um contexto. A reportagem, para facilitar a compreensão do conteúdo por parte do 
leitor, quando é noticiosa segue uma estrutura padrão com título, linha fina, lead e corpo da reportagem.

A reportagem é o relato em texto, áudio ou vídeo, de determinada ocorrência a partir do contexto para o público. Os textos com essas características têm a função de transmitir, com objetividade e transparência, as informações mais relevantes sobre o fato. A criação de reportagens precisa começar com uma apuração feita com qualidade para que os conteúdos, produzidos por jornalistas, sejam levados ao público respondendo às seguintes questões básicas: o que, quem, quando, onde, como e por que.

Em termos de estrutura gramatical, a reportagem jornalística geralmente apresenta frases curtas e ideias sucintas para evidenciar a objetividade do texto. E, embora possua uma linguagem denotativa, sem ambiguidades, jornais e revista abrigam diferentes gêneros textuais que podem, também, reunir conteúdos com linguagem figurada.

\section{Mídias sociais}

Sistemas tecnológicos e de comunicação projetados para possibilitar a interação de pessoas, grupos e organizações a partir do compartilhamento e da criação colaborativa de informações em diferentes formatos. As mídias sociais têm ocupado espaço crescente no Brasil por possibilitarem a publicação de conteúdos por qualquer pessoa que, com custo baixo ou inexistente, conseguir produzir e distribuir seus temas de interesse.

Considerando que os custos com propagandas, nos meios tradicionais, geralmente têm custos elevados, na Internet as divulgações por mídias sociais têm uma escalabilidade responsável por alcançar milhares de usuários com custos relativamente baixos. Elas estreitam o relacionamento entre pessoas e organizações, o que contribui para a resolução de problemas e a possibilidade de maior engajamento dos públicos.

\section{Mural}

Nas organizações, os jornais murais são ferramentas importantes de comunicação interna, geralmente posicionados em lugares com ampla circulação de para entregar, de forma dinâmica e eficiente, conteúdos relevantes aos funcionários. 
Geralmente, o jornal mural tem maior periodicidade em relação a outros meios de comunicação interna, sendo criado com textos curtos e linguagem clara. Dependendo do tipo de organização, ele pode ser o mais importante veículo de comunicação interna, sendo por isso necessário que seja elaborado a partir de um planejamento detalhado que considere o perfil editorial e gráfico da publicação.

\section{Newsletter}

E-mail informativo com recorrência de disparos em que a mensagem não é focada em uma oferta específica, mas em um conjunto de conteúdos atraentes que possam despertar no interlocutor a vontade de aderir e participar do que está sendo apresentado. Muitas vezes é uma forma de disseminação dos temas de interesse das organizações para seus públicos de interesse.

\section{Press release}

Considerado uma das principais ferramentas de assessoria de imprensa, 0 press release consiste em um texto jornalístico sobre um determinado cliente ou assunto específico. Este conteúdo não é enviado ao público em geral, mas diretamente aos jornalistas com uma linguagem e estratégia definidas.

$\mathrm{Na}$ maior parte das vezes o release é uma forma de divulgar algo relevante ao jornalista, que sempre tem interesse em receber materiais atualizados e relevantes para a elaboração de reportagens. Muitas vezes, o release pode ser publicado na íntegra, sobretudo pelos veículos de comunicação de pequeno e médio portes.

Nos veículos maiores, o principal objetivo do release é chamar a atenção do jornalista ao tema em questão, despertando nele o interesse em aprofundar a discussão.

Entre os pontos negativos, está o fato de que, como este formato é ostensivamente utilizado por praticamente todas as assessorias de imprensa, a concorrência costuma ser grande. Todos os dias, a imprensa recebe uma quantidade infindável de textos parecidos. É fundamental que os textos enviados sejam sempre de temas realmente relevantes, para de fato despertar a atenção do jornalista e mantêlo confiante da qualidade do seu material. 


\section{Rádio}

Recurso de telecomunicação utilizado para gerar uma comunicação bidirecional fundamentada na transmissão de dados e informações codificadas em um sinal eletromagnético que se propaga no espaço.

\section{Relatório de atividades}

Recurso utilizado para gerar transparência às ações e prestar contas à sociedade, em especial aos públicos de interesse, do trabalho desenvolvido durante determinado período. No documento, geralmente, as principais realizações e os indicadores de sucesso de cada área e da organização são destacados.

\section{Relatório de sustentabilidade}

Conteúdo com crescente utilização por parte de muitas empresas em todo o mundo, que tem publicado relatórios de sustentabilidades com base nas diretrizes do Global Reporting Iniciative (GRI). Elaborados ou não a partir desse modelo, os relatórios de sustentabilidade apresentam os progressos da organização em relação à sustentabilidade, sendo uma ferramenta importante para a identificação das principais ações socioambientais.

\section{Revista}

Publicação periódica de caráter informativo, jornalístico ou de entretenimento direcionada para o público em geral ou grupos específicos.

\section{Site}

Site é um conjunto de páginas online compostas por textos, imagens, animações e, eventualmente, sons. Frequentemente é utilizado para apresentação de empresas, produtos, notícias, informações e comércio. Presentes na maioria das organizações contemporâneas, os sites são considerados hoje espaços estratégicos para a visibilidade da organização e da sua comunicação organizacional.

\section{Televisão corporativa}

Meio que vem mostrando utilidade crescente e resultados importantes sobretudo em organizações de médio e grande portes, em que muitos colaboradores 
precisam ter acesso a informações e novidades. Em geral ela tem ótima inserção, pois chama a atenção do público, que recebe o conteúdo de forma mais interessada e espontânea.

\subsection{Estilos de linguagem}

Faculdade cognitiva que permite aos seres humanos aprender e usar sistemas de comunicação complexos. Ela está fundamentada em um diversificado sistema de símbolos repletos de significados que resultam em um número indefinido de expressões.

O uso da linguagem tem se tornado presente na história da evolução humana no processo de comunicação e, também, como expressão de identidade e de estratificação social.

Figura 7: Estilos de linguagem na comunicação para a sustentabilidade

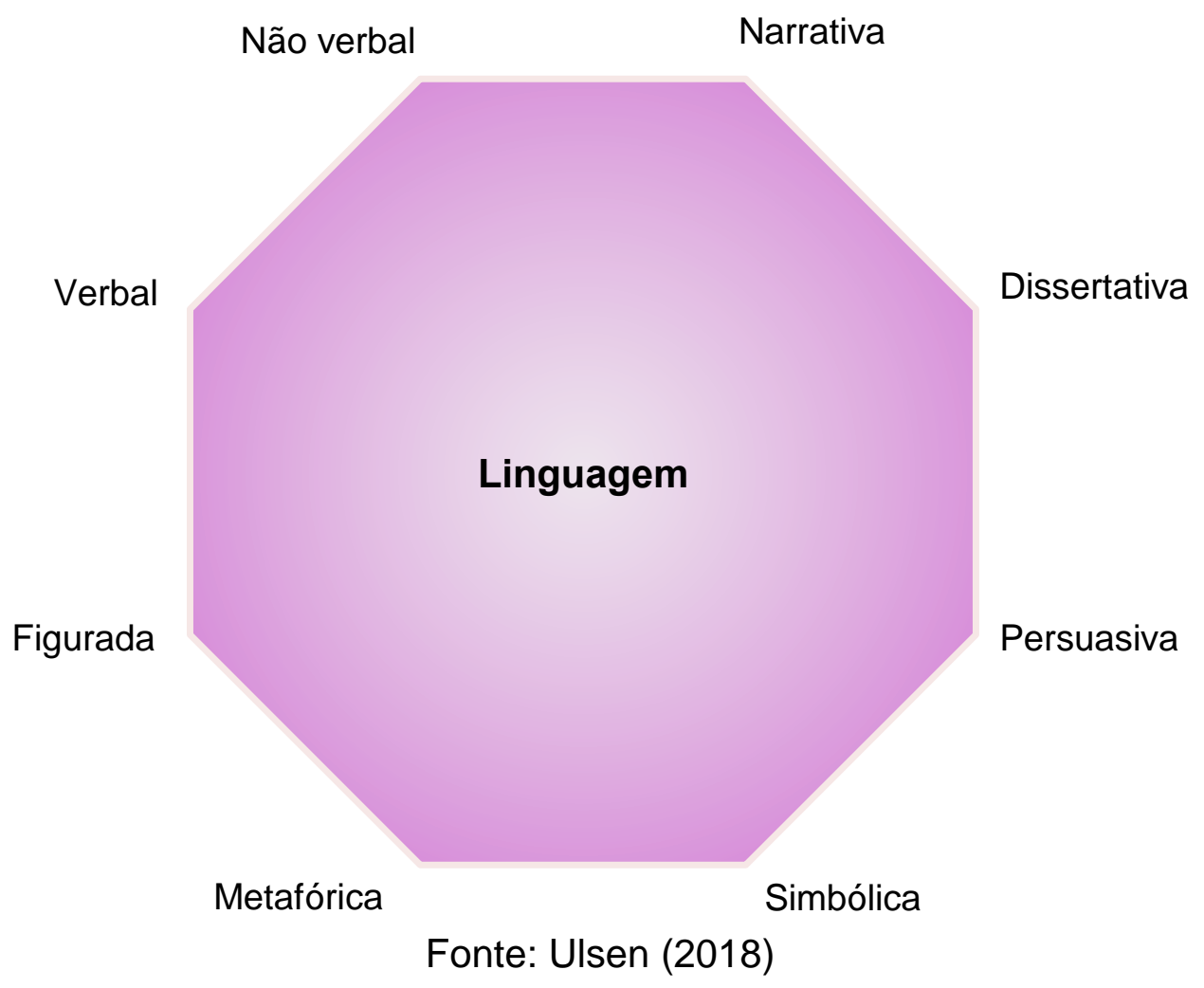




\section{Narrativa}

A narração é um tipo de texto que relata determinada sequência de fatos, reais ou imaginárias, em que os personagens atuam em um espaço e tempo. A linguagem narrativa está baseada em uma história apresentada por um narrador e é construída em certa estrutura e os seus elementos incluem. A narrativa costuma ser centrada em um conflito vivido pelos personagens, que são retratados com suas características físicas e psicológicas. Normalmente há um protagonista (personagem principal) e um antagonista (aquele que age contra o protagonista). As narrativas também costumam destacar a presença de coadjuvantes, os personagens secundários que também fazem parte da história.

\section{Dissertativa}

Palavra originada do latim disertatio, é uma modalidade de redação escrita em prosa ou apresentada de forma oral a respeito de determinado tema sobre o qual se se apresentam e discutem argumentos, provas e exemplos. A dissertação pressupõe a aplicação de um método de análise e interpretação.

Em termos de estrutura, a dissertação pode incluir descrições, narrações e comparações apresentadas, geralmente em três partes principais: introdução, com apresentação da ideia principal de acordo com o tema; desenvolvimento, para a articulação dos argumentos; e conclusão, com o resumo das ideias discutidas e a revelação dos resultados finais.

\section{Persuasiva}

A persuasão é uma estratégia de comunicação que consiste na utilização de recursos emocionais ou simbólicos com o objetivo de induzir alguém a aceitar determinada ideia ou realizar uma ação. O discurso criado dessa forma reúne argumentos, legítimos ou não, para convencer outras pessoas a adotarem alguma decisão, conduta, teoria ou crença.

A publicidade tem investido muito em pesquisas sobre a área de psicologia para entender melhor como pode otimizar a venda de produtos ou serviços, da seleção das mensagens até o horário mais adequado para exibição da propaganda. Nesse caso, a persuasão depende muito de como o consumidor recebe as informações e qual é o grau de credibilidade e relevância que atribui à mensagem e a quem a emitiu. Quanto 
maior o prestígio da organização que a produziu, melhor será o poder de recepção do conteúdo.

O processo de persuasão pode ocorrer pacificamente ou de maneira coercitiva, com o uso de ameaças ou violência. A persuasão, dependendo do objeto e da forma de manipulação, pode gerar efeitos jurídicos e configurar crime. Além disso, muitas vezes a persuasão está inserida em conteúdos ideologicamente produzidos para influenciar as atitudes e percepções de indivíduos e grupos sociais.

\section{Simbólica}

A linguagem simbólica é uma forma de expressão do inconsciente e apresentase, sobretudo, como imaginação. Além disso, ela gera imagens, é fortemente emotiva, tem apelo afetivo e seu conteúdo revela significados diferentes. Uma das obras mais conhecidas sobre o tema foi publicada pelo psiquiatra suíço Carl Gustav Jung (18751961) com o título de "O homem e seus símbolos". O conteúdo reúne os principais conceitos formulados por Jung sobre símbolos e o inconsciente coletivo para o público leigo. Além de ser um trabalho relevante para psicólogos, ele também é essencial para comunicadores, estudiosos de religiões e antropólogos.

\section{Metafórica}

A metáfora é uma figura de linguagem em que uma palavra ou expressão é utilizada em um sentido não muito comum, mas que revela uma relação de semelhança entre dois termos. Ela consiste na comparação de palavras em que um termo substitui outro subentendido. No cotidiano da comunicação interpessoal, a metáfora é um recurso frequentemente utilizado para as pessoas expressarem o que realmente estão sentindo.

\section{Figurada}

Consiste na utilização de figuras de linguagem para expressão de um sentido não literal. Ela costuma ser usada para gerar mais expressividade ao discurso ou criar significados diferentes dos habituais. Importante destacar que a interpretação da linguagem figurada depende do repertório de cada pessoa, pois é um tipo de linguagem que depende muito da interpretação. 


\section{Verbal}

A comunicação verbal corresponde à transmissão de informações desenvolvida por meio da linguagem falada. O sucesso dessa comunicação depende da clareza das mensagens e está diretamente relacionado com o vocabulário das pessoas envolvidas nesse processo. Apesar de todos os avanços tecnológicos, a comunicação verbal ainda é fundamental para a transmissão de informações nas relações interpessoais.

\section{Não verbal}

Comunicação não verbal é a expressão do pensamento por meio de elementos comunicativos sem o uso de palavras. São exemplos placas, figuras, gestos, objetos e cores. O uso da simbologia é uma forma de comunicação não verbal, muito utilizada em charges, desenhos e anúncios publicitários. Com a combinação destes elementos, é possível explorar ideias e conceitos sendo que o nível de conhecimento de cada interlocutor é o que determina a capacidade de interpretação.

Ela é tão importante que, mesmo entre diferentes países, com pessoas de culturas e idiomas distintos, há elementos corporais universais que facilitam a compreensão de algumas mensagens.

Além disso, a comunicação não verbal está sendo valorizada, inclusive por conta do avanço da tecnologia, que utiliza ícones para complementar a fala ou estabelecer a comunicação entre duas pessoas. Da mesma forma, os sinais corporais também têm sido essenciais, em um mundo mais globalizado e plural, para facilitar a troca de informações entre as pessoas.

Neste caso, cabe destacar a contribuição do famoso livro "O corpo fala: a linguagem silenciosa da comunicação não verbal" (2013), de Pierre Weil e Roland Tompakow. Em determinado momento da obra, eles respaldam suas pesquisas em Ray Birdwhistell, antropólogo americano, fundador da cinesia como um campo de pesquisa com foco no estudo de expressões faciais, gestos e posturas como forma de comunicação.

Birdwhistell estima entre 2.500 e 5.000 - e às vezes até 10.000 "bits" (unidades simples) - o número de sinais informativos que fluem, por segundo, entre duas pessoas. Isto, evidentemente, inclui todas as mudanças que possam, em grau mínimo, ser discernidas por aparelhos registradores de alterações nas faixas percebidas como 
som, imagem, temperatura, tato, odor corporal etc. (WEIL; TOMPAKOW, 2013, p. 20).

Seguindo ainda com a contribuição de Birdwhistell, o pesquisador norteamericano Ray Birdwhistell fez uma estimativa da proporção verbal e não verbal do comportamento e chegou à conclusão que até $55 \%$ das mensagens são transmitidas via linguagem corporal. Segundo o mesmo estudo, a voz é responsável por 38\% dessa transmissão e, as palavras, apenas por $7 \%$.

\subsection{Sentidos humanos}

O corpo humano é composto por sentidos que formam o sistema sensorial, responsável por enviar as informações obtidas ao sistema nervoso central, que analisa e processa a informação recebida. Essas capacidades estão relacionadas e correspondem às percepções das pessoas no mundo, o que ocorre por meio da tradução, análise e processamento das informações sensoriais. A citação a seguir, embora trate mais especificamente de publicidade, é importante para destacar a importância da integração dos sentidos na criação de peças de comunicação.

Como seres humanos, somos de longe mais receptivos quando operamos nas cinco faixas (nossos cinco sentidos); ainda assim, pouquíssimas campanhas publicitárias se preocupam em usar mais do que a visão e a audição para transmitir suas mensagens. (LINDSTROM, 2011, p. 14)

Com base nessa compreensão, na Figura 8 estão apresentados cada um dos sentidos e a relevância que eles têm nesse movimento de comunicação para a sustentabilidade. 
Figura 8: Sentidos humanos na comunicação para a sustentabilidade

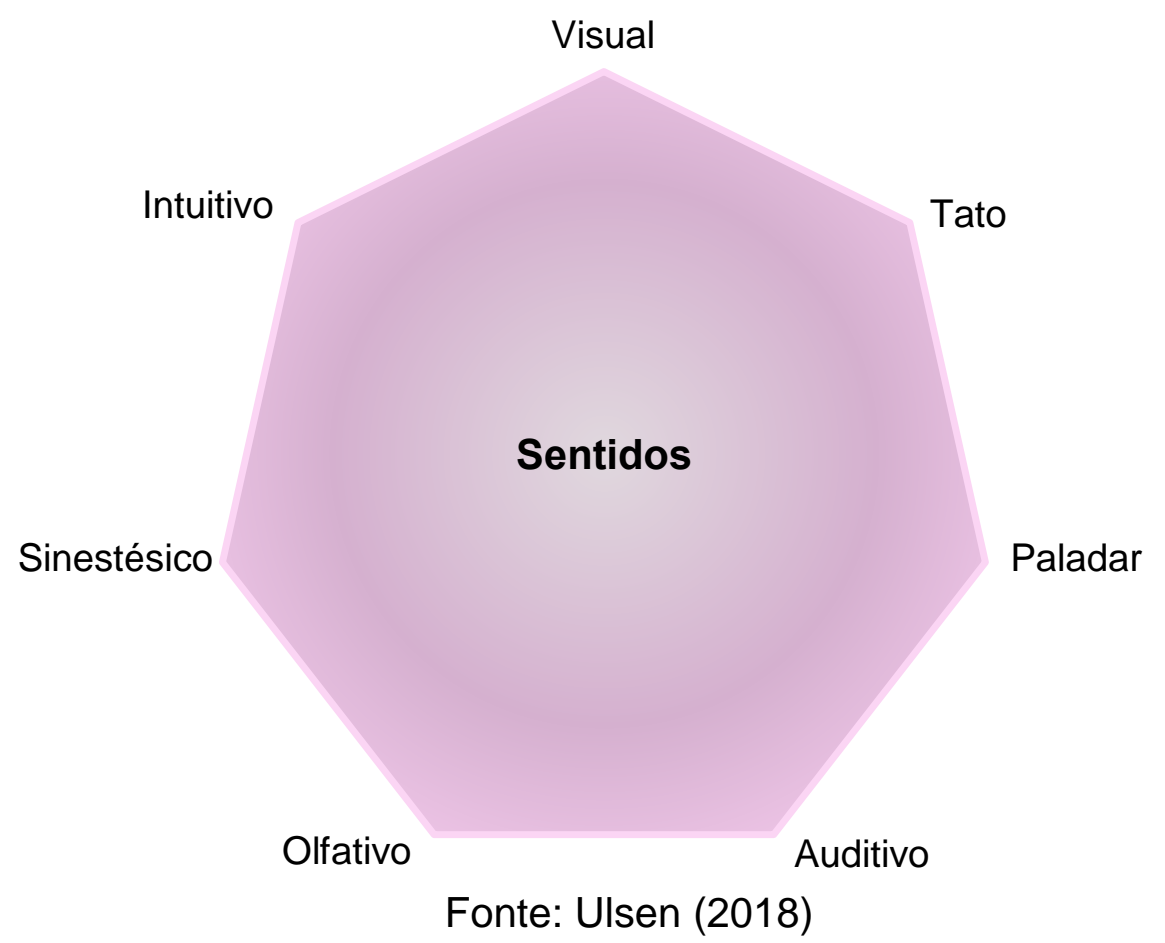

\section{Visual}

Os olhos são os órgãos responsáveis pela visão, possivelmente o sentido mais utilizado pela maioria das pessoas. Em termos de publicidade, trata-se do sentido mais explorado pois é pela aparência que os consumidores costumam ter o primeiro contato com determinado produto novo. Esse entendimento está também associado com uma cultura que reforça o paradigma de que uma imagem comunica mais que mil palavras.

Nesse sentido, existem elementos importantes para serem observados e trabalhados, como é o caso das cores e dos formatos, responsáveis por diferenciar produtos concorrentes a partir do estímulo às emoções do interlocutor.

\section{Tato}

Diferentemente dos outros sentidos, o tato não está delimitado a apenas uma região específica, mas está presente em todas as regiões do corpo. A pele é o maior órgão do corpo humano, sendo repleta de terminações nervosas capazes de captar estímulos térmicos, mecânicos ou dolorosos.

O sentido do tato é o primeiro a se desenvolver em um recém-nascido e é essencial para o desenvolvimento da criança, pois é por meio do toque que ela recebe 
estímulos de outras pessoas e adquire confiança e autoestima. O tato também é o único sentido que permanece alerta enquanto o indivíduo está dormindo e opera como uma espécie de guarda do sono.

Pessoas com deficiência visual podem escrever e ler textos, números e notas musicais utilizando os dedos por conta da grande quantidade de receptores táteis existentes nas pontas dos mesmos. Criado pelo francês Louis Braille, o alfabeto em braille pode ser muito útil nesse sentido, sendo um dos sentidos por meio do qual a comunicação pode ser praticada.

\section{Paladar}

Trata-se de uma sensação química percebida por células específicas, denominadas papilas gustativas, localizadas na língua e palato que promovem sensações táteis e relacionadas aos sabores. O paladar e o olfato estão quimicamente ligados e integrados, sendo o primeiro despertado pelo olfato.

\section{Auditivo}

Capacidade de perceber sons. Funciona a partir das ondas sonoras, que chegam até o aparelho auditivo, vibram o tímpano e, depois, os três ossos da orelha (martelo, bigorna e estribo). Assim, as vibrações são transmitidas à cóclea, quando se tornam impulsos nervosos transmitidos ao cérebro pelo nervo auditivo.

\section{Olfativo}

As narinas são responsáveis pela captação dos odores. Ao respirarmos, milhares de moléculas são transportadas às nossas fossas nasais, quando impulsos nervosos são gerados e transmitidos até nosso cérebro, que os interpreta e nos gera a sensação de cheiro. O sabor dos alimentos, por exemplo, não é gerado somente pelo paladar, mas também pelo olfato, que absorve o vapor dos alimentos. $O$ ser humano tem habilidade de se recordar de situações vividas, e isso pode ser estimulado por alguma associação ao cheiro de determinada lembrança.

Segundo Mark Batey, consultor e professor de publicidade, o olfativo é o "sentido que tem acesso neurológico direto ao sistema límbico do cérebro - que guarda e intermedia as memórias" (Batey, 2010, p. 117), o que faz com que as memórias sejam rapidamente acessadas por meio deste estímulo. 


\section{Sinestésico}

Fenômeno que consiste na produção de duas sensações diferentes a partir de um único estímulo. Ele se caracteriza como uma experiência sensorial em que sensações correspondentes a certo sentido são associadas a outro sentido. Trata-se de um campo de estudos recente e novas pesquisas proporcionarão uma melhor compreensão sobre o tema.

\section{Intuitivo}

A interpretação do mundo pelo homem é criada a partir da análise que seus sentidos proporcionam, por meio de um conhecimento que se constrói por meio de memórias de experiências passadas e comparações com situações atuais. Trata-se da análise por associação, que entende mecanismos de causa e consequência.

Intuição é um processo pelo qual os humanos chegam a uma conclusão sobre algo por meio de uma percepção do inconsciente. Seu funcionamento tem sido tema de muitos debates e, apesar de já existirem teorias mais consolidadas sobre o assunto, nenhuma delas é dada ainda como definitiva. Na prática, a intuição leva o sujeito a acreditar, com determinação, que algo poderá acontecer. Ela consiste na capacidade de saber algo sem compreender seu funcionamento e está fundamentada em uma experiência sensorial.

Para o filósofo francês Henri Bergson, intuição significa apreensão imediata da realidade, por coincidência, com o objeto. Trata-se, para ele, da realidade sentida e compreendida absolutamente de modo direto, sem utilização das ferramentas lógicas do entendimento, como análise e tradução. Assim, a intuição é uma forma de conhecimento que acessa diretamente o ser humano sem a racionalização. Isso porque a análise é o recorte da realidade e a tradução é a composição de símbolos que também servem de mediadores.

Henri Bergson, que também foi um dos primeiros a fazer referência ao inconsciente, foi o expoente da linha de filosofia intuicionista, assim considerada pois defende que o verdadeiro conhecimento não ocorre por meio do intelecto racional, mas na apreensão imediata da intuição. Segundo o filósofo, há duas formar para se conhecer determinado objeto: mediante o conceito e mediante a intuição. 


\subsection{Frequência cerebral}

O cérebro opera por meio de impulsos elétricos, que formam ondas eletromagnéticas com quatro frequências distintas. As células cerebrais (neurônios) utilizam esses impulsos elétricos para se comunicarem entre si e fazer os músculos contraírem para que os membros e o corpo se movimentem. Cada neurônio produz uma descarga elétrica com para se comunicar com as outras células.

Considerando que o cérebro possui atividade elétrica, ele gera ondas eletromagnéticas que podem ser medidas por aparelhos, como é o caso do eletroencefalograma, que classifica as ondas elétricas cerebrais em frequências em ciclos ou hertz $(\mathrm{Hz})$.

A atividade cerebral é constante na atividade humana e sempre opera em qualquer processo de comunicação, razão pela qual está detalhada na Figura 9. Não existe nenhuma comunicação intrapessoal ou interpessoal que não envolva a atividade mental em determinadas frequências cerebrais.

Figura 9: Níveis de ondas cerebrais

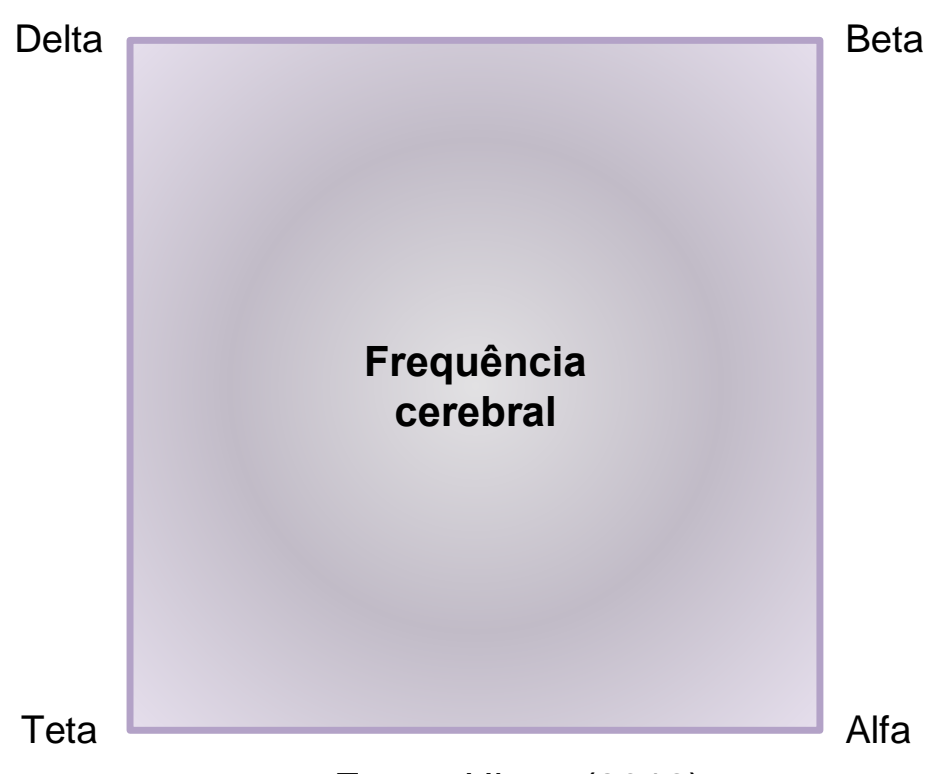

Fonte: Ulsen (2018)

\section{Beta}

Neste estado a pessoa está acordada e a mente está concentrada, pronta para trabalhos que exigem atenção total. Esta frequência situa-se entre os 13 e $30 \mathrm{~Hz}$, e 
está associada à atenção, à acuidade visual e à coordenação motora, atividades práticas, corriqueiras fundamentais em processos que envolvam a concentração, como a aprendizagem, a análise e organização de informações.

\section{Alfa}

Neste estado a pessoa está mais relaxada e menos ansiosa, o que amplia a percepção da consciência interna, dos pensamentos, das sensações, emoções e conflitos internos. Quando uma pessoa está em alfa, tende a ampliar sua criatividade e a experimentar uma sensação de bem-estar. Situada na frequência de 7 a $13 \mathrm{~Hz}$, a faixa alfa também está associada à resolução de problemas, à memorização, ao relaxamento, ao pensamento abstrato e à imaginação.

\section{Teta}

Estado um pouco mais profundo de relaxamento, a atividade cerebral diminuiu a cai praticamente ao nível do sono. Aqui passam a surgir imagens inconscientes com origem indeterminada. $\mathrm{O}$ nível teta situa-se entre 4 e $7 \mathrm{~Hz}$, gerando na pessoa a sensação de estar sonhando acordada, com propensão ideal de acesso a memórias, aprendizagem acelerada, criatividade e reprogramação mental.

\section{Delta}

Nível situado entre 0,1 e $4 \mathrm{~Hz}$, é o mais baixo de todas as frequências de ondas cerebrais. É a condição em que se produz a regeneração celular, a cura e o acesso profundo ao inconsciente e à intuição. Este nível, assim como os demais, pode ser atingido mediante a aplicação de técnicas já amplamente conhecidas, como o relaxamento e a hipnose.

\subsection{Públicos de interesse}

O profissional da comunicação que conhece bem os seus públicos sabe que lidar com a multiplicidade deles é um grande desafio. É cada vez mais evidente que não basta a organização pensar sempre a partir de si própria na veiculação de suas mensagens e agir somente como emissores de conteúdo. 
Os públicos influenciam a comunicação das organizações e estabelecem dinâmicas próprias para isso. Esses mesmos públicos têm acesso a meios de comunicação capazes de reproduzir suas mensagens para a própria organização e, também, para outros públicos.

Lidar com a variedade de públicos em um trabalho de comunicação para a sustentabilidade acrescenta, na atuação do gestor de comunicação, a definição clara de qual mensagem está sendo enviada, por qual canal, com qual linguagem, para qual público e uma previsão de como o interlocutor deve reagir a esta mensagem. A sistematização a seguir propõe o mapeamento de públicos estratégicos nesse processo.

\section{Comunidades locais}

População humana organizada que vive próxima a determinado espaço, como por exemplo a comunicação do entorno de empresas. Em escala pequena, a comunidade local integra população e território.

\section{Consumidores}

Definido como pessoas físicas ou jurídicas que adquirem algum produto ou serviço. O consumidor tem acesso a diferentes opções de escolha, participando do processo de compra e venda desde a sua concepção até o seu consumo. Ele é essencial em uma estrutura capitalista pois o consumo de produtos e serviços é uma forma de impactar na economia das empresas e dos países.

\section{Entidades de classe}

Podem ser entendidas como um conjunto organizado de pessoas de mesma categoria profissional com personalidade de direito. Elas estão constituídas em associações ou sociedades civis conhecidas como institutos, clubes, centros, ordens cooperativas, sindicatos ou partidos políticos, entre outros.

\section{Fornecedores}

Aquele que fornece mercadorias ou serviços ao consumidor. Segundo o Código de Defesa do Consumidor, fornecedor é toda pessoa física ou jurídica, pública ou privada, nacional ou estrangeira, que desenvolve atividades de produção, montagem, 
transformação, beneficiamento, acondicionamento, criação, construção, importação, exportação, distribuição ou comercialização de produtos ou prestação de serviços.

\section{Funcionários}

Profissional que desempenha função remunerada em estabelecimento público ou particular. Também é sinônimo de empregado e se constitui no público interno mais importante de qualquer organização. Ele deve receber atenção especial da comunicação como forma de reconhecer o significado do seu trabalho e ser um representante legítimo das iniciativas da organização.

\section{Imprensa}

Definição coletiva dos veículos de comunicação que atuam com jornalismo e outras atribuições de comunicação noticiosa. Embora o momento atual seja de diminuição do poder da imprensa no Brasil, os jornalistas continuam sendo um público estratégico para as organizações, sobretudo para levar ao público análises confiáveis e com credibilidade.

\section{Investidores}

De acordo com a Instrução da Comissão de Valores Mobiliários (CVM) 554/2014, investidores profissionais são pessoas físicas e jurídicas que possuem aplicações financeiras em valor igual ou superior a $R \$ 10$ milhões. São investidores também instituições financeiras, companhias seguradoras, sociedades de capitalização, entidades de previdência complementar, fundos de investimento, clubes de investimento, agentes autônomos de investimento e administradores de carteira

\section{ONGs}

Organizações sem fins lucrativos, constituídas formalmente e autonomamente, caracterizadas por ações de solidariedade para a criação de políticas públicas e o exercício de pressões em benefício de alguma causa coletiva. No Brasil, o termo Organização Não Governamental (ONG) não tem valor jurídico, sendo que a qualificação de Organização da Sociedade Civil de Interesse Público (Oscip) é o reconhecimento legal mais próximo do que se entende por ONG. 


\section{Poder público}

Conjunto dos órgãos com autoridade para realizar os trabalhos do Estado, constituído de Poder Legislativo (aquele que cria e modifica leis), Poder Executivo (aquele que desenvolve políticas de governo) e Poder Judiciário (aquele que aplica essas normas). Os poderes públicos estão associados aos organismos estatais e são responsáveis pela garantia das condições de desenvolvimento e justiça social.

\section{Universidades}

Instituições de ensino superior de formação de profissionais de nível superior, pesquisa e extensão. A universidade fornece educação em nível de graduação e pósgraduação e tem autonomia para executar suas finalidades administrativas e pedagógicas, ainda que sob acompanhamento do Estado.

\section{Voluntários}

Pessoa que realizam determinada ação, de livre e espontânea vontade, sem o recebimento de qualquer remuneração ou lucro. Um voluntário está, normalmente, inserido em um programa de voluntariado, um conjunto de ações de interesse social e comunitário em que todas as atividades desempenhadas são revertidas em benefício de uma causa coletiva. $\mathrm{O}$ trabalho voluntário tem sido importante para o crescimento das organizações do terceiro setor.

\subsection{Repertório envolvido}

Todo e qualquer processo de comunicação humano está, necessariamente, inserido em um intercâmbio de percepções e conhecimentos distintos. Cada ser humano é único e, por diferentes razões, reúne repertórios diferentes de forma que estar alinhado com os níveis dos repertórios dos interlocutores sempre amplia o potencial da comunicação. 
Figura 10: Repertórios envolvidos para interpretação das mensagens

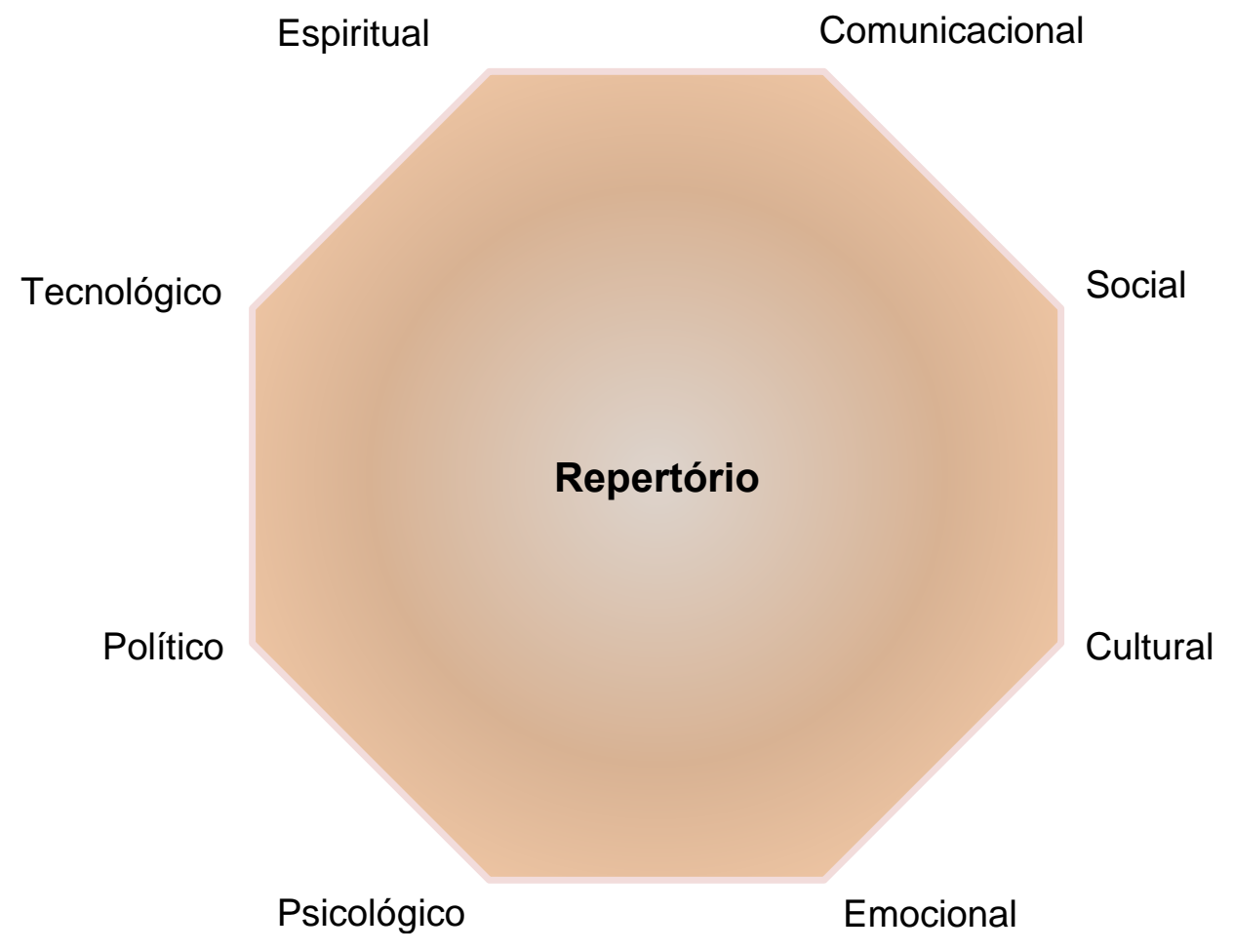

Fonte: Ulsen (2018)

\section{Comunicacional}

Diz respeito ao conhecimento acumulado de cada um e às habilidades desenvolvidas em termos de comunicação. Como exemplos do repertório comunicacional estão o vocabulário utilizado, a correção gramatical e o domínio linguístico. Importante destacar que a comunicação humana, ao envolver o intercâmbio de informações, envolve o encontro de experiências distintas, podendo levar a ruídos e interpretações equivocadas sobre determinadas mensagens.

\section{Social}

Está relacionado com a origem social das pessoas envolvidas com determinado processo de comunicação. Especialmente no Brasil, em que as diferenças de origem social são contrastantes, a vivência de cada um exerce influência direta na formatação de diferentes repertórios. Para que a comunicação seja efetiva, o leigo em determinado assunto deve adquirir parte dos conhecimentos do interlocutor e, aqueles que narram determinadas situações, também precisam saber traduzir a complexidade 
de termos técnicos para o outro. Um dos segredos para a boa comunicação organizacional é considerar o repertório social do interlocutor.

\section{Cultural}

O repertório cultural é a integração dos conhecimentos acumulados por determinada pessoa em sua vida e abrange as experiências praticadas, como grau de escolaridade, habilidades, competências, leituras e acesso a demais elementos de formação, como peças de teatro, filmes, exposições, cursos e viagens, entre outros.

$\mathrm{Na}$ prática, trata-se do conjunto de vivências profissionais e pessoais que 0 profissional agrega, o que define a personalidade e a compreensão de mundo deste indivíduo. Para que a comunicação flua com excelência, os repertórios culturais dos participantes devem estar alinhados para que os envolvidos compartilhem a mesma linguagem. Além disso, essa convergência é necessária pois muitos conflitos de relacionamentos ocorrem em decorrência do encontro de diferentes repertórios e da incapacidade dos envolvidos de compreender o ponto de vista do outro.

\section{Emocional}

A receptividade ou rejeição a determinadas mensagens também passam pelo crivo emocional das pessoas envolvidas. A emoção é uma resposta do organismo diante de estímulos externos, o que pode causar consequências fisiológicas em determinadas situações, como nervosismo, euforia ou estímulo corporal. Emoções e sentimentos estão estreitamente relacionados, sendo que, entre as emoções mais desejáveis, está a felicidade. As emoções podem ser entendidas como algo pessoal, mas também podem ser manifestadas de maneira coletiva em grupos que compactuam de percepções similares.

\section{Psicológico}

Está relacionado aos comportamentos individuais e sociais e às funções mentais associadas aos processos fisiológicos e biológicos que acompanham as funções cognitivas. As mensagens transmitidas também passam pelo filtro da constituição psicológica humana que integra conceitos como percepção, cognição, atenção, emoção, Inteligência, fenomenologia, motivação, personalidade, comportamento e relacionamentos interpessoais. Além das áreas terapêutica e 
científica, a psicologia aplicada também é utilizada em áreas mais relacionadas ao comportamento humano, como a psicologia do trabalho nos ambientes organizacionais, a psicologia educacional, a psicologia esportiva, a psicologia da saúde, a psicologia do desenvolvimento e a psicologia jurídica.

\section{Político}

Diz respeito à influência que a orientação política e a qualificação para entender essa área encontra similaridades ou conflitos com o interlocutor, podendo abrir ou fechar canais de comunicação. O Brasil hoje assiste a constantes conflitos, especialmente nas mídias sociais, de defensores e acusadores de determinadas correntes e partidos políticos. Curioso observar que, ainda que as pessoas tenham percepções semelhantes, muitas vezes entram em conflito ao acusar o interlocutor de determinadas posturas políticas e fecham o acesso para dialogar sobre outros temas comuns de interesse.

\section{Tecnológico}

O repertório tecnológico diz respeito à capacidade de as pessoas manipularem e integrarem à rotina a utilização de dispositivos capazes de codificarem e decodificarem suas mensagens. Em se tratando de comunicação organizacional para a sustentabilidade, o nível de qualificação dos públicos de interesse em utilizar ou não tais dispositivos é fator determinante para a frequência da transmissão de mensagens por meio desses recursos.

\section{Espiritual}

Propensão humana na busca de significado para a vida por meio de mecanismos que transcendem o tangível para a procura de um sentido de conexão com algo maior. A espiritualidade é vivida por aqueles que buscam alcançar a plenitude da sua existência com relação com elementos transcendentais.

\subsection{Perfil do gestor}

Em termos de convergência entre comunicação e sustentabilidade, o grande desafio que se apresenta é a clara conceituação do tema proposto e a prática do 
discurso. Nas organizações, as ações são mais desenvolvidas quando planejadas, sendo o gestor de comunicação estratégico para estabelecer conexões entre todas as áreas da organização. A comunicação para a sustentabilidade requer um trabalho efetivo e pode oferecer às gerações futuras o desenvolvimento da sustentabilidade como um valor.

Retomando a dissertação de mestrado defendida por Pedro Ulsen (2012) na Escola de Comunicações e Artes da Universidade de São Paulo (ECA-USP), percebese que existe um perfil mais preparado para esta atuação. Ele é essencial, pois é o profissional que lida com as narrativas, produz os materiais de comunicação e os oferece de modo customizado para os púbicos envolvidos.

Assim, foi desenvolvida uma sugestão de perfil do gestor de comunicação que contemple os elementos de formação, tendências contemporâneas, tendências de mercado, atribuições, competências, habilidades, perspectiva de atuação, valores, posicionamento e desafios, conforme defendido por mim no livro "O perfil do gestor de comunicação: como gerar impacto e promover a sustentabilidade" (Ulsen, 2017).

\section{Formação}

O foco sobre a formação dos profissionais de comunicação decorre de diferentes fatores, inclusive dos desafios contemporâneos. Uma obra de valiosa contribuição para estas discussões foi publicada em 2007 sob o título "Ensino de comunicação: qualidade na formação acadêmico-profissional", organizada por Margarida Kunsch, com doze artigos oriundos do I Fórum Nacional em Defesa da Qualidade do Ensino de Comunicação (Endecom).

O artigo da organizadora do livro, "Perspectivas e desafios para as profissões de comunicação do terceiro milênio", apresenta uma extensa análise sobre a comunicação, seu poder e as perspectivas de expansão. A autora encerra o texto defendendo uma formação mais integrada.

O perfil desejado do formando em comunicação social hoje envolve uma carga de formação geral humanística e técnico-profissional que o capacite a ser um agente comprometido com as transformações sociais, não um mero técnico-profissional, preocupado apenas com o "fazer" e o "como-fazer" (KUNSCH, 2007a, p. 100). 
Nesta obra, o texto "Comunicação corporativa: profissão do futuro", escrito por José Luiz Schiavoni, apresenta uma trajetória histórica do gestor de comunicação apresentada e defende a integração entre formados em jornalismo, relações públicas e publicidade é defendida.

Transitando para a transdisciplinaridade da comunicação, é oportuno retomar Edgar Morin (2006), que trata da desunião entre o pensamento cartesiano e o humanista. Segundo ele, o conhecimento não deve ser dividido em especializações, mas tratados sob uma nova visão mais ampla. Ao tratar do ensino universitário, por exemplo, Morin também trata do desafio de se reinventarem.

\section{Tendências contemporâneas}

Interpretar o contexto contemporâneo é essencial para compreender os conceitos apresentados até o momento. No livro "Condição Pós-Moderna", David Harvey (2010) aborda a evolução da modernidade para a pós-modernidade e as mudanças culturais, políticas e econômicas envolvidas. Para o autor, existe uma relação da ascensão de formas culturais pós-modernas com a flexibilização dos formatos de acumulação do capital com uma nova compreensão do tempo-espaço e a criação de novas redes mais diversas e complexas de interação social. Trata-se de um momento de reestruturação das relações de trabalho, com subcontratação, inseguranças e incertezas.

Castells (2003) afirma que a Internet reitera e amplia a flexibilidade da comunicação, alterando o relacionamento de organizações com investidores, fornecedores, compradores e funcionários e sendo decisiva para a produtividade. Para o autor, trata-se de um recurso de elevada capacidade, velocidade e interatividade, sendo que também é uma tendência o fato do mercado apresentar uma interdependência crescente com negociações mais rápidas e competitivas.

\section{Tendências profissionais}

Em termos de tendências profissionais é válido destacar o atual momento de instabilidade já adiantado anteriormente. Nas organizações brasileiras é tem se tornado comum a migração para um modelo de insegurança, o que reforça a mais flexibilidade dos profissionais em termos de relacionamentos. Isso está inserido em um contexto mais amplo da pós-modernidade, sendo que há outros fatores que 
influenciam as tendências, como a globalização, a própria sustentabilidade e a busca crescente das pessoas por mais bem-estar pessoal.

\section{Atribuições}

A partir de agora, é o momento de apresentar de forma mais sistematizada o próprio perfil do gestor de comunicação proposto. Considerando as organizações como sistemas de interações constantes, a proposta é a de uma comunicação mais transparente e participativa. No livro "O gerente comunicador", José Eustáquio Oliveira de Souza (2010) indica vinte atribuições para o líder em sustentabilidade, sendo dez intrinsecamente relacionadas com a comunicação, tendo o gestor de comunicação todas as condições de ser protagonista. Após a realização da pesquisa apresentada, as atribuições propostas pela pesquisa desenvolvida por mim (Ulsen, 2012) são as seguintes: formulação estratégica, elaboração de um plano de comunicação, mapeamento de públicos, seleção de canais de comunicação, construção de narrativas e gestão do conhecimento.

\section{Competências}

Sobre as competências do gestor de comunicação, no cotidiano das organizações, há algumas situações práticas que exigem do profissional o senso de organização para obter soluções exequíveis. Muitas vezes essa capacidade está associada com a agilidade para tomar decisões, o que exige ideias bem definidas e a necessidade de criação de canais. Sendo assim, as seguintes competências são propostas para esse gestor da área: ampliar diálogo e motivação, gerar e mensurar resultados, liderar equipe, lidar com tempo, lidar com recursos financeiros e gerenciar crises.

\section{Habilidades}

Para tratar das habilidades, é importante dizer que nem todas estão especificamente associadas com a comunicação, mas todas a seguir se adequam ao gestor dessa área: lidar com novas mídias, conviver com o contraditório e a incerteza, lidar com expectativas dos públicos, criar redes de relacionamento e colocar-se no lugar do outro. 


\section{Perspectiva de atuação}

A perspectiva de atuação significa exercitar uma reflexão sobre a projeção que o comunicador realiza da sua atuação profissional. Pensar, planejar e executar em perspectiva é complexo e requer um desempenho mais estruturado que a simples execução de tarefas. Visão sobre a área, forma de ação, método e rotina de trabalho são os elementos que compõem o cotidiano dos gestores, sendo perspectivas de atuação propostas por este artigo as seguintes: visão sistêmica, ação transdisciplinar, equilíbrio, inovação, criatividade, empreendedorismo e flexibilidade.

\section{Valores}

Sendo o comunicador um ser humano que estabelece a mediação das organizações com seus públicos, também constituídos por humanos, os profissionais envolvidos têm diferentes valores, princípios, expectativas e preferências por canais de comunicação. Sendo a proposta sugerir um perfil, é necessário considerar variáveis humanas que fundamentam a atuação dos profissionais. Muitas vezes os valores orientam as pessoas, e aqueles que atuam pelo desenvolvimento da sustentabilidade devem ter alguns próprios e mais específicos, como ética, integridade, fraternidade, resiliência e a própria sustentabilidade.

\section{Posicionamento}

$\mathrm{Na}$ comunicação organizacional o posicionamento compreende uma envergadura de atuação elástica, ampla e flexível, havendo sendo necessária uma visão crítica que estimule a criação de novas ações e uma atuação propositiva. Por outro lado, nas organizações um aspecto notável é a ressignificação do conceito de relacionamento em que a hierarquia segue existindo, mas novos modelos de liderança têm sido experimentados, principalmente nas organizações mais inovadoras.

Finalmente, as novas mídias representam uma guinada na tecnologia alinhada com a revolução da mobilidade com a disseminação de celulares e computadores pessoais. Nesse contexto, a maioria das organizações tem tido uma atuação principalmente direcionada apenas para a divulgação de notícias. Na dissertação anteriormente citada, foi sugerido que as mídias sociais sejam utilizadas de forma mais completa, a partir de cinco abordagens: divulgação, interação, relacionamento, monitoramento e posicionamento. 


\section{Desafios}

Os desafios estão sintonizados com a perspectiva apresentada e demonstram que, embora se perceba um avanço nas pesquisas e na atuação do gestor de comunicação, novos desafios estão sendo apresentados a uma área cada vez mais estratégica. Por essa razão, os desafios merecem ser destacados e, na medida que forem superados, devem tornar a comunicação organizacional mais precisa. São cinco os desafios indicados a seguir: mensurar, customizar, profissionalizar, humanizar e transformar.

\subsection{Prazo das ações}

Ter objetivos claramente definidos é essencial para o sucesso de qualquer comunicação planejada. Todas as ações, quando organizadas, tendem a facilitar a concretização das metas, e estão, obrigatoriamente, associadas a uma escala de tempo. Por essa razão, é relevante considerar na Figura 11 os prazos envolvidos com esse processo: curto, médio e longo.

Figura 11: Prazo das ações de comunicação

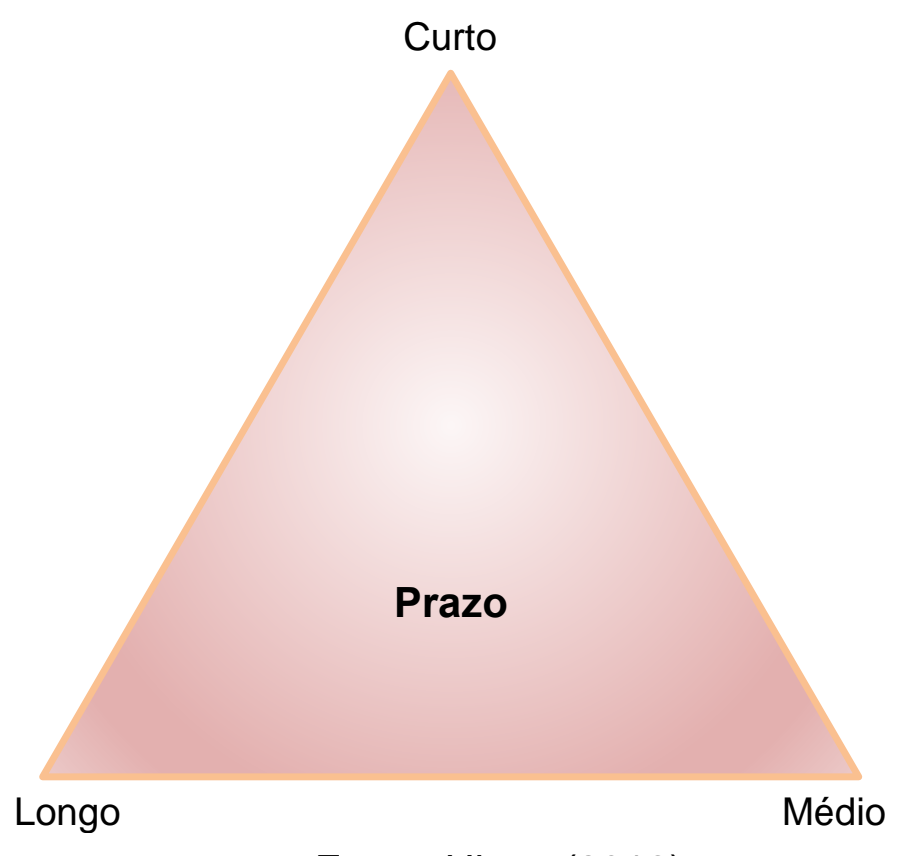

Fonte: Ulsen (2018) 


\section{Curto}

Elaborar um planejamento de curto prazo significa criar um ou mais planos de ação para atingir metas e objetivos em um futuro próximo. Para tanto, é necessário avaliar necessidades, demandas e recursos disponíveis para o estabelecimento de uma estratégia que fundamente a implementação das atividades.

Um bom planejamento também precisa de um cronograma de execução e configura-se como uma forma de antecipação dos fatos, o que torna mais fácil lidar com as dificuldades e os desafios cotidianos das organizações. Em geral, metas de curto prazo são as que se pretende realizar em menos de um ano.

Sendo uma ferramenta de gestão essencial para a estratégia de qualquer empresa, o planejamento também uma técnica que confere mais segurança para que os resultados sejam atingidos. Quando o planejamento é feito com técnicas apropriadas, é uma das melhores ferramentas que um gestor tem para atingir o sucesso.

\section{Médio}

As metas de médio prazo são os objetivos que, espera-se, sejam concretizados no período de um a cinco anos. Trata-se do segundo nível do planejamento tático, pois cria a vinculação entre as ações mais estratégicas e os planos operacionais. $\mathrm{Na}$ concepção do plano de médio prazo, é necessário que o gestor da área faça uma avaliação a respeito da disponibilidade de recursos financeiros para o período correspondente ao planejamento.

Como é comum ocorrer variações entre os procedimentos adotados neste nível de planejamento, este ciclo pode ser atualizado periodicamente. Assim, a cada vez que o replanejamento é feito, é importante gerar relatórios para conferir transparência para a alta direção da organização quanto ao andamento das ações. Nesse estágio, também já é possível detalhar melhor alguns indicadores que demonstrem o avanço do trabalho desenvolvido e os próximos a serem superados.

\section{Longo}

As ações de longo prazo são aquelas que se imagina realizar em um período superior a cinco anos. Neste caso, as definições costumam ser realizadas pela alta direção das organização e avaliação do Conselho de Administração, quando houver. 
Qualquer planejamento de comunicação para o futuro corre o risco de incorrer em erros graves, tamanha é a velocidade com que o cenário se transforma no meio.

Ainda assim, um planejamento consistente, realizado com seriedade $\mathrm{e}$ profissionalismo, fundamentado em pesquisas, confere aos gestores de todos os níveis da organização um horizonte a partir do qual as demais ações podem ser inspiradas. Da mesma forma que o planejamento de médio prazo, no entanto, essas definições podem e devem ser atualizadas periodicamente para que estejam sempre alinhadas com as transformações sociais, econômicas, políticas, tecnológicas e comunicacionais.

Finalmente, planejar sempre é um ato de direcionar objetivos e metas. Sendo assim, ainda que o prazo seja longo, é ele que vai orientar as equipes sobre qual direção seguir.

\subsection{Escala de mudança}

Considerando a comunicação para a sustentabilidade dentro de um processo de transformação, é eminente observar que tal movimento possa ou deva ocorrer a partir de uma escala que revele os estágios pelos quais ele ocorre. Essa classificação pressupõe uma evolução dos resultados e o grau de interação das pessoas impactadas com as mensagens.

Cabe destacar que seria incorreto determinar que uma possível meta seja o envolvimento dos públicos para o nível mais elevado de compreensão já que, diante da multiplicidade de personalidades e interesses envolvidos, o mais adequado é ter essa classificação como um parâmetro que balize as ações de comunicação. A citação a seguir, de Ignacy Sachs (2004), também fundamenta este raciocínio.

[A sustentabilidade ambiental] é baseada no duplo imperativo ético de solidariedade sincrônica com a geração atual e de solidariedade diacrônica com as gerações futuras. Ela nos compele a trabalhar com escalas múltiplas de tempo e espaço, o que desarruma a caixa de ferramentas do economista convencional. Ela nos impele ainda a buscar soluções triplamente vencedoras, eliminando o crescimento selvagem obtido ao custo de elevadas externalidades negativas, tanto sociais quanto ambientas. Outras estratégias, de curto prazo, levam ao crescimento ambientalmente destrutivo, mas socialmente benéfico, ou crescimento ambientalmente benéfico, mas socialmente destrutivo (SACHS, 2004, p.15). 
A operacionalização do trabalho pode ser iniciada com um planejamento inicial, focado nas atribuições e nos desafios de comunicação e sustentabilidade, com a integração de pesquisas atualizadas sobre o tema e o grupo de pessoas interessadas, ainda que atuem em diferentes departamentos da organização. A citação a seguir é de David Canassa, gerente de Sustentabilidade Grupo Votorantim, e revela como esse trabalho pode ser implementado em uma organização.

Definidas as estratégias de criação da área de Sustentabilidade,
passamos a desenvolver um processo interno para construir o
planejamento estratégico da companhia com base em novos modelos
e teorias - que fugiam aos formatos convencionais. O desafio foi
mostrar às equipes de planejamento das empresas do Grupo,
formadas no modelo convencional, que existem situações internas e
externas à companhia que precisam ser consideradas no processo.
Assim, foi colocado em debate: como aprimorar o trabalho dos
departamentos, tornando-os mais integrados: como mitigar riscos e
aproveitar oportunidades; como utilizar o fluxo de informações, de
processos e de dinheiro em favor da perenidade do negócio
(CANASSA, 2014, p. 31).

A trajetória está apresentada na Figura 12 e ilustra qual caminho deve ser percorrido para que os públicos selecionados recebam materiais de comunicação da organização em questão e evoluam coletivamente para a transformação de suas realidades para uma sociedade mais justa e equilibrada. Cabe destacar que os níveis a seguir também podem embasar a elaboração do diagnóstico inicial e final de cada projeto específico de sustentabilidade de forma a fundamentar a avaliação dos resultados gerados. 
Figura 12: Escala de mudança dos interlocutores

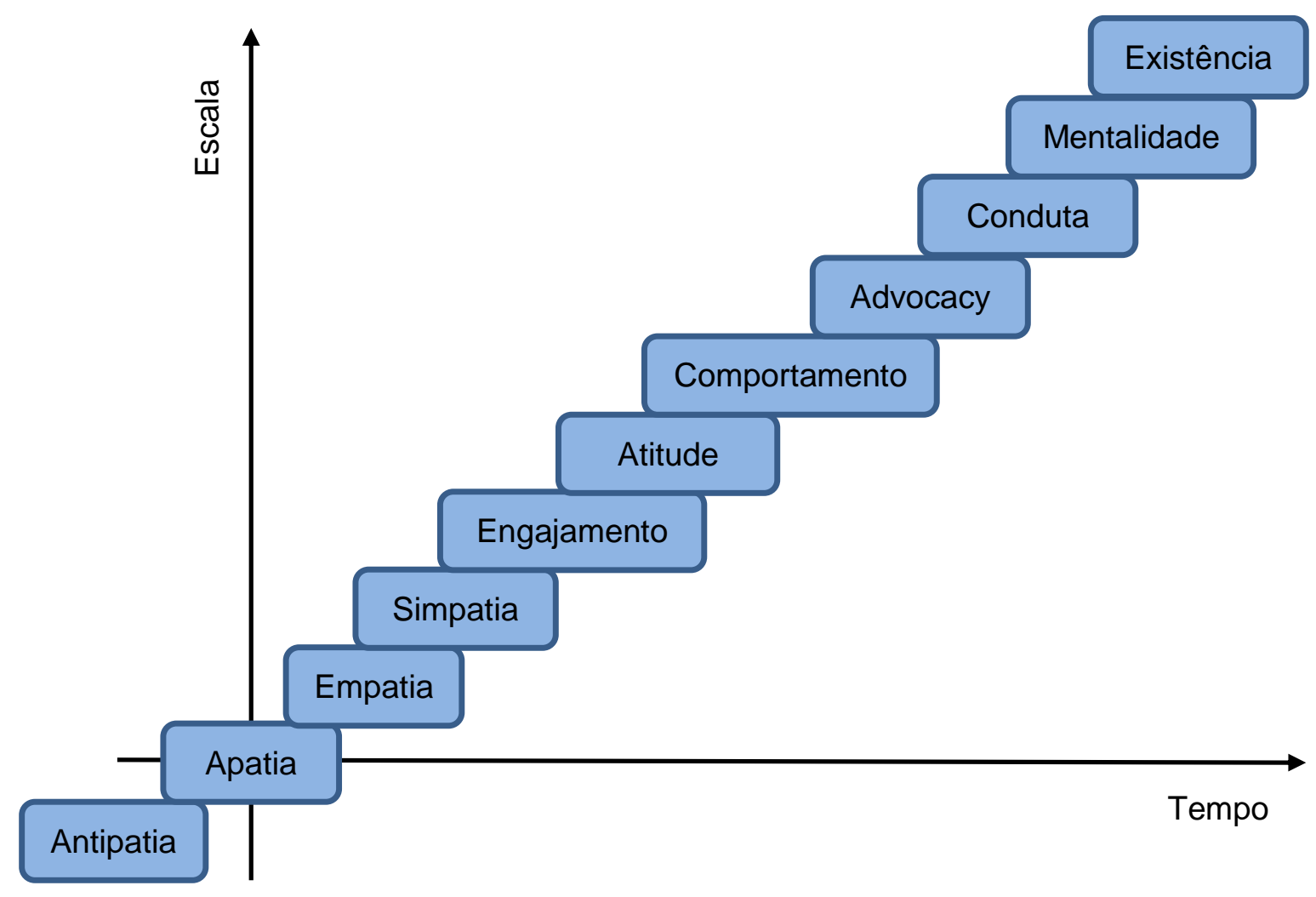

Fonte: Ulsen (2018)

\section{Antipatia}

A antipatia é um sentimento de repulsa diante de alguém ou algo com sentimento de discordância e desarmonia entre dois indivíduos. Etimologicamente, a palavra tem origem na palavra grega antipatheia, formada pela junção dos termos anti (contra) e patheia (afeição), ou seja, um substantivo que representa o antônimo de afeição. A antipatia também é o oposto da simpatia, este sim um sentimento de afeto que faz com que duas ou mais pessoas se mantenham unidas.

\section{Apatia}

Condição psicológica designada por um estado emocional de indiferença. Trata-se da falta de emoção ou motivação de uma pessoa perante algo ou alguém, tendo como característica a inércia e a falta de abertura para o diálogo. Esta palavra tem origem no grego apatheia e representa a indisponibilidade do interlocutor se emocionar devido à ausência de sensibilidade ou sentimento. 
A apatia pode estar ligada a algumas doenças, como a depressão, e pode ser a manifestação de um esgotamento nervoso, quando é caracterizada por indolência e marasmo. Ela também pode ser caracterizada por frieza e afeta o medo, o desejo, o prazer e a disponibilidade para mudanças, fazendo com a pessoa apática permaneça indiferente em relação a esses sentimentos.

\section{Empatia}

Empatia é a capacidade psicológica que uma pessoa tem para sentir o que seu interlocutor sentiria caso estivesse em uma mesma situação a partir da compreensão de sentimentos e emoções. Ela leva as pessoas a se ajudarem e está relacionada ao altruísmo e à capacidade de ajudar. Quando um indivíduo sente a dor ou o sofrimento do outro, desperta em si a vontade de ajudar e de agir seguindo determinados valores e princípios.

Essa capacidade de se colocar no lugar do outro, em termos de comunicação, ajuda a compreender melhor o comportamento do interlocutor em determinadas circunstâncias e a forma como ele toma decisões. Além disso, ser empático é ter afinidades e saber ouvir para compreender as emoções dos outros. Ainda, a empatia é diferente da simpatia, já que a empatia está mais associada a uma conexão afetiva e intuitiva.

\section{Simpatia}

Trata-se do sentimento de afinidade que leva uma pessoa a criar harmonia com outra envolvendo laços de afeto e amizade, participando das emoções alheias com variações entre a compreensão dos sentimentos do próximo e a identificação dos seus próprios estados emotivos com o do interlocutor.

A simpatia pode ser uma atração a algo também, ou mesmo a uma ideia, ou seja, gostar e se envolver emocionalmente com determinado tema ou situação que desperte seu interesse.

\section{Engajamento}

O engajamento é o ato de participar de forma voluntária em algum trabalho ou atividade. Seu uso tem sido cada vez mais comum em causas filantrópicas e, também, no âmbito das organizações. A mudança de patamar do público, que sai de uma 
condição empática para o engajamento, está na disponibilidade e na execução prática de esforços em benefício de determinada ação. Uma pessoa engajada já entende a relevância da sua participação na ação e cria mecanismos de empenhar seus próprios recursos para promover uma mudança que entende ser necessária.

\section{Atitude}

Atitude é a concretização de determinada intenção ou propósito e diz respeito a ações mantidas de forma habitual em circunstâncias diferentes. As atitudes expressam a individualidade de cada pessoa e está diretamente relacionada ao seu caráter e à forma de se comportar em sociedade.

A atitude contribui, ainda, para determinar uma variedade de comportamentos com a formatação de conviç̧ões e sentimentos em relação a determinadas situações. A própria educação formal tem como um dos objetivos a formação de atitudes favoráveis ao equilíbrio do indivíduo e ao desenvolvimento equilibrado da sociedade. Além disso, a atitude consiste em um sistema de valores e crenças de um indivíduo ou grupo.

\section{Comportamento}

O comportamento é o conjunto de reações de um sistema dinâmico face às interações e renovação propiciadas pelo meio onde está envolvido. Entre os exemplos de comportamentos, estão o social, o humano, o informacional o animal e o atmosférico, entre outros.

Na prática, quando relacionado com os seres humanos, o comportamento é a maneira que as pessoas têm de se comportarem ou conduzirem determinadas decisões. A comunicação para a sustentabilidade que tem como objetivo mudar o comportamento das pessoas é mais trabalhosa e precisa de muito tempo para que gere resultados.

Porém, quando o comportamento de alguém é alterado, novas possibilidades são criadas já que, pelo exemplo ou pela liderança, essa pessoa para a disseminar uma nova forma de agir socialmente, influenciando outras pessoas do seu convívio. 


\section{Advocacy}

É uma prática política reiterada por determinado indivíduo, organização ou grupo social para influenciar a formulação de políticas e a alocação de recursos. 0 advocacy pode envolver diferentes atividades por meio de um conjunto de ações estratégicas e planejadas fundamentada na liderança e no trabalho em rede de mobilização das pessoas para determinada causa.

Entre os exemplos estão campanhas de cunho socioambiental e o envolvimento da imprensa e outros stakeholders para defender objetivo prédeterminados de mobilização civil e ações coletivas para a defesa dos interesses públicos ou particulares.

\section{Conduta}

Conduta é a forma como as pessoas se comportam, referindo-se às ações realizadas por cada indivíduo com base em sua vivência cultural, sociológica, financeira e outras. A conduta também pode ser entendida como o conjunto de comportamentos observáveis em uma pessoa, gerando exemplo para os demais que podem reproduzir ou refutar esse modelo.

\section{Mentalidade}

A programação mental (mindset) pode determinar o sucesso ou o fracasso de ações pessoais e profissionais. A partir dessa compreensão, a comunicação para a sustentabilidade, quando quer atingir um nível mais profundo de transformação, deve considerar a necessidade de influenciar a mentalidade das pessoas.

\footnotetext{
A mente é a inteligência de todas as coisas. A consciência o torna sabedor. E o pensamento é como o leme de um barco. Ele o guia ao longo da vida e, se você aprender a usá-lo corretamente, poderá guiar seu próprio caminho pela vida afora de um modo bem melhor do que jamais imaginou. Você pode mudar de uma realidade para outra (NEILL, 2014, p. 38).
}

Para tanto, é necessário que haja um foco sobre a eliminação de conflitos e crenças limitantes, resultantes geralmente de experiências negativas, traumas ou medos transmitidos diariamente. 
A forca motriz à qual nos referimos é chamada mentalidade. Como Albert Einstein disse de maneira tão eloquente: "Não podemos solucionar os problemas com o mesmo tipo de mentalidade que os criou". Mentalidades criam o mundo. As estruturas do pensamento econômico de ontem se manifestam nas estruturas das instituições e nas ações de hoje. Se quisermos fazer o upgrade do nosso sistema operacional econômico global, precisamos começar atualizando a mentalidade que o fundamenta; precisamos atualizar a essência do pensamento e da lógica econômica.

Utilizando o modelo do iceberg que orienta a jornada deste livro, nos referimos a essa camada mais profunda como "mentalidade", "modelos mentais" ou paradigmas do pensamento econômico. Modelos mentais obsoletos levaram a uma verdadeira falência intelectual: a falência do pensamento econômico convencional (SCHARMER; KAUFER, 2014, p. 12).

Para que haja uma mudança de mentalidade, é importante que a pessoa interessada se liberte de suas crenças limitantes, que em geral são as experiências negativas, os traumas ou os medos vivenciados. Isso ocorre pois, se as pessoas basearem suas ações futuras nas experiências passadas, dificultarão a trajetória de conquistas e realizações.

\section{Existência}

A mudança de existência consiste no nível máximo de transformação do indivíduo. Ela ocorre quando a pessoa já atravessou todas as demais etapas previamente indicadas e passa a viver de acordo com o que acredita. Essa vivência é manifestada em suas atividades cotidianas, sendo sua existência coerente com as opiniões que defende.

\subsection{Recursos envolvidos}

Recurso é qualquer elemento necessário para alcançar um determinado objetivo. Considerando a amplitude desta concepção, o termo pode ser utilizado em diferentes circunstâncias. Ainda assim, existem algumas áreas em que sua utilização apresenta limites bem definidos, como é o caso do foco desta pesquisa em recursos organizacionais detalhados na Figura 13. 
Figura 13: Recursos envolvidos na comunicação organizacional

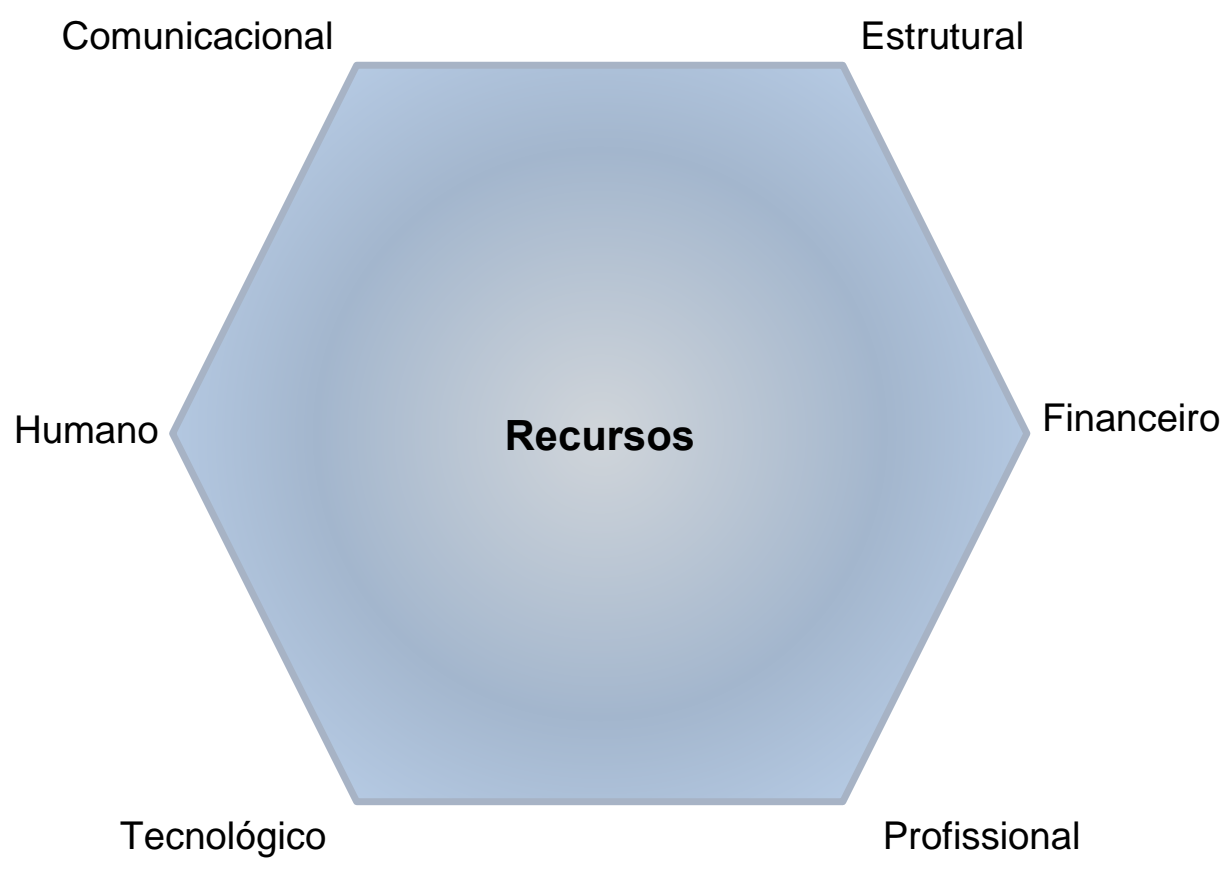

Fonte: Ulsen (2018)

\section{Estrutural}

Também conhecidos como recursos físicos ou materiais, a infraestrutura de uma organização é um recurso importante para o desenvolvimento pleno das atividades de uma organização do terceiro setor. A infraestrutura é todo bem tangível que permite oferecer esse trabalho com qualidade, entre eles as instalações imobiliárias e mobiliárias de trabalho.

O sucesso de qualquer organização está diretamente relacionado com a gestão eficiente de todos os recursos. De forma geral, eles podem ser potencializados por meio de investimentos que permitam mantê-los e renová-los.

\section{Financeiro}

Os recursos financeiros são os ativos com algum grau de liquidez, entre eles o dinheiro em espécie, os créditos e os investimentos que a organização faz. No caso das empresas, esse tipo de recursos costuma ser gerado a partir de diversas atividades, como a venda de produtos e serviços, a emissão de ações, os ciclos de financiamento, os empréstimos e os subsídios governamentais. 
No terceiro setor a situação é diferente e as organizações desse meio buscam o financiamento de suas atividades por meio de doações, prestação de serviços, permuta e campanhas de financiamento de determinados projetos.

Aquele que se responsabiliza por administrar os recursos financeiros deve planilhar o fluxo para facilitar o controle de custos operacionais e investimentos. Nesse sentido, os orçamentos e os balanços financeiros são essenciais para indicar as entradas e as saídas de dinheiro da tesouraria da organização. Quando bem realizada, essa gestão também confere credibilidade e transparência ao trabalho e facilita a conquista de novos investidores na missão da organização.

\section{Profissional}

Coordenar adequadamente os recursos profissionais de determinada organização é uma responsabilidade estratégica e desafiadora, pois esta é uma área muito sensível que pode criar condições de trabalho positivas (quando bem executadas) ou constrangedoras (quando desvirtuadas). Essa atuação também depende de aspectos determinantes, como estrutura, cultura, tecnologia, processos e outras variáveis importantes.

A comunicação é essencial no processo de gestão de recursos profissionais. Quando utilizada de forma correta, a comunicação pode garantir uma melhor adesão dos envolvidos nas ações da organização, evitando erros básicos de interpretação e de execução. Além disso, é a comunicação que garante a construção de relações interpessoais, e oferece os mecanismos de funcionamento para a criação de um ambiente organizacional harmonioso e cooperativo.

\section{Tecnológico}

Atualmente, os recursos tecnológicos têm sido cada vez mais imprescindíveis para as pessoas desempenharem suas atividades. Uma organização com equipamentos modernos, acesso à Internet de alta velocidade, redes informatizadas e equipamentos multifuncionais facilitam as condições de atuação no terceiro setor.

Isso ocorre, pois, os recursos tecnológicos contribuem para o desenvolvimento de operações cotidianas e a implementação de pesquisas e demais atividades de gestão da comunicação. 


\section{Humano}

O recurso humano não é o recurso profissional. O recurso humano é a identidade de cada pessoa exercida no cotidiano de suas vidas e, por correspondência, nas organizações. A multiplicidade de estilos pessoais, cada um com sua experiência de vida, é o que traz diversidade e criatividade aos grupos.

Claro que, em uma organização, inclusive as do terceiro setor, essa variedade deve compor um grupo integrado que seja solidário e entenda a importância de se respeitar cada um do jeito que é. Cada ser humano tem seus valores, suas experiências de vida, seus traumas, seus ressentimentos e seus sonhos. A sinergia corretamente liderada desse encontro de universos pessoais tende a criar condições para a superação coletiva de qualquer desafio.

\section{Comunicacional}

Diz respeito às condições materiais, estruturais, financeiras, tecnológicas profissionais e humanas colocadas à serviço da comunicação. Nas organizações, por exemplo, está relacionada com os equipamentos disponíveis para o bom desenvolvimento do trabalho, o empenho da liderança em conduzir sua equipe para objetivos exequíveis e coletivos e à composição de profissionais que sejam solidários para atuar em prol da sustentabilidade, por exemplo.

Os recursos de comunicação têm se tornado cada vez mais necessários e estratégicos em todos os setores, considerando a ampla quantidade de conflitos e ruídos existentes pela incapacidade da maioria dos profissionais das mais diversas áreas se comunicarem com eficiência e transparência.

\subsection{Percurso sugerido}

A concepção de comunicação para a sustentabilidade em organizações do terceiro setor pressupõe, também, um percurso que oriente e fundamente as ações implementadas. Na sugestão indicada na Figura 14, quatro abordagens diferentes e complementares estão apresentadas de como esse processo pode ocorrer, sendo que cada uma delas encontra-se fundamentada na sequência. 
Figura 14: Percurso da comunicação para a sustentabilidade no terceiro setor

Mudar o mundo

\section{Transformar}

o mundo
Melhorar o

mundo
Construir novo mundo

Fonte: Ulsen (2018)

\section{Mudar o mundo}

Mudar o mundo é o sonho e a utopia da maioria dos adolescentes engajados politicamente que, quando se deparam com uma realidade com a qual não concordam, se envolvem de forma passional na tentativa de alavancar mudanças alinhadas com suas crenças e ideologias. Essa concepção, muitas vezes sincera e bem-intencionada, é recorrente em pessoas que se envolvem com a causa socioambiental e desejam mudar a realidade para que os menos favorecidos tenham melhores condições de desenvolvimento.

Sem dúvida, uma compreensão legítima, muitas vezes bem fundamentada e assumida como uma causa. A única ressalva nessa perspectiva é quanto à operacionalização desse entendimento e à compreensão de que o mundo, externo, necessariamente, tem o poder de moldar e determinar o destino das pessoas. Sob essa máxima, o externo tem a capacidade de criar ou não condições de desenvolvimento pessoal e social, e cada indivíduo é observado como fruto do seu meio, sem alternativa de aplicação das suas próprias habilidades.

\section{Transformar o mundo}

Instância que reconhece a impossibilidade de mudar todo o mundo, mas mantém um elevado grau de indignação diante de tanta injustiça social e desequilíbrio em diferentes âmbitos, inclusive o ambiental. A transformação do mundo fundamenta a atuação voluntária de muitas pessoas e organizações do terceiro setor que querem um modelo diferente de desenvolvimento, que seja inclusivo, participativo e justo.

O contemporâneo não é apenas aquele que, percebendo o escuro do presente, nele aprende a resoluta luz; é também aquele que, dividindo e interpolando o tempo, está à altura de transformá-lo e de colocá-lo em relação com os outros tempos, de nele ler de modo inédito a história (AGAMBEN, 2009, p. 72). 
Seguindo a citação acima, este é o contemporâneo, uma pessoa que assume a responsabilidade que tem como cidadão do mundo e a possibilidade real de transformar determinadas realidades em prol de um projeto mais coletivo e solidário.

\section{Melhorar o mundo}

A melhoria do mundo é um recuo em relação às demais compreensões apresentadas até o momento e uma tentativa de adaptação à realidade mesclada com a manutenção de um ímpeto de melhoria da realidade socioambiental e de justiça social. Melhorar o mundo também é uma decisão legítima, bem fundamentada e bemintencionada. Na maior parte das vezes ela é conduzida por pessoas e organizações interessadas em condições mais harmônicas de desenvolvimento.

\section{Construir novo mundo}

A construção de um novo mundo é uma instância diferente das demais. Ela não desconsidera as outras apresentadas até o momento. Ao contrário. Ela as integra e as complementa. Aqui, a pessoa que quer construir um novo mundo não é moldada pelo externo, mas tem protagonismo, liderança e recursos suficientes e poderosos para implementar um novo modelo em sua própria realidade.

\footnotetext{
Segundo o modelo predominante em nossa cultura, nossa experiência de vida é criada de fora para dentro - ou seja, aquilo que nos acontece do lado externo determina nossa experiência internamente. As pessoas ou circunstâncias "nos tornam" felizes, irados, tristes, temerosos ou amorosos, e o jogo da vida consiste em encontrar, atrair, criar ou revelar as pessoas e circunstâncias "certas" a fim de sentir mais sentimentos bons e menos sentimentos ruins.

Uma variação desse modelo (que chamo de "o poder de fora para dentro") argumenta que não é tanto o que nos acontece, e sim o que fazemos com o que nos acontece que determina nossa experiência. Se fizermos isso, podemos parar de agir como vítimas dos eventos da vida e passar a responder como criadores, fazendo limonada com os limões dados e criando as relações e circunstâncias que nos trarão felicidade e satisfação.

Uma segunda variação (que chamo de "o de fora para dentro iluminado") diz que as pessoas e circunstâncias realmente importam, porém ainda mais importante é aquilo que pensamos sobre as pessoas e as circunstâncias (NEILL, 2014, p. 42).
}

A construção de um novo mundo é, na prática, a formação de grupos alinhados com os mesmos horizontes e métodos semelhantes de equilíbrio, justiça social e 
sustentabilidade. As pessoas envolvidas com essa perspectiva entendem os esforços legítimos dos bem-aventurados, mas não se dobram ao entendimento de uma realidade exterior opressora.

Tudo, desde a terapia cognitiva e racional-emocional até a maioria dos movimentos de autoajuda, mostra que, se você substituir um pensamento, crença ou atitude negativa em relação às pessoas ou às circunstâncias por algo positivo, a sua mudança não só ocorrerá imediatamente como também muito antes de as pessoas e circunstâncias mudarem - e, se isso não acontecer, pelo menos os seus pensamentos e atitudes positivas permitirão que você transforme uma situação ruim na melhor possível.

Se por um lado essas variações promovem maior efetividade no local de trabalho e uma experiência mais agradável de estarmos vivos, por outro têm um escopo limitado do impacto que exercem (NEILL, 2014, p. 42).

Finalmente, quem quer construir um novo mundo dialoga, forma grupos de trabalho, se interessa pelo coletivo, pesquisa sobre o assunto, propõe e, principalmente, implementa soluções.

\subsection{Abrangência das ações}

Qualquer ação de comunicação para a sustentabilidade no terceiro setor abrange, necessariamente, determinado impacto em determinada escala. Nesse sentido, na Figura 15 estão indicadas as principais possibilidades em termos de abrangência das ações de comunicação: individual, familiar, local, municipal, regional, estadual, interestadual, nacional, internacional e global. 
Figura 15: Abrangência das ações de comunicação para a sustentabilidade

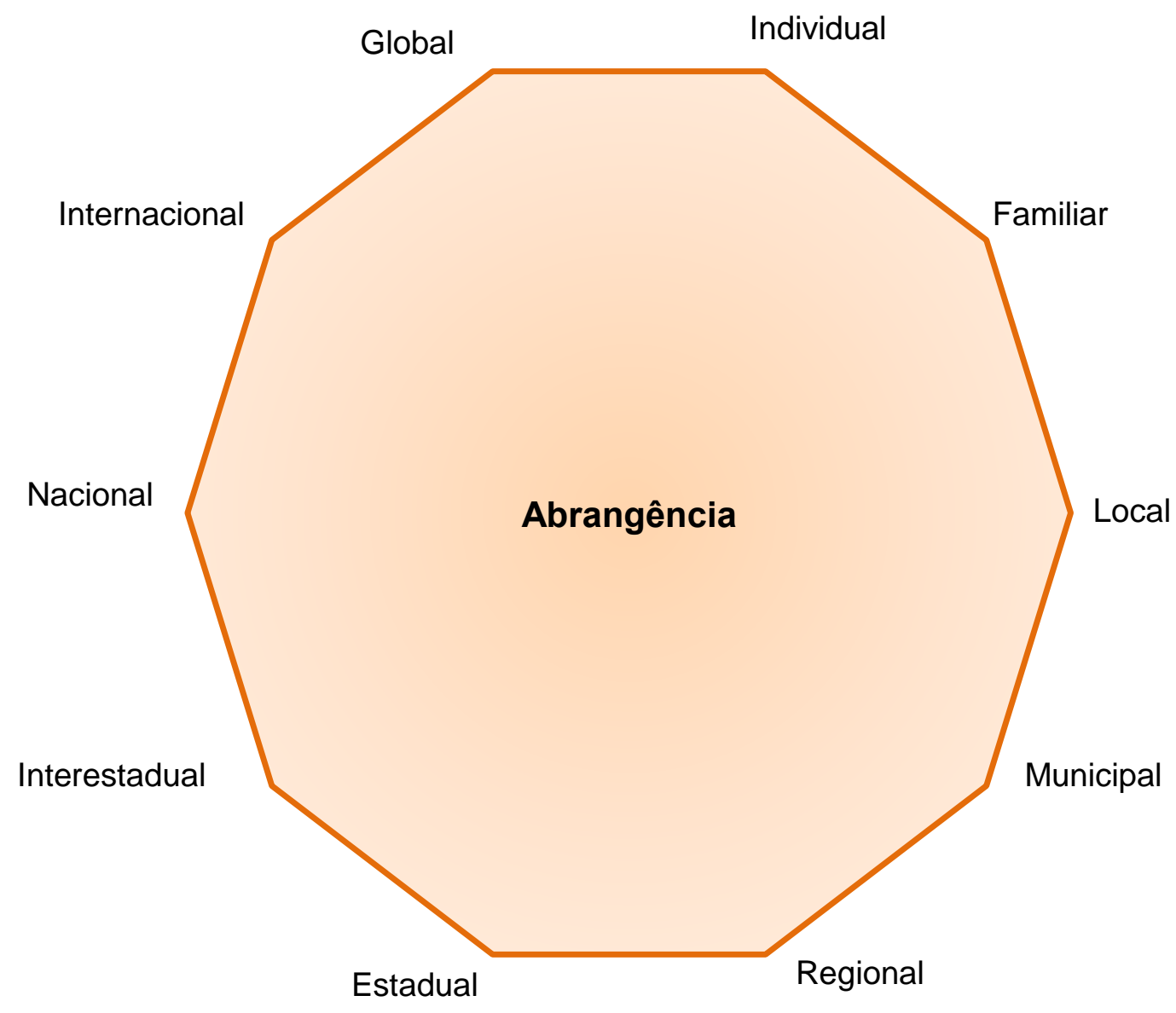

Fonte: Ulsen (2018)

\section{Individual}

A abrangência individual está relacionada a um ser individual reconhecido por sua existência única e exclusiva. No caso das ciências humanas, o indivíduo é visto como o cidadão que possui uma identidade própria distinguindo-se dos demais, mas ainda assim inserido em um ambiente social. São os indivíduos os responsáveis por formar as sociedades, e são elas, as sociedades, que exercem influência direta na formação dos indivíduos, que seguem regras e condutas que determinadas pelo ambiente social.

\section{Familiar}

A família é formada por pessoas com um determinado número de indivíduos com ancestrais em comum e/ou ligados por laços afetivos. Dentro de uma família, 
existe, sempre, algum grau de parentesco. Nas mais diversas culturas, a família é considerada uma das unidades básicas da sociedade.

\section{Local}

Normalmente diz respeito a uma comunidade de menor escala com públicos menos abrangentes e com maior presença do relacionamento familiar ou interpessoal. A comunicação praticada nesse tipo de espaço costuma ser melhor desenvolvida quando se aproxima da realidade das pessoas e da situação vivida diariamente por elas.

Esse tipo de grupo em geral tem uma identidade histórica comum e a sustentabilidade para eles tende a ser mais simples e direta. Assim, o cenário favorece o desenvolvimento da comunicação comunitária, desenvolvida a partir da participação e do compromisso com as pessoas. O foco é direcionado para a comunidade, identificando e transmitindo os interesses das pessoas que dela participam.

\section{Municipal}

Um município é uma divisão administrativa que possui governo e jurisdição própria. O termo é derivado do francês municipalité e do latim municipium e refere-se a um território dotado de personalidade jurídica e certa autonomia, com órgãos administrativos e políticos. A comunicação praticada nessa abrangência deve considerar a civilização que nela vive, bem como os laços de identidade e interesses socioambientais e econômicos.

\section{Regional}

A abrangência regional envolve um público mais abrangente, se comparado com o local. Neste caso, já se trata de uma área territorial de algumas cidades que se identificam como uma região, muitas vezes com alguma influência da capital estadual, mas também espelhada em alguma cidade mais populosa da região que se torna polo de empregos, serviços e educação dos municípios menores.

Em muitos casos, as regiões também assumem determinado perfil socioeconômico e, embora passem por transformações, passam a ser identificadas por outras regiões por características próprias. Em alguns casos, esses elementos são mais marcantes, e isso ocorre quando o perfil é mais determinante ou quando os 
moradores assumem essa personalidade. Com a globalização, no entanto, muitas diferenças tendem a diminuir, e a homogeneização da cultura também convive nesse cenário.

\section{Estadual}

Abrangência relacionada às unidades federativas. Sob esta perspectiva, a influência da capital costuma ser mais marcante sobretudo em termos de disseminação de ideologias e valores produzidos pelos meios de comunicação de massa.

Quando a comunicação para a sustentabilidade no terceiro setor é praticada nesse âmbito, que pode ser mais teórico que prático, algumas particularidades também podem ser utilizadas para tornar a mensagem mais efetiva, a exemplo do resgate da identidade estadual e da interlocução com valores mais típicos dos moradores. Dependendo do estado, a tradição pode se manifestar com mais força e incorporada ao discurso da sustentabilidade.

\section{Interestadual}

Comunicação praticada em mais de uma unidade federativa, ocorre quando a organização do terceiro setor ultrapassa as fronteiras e envolve outras culturas e públicos com diferentes trajetórias sociais, econômicas e educacionais. Nesse caso, a comunicação precisa ser mais profissional e desenvolvida por uma equipe qualificada que entenda que o cenário já é mais complexo e desafiador.

\section{Nacional}

Em nossa realidade, trata-se da comunicação praticada com a perspectiva de atingir públicos de todo o Brasil. Diante da multiplicidade cultural nacional, e das peculiaridades localizadas em cada região do País, certamente a comunicação em abrangência nacional é um desafio constante e costuma ser praticada de forma eficiente somente por organizações de grande porte.

A palavra nação tem origem no latim natio e está relacionada também a uma comunidade estável, historicamente constituída por um grupo de indivíduos, com base em um território e um idioma. Além disso, essas pessoas são, geralmente do mesmo 
grupo étnico, têm costumes parecidos que se mantêm unidas por hábitos, tradições, religião, língua e consciência nacional.

Este trabalho requer uma equipe altamente capacitada e ciente da necessidade de envolver pessoas com experiências de vida completamente diferentes a partir de alguma convergência. Considerando também a ausência de um sentimento identitários nacional no Brasil, este trabalho se torna ainda mais difícil. Ainda assim, as soluções encontradas pelas organizações mais profissionalizadas do terceiro setor têm revelado surpresas positivas para disseminar práticas sustentáveis e inspirar novos líderes a entender esse conceito e a implementar soluções mais regionais e locais.

\section{Internacional}

Ações desenvolvidas em mais de um país, pode ser uma oportunidade para estimular reflexões inovadoras sobre determinado tema. Por outro lado, gera mais resultados quando é fruto de uma parceria que ajusta as diferenças e trabalha em sinergia identificando possibilidades de inovação e limites que não interfiram negativamente ou ofendam determinado país.

Boas práticas podem ser utilizadas nesse sentido para que o intercâmbio de ideias e ações sejam revelados e engajem as pessoas a praticar uma comunicação mais inovadora e sustentável. As ações desenvolvidas nesse âmbito envolvem uma diversidade de assuntos, incluindo globalização, soberania, sustentabilidade, energia, nacionalismo, desenvolvimento econômico, sistema financeiro, segurança, intervencionismo e direitos humanos.

\section{Global}

O âmbito global pressupõe a integração do que há de melhor e mais qualificado em termos de pesquisas e práticas de comunicação e sustentabilidade nas organizações do terceiro setor. Qualquer ação nesse sentido só pode ser operacionalizada com uma equipe altamente profissional com a sinergia de pessoas das mais diversas formações, culturas e experiência de vida.

Ações globais tem o potencial de exportar exemplos de sucesso e revelar tendências que têm despertado a atenção dessas organizações. A Organização das Nações Unidas (ONU), por exemplo, é uma fonte fidedigna e confiável de organização 
que reúne líderes de todo o mundo para pensar a sustentabilidade e demais temas sensíveis de forma global.

Ainda assim, esse trabalho, por mais profissional e competente que seja, não substitui, e nem deve substituir, as ações implementadas nas demais escalas, inclusive em comunidades locais. A perspectiva global sempre reunirá melhores práticas e tendências, porém as soluções práticas em geral são melhor desenvolvidas a partir desta inspiração internacional somada à aplicação local.

\subsection{Frequência das ações}

A frequência é uma unidade de medida que indica o número de ocorrências de um evento em determinado intervalo de tempo. Esse tempo em particular recebe o nome de período, o que faz com que a frequência seja o inverso do período. $A$ frequência é condição essencial para o desenvolvimento ou o fortalecimento de relações sociais, pois possibilita a convivência habitual entre as pessoas de um grupo.

Considerando que qualquer ação de comunicação é uma ocorrência inserida em determinado tempo, atividades de comunicação para a sustentabilidade são, necessariamente, participantes de uma frequência. A sistematização da Figura 16 sugere frequências em que esse trabalho ocorre como forma de facilitar sua compreensão, e, também, o planejamento prévio de ações em determinada frequência para facilitar a criação de condições favoráveis para esse processo. 
Figura 16: Frequência das ações da comunicação para a sustentabilidade

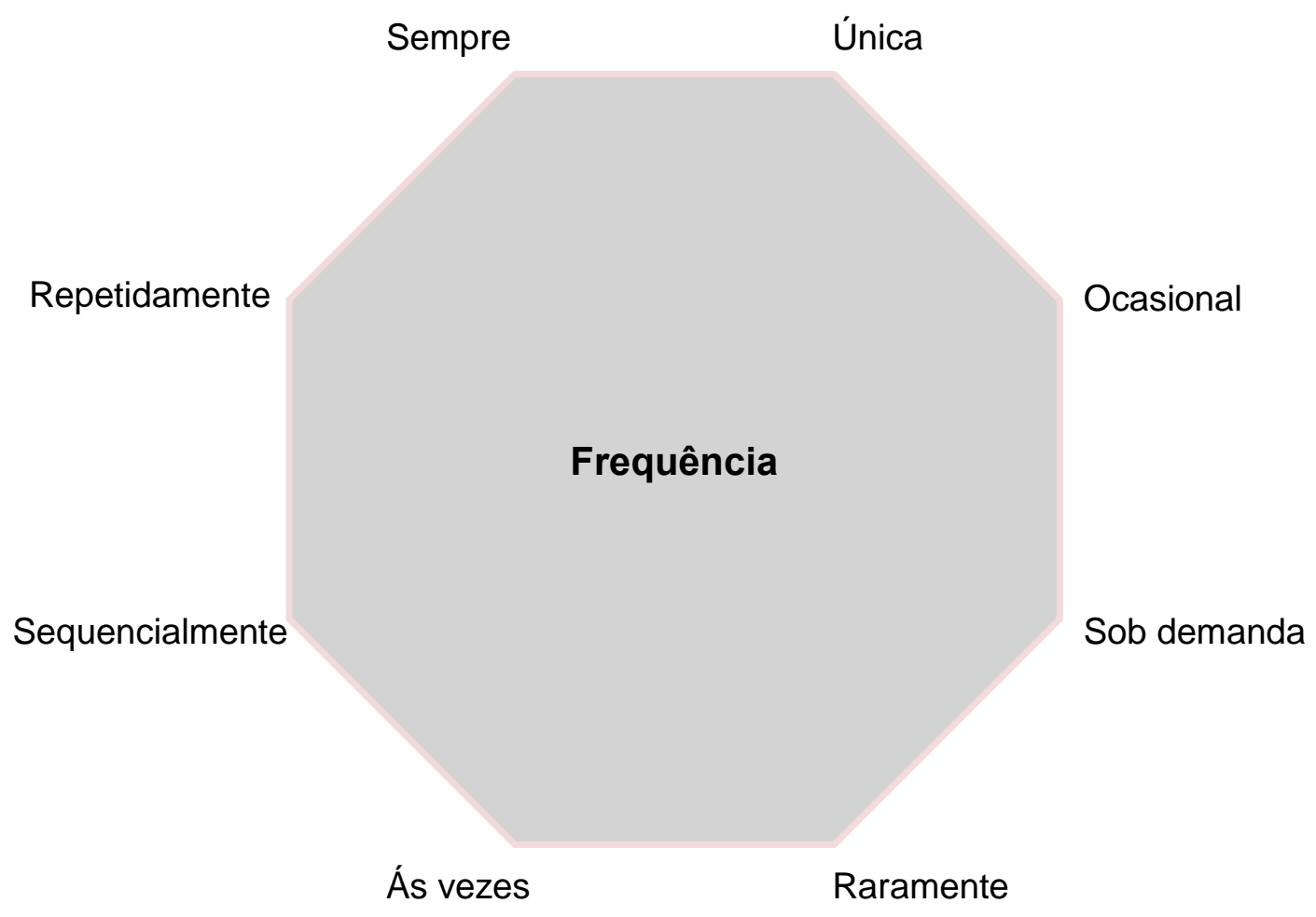

Fonte: Ulsen (2018)

\section{Única}

Como o próprio nome indica, trata-se de uma ação isolada, única, desconectada de outras, feita apenas uma vez sem previsão de repetição.

\section{Ocasional}

Diz respeito a ações realizadas de forma esparsa, às vezes, sem qualquer constância em termos de frequência. Também está relacionada com atividades episódicas, circunstanciais, imprevistas e aleatórias.

\section{Sob demanda}

Operacionalizada quando é requisitada, pode ser realizada, por exemplo, quando a área de comunicação de uma organização atua de forma apenas instrumental e é solicitada a desempenhar alguma divulgação específica sob orientação de outro departamento. A atividade sob demanda também é menos 
assertiva e dificulta a criação de um trabalho de comunicação mais planejado e profissionalizado.

\section{Raramente}

Está relacionada com ações desempenhadas com baixíssima frequência, com pouca previsibilidade de repetição e demora para a sua continuidade.

\section{Às vezes}

Ações desenvolvidas de vez em quando, sem compromisso de estarem inseridas em um trabalho mais integrado que contemple início, meio e fim.

\section{Sequencialmente}

Frequência um pouco mais constante, pode começar a incorporar ações mais planejadas e constantes, com previsibilidade de que continuem e envolvam mais profissionalismo na estruturação de mensagens a partir de canais e públicos prédefinidos.

\section{Repetidamente}

Relacionada com frequência previsível e constante. Já pressupõe a concepção de uma comunicação ainda mais profissional, planejada, consistente, com mapeamento de públicos estratégicos e envio de mensagens a partir de canais determinados.

\section{Sempre}

Frequência mais constante de operação, está relacionada com uma comunicação mais sofisticada, que tem embasamento estratégico e fundamentação científica. Além disso, as ações de comunicação podem ser customizadas e estão integradas com as outras áreas da organização e representam benefícios relevantes que podem ser analisados e mensurados. 


\subsection{Considerações e desafios}

Ao evidenciar a comunicação para sustentabilidade, a perspectiva é utilizar os potenciais da área para geração de mudanças, o que subentende a aplicação do verdadeiro sentido das relações públicas comunitárias. Desse ponto de vista, as relações públicas comunitárias autênticas pressupõem ações estruturadas que vão muito além de ações sociais, demandando uma atuação ativa com participação profissional na comunidade e em função dela.

As pesquisas sobre comunicação e relações públicas comunitárias revelam que o campo de trabalho nessa área vem crescendo nos últimos anos em decorrência da necessidade de comunidades se comunicarem cada vez mais com a sociedade, reivindicando seus direitos e ações de cidadania.

No Brasil, as relações públicas comunitárias têm passado, nas duas últimas décadas, por processos de organização e gestão de movimentos de organizações sociais populares, pois sua atuação abrange não apenas a comunicação nas comunidades, mas todos os processos comunicativos. Uma das características mais marcantes da comunicação comunitária desde o início tem sido o estímulo participação das pessoas, por apresentar elementos alinhados com as expectativas de movimentos e organizações populares (Peruzzo, 2002). A importância das relações públicas comunitárias está principalmente no poder de contribuição para a transformação social, ou seja, ajudar comunidades a partir de técnicas e instrumentos para desenvolver ações direcionadas a fins coletivos.

Foi a partir da década de 1980 que começou a se falar concretamente em relações públicas comunitárias, o que ocorreu na sequência do desenvolvimento alcançado pela comunicação alternativa. Com isso houve o crescimento do interesse pelas relações públicas comunitárias, distanciando-se cada vez mais, da visão tradicional de ações de empresas desenvolvidas para a comunidade. Segundo Kunsch (2007b, p. 172), as relações públicas comunitárias autênticas são muito mais que um trabalho para a comunidade, dentro de um padrão tradicional de ações paternalistas. Ao contrário disso, elas pressupõem uma atuação interativa que deve ter a participação de um profissional atuante como articulador e incentivador, além de um simples transmissor de saberes e aplicador de técnicas.

A autora defende que as relações públicas comunitárias implicam na participação na comunidade, dentro dela, e em função dela, sendo que o profissional 
deve atuar para resolver os problemas e os conflitos da comunidade, preferencialmente de forma interdisciplinar, em conjunto com outras áreas da comunicação. A contribuição do profissional de relações públicas pode ser bastante ampla, uma vez que ele dispõe de técnicas eficientes para desenvolver ações e projetos que de fato transformem a comunidade. Para tanto, ele deve estar inserido na comunidade, vivenciando a sua realidade e suas aspirações, para trabalhar de forma conjunta para o bem-estar da coletividade.

Segundo Escudero (2007, p. 86), a comunicação comunitária é uma via de mão dupla, pautada pela comunhão entre sujeitos que participam de um contexto comum que os transformam dialeticamente. Esse envolvimento gera compromisso e amadurecimento do movimento e de seus membros, além dos profissionais que atuam nele. A autora considera que, no relacionamento comunitário, deve haver um interesse comum das pessoas envolvidas em superar os conflitos existentes, uma vez que a atuação comunitária requer constante avaliação entre as partes envolvidas. Assim, é importante que as atividades sejam realizadas em equipes, para que não existam ações voltadas a interesses pessoais ou corporativistas.

De acordo com Peruzzo (2002), as relações públicas podem contribuir muito com as comunidades e as organizações populares. Vejamos os exemplos seguintes: levantamento de dados ou diagnósticos para subsidiar ações; planejamento para a implementação de programas ou políticas públicas a partir da participação coletiva; aperfeiçoamento da comunicação com práticas de incentivo dentro da comunidade; organização de eventos educativos, culturais, feiras, exposições e na preparação de pesquisa de opinião.

Partindo para a compreensão dos instrumentos, é importante destacar que, como as relações públicas comunitárias buscam se relacionar com vários públicos, um dos recursos mais utilizados é o da comunicação dirigida, com os seguintes aspectos: orais, escritas, audiovisuais e aproximativas. O papel do profissional de relações públicas é envolver todas as pessoas para o desenvolvimento de um trabalho conjunto. Além de usar a comunicação escrita, é essencial a utilização da comunicação aproximativa direcionada para a coordenação de visitas, eventos comunitários, culturais e sociais (Kunsch, 2007b).

O desenvolvimento de projetos comunitários de relações públicas envolve a participação de pessoas e áreas distintas. Para o desenvolvimento de ações de 
comunicação para a sustentabilidade, trata-se de um excelente recurso, capaz de envolver diferentes públicos interessados no tema, e sistematizar projetos efetivos direcionados para fins coletivos.

De forma complementar, a história da comunicação organizacional também revela a evolução da área e indica alguns de seus desafios mais contemporâneos. Os desafios atuais da comunicação organizacional são complexos, pois sua envergadura de atuação é ampla e varia de acordo com contextos específicos. Para que possa haver uma sistematização mais relacionada ao formato desta pesquisa, optou-se por indicar e discutir alguns desafios atuais da comunicação organizacional.

Um deles é o da mensuração de resultados, tema ainda complexo aos comunicadores. A mensuração em comunicação representa um estágio a ser conquistado pela área de comunicação, e pode ser visto basicamente de dois modos. Há aqueles que creem no empecilho criado por este desafio, e têm dificuldade em lidar com números e métricas para provar a importância da comunicação. Por outro lado, há os que apostam que utilizar tal método é garantir a continuidade da evolução da comunicação organizacional, para que se prove como imprescindível.

De acordo com Mitsuru Yanaze (2010), principal ator da obra "Retorno de Investimentos em Comunicação: Avaliação e Mensuração", a interface da comunicação com as finanças é inovadora, e tal perspectiva está respaldada pela necessidade que existe de profissionais com formação mais completa e menos especializada. Conceitualmente, a lógica da mensuração está associada à compreensão da comunicação como um investimento, pressuposto a partir do qual métricas são desenvolvidas.

Outro desafio proposto é da customização de conteúdos, relacionado com a necessidade de um repensar em públicos e canais. Isso ocorre em decorrência de fatores humanos, sociais, econômicos, e também comunicacionais, pois o mapeamento mais tradicional de públicos, embasado nas teorias da comunicação mais antigas, não responde mais aos conceitos mais recentes de público.

Atualmente, os estudos sobre a mídia estão ainda amplamente presentes. Certamente trata-se de um conceito importante e aplicável, mas é crescente a necessidade de relativização de tal conceito já que o dinamismo dos fluxos de comunicação e das pessoas evoluiu nos últimos anos, assim como se multiplicou o acesso a diferentes canais de comunicação, como as redes sociais. A customização 
efetiva entende que os públicos a quem a comunicação organizacional quer destinar suas mensagens estão acessíveis, possivelmente, por outros canais que não somente os tradicionais.

Na prática, propõe-se um repensar sobre a comunicação, no sentido de que ações antes voltadas para o grande público, em apenas um canal de comunicação, carregam a necessidade, cada vez maior, de serem revistas para um posicionamento institucional da organização que seja multicanal, porém com customização de público e linguagem.

Último desafio apresentado aqui é o da estruturação e manutenção de uma equipe de profissionais. Este pode ser um gargalo para o crescimento da comunicação nas organizações, sobretudo em um momento em que tal área se consolida como estratégica e tem demonstrado provas das suas atribuições.

A estruturação de equipes de comunicação requer a compreensão de vários fatores, a começar pela formação dos envolvidos. Conforme será detalhado ao longo deste trabalho, a formação dos profissionais de comunicação não tem contemplado a necessidade de uma visão mais holística e menos fragmentada da comunicação. É fundamental aprender os aspectos instrumentais, sem dúvida. No entanto, o que se vê em muitos profissionais é a dificuldade em extrapolar a formação que recebeu e observar sua atuação e sua área sob um ponto de vista mais amplo.

Discorrendo ainda sobre este aspecto, a visão que a equipe deve ter não condiz com a que muitos profissionais têm hoje. Uma visão sistêmica é o que dá ao profissional a capacidade de antever situações e propor ações efetivas, que se encaixem no planejamento e causem resultados na ponta da ação.

Ainda sobre a equipe de comunicação, é de se destacar o perfil destes profissionais, sendo oportuno adiantar que há uma série de competências e habilidades exigidas por parte das organizações que devem privilegiar mais proatividade, flexibilidade e dinamismo. Isso tende a ser mais importante nas próximas décadas, assim como o respaldo de um conteúdo bem articulado, planejado e sistematizado. São, enfim, desafios próprios de uma área que cresceu e tem diante de si mais uma vez o desafio do novo, para ocupar lugares de destaque nas organizações e contribuir para a democratização da informação e do conhecimento. 


\section{Capítulo 5. A visão das organizações do terceiro setor}

A pesquisa empírica "Comunicação para a sustentabilidade em organizações do terceiro setor" teve como objetivo principal pesquisar e analisar como a comunicação organizacional é desenvolvida no terceiro setor e quais seriam os impactos das ações dessas organizações direcionadas à sustentabilidade para o benefício da sociedade.

Como objetivos específicos foram estabelecidos: analisar as práticas de comunicação e sustentabilidade adotadas pelas organizações no terceiro setor; verificar se a comunicação no terceiro setor tem contribuído para aumentar a consciência sobre a importância da sustentabilidade; buscar aportes teóricos para uma base conceitual da comunicação para a sustentabilidade e fundamentos para ampliar a sustentação da conceituação desse processo; apurar a incorporação do conceito de sustentabilidade nas organizações pesquisadas e contribuir para gerar mais consciência social com uma comunicação estratégica.

\subsection{Universo e amostra}

O universo foi composto a partir da montagem de banco de dados, tendo por base principal as organizações que atuam com foco em sustentabilidade listadas no Portal da Associação Brasileira de Organizações Não Governamentais (Abong) (www.abong.org.br) e na plataforma ONGs Brasil (www.ongsbrasil.com.br), com organizações de todos os portes para identificar quais trabalhavam com a questão da sustentabilidade e de assuntos correlatos. Foram, ao todo, 4.876 organizações, conforme os Apêndices 2 e 3, sendo 237 da Abong e 4.639 da plataforma ONGs Brasil.

Desde total, como existiam muitos casos de organizações indicadas de forma repetida, com presença em mais de uma categoria, e também a presença de e-mails inválidos, o questionário foi enviado para 1.597 organizações. No Quadro 1 estão indicadas todas as categorias de organizações disponibilizadas no portal da Associação Brasileira de Organizações Não Governamentais (Abong).

Quadro 1: Categorias das organizações disponibilizadas no portal da Abong

\begin{tabular}{|l|}
\hline Agricultura \\
\hline Arte e cultura \\
\hline
\end{tabular}




\begin{tabular}{|l|}
\hline Assistência social \\
\hline Comunicação \\
\hline Comércio \\
\hline Crianças e adolescentes \\
\hline DST/AIDS \\
\hline Discriminação racial \\
\hline Discriminação sexual \\
\hline Economia solidária \\
\hline Educação \\
\hline Esporte \\
\hline Fortalecimento de outras ONGs/ Movimentos populares \\
\hline Justiça e promoção de direitos \\
\hline Meio Ambiente \\
\hline Organização popular/ Participação popular \\
\hline Orçamento público \\
\hline Questão indígena \\
\hline Questões agrárias \\
\hline Questões urbanas \\
\hline Relações de consumo \\
\hline Relações de gênero \\
\hline Saúde \\
\hline Segurança alimentar \\
\hline Segurança pública \\
\hline Trabalho e renda \\
\hline Outras \\
\hline
\end{tabular}

No Quadro 2 estão indicadas as categorias selecionadas de organizações que atuam com sustentabilidade e com finalidades afins disponibilizadas no portal da Associação Brasileira de Organizações Não Governamentais (Abong). O critério foi selecionar organizações que atuam com elementos econômicos, sociais e ambientais ou atividades relacionadas direta ou indiretamente a essas.

Quadro 2: Categorias de organizações selecionadas no portal da Abong

\begin{tabular}{|l|}
\hline Agricultura \\
\hline Assistência social \\
\hline Comércio \\
\hline Economia solidária \\
\hline Meio ambiente \\
\hline Trabalho e renda \\
\hline
\end{tabular}


No Quadro 3 estão indicadas todas as categorias de organizações disponibilizadas na plataforma ONGs Brasil.

Quadro 3: Categorias de organizações disponibilizadas no site ONGs Brasil

\begin{tabular}{|l|}
\hline Ações integradas de reabilitação \\
\hline Ambulatório médico \\
\hline Amparo a crianças e adolescentes \\
\hline Amparo à maternidade \\
\hline Amparo aos idosos \\
\hline Amparo em situação de crise social \\
\hline Amparo social com moradia \\
\hline Aplicação educacional de tecnologia \\
\hline Apoio à aprendizagem \\
\hline Apoio à permanência escolar \\
\hline Arte-educação \\
\hline Artes plásticas e visuais \\
\hline Assistência jurídica \\
\hline Assistência para moradia \\
\hline Associações de crédito e poupança \\
\hline Atendimento domiciliar \\
\hline Atendimento hospitalar e de emergência \\
\hline Atividades artísticas e de espetáculos \\
\hline Atividades complementares à escola \\
\hline Atividades literárias e humanísticas \\
\hline Auxílio à renda e sustento \\
\hline Capacitação para o trabalho \\
\hline Centro de educação infantil \\
\hline Civismo \\
\hline Clínica de reabilitação física \\
\hline Clínica de repouso com internação \\
\hline Complementação diagnóstica \\
\hline Complementação terapêutica \\
\hline Controle e diminuição de danos ambientais \\
\hline Controle, ajuda e prevenção de desastres e emergências \\
\hline Creche \\
\hline Cursos de graduação \\
\hline Cursos de pós-graduação \\
\hline Defesa dos direitos civis \\
\hline Defesa dos direitos humanos \\
\hline Defesa dos direitos socioassistenciais \\
\hline Desenvolvimento comunitário e social \\
\hline
\end{tabular}


Desenvolvimento econômico

Desenvolvimento/ apoio rural e agrícola

Doação de órgãos

Ecoeficiência

Educação ambiental

Educação especial

Educação fundamental

Educação média de formação geral

Educação preventiva para saúde

Educação supletiva

Ensino à distância

Ensino pré-escolar

Estágio e emprego

Farmácia e distribuição de medicamentos

Financiadoras de projetos

Formação continuada de agentes de saúde

Formação continuada de educadores

Formação de multiplicadores

Formação técnica e profissional

Garantia do acesso ao conhecimento dos direitos socioassistenciais

Geração de renda familiar

Hospitais psiquiátricos

Incentivo à inclusão no ensino superior

Inclusão digital

Intervenção em crises

Liberdade assistida

Mídia e comunicações

Mobilização e articulação pela educação

Nutrição

Outras

Pesquisa em ciências biológicas e naturais

Pesquisa em ciências físicas e tecnológicas

Pesquisa em ciências sociais, políticas e humanas

Pesquisa médica

Pesquisas sociais

Preservação cultural e histórica

Preservação e proteção da vida selvagem

Prevenção ao crime

Prevenção e saúde pública

Produção eco-sustentável

Promoção da participação social e política

Promoção do voluntariado 


\begin{tabular}{|l|} 
Promoção humana e social \\
\hline Proteção à família \\
\hline Proteção e conservação do patrimônio natural \\
\hline Segurança e cidadania \\
\hline Serviços de prevenção e reabilitação para dependentes químicos \\
\hline Serviços odontológicos \\
\hline Serviços sociais de apoio à saúde \\
\hline Suporte a vítima \\
\hline Terapia psicológica e ocupacional \\
\hline Tratamento da saúde mental sem internação \\
\hline
\end{tabular}

No Quadro 4 estão indicadas as categorias selecionadas de organizações que atuam com sustentabilidade disponibilizadas na plataforma ONGs Brasil. O critério foi selecionar organizações que atuam com elementos econômicos, sociais e ambientais ou atividades relacionadas direta ou indiretamente a essas.

Quadro 4: Categorias de organizações selecionadas no site ONGs Brasil

\begin{tabular}{|l|}
\hline Associações de crédito e poupança \\
\hline Controle e diminuição de danos ambientais \\
\hline Ecoeficiência \\
\hline Educação ambiental \\
\hline Desenvolvimento econômico \\
\hline Desenvolvimento e apoio rural e agrícola \\
\hline Preservação e proteção da vida selvagem \\
\hline Produção ecosustentável \\
\hline Proteção e conservação do patrimônio natural \\
\hline
\end{tabular}

\subsection{Análise dos resultados obtidos}

\section{Questão 1 - Nome da organização}

O Apêndice 4 indica a relação das 218 organizações que responderam ao questionário desta pesquisa. A apresentação das organizações não ocorre por ordem alfabética, mas sim de forma cronológica, revelando a amostra voluntária que, por uma questão de transparência, é apresentada com datas e horários em que cada um respondeu ao questionário. Os nomes constam da mesma forma conforme foram apresentados pelos seus respondentes. A primeira coluna da esquerda remete aos 
números com os quais cada uma das organizações será indicada nas próximas análises.

\section{Questão 2 - Unidade federativa}

Esta questão perguntava a unidade federativa de cada organização que respondeu ao questionário. O conteúdo foi enviado para organizações de todas as unidades federativas do Brasil. Para melhorar a qualificação e a representatividade da pesquisa, a porcentagem de organizações existentes nos bancos de dados da Associação Brasileira de ONGs (Abong) e da plataforma ONGs Brasil das regiões geográficas brasileiras é proporcional à porcentagem de respostas obtidas de organizações de cada uma das regiões do país, o que significa que a amostra é representativa do universo. Isso explica na predominância de respostas da região Sudeste principalmente de São Paulo e Minas Gerais e Rio de Janeiro. Também é nítida a presença de muitas organizações da região Sul por exemplo do Paraná e do próprio Rio Grande do Sul. O Quadro 5, abaixo do gráfico, também revela a distribuição geográfica do universo comparada à amostra por região, estabelecendo qual é a porcentagem em relação às 218 respostas.

A única unidade federativa que não recebeu nenhuma resposta foi o Amapá, embora tenha recebido todo o empenho para pontuar também no questionário por meio de contatos por e-mail e telefone. Todas as demais unidades federativas estão representadas no Gráfico 1. 
Gráfico 1: Unidade federativa

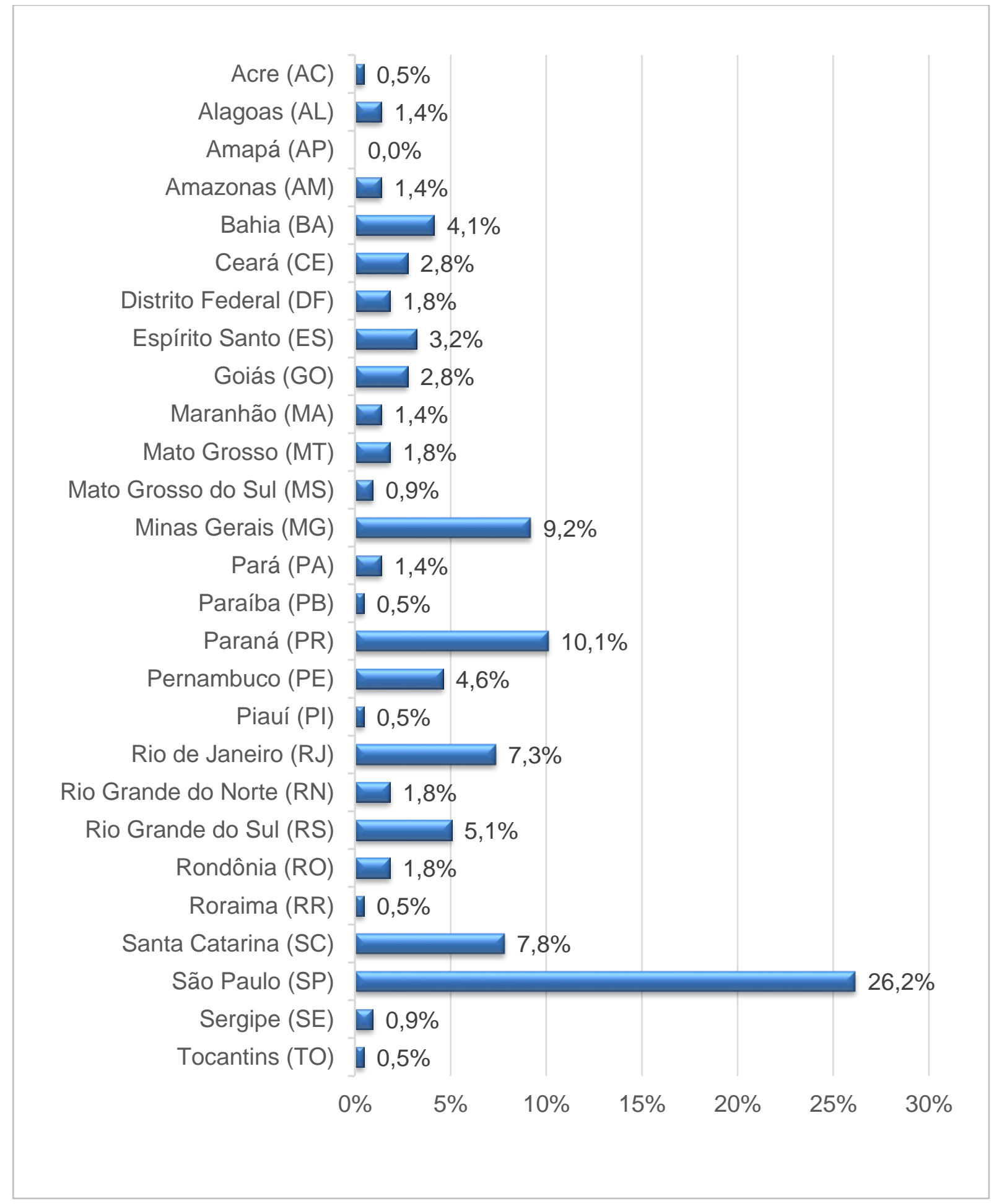

Fonte: Ulsen (2018)

Sendo a amostra é representativa do universo, o Quadro 5 compara a distribuição geográfica das organizações do terceiro setor que atuam com sustentabilidade em âmbito nacional com a amostra da pesquisa. 
Quadro 5: Distribuição geográfica do universo comparada à amostra por região

\begin{tabular}{|c|c|c|}
\hline Região & Universo & Amostra \\
\hline Centro-Oeste & $6,76 \%$ & $7,33 \%$ \\
\hline Nordeste & $18,99 \%$ & $17,90 \%$ \\
\hline Norte & $4,18 \%$ & $5,96 \%$ \\
\hline Sudeste & $48,52 \%$ & $45,87 \%$ \\
\hline Sul & $21,52 \%$ & $22,94 \%$ \\
\hline
\end{tabular}

\section{Questão 3 - Endereço completo}

Esta questão também está relacionada ao primeiro bloco do questionário, ou seja, de identificação das organizações. Alguns endereços não foram recebidos na íntegra, mas a identificação de cada um dos questionários possibilitou revelar a cidade e o Estado em que estas organizações estão localizadas, conforme Apêndice 5. Nesses casos de endereços informados de forma incompleta, buscas complementares na Internet foram realizadas para apresentar a seguir as informações na íntegra. Considera-se que este levantamento pode ser especialmente útil para facilitar o contato em futuras pesquisas.

\section{Questão 4 - Ano de criação}

Pergunta destinada a entender desde quando vem ocorrendo a criação de organizações do terceiro setor no Brasil, apresenta no Gráfico 2 uma separação didática por décadas. Fica nítido observar que, com exceção da década de 1940, houve uma evolução numérica importante ao longo do tempo de novas organizações sendo criadas.

Um grande salto pode ser observado na década de 1980, o que está alinhado, conforme a revisão bibliográfica já havia indicado, com o período de redemocratização política do Brasil. Quase metade delas (45,4\%) passaram a operar entre 2001 e 2010, período em que políticas de desenvolvimento social e de distribuição de renda passaram a ser mais priorizadas pelo Estado brasileiro. 
Gráfico 2: Ano de criação

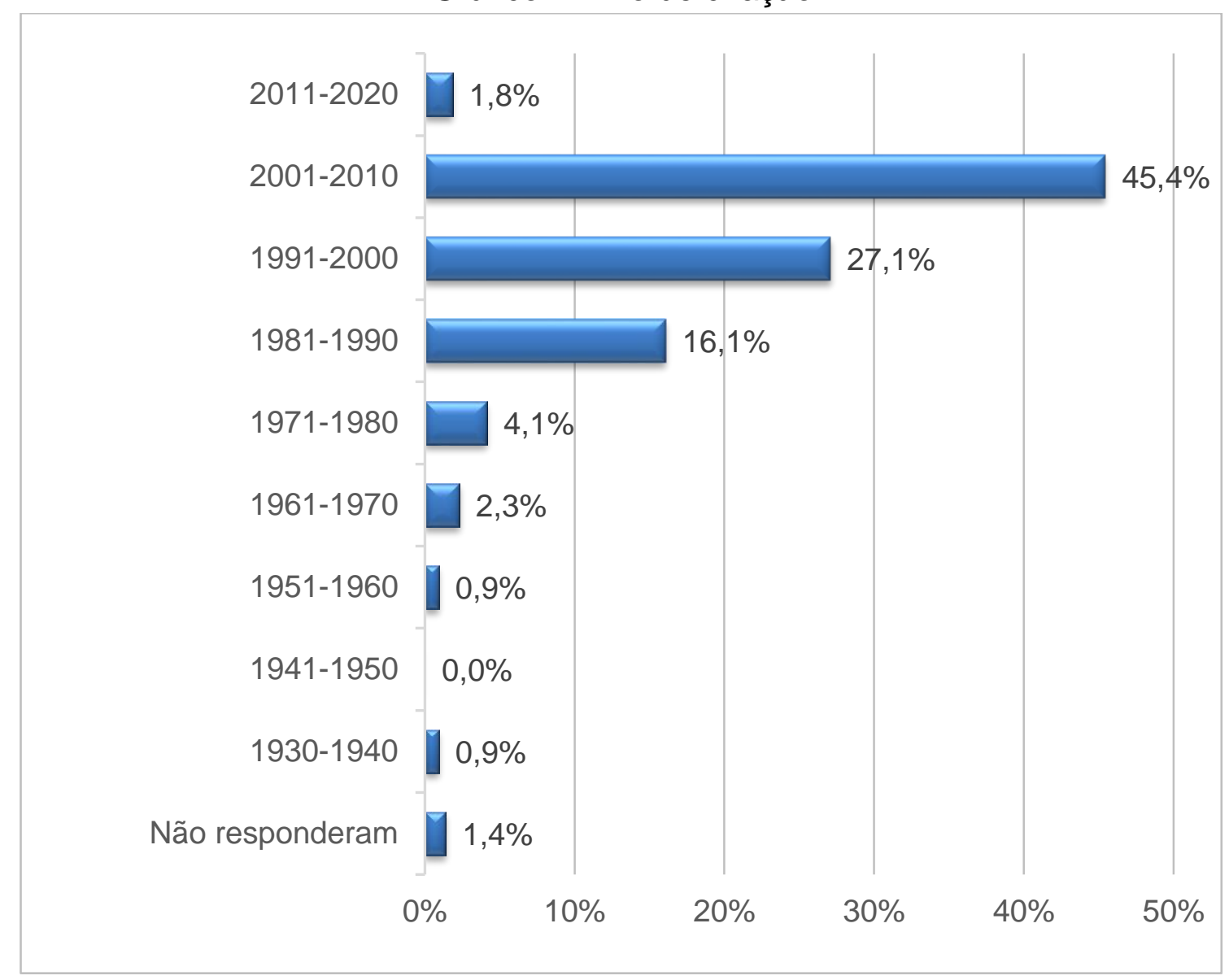

Fonte: Ulsen (2018)

\section{Questão 5 - Nome do responsável pelas informações}

Criada para identificar o nome do respondente pelo fornecimento das informações, conforme Apêndice 6. Na sequência, também foram perguntadas outras informações a respeito desta pessoa. $O$ objetivo também foi o de identificar quem são os responsáveis e facilitar o contato em futuras pesquisas.

\section{Questão 6 - E-mail do responsável pelas informações}

O e-mail do respondente pelas informações também está indicado conforme Apêndice 7 , sendo que o número da primeira coluna corresponde às organizações identificadas no Apêndice 4. 


\section{Questão 7 - Telefone do responsável pelas informações}

Mais uma questão para identificar quem está fornecendo as informações, neste caso o telefone para facilitar o acesso em futuros contatos e novas pesquisas, conforme Apêndice 8.

\section{Questão 8 - Cargo do responsável pelas informações}

Questão elaborada para identificar o cargo da pessoa responsável pelo fornecimento das informações. A surpresa é que $25,9 \%$ das respostas foram enviadas por presidentes ou vice-presidentes das organizações. Na sequência hierárquica, $15,1 \%$ das respostas vieram de diretores e $10,6 \%$ de gerentes. Se considerarmos a soma de presidentes e diretores são $41 \%$ das respostas obtidas por pessoas deste nível hierárquico, o que demonstra o comprometimento deles em atender a pesquisa.

Se somarmos os cargos de gerentes e diretores, chegamos a $52,6 \%$ das informações respondidas por pessoas deste nível hierárquico. Outro dado interessante é observar que $20,6 \%$ das respostas foram enviadas por pessoas que estão em cargo de coordenação ou supervisão. Analistas respondem por $3,2 \%$ do total, estagiários por 2,8\% e 11\% das pessoas são de outro cargo. Nenhuma resposta foi obtida por pessoas em cargos identificados na categoria trainee. As informações indicam um comprometimento dos gestores em atender a pesquisa e a percepção deles sobre a relevância que os estudos científicos podem ter para colaborar com o enfrentamento dos futuros desafios de cada uma das organizações. 
Gráfico 3: Cargo do respondente

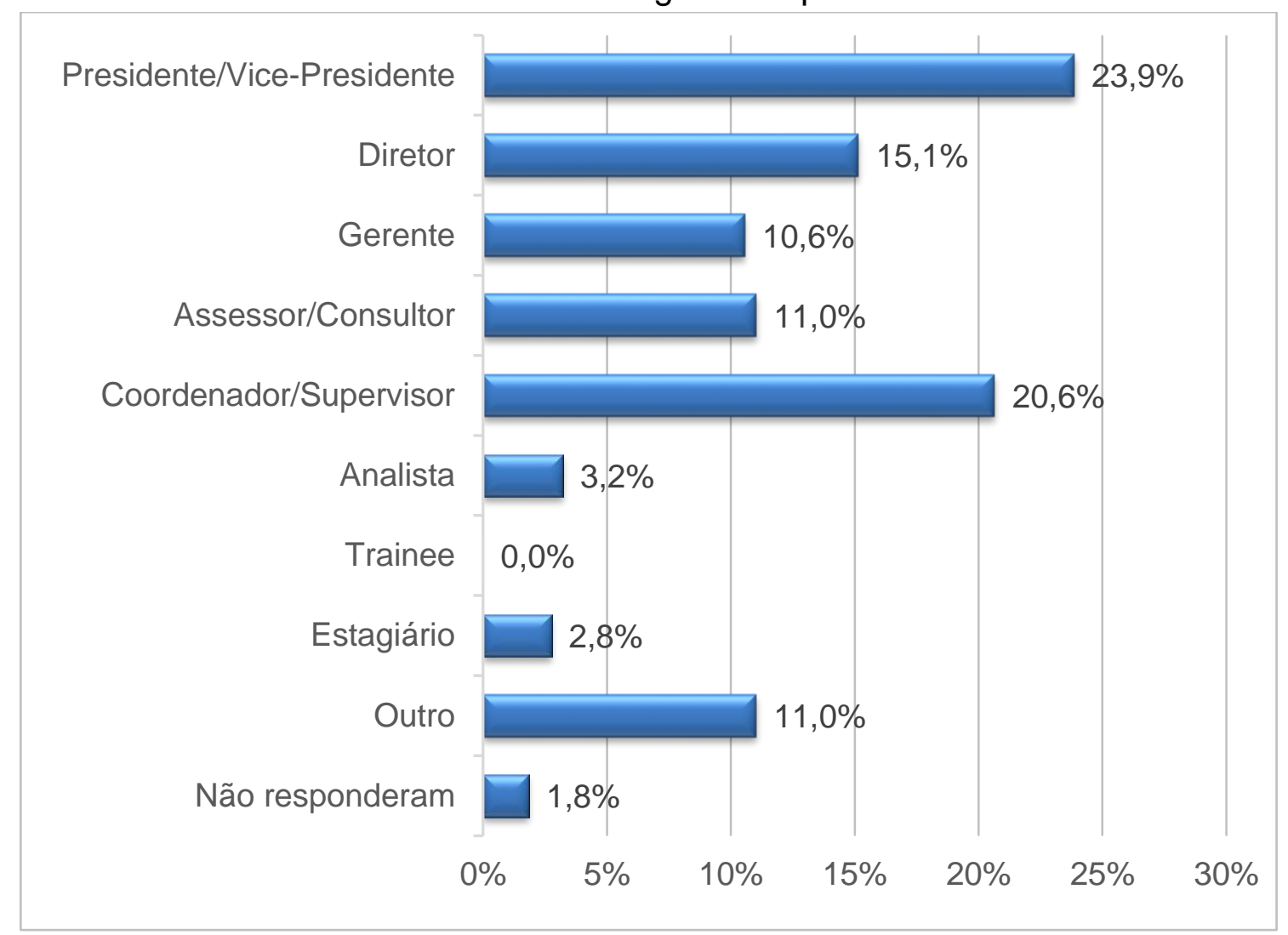

Fonte: Ulsen (2018)

\section{Questão 9 - Escolaridade do responsável pelas informações}

A escolaridade do responsável pelas informações foi perguntada com o objetivo de compreender qual é a qualificação formal das pessoas que estão liderando ou participando ativamente dessas iniciativas de pesquisas sobre comunicação e sustentabilidade nas organizações pesquisadas.

Surpreendentemente, $8,7 \%$ das respostas foram recebidas de pessoas que estão com doutorado completo ou em andamento. $14,7 \%$ deles têm mestrado completo ou em andamento e 34,9\% estão cursando especialização ou já a concluíram. O maior índice de respostas ficou por conta daqueles que concluíram ou estão cursando a graduação (36,7\%). Apenas $3,7 \%$ das respostas vieram de pessoas com nível de ensino médio completo ou em andamento.

Se considerarmos a soma de pessoas com nível de pós-graduação, ou seja, doutorado, mestrado e especialização, a porcentagem é de $58,3 \%$ de respostas oriundas de pessoas com essa formação. Se considerarmos a soma de pessoas envolvidas na graduação e pós-graduação cursando ou em andamento esse valor 
sobe para 95\%, revelando a importância que os respondentes dão ao curso superior e, possivelmente, a relevância que atribuem à necessidade de buscar mais qualificação para a atuação profissional. Os dados contrapõem a falsa percepção de que muitas organizações do terceiro setor, por pequenas que são, carecem de um quadro profissional qualificado e de pessoas com elevado nível de formação.

\section{Gráfico 4: Escolaridade do respondente}

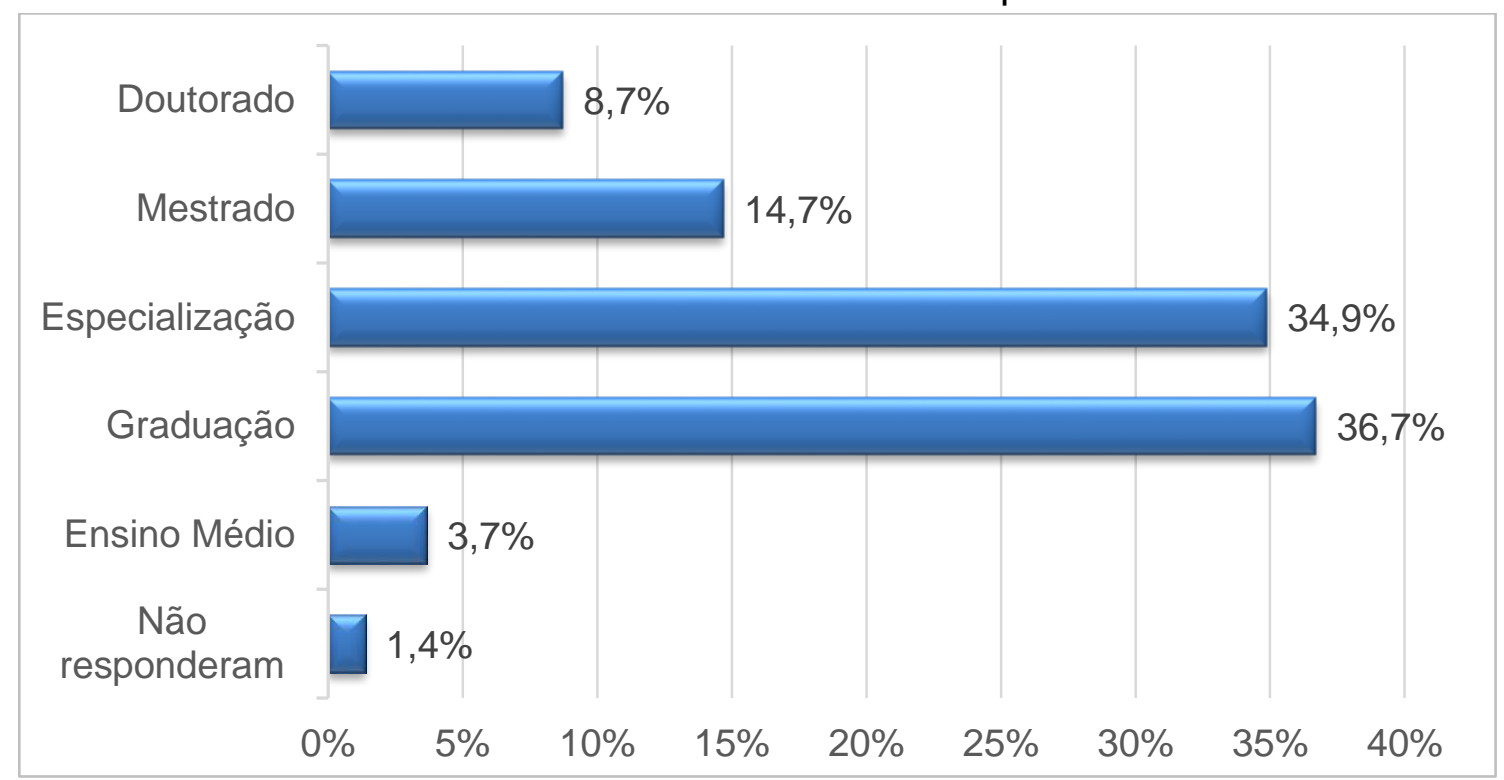

Fonte: Ulsen (2018)

\section{Questão 10 - Principal área de formação do responsável pelas informações}

Sobre a principal área de formação do responsável pelas informações, nenhuma surpresa quanto à predominância do curso de Administração entre os perguntados. $22,9 \%$ das pessoas são oriundas dessa área. Em termos de comunicação social, sobre o que há um interesse especial em saber, 14,2\% das pessoas são formadas nessa área, sendo o detalhamento a seguir: Jornalismo com 7,8\%; Relações Públicas com 4,1\%; e Publicidade e Propaganda com 2,3\%. A soma das formações em comunicação social revela este curso como o terceiro mais indicado nas respostas, sendo que a opção de detalhar a habilitação foi colocada para identificar se havia predominância de uma habilitação em relação à outra, o que de fato se notou. Formados em Jornalismo predominam em relação aos formados em Relações Públicas, que por sua vez representam quase o dobro dos formados em Publicidade e Propaganda. 
Nas Ciências Biológicas foram 9,2\% das respostas, egressos da Engenharia 5,5\%, da Economia 5,5\% e da Agronomia 2,3\%. 2,3\% são egressos da área da saúde e apenas $0,5 \%$ têm no Marketing a principal área de formação. 30,3\% das pessoas, ou seja, a maior porcentagem, tem origem em outras formações, indicadas a seguir: arqueologia pré-histórica, arquivologia, artesanato, biblioteconomia, ciência da computação, ciências contábeis, ciências da religião, ciências humanas, ciências socioambientais, desenvolvimento sustentável, direito, economia, ecoturismo, educação, filosofia, geografia, gestão ambiental, gestão costeira, gestão das organizações do terceiro setor, recursos humanos, história, letras, medicina veterinária, meio ambiente, psicologia, relações internacionais, serviço social, tecnologia da informação, teologia e turismo.

Gráfico 5: Principal área de formação do respondente

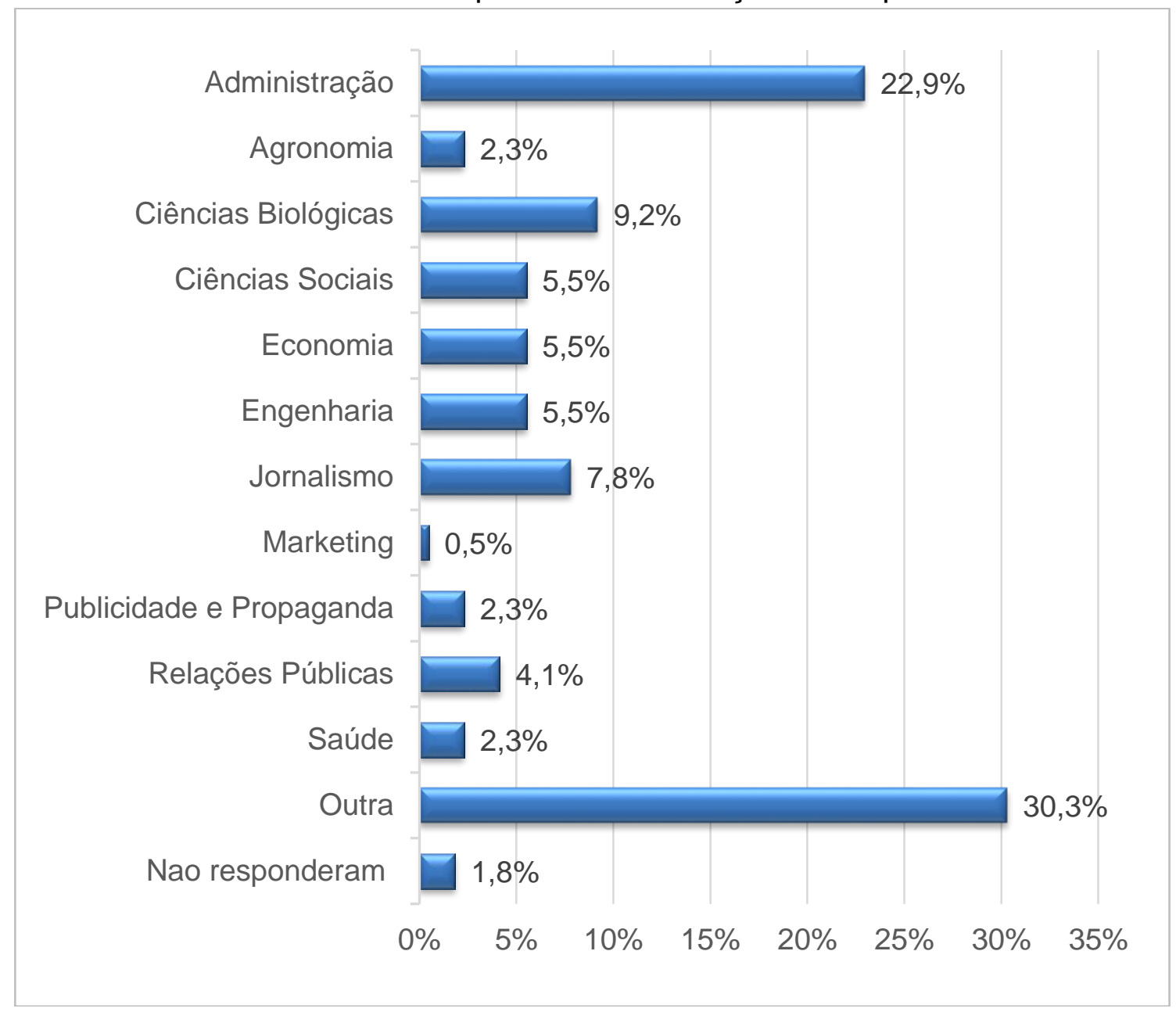

Fonte: Ulsen (2018) 


\section{Questão 11 - Principal foco de atuação da organização}

Com relação ao principal foco da atuação, fica evidente entre as organizações consultadas a predominância daquelas que atuam com a temática do meio ambiente (total de $46,3 \%$ ) distribuídas com os seguintes focos: conservação do meio ambiente $(13,3 \%)$, controle e diminuição de danos ambientais $(1,8 \%)$, desenvolvimento ambiental (5\%), educação ambiental $(5,5 \%)$, meio ambiente $(19,3 \%)$ e preservação da natureza $(1,4 \%)$.

O índice representa quase metade das respostas, o que está alinhado com as pesquisas bibliográficas que, em diferentes momentos evidenciaram a maior preocupação das organizações do terceiro setor com a temática ambiental, em comparação com outras necessidades alinhadas com a sustentabilidade.

O desenvolvimento social foi o item com a maior quantidade de respostas (19,7\% do total), seguido do desenvolvimento econômico (7,8\%), desenvolvimento rural $(6 \%)$, inclusão social $(4,1 \%)$ e trabalho e renda $(4,1 \%)$. Neste caso $2,8 \%$ não responderam, 1,8\% assinalaram a opção da participação popular e somente $0,5 \%$ destacaram o orçamento público como o principal foco de atuação da organização. 
Gráfico 6: Principal foco de atuação

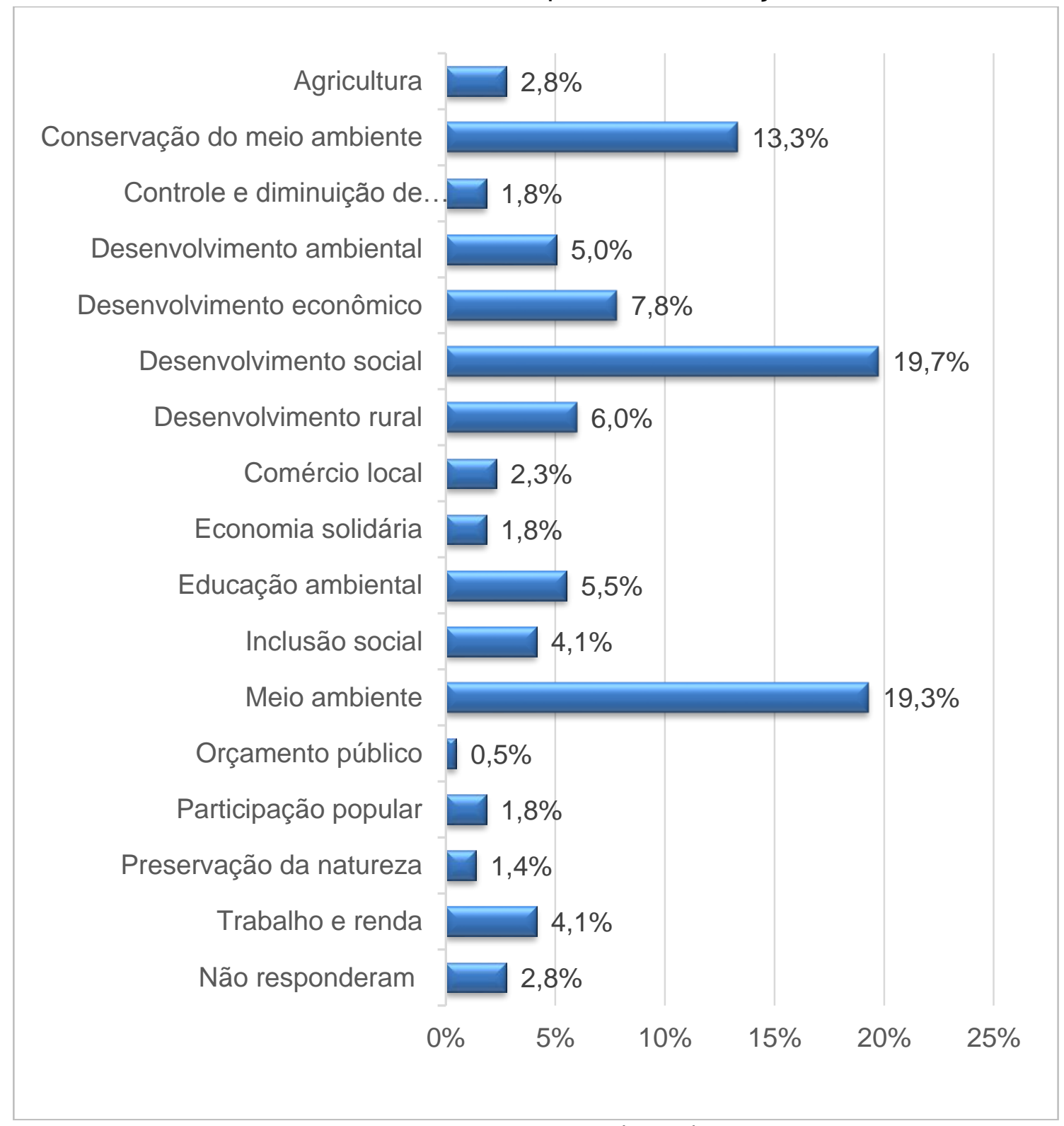

Fonte: Ulsen (2018)

\section{Questão 12 - Faturamento anual em 2016}

Esta questão revelou uma ampla assimetria entre as organizações. Por um lado, aquelas com faturamento anual inferior a $\mathrm{R} \$ 50 \mathrm{ml}(25 \%)$. Por outro lado, organizações com orçamento anual de mais de $R \$ 1$ milhão com $31,1 \%$ do total de respostas.

Aquelas com orçamento entre $R \$ 50$ mil e até $R \$ 1$ milhão somaram, juntas, $43,8 \%$, distribuídas conforme o Gráfico 7 . Também chama a atenção que $65,2 \%$ delas 
não responderam, talvez em decorrência do fato da resposta não ser considerada obrigatória.

Gráfico 7: Faturamento anual em 2016

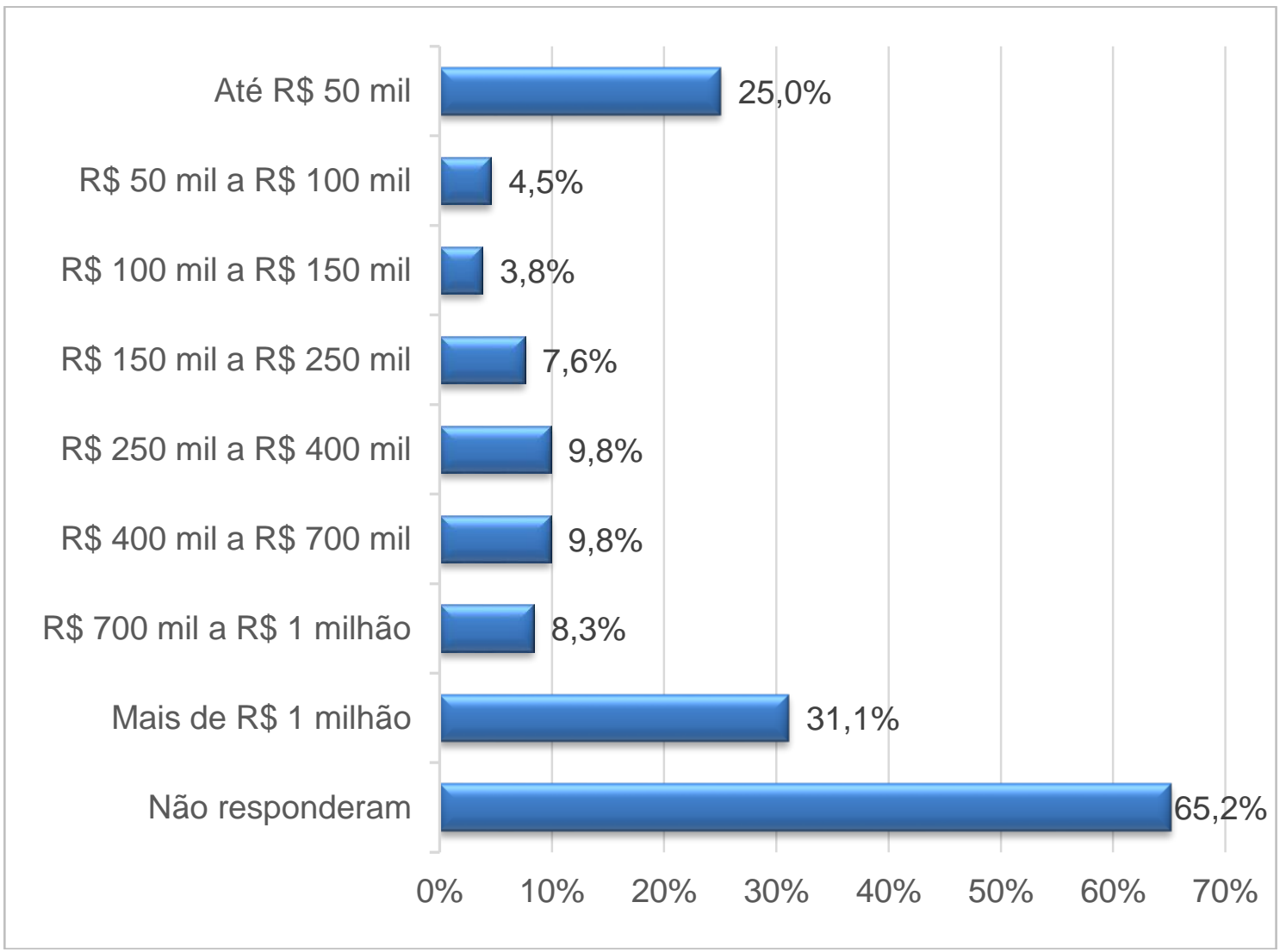

Fonte: Ulsen (2018)

\section{Questão 13 - Quantidade de funcionários, colaboradores e voluntários}

Em termos do tamanho da equipe envolvidas com as causas, é perceptível a ampla predominância de organizações com poucas pessoas envolvidas já que $61,5 \%$ delas têm até 20 funcionários, colaboradores e voluntários. De forma geral, quanto maior a porcentagem, menor a quantidade de profissionais, com exceção das organizações com mais de 400 pessoas $(3,7 \%)$, o que também revelou a representativa das grandes organizações no terceiro setor do Brasil.

Finalmente cabe esclarecer que a pergunta integrou funcionários com colaboradores e voluntários pois o terceiro setor brasileiro tem reunido, historicamente, muitas pessoas na condição de parceiros voluntários não necessariamente integrados ao quadro de funcionários e colaboradores. 
Gráfico 8: Quantidade de funcionários, colaboradores e voluntários

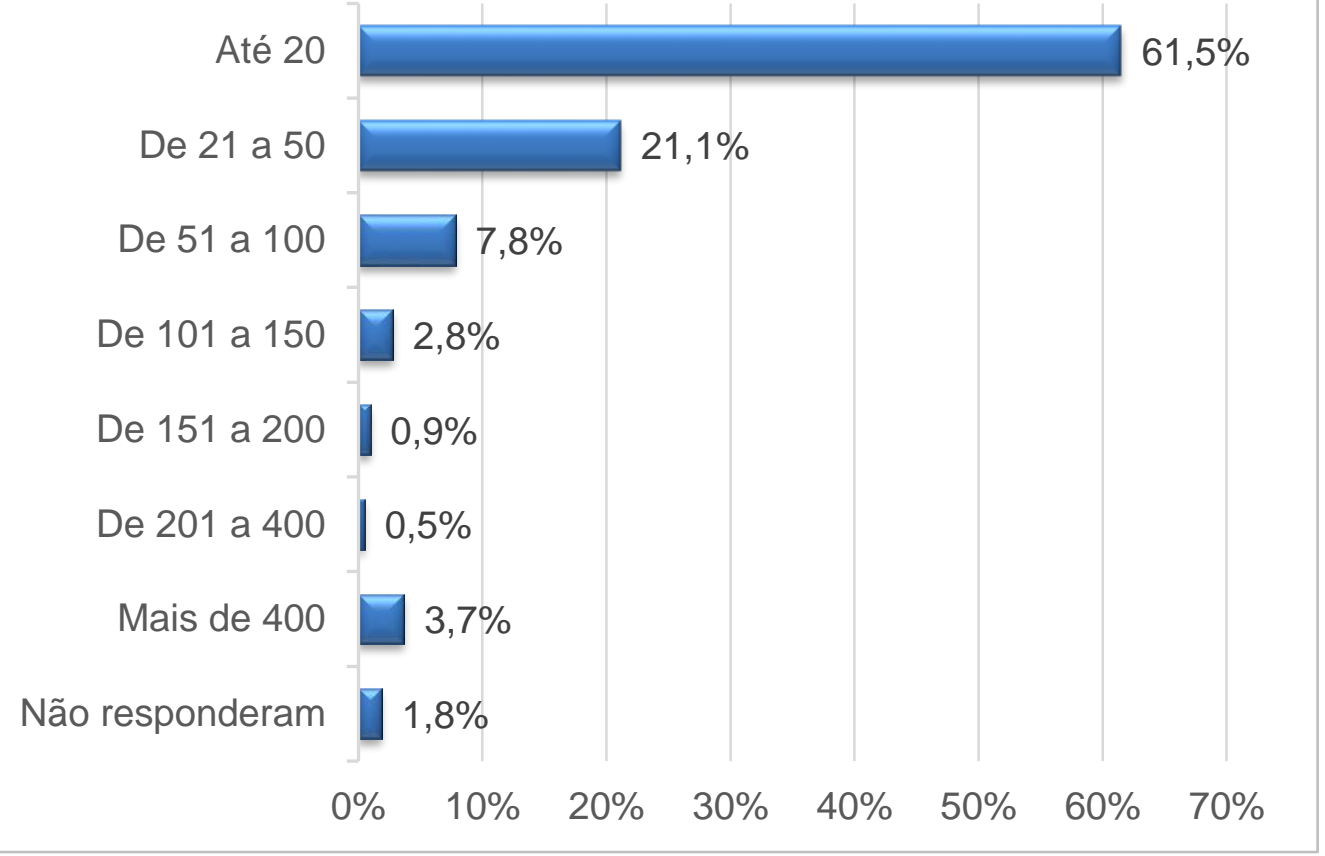

Fonte: Ulsen (2018)

\section{Questão 14 - Liderança da sustentabilidade}

Como era de se esperar, a Diretoria consta nesta questão como a principal área mais indicada responsável opor liderar as iniciativas de sustentabilidade (38,5\%), o maior índice entre as respostas. Na sequência, o Conselho de Administração também se revelou expressivo com $24,8 \%$ das respostas.

As áreas de Marketing e o Jurídico foram pouco citadas (apenas $0,5 \%$ cada) e a Comunicação, estranhamente, simplesmente não recebeu nenhuma resposta $(0 \%)$. Este dado revela uma aparente contradição com outros dados de pesquisa, por exemplo o Gráfico 11, que será apresentado na sequência e indica que $62,8 \%$ dos respondentes consideram a Comunicação como totalmente relevante dentro das organizações do terceiro setor.

Em termos de Outra área, foram apresentadas respostas abertas pelos respondentes, entre os quais constaram as seguintes informações: assembleia, colegiado, conselho deliberativo, coordenação colegiada, coordenação socioambiental, coordenação de projetos, definições coletivas, educativo, equipe executiva, equipe técnica, gerências sociais, grupo técnico vinculado à presidência, mobilização de recursos, pedagógica, pesquisa científica, secretaria executiva, superintendência e todas as áreas. 
Gráfico 9: Liderança da sustentabilidade

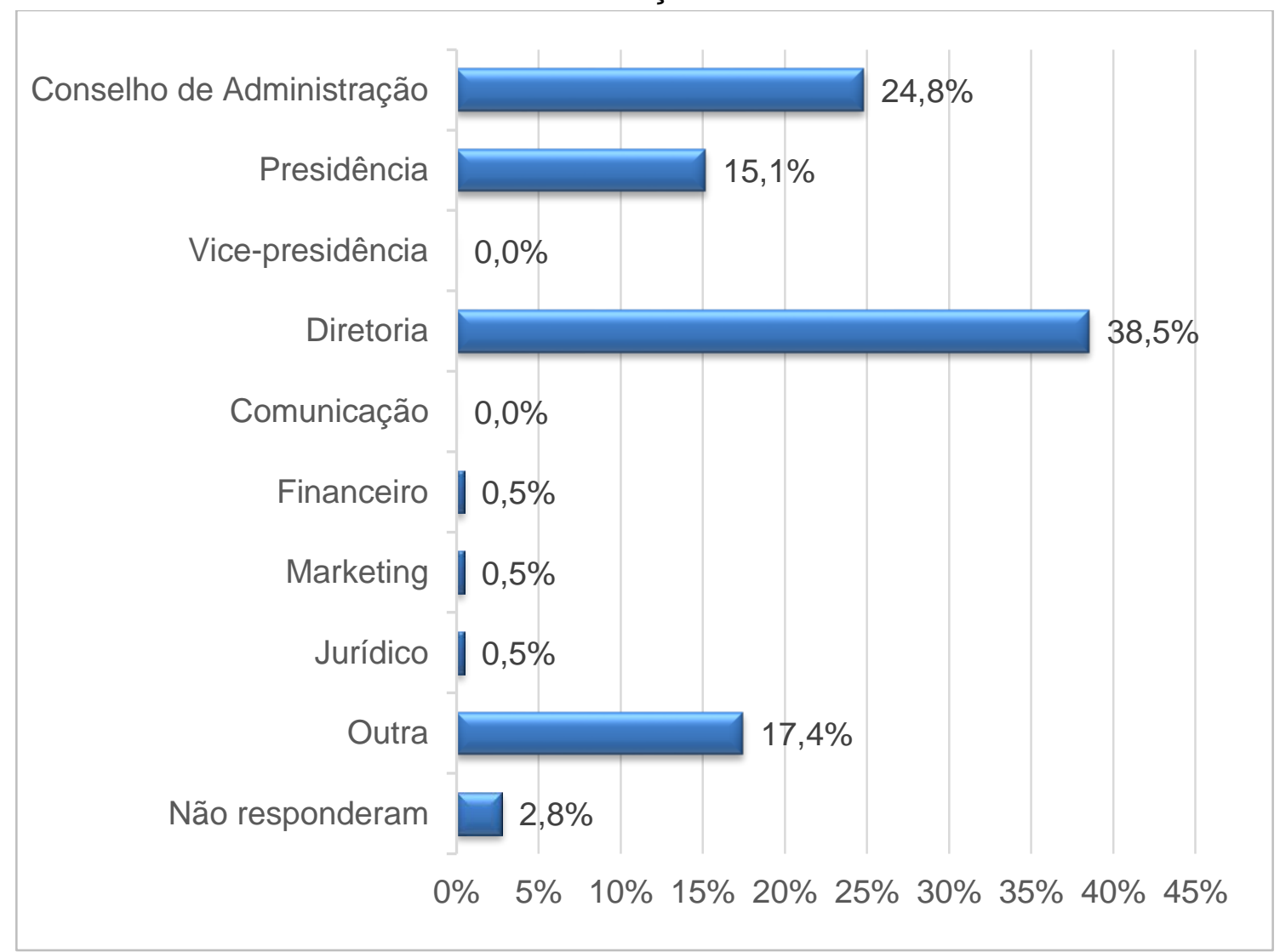

Fonte: Ulsen (2018)

\section{Questão 15 - Melhor definição de sustentabilidade}

Questão formulada para identificar, entre as definições apresentadas de sustentabilidade, qual é a opção que mais se aproxima do que a organização utilizar para fundamentar suas ações. Além das sete definições apresentadas, o respondente podia escolher ainda a opção que indicava nenhuma das anteriores ou, também podia optar por não responder.

As respostas estão indicadas conforme indicado a seguir (definição e autor), porém cabe esclarecer que, para não influenciar as respostas, a definição foi apresentada no questionário sem o respectivo autor.

O maior índice disparado (44\%), neste caso, coube à definição de sustentabilidade atribuída a John Elkington, consultor britânico que, de fato, é muito conhecido no meio de responsabilidade social e ambiental, sobretudo pela boa aceitação que tem em ambientes corporativos em empresariais. Trata-se do autor conhecido como o criador do termo triple bottom line, o tripé da sustentabilidade que 
corresponde aos resultados de uma organização medidos em termos sociais, ambientais e econômicos.

O elevado número de respostas dedicadas a esta definição pode ser explicada devido a esta expressão ser amplamente difundida. Caso a pesquisa estivesse sendo feita somente com empresas, esse elevado índice seria mais coerente. Porém, em se tratando exclusivamente de organizações do terceiro setor focadas em sustentabilidade, esperava-se que outras definições também tivessem sido mais citadas.

Em segundo lugar, com 16,5\% das respostas, está a definição do brasileiro Leonardo Boff, considerado pioneiro na incorporação das bandeiras ecológicas à teologia da libertação, crítico da concepção do progresso infinito e defensor da realidade de maneira holística como condição necessária para a sobrevivência de todos os seres vivos, não somente do ser humano. Este dado se revelou uma surpresa positiva pois, de certa forma se contrapôs à visão predominante anterior, mais corporativa e empresarial, de John Elkington.

Com $11,5 \%$ das respostas, está a definição atribuída a Lester Brown, que entende a sociedade sustentável como aquela capaz de satisfazer suas necessidades sem comprometer as chances de sobrevivência das gerações futuras. Sob esta ótica, o autor entende a importância do estabelecimento de critérios de desenvolvimento ambientalmente corretos com ações conscientes contrárias ao consumismo desenfreado para as gerações futuras, ainda que predomine um olhar mais centrado nas ações humanas.

Para 6,4\% das organizações, a melhor definição de sustentabilidade é aquela atribuída ao austríaco Fritjof Capra, físico teórico e escritor que desenvolve pesquisas no âmbito da educação ecológica e é uma referência para o pensamento sistêmico, aquele que enxerga o todo como indissociável de forma que o estudo das partes não permite conhecer o funcionamento dos organismos.

4,6\% dos respondentes selecionaram a definição de Enrique Leff, sociólogo ambientalista mexicano, crítico do modelo de desenvolvimento econômico contemporâneo e um dos principais pesquisadores dos desafios globais em termos de economia ecológica, ecologia política e educação ambiental.

Para 4,1\% das organizações, a definição mais adequada é aquela atribuída ao economista polonês Ignacy Sachs, segundo quem o desenvolvimento é uma 
combinação de crescimento econômico, aumento igualitário do bem-estar social e preservação ambiental. Há mais de trinta anos, Ignacy Sachs lançou fundamentos importantes sobre a necessidade de um novo paradigma de desenvolvimento fundamentado na convergência entre economia, ecologia, antropologia cultural e ciência política.

A fundamentação da sustentabilidade e do cenário atual de desenvolvimento menos selecionada nesta pesquisa $(1,4 \%)$ é aquela atribuída ao engenheiro e pesquisador Fernando Almeida. Com mais de trinta anos de experiência profissional nos setores empresarial, governamental e acadêmico, o autor é uma das maiores referências em sustentabilidade no Brasil. Como escritor, conferencista e estrategista, tem ajudado as empresas a alinharem responsabilidade socioambiental com 0 sucesso do negócio.

Para 8,3\% das organizações, a melhor definição de sustentabilidade não é nenhuma das anteriores e 3,2\% não responderam.

Quadro 6: Definição de sustentabilidade

\begin{tabular}{|c|c|c|}
\hline Sigla & Definição & Autor \\
\hline A & $\begin{array}{l}\text { "O desenvolvimento sustentável envolve a busca simultânea da } \\
\text { prosperidade econômica, da qualidade ambiental e da igualdade } \\
\text { social. As empresas que buscam a sustentabilidade precisam } \\
\text { empenhar-se não somente na direção de uma única linha de } \\
\text { resultados, a financeira, mas sim na linha dos três pilares" }\end{array}$ & John Elkington \\
\hline$B$ & $\begin{array}{l}\text { "Para a implantação do projeto do ecodesenvolvimento são } \\
\text { necessárias reflexões acerca do atual modelo de produção, que } \\
\text { gasta mais energia para produzir determinados alimentos em } \\
\text { relação à energia resultante no final do processo, e aos efeitos } \\
\text { residuais no ambiente. Imaginação, vontade política, o [...] } \\
\text { reaparelhamento da economia com tecnologias poupadoras de } \\
\text { recursos ou a promoção de sistemas que exigem tempo e } \\
\text { investimentos consideráveis também são requisitos" }\end{array}$ & Ignacy Sachs \\
\hline C & $\begin{array}{l}\text { "A efetivação de um modelo de desenvolvimento ecotecnológico, } \\
\text { bem como de uma racionalidade ambiental que o fundamente, } \\
\text { deve fazer parte de um projeto histórico mais amplo, conduzido } \\
\text { pela sociedade civil, através da conscientização, reivindicação e } \\
\text { atuação dos movimentos sociais, sejam de caráter ambiental, } \\
\text { étnico, cultural, 'consumerista' ou simplesmente cívico" }\end{array}$ & Enrique Leff \\
\hline D & $\begin{array}{l}\text { "As megamudanças nos ecossistemas que são a base da nossa } \\
\text { sobrevivência estão induzindo crescentes alterações no } \\
\text { comportamento de diversos atores no setor público, no setor } \\
\text { privado e na sociedade civil. Aumentaram a regulamentação por } \\
\text { parte dos governos e a pressão exercida sobre as empresas } \\
\text { pelos grupos de interesse, sejam eles acionistas, organizações } \\
\text { não governamentais ou clientes. A tendência é que esse quadro }\end{array}$ & $\begin{array}{l}\text { Fernando } \\
\text { Almeida }\end{array}$ \\
\hline
\end{tabular}




\begin{tabular}{|c|c|c|}
\hline & $\begin{array}{l}\text { se torne cada vez mais complexo, à medida que os diversos } \\
\text { grupos de interesse vão aferindo a gravidade da situação" }\end{array}$ & \\
\hline $\mathrm{E}$ & $\begin{array}{l}\text { "Sustentabilidade é toda ação destinada a manter as condições } \\
\text { energéticas, informacionais, físico-químicas que sustentam todos } \\
\text { os seres, especialmente a Terra viva, a comunidade de vida e a } \\
\text { vida humana, visando a sua continuidade e ainda a atender as } \\
\text { necessidades da geração presente e das futuras de tal forma que } \\
\text { o capital natural seja mantido e enriquecido em sua capacidade } \\
\text { de regeneração, reprodução e coevolução" }\end{array}$ & Leonardo Boff \\
\hline $\mathrm{F}$ & $\begin{array}{l}\text { "Satisfazer plenamente as necessidades de forma a preservar as } \\
\text { condições para que as gerações futuras também o façam. As } \\
\text { atividades processadas por agrupamentos humanos não podem } \\
\text { interferir prejudicialmente nos ciclos de renovação da natureza e } \\
\text { nem destruir esses recursos de forma a privar as gerações } \\
\text { futuras de sua assistência" }\end{array}$ & Lester Brown \\
\hline G & $\begin{array}{l}\text { "Consequência de um complexo padrão de organização que } \\
\text { apresenta cinco características básicas: interdependência, } \\
\text { reciclagem, parceria, flexibilidade e diversidade. Se estas } \\
\text { características, encontradas em ecossistemas, forem 'aplicadas' } \\
\text { às sociedades humanas, essas sociedades também poderão } \\
\text { alcançar a sustentabilidade" }\end{array}$ & Fritjof Capra \\
\hline $\mathrm{H}$ & Nenhuma das anteriores & \\
\hline l & Não responderam & \\
\hline
\end{tabular}

Gráfico 10: Melhor definição de sustentabilidade

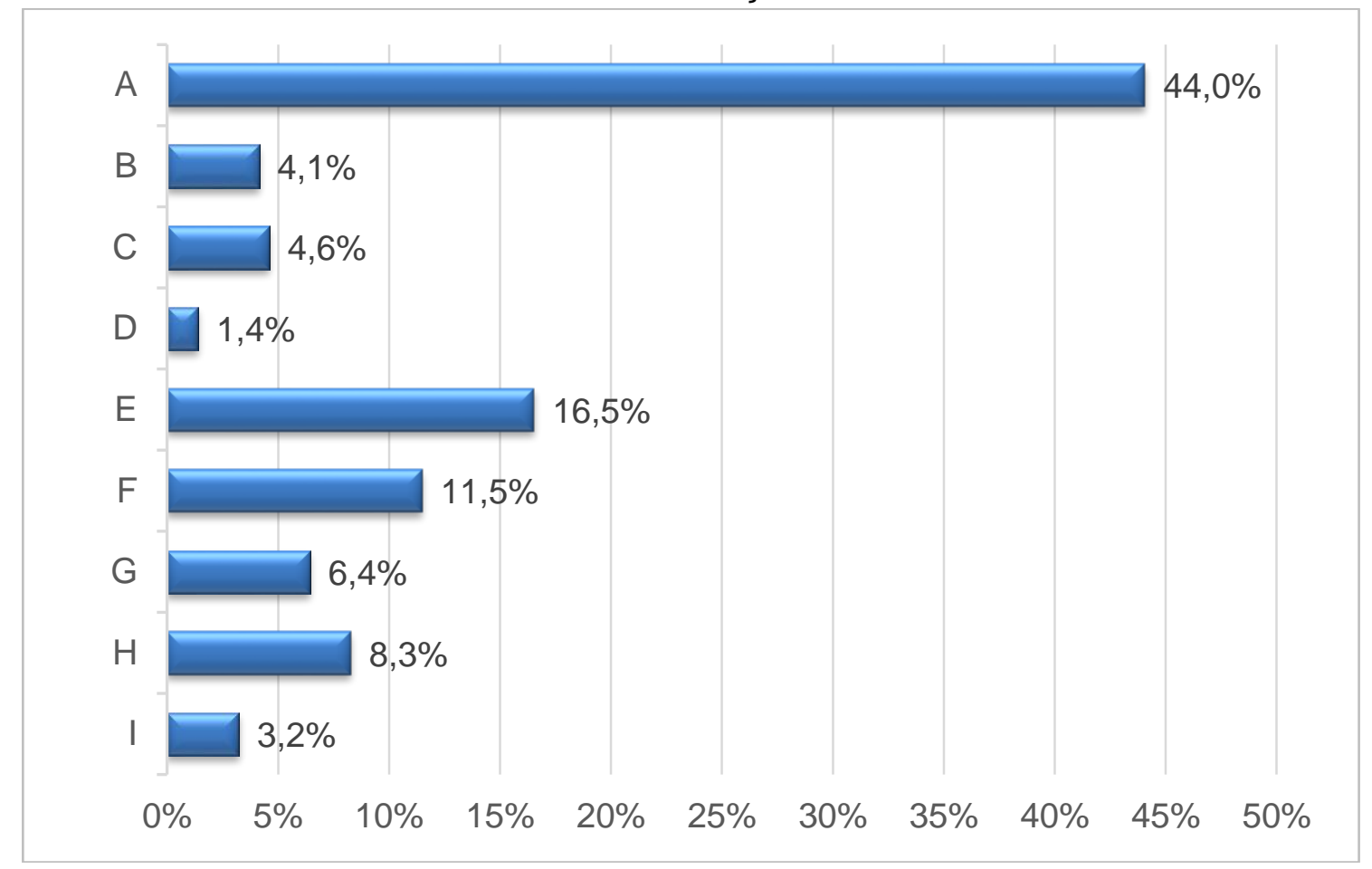

Fonte: Ulsen (2018) 


\section{Questão 16 - Relevância da comunicação para disseminar ações sustentáveis}

Com exceção dos que não responderam $(0,9 \%)$, todos consideram algum grau de relevância, pois ninguém assinalou a opção irrelevante. Predomina neste caso a percepção do totalmente relevante $(62,8 \%)$, seguindo de $23,4 \%$ que consideram a comunicação muito relevante para disseminar ações sustentáveis.

Apesar dos números amplamente favoráveis à Comunicação, estas respostas contradizem os dados do Gráfico 9 (relevância estratégica da Comunicação para disseminar ações sustentáveis), pois a Comunicação simplesmente não recebeu nenhuma resposta ( $0 \%$ ) em comparação com outras áreas, como Diretoria, Conselho de Administração, Presidência e Outra.

Gráfico 11: Relevância estratégica da comunicação

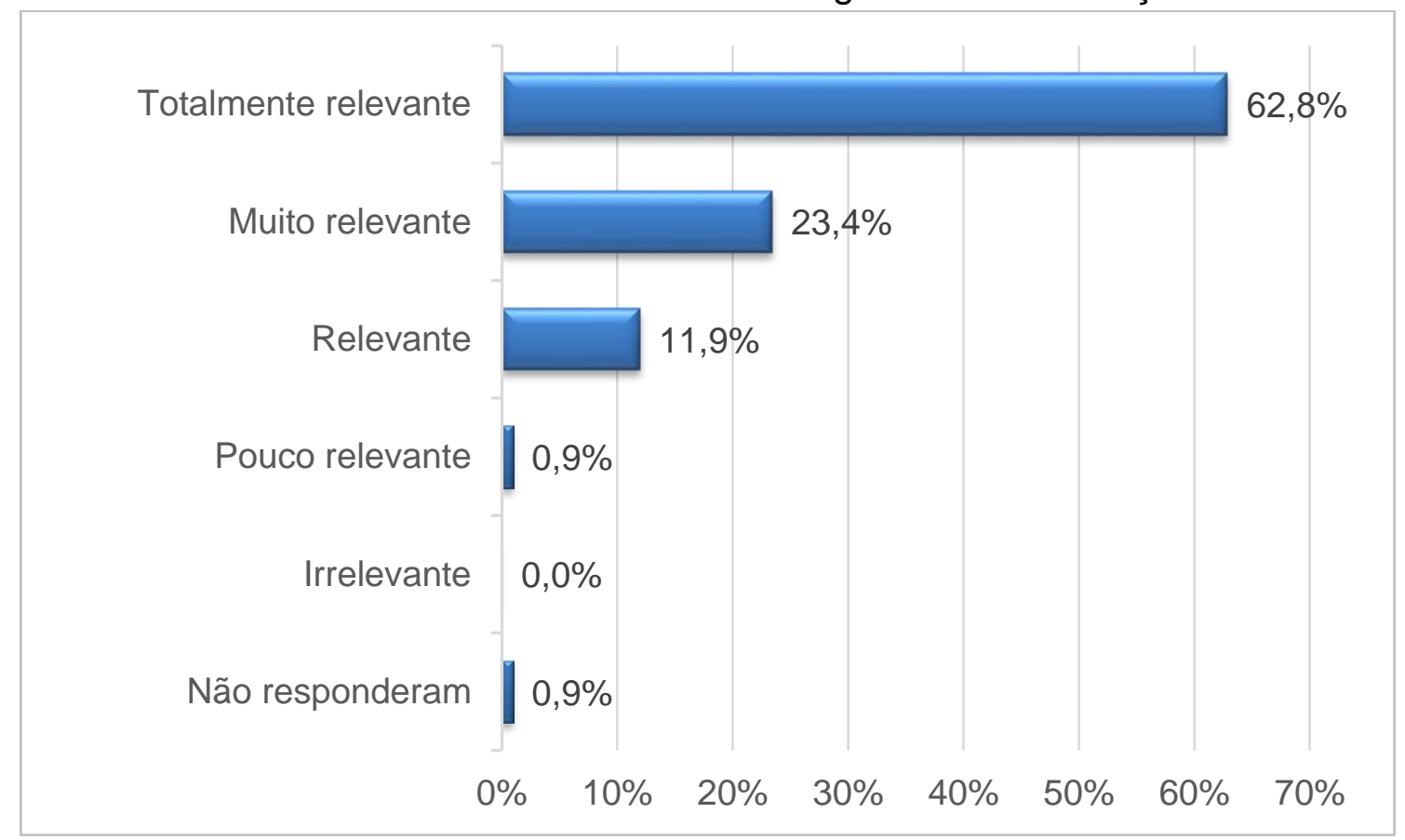

Fonte: Ulsen (2018)

\section{Questão 17 - Investimento em comunicação em 2016}

Quase metade das organizações $(49,5 \%)$ não responderam esta questão, que não era obrigatória, mas foi formulada para compreender melhor o volume de recursos financeiros disponível no terceiro setor brasileiro. Os dados também revelam que 33\% delas investiram em Comunicação no ano de 2016 até $R \$ 30$ mil, seguidas das que investiram de $R \$ 30$ mil a $R \$ 50$ mil $(7,3 \%)$, de $R \$ 50$ mil a $R \$ 75$ mil (2,8\%). 3,2\% 
responderam que foram investidos de $R \$ 200$ mil a $R \$ 500$ mil, $0,5 \%$ entre $R \$ 500$ mil e $\mathrm{R} \$ 1$ milhão e nenhuma investiu mais de $\mathrm{R} \$ 1$ milhão.

Gráfico 12: Investimento em comunicação em 2016

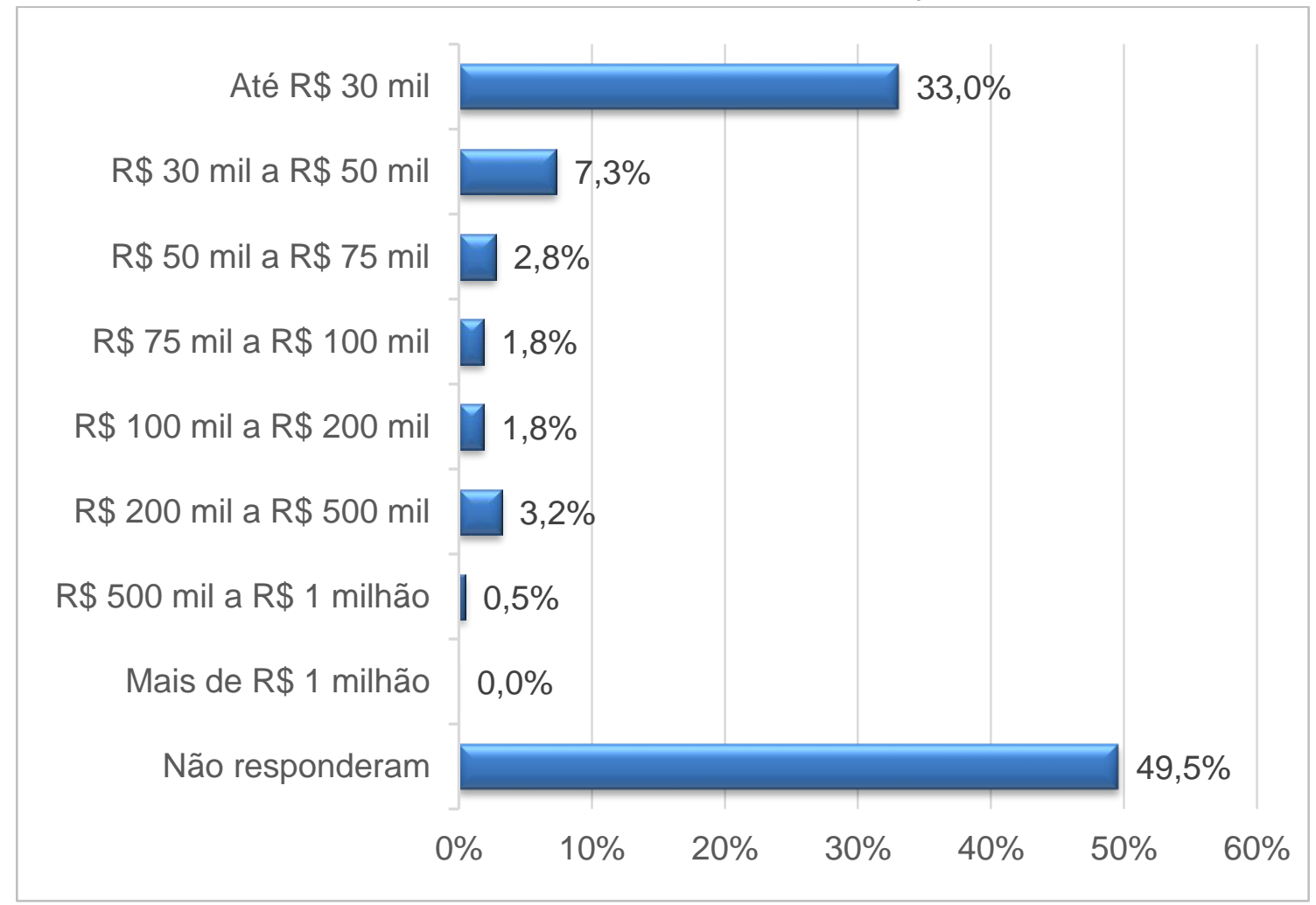

Fonte: Ulsen (2018)

\section{Questão 18 - Estrutura da área de comunicação na organização}

Em termos de estrutura da área de Comunicação, um índice baixo das que não responderam ( $0,5 \%)$. Em contrapartida, $41,3 \%$ informaram que a organização não tem uma área específica de comunicação, o que está alinhado com a percepção de que a maior parte das organizações consultadas e atuantes no Brasil é de pequeno porte e, apesar de todos os esforços, ainda precisam aprimorar a profissionalização das atividades. Apenas $1,8 \%$ das organizações têm a comunicação em nível de diretoria, $5,5 \%$ em nível gerencial, $23,4 \%$ em nível de coordenação e $8,7 \%$ na função de um analista. 
Gráfico 13: Estrutura da área de comunicação

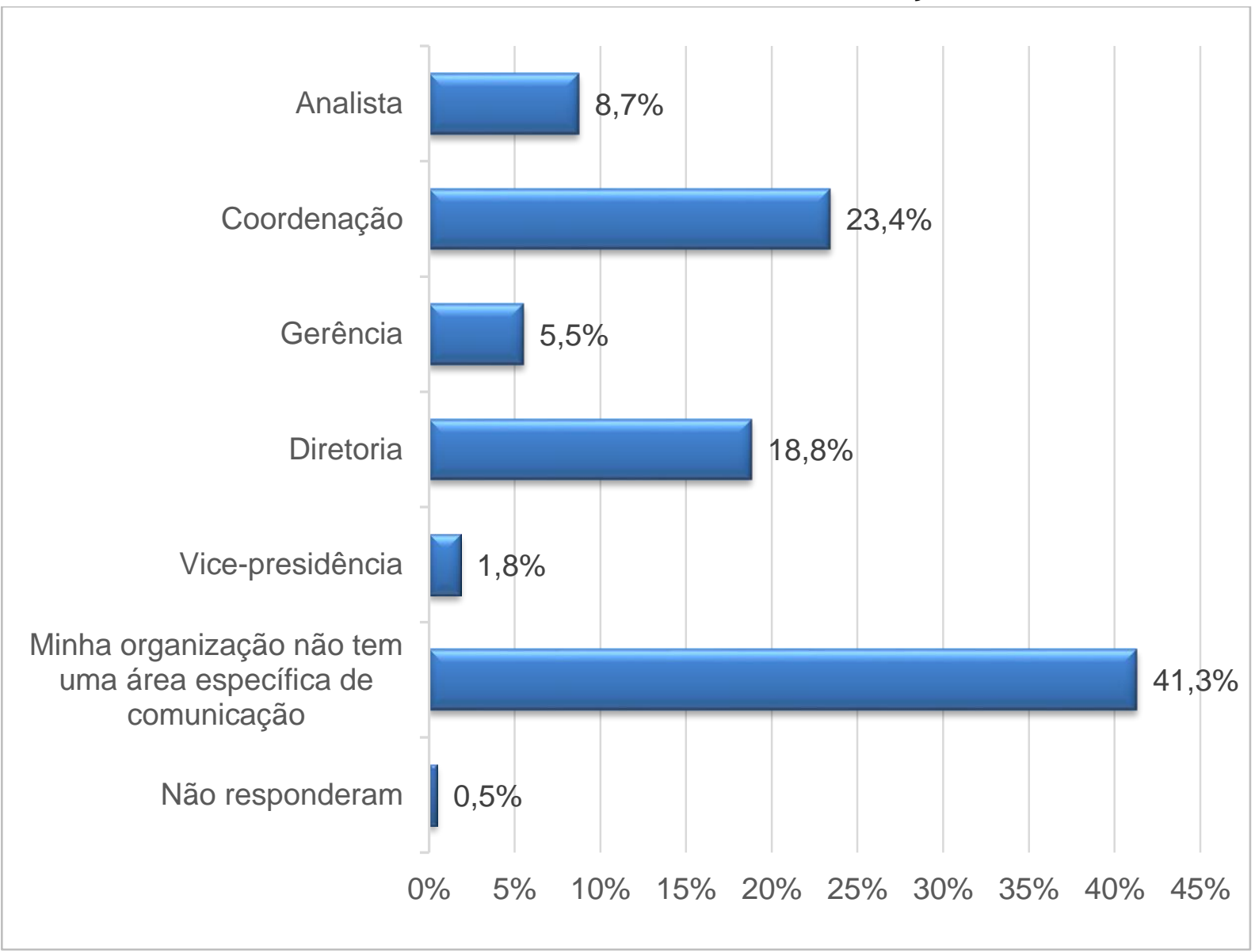

Fonte: Ulsen (2018)

\section{Questão 19 - Nível de colaboração entre comunicação e sustentabilidade}

Novamente as respostam evidenciam que, na maior parte dos casos, a estrutura das organizações consultadas não comporta áreas distintas para Comunicação e Sustentabilidade, o que resultou em $46,3 \%$ informando que não existe esta divisão. O segundo maior índice de respostas (17\%), ainda, indicou que comunicação e sustentabilidade são unificadas, integrando a mesma área.

Apenas 1,4\% afirmaram que não há nenhum nível de colaboração entre as áreas, 0,5\% que há uma equipe de sustentabilidade dentro da área de comunicação, 9,2\% que a área de Comunicação dá suporte nas operações de sustentabilidade, $11,5 \%$ que as áreas colaboram no nível estratégico e compartilham o processo de tomada de decisões, $12,4 \%$ que as áreas colaboram no nível operacional, compartilham informações e dados na formulação e execução dos projetos e 1,8\% não responderam. 
Gráfico 14: Colaboração entre comunicação e sustentabilidade

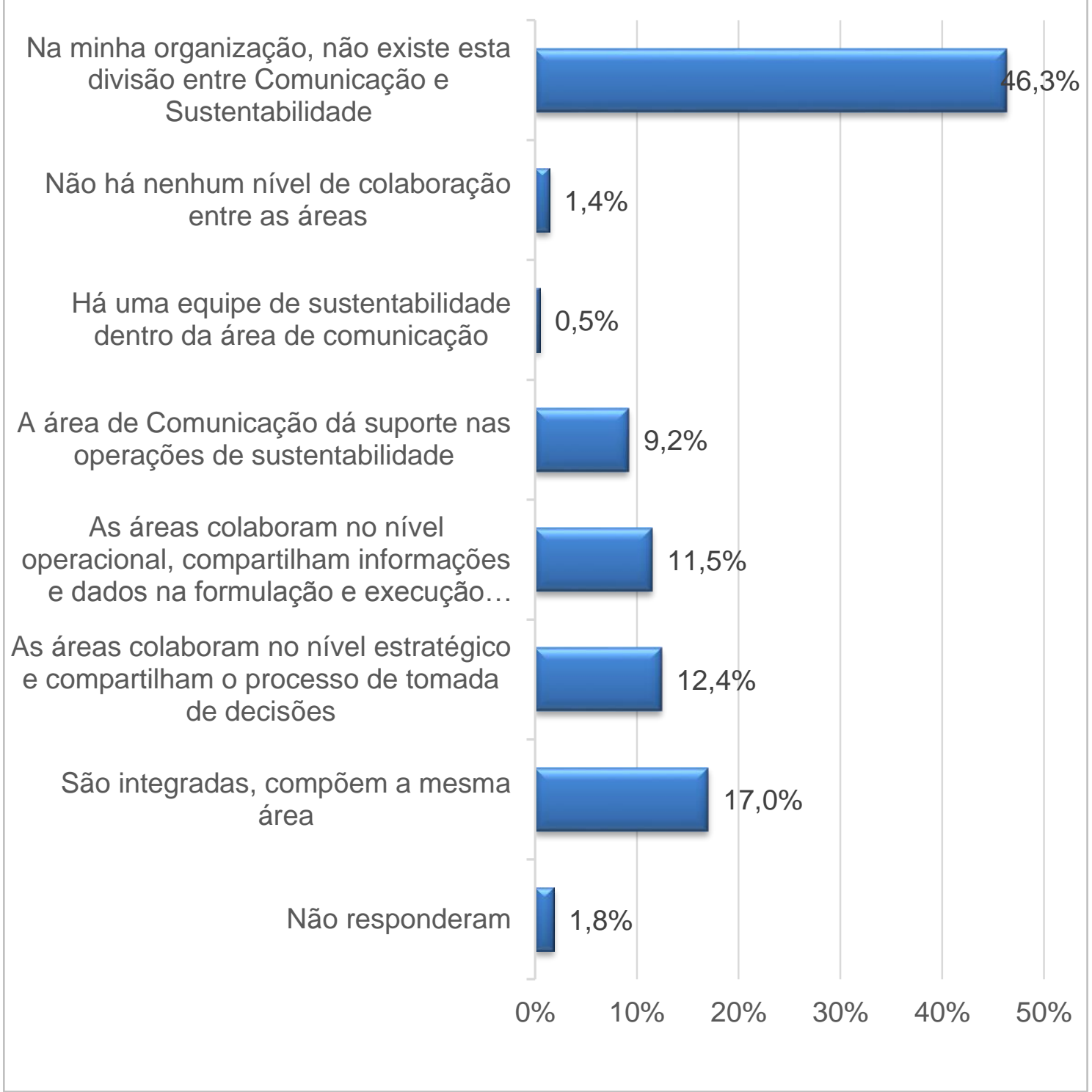

Fonte: Ulsen (2018)

\section{Questão 20 - Atividades desenvolvidas pela área de comunicação}

A partir dessa questão, as organizações continuaram respondendo perguntas fechadas, porém com opções de múltipla escolha em que várias alternativas foram apresentadas e o pesquisado teve a oportunidade de assinalar mais de uma opção para gerar mais pluralidade à pesquisa.

Entre as atividades desenvolvidas pela Comunicação, 17 opções foram apresentadas, sendo que gerenciamento de mídias sociais foi a mais escolhida, com $63,8 \%$ das respostas. Não foi um dado que surpreendeu, sobretudo considerando que 
a comunicação organizacional, em todos os setores e segmentos, tem dedicado uma atenção crescente a esta área. Com 55\% das respostas, a produção de materiais institucionais revela a importância do preparo de conteúdos que divulguem a essência das organizações para diversos públicos e demonstra a atualidade do trabalho de Relações Públicas, habilitação historicamente mais afeita a este olhar institucional das organizações.

Com 50,9\% das respostas, a assessoria de imprensa mostrou que, por outro lado, apesar da diversidade crescente de novas mídias, a imprensa continua sendo bastante relevante no Brasil e um foco importante de atuação das equipes de comunicação. A organização de eventos, com $50 \%$ das respostas, também foi uma surpresa com alto índice, acima de outras também estratégicas indicadas a seguir no Gráfico 15.

Mobilização social consta com 46,3\% das respostas, um dado importante e inspirador que demonstra que, apesar de inúmeras dificuldades, permanece no terceiro setor o cuidado com ações direcionadas para o envolvimento de públicos com fins de transformação social. Com 45,4\% das respostas, o fortalecimento da imagem e reputação também indica que as organizações entendem a importância de se dedicar a essa temática e destiná-la para os profissionais de comunicação.

De forma positiva ainda se destacaram nas respostas o gerenciamento dos canais de comunicação $(38,1 \%)$, relacionamento com comunidades $(34,9 \%)$, engajamento dos públicos (32,6\%), treinamentos e capacitações $(23,9 \%)$, mobilização de recursos (19,7\%), pesquisas de opinião $(17,4 \%)$ e preparação de lideranças $(9,6 \%)$. 
Gráfico 15: Atividades desenvolvidas pela comunicação

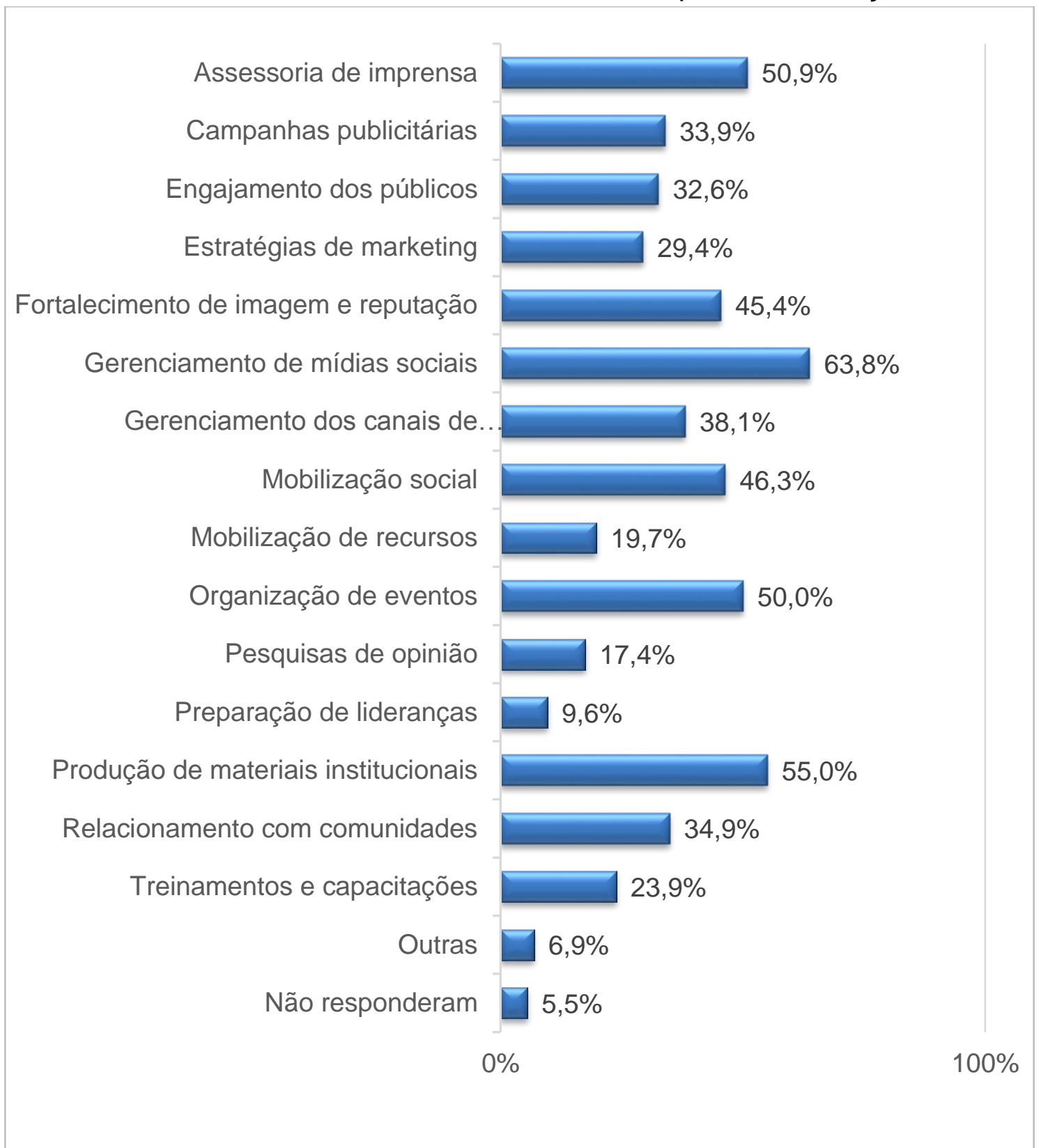

Fonte: Ulsen (2018)

\section{Questão 21 - Públicos estratégicos para a área de comunicação}

Esta questão de múltipla escolha também permitia a escolha de várias respostas e foi criada com o objetivo de revelar quais são os públicos estratégicos mais especificamente para a área de comunicação das organizações estudadas. $O$ vínculo delas com a realidade mais local dos ambientes sociais em que estão inseridas sugere o elevado número de escolhas para a opção comunidades locais $(75,7 \%)$, índice bem superior aos próximos resultados dessa mesma questão. 
Ainda nesse quesito, $54,1 \%$ das organizações escolheram o poder público, $42,2 \%$ outras organizações não governamentais e $41,3 \%$ a imprensa. Dois dados que se destacaram de forma positiva, por não serem em geral muito lembrados nesses casos, foram as universidades $(39,4 \%)$ e as entidades de classe $(30,3 \%)$.

Voluntários receberam a atenção de $39 \%$ das respostas, o que não surpreende, pois essas organizações, em geral, costumam precisar de apoio de diversas pessoas. Da mesma forma, o índice de $29,4 \%$ para investidores reforça a necessidade das organizações do terceiro setor precisarem, constantemente, de formas de financiamento de suas atividades.

O público de funcionários recebeu $28 \%$ das respostas, o que supõe iniciativas mais específicas direcionadas para o público interno. Outros (13,3\%) refere-se aos seguintes públicos: agricultores, associações comerciais locais, associados, comunidade em geral, comunidade escolar, conselhos, comitês, comissões interinstitucionais, doadores, empreendedores sociais, empresas, famílias de agricultores e suas organizações sociais, indígenas e populações tradicionais, jovens, mercado internacional segmentado, moradores, movimentos sociais, população de baixa renda, professores e sociedade civil em geral. 
Gráfico 16: Públicos estratégicos

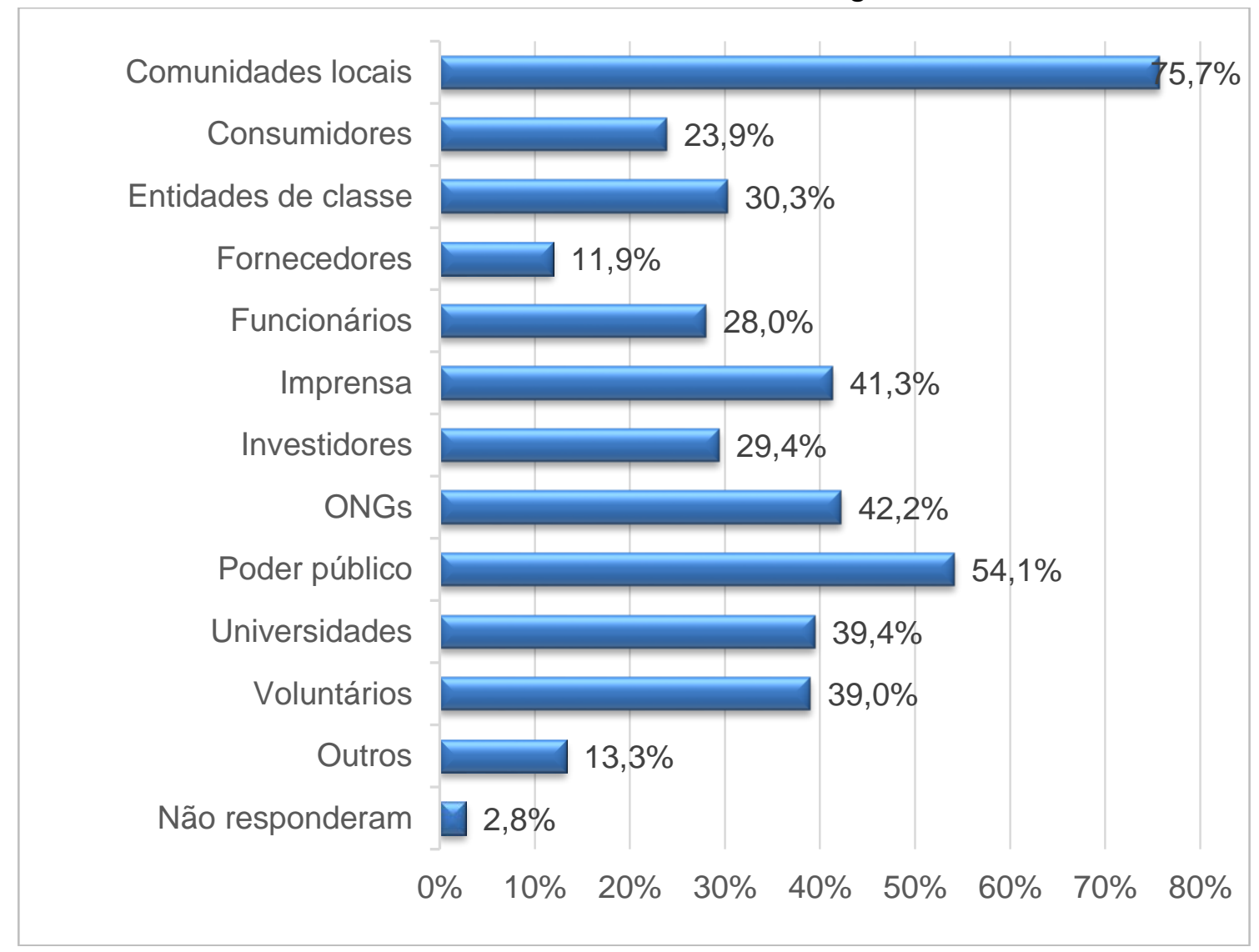

Fonte: Ulsen (2018)

\section{Questão 22 - Principais meios de comunicação utilizados}

A questão sobre os principais recursos de comunicação também permitia aos respondentes a seleção de mais de uma resposta justamente para facilitar a pluralidade de opções a facilitar a compreensão da realidade vivida pelas organizações do terceiro setor que atuam em prol da sustentabilidade no Brasil.

A utilização de redes sociais ficou evidente com $75,2 \%$ optando por esse recurso, o que demonstra a consolidação dessa opção como estratégica para essas organizações, que são de diferentes portes e estão presentes em todo o território nacional.

Ainda nessa questão, $65,6 \%$ dos respondentes escolheram o site como um dos principais meios, dado que também reforça a importância atual dos meios eletrônicos de comunicação. Merece destaque que $47,7 \%$ selecionaram eventos na resposta e 43,1\% assinalaram relatório de atividades, o que pode reforçar a importância de um trabalho consistente de comunicação para o objetivo desta pesquisa, mas também como campo de atuação profissional. 
A partir de então, todas as respostas estão com menos de metade das escolhas, conforme apresentado a seguir: matérias da imprensa $(34,9 \%)$, comunicados $(31,7 \%)$, newsletter $(24,3 \%)$, campanhas internas $(23,9 \%)$, mala direta $(23,9 \%)$, cursos $(22,9 \%)$, blog $(20,6 \%)$, rádio $(16,5 \%)$, jornal impresso $(12,8 \%)$, anúncios publicitários $(11,9 \%)$, balanço social $(11,5 \%)$, mural $(11 \%)$, revista $(11 \%)$, treinamento $(11 \%)$, intranet $(9,2 \%)$, outros $(7,8 \%)$, televisão $(5 \%)$, relatório de sustentabilidade $(4,6 \%)$, e não responderam $(2,3 \%)$. 
Gráfico 17: Principais meios de comunicação

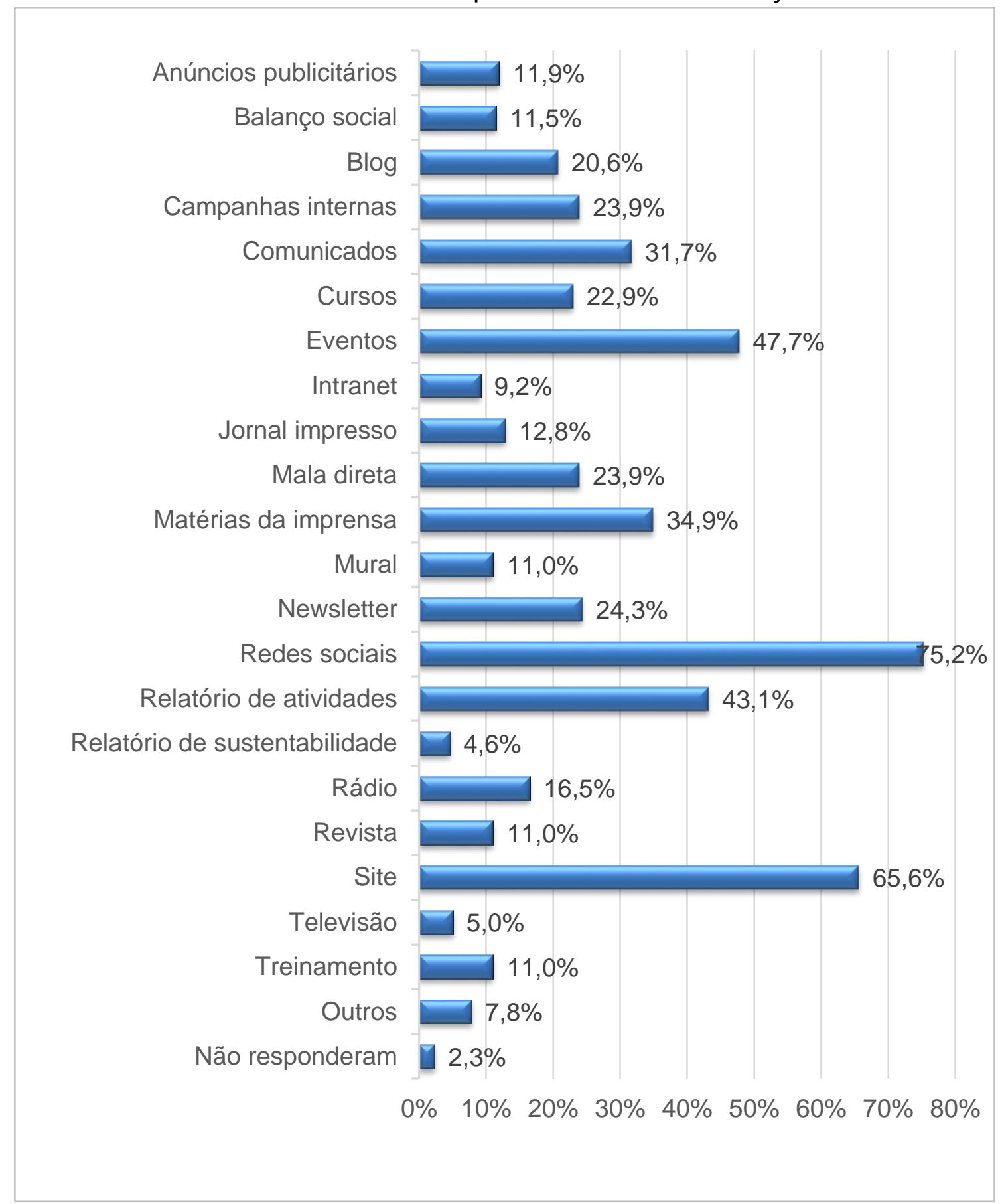

Fonte: Ulsen (2018)

\section{Questão 23 - Linguagem preferencialmente usada em ações de comunicação}

Neste quesito, a resposta de múltipla escolha era de resposta simples, com opção de selecionar apenas uma alternativa. $O$ elevado nível de linguagem não determinada $(37,2 \%)$ revela, do ponto de vista da comunicação, uma incerteza ou indeterminação quanto à importância desta decisão para o sucesso da mensagem 
divulgada. Considerando que todo conteúdo transmitido transporta, junto consigo, uma linguagem inerente, esse dado demonstra que ainda há espaço para a comunicação ser mais profissionalizada no terceiro setor.

Esta avaliação também reforça a justificativa apresentada no início desta pesquisa quanto à necessidade de uma comunicação mais científica e assertiva para ampliar as iniciativas de sustentabilidade na sociedade.

Nenhum respondente informou preferir a linguagem dramática/alarmista como preferencialmente usada. 32,6\% avaliaram ser melhor a opção lógica/racional, 22,9\% a alternativa envolvente/sensitiva e 5,5\% a emocional/indutiva. Apenas $1,8 \%$ das organizações não responderam esta questão.

Gráfico 18: Linguagem preferencialmente utilizada

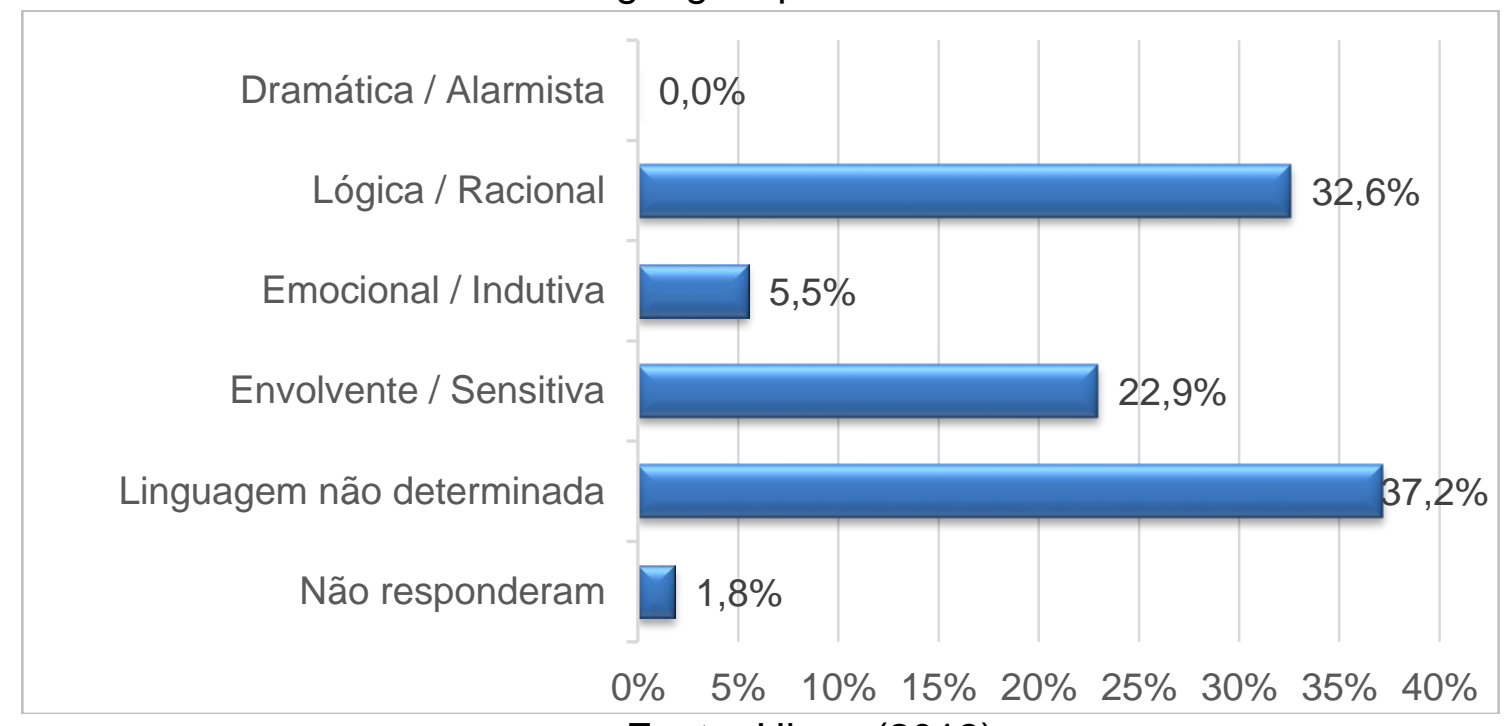

Fonte: Ulsen (2018)

\section{Questão 24 - Objetivos estratégicos nas ações de sustentabilidade}

Esta questão foi formulada para apurar as razões pelas quais as ações de sustentabilidade têm sido desenvolvidas nas organizações do terceiro setor. Quase metade dos respondentes $(48,2 \%)$ consideraram como objetivo estratégico contribuir para o desenvolvimento social a partir da inclusão de iniciativas práticas de sustentabilidade. Na sequência, com índice bem próximo, a opção contribuir para transformar a sociedade por meio da ampliação da consciência sobre sustentabilidade foi selecionada por $47,2 \%$ das organizações. Ainda em uma definição próxima, $45 \%$ 
optaram por escolher a opção do objetivo estratégico aquele direcionado a promover o desenvolvimento, por meio da inclusão ambiental, econômica e social.

A partir de então, a porcentagem cai quase pela metade, caso do item disseminar valores éticos na promoção da sustentabilidade e ser referência no tema, selecionado em $26,1 \%$ dos casos. Com porcentagem próxima, 23,4\% escolheram zelar para que o atual modelo de produção gere menos impacto para a sociedade e o meio ambiente.

Desenvolver novos produtos e processos direcionados para a sustentabilidade ficou com 16,1\% das respostas, gerenciar os interesses dos públicos envolvidos para atender suas demandas de forma sustentável com 15,1\% e 4,1\% não responderam.

Gráfico 19: Objetivos estratégicos da sustentabilidade

Contribuir para transformar a sociedade por meio da ampliação da consciência sobre sustentabilidade

Contribuir para o desenvolvimento social a partir da inclusão de iniciativas práticas de sustentabilidade

Desenvolver novos produtos e processos direcionados para a sustentabilidade

Disseminar valores éticos na promoção da sustentabilidade e ser referência no tema

Gerenciar os interesses dos públicos envolvidos para atender suas demandas de forma sustentável

Promover o desenvolvimento, por meio da inclusão ambiental, econômica e social

Zelar para que o atual modelo de produção gere menos impacto para a sociedade e o meio ambiente

Não responderam
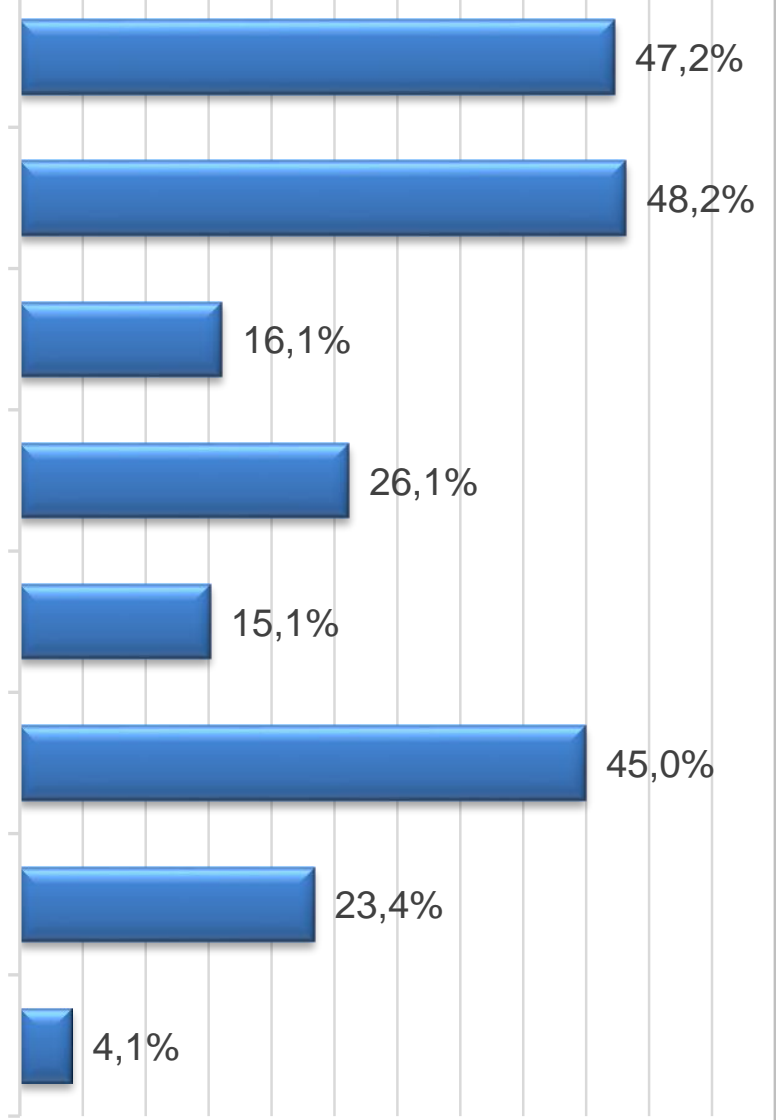

0\% 5\%10\%5\%20\%25\%30\%5\%/40\%5\%/50\%5\%

Fonte: Ulsen (2018) 


\section{Questão 25 - Frequência de envolvimento da comunicação nas decisões}

Esta questão foi formulada pois, em termos de comunicação organizacional, a frequência (número de ocorrências de um evento em um determinado intervalo de tempo) é um indicador da importância dada a determinadas ações. Especificamente tratando de comunicação para a sustentabilidade, frequências mais elevadas revelam a seriedade do envolvimento da comunicação das decisões, ao contrário do que se observa por exemplo em ações isoladas, sem continuidade.

Nesse sentido, a maior quantidade $(30,7 \%)$ é das organizações que indicaram que, na maioria das vezes, envolve a comunicação nos processos de tomada de decisão, seguida dos $27,1 \%$ que o fazem com frequência intermediária. O envolvimento ocorre sempre, de acordo com o Gráfico 20 , para $23,4 \%$ dos respondentes, raramente para $11,9 \%$ e nunca para $3,7 \%$. Apenas $3,2 \%$ não responderam.

Apesar da comunicação não ser sempre envolvida, na maioria dos casos $(81,2 \%)$ isso ocorre pelo menos com frequência intermediária. Em $15,6 \%$ das situações a comunicação raramente ou nunca é envolvida no processo de tomada de decisões, revelando o reconhecimento de uma atuação estratégica para as organizações.

Gráfico 20: Frequência do envolvimento da comunicação nas decisões

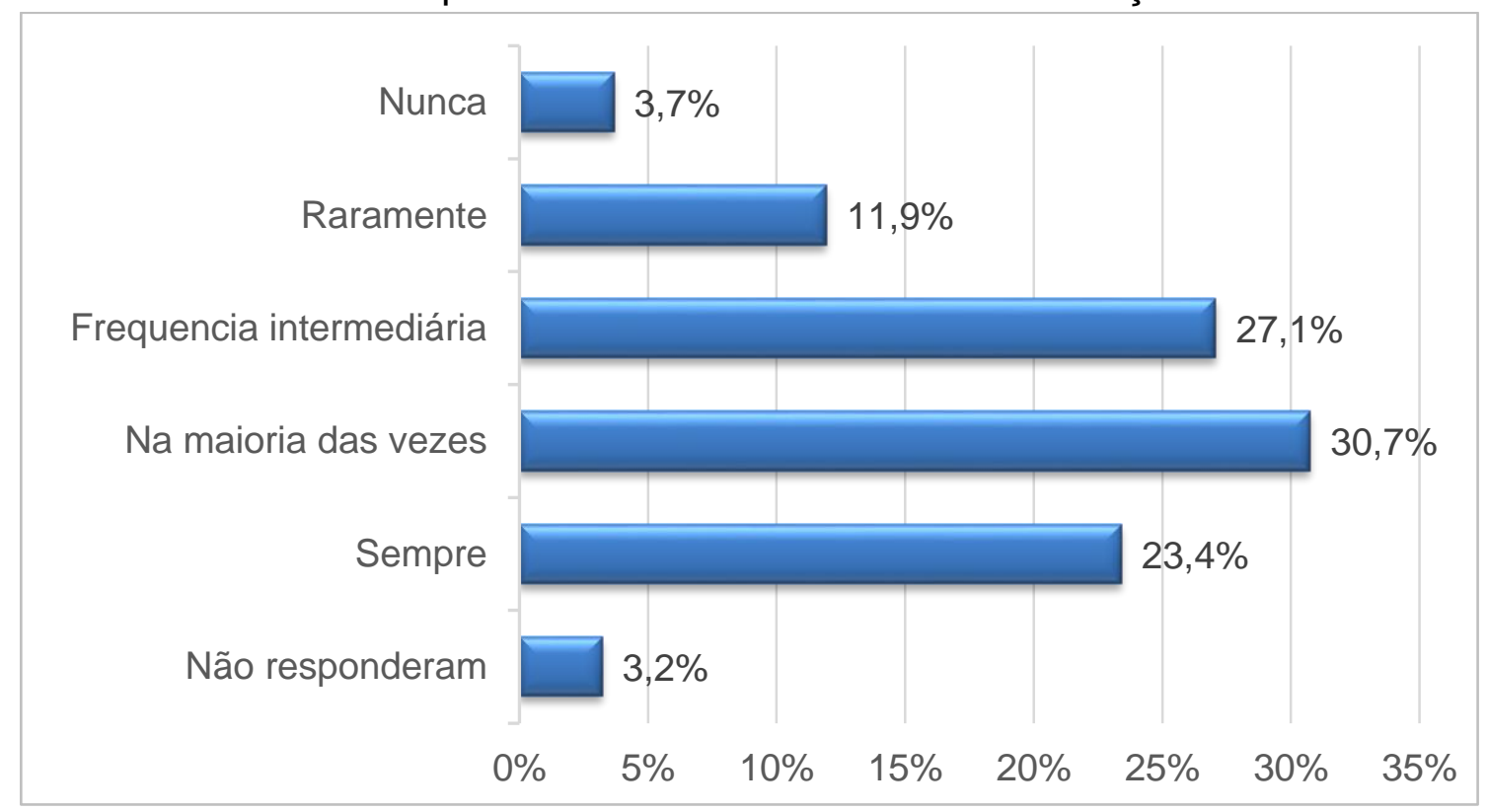

Fonte: Ulsen (2018) 


\section{Questão 26 - Desafios atuais da área de comunicação}

Com relação aos atuais desafios da área de comunicação das organizações consultadas, esta pergunta de múltipla escolha permitia a escolha de mais de uma opção. Com $43,1 \%$ das respostas, o desafio mais citado está relacionado à manutenção do público informado e engajado, algo de fato relacionado diretamente com as atribuições de comunicação no sentido de transmissão das informações e da criação de mecanismos de engajamento.

Desafio semelhante recebeu $39,4 \%$ das respostas: engajar os públicos com os valores da ONG, o que demonstra que envolver as pessoas tem se tornado cada vez mais relevante para criar ações de transformação, especialmente no terceiro setor em que as organizações, em princípio, atuam com base em valores pré-definidos.

Com $41,7 \%$ das respostas, ter e manter um orçamento adequado também mereceu destaque, dado que não surpreende e confirma a necessidade constante que as organizações do terceiro setor brasileiras têm, especialmente as de menor porte, de criar condições para a manutenção de condições financeiras para desempenharem suas atividades com os recursos necessários. O mesmo entendimento aplica-se aos $35,8 \%$ que selecionaram como desafio atual a estruturação de uma equipe qualificada.

Empoderar e ampliar a participação das pessoas envolvidas recebeu 35,3\% das respostas, desenvolver uma Comunicação Integrada foi selecionada por $32,6 \%$ das organizações e atingir maior integração com outras áreas ficou com $26,6 \%$ das respostas. São dados que também demonstram a importância que a comunicação organizacional do terceiro setor tem dedicado a estabelecer mecanismos de integração na comunicação e com as demais áreas e o potencial dessa abordagem para tornar as ações mais estratégicas e transformar a sociedade.

As demais respostas constaram da seguinte forma: customizar mensagens para públicos diferentes $(25,7 \%)$, mensurar os resultados na gestão da Comunicação $(23,9 \%)$, alcançar mais transparência nos processos (16,1\%), provar a relevância e os impactos da Comunicação (15,6\%), adequar-se à legislação que trata da sustentabilidade $(8,7 \%)$, modificar processos para humanizar os relacionamentos (7,8\%). Apenas 3,2\% não responderam. 
Gráfico 21 Desafios da comunicação

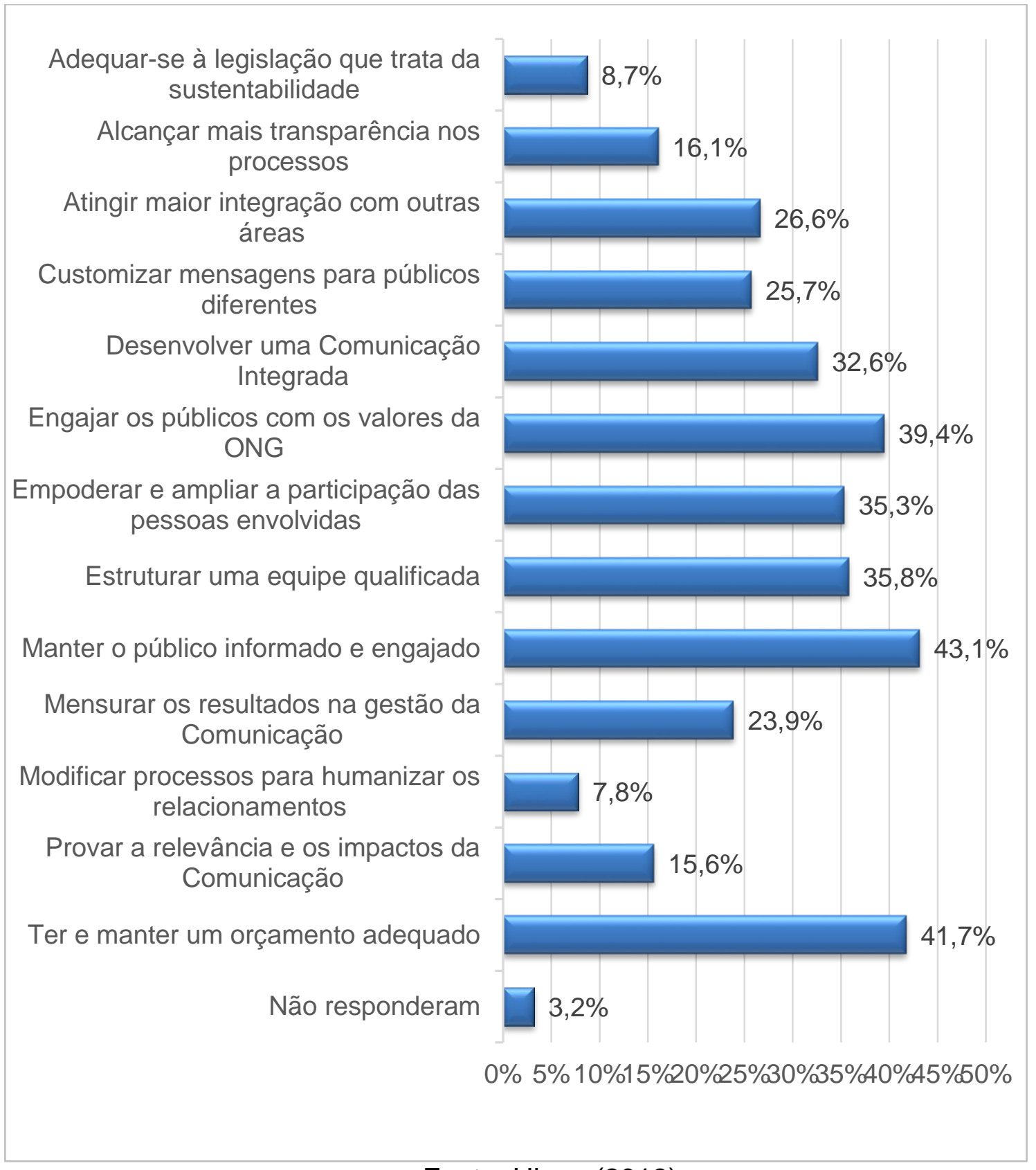

Fonte: Ulsen (2018)

\section{Questão 27 - Principais impactos da comunicação para a sustentabilidade}

Esta questão foi formulada para identificar, junto às organizações selecionadas, quais são os principais impactos esperados em termos de ações de comunicação direcionadas para a sustentabilidade. Com $59,2 \%$ das escolhas, ou seja, mais de metade das respostas, criar mais consciência coletiva sobre a sustentabilidade foi a opção mais selecionada. A segunda resposta mais selecionada, com $56,9 \%$ das escolhas, foi ampliar o conhecimento da sociedade, revelando também a necessidade 
de a comunicação continuar trabalhando como meio de transformação social. Promover ações de desenvolvimento e transformação social foi indicado em 51,4\% das respostas e conquistar novos recursos financeiros foi a opção em 50,9\% dos casos.

As respostas com menos de $50 \%$ das escolhas constaram da seguinte forma: engajar colaboradores e voluntários $(44,5 \%)$, promover entendimento dos públicos sobre a missão da ONG (42,2\%), favorecer a circulação de informações $(38,5 \%)$, empoderar os públicos envolvidos (33\%), mudar atitudes e comportamentos $(33,9 \%)$, fortalecer iniciativas e melhorar a reputação da ONG (31,2\%), diferenciar a organização $(26,6 \%)$, desenvolver lideranças $(25,7 \%)$, formar profissionais com senso crítico $(19,7 \%)$, fornecer dados estratégicos para os líderes da ONG $(18,3 \%)$, atrair e reter novos talentos $(18,3 \%)$, melhorar o relacionamento do público interno $(17,7 \%)$, contribuir para a criação de produtos sustentáveis (15,6\%). Apenas $4,1 \%$ não responderam. 
Gráfico 22: Principais impactos das ações de comunicação para sustentabilidade

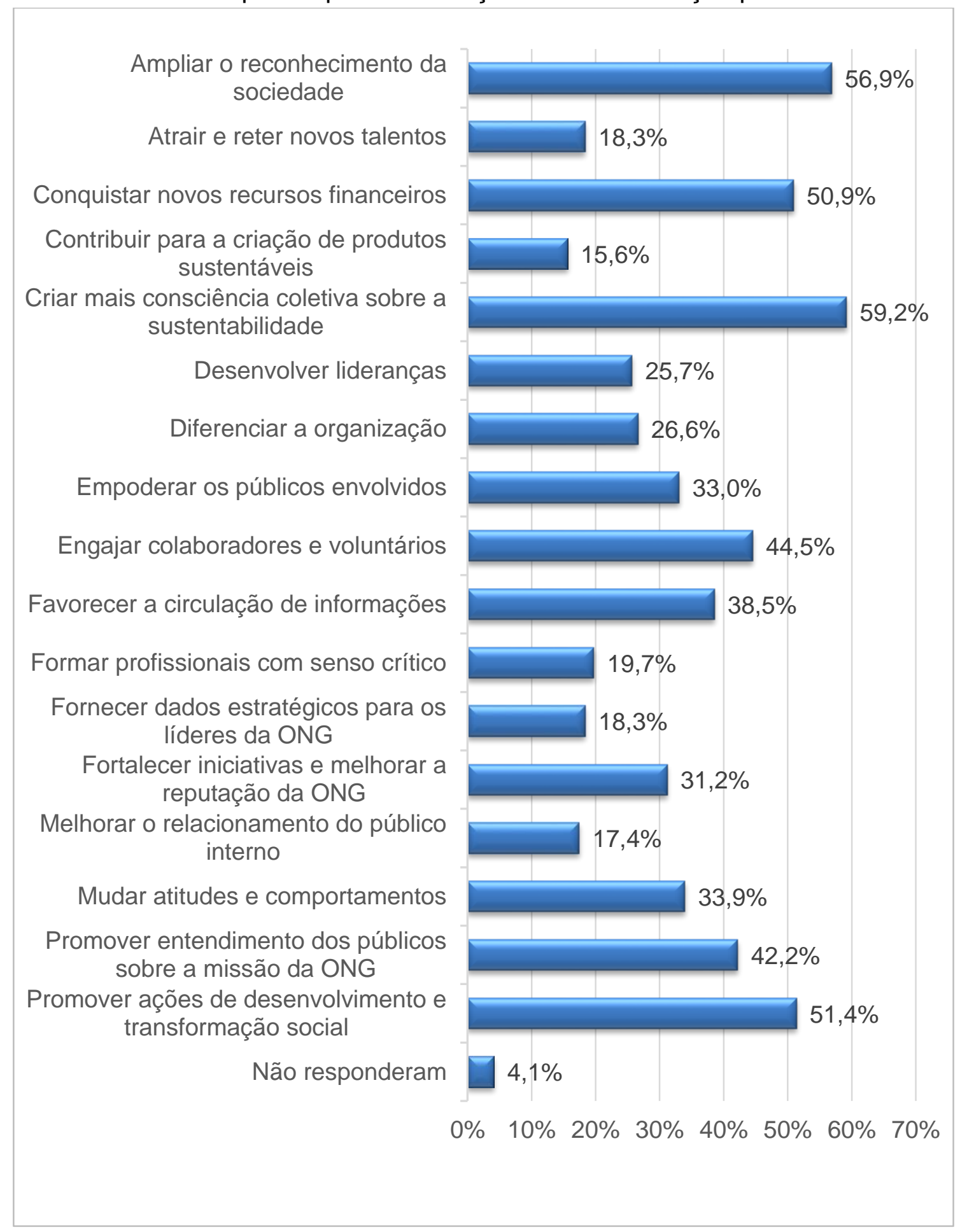

Fonte: Ulsen (2018)

\section{Questão 28 - Como a comunicação é avaliada pela organização}

Pergunta de extrema relevância, foi formulada para compreender de que forma a avaliação da comunicação está sendo realizada. As opções de respostas apresentadas levaram em consideração uma diversidade de possibilidades 
justamente para que a pesquisa apresente resultados fidedignos e detalhados. Com $50 \%$ das respostas, a opção que indica a avaliação da comunicação como sendo feita mediante a repercussão das ações nas redes sociais é um dado importante que revela a consolidação da importância da comunicação digital atualmente. A comunicação organizacional contempla diversas ações complementares, porém a pesquisa evidenciou a força das redes sociais como recurso de comunicação, mas também como forma da área ser avaliada.

Em seguida, a melhoria da imagem da organização recebeu $49,1 \%$ das respostas, demonstrando que as organizações do terceiro setor também pautam suas ações e entendem a importância da comunicação para desenvolver atributos de imagem. Com 37,2\% das respostas está o engajamento dos principais públicos envolvidos e com $30,3 \%$ está a avaliação a partir do aumento na captação de recursos financeiros.

Nesta última questão do formulário, as respostas constaram da seguinte forma: aumento do número de colaboradores e voluntários (26,1\%), clipping de notícias veiculadas na imprensa $(28,4 \%)$, relatórios quantitativos e qualitativos $(27,1 \%)$, conquista de prêmios de reconhecimento $(13,8 \%)$, pesquisas para avaliação dos resultados (11\%), outra ( $8,7 \%)$. Apenas $4,1 \%$ não responderam. 
Gráfico 23: Avaliação da área de comunicação

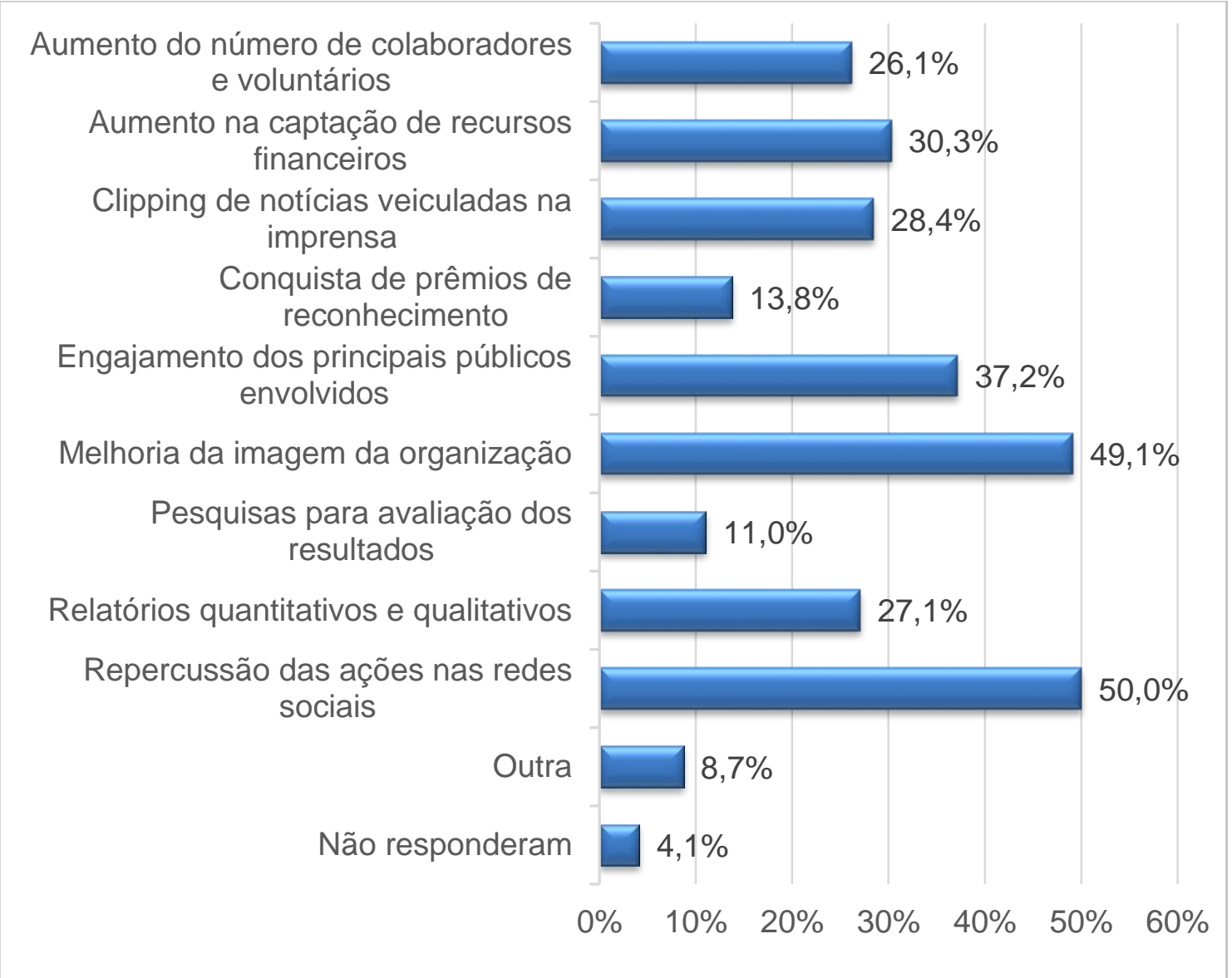

Fonte: Ulsen (2018)

\subsection{Conclusões}

A análise e a interpretação dos dados estiveram apoiadas na metodologia da hermenêutica de profundidade proposta por Thompson (1995), em que defende a interpretação como método de produzir conhecimento sobre a realidade social. Desse modo, foi garantido um aspecto central à interpretação com o uso de diversas técnicas de apreensão da realidade.

Ela também sugere uma série sistematizada de procedimentos que possibilitam a análise cultural pela interpretação do pesquisador e está alinhada com as premissas defendidas no referencial teórico, pois inscreve suas análises no âmbito da vida cotidiana. Um dos principais cuidados, nesse sentido, foi a contextualização da pesquisa às conjunturas social e histórica, com base em um referencial metodológico amplo e uma interpretação crítica do discurso. 
Tendo como base os 218 questionários respondidos, a pesquisa empírica "Comunicação para a sustentabilidade em organizações do terceiro setor" chegou a resultados importantes. Além dos dados de identificação das ONGs, foi possível perceber que a profundidade com que este estudo abordou cada uma das questões foi determinante para compreender o universo de atuação das organizações analisadas em âmbito nacional.

A amostra representa a situação das organizações do terceiro setor do País e retrata de forma realista de que forma a comunicação tem sido praticada nesses casos. Destaca-se a dificuldade de se conseguir as respostas, o que só foi possível após o monitoramento de cada etapa e ligações frequentes para reforçar o convite à participação das organizações consultadas e atingir o máximo de questionários respondidos dentro do prazo disponível.

Entre os resultados que se destacaram, cabe indicar que, se considerarmos a soma de respostas de presidentes e diretores, em $41 \%$ dos casos o questionário foi preenchido por pessoas deste nível hierárquico. Em termos de educação formal, considerando-se a soma de pessoas envolvidas na graduação e pós-graduação, esse índice vai a 95\%. Sobre a área de formação, 30,3\% das pessoas, ou seja, a maior porcentagem, tem origem em formações não indicadas, revelando a multiplicidade de embasamento educacional das pessoas que trabalham com essa área.

Em termos de principal foco da atuação, é evidente a predominância de organizações que atuam com meio ambiente (46,3\%), o que confirma a percepção de que ações do terceiro setor, quando direcionadas para a sustentabilidade, costuma priorizar, atualmente essa área. A pesquisa também questionou sobre a principal definição de sustentabilidade sobre a qual o trabalho é fundamentado, revelando amplo destaque à definição de sustentabilidade de John Elkington (44\%).

Já em termos do tamanho das equipes, a ampla predominância é de organizações pequenas, pois $61,5 \%$ delas têm até 20 funcionários, colaboradores e/ou voluntários. Sobre o valor investido em comunicação no último ano, 33\% delas investiram até $R \$ 30$ mil. A respeito da estrutura da comunicação, 41,3\% delas não têm uma área específica da área, o que reforça que a maior parte das organizações é de pequeno porte e ainda precisam profissionalizar mais suas atividades.

Entre as atividades desenvolvidas pela comunicação, foram apresentadas 17 opções, sendo que gerenciamento de mídias sociais foi a mais escolhida $(63,8 \%$ das 
respostas). A utilização de redes sociais também ficou evidente na pergunta que tratava sobre o principal recurso de comunicação, com 75,2\% das respostas, demonstrando a consolidação dessa opção para essas organizações. A pesquisa questionou ainda sobre quais são os públicos estratégicos, revelando que o vínculo delas com a comunidades locais é marcante ( $75,7 \%$ das respostas).

O envolvimento da comunicação nos processos de tomada de decisão ocorre em $30,7 \%$ dos casos, seguida de $27,1 \%$ que o fazem com frequência intermediária. Sobre os desafios da comunicação, $43,1 \%$ das organizações indicaram a manutenção do público informado e engajado. Finalmente, a última questão perguntava sobre como a área de comunicação é avaliada, tendo $50 \%$ das respostas indicando que isso ocorre a partir da repercussão das ações nas redes sociais. Em seguida, a melhoria da imagem da organização foi selecionada em $49,1 \%$ dos casos. 


\section{Capítulo 6. A opinião dos gestores de comunicação}

O propósito desta tese foi aliar uma pesquisa qualitativa à análise quantitativa. Neste sentido, acreditou-se ser necessário ouvir os gestores de comunicação com experiência comprovada em organizações do terceiro setor.

Para tanto, foram selecionados seis profissionais (Afra Balazina, da SOS Mata Atlântica; Bruno Weis, do Instituto Socioambiental; Mariana Moraes, do Grupo de Institutos Fundações e Empresas; Mauricio Bianco, da Conservação Internacional; Rejane Romano, do Instituto Ethos; Renato de Paiva Guimarães, do Greenpeace) que têm se destacado pelas suas atuações na gestão da comunicação das empresas em prol da sustentabilidade.

Com base no método qualitativo, foram realizadas entrevistas em profundidade com os profissionais escolhidos. Para a realização da pesquisa qualitativa, foi criado um roteiro de entrevista, conforme Apêndice 9.

\subsection{Amostra}

A seleção dos entrevistados foi intencional e baseada em especialistas reconhecidos com conhecimento e vivência profissional sobre o assunto em questão.

Quadro 7: Formato das entrevistas com gestores de comunicação

\begin{tabular}{|c|c|c|}
\hline Entrevistado & Organização & Formato \\
\hline Afra Balazina & SOS Mata Atlântica & Telefone \\
\hline Bruno Weis & $\begin{array}{c}\text { Instituto Socioambiental } \\
(\text { ISA })\end{array}$ & Telefone \\
\hline Mariana Moraes & $\begin{array}{c}\text { Grupo de Institutos } \\
\text { Fundações e Empresas } \\
(\text { Gife })\end{array}$ & Telefone \\
\hline Mauricio Bianco & $\begin{array}{c}\text { Conservação } \\
\text { Internacional (Cl) } \\
\text { Instituto Ethos }\end{array}$ & Telefone \\
\hline Rejane Romano & Greenpeace & E-mail \\
\hline Renato de Paiva Guimarães & & Telefone \\
\hline
\end{tabular}




\subsection{Análise e interpretação dos dados}

O conteúdo a seguir reúne a análise e a interpretação dos dados das entrevistas realizadas com os gestores de comunicação cujas respostas acredita-se que trazem contribuições relevantes para uma comunicação para a sustentabilidade em organizações do terceiro setor.

1. Na sua avaliação, como a comunicação tem contribuído para criar mensagens que engajem públicos para a prática da sustentabilidade nas organizações?

Esta primeira pergunta foi criada com o objetivo de apurar a relevância da comunicação organizacional sobretudo no processo de engajamento dos públicos para a sustentabilidade. A questão foi apresentada a seis profissionais com larga experiência no setor para explorarem suas experiências realizadas no Brasil e no exterior.

Para Renato Guimarães, o cenário é complexo, sobretudo se for considerada a atual configuração de múltiplas mídias, com excesso de conteúdos produzidos e emitidos, porém com pouca atenção da maioria das pessoas para a recepção da informação.

A comunicação não se dá na emissão, mas quando a pessoa do outro lado a recebe. Como é mais fácil compreender a emissão, muitas pessoas param aí. A comunicação tem muita dificuldade de chegar e como avaliar o que ela recebe, o impacto que ela recebe. Esse aspecto é o mais complexo, pois o processo de típico da comunicação era mais ou menos estável. Os meios eram mais ou menos conhecidos. Com as mídias sociais prevalentes, as pessoas se tornaram emissoras de comunicação de forma fluida, e isso ficou mais complicado ainda, pois depende da interpretação e da reinterpretação das pessoas. Este é o mundo fragmentado das mídias. Existem várias tentativas de trazer sustentabilidade para o cotidiano das pessoas (GUIMARÃES, 2017, entrevista exclusiva).

A avaliação de Guimarães decorre da experiência que tem no Greenpeace Brasil há mais de dois anos e da atuação profissional desempenhada em outras organizações do terceiro setor. A resposta acima também está alinhada com a frase atribuída ao que disse o inglês David Ogilvy, fundador da Ogilvy\&Mather e um dos 
principais nomes da publicidade "Comunicação não é o que você diz, é o que o outro entende".

Maurício Bianco destacou a vertente estratégia da comunicação neste setor, demonstrou a necessidade de uma atuação prática da sua execução e colocou a análise da trajetória da comunicação em uma perspectiva de evolução.

Quando eu falo de comunicação eu não falo só da necessidade dela, mas a forma como você faz ela, os meios que você utiliza para fazer. Tudo isso passa a ser extremamente importante para você dar o seu recado para um público que normalmente não te conhecia. Eu acredito piamente no que é necessário e isso não só é verdade porque eu acredito, mas se percebe claramente que o papel da comunicação na estratégia organizacional dessas organizações do terceiro setor é cada vez mais estratégico. Ela não está só na comunicação para fazer o folder, fazer o site e o vídeo. Ela está hoje em um papel mais estratégico para posicionar a organização, por meio da sua mensagem, para uma reputação e o que se refere se branding. Imagina, branding era uma coisa que nem se falava em organizações do terceiro setor alguns anos atrás. Então esse tipo de coisa eu acho que está de fato evoluindo muito (BIANCO, 2017, entrevista exclusiva).

Bianco ainda complementou essa resposta inicial analisando a comunicação do terceiro setor a partir de um ponto de vista global, de crescimento de importância a partir da percepção de que é ela a responsável por disseminar a missão das organizações aos mais diversos públicos.

Eu vejo a comunicação como um meio, eu não estou olhando a comunicação como um fim. Nesse caso aqui ela é bem meio mesmo e, com relação a isso, sabe-se que, por mais que a atuação do terceiro setor seja na área social, ambiental, de desenvolvimento, direitos humanos, em todas as áreas em que tenham sido trabalhadas há muito tempo, não só no Brasil, mas globalmente, a comunicação, na maioria das vezes, nunca foi um objeto a ser considerado estratégico até, digamos assim, 20, talvez 25 anos. Então era 'vamos fazer o que a gente precisa fazer e não precisa contar para ninguém'. $E$ na perspectiva que só o fazer já seria suficiente para entregar o que a missão e que a organização se propunha. Na medida em que você tem novos meios de comunicar com as pessoas e as pessoas têm acesso às informações com muito mais frequência e em um patamar muito maior, é importante você começar a dar uma mensagem clara não só no que você se propõe em termos de projetos e programas que você vai desenvolvendo, mas principalmente no que você se propõe a fazer institucionalmente, como que é a sua participação e a sua missão dentro da sociedade. $E$ aí eu vejo a comunicação como um meio extremamente importante para dar vazão a essa necessidade que, 
para algumas organizações, ela é muito maior porque entendeu que é essa missão faz a gente chegar no público mais amplo, e algumas que estão já começando a entender isso de forma mais recente (BIANCO, 2017, entrevista exclusiva).

Bruno Weis optou por direcionar a resposta, inicialmente, para o momento especial vivido por esses profissionais em decorrência da intensificação do uso de redes sociais. Weis foi enfático ao destacar a mudança de modelo pela qual estamos passando, sendo mais específico em relação aos desafios envolvidos no acesso a públicos cada vez mais segmentados.

Nós temos na verdade um momento bastante interessante para a comunicação das organizações do terceiro setor que é o uso das redes sociais, que abriram diversos canais de comunicação com públicos segmentados e públicos específicos que têm assim uma escolha de consumo de informação mais autônoma e menos focada no que os grandes veículos de comunicação escolhem como notícia. Então eu posso simplesmente abrir mão de me informar pela grande imprensa e posso assinar canais do YouTube, posso seguir perfis no Twitter, posso seguir perfis no Facebook e assim por diante. Dessa forma, existe outra lógica de consumo e produção da informação que não deixa de ser uma grande oportunidade para as organizações não governamentais serem produtoras de conteúdo com um custo inclusive bem mais baixo (WEIS, 2017, entrevista exclusiva).

Para Afra Balazina, a aderência da comunicação é direta com a conscientização de pessoas sobre a temática socioambiental, a educação e o exercício da cidadania.

Hoje existem muitas causas, e isso gera até concorrência entre as organizações que atuam com sustentabilidade. Nesse cenário, precisamos engajar as pessoas e minha experiência com o terceiro setor e na SOS Mata Atlântica é de que precisamos muito da comunicação digital para chegar em todo o País, até mesmo por não termos recursos financeiros suficientes para realizar campanhas em mídias mais caras, como a televisão. Para nós, a comunicação está muito alinhada com o engajamento. Antes, atuávamos mais em São Paulo, e o trabalho sempre foi muito bom, hoje as demandas são muito maiores e precisamos ir além, até o detalhe de pensamos sobre dicas para postagens nas redes sociais. Tudo isso tem ajudado a conscientizar mais as pessoas quando fazemos parte do dia a dia delas. Com o nosso estímulo, ela pode fazer um abaixo assinado exercendo a cidadania e fazendo pressão nos órgãos competentes pela comunicação, e liderar campanhas de petições pela Internet. Não adianta criar petições em pensar a comunicação. Temos muita concorrência e são muitos os problemas, são muitas as causas e fazer 
com que as pessoas se interessem é um desafio. Atualmente 145 milhões de pessoas vivem na Mata Atlântica, mas elas não sabem falar sobre isso. Existe ainda uma questão educacional e nosso desafio é comunicar educando, mas sem um tom muito professoral. Temos que ser divertidos para que as pessoas assimilem. É importante realizarmos a comunicação aliada a uma estratégia eficiente para trazermos as pessoas e o engajamento é muito importante para nos ajudar a desenvolver políticas para o meio ambiente (BALAZINA, 2017, entrevista exclusiva).

Para Mariana Moraes, o engajamento está diretamente relacionado com a comunicação, o que deve ocorrer com o envolvimento da comunicação em decisões da administração do terceiro setor.

É importante primeiro dizer que engajamento é uma das curvas da comunicação. É muito difícil conseguir o engajamento de qualquer causa sem que as pessoas saibam que essa causa existe, sem que as pessoas recebam a explicação do porquê da causa ou sejam impactadas de alguma forma com a causa, com a organização. Então não existe engajamento, é muito difícil, eu não conheço nenhum caso, em que o engajamento aconteça sem o papel fundamental da comunicação envolvida no processo. E ela precisa estar envolvida desde o começo, desde o marco zero, desde o momento em se decide fazer alguma coisa ou que tenha uma organização com um determinado projeto. É a comunicação que provoca o projeto e a organização a pensarem com quem se quer falar, por que, como, quando, onde. E a comunicação que ajuda a fazer um diagnóstico do cenário antes de se colocar o carro na rua. E a comunicação, para ser engajadora, tem que ter, primeiro, muita clareza de qual é a causa sobre o que se quer dizer, muita simplicidade na mensagem. Não pode ser uma mensagem simplista, mas para se falar com as pessoas tem que haver uma mensagem simples, é necessário falar uma linguagem que qualquer pessoa entenda e, principalmente, tocar o coração. Para se tocar o coração das pessoas, normalmente existe uma combinação da mensagem bem clara, relevante, interessante e que, de algum jeito, toque o outro, porque é uma causa que o outro já se interessa, somado ao momento da sociedade, a uma oportunidade que se coloca alguma situação em que seja o momento perfeito para a coisa acontecer (MORAES, 2017, entrevista exclusiva).

Rejane Romano também revelou a atualidade das redes sociais no cotidiano de suas ações e detalhou de que forma cada uma das redes é utilizada com diferentes linguagens e públicos.

No Instituto Ethos trabalhamos com Twitter, Linkedln e Facebook, cada um com uma linguagem própria de acordo com o perfil. No Linkedln, por exemplo, o foco é na empresa e por isso usamos uma 
linguagem que busca a sensibilização das pessoas que estão no mercado. Já no Facebook trabalhamos com a pessoa física, pontuando nossas ações de forma a tornarmos conhecidas as iniciativas que o Ethos abarca (ROMANO, 2017, entrevista exclusiva).

Partindo para um contexto mais amplo de comunicação organizacional, além do cenário digital já explorado até o momento, Bruno Weis comparou suas atribuições atuais com o cenário de algumas décadas atrás. Para ele, os custos envolvidos e a possibilidade de alcance dos conteúdos gerados pelas organizações do terceiro setor sofreram uma transformação marcante a ponto de tornar-se a interatividade um dos principais focos do profissional contemporâneo de comunicação.

Eu lembro que, antigamente, quando você queria produzir e publicar um anúncio no jornal, os custos eram inviáveis para uma ONG. Com todas essas redes se ampliando, é possível acessar o público em uma escala bastante interessante com um custo relativamente pagável, viável. Eu trabalhei muitos anos em revistas e jornais e você tinha uma circulação média de dez, vinte, trinta, quarenta, cinquenta mil exemplares de uma revista. Então, digamos que a revista chegava em cem mil pessoas. Hoje um bom vídeo que tenha conseguido atingir a sua base no Facebook, por exemplo, você tem um alcance de meio milhão de pessoas. Então você tem um acesso à opinião pública muito mais democratizado em função da Internet e das redes sociais. O fator da interatividade das redes sociais também facilita que o debate seja mais expandido e as pessoas participem mais e que esses conceitos avancem mais. O papel de produtor de conteúdo e consumidor de conteúdo hoje em dia ele está difuso. Os papéis não são estanques. Hoje você é um produtor e, ao mesmo tempo, consumidor de informação como usuário da rede. Nós estamos consumindo e produzindo informação. Isso vale para as ONGs também. A interatividade é a marca das redes sociais, tem muita gente que estuda esse assunto e diz que, hoje, na rede social, você não tem que se preocupar só com o que você vai dizer, mas, sobretudo, como você vai escutar o que está sendo dito no esteio da sua comunicação e como você vai se posicionar em relação a isso. Isso envolve desde uma capacidade de interlocução com públicos que não necessariamente estão aderindo aos seus valores, e também políticas de lidar com haters, com discurso de ódio, de racismo. Tudo isso é um desafio para quem está nessa fronteira da comunicação. É bem interessante (WEIS, 2017, entrevista exclusiva).

Voltando à Mariana Moraes, ela também associou engajamento com a necessidade de um trabalho feito com tempo, até para que gere as transformações necessárias. Moraes também apresentou exemplos do próprio Gife para explicar como a comunicação tem atuado nessa questão. 
Então, engajamento tem muito a ver com a construção de mensagem ao longo do tempo, dar tempo ao tempo para que as coisas aconteçam. As pessoas querem muito que as coisas sejam para amanhã, mas mudança de cultura, mudança de comportamento, mudança de valores, todas essas mudanças que uma grande causa mexe, elas levam muito tempo. [...] Em relação ao Gife, a comunicação tem nos ajudado, primeiro, a disseminar as nossas causas para mais gente e, segundo, o que eu destaco muito e continuarei destacando, é sobre a importância de começarmos a traduzir essa linguagem de nicho, que é a linguagem do terceiro setor, a linguagem do investimento social, para a sociedade civil. O que é que nós estamos falando quando abordamos recursos privados para o bem público? Estamos falando de grandes famílias, de grandes fortunas que pegam o dinheiro delas e querem desenvolver uma sociedade. Quais são as implicações disso? Quais são as problematizações disso? É muito importante traduzir sempre o que a organização está fazendo. Para mim, uma forma da comunicação engajar é quando ela consegue realmente traduzir uma mensagem de uma forma que toque o outro (MORAES, 2017, entrevista exclusiva).

Resgatando Maurício Bianco, ele destacou que, embora a organização em que atua tenha mais de 25 anos de operação, o destaque para a vertente estratégica da comunicação é relativamente recente.

\begin{abstract}
Posso dizer que a Conservação Internacional, onde eu trabalho hoje, acordou para essa questão recentemente, talvez em menos de dez anos para cá. Ela tinha garantido fundos por determinadas fontes então teoricamente não precisava envolver muita gente e contar o que ela estava fazendo para captar mais recurso ou mesmo para envolver uma audiência maior, os stakeholders de forma geral. Então não tinha nenhuma necessidade de comunicação e, se fazia, fazia de forma muito tímida. Na medida em que você sabe que, para ter uma transformação efetiva, você precisa efetivamente envolver uma quantidade maior de audiência, e aí vamos ser bem sinceros, de um público que normalmente não está diretamente relacionado com você, não é seu público que vai ter interesse direto contigo, mas que você precisa se comunicar, que é que chamamos de convertidos, se eu preciso ir para um público mais amplo, então a comunicação passa a ser importante (BIANCO, 2017, entrevista exclusiva).
\end{abstract}

A nuvem de palavras da Figura 17 ilustra e destaca os principais conteúdos apresentados pelos entrevistados em resposta a esta pergunta. Na figura indicada, quanto maior o tamanho da palavra, mais vezes ela foi utilizada pelos entrevistados. Fica evidente, nesse caso, a utilização frequente dos termos comunicação e pessoas. Além disso, a visualização das respostas dos entrevistados mostra que, em relação à questão apresentada, também foram frequentemente destacadas as seguintes 
palavras: bem, engajamento, público, momento, organização, causa, mensagem e tempo.

Figura 17: Nuvem de palavras comunicação e engajamento

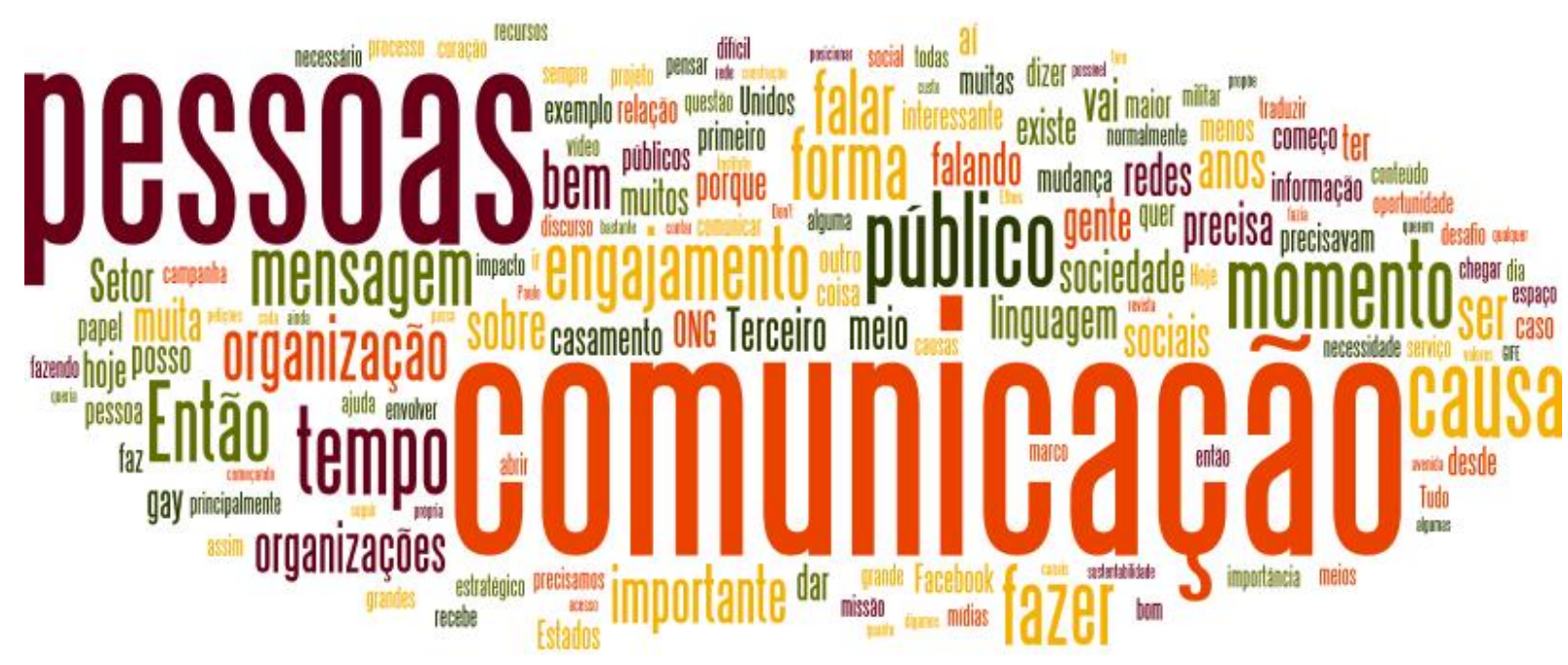

Fonte: Ulsen (2018)

2. Você consegue delimitar os potenciais e os limites da comunicação para ampliar a consciência das pessoas sobre os atuais problemas sociais e ambientais?

Esta pergunta foi elaborada para entender até que ponto a comunicação tem capacidade para ser efetiva e quais são os obstáculos. Afra Balazina foi clara quanto ao potencial e, também, às limitações, exemplificando como a organização em que atua segmenta os públicos a partir do conhecimento que eles têm da SOS Mata Atlântica com o objetivo de gerar engajamento.

A comunicação é muito estratégica, mas não resolve todas as questões. $\mathrm{E}$ importante para as ações de apresentação, relacionamento e acompanhamento dos públicos. Na SOS Mata Atlântica, temos um modelo que é o de uma pirâmide em que, na base, estão as pessoas que nos conhecem. Um nível acima, as pessoas um pouco mais engajadas, no terceiro nível a pessoa mais atuante, aquelas que são voluntárias ou filiadas e tem uma atuação mais 
efetiva. Em nossas ações de comunicação, falamos muito com o primeiro e o segundo nível. No terceiro nível, temos que ir além, e precisamos de mais conteúdo para gerar oportunidades, por exemplo, para os voluntários. Então, com a comunicação apenas, conseguimos ir até um limite. Para conseguirmos ter uma pessoa engajada, é necessário ir além da comunicação, e integrar outras áreas, como eventos e administração (BALAZINA, 2017, entrevista exclusiva).

Renato Guimarães destacou que a inovação por meio de tentativa de novos formatos também é importante, gerando mais resultado quando previamente testados para apurar o possível engajamento decorrente.

No Greenpeace, temos tentado muito pensar e testar formas de conteúdos com pessoas antes de torná-los públicos. Por exemplo, o tema da luta contra a implantação de projetos na Amazônia e os impactos sobre o meio ambiente. Como as pessoas percebem que o tema da Amazônia tem a ver com a vida dela em São Paulo? Fazemos testes de como isso impacta cada público. Usamos muito mídias sociais, criamos postagens com diferentes aspectos, testes com pessoas diferentes, e aplicamos. Dependendo do retorno, avaliamos qual frase e qual foto traz mais engajamento. Isso deu muito certo na campanha Tapajós. Esse teste ajuda muito a posicionar melhor a comunicação. Parte dos conteúdos das organizações não faz isso. Essa capacidade de segmentar os conteúdos será absolutamente fundamental (GUIMARÃES, 2017, entrevista exclusiva).

Rejane Romano adotou uma abordagem diferente defendendo que não enxerga essa possibilidade uma delimitação dos potenciais e dos limites da comunicação. Por outro lado, na resposta a seguir, esclareceu que existem temas que, atualmente, geram mais comoção, a exemplo da ética.

Não há como delimitar, mas existe uma percepção de quais temas têm maior ou menor aceitação, levando-se em consideração ainda 0 momento da sociedade, que muda ao soprar dos ventos. Atualmente, é perceptível uma comoção nacional com assuntos que estejam relacionados à ética (ROMANO, 2017, entrevista exclusiva).

Retomando a fala de Afra Balazina, a atuação profissional da equipe de comunicação que atua em organizações do terceiro setor focadas em sustentabilidade é permeada por dilemas cotidianos. Nesse sentido, alguns elementos contribuem para tornar a comunicação mais importante, a exemplo do planejamento, da definição de metas e de um posicionamento proativo. 
O planejamento é muito importante. Queremos agilidade, mas temos também objetivos a perseguir. Esse dilema nós vivemos todos os dias. Então, na SOS Mata Atlântica, temos, na área de Comunicação, pessoas focadas em determinadas atribuições. Todos os profissionais hoje estão alinhados para chegar aos jovens e cada vez mais ampliar o público que nos conhece. E existe uma meta para a área como um todo. Isso ajuda muito a instituição a entender e a comunicação tem que estar integrada, pois assim realizamos nossas ações. O planejamento também tem que existir já que não podemos apenas reagir aos acontecimentos, e a comunicação é cada vez mais importante. A comunicação às vezes é vista como um meio, mas ela também é um fim, então precisa ser muito planejada (BALAZINA, 2017, entrevista exclusiva).

Partindo nesse momento para uma resposta mais analítica da questão, Maurício Bianco foi claro quanto à amplitude do potencial da comunicação o que é limitado, apenas, em decorrência da dificuldade de recursos humanos e financeiros. De forma complementar, Bianco destacou que esta comunicação das organizações do terceiro setor tem se direcionado, cada vez mais, a nichos.

Eu parto do princípio de que se você não der conta de mostrar que esses problemas e essas situações existem, teoricamente você vai ter um grupo muito pequeno de ajuda. E se você está buscando envolver um público mais amplo para poder gerar uma discussão maior, sem a comunicação você vai estar extremamente limitado no que se refere ao poder de transformação que você tende a fazer, seja na área social, seja na área ambiental. Então existe a limitação sim, ela é muito mais ligada a recursos humanos e financeiros, mas não existe uma limitação em termos do que pode ser feito em comunicação. Existem hoje iniciativas de comunicação espalhadas no terceiro setor em vários países que são de uma criatividade e de um alcance tamanho que isso, para mim, é o potencial da comunicação. Ele é enorme e acaba não tendo limites de fato, porque você de fato consegue ter um impacto muito grande. Agora, o que se vê hoje, e não é uma verdade só para a sustentabilidade das organizações, é que cada vez mais estamos falando em nichos. Nós antes podíamos usar, por mais ruim que pareça essa expressão, uma bala de canhão e acabava atingindo muitas pessoas. Hoje não adianta mais. Se você não trabalhar com nichos e com mensagens para o nicho, na forma para o nicho, você pode estar usando uma bala de canhão à toa, que vai voltar vai voltar para você. Então isso torna ainda mais complexo esse caminho que a comunicação percorre no terceiro setor. Porque, se uma forma estamos falando que a comunicação é relativamente nova no terceiro setor, e que no geral ela tem certa inovação, quando você começa a trabalhar a comunicação no terceiro setor, já começa a se deparar com uma ferramenta que não é uma única mensagem para todos, como já foi no passado no primeiro e no segundo setor (BIANCO, 2017, entrevista exclusiva). 
Mariana Moraes destacou inicialmente o desafio de desenvolver ações de comunicação em um ambiente repleto de excesso de informações, em que o acesso aos canais vem se tornando cada vez mais fácil e poderoso.

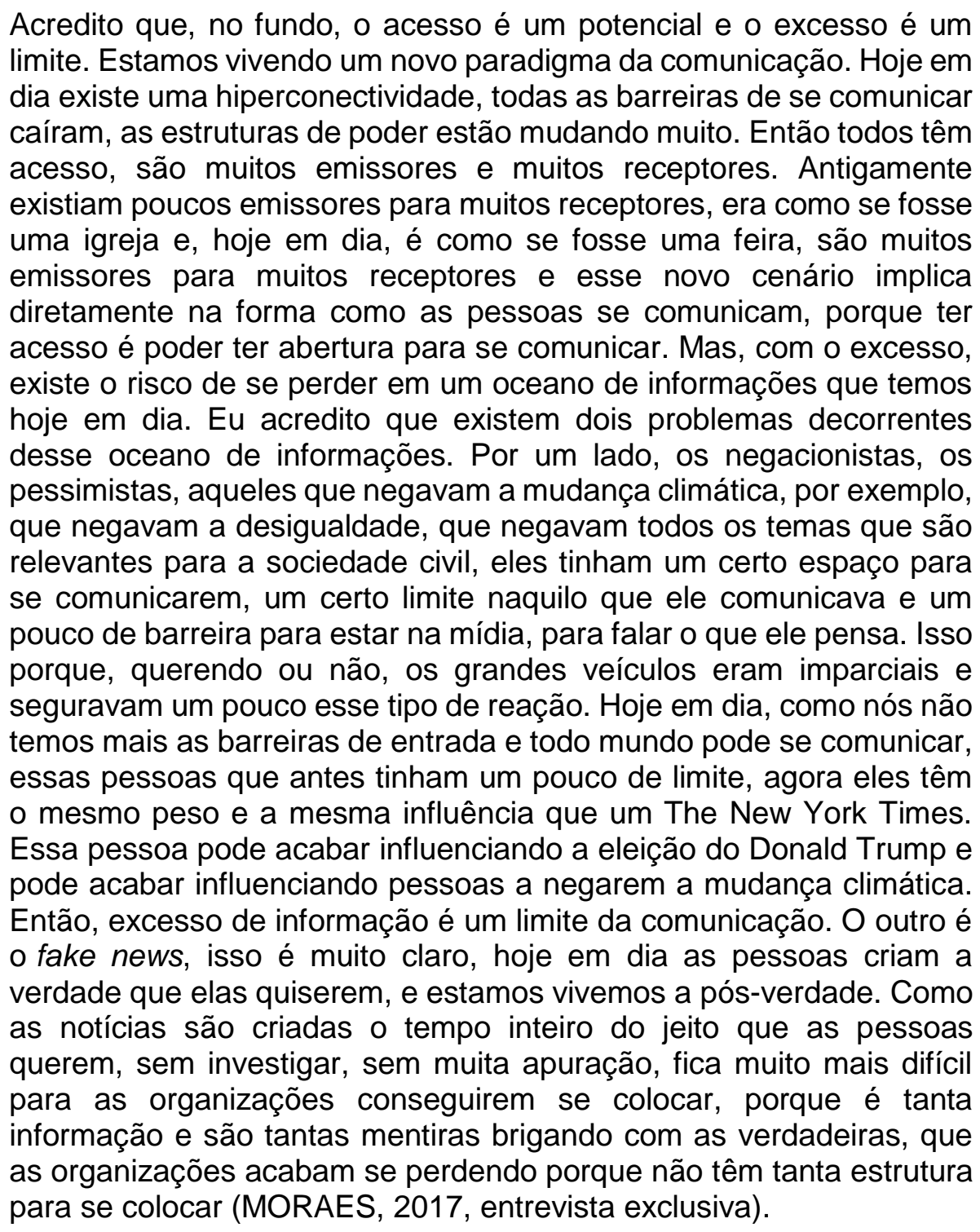

Por outro lado, a gerente de comunicação do Gife também destacou potenciais que são inerentes do terceiro setor, como, por exemplo, a apresentação de opiniões e análises qualificadas sobre determinados assuntos.

Tem dois potenciais muito grandes do terceiro setor. Um deles é que o terceiro setor sempre foi e é peça-chave como uma organização de denúncia. Então, o Greenpeace é quem vai dizer que $60 \%$ da Amazônia é desmatada por gado, que os supermercados estão vendendo carnes sem rastrear a origem, e indicar para Pão de Açúcar, 
Walmart, Carrefour que é responsabilidade deles criar critérios para que a compra de carne que não seja oriunda de desmatamento da Amazônia e questionar o que eles vão fazer em relação a isso. Esse é só um exemplo, e eu realmente acho que as organizações têm como potencial ser um elemento de denúncia, de controle social, uma organização que fica o tempo inteiro investigando, determinando e pressionando para que as coisas sejam denunciadas. Isso é muito importante, é um papel que o terceiro setor tem de mais precioso e que, somado a isso, principalmente com essa crise da mídia, com a forma como os grandes veículos estão vivendo hoje, sempre com muita dificuldade de averiguar, apurar, buscar dados, eu acredito que um potencial do terceiro setor é aproveitar para comunicar seus dados. Porque o terceiro setor é que tem os dados, tem o olhar na ponta, que conseguiu apurar exatamente como está uma região. Se for perguntar para o Instituto Alana, eles sabem exatamente dizer como está a região do Pantanal Paulista. Se falar com o projeto Arrastão, eles sabem como está o Campo Limpo. Eles têm como apurar os problemas e as soluções para a região em que estão atuando. Se quiser conversar sobre saúde da criança, a Vera Cordeiro vai falar que sabe exatamente o grande problema das crianças que vão para 0 hospital. Ela diz que as crianças moram em casas úmidas, insalubres, as famílias não sabem lidar com uma criança recém curada e as crianças acabam voltando para o hospital ainda mais doentes (MORAES, 2017, entrevista exclusiva).

Bruno Weis aproveitou a oportunidade para destacar a experiência vivida no Instituto Socioambiental (ISA) e direcionou sua análise para a necessidade de criação de condições para a manutenção da credibilidade da organização em que atua. Segundo ele, os critérios para a determinação dos esforços profissionais e o envolvimento de recursos para as ações planejadas devem ser claros para que seja profissional e não coloque em risco a confiança do público sobre a importância dessas mensagens.

Vou falar do ponto de vista do Instituto Socioambiental. Eu acho que tem alguns valores nossos que nunca podem sofrer arranhões, ainda que o nosso objetivo de ampliação de alcance seja crescente. Nós temos uma credibilidade, o que é fundamental quando a gente tem um assunto que merece uma comunicação. Então nesse momento, por exemplo, o Senado Federal está votando duas provisórias que vão reduzir o limite das unidades de conservação de proteção integral no estado do Pará. Elas estão tendo os limites revistos no Senado, já passou pela Câmara e agora está no Senado. Este é um assunto de uma gravidade tremenda que merece todo o esforço de comunicação das organizações como o ISA, mas não só, para alertar a população para que todos possam fazer pressão em relação aos políticos em que elas votaram, avisar a imprensa, tentar fazer uma pressão para que essa votação não aconteça ou que não sejam aprovadas as Medidas Provisórias. O ponto é que, quando o assunto não tem essa 
importância toda, e você vira refém dos likes, de algo assim, você acaba gerando um alarmismo, ou há o risco de gerar um alarmismo excessivo para você ganhar uma evidência uma disputa no feed das pessoas. Porque, no fundo, estamos em uma disputa que é o seguinte: você tem diversas causas competindo pela atenção e pelo engajamento das pessoas. Há a causa ambiental, a causa indígena, a causa dos direitos humanos, a urbana, o direito à moradia, o direito de legalização das drogas. Tem várias causas e todas elas estão disputando um público relativamente parecido, existe uma convergência de um olhar progressista de pessoas que comungam de valores ligados a uma visão do mundo de esquerda, de que as minorias devem ter seus direitos respeitados. Se você entra numa disputa fraticida com os seus pares para ganhar mais espaço há um risco da sua credibilidade sofrer danos, ou seja, tem que ter muita calma na hora de você fazer uma imagem no Facebook dizendo que é urgente, aqui, agora. É como aquela coisa, você conta dez vezes uma mentira e, na hora que vai contar uma verdade, ninguém vai te ouvir. Tem que ter um certo cuidado para você dosar de fato a comunicação no calibre do que o assunto em si merece. Tem momentos em que você tem que fazer uma comunicação um pouco mais austera, um pouco mais sóbria porque o assunto talvez não mereça ou você não tem nem informação suficiente para cravar um posicionamento institucional. A busca pelo engajamento nunca deve colocar a sua credibilidade enquanto organização em risco (WEIS, 2017, entrevista exclusiva).

Maurício Bianco encerrou a análise apontando os desafios envolvidos com essa atuação, como por exemplos instrumentos de pesquisas para a definição de públicos, meios e profissionais envolvidos. Bianco ainda aproveitou o espaço para esclarecer que o terceiro setor convive com o acompanhamento constante dos investimentos que recebe e, até mesmo por isso, precisa incorporar mecanismos de retorno de investimentos em comunicação.

Ou seja, você precisa trabalhar de forma focada no público-alvo, então se torna uma coisa ainda mais complexa. E tudo o que está atrelado a isso, o sistema de pesquisa do seu público-alvo que você precisa, que tipo de informação e por que meio que vai público, aí fica bem mais complexo mesmo para um conjunto de organização que têm limitação de recursos e pessoas para fazer, isso então é um desafio muito maior. Hoje estamos falando de microtarget hoje, ir no target bem específico para você dar o recado para a pessoa certa. Isso para o terceiro setor é extremamente importante, porque ninguém mais que o terceiro setor olha para o ROI, o retorno sobre investimentos da comunicação, do que o próprio terceiro setor, porque os recursos são limitados, normalmente de origem de doadores, sejam eles de empresas privadas, do governo, ou de organizações multilaterais, mas, enfim, é um dinheiro que é muito mais vigiado, e tem que ser mesmo, então é necessário que a atuação seja muito mais certeira e muitas vezes não vai ter perdão de você não fazer um negócio bem 
feito. Isso pode custar uma grande ferida na organização se você investir em recursos que não vão ter um resultado tão significativo (BIANCO, 2017, entrevista exclusiva).

$\mathrm{Na}$ Figura 18 a nuvem de palavras revela os principais conteúdos apresentados. Nesse caso, a comunicação novamente assumiu o protagonismo da questão, mas também mereceram destaque os termos pessoas e terceiro setor. Foram também destacadas as palavras organizações, potencial, exemplo, fazer e hoje.

Figura 18: Nuvem de palavras sobre potenciais e limites da comunicação

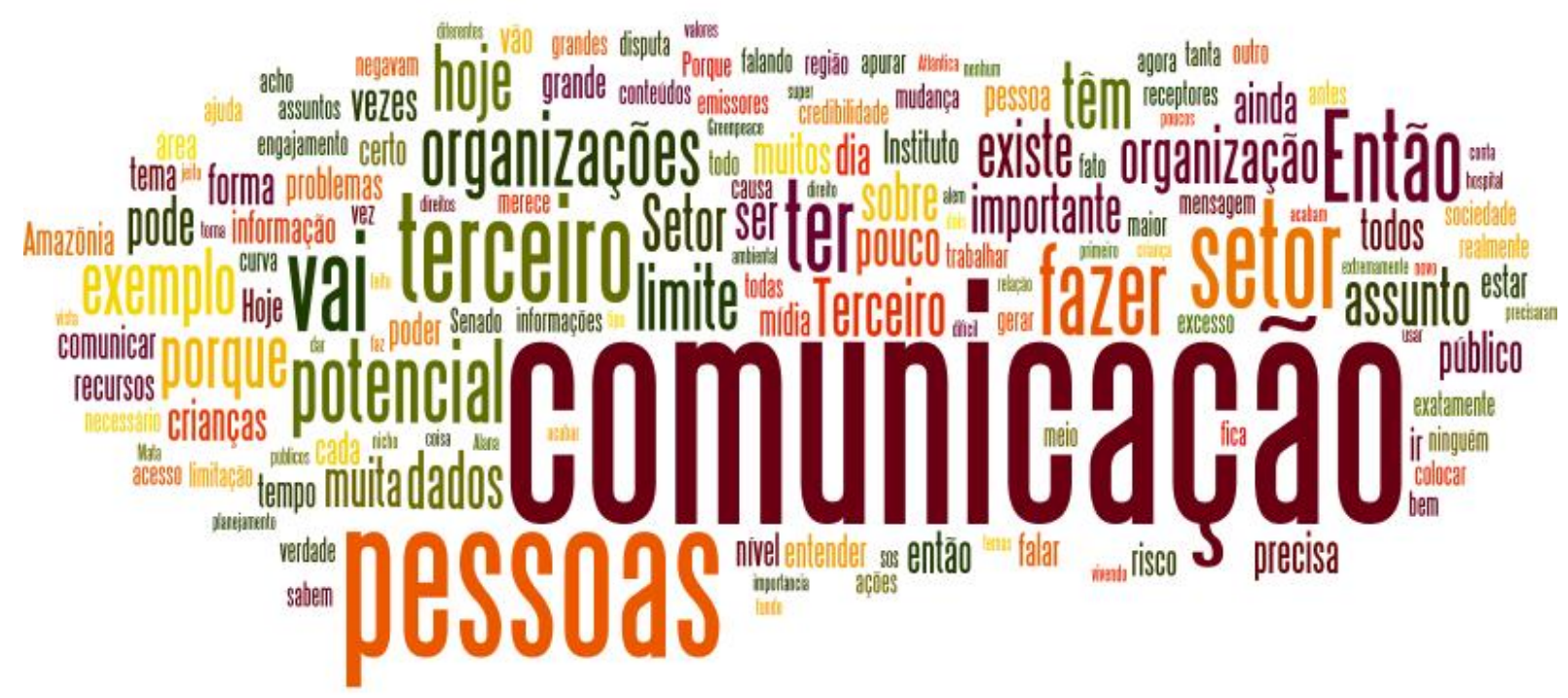

Fonte: Ulsen (2018)

3. Quais são os benefícios que a integração entre comunicação e sustentabilidade podem gerar para a sociedade?

Esta questão foi elaborada para detalhar com mais propriedade os possíveis benefícios envolvidos com a integração dessas duas áreas. Considerando que esta pesquisa foi desenvolvida justamente para delinear os potenciais de transformação social a partir de uma comunicação estratégica com foco em sustentabilidade, a questão ganha ainda mais pertinência ao envolver na discussão a opinião desses 
gestores, que estão habituados, no cotidiano de suas respectivas atuações profissionais, a refletir sobre essa temática e criar mecanismos funcionais.

Começando com Afra Balazina, ela entende a importância dessa integração, mas esclarece que ainda existe o desafio de se superar a superficialidade da forma com que as empresas conduzem essa questão. Além disso, Balazina compartilhou uma experiência interessante ocorrida na organização em que atua e que demonstra de que forma a sustentabilidade pode estar no centro do negócio.

\begin{abstract}
Os benefícios da integração entre comunicação e sustentabilidade são muito importantes para a sociedade. Cada vez mais as empresas levam isso em consideração, mas ainda de forma superficial. $O$ desafio é sair do discurso é ir mais a fundo. Muita gente ainda usa materiais impressos em divulgações, por exemplo. Recentemente, em uma ação de Carnaval, tivemos uma ideia de fazer máscaras com imagens de animais da Mata Atlântica para chamar a atenção para a necessidade de preservação deles. Mas, depois, avaliamos que isso poderia gerar um lixo desnecessário e que poderíamos acabar poluindo as ruas, e repensamos a estratégia. Atualmente, se a organização não tem a sustentabilidade no centro do negócio, é a primeira área a ser cortada. Além disso, muitas vezes, nas empresas, comunicação e sustentabilidade estão em áreas separadas, e não há a sinergia que deveria, pois a sustentabilidade não permeia toda a organização (BALAZINA, 2017, entrevista exclusiva).
\end{abstract}

Para Rejane Romano as duas áreas são interligadas e a integração é cada vez mais necessária. Para a coordenadora de comunicação do Instituto Ethos, é importante, nesse caso, extrapolar o apego da sustentabilidade com a temática ambiental, e incorporar outros elementos de desenvolvimento importantes também.

Ambas estão intrínsecas e a grande sacada é trabalhar a transversalidade das questões. A começar por evidenciar o quanto sustentabilidade não se refere apenas a questões de meio ambiente, mas sim todo escopo abrangido pela responsabilidade social (ROMANO, 2017, entrevista exclusiva).

Maurício Bianco foi categórico ao dizer que enxerga a comunicação cada vez mais estratégica e defendeu a necessidade de profissionais da área envolvidos nesse processo. Ele destacou ainda que a qualidade do resultado é diretamente proporcional à capacitação e à formação técnica dos comunicadores. 
E eu vejo a comunicação cada vez mais estratégica para o desenvolvimento da sustentabilidade. Se você fizer com profissionais da comunicação, e der para esses profissionais recursos e equipamentos para fazerem alguma coisa bem-feita, e tem um retorno com isso. O que é interessante olhar, e eu vivencio isso de forma cotidiana, é que parece que de medicina e comunicação todo mundo entende um pouco. Sempre tem um remédio que alguém quer receitar, assim como sempre tem alguma sugestão que alguém acha que isso é importante em termos de comunicação. E não estou dizendo que não deva ser feito. Gosto muito de decisões colegiadas, mas existe um técnico, uma pessoa que estudou e, teoricamente, tem condições de dar opiniões estratégicas sobre isso. $E$ muitas vezes não é assim que funciona. Então, colocar na comunicação pessoas que foram capacitadas para isso, e dar oportunidade, entenda-se recursos para ela desenvolver a estratégia, me parece importante para você avaliar se essa comunicação foi bem-feita ou não. Porque, se não for assim, você mata a comunicação antes. Alguém que não tenha o perfil não vai conseguir fazer o trabalho para você. Basta a gente convencer os outros que eles têm que olhar por esse lado também (BIANCO, 2017, entrevista exclusiva).

Renato Guimarães respondeu com base em uma análise do atual cenário vivenciado pela comunicação, de múltiplas mídias sendo utilizadas por diferentes públicos para a produção de conteúdo (qualificado ou não). Diante desse contexto, revelou que a curadoria do conteúdo tende a se tornar mais importante e se incorporar às atribuições da comunicação, até por uma questão de visibilidade dos impactos gerados pelas organizações do terceiro setor.

Hoje em dia observamos, por um lado, as pessoas sendo produtoras e reprodutoras de conteúdo, uma democratização massiva da comunicação. Por outro lado, com as margens para pós-verdades e interpretações negativas, isso aumenta a relevância da curadoria. Hoje isso é uma oportunidade importante para a comunicação, serve para separar o joio do trigo. Comunicação é fundamental, é fluida, assim começamos a atingir as pessoas. A curadoria se tornará mais importante na sustentabilidade, é como se tangibiliza isso. Comunicação mais fragmentada, diluída, ela força isso. As pessoas querem saber como isso impacta na vida. Conteúdos genéricos, muito profundos, técnicos demais, não conseguem comunicação para as pessoas. Os conteúdos que mostram os problemas, como eles impactam, que chamam para a ação, com boa formatação visual são os que têm mais impacto (GUIMARÃES, 2017, entrevista exclusiva).

Opinião semelhante apresentou Mariana Moraes, segundo quem a causa tem que estar muito evidenciada nesse processo, sendo a comunicação a responsável por diversas atribuições, entre elas a disseminação de informações, a criação de vínculos e o direcionamento de denúncias. 
Ainda, da mesma forma que Renato Guimarães apontou na resposta acima, Mariana Moraes também mostrou preocupação com o excesso de informações geradas e, por outro lado, a necessidade de qualificação e discernimento para se contrapor a esse cenário.

\begin{abstract}
Fazendo um resumo de tudo em relação a comunicação para a sustentabilidade, acredito que comunicar para o terceiro setor, comunicar a sustentabilidade, comunicar causas é algo sobre o que é preciso ter muita clareza da causa, precisa ter muita paciência porque requer muito tempo, então não atravesse, não corra, precisa não perder o timing. Então, identificar o que a sociedade está pedindo e se adequa e precisa avaliar depois. Eu diria que comunicação é uma peça-chave para qualquer organização porque a comunicação é a forma como nos colocamos no mundo. Sem comunicação não há disseminação, então assim estabelecemos diálogos, criamos vínculos, avisamos, denunciamos, nos colocamos, fiscalizamos. A organização que não se comunica está, por si só, errando, perdendo uma oportunidade. Comunicação é um requisito fundamental para a transformação, quem não se comunica não está dialogando com ninguém e a mudança de valor requer comunicação.

Por fim eu acredito que é importante falar que os tempos são outros, nós estamos vivendo a hiperconectividade, a falta de tempo, a comunicação mudou de paradigma completamente. Qualquer pessoa é produtora de conteúdo, são muitos emissores para muitos receptores, comunicar ganhou uma relevância muito grande porque, como é que se faz para se destacar em um oceano de informações? Então é necessário nos adequarmos à comunicação que existe hoje e nunca esquecermos de tocar o coração das pessoas, porque, no fundo, quando estamos falando de causa, estamos falando: Ei, você aí! (MORAES, 2017, entrevista exclusiva).
\end{abstract}

Voltando a Maurício Bianco, a comunicação deve estar a serviço da transparência, no sentido de tornar as ações públicas, até mesmo para apresentar os resultados e impactos positivos.

Para mim o mais importante, a primeira coisa, é ter conhecimento e transparência. Ou seja, você ter a comunicação em um espírito de tornar público o que você faz, na medida em que isso traz transparência e conhecimento para as pessoas. Só por isso entendo que já é benefício extremamente bem pago. Ou seja, fazer uma comunicação para mostrar o que você faz, que é normalmente de impacto coletivo, então você precisa de fato olhar para isso. Depois tem a questão que, ao fazer uma comunicação devida, você está gerando um awareness para a sua organização, para a sua causa, para 0 seu projeto e, consequentemente, está alavancando possibilidades de novos recursos para gerar uma transformação ainda maior. Então tem esse lado de comunicação para a captação de 
recursos, que é extremamente importante. É pouco provável que você consiga ter investimento na sua causa, na sua organização, se você não for conhecido ou for pouquíssimo conhecido, então é a sustentabilidade financeira da própria organização. Ainda tem esse outro ponto. Então eu considero que são benefícios extremamente importantes para se investir em comunicação ligada à sustentabilidade (BIANCO, 2017, entrevista exclusiva).

Afra Balazina destacou que, após trinta anos de atuação, a SOS Mata Atlântica continua vivenciando desafios constantes e a necessidade de envolver e atingir as pessoas nas discussões atuais. Como exemplo, Balazina citou a recente crise hídrica pela qual os moradores de São Paulo passaram.

A missão atual da SOS Mata Atlântica, depois de trinta anos de história, é inspirar a sociedade na defesa da Mata Atlântica. Nós não queremos só beneficiar animais e florestas. Ao contrário, queremos também incluir o ser humano. Na crise hídrica ocorrida no Estado de São Paulo, observamos que houve uma redução da qualidade da água. Todos têm que pensar sobre isso. Nesse período, muitas empresas pararam as atividades, pois não tinham água para operar. O desafio é as pessoas entenderem essa relação. Se você quiser discutir mudanças climáticas, por exemplo, todos acham que isso é muito distante. $\mathrm{E}$, apesar das pessoas saberem mais sobre o meio ambiente, elas também se interessam cada vez menos pelo tema. Então, a comunicação não pode ser chata. Nós falamos muito "não". Por exemplo, "não lave seu carro", "não demore no banho". Esse é o desafio da comunicação. Temos que pensar em como atingir as pessoas (BALAZINA, 2017, entrevista exclusiva).

Mariana Moraes também respondeu com base em sua experiência profissional e foi enfática na defesa da participação da comunicação em toda a organização. Em diferentes momentos da entrevista, conforme destacado a seguir, Moraes disse que a comunicação deve estar no que chamou de "marco zero" das ações do Gife.

Falando agora sobre como são planejadas as ações de comunicação no terceiro setor, eu posso contar como elas são planejadas no Gife. Em todas as ações, a comunicação tem que ser acionada desde o marco zero, sempre, então quem está pensando em fazer alguma ação já nos avisa porque é a comunicação que vai provocar com quem se quer falar, porque se quer falar, quando se quer falar, como se quer falar, qual é a mensagem que se quer tirar daquilo, qual é a real causa por trás, que é sempre o que causa ruído quando não está muito claro o que se quer comunicar. Então nós sempre envolvemos redes sociais, assessoria de imprensa, matérias no próprio site do Gife, o nosso boletim e, depois, a gente continua replicando tudo nos nossos veículos (MORAES, 2017, entrevista exclusiva). 
Bruno Weis fez um contraponto interessante, causando um ponto de inflexão nas discussões apresentadas até o momento. Para ele, a integração entre comunicação e sustentabilidade não gera apenas benefícios, mas também pode ser usada para legitimar práticas danosas ao meio ambiente e à sociedade com uma aparência supostamente correta.

Eu acho que há um lado negativo que é importante ser ressaltado que é o famoso greenwashing. A comunicação, como muitas ferramentas do establishment, se apropria de conceitos que nascem revolucionários, mas logo são totalmente incorporados pelo sistema dominante. Então, tendo um discurso de sustentabilidade pelas empresas, com departamentos de responsabilidade socioambiental, nisso a comunicação acaba sendo a protagonista nas empresas desse tipo de discurso, mas isso não se reflete nas práticas dos negócios das empresas, nas cadeias produtivas que são envolvidas. Então eu acho que na verdade tem um lado B aí bastante importante de ser observado (WEIS, 2017, entrevista exclusiva).

Seguindo com a reflexão de Weis, ele detalhou em suas respostas de que forma a comunicação tem se apropriado de um discurso para retratar a situação crítica de implementação da usina de Belo Monte.

A comunicação promove a consciência das pessoas, promove a sustentabilidade, mas ela promove muito mais hoje o greenwashing, sobretudo no segundo setor, nas empresas. Vamos pegar o caso de Belo Monte. Acho que o Belo Monte é um caso fantástico para olhar como o Governo Federal se apropriou de um discurso para dizer que ali foi tudo resolvido, que a hidrelétrica era moderna, não geraria passivo ambiental, não geraria passivo social. E isso, inclusive para quem visitou as obras durante sua execução, eu fui uma dessas pessoas, dentro de um ônibus da empresa Norte Energia, você estava ali ouvindo discurso onde pensava que aquilo era uma maravilha do mundo, tudo perfeito, tudo equacionado, não vai ter mais problema nenhum. Hoje, a usina só funciona porque ela tem um mecanismo de suspensão de segurança que impede que a justiça interrompa o seu funcionamento em função das multas que foram aplicadas pelo lbama e nunca foram pagas, dada a quantidade de passivos e pendências socioambientais. Então eu acho que tem exemplos no governo e nas empresas que recorrentemente falam de sustentabilidade da boca para fora, um discurso vazio, e isso é uma coisa que a cultura brasileira ainda vai ter que amadurecer muito para separar o joio do trigo mesmo (WEIS, 2017, entrevista exclusiva). 
A nuvem de palavras evidencia a utilização extremamente marcante e destacada da palavra comunicação. Além dela, os termos sustentabilidade, pessoas e importante também foram bastante citados, conforme apresentado na Figura 19.

Figura 19: Nuvem de palavras de integração de comunicação e sustentabilidade

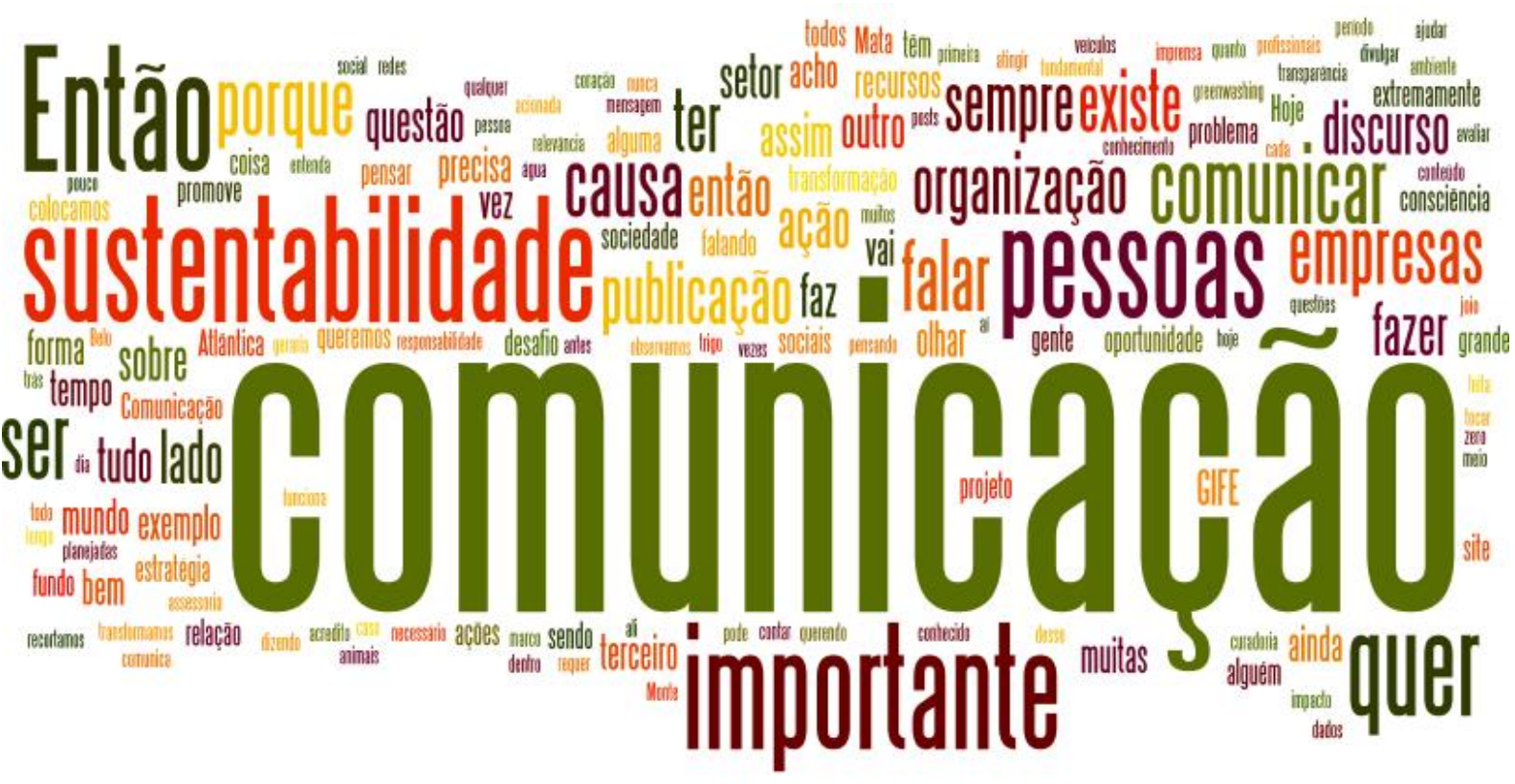

Fonte: Ulsen (2018)

4. Quais recursos são necessários e como devem ser planejadas as ações de comunicação no terceiro setor?

A quarta questão apresentada aos gestores de comunicação foi criada com o objetivo de compreender com base em quais recursos as atividades podem ser planejadas e desenvolvidas no âmbito da comunicação para a sustentabilidade no terceiro setor. Importante destacar que todo trabalho efetivo e de impacto depende da qualidade da equipe, mas também das condições profissionais oferecidas para que a pessoas desempenhem um trabalho relevante.

Nesse sentido, Rejane Romano começou destacando a necessidade de condições financeiras, complementada, de preferência, com a criatividade e 0 engajamento das pessoas. 
Uma boa estratégia requer investimento financeiro e, como esta é uma questão delicada para muitas organizações do terceiro setor, a criatividade se torna preponderante. $O$ engajamento é um recurso imprescindível e neste ponto as redes sociais são fortes meios de disseminação e atração de pessoas (ROMANO, 2017, entrevista exclusiva).

Afra Balazina também entende a necessidade de recursos, sobretudo para o planejamento de um trabalho responsável com os resultados no longo prazo. Ela também revelou que a SOS Mata Atlântica entende que os recursos para a comunicação também podem ser oriundos de outras áreas, pois cada novo projeto considera a necessidade de envolver a comunicação para a sua implementação.

Queremos um trabalho sério, um compromisso de longo prazo, então
precisa haver esse planejamento e tem que ser algo constante.
Precisamos investir em recursos. Profissionalizar a nossa atuação traz
retorno de mídia e faz diferença. Atualmente, os projetos que são da
instituição têm que reservar recursos para as ações de comunicação.
Se eu vou falar daquele projeto, preciso de recursos daquela área.
Temos muitas necessidades, salários das pessoas, custos previstos,
então nós temos realizado esse trabalho. Existem projetos que alocam
mais verba e outros feitos de forma voluntária. E os coordenadores
dos projetos institucionais da SOS Mata Atlântica, desenvolvidos com
apoio das empresas, têm que entender isso e passam a valorizar mais
o nosso trabalho (BALAZINA, 2017, entrevista exclusiva).

Maurício Bianco voltou a defender, de início, a necessidade de um corpo profissional qualificado. No contexto do terceiro setor, em que o recurso financeiro tende a ser mais escasso, Bianco foi enfático ao destacar que os aportes de verba também são fundamentais para o sucesso das ações.

O primeiro ponto é o recurso humano. Pode até parecer clichê, mas se você não tiver um profissional minimamente capacitado da área para fazer esse tipo de ação, você não pode esperar um resultado positivo. Se for positivo, vai ser uma consequência ótima, mas vai ser coincidência. Se você de fato entende que a comunicação tende a aportar, invista em mão de obra capacitada. Tem um monte de gente saindo da faculdade hoje, e existe um mercado no terceiro setor, então que o terceiro setor também olhe para investimentos em comunicação primeiramente contratando pessoas da área. Isso seria a principal. Segundo, que é mais complicado, mas que devemos brigar por isso, é ter orçamentos, entenda-se dinheiro, investimento, para poder fazer uma boa ação. Porque também não adianta colocar um profissional da comunicação para fazer o trabalho e, se você não tiver dinheiro, ele vai conseguir fazer muito pouco e aí, logicamente, os resultados vão ser igualmente pequenos. Então eu tenho um mantra que é bem 
básico, eu acredito muito nele e diz que what you pay is what you get. Então, o que você paga é o que você tem. Se você não paga, você não tem. Se tiver, é uma coisa muito marginal. Isso é verdade não só na comunicação, mas em qualquer outra coisa. Isso me remete a outra questão (BIANCO, 2017, entrevista exclusiva).

Este foi o tema de pesquisa da dissertação de mestrado defendida por este autor (Ulsen, 2012) que, ao tratar dos desafios do gestor de comunicação, também abordou a importância crescente de atenção sobre a necessidade de profissionalização da equipe. Na entrevista concedida para esta pesquisa, Renato Guimarães também considerou essa questão importante. Da mesma forma que os demais, citou a maneiras de diminuir custos, mas também defendeu investimentos financeiros. Além, disso, Guimarães também direcionou a resposta para a necessidade de reflexão sobre o perfil do gestor responsável por essas ações.

Com a utilização de recursos de economia criativa, conseguimos diluir custos, mas a questão principal é que este aspecto é fundamental. As pessoas devem incluir recursos para a comunicação, para profissionais que pensem a comunicação além da produção de conteúdo, focada em engajamento. Às vezes, um relatório tem menor impacto que uma campanha bem construída. Pensar a estratégia é o que mais faz falta para as organizações que atuam com sustentabilidade atualmente. A visão estratégica deveria estar no centro da organização, que deve ter um profissional que não tenha 0 um perfil de um assessor de imprensa tradicional, mas que seja um gestor de engajamento e mobilização (GUIMARÃES, 2017, entrevista exclusiva).

Partindo para a exemplificação, Afra Balazina comentou sobre como a SOS Mata Atlântica tem trabalhado, recentemente, com a gestão dos recursos humanos. Ela disse que eles têm uma equipe interna, mas que, também contam com parceiros terceirizados para determinadas atividades. Além disso, Balazina aproveitou para mostrar que ações pro bono podem ser até bem-vindas, mas nem sempre adequadas.

Na SOS Mata Atlântica temos uma equipe grande e uma assessoria de imprensa terceirizada, e isso tem funcionado bem e nos permite pensar também em produção de conteúdos, como artigos e pesquisas. Sobre os recursos financeiros, não investimos em anúncios. $O$ gasto extra é para produção de conteúdo e assessoria de imprensa. Antigamente tínhamos muitas ações pro bono, em benefício do público, que não eram de necessariamente com temas do nosso interesse. Por exemplo, a campanha de xixi no banho que a agência F/Nazca Saatchi \& Saatchi fez, ganhou inúmeros prêmios, até em no 
Festival de Publicidade de Cannes, na França. A campanha ficou muito famosa. Nós adoramos esta campanha, mas não necessariamente as pessoas a associam com a SOS Mata Atlântica. Então, repensamos isso (BALAZINA, 2017, entrevista exclusiva).

Seguindo com essa compreensão de ações desenvolvidas no formato pro bono, ou de parcerias, Maurício Bianco apresentou uma opinião semelhante. Para ele, esse modelo pode até funcionar, mas não será considerado prioritário pelo prestador de serviço se for necessário que ele escolha entre realizar esse trabalho ou outro que o está remunerando.

No terceiro setor é comum que se façam muitas parcerias. E quando eu falo parcerias, eu falo de troca de conhecimentos que não envolvem recursos financeiros. Isso é muito importante acontecer, deve acontecer, sou muito partidário a essa estratégia, mas existem coisas que a gente sabe são limitantes também. Se você tem uma agência de publicidade que vai te ajudar, em forma de parceria para alguma estratégia, é bem provável que, no começo ela dê um gás bacana, no meio prazo você continue tendo um parceiro, mas eu vou ser bem sincero. Se ela tiver que optar em escolher você, ou atender alguém que está remunerando, ela vai escolher a remuneração. E está certo. Ela tem de pagar custos, pessoas, equipamento, infraestrutura e tudo mais. Então, se você tem uma parceria que te ofereça voluntariamente esses serviços, saiba que esses serviços vão ser condizentes com o que você está pagando, que é nada. Eu não estou generalizando, mas na média é isso basicamente o que acontece. Isso está totalmente ligado à necessidade de profissionalização do setor. Eu acredito de verdade que as parcerias podem acontecer. Acredito mesmo. Agora, vou ser bem sincero. Na medida em que uma empresa abre mão de ganhar dinheiro com o serviço que ela está oferecendo, ela está vendendo a galinha dos ovos de ouro. Então você tem que estar bem certo que alguém está pagando o tempo dessa pessoa. Então, se você puder remunerar pelo serviço, você também está valorizando o profissional de comunicação que está do outro lado. Então eu acho isso importante que isso, na medida do possível, aconteça. Com isso eu quero dizer que, quando você prevê orçamentos para projetos, para grandes iniciativas, ou mesmo para uma organização, você tem que prever orçamento para remunerar a comunicação também. Porque ela é igualmente importante como outros meios. Então em termos de recursos necessários é pessoal capacitado e recursos financeiros, e aí estou incluindo equipamentos, software, computadores, filmadoras, que vai depender da sua estratégia de comunicação (BIANCO, 2017, entrevista exclusiva).

Bruno Weis reconheceu a relevância de todos os recursos citados até o momento. Foi claro ao defender também a necessidade de recursos financeiros, 
tecnológicos e humanos. Mas, foi além, defendendo o que chamou de capital social, conforme destacado a seguir.

\begin{abstract}
Eu acho que recursos financeiros, tecnológicos e humanos são fundamentais. Mas eu acrescentaria uma coisa chamada capital social, que é o acúmulo de relações que o profissional gera ao longo da sua carreira, da sua performance profissional, da sua trajetória. Capital social é o conhecimento de redes, coletivos, são profissionais que podem contribuir com o seu projeto e a sua estratégia. Dinheiro é um recurso importante, uma equipe interna também é um recurso humano fundamental, assim como uma infraestrutura de tecnologia. Agora, o capital social, estar em contato com o mundo lá fora, saber quem está fazendo as coisas com inovação com criatividade, quebrando paradigmas, isso é um valor subestimado. É bem importante acumular relações em que você consiga com isso ativar talentos de maneira estratégica (WEIS, 2017, entrevista exclusiva).
\end{abstract}

Mariana Moraes aproveitou a oportunidade para incluir pesquisas atualizadas em sua resposta, destacando números relevantes do Censo Gife, estudo realizado a cada dois anos com várias questões, inclusive de comunicação.

Sobre as áreas de comunicação dos institutos e fundações associados ao Gife, no Censo Gife, que é a nossa pesquisa produzida a cada dois anos, existem algumas poucas perguntas relacionadas à comunicação. Posso te adiantar alguns resultados. Foram 100 respondentes, o que equivale a mais de $90 \%$ dos associados. A pesquisa revelou que $50 \%$ dos respondentes têm equipe interna destinada à comunicação, 33\% possuem equipe de comunicação terceirizada contratada diretamente pelo associado. Parece que uma se sobrepõe a outra isso, e isso é meio curioso. $45 \%$ dividem estrutura de comunicação com a empresa mantenedora e isso é um grande conflito porque a estrutura de comunicação da mantenedora, dos empresariais, por exemplo, normalmente é incrível, mas a comunicação do instituto, da fundação, fica à mercê de um tempo livre da equipe que está envolvida com as ações deles, e é difícil fazer com que elas se envolvam. Tem uma observação no censo que diz que, neste último caso, ressalta-se o quanto o compartilhamento da estrutura de comunicação com a mantenedora pode prejudicar a comunicação da atuação social da organização dada a dificuldade de encontrar comunicadores que compreendam o setor e possam evidenciar práticas sem cair nas leituras mais restritas como as de cunho assistencialista, por exemplo. Não há ninguém que esteja superpreparado para dialogar sobre os conflitos do setor. Fica aquela coisa do profissional do marketing querendo falar sobre os projetos sociais com aquele olhar de que estão fazendo assistencialismo mesmo. A pesquisa também revelou que $5 \%$ dos respondentes não possuem nenhuma estrutura de comunicação e 3\% afirmam que nem fazem nenhum tipo de comunicação (MORAES, 2017, entrevista exclusiva). 
Moraes também respondeu sobre a necessidade de customizar cada vez mais as mensagens contextualizando suas observações no comportamento que vem observando por parte do público que pode ter interesse em ações desenvolvidas pelo Gife e demais organizações do terceiro setor.

Eu acredito muito que comunicar para a sociedade em geral não funciona, não existe, não existe mais comunicação de massa, ela não é mais muito eficaz, de forma nenhuma, principalmente porque as pessoas estão se comunicando de forma muito mais fragmentada. Quando se decide comunicar para a sociedade em geral, não se está comunicando para ninguém. As pessoas hoje em dia podem ter acesso só ao que querem ver, esse é um dos grandes problemas das redes sociais. Então se achar que vai comunicar para um público enorme com a mesma mensagem é difícil, não sei se funciona nesse caso das ONGs (MORAES, 2017, entrevista exclusiva).

Pela nuvem de palavras da Figura 20, novamente a comunicação foi bastante destacada. Além dela, os termos recursos, equipe, estrutura e profissional também foram citados com frequência.

Figura 20: Nuvem de palavras de recursos necessários e ações de planejamento

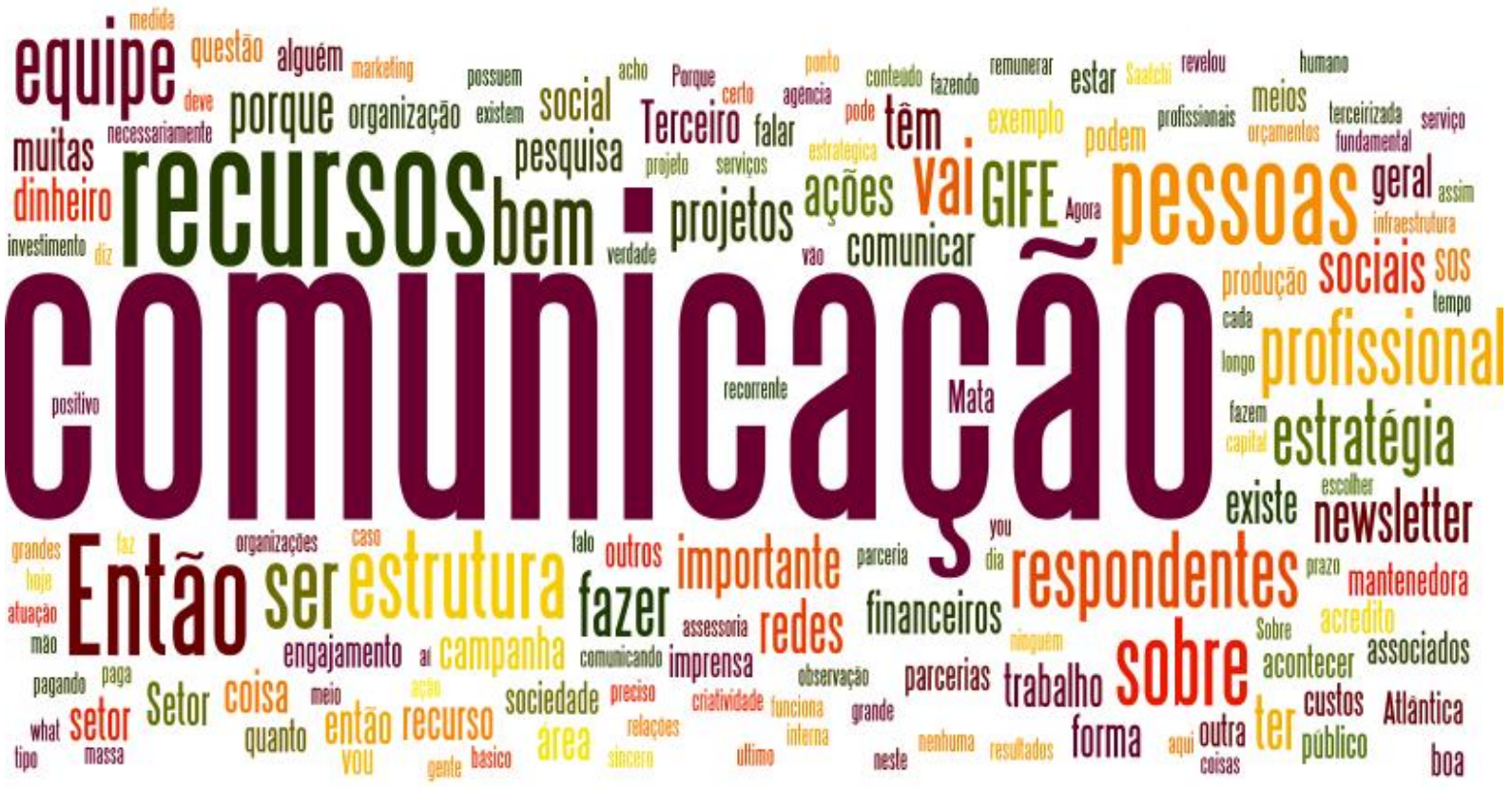

Fonte: Ulsen (2018) 
5. Você pode descrever como é possível avaliar a comunicação no terceiro setor em ações de sustentabilidade e quais são os principais desafios para isso?

A última questão apresentada aos entrevistados selecionados para esta pesquisa foi criada com a proposta de entender de que forma a comunicação é avaliada nas organizações e com quais desafios eles têm se deparado no cotidiano das suas atividades profissionais.

Começando com Renato Guimarães, ele defendeu essa temática e informou que a mensuração dos resultados só é coerente quando incorpora indicadores de desempenho. Sobre os desafios, Guimarães citou a necessidade de mais integração com a educação e com a curadoria de conteúdo.

A mensuração deve ser feita sempre em comparação com alguma
coisa. O setor privado tem este conceito muito forte do plano, objetivo,
ação e indicadores de performance. Qualquer processo de
mensuração só faz sentido se antes foi realizado um indicador de
desempenho. Esse indicador é o princípio da coisa. Assim, eu consigo
implementar a mensuração, e é muito difícil. Esse processo tem que
estar muito claro e alinhado com os objetivos da organização. Hoje já
existem muitas opções disponíveis e isso é um processo de
descoberta. Com relação aos desafios, a educação tem que estar
muito relacionada à comunicação, por exemplo, pensando sobre como
entregar as mensagens chegar nas novas gerações, pois é muito difícil
mudar quem está no poder. É um desafio muito grande nos
comunicarmos, utilizando não somente a educação formal, mas, com
as novas gerações, outros formatos são importantes. No caso da
comunicação integrada à sustentabilidade, essa fragmentação traz o
desafio que há cada vez menos especialistas e potenciais curadores
confiáveis. É importante refletir sobre como estão sendo formados os
curadores, oferecendo informações confiáveis e qualificadas, com
conteúdos relevantes. Os curadores que têm credibilidade junto às
suas comunidades e outros públicos, mas que falem com propriedade
e levem mensagens aos públicos. Assim, como geradoras
publicações, as organizações se tornam parte do processo de
transferência de conteúdo para as pessoas (GUIMARÃES, 2017,
entrevista exclusiva).

Bruno Weis, embora atue no Instituto Socioambiental, respondeu com uma visão mais ampla, incluindo outras organizações, e comentou também sobre outras organizações do terceiro setor que têm atuado com objetivos semelhantes. Para Weis, 
o principal desafio é a incorporação, no cotidiano, das pessoas, de um novo olhar sobre o impacto das escolhas que cada um faz.

O nosso grande desafio, no ISA, no Akatu, no Greenpeace, é fazer com que as pessoas incorporem no seu dia a dia o valor delas em relação ao que elas consomem e aos hábitos delas dia. Se as pessoas incorporarem que o impacto de cada escolha feita, seja de consumo, seja de hábito de vida, tem um elo muitas vezes invisível com questões muito maiores. Por exemplo, com a questão da Amazônia, a questão climática, a questão hídrica. Facilitar esse entendimento, aproximar o microcosmo do dia a dia do indivíduo com as grandes questões planetárias é a nossa missão diária numa organização como o ISA e outras parecidas. Traduzir e simplificar os caminhos para as pessoas entenderem que nada está descolado, tudo está relacionado e que, por maior que as causas aparentam ser, o que eu posso fazer pelo degelo do Ártico, isso é bastante desmobilizador. Então eu acho que não pode ter um discurso vazio de que você vai salvar o Ártico, você José da Silva que mora em Pindamonhangaba. Não é isso. Mas ele tem uma série de decisões diárias que ele pode fazer que, somadas às decisões diárias de seus colegas contemporâneos, vai gerando um caldo de cultura para quem sabe um dia os desafios não sejam mais tão insuperáveis. Acho que esse é um desafio da comunicação como um todo para quem trabalha nessa pauta. Tem uma questão que sempre aparece em nosso dia a dia de alguns indicadores de resultados que são aferidos e os que não são aferidos (WEIS, 2017, entrevista exclusiva).

Rejane Romano também mostrou preocupação em extrapolar esse discurso, fazendo com que a comunicação para a sustentabilidade esteja ainda mais integrada à estratégia organizacional.

O desafio é que esta comunicação não se torne apenas de nicho, mas sim que se entenda a relevância das ações. Desde as mais simples, como posts que pontuem datas, até a divulgação de eventos. Questões que podem ser consolidadas com um plano de comunicação que alinhe redes sociais e site institucional, além de influenciadores e articulistas que possam embasar o plano de ação (ROMANO, 2017, entrevista exclusiva).

Maurício Bianco também adotou uma linha pragmática em sua resposta e disse que a avaliação da comunicação no terceiro setor não difere daquela exercitada em empresas e no governo, defendendo a necessidade de compreensão sobre os retornos de investimentos. 
Primeiro que acho que a comunicação e o terceiro setor, quando se fala em como avaliar, não difere em nada de qualquer outro tipo de avaliação que se faz em uma empresa, ou que se faz no governo. Ou seja, se você está fazendo um trabalho de assessoria de imprensa, vai medir com análise de mídia. Se você está fazendo publicidade, vai fazer retorno sobre investimento mesmo, o que está vindo para você em função do que você investiu. Não pode abrir mão pelo fato de ser uma organização do terceiro setor. Não pode abrir mão de usar as ferramentas de avaliação que estão disponíveis hoje no governo e na empresa privada. Esse é o primeiro ponto. E em termos de desafios, eu acho que são muitos, porque buscar grandes resultados com, normalmente, poucos recursos, é sempre um grande desafio. Pode ser muito bom, porque te exige buscar caminhos alternativos. Então, o advento da comunicação online é muito propício para quem está trabalhando no terceiro setor. Então você faz Facebook Ads, Google Ads, qualquer coisa do tipo, você está pagando o que tem de retorno. Se a pessoa acessa, você paga, se a pessoa não acessa você não paga. Isso é muito mais, entre aspas, justo, do que uma mídia tradicional, como jornal ou televisão. Isso é um potencial muito grande de como usar as novas mídias para fortalecer a comunicação do terceiro setor. Parece-me mais interessante. E também procurar novas mídias para usar no terceiro setor, e isso é um desafio muito maior (BIANCO, 2017, entrevista exclusiva).

Afra Balazina também se mostrou interessada em demonstrar que a SOS Mata Atlântica tem formas de mensuração desse trabalho e citou, a seguir, exemplos de como isso é feito na prática.

Na SOS Mata Atlântica, nós temos formas de mensurar. Utilizamos o clipping da assessoria de imprensa, controle da quantidade de e-mails que foram abertos nas campanhas que fazemos, quantidade de pessoas em nossa base de dados, avaliamos a qualidade das informações, o alcance, a quantidade de fãs, o nível de engajamento das pessoas. Temos relatórios mensais com esses dados e, anualmente, centimetragem da nossa presença na imprensa, com média de equivalência comercial de até $R \$ 60$ milhões por ano. Mesmo com o crescimento das redes sociais, o investimento em assessoria de imprensa continua importante (BALAZINA, 2017, entrevista exclusiva).

Mariana Moraes exemplificou como o Gife tem atuado no sentido de estabelecer e atingir metas em termos de comunicação, e com base em quais indicadores a análise é elaborada. A gerente de comunicação do Gife também deixou claro que, embora a mensuração seja importante, há dificuldades ainda por parte das organizações da sociedade civil de identificar formas para colocá-la em prática. 
Em relação à avaliação e aos recursos, aqui no Gife o que fazemos é que temos algumas metas para apresentar ao Conselho, mas elas não são perfeitas. Elas são relacionadas a compartilhamentos no Facebook, número de seguidores, número de pessoas que se cadastram para receber a newsletter do Gife, número de matérias que são publicadas, então consideramos importante acompanhar a assessoria de imprensa, a mídia é muito importante. Então, é relacionado às redes sociais, ao número de visualizações do site e à imprensa. São esses três macro indicadores com pequenos indicadores dentro de cada um desses.

Então as organizações da sociedade civil não têm muita clareza ainda de como medir, assim como as empresas também não têm, porque o tempo é outro e a comunicação é muito dinâmica, muito rápida, e as ações vão tendo impacto ao longo do tempo. Mas não pode desistir de avaliar, acredito que isso é o mais importante, sempre se preocupar em avaliar independente se está certo ou está errado, você vai acertando no caminho. A avaliação, mais do que servir para saber se deu certo ou não deu certo, ela serve para ter um retorno sobre a iniciativa do que se está fazendo. Ela é mais para alinhar a carruagem e continuar seguindo do que para ver o sucesso que fez. Os retornos de congressos para nós são muito fundamentais, nós avaliamos todos os encontros com feitas com os associados. Todos os congressos e os retornos são sempre fundamentais para podermos redirecionar caminhos. O importante da avaliação não é saber se houve sucesso ou não, mas sim aproveitar a avaliação para repensar os projetos e a organização (MORAES, 2017, entrevista exclusiva).

Retomando a resposta de Bruno Weis, ele comentou sobre certa campanha que eles desenvolveram e qual foi o alcance do público impactado por ela. Trata-se de um indicador importante, que revela um número, mas que vem acompanhado, também, de uma margem intangível considerando que não significa que essa ação tenha mudado, necessariamente, o receptor da mensagem.

Então vou pegar o exemplo de uma campanha nossa que deu muita repercussão e era um filme chamado 'Menos preconceito e mais índio'. Não sei se você chegou a ver, era um filme de noventa segundos e conseguimos veiculação em TV aberta, TV fechada, cinema, todos os meios digitais. Chegamos a uma conta de vinte e dois milhões de brasileiros que viram esse filme Somando todas as plataformas e mídias. Em um cálculo conservador nosso, vinte e dois milhões de brasileiros viram o filme. Isso já é indicador de resultado. Conseguir passar no horário nobre da Rede Globo também é um indicador de resultado. Agora, esse filme tinha uma proposta que era discutir um preconceito entranhado em muita gente no Brasil sobre os índios que usam aparatos tecnológicos, usam bens e hábitos da sociedade branca. $O$ fato de o indivíduo ver esse filme não significa que ele mudou a cabeça dele necessariamente. Então eu tenho sempre uma margem que eu não consigo aferir de resultado, que é a mudança do pensamento das pessoas. Eu cheguei em vinte e dois milhões de 
pessoas, consegui entrar na Rede Globo, tudo isso é indicador. A minha página no Facebook aumentou em 30\% em um mês, eu consegui tantos doadores para o ISA. Tudo isso é objetivo concreto aferido. Mas tem uma fatia de mudança de pensamento. Vamos pegar esse exemplo. A pessoa viu a campanha e concluiu que não precisa ter esse preconceito. Só que, digamos que ele mudou a cabeça dele, mas não se tornou filiado ao ISA, não começou a assinar a minha newsletter. Então eu não tenho um indicador concreto de que essa pessoa entrou para minha base de apoiador. Mas ele mudou a cabeça dele, ele vai parar de falar para os amigos dele que índio que usa celular não é mais índio. Então o meu macro objetivo foi atingido. Ele mudou, ele não tem mais o preconceito. Mas como é que eu vou aferir isso? Eu tenho que conhecer essa pessoa. São vinte e dois milhões de brasileiros. Então, tem sempre uma margem de resultado que é intangível e isso não impede que eu tenha uma série de outros indicadores possíveis de mensurar, mas quando estamos falando de incidência política, de mudança de pensamento, existe uma margem. Temos que fazer o máximo para que o conteúdo seja efetivo, ele tem que ser veiculado no máximo de lugares possíveis e desejar que as pessoas façam sua reflexão. Agora, o que essa reflexão vai ensejar na pessoa, muitas vezes eu perco aí o fio da meada. Até onde essa mudança gerar um convertido à causa ou apenas uma pessoa que vai parar de propagar preconceito. É uma questão para a gente isso. Talvez na próxima eleição ele vote em um candidato que esteja um pouco menos alinhado com uma pauta preconceituosa. Não dá para aferir tudo. Tem muita coisa subjetiva também (WEIS, 2017, entrevista exclusiva).

Novamente abordando Maurício Bianco, ele também optou por oferecer um exemplo de como um elemento visual da comunicação, que jamais havia sido pensado como mídia, se tornou espaço para publicidade e arrecadação de fundos.

Vou te dar um exemplo. Se eu não me engano foi a organização Save the Children, que é uma organização internacional, que buscou uma forma nova de mídia. Por exemplo, você deve ter na sua área de trabalho do seu computador um monte de ícones com seus arquivos. É um exemplo bem específico para chegar ao ponto que quero destacar. Essa organização, Save the Children, buscou em usuários de computador, que têm esses ícones, vender o ícone para que empresas privadas consigam colocar as suas marcas e as suas mensagens no ícone do seu computador. O que é isso? Sabe aquele ícone do Word, do Excel que você tem ali por acaso, vai estar escrito Off, que é a marca do repelente de mosquito. Basta baixar um programa que faz com que, automaticamente, todos os ícones da sua área de trabalho tenham alguma uma marca. Ou seja, o recurso dessa mídia, a venda dessa mídia, é revertida na causa da Save the Children. Então eu estou dando um exemplo de uma coisa que não é mídia. É o ícone de computador, então foi inventado isso como mídia, transformou isso em mídia. Tem também uma experiência que a Médicos sem Fronteiras fez na Espanha, que é vender remédio para a dor alheia. Eles estavam vendendo chiclete e, ao você comprar esse 
chiclete dos Médicos sem Fronteiras, o recurso era revertido para comprar equipamento para quem estava precisando em algum lugar do mundo. Então você está comprando remédio para a dor do outro. Então você adquire um produto que compraria de qualquer forma para mascar, mas que está ajudando o outro. Então você achou um elemento que não existia e passou a ser um veículo de comunicação para ajudar a causa que você está defendendo. Então, quando eu falo de achar outras mídias, é um desafio enorme você poder chegar nesse tipo de estratégia. O online já não dá para não mais para desconsiderar. Mas, achar mídia nova para o seu produto, entenda-se a causa da sua própria organização, para que você seja conhecido, seja apoiado, é uma coisa fantástica. Então eu só dei esses exemplos para fortalecer esse ponto de que é um desafio enorme e não tem fronteira, não tem limite. O limite mesmo é a criatividade. Enfim, é o que eu venho recolhendo de experiências dos últimos anos em que eu tenho atuado terceiro setor (BIANCO, 2017, entrevista exclusiva).

A nuvem de palavras da Figura 21 indica os principais conteúdos apresentados pelos entrevistados sobre esta pergunta. Ela revela uma ampla diversidade de termos apresentados, com menor expressão de apenas uma palavra, o que demonstra a diversidade de abordagens em relação ao tema. Entre os muitos termos apresentados, os mais destacados foram comunicação, pessoas, organização, sempre, mídia, exemplo, terceiro setor e exemplo.

Figura 21: Nuvem de palavras sobre avaliação da comunicação no terceiro setor

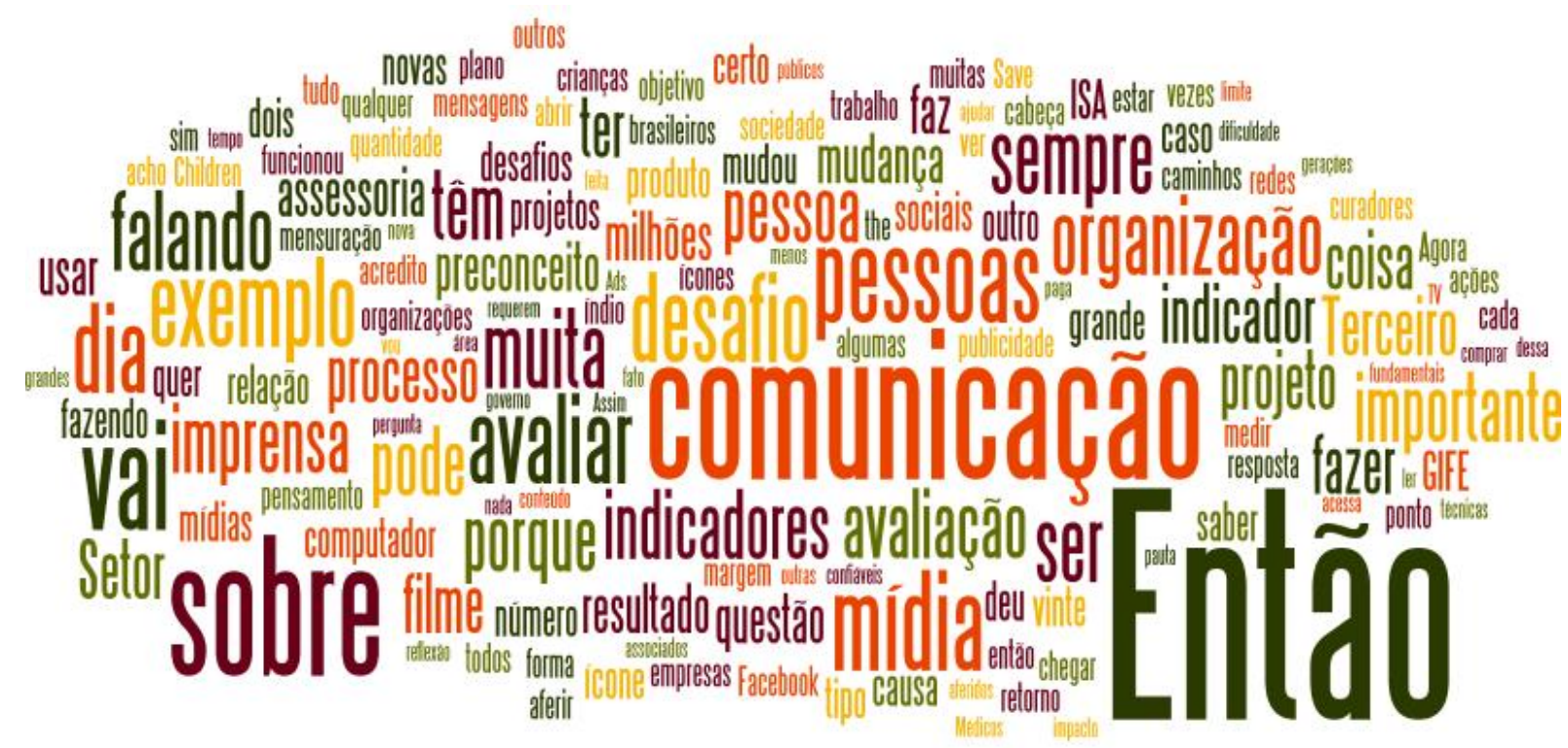

Fonte: Ulsen (2018) 


\subsection{Conclusões}

Todas as respostas foram de grande valia para compreender de que forma a comunicação organizacional tem sido desenvolvida pelos gestores da área em experiências do terceiro setor. A experiência comprovada de cada um dos entrevistados foi fundamental para compreender o objeto de pesquisa e desenhar um modelo mais efetivo de comunicação focada no desenvolvimento sustentável.

Com relação à primeira questão que indicava de que forma a comunicação tem contribuído para criar mensagens que engajem os públicos para a prática da sustentabilidade nas organizações, conclui-se que, segundo os entrevistados, o cenário é complexo e deve ser visto a partir dessa ótica de evolução da própria comunicação no sentido de criação constante e cada vez mais frequente de múltiplas mídias. Elementos complementares também foram destacados, como diversidade dos públicos envolvidos nas mensagens direcionadas, segmentação e aumento das possibilidades de interatividade entre indivíduos e organizações.

Essas questões levam ao entendimento de que, embora estratégica e determinante para a criação de mensagens que realmente engajem os públicos, a comunicação também vivencia uma dificuldade cotidiana nas organizações de apurar a qualidade na recepção desse conteúdo pelas pessoas.

Nesse cenário evidenciou-se que o mapeamento de todas as variáveis ou as possíveis variáveis envolvidas nesse processo, conforme apresentado nesta pesquisa, certamente determina maior assertividade na comunicação. Ainda sobre esta questão cabe deixar claro que, necessariamente, a comunicação deve estar associada ao processo de desenvolvimento da cidadania e de conscientização dos públicos envolvidos.

Com relação à segunda questão, elaborada para que os entrevistados delimitassem potenciais e limites para a comunicação com o objetivo de ampliar a consciência das pessoas a respeito dos atuais problemas socioambientais, evidenciou-se que, embora estratégica, a comunicação não resolve todos os problemas, sendo necessário que atue de forma integrada com outras áreas.

Uma possibilidade aventada neste caso é que a inovação implementada com a operacionalização de novos formatos e a criação de modelos diferentes de transmissão e recepção de mensagens deve tornar as ações organizacionais mais públicas a partir da compreensão de conteúdos formatados e segmentados para os 
diferentes públicos. Outra possibilidade é o alinhamento da comunicação com temas de apelo nacional para que os potenciais sejam ampliados.

Por outro lado, assuntos presentes na grande mídia ou muito próximos da realidade local das pessoas envolvidas também têm maior chance de serem melhor recebidos. Existe ainda nesse cenário um potencial que está diretamente relacionado à quantidade e à qualidade de recursos humanos e financeiros disponíveis para investimentos nas ações. Essa questão também esclareceu que o comunicador que atua no terceiro setor com foco em sustentabilidade vive dilemas profissionais, pois precisa buscar objetividade, planejamento e foco, porém, em muitas situações, se depara com estruturas e recursos escassos ou insuficientes para a operacionalização do trabalho.

Além disso, outra dificuldade é o excesso de canais atualmente presentes e o desafio de focar em ações de comunicação focadas em nichos tendo como possível solução suporte dos discursos praticados pelas organizações em opiniões qualificadas para gerar maior respaldo e credibilidade. Finalmente, o potencial é maior quando há credibilidade da organização e na mensagem direcionada, o que também está relacionado com o desenvolvimento de campanhas assertivas e seletivas, com discurso claro sobre temas de fato relevantes para a sociedade.

Em termos de possíveis benefícios da integração entre comunicação e a sustentabilidade, tema da terceira questão, ficou claro que a efetividade é necessariamente considerada quando há entrada dessas áreas no centro do negócio e associada à implementação de um plano prático de ação. São áreas necessariamente integradas, sobretudo no terceiro setor, e possíveis de serem articuladas com outras áreas importantes. O grande desafio nesse sentido é superar a superficialidade na discussão dos temas, sendo para isso o elemento técnico imprescindível e a formação na área de comunicação determinante como uma garantia complementar para que haja sucesso nas ações desenvolvidas.

Ficou claro também a necessidade de aprimoramento na curadoria de conteúdo que priorize a visibilidade nos impactos gerados pela comunicação. Destaca-se ainda que a comunicação deve estar, neste caso, a serviço da transparência para tornar as ações mais públicas e apresentar os resultados positivos. Importante ainda esclarecer que a integração entre as áreas não gera necessariamente apenas benefícios, mas também pode ser usada para legitimar práticas destrutivas, o que costuma ser 
frequentemente feito no caso de empresas pouco preocupadas com o meio ambiente e mais interessadas em agregar o valor da sustentabilidade com ações de fato pouco práticas.

Na sequência também foi questionado aos entrevistados quais são os recursos necessários e como devem ser planejadas as ações de comunicação do terceiro setor, questão criada com o objetivo de compreender de que ponto de partida tem esses profissionais para desempenhar o seu trabalho. As condições financeiras foram apresentadas como necessariamente ligadas ao engajamento da equipe e como elemento essencial, embora não tire o mérito e a relevância de contribuições voluntárias.

Ainda assim, uma equipe altamente profissional só consegue ser estruturada a partir de recursos previamente planejados e, neste caso, também se apresentou uma experiência interessante, em que os recursos para a comunicação de determinada organização são direcionados para esta área, porém, também, oriundos de outras áreas interessadas em divulgar as suas ações ou criar melhores condições de envolvimento dos seus trabalhos estratégicos. Os recursos evidenciados também destacaram a necessidade de investimento em tecnologia e no elemento humano, além do profissional. O elemento humano está mais ligado à qualidade dos valores individuais e menos associado às atribuições profissionais dos membros da equipe.

Partindo para a última questão, a respeito dos possíveis métodos de avaliação da comunicação no terceiro setor em ações de sustentabilidade, há dificuldades ainda nesse processo. Permanece o desafio cotidiano de incorporar um novo olhar sobre os embates das ações desenvolvidas, o que está alinhado com a necessidade crescente de compreensão a respeito dos retornos de investimentos na área. Também ficou claro que há diferentes formas complementares de mensuração, sendo necessária a incorporação de indicadores de desempenho específicos da área passiveis de compreensão por profissionais que atuam em outras linhas de frente. Houve também a defesa de que a avaliação desses resultados não deve se diferenciar daquela já praticada por empresas e governos e que o elemento da integração com outras áreas também deve estar contemplado no processo.

O alcance do público e a qualidade das metas atingidas são também fontes para possíveis indicadores. Ainda assim, também ficou claro que, em termos de aderência das mensagens e incorporação do seu conteúdo em processos de 
mudança de atitude e comportamento, entre outros, existe sempre a permanência latente de uma margem intangível qualitativa dificilmente mensurada, o que não elimina o mérito dos processos de avaliação e mensuração desenvolvidos, mas, ao contrário, reforça a necessidade de constante evolução e desenvolvimento científico da área.

Figura 22: Nuvem de palavras de todas respostas dos gestores de comunicação

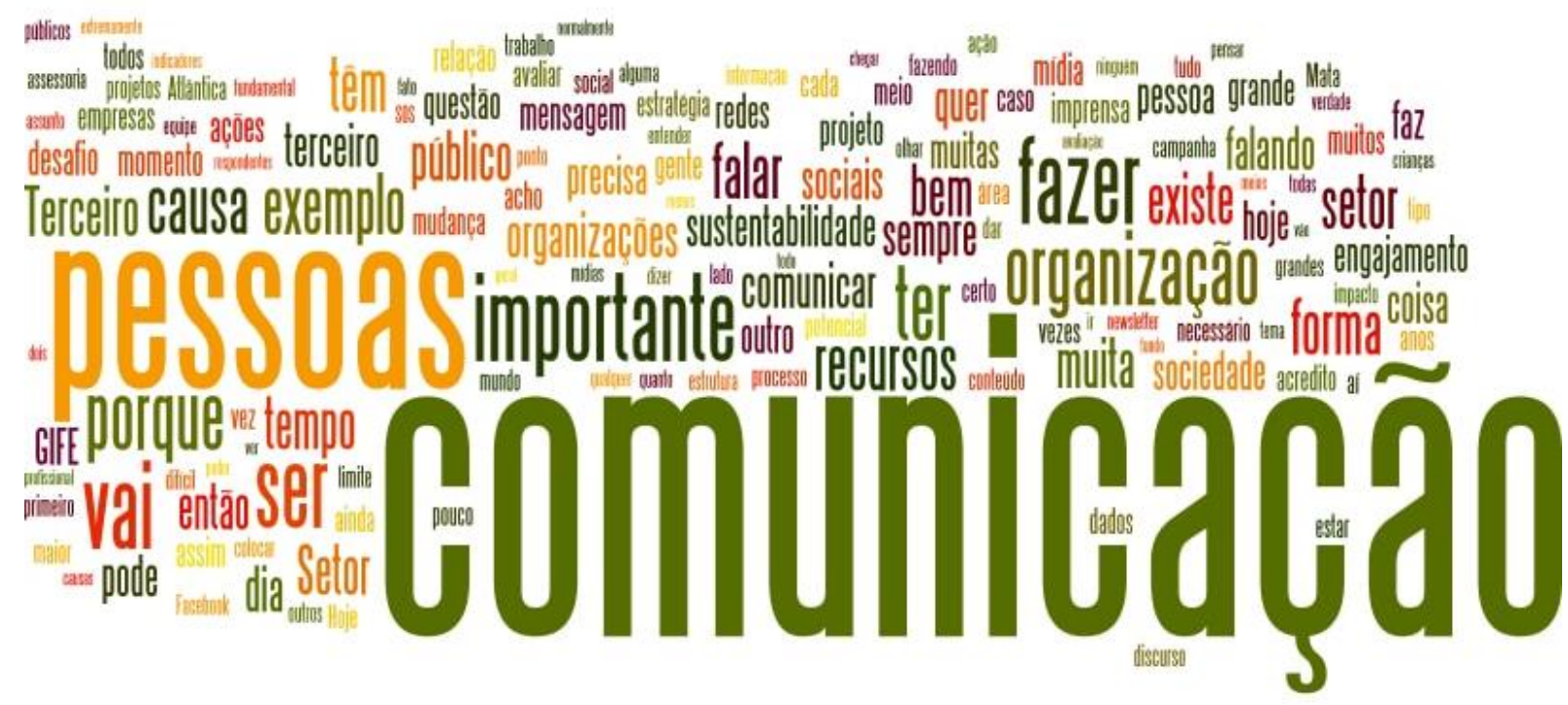

Fonte: Ulsen (2018)

Figura 23: Nuvem de palavras com respostas de Afra Balazina

campanhas

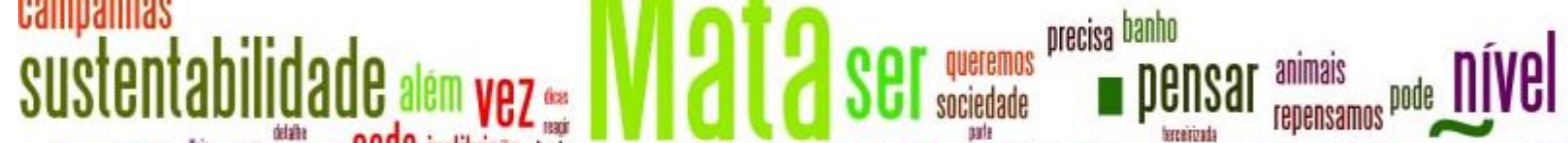

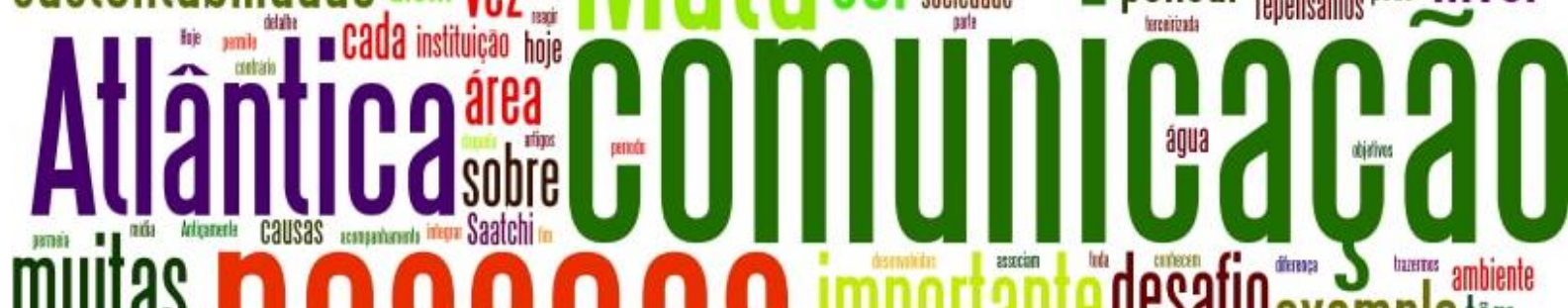

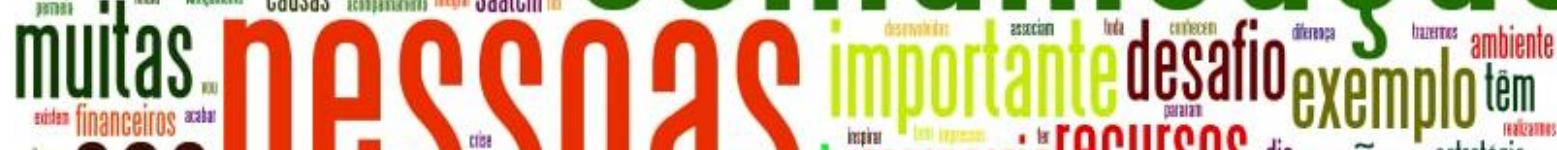

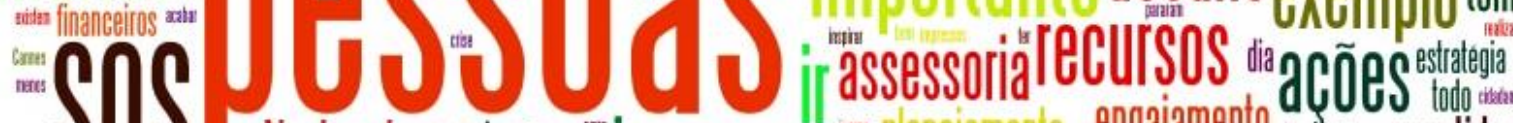

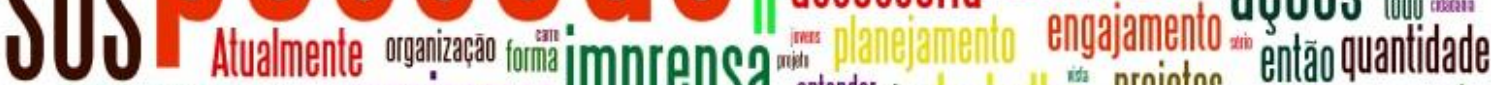

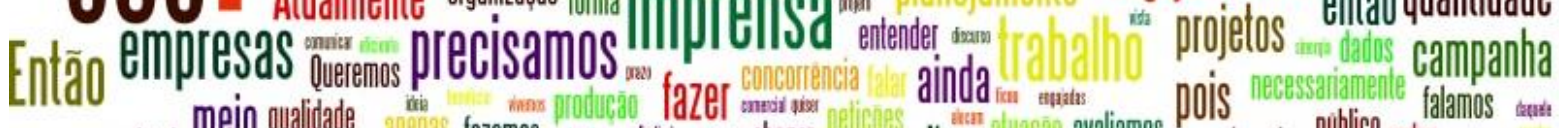

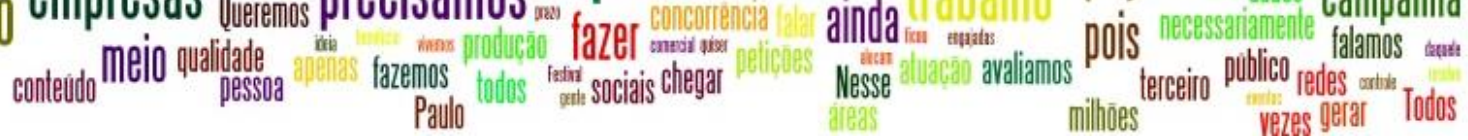

Fonte: Ulsen (2018) 
Figura 24: Nuvem de palavras com respostas de Bruno Weis

recurso othar

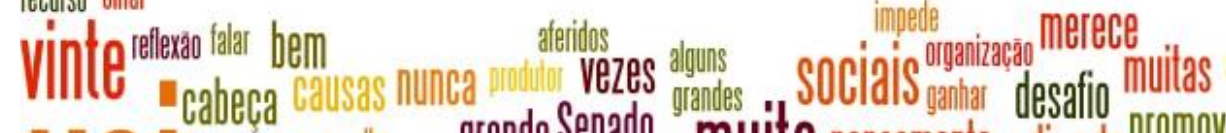

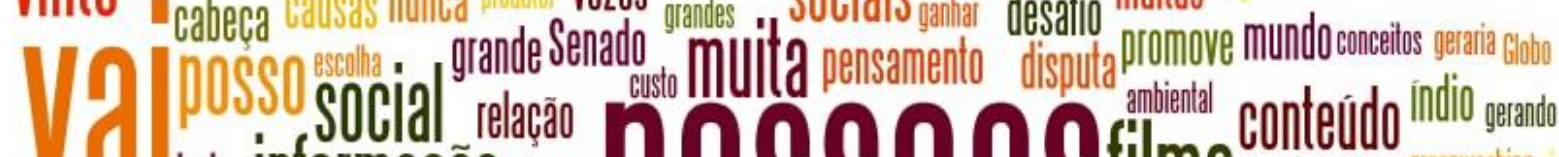

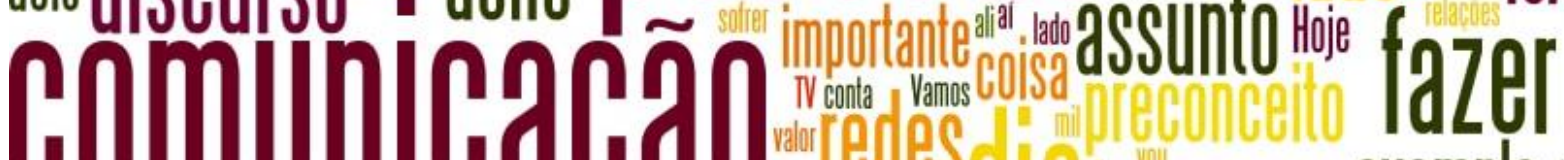
Gomuluab̧a metes Facebook canais margem bastante

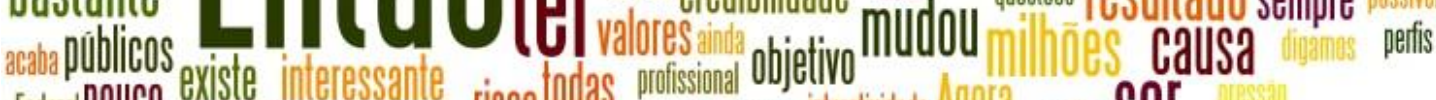

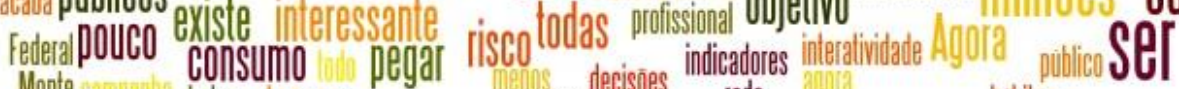

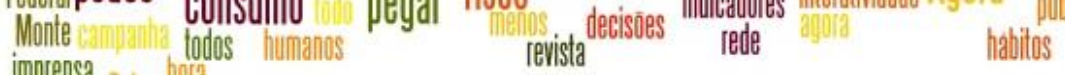
imprensa pelo horas

Fonte: Ulsen (2018)

Figura 25: Nuvem de palavras com respostas de Mariana Moraes

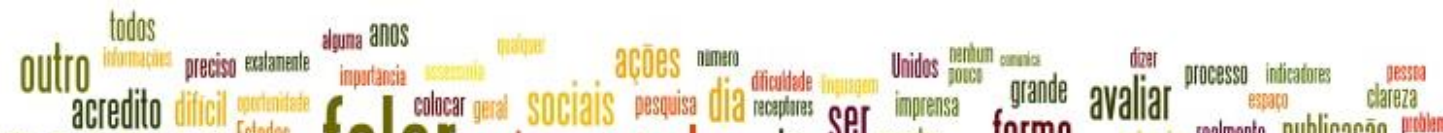

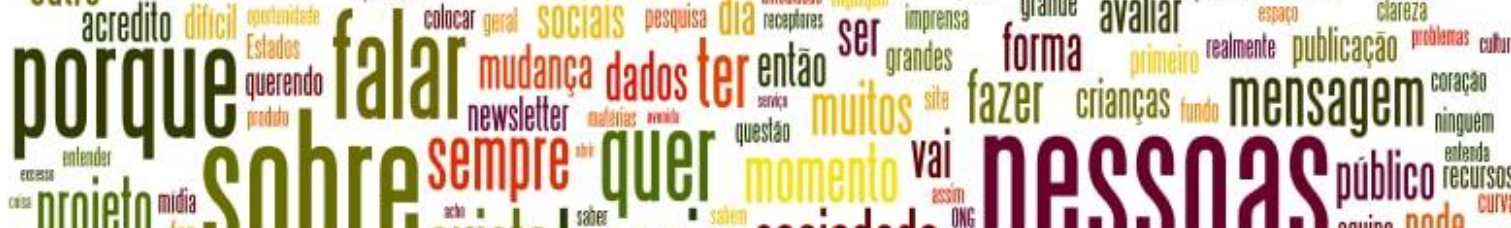
tempo-

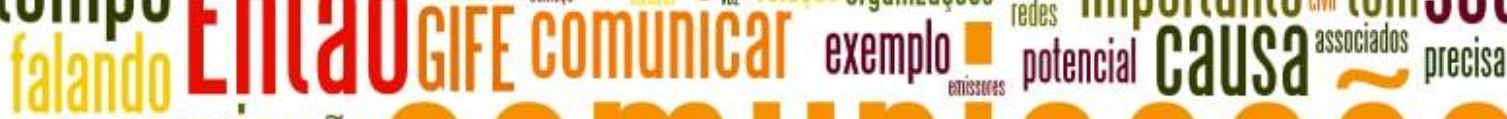
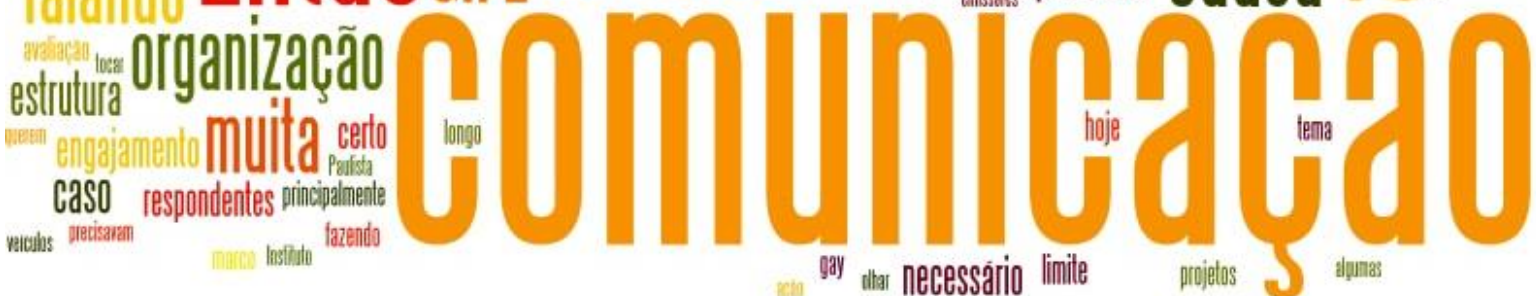

Fonte: Ulsen (2018) 
Figura 26: Nuvem de palavras com respostas de Maurício Bianco

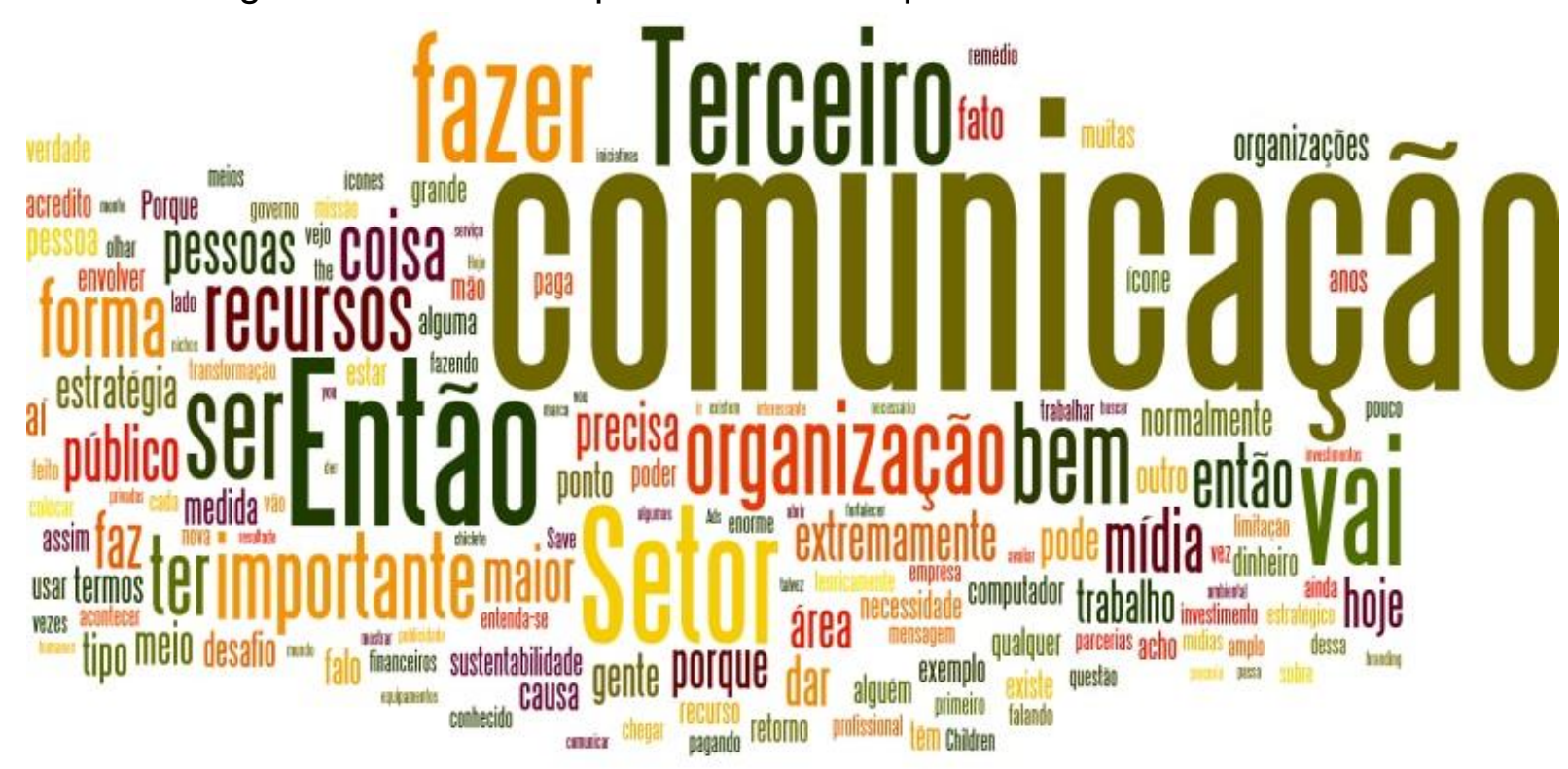

Fonte: Ulsen (2018)

Figura 27: Nuvem de palavras com respostas de Rejane Romano

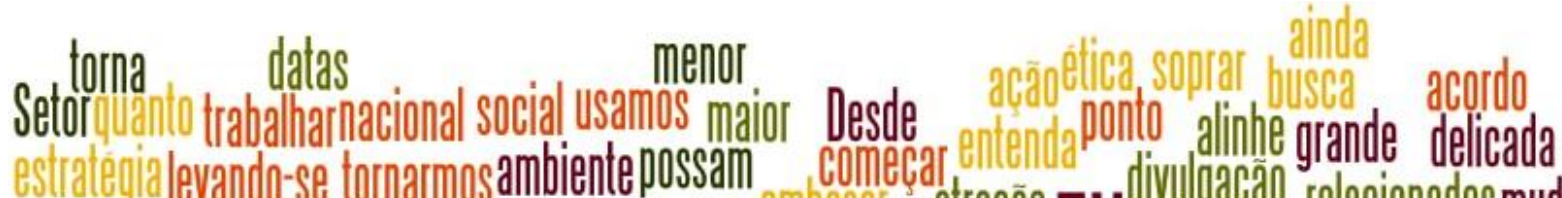
estrałégia levando-se tornarmosambientepossam começar atracãa divulgaçäo relacionadosmuda

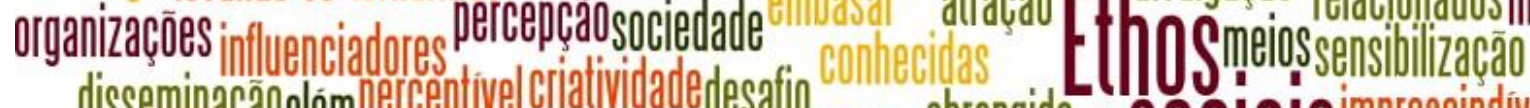
disseminaçäoalémpercêptivel criatividadedesafio sustentabilidade preponderantexempon transversalidade a dinn

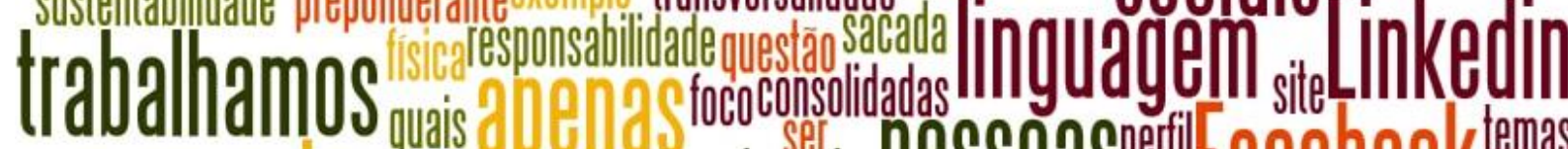
refere ? : têmm

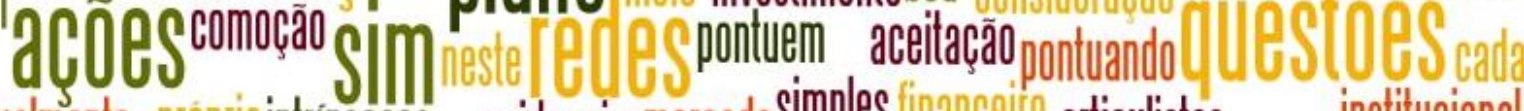
Atualmente prónciaintrinsecas evidenciarmercadosimples financeillo articulistas anicinstitucional Questöes todo relevância momentoventos forma existe instituto eventos fortes Ambas abarca

Fonte: Ulsen (2018) 
Figura 28: Nuvem de palavras com respostas de Renato Guimarães

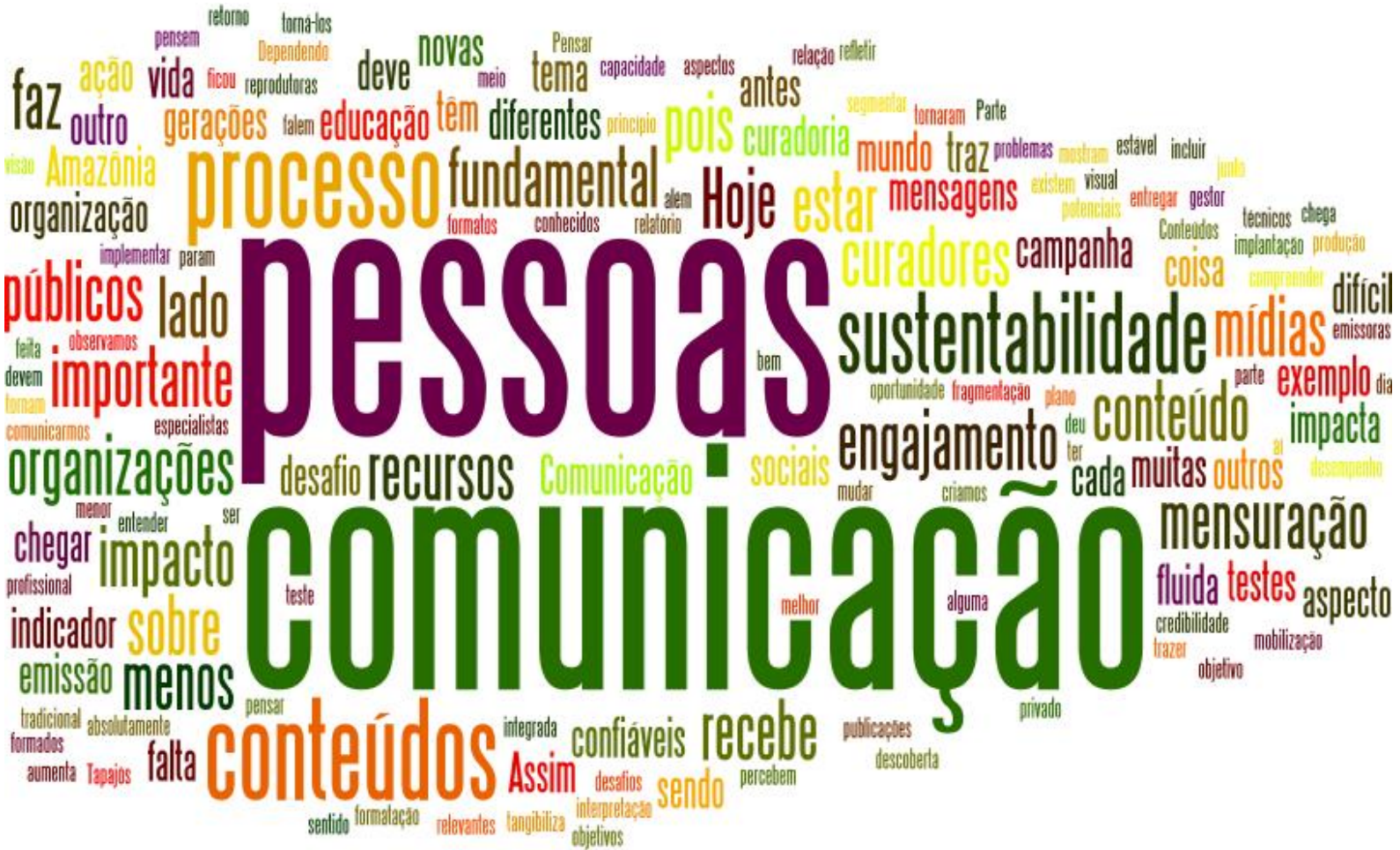

Fonte: Ulsen (2018) 


\section{Capítulo 7. A opinião dos especialistas em sustentabilidade}

Para aliar à pesquisa quantitativa um estudo qualitativo, também foram entrevistados seis profissionais que têm se destacado pelas suas atuações em prol da sustentabilidade na gestão da comunicação de diferentes organizações, especialmente do terceiro setor. É o caso de Denise Hamú, Enrique Leff, Fernando Almeida, Leonardo Boff, Oded Grajew e Pedro Jacobi. Com base no método qualitativo, foram realizadas entrevistas em profundidade com os especialistas selecionados. Para a realização da pesquisa qualitativa, foi criado um roteiro de entrevista, conforme Apêndice 10.

\subsection{Amostra}

A seleção dos entrevistados foi intencional e baseada em especialistas reconhecidos com conhecimento e vivência profissional sobre o assunto em questão.

Quadro 8: Formato das entrevistas com especialistas em sustentabilidade

\begin{tabular}{|c|c|c|}
\hline Entrevistado & Atuação & Formato \\
\hline Denise Hamú & $\begin{array}{r}\text { Organização das Nações Unidas } \\
\text { (ONU) }\end{array}$ & Telefone \\
\hline Enrique Leff & $\begin{array}{c}\text { Palestrante, escritor, pesquisador } \\
\text { e professor universitário }\end{array}$ & Presencial \\
\hline Fernando Almeida & $\begin{array}{c}\text { Engenheiro, escritor, consultor, } \\
\text { conferencista e pesquisador }\end{array}$ & Telefone \\
\hline Leonardo Boff & $\begin{array}{r}\text { Teólogo, escritor, ativista } \\
\text { ambiental e dos direitos humanos }\end{array}$ & E-mail \\
\hline Oded Grajew & $\begin{array}{c}\text { Instituto Ethos e Oxfam Brasil } \\
\text { Instituto de Estudos Avançados } \\
\text { da Universidade de São Paulo } \\
\text { (IEA-USP) }\end{array}$ & Telefone \\
\hline
\end{tabular}




\subsection{Análise e interpretação dos dados}

O conteúdo apresentado na sequência reúne a análise e a interpretação dos dados das entrevistas realizadas com os especialistas em sustentabilidade capazes de contribuir com a construção de um formato fundamentado e efetivo de comunicação para a sustentabilidade em organizações do terceiro setor.

1. Qual é o papel dos governos e dos grupos intergovernamentais para o cumprimento dos acordos firmados em conferências sobre o clima no âmbito internacional?

Esta questão, aberta, foi formulada para todos os entrevistados da amostra para compreender, do ponto de vista mais amplo, as atribuições e o poder de alcance das organizações governamentais e intergovernamentais. Sobre o tema, o sociólogo ambientalista Enrique Leff esclareceu a importância desses acordos e destacou que existem alguns mecanismos de avaliação que não permitem uma avaliação transparente do seu cumprimento.

Em princípio, se eles assinaram, devem cumprir. Mas eles têm diversas vias para cumprir ou não cumprir. Isso ocorre quando estão tentando cumprir, através de certos mecanismos e projetos econômicos, e como contabilizam essa questão para reportar os sucessos desses compromissos. Então, aí é um campo um pouco ambíguo também de como eles estão cumprindo com esses compromissos. Entra dentro de certas lógicas de avaliação dos cumprimentos dos compromissos dos acordos, das metas do milênio e de todos os grupos internacionais (LEFF, 2017, entrevista exclusiva).

Para Oded Grajew, os governos têm responsabilidade sobre o que assinam e precisam criar mecanismos de operacionalização que se integrem com outros públicos, como a sociedade civil, para atingir os objetivos. Grajew também esclareceu que essa responsabilidade é inerente aos governos que são sérios e se empenham em cumprir os compromissos firmados, o que nem sempre ocorre.

O papel dos governos é fazer cumprir. Quer dizer, este é o compromisso do governo que assume. Então eles são os responsáveis, têm a responsabilidade de cumprir os acordos porque são eles que assinam. Os acordos são assinados pelos governos, então eles têm que estabelecer um caminho para o acordo ser cumprido porque eles geralmente preveem prazos. Cabe aos governos estabelecer os prazos e identificar o que é necessário para 
fazer cumprir os acordos. Geralmente, demanda uma articulação do governo como um todo porque os acordos geralmente abrangem vários ministérios, e isso demanda muitas vezes a participação e a cooperação de outras instâncias do governo, que podem ser estaduais, municipais ou regionais, depende do país. Existe todo um trabalho de articulação com essas outras instâncias porque isso depende, quase sempre, da participação do governo em outras instâncias. Se o governo for realmente sério no cumprimento dos acordos, é preciso formar uma instância de acompanhamento em que haja também a participação da sociedade civil para garantir o cumprimento, a qualidade, e o cumprimento dos acordos. Isso quando o governo quer levar a sério esses compromissos, esses acordos, que têm força de lei. Além disso, o governo muitas vezes tem que adequar os acordos internacionais para a legislação local. Então, por exemplo, no caso do Acordo de Paris, o governo brasileiro, além de assumir o compromisso internacionalmente, tem que adequar nacionalmente para fazer uma legislação, ou às vezes um decreto, para a legislação local e nacional (GRAJEW, 2017, entrevista exclusiva).

Para Fernando Almeida, o tema já é complexo pela dificuldade de compreensão da sustentabilidade pela sociedade. Ainda assim, ele avalia que os acordos têm força de lei, porém, concordando com Grajew, comentou a ausência de confiança no governo, especialmente o brasileiro, para o cumprimento da legislação vigente. De forma complementar, Almeida também revelou que observa a perde de liderança do Brasil nesse tema e a participação cada vez menor em projetos de sustentabilidade.

A primeira questão é que este é um dos temas mais difíceis da atualidade, pois o primeiro problema é que a sustentabilidade é um termo extremamente hermético para a sociedade em geral. Eu sempre expliquei sustentabilidade da seguinte forma: é sobrevivência. Mas, sobrevivência de quem? Sobrevivência dos ativos ambientais para uma sociedade mais justa e sobrevivência das empresas, naturalmente. Sustentabilidade é sinônimo de sobrevivência.

Existem vários acordos, o do clima é o mais badalado. Os acordos feitos no âmbito da ONU têm força de lei. Uma vez assinados, têm força de lei dentro dos países que estão ratificando. Se ratificou, tem força de lei. No Brasil, sabemos que há algumas leis que são aceitas, outras que não são aceitas e fica por isso mesmo. Mas ele tem força de lei. Essa é uma primeira questão. O que eu tenho visto é uma participação do governo cada vez menor. Eu vejo os governos, nos últimos dez anos, cada vez mais afastados desses temas, sendo que - Brasil já teve maior liderança nisso na América do Sul e mesmo a nível mundial em alguns aspectos. Hoje isso não acontece (ALMEIDA, 2017, entrevista exclusiva).

Pedro Jacobi defendeu o avanço de acordos internacionais, mas também destacou a necessidade de decisões implementadas em nível nacional para a criação 
de resultados importantes de transformação da sociedade. O pesquisador da USP também entende que existe uma escala para o cumprimento dos acordos.

\begin{abstract}
É importante que ocorram esses avanços, o cumprimento de metas, mas os acordos internacionais podem fazer isso independentemente de decisões em nível nacional. Então, na medida em que prefeituras avançam em programas, na medida em que governos locais avançam na implementação de iniciativas, nós podemos concretamente ter resultados importantes, não necessariamente vinculados diretamente aos acordos internacionais. Então, grupos intergovernamentais é uma expressão um pouco genérica, mas se você estiver falando de agências intergovernamentais, fica mais completo e vejo relação com a mudança climática. A questão do cumprimento dos acordos é que eles são voluntários, então a questão é sempre a limitação em relação ao que significa um acordo voluntário e a escala desse acordo, a capacidade de realmente responder a esses acordos entre governos (JACOBI, 2016, entrevista exclusiva).
\end{abstract}

Voltando a Grajew, esta resposta também foi complementada por ele no sentido de destacar a relevância de uma sociedade civil forte e atuante. Esse argumento, apresentado a seguir, foi frequentemente reiterado pelo entrevistado em resposta às demais perguntas e também consta na entrevista concedida à edição 26 da Revista Brasileira de Comunicação Organizacional e Relações Públicas (Organicom), publicada no primeiro semestre de 2017.

O fato de existirem alguns acordos que são voluntários, de assinatura voluntária, não necessariamente pode ter alguma influência negativa para esse cumprimento. Se o governo assina um compromisso, ele já deixa de ser voluntário. O que pode ser voluntário é a extensão do compromisso ou, às vezes, o prazo do compromisso. Mas aí que tem que entrar o papel da sociedade, ou seja, fazer pressão para que o acordo deixe ser voluntário e seja um compromisso mandatório. Além disso, pré-estabelecer o prazo e a qualidade do acordo. É aí entra que entra o papel da sociedade civil para pressionar para que o acordo não seja apenas voluntário, mas que seja realmente cumprido (GRAJEW, 2017, entrevista exclusiva).

Com esta ideia concorda o engenheiro Fernando Almeida, que também defendeu a necessidade de uma sociedade civil mais organizada e a integração dessas demandas com o trabalho, já desempenhado pelas organizações não governamentais.

Os grupos intergovernamentais e as entidades governamentais até tentam fazer um certo tipo de pressão, mas muitas vezes a maior 
pressão que se pode conseguir é a da sociedade como um todo, não apenas da sociedade civil organizada e das ONGs. Eu não quero politizar a discussão, porque a sustentabilidade não é uma questão de natureza intrinsecamente política. Como ela atinge todo mundo, deveríamos caminhar juntos nesse sentido, mas não é a realidade (ALMEIDA, 2017, entrevista exclusiva).

Almeida também destacou, nesta resposta, a importância da implementação de políticas públicas como forma de transformação da sociedade e alinhada com o conceito de ruptura planejada.

Sobre políticas públicas, podemos exemplificar com diferenças estaduais. O governo de Minas Gerais, de uma forma ou de outra, deu incentivo à adoção de energia solar e neste Estado existe hoje o parque solar mais desenvolvido do País e a forma mais fácil e mais barata de gerar energia, sem burocracia, com possibilidade ainda de vendê-la para empresas de energia elétrica. No Estado do Rio de Janeiro foi o contrário. Impostos foram mantidos em nível tão elevado que praticamente nãos se encontra geração domiciliar de energia a partir de células fotovoltaicas. Então existe a política pública, que facilita a aplicação das mesmas ideias de algumas decisões acertadas de criação de unidades ambientais e, por outro lado, decisões completamente incoerentes na área ambiental inviabilizando atividades que sempre existiram. Ainda sobre políticas públicas, há muitas lacunas. Os governos não estão avançando na questão e, se existe um senso de urgência no rumo da sustentabilidade, esta transformação não virá via melhoria contínua, e sim via ruptura planejada. Esta estratégia está baseada no conceito de destruição criativa de Joseph Schumpeter, descrito no capítulo 5 do meu livro "Os desafios da sustentabilidade" (ALMEIDA, 2017, entrevista exclusiva).

Para o teólogo Leonardo Boff, os acordos são frágeis enquanto não forem obrigatoriamente assumidos. Em sua resposta a esta pesquisa, Boff também lembrou sobre o poder das grandes corporações globais e a influência que exercem sobre os governos.

Enquanto os acordos não forem vinculantes e realmente assumidos obrigatoriamente pelos Estados, há pouco campo de ação efetiva dos movimentos de obrigarem a aceitação dos acordos de Paris. As grandes corporações mandam na globalização e são mais fortes que a maioria dos estados e dos governos. Elas vêm os acordos como algo antissistêmico, quer dizer, algo que vem prejudicar seus negócios e os níveis de sua acumulação. Esta é cada vez mais concentrada. Estes são inimigos da ecologia. Não creem no aquecimento global ou se creem relegam para os anos vindouros a tomada de decisões efetivas. Mas vale sempre pressionar e apelar pelo valor ético das decisões 
tomadas e dos apelos por mudanças que elas implicam (BOFF, 2016, entrevista exclusiva).

Denise Hamú também optou por reconhecer o potencial dos governos e dos grupos intergovernamentais para o cumprimento dos acordos, mas também decidiu apresentar uma visão mais propositiva e permeada pela identificação de possíveis soluções práticas dentro do atual cenário.

Os governos e os grupos intergovernamentais podem desenvolver ações muito importantes, mas só o governo não resolve. A sustentabilidade é uma tarefa de todo mundo, de todos os habitantes desse planeta. Claro que não podemos ser John Lennon e cantar Imagine. Nós temos que ser bem objetivos, mas sem o terceiro setor nós não conseguimos implementar a Agenda 2030. Ela é realmente o nosso caminho, o que foi acordado inclusive pelo terceiro setor por meio do Pacto Global, dos stakeholders, e dos major groups. Pela Agenda 2030 houve um processo de consulta extremamente importante e relevante. As Nações Unidas implementaram esse processo que culminou com a adoção do documento da Agenda 2030 e nela está escrito que, primeiro, nós não podemos deixar ninguém para trás, ou seja, envolver as pessoas do norte, sul leste e oeste, e temos que envolver todos os setores. Tanto é que tem um dos "Ps" do documento é de parceria. Nós não podemos fazer nada sozinhos (HAMÚ, 2017, entrevista exclusiva).

Se por um lado é importante destacar a necessidade de cumprimento dos acordos firmados pelos governos, também são evidentes a incapacidade e a inoperância de representantes do poder público, inclusive no Brasil, de criar condições para o desenvolvimento de uma agenda de desenvolvimento sustentável contínua e eficiente.

A sociedade civil, no caso brasileiro, apesar de todos os esforços, ainda não está de fato organizada para impor essa discussão e avançar nesse tema, o que reforça a importância do trabalho desenvolvido pelas atuais organizações do terceiro setor e impõe um limite aos mais diversos públicos para a implementação de uma agenda mais prática e cotidiana para a transformação da sociedade.

De forma ilustrativa, a nuvem de palavras a seguir destaca o conteúdo apresentado pelos entrevistados em resposta a esta pergunta. Na Figura 29, quanto maior o tamanho da palavra, mais vezes ela foi utilizada pelos entrevistados. 
Figura 29: Nuvem de palavras sobre papel de governos e grupos intergovernamentais

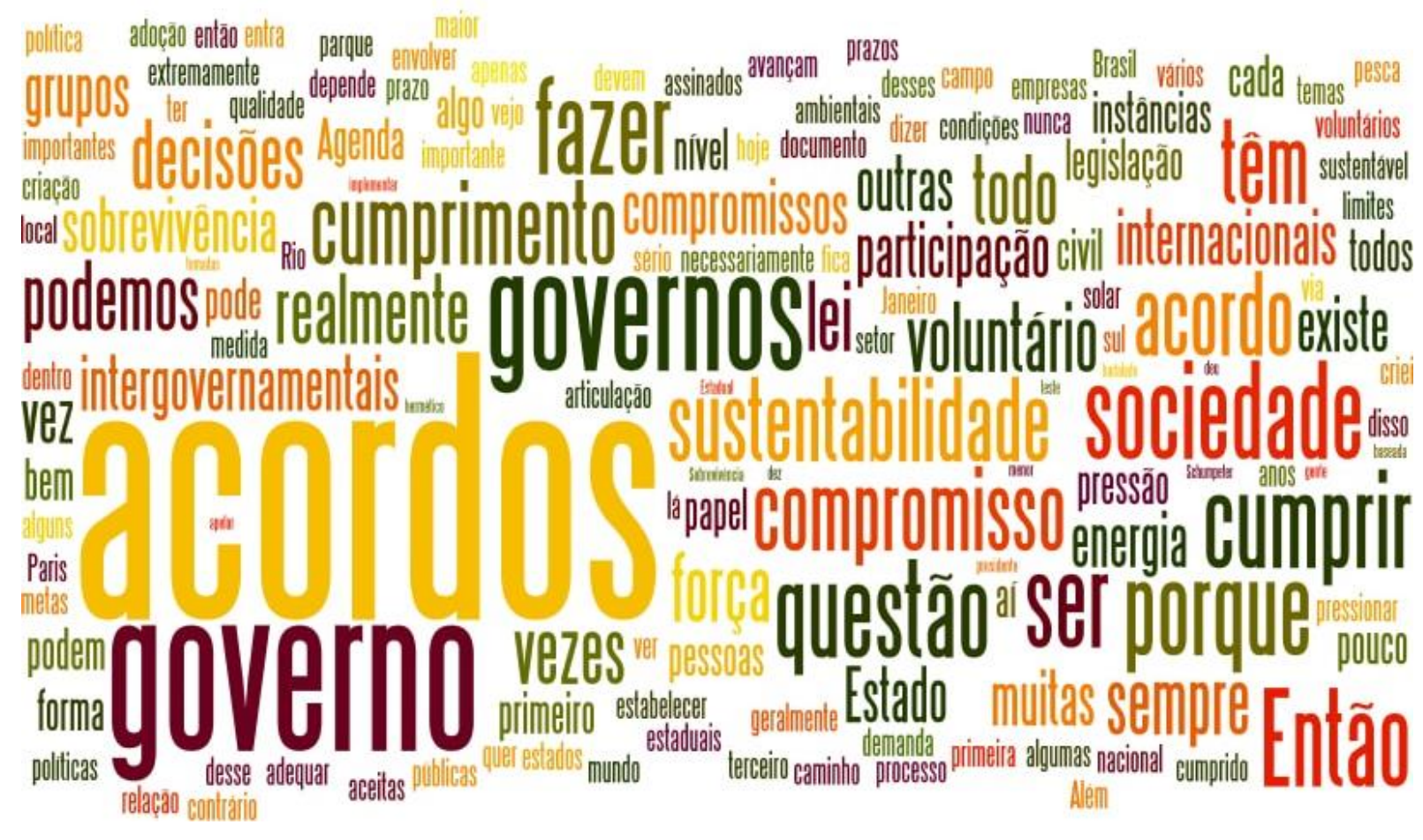

Fonte: Ulsen (2018)

2. Como as organizações, especialmente as do terceiro setor, têm possibilidade de contribuir para reduzir os impactos sociais e ambientais e diminuir os problemas de preservação do planeta?

Esta pergunta foi elaborada com o objetivo de ajudar a delinear o potencial e os limites das organizações do terceiro setor para ampliar a disseminação de práticas sustentáveis. Sem entrar diretamente no mérito desta questão, o teólogo Leonardo Boff direcionou suas críticas ao sistema capitalista e ao atual modelo de desenvolvimento consumista. Para ele, as soluções só serão efetivas quando a sociedade exercer pressão e a humanidade perceber que está no limite da mudança do comportamento atual, sob pena de colocar em risco a continuidade da vida.

Não podemos esperar que as soluções venham de cima. O sistema capitalista e o neoliberalismo são tão consolidados que dificilmente se movem na direção de uma mudança no modo de produção, de relação para com a natureza e as formas do consumo. Este sistema é antivida 
e possui uma tendência suicida, como o Papa na sua encíclica sobre a ecologia o afirma. Tudo deverá vir de baixo, com pressões, com boicotes dos produtos das grandes empresas, com desestímulo de aplicação de ativos financeiros nestas corporações e na denúncia permanente de que elas, por sua irresponsabilidade, estão pondo o sistema-terra e o sistema-vida em alto risco. Sou da opinião que todos mudarão quando a grande crise chegar, alguma tragédia ecológicosocial ou mesmo uma guerra nuclear de baixa intensidade (a de alta destruiria toda a vida no planeta), aí a humanidade vai despertar e dizer: ou mudamos ou morremos. Então poderá surgir uma governança global com poderes plurais, para debelar os problemas globais (BOFF, 2016, entrevista exclusiva).

Oded Grajew respondeu à pergunta de forma mais direta, pontuando que a atuação efetiva das organizações do terceiro setor é essencial para se contrapor à lógica dos governantes que, especialmente no Brasil, têm se dedicado mais a se manterem no poder, em detrimento da criação de políticas públicas a médio e longo prazo direcionadas para o desenvolvimento da sustentabilidade.

Elas são fundamentais, como nós temos visto. A lógica dos governos é a lógica do poder, e o poder se disputa a cada dois ou a cada quatro anos. Se você assistir alguma reunião de qualquer partido político, e eu não estou falando só do Brasil, mas do mundo, a discussão é sempre como é que se chega no poder e, se já está no poder, como é que se permanece no poder. Essa equação se resolve geralmente a cada dois ou a cada quatro anos, depende da legislação eleitoral de cada país, o que na realidade é um prazo curto quando nos referimos à questão da sustentabilidade. Quando falamos em sustentabilidade, temos que pensar sempre no médio e longo prazo, com projetos, políticas ou mudanças que geralmente tenham uma maturação maior que esses quatro anos. Isso geralmente não entra na perspectiva dos governos porque eles têm essa visão de curto prazo. Se você quer mudar a matriz energética, por exemplo, é necessário fazer investimentos que vão resultar em mudanças em cinco, seis, sete, oito, nove, dez anos, com resultados em dez ou doze anos. Ou, por exemplo, no caso dos Objetivos de Desenvolvimento Sustentável (ODS), que são metas até 2030, mas os governos estão pensando na próxima eleição. Essa é uma enorme dificuldade (GRAJEW, 2017, entrevista exclusiva).

Enrique Leff, crítico das iniciativas pouco eficientes e mal fundamentadas no âmbito da sustentabilidade, reconheceu a relevância das organizações do terceiro setor para mobilizar comunidades e defenderem interesses locais muitas vezes suprimidos em decorrência da pressão de grandes grupos econômicos. De forma 
complementar, Leff observa nessas organizações do terceiro setor o espaço de construção da cidadania.

As organizações do terceiro setor são muito importantes porque estão mobilizando a inquietude social sobre essa questão da sustentabilidade e às vezes esses movimentos são de pessoas de comunidades que estão defendendo uma questão mais particular, mais pontual, dentro das suas condições de vida, não somente uma ideia geral. Então estão se defendendo contra muitas vezes certos empreendimentos que afetam diretamente essas condições de vida. Então seria importante para eles ganharem, nessa luta política, seus direitos para resolverem essas questões a seu favor. Mas, também, porque nesses processos vão se mostrando também as resistências da cidadania e dos grupos sociais sobre o direito de o capital desapropriar certos territórios e certos espaços para seus projetos de desenvolvimento econômico (LEFF, 2017, entrevista exclusiva).

Para Fernando Almeida, o terceiro setor tem muito potencial para contribuir com essa questão, neutralizado o ambiente de desconfiança que existe no Brasil na relação entre empresas e governos e estabelecendo ligação entre empresários e governantes. Almeida também considera que o terceiro setor, juntamente com as universidades, podem ser operadores de diferentes iniciativas e setores da sustentabilidade, o que pode e deve ser aperfeiçoado com a utilização de métricas.

O terceiro setor é um elo de ligação entre esses dois setores, mas ainda existe muita desconfiança entre empresas e governos. Não estou falando do caminho corrupto, que está muito prevalente atualmente, mas destacando que normalmente existe desconfiança. Um acha que o outro é capitalista selvagem, o outro acha que o um é burocrata, lento e ineficiente. Muitas vezes, o terceiro setor pode facilitar essa questão, ser um elo de ligação, um facilitador, inclusive na obtenção de recursos para a implementação de projetos na medida que hoje boa parte do terceiro setor tem a técnica. Muitas entidades têm a técnica.

O terceiro setor também é um garantidor, pode oferecer uma credibilidade que nem o governo tem, nem o setor empresarial tem. $O$ terceiro setor também tem tudo para ser um bom operador de vários setores no caminho da sustentabilidade, como parques nacionais, reservas, reversão de pobreza, saúde e, especialmente, na educação, que é dificílimo. Sempre que se falar de operador, de eficiência e de conseguir mais com pouco recurso, existe um item fundamental que se chama métrica. Métrica. Tem que medir e essa medida tem que ser garantida por um conselho externo à entidade. E, junto com o terceiro setor, eu colocaria a academia, porque tive o privilégio de ter tido a experiência de academia durante muitos anos. Trabalhei no governo, trabalhei em empresas e no terceiro setor, no caso do CEBDS (ALMEIDA, 2017, entrevista exclusiva). 
Complementando esse raciocínio de enxergar o terceiro setor como um garantidor, Fernando Almeida comentou sobre como costumava analisar a credibilidade dos relatórios produzidos por empresas multinacionais no período em que presidiu o Conselho Empresarial Brasileiro para o Desenvolvimento Sustentável.

Me lembro que, quando eu estava no CEBDS, recebia por dia cinco ou seis relatórios de grandes empresas multinacionais do mundo inteiro e a primeira coisa que eu olhava nesses relatórios era 0 seguinte: existe algum grupo do terceiro setor, eventualmente do governo, da academia, que confirma se aquilo é verdade? A primeira coisa que eu ia olhar. Se não tinha, eu descartava. Mandava para a biblioteca. Perdia o interesse, porque eu não acredito que alguém possa falar de si mesmo com a credibilidade que o tema impõe. Agora, eu acredito no seguinte: se forem selecionadas pessoas respeitadas do terceiro setor ou até de empresas que sejam reconhecidamente sérias e militantes desse assunto, e chegar o dado dessa empresa, aí é completamente diferente. Na época a gente chamava de assurance committee, ou seja, aquele que dá a garantia da métrica (ALMEIDA, 2017, entrevista exclusiva).

Pedro Jacobi preferiu responder apresentando como experiência o que tem acompanhado no Greenpeace como membro do Conselho Nacional. Esta é, segundo ele, a maior organização mundial do terceiro setor, com amplo potencial de adesão e que convive, por outro lado, com muitas outras organizações pequenas com pouco poder de engajamento. Para Jacobi, em todos esses casos, as organizações dependem de financiamento e, portanto, de uma atuação disciplinada por parte da sociedade civil.

Eu sou membro do conselho nacional da maior organização mundial do terceiro setor, que é o Greenpeace. O Greenpeace tem hoje mais de três milhões e duzentos mil doadores, então é atualmente, dentre as organizações planetárias, provavelmente a que tem maior potencial de adesão. Então, o que nós temos é um número muito grande e importante de organizações, com as melhores intenções, mas com uma capacidade muito pequena de poder envolver um número maior de pessoas. Então, hoje nós temos também uma questão que é o fato de que o setor privado cria muitas fundações e elas obviamente têm agendas que, às vezes, não são as agendas mais interessantes para a sociedade. Então nós temos uma questão altamente complicada de que a sociedade civil às vezes tem uma atuação ambígua, mas há um esforço sempre em manter as organizações. Agora, essas organizações dependem sempre de financiamento. No caso do Greenpeace, o melhor exemplo é justamente porque o financiamento 
é feito por meio de doadores e não de convênios, de contratos da dependência dos humores das empresas. São temas fundamentais. Se o Greenpeace, por exemplo, por alguma razão, por uma campanha equivocada, e isto despertasse o desinteresse dos doadores, acabaria o Greenpeace, ou perde o seu poder de atuação. Então, isso é importante destacar porque essas agendas surgem como iniciativas de resistência a determinadas formas de funcionamento do sistema capitalista ou não capitalista, mas pelo menos do sistema produtivo e da forma como ele acaba sendo um predador do ponto de vista dos órgãos e das instituições da sociedade civil. São ações que se organizam para reagir a partir de uma agenda que motive esses atores a questionar, por exemplo, a questionar a construção de mais hidrelétricas na Amazônia, a promover as energias alternativas, a questionar a caça da baleia, como foi no início do Greenpeace (JACOBI, 2016, entrevista exclusiva).

Denise Hamú citou alguns exemplos de iniciativas desenvolvidas para analisar o quanto tem sido feito nesse sentido. Para Hamú, a situação é paradoxal pois, embora muito tenha sido feito, persiste uma dificuldade de visão sobre o futuro. Para tanto, ela voltou a defender nessa resposta a necessidade de maior envolvimento e integração entre os atores sociais, o que certamente fará as discussões avançarem e as decisões serem implementadas com mais rapidez e qualidade.

Nós organizamos recentemente um simpósio no Museu do Amanhã, no Rio de Janeiro, em que nós discutimos o que avançamos da Rio 92 até hoje. Realmente nós caminhamos muito, mas sempre temos a sensação, na área ambiental em particular, que estamos sempre chegando atrasados. Nós acordamos de manhã e percebemos que nunca conseguimos nos antecipar. Nós somos péssimos de visão, mas temos conseguido, se olharmos para trás de 1992 para cá, a quantidade de ações que foram construídas. Nós já conseguimos muitas coisas. Então, por exemplo, há 15 anos não existia nenhum lugar em que você trabalhava uma área de mudanças climáticas. Por exemplo, quando eu cheguei no WWF, em 2003, nós não tínhamos nem uma área de agricultura. Nós falávamos só de biomas, Mata Atlântica, Amazônia, Pantanal.

Então, nós começamos a ver que não adiantava só localizar as coisas, mas precisávamos tratar daqueles assuntos que permeavam todos os biomas e toda essa questão de não ter fronteira, pois estamos falando de um só planeta. Ponto. Todos nós dependemos uns dos outros, seja em termos de recursos naturais, em termos de áreas agriculturáveis, em termos de ar de qualidade para respirarmos, de saneamento. $A$ discussão sobre cidades, por exemplo, não estava no contexto. A Agenda 21 trouxe essa contribuição, mas pouco se falava. Então, fomos evoluindo. Os últimos dez anos foram incríveis. Se você olhar o conhecimento novo que foi gerado na área de mudanças climáticas é uma grandeza. Há vinte anos tínhamos muito pouco. Isso porque ainda temos um Donald Trump questionando a ciência. Mas, de qualquer forma, sabemos que caminhamos demais. Temos o trabalho 
maravilhoso do Painel Intergovernamental sobre Mudanças Climáticas (IPCC), que tem congregado a ciência toda e tentado traduzir isso de uma maneira mais palatável, onde falta muito a comunicação. Mas temos também o Al Gore que tem feito um trabalho importantíssimo de sensibilização e de conscientização pública no mundo todo. E ele tem esse poder da comunicação. O Al Gore chega e encanta todo mundo por onde ele passa (HAMÚ, 2017, entrevista exclusiva).

Retomando Fernando Almeida, a análise a seguir está alinhada com o que foi dito por Denise Hamú a respeito da necessidade de integração, complementada com um olhar mais direcionado às responsabilidades das empresas para gerar uma sociedade mais justa e equilibrada.

\begin{abstract}
Eu vivi isso a vida inteira. Sustentabilidade não existe sem as três dimensões (ambiental, social e econômica) e não existe sem os três atores (sociedade civil, governo e empresas). E a eficácia e a eficiência no caminho da sobrevivência dependem do entendimento dos três setores. Essa é uma questão fundamental. No caso do setor empresarial, tirando exemplos que não confirmam a regra, a preocupação em 99\% dos casos é basicamente gerar renda e recurso, ter o faturamento mais alto possível. Participei de vários conselhos consultivos de empresas e, no geral, não existe um envolvimento diferente desse.

Participei da criação do Conselho Empresarial Brasileiro para o Desenvolvimento Sustentável (CEBDS) em 1997 e saí de lá em 2010. O Conselho não era, na minha forma de ver, um instrumento de defesa do setor empresarial. Muito pelo contrário. Era uma alavanca para que eles se aproximassem o mais rápido possível do caminho da sobrevivência e da sustentabilidade, até para eles. Mas não acho que isso tenha avançado tanto assim. Hoje, o Conselho se tornou algo que defende as empresas. Eu nunca defendi empresa nenhuma, eu defendia esse caminho e, muitas vezes, tive embates duros lá. As empresas, na minha opinião, têm pouco envolvimento, até porque, em gral, conhecem pouco o tema. E os governos têm a função, desses três atores, de normatizar, dar estímulos e controlar (ALMEIDA, 2017, entrevista exclusiva).
\end{abstract}

Encerrando a interpretação das respostas para esta pergunta, é oportuno resgatar a experiência de Oded Grajew, para quem os executivos empresariais também estão sujeitos a pressões, sobretudo para a entrega de resultados financeiros. Segundo Grajew, a saída para essa situação, para torná-la mais equilibrada, está na sociedade civil organizada, que pode ter o poder da cidadania e da democracia para determinar a representatividade de interesses menos unilaterais e mais coletivos. 
Da mesma forma, existem dificuldades no caso das empresas porque os presidentes dessas companhias estão muito pressionados atualmente pelos resultados trimestrais. Se o presidente de uma empresa não apresentar lucro em um trimestre, ou nos dois trimestres seguidos, já é cogitada a demissão dele. É aí que entra a sociedade civil, que tem outra perspectiva, outro horizonte, outro calendário e outro prazo. Porque, na realidade, a sociedade civil tem força tanto como grupo de eleitores, quanto enquanto consumidores. $\mathrm{Na}$ realidade, o poder está na mão da sociedade porque são os eleitores que decidem qual é o governo que teremos, e são os consumidores que dizem se vão comprar ou não os produtos daquela empresa. $A$ pressão da sociedade nesse sentido é boa, e colocar uma política que aponte para melhorias ambientais e a preservação do planeta é fundamental. Essa percepção é muito importante (GRAJEW, 2017, entrevista exclusiva).

A nuvem de palavras da Figura 30 ilustra as respostas apresentadas pelos entrevistados para esta pergunta e também revelam quais foram as principais expressões utilizadas. Percebe-se, nesse caso, a presença de diferentes palavraschave citadas várias vezes (empresas, terceiro setor, sociedade, governos, sustentabilidade, exemplo e poder) sem o exagero na utilização de algumas específicas.

Figura 30: Nuvem de palavras sobre potenciais do terceiro setor

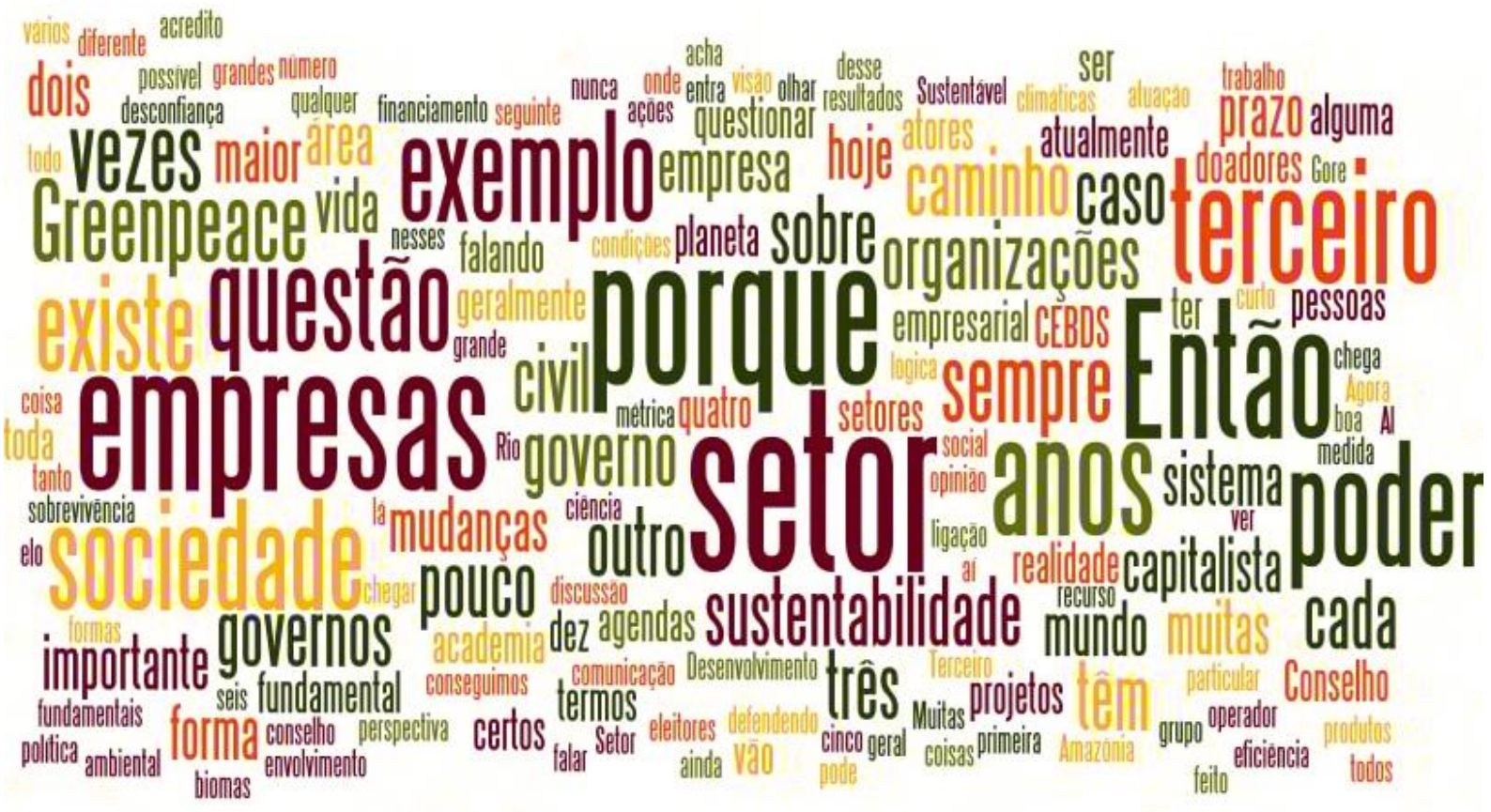

Fonte: Ulsen (2018) 
3. Na sua avaliação, a comunicação praticada pelas organizações tem contribuído para incentivar o debate sobre sustentabilidade e sensibilizar as pessoas para criarem ambientes mais sustentáveis?

Esta pergunta foi apresentada aos entrevistados para apurar melhor como eles enxergam, de forma mais específica, as ações de comunicação desenvolvidas pelas organizações do terceiro setor. Embora estes entrevistados não sejam necessariamente comunicadores, todos são, reconhecidamente, líderes e formadores de opinião na área de sustentabilidade, com experiência relevante para avaliar a comunicação e até fazer algumas sugestões.

Nesse sentido, Denise Hamú foi enfática ao destacar a necessidade de uma comunicação estratégica desenvolvida dentro da gestão organizacional.

Antes de mais nada, eu quero dizer que a comunicação é fundamental.
Você selecionou um tema fascinante e necessário, mesmo porque, e
você já deve ter percebido pela sua escolha, que a comunicação para
a área de sustentabilidade e o meio ambiente, especialmente, é um
instrumento de gestão. Ela é parte de um projeto, não é apenas para
comunicar os resultados. Não. Ela é essencial, inclusive no terceiro
setor, e eu fui CEO do WWF Brasil por quase nove anos, uma
organização muito relevante no mundo, presente em 120 países.
Todos os projetos do WWF têm um comunicador. Eu não precisava
convencer ninguém. Era o sonho porque a comunicação, e os modelos
de comunicação eram muito utilizados com grupos focais, por
exemplo, atuavam em tudo até na preparação para as reuniões. Tudo
isso é comunicação e, normalmente, as pessoas confundem com
Relações Públicas. Então, a comunicação é um tema fascinante, eu
vejo como um ingrediente essencial e quero te dar os parabéns pela
escolha do tema (HAMÚ, 2017, entrevista exclusiva).

Opinião semelhante apresentou Pedro Jacobi, que também defendeu a importância da comunicação e, novamente, exemplificou a resposta com o que observa como membro do Conselho Diretor do Greenpeace Brasil e demais iniciativas bem-sucedidas de comunicação e sustentabilidade.

A comunicação é fundamental! Ela é absolutamente fundamental! Ela é tão fundamental que é uma das grandes preocupações do Greenpeace. Já dizia o Chacrinha que quem não se comunica se trumbica. Então, nós temos aí uma questão muito concreta, ou seja, a 
comunicação que alimente, de alguma maneira, a identidade com uma causa. Então, o que você observa um pouco hoje em dia, é: Quantas organizações se comunicam? Como se comunicam? Quantos sites vinculados ao tema ambiental que haviam e que deixaram de existir? Um site por exemplo que eu lembro muito bem, chamado Mercado Ético, deixou de existir e era apoiado por empresas. Hoje, em termos ambientais, existem poucos sites realmente funcionando. Um deles é o Envolverde, que é um site que eu conheço muito bem os responsáveis, mas que também está sofrendo muito (JACOBI, 2016, entrevista exclusiva).

A este respeito, o pragmático Fernando Almeida decidiu partir para uma análise sobre como a comunicação pode cumprir essa função e contribuir para incentivar o debate sobre sustentabilidade e sensibilizar as pessoas para criarem ambientes mais sustentáveis. De acordo com ele, o ponto de partida é a definição de uma linguagem assertiva que tenha poder de convencimento de novos públicos, aqueles ainda não envolvidos com a temática.

Almeida também abordou a necessidade de a comunicação estar bem fundamentada tecnicamente para a correta fundamentação do discurso e a evolução do debate. Além disso, segundo o entrevistado, a comunicação tem potencial para participar do nível estratégico de tomada de decisões nas organizações, inserindo a sustentabilidade como parte dos ativos intangíveis, como marca e reputação, para valorizar os investimentos nessa área.

Na questão da comunicação, a primeira questão é a linguagem. Não adianta falar para quem já está convencido e é necessário ter casos exemplares. Sempre me perguntavam como se começa com sustentabilidade. Eu falava: para você convencer o seu superior e chegar até o seu presidente, comece com produção mais limpa, ecoeficiência. Primeiro porque é bom para a empresa, segundo porque é bom para a sociedade, e terceiro porque é bom para os ativos ambientais. Então é mais fácil e mais palatável. Agora, tem que ter casos exemplares com garantia, selo de alguma entidade ou conselho. Essa questão é fundamental.

Além disso, em termos comunicação e sustentabilidade, eu vejo também a necessidade de fundamento técnico, pois muitos jornalistas, até bem-intencionados, às vezes falam bobagem. Por que? Não tiveram tempo nem paciência de estudar o assunto. Tem uma técnica relacionada a cada questão dessa. Eu cansei de ter debates, porque eu tinha que dizer o seguinte: "Olha, o que o senhor está falando não é assim, cientificamente é diferente". Eu fiz meu mestrado em Nova York, eu dou aula há 30 anos. Eu perguntava: "Qual é o livro técnico que o senhor me recomenda que dá garantia ao que o senhor está falando?". Então tem que ter a garantia de que está correto e tem que ter alguém que garanta. 
Outro ponto é que, na comunicação, há uma questão fundamental que facilita quando se vai ao nível estratégico de tomada de decisão, no governo, nas empresas e no terceiro setor. Trata-se dos ativos intangíveis: marca e reputação. Possivelmente a marca Bayer, por exemplo, vale de $70 \%$ a $90 \%$ da empresa, ou seja, os ativos intangíveis valem muito mais do que os ativos tangíveis e sustentabilidade é um Headge, um seguro para que você não perca o seu valor nos ativos intangíveis. Isso em comunicação é fundamental. Eu cansei de convencer muitos CEOs e diretores de empresas com esse argumento. Um outro ponto é o marketing sustentável. Eu não tenho nada contra, eu acho que não há nenhum problema com o marketing sustentável. A única questão que eu coloco é que ele seja ético. Não concordo com greenwashing porque a pior situação é aquela pincelada verde que acha que convence as pessoas. Isso tem um período muito curto de convencimento (ALMEIDA, 2017, entrevista exclusiva).

Para Oded Grajew, a comunicação já tem executado o debate sobre sustentabilidade e sensibilizado as pessoas para criarem ambientes mais sustentáveis. Ele, no entanto, pontua que existe a necessidade de se avaliar se os resultados atuais são suficientes.

Isso tem sido feito. A pergunta é se isso é o suficiente. Há alguns anos,
isso não era assunto, não estava na agenda, não se entendia do que
realmente se tratava e hoje, pelo menos, está na agenda. Agora, entre
estar na agenda e ser implementado é uma outra questão. Na
realidade a comunicação tem ajudado, isso foi conseguido, isso foi
feito de uma forma satisfatória, agora o desafio é avançar da agenda,
da primeira etapa. Essa discussão não estava na agenda porque se
falava do desenvolvimento de qualquer maneira, construir túneis fazer
estradas. Agora está na agenda, está no discurso (GRAJEW, 2017,
entrevista exclusiva).

Em linha com as argumentações favoráveis à importância da integração entre comunicação, sustentabilidade e terceiro setor, a representante da ONU Meio Ambiente no Brasil, Denise Hamú, defendeu a simplificação dos processos e o engajamento de diversos públicos para a realização de trabalhos coletivos. Hamú ainda destacou a importância de envolver novas pessoas nas discussões sobre sustentabilidade para que novas contribuições possam ser apresentadas e implementadas.

Eu acho a comunicação essencial. Ela é essencial, inclusive a sustentabilidade deve ser conjugada no plural. A sustentabilidade é a essência do coletivo. Nós não podemos fazer nada sozinhos. A 
comunicação é a cola. Muitas vezes nós tendemos a fazer a comunicação exposed. Ou seja, quando temos algum material, pensamos em fazer um release, e às vezes não tem nada a ver com determinadas estratégias, pois precisamos ouvir as opiniões. Eu acho que, por exemplo, nós das Nações Unidas temos um papel nessa agenda que é servir de plataforma de diálogo, promover encontros desses mundos. Não estamos falando só com governos. Claro que, aqui, eu represento a ONU Meio Ambiente, nós inclusive mudamos de nome do Pnuma inclusive nessa linha que você está falando. O nosso nome fantasia agora é ONU Meio Ambiente, porque já existe o Programa das Nações Unidas para o Meio Ambiente. O nosso nome fantasia agora é ONU Meio Ambiente, o que está absolutamente na sua linha porque Programa das Nações Unidas para o Meio Ambiente (Pnuma) não quer dizer muita coisa. O nosso novo diretor executivo determinou uma ordem interna que baniu Pnuma e Unep. Todas as divisões do Pnuma, os departamentos, tinham nomes muito extensos. Mudamos todos.

Isso porque nós estamos percebendo que, na área de sustentabilidade, estamos falando para os convertidos. Nós temos que romper esses silos. Estamos um pouco inebriados, até por essa agenda ter tomado alguma relevância, e por conta da importância do Acordo de Paris, que estamos falando apenas para os nossos pares. E aí não estávamos alcançando os de fora. Nosso diretor executivo mudou isso agora e nós não podemos seguir fazendo o que fazíamos. Temos que avançar nessa questão. A comunicação agora é o não uso de acrônimos, não podemos dizer sigla nenhuma porque ele disse que se as pessoas não identificam a ONU Meio Ambiente como um espaço aberto de aprendizado, de idas e vindas, de mão dupla, como é que que nós queremos achar que vamos realizar o nosso mandato? Estamos caminhando muito nessa linha. É uma tarefa enorme, mas estamos bem comprometidos para que as coisas aconteçam (HAMÚ, 2017, entrevista exclusiva).

Para Fernando Almeida, existem alguns exemplos de ações interessantes de comunicação que têm sido realizadas com certo sucesso, destacando o exemplo dos produtos orgânicos que têm conseguido converter pessoas sobre sua importância a partir do discurso sobre a importância da qualidade de vida. Almeida, da mesma forma que Hamú, defendeu a necessidade de uma ampla e eficiente relação das organizações com públicos de interesse.

Um exemplo interessante, que vem ganhando muito espaço mundial, nacional, regional e local, e que tem dado certo, é o dos produtos orgânicos. Esse é um setor que está conseguindo penetrar no mercado, inclusive com preço mais alto, mas com base na visão da melhoria da saúde das pessoas.

Outro item fundamental é a relação com stakeholders, ou grupos de interesse, em português. Para a implantação de uma nova usina, uma nova planta, de uma Dupont ou de uma Alcoa, por exemplo, ou de uma empresa de grande porte, e em geral essas empresas já são 
conscientes disso, é necessário construir uma relação com o entorno. Ou seja, o stakeholder é aquele que você influencia e por quem você é influenciado. É preciso selecionar um raio de cinco, dez quilômetros, e identificar os grupos de interesses mais significativos e as lideranças, para dialogar com eles para que a instituição seja feita ali. Essa é uma comunicação sofisticada, não é fácil, pois qualquer empresa dessa está sujeita a acidentes. Se existe uma relação forte, mecanismos com stakeholders, o acidente pode ser considerado um acidente. Se não existe, o acidente será considerado uma irresponsabilidade e isso inclui governo local, governo regional, às vezes até governo nacional, dependendo de onde a empresa estiver (ALMEIDA, 2017, entrevista exclusiva).

Para ele, praticar uma boa comunicação é um desafio, sobretudo para engajar públicos dispersos que ainda não desenvolveram relação com a sustentabilidade e temas correlatos.

Eu já fiz política profissional e já fui candidato, então sei o quanto é difícil acessar as pessoas em uma questão um pouco mais profunda. Se você disser que vai juntar trinta pessoas para falar sobre sustentabilidade, não vai ser fácil. Hoje, a comunicação é importante para acessar essas pessoas e a sociedade em geral. Não quem já está embarcado, porque esses não são a minha preocupação, mas aqueles que não têm nenhuma vinculação com o tema (ALMEIDA, 2017, entrevista exclusiva).

Seguindo com a indicação de desafios, cabe destacar a seguir a resposta concedida por Oded Grajew para esta questão, esclarecendo que a comprovação prática do discurso é extremamente importante para ganhar credibilidade e gerar engajamento das pessoas. Nesse sentido, todo trabalho de comunicação sério e eficiente, com apresentação de dados, tem maior potencial de gerar resultados e ampliar o impacto do trabalho realizado.

O grande desafio da comunicação é se isso está sendo realmente levado a sério, se está sendo implementado e, ao mesmo tempo, mostrar casos exemplares, casos de sucesso, mostrar que é possível. A comunicação é muito forte quando se faz um discurso e mostra que esse discurso é factível, que não se está sonhando. Então é importante compartilhar se existe uma cidade que reduziu uma determinada quantia do consumo de água, diminuiu o desperdício na rede de distribuição, ou se existe uma cidade que eliminou $o$ combustível fóssil no transporte coletivo. Se você mostra quem já fez, aí você constrange quem não faz, porque essas pessoas não vão poder dizer que é um sonho, que é irreal. É importante denunciar os governos que não fazem ações nesse sentido, denunciar na época pré-eleitoral para mostrar ao político que a eleição dele, o poder que 
ele quer depende disso. Então agora temos que pensar em uma outra etapa, porque a discussão já está na agenda, já está no discurso. A própria ONU já estabeleceu os Objetivos de Desenvolvimento Sustentável para toda a humanidade, para todos os países. Isso está no discurso dos políticos, no discurso das empresas, na mídia. Agora é a hora da implementação e a comunicação tem que se concentrar nisso. Isso está muito ligado à questão de transparência, de ética, de fazer circular essas informações. Compartilhar iniciativas de quem faz, para valorizar, e informar à população quem não faz.

Agora não é mais possível ter só o discurso de que é importante tratar do meio ambiente porque o futuro da humanidade depende disso, que o aquecimento global é um risco para a humanidade e vai acabar com a natureza e que estamos gastando mais do que o planeta é capaz de repor. Isso foi comunicado, já chegou em todos. Agora, a comunicação, do meu ponto de vista, tem que ser sobre o que tem que ser feito, o que está sendo feito e o que não está sendo feito (GRAJEW, 2017, entrevista exclusiva).

Interessante observar que esta afirmação está alinhada com o quadro teórico de referência apresentado no início desta tese, sobretudo com o que defende Baldissera (2009a, 2009b) em suas publicações. Na sequência, novamente abordando a importância de uma linguagem clara e envolvente, Fernando Almeida defendeu que esse fator está diretamente associado com o sucesso da comunicação e a própria capacidade da sociedade civil conseguir compreender de que forma os governos estão tratando a agenda da sustentabilidade.

Uma das primeiras questões nesse sentido é a da linguagem, que não pode ser acadêmica, para não ficar restrita a poucas pessoas. Eu tive um programa chamado Viver Melhor, na rádio CBN, durante três anos, todos os dias da semana. O que eu fazia? Eu gravava o programa e, quando estava no táxi e aparecia a minha voz, eu perguntava ao motorista se ele estava entendendo o que estava sendo falado. Esse era um teste que eu fazia. O segundo teste era pedir para a minha empregada ouvir todo dia. Até o momento que ela começou a entender. O significado era tentar envolver um maior número de pessoas nesse tema. Eu tinha que falar nessa linguagem. Utilizar a linguagem de professor da UFRJ, onde fui professor por 30 anos, era fácil.

Então, acho que os governos, e cansei de falar isso em reuniões com eles, precisam tratar o tema de forma muito mais palatável à população em geral para ter mais adeptos ao tema. Não vejo que isso tenha surtido tanto efeito. Eles falam em uma linguagem tão sofisticada que a impressão que dá é que eles estão com medo que as pessoas entendam e depois venham cobrar o erro deles. Essa é a impressão que eu tenho.

Então, além de fazer cumprir os acordos, que têm força de lei, também existe a responsabilidade dos governos comunicarem adequadamente o tema. É muito difícil um ministro do Meio Ambiente, ou um ministro 
dessa área, pressionar um presidente para assinar qualquer acordo. Mas as entidades, na sua base, com o corpo técnico, têm o conhecimento, porque trabalham com isso. Então a pressão ao próprio governo é um fator fundamental para que esse sistema avance (ALMEIDA, 2017, entrevista exclusiva).

Pedro Jacobi reconheceu que a comunicação é estratégica, mas também esclareceu que é necessário que se defina que tipo de comunicação é praticado. Segundo ele, o envolvimento dos públicos é essencial, assim como o estabelecimento de metas está diretamente relacionado com o sucesso do trabalho realizado e a ampliação do impacto social e ambiental das organizações do terceiro setor.

Então, comunicação é absolutamente estratégica, mas a questão é que tipo de comunicação, como comunicar. O Greenpeace se mobiliza para se envolver em uma campanha, assim como os Médicos sem Fronteiras se comunicam o tempo inteiro porque precisam das doações para desenvolverem campanhas. Eu, por exemplo, no dia de hoje, apesar de ser do Greenpeace do Brasil, eu recebo o tempo inteiro, todos os dias, mensagens do Greenpeace internacional, e principalmente do Greenpeace americano, para apoiar as iniciativas do Greenpeace dos Estados Unidos preocupadíssimos com a chegada do Donald Trump ao poder. Então, existe um trabalho permanente de comunicação, até exaustivo. Mas esse é um dos grandes desafios e eu acho que, sem dúvida, a comunicação e a capacidade de uma comunicação que te envolva, que te motive a apoiar, e até de indagar. Indagar é mais difícil porque existe um corpo de pessoas envolvidas profissionalmente, antes 0 Greenpeace dependia mais de voluntários e hoje não é bem uma coisa de voluntários, hoje tem o compromisso com uma gestão que é quase como uma gestão empresarial, porém orientada para uma ação da sociedade. Porque tem metas, tem que cumprir metas. $O$ Greenpeace hoje tem no Brasil 61 mil apoiadores e a meta é, nos próximos dois anos, de chegar a 150 mil. Isso é uma meta empresarial, literalmente uma meta empresarial. E uma meta empresarial porque o Greenpeace no Brasil é um dos ecossistemas mais importantes para a atuação do Greenpeace, mas o Brasil depende ainda bastante, para a realização da sua agenda, de recursos do Greenpeace internacional, mas cada vez menos. Ele já dependeu de $70 \%$ a $80 \%$, depois dependeu $50 \%$, hoje depende $30 \%$ de recursos internacionais. $E$ a ideia é que ele não tenha mais nenhum tipo de dependência, então isso significa que você tem que ter apoiadores. Como mobilizar esses apoiadores? A partir de telemarketing, a partir de todas formas de comunicação (JACOBI, 2016, entrevista exclusiva).

Já Enrique Leff, ao ser questionado a este respeito, apresentou uma visão mais crítica sobre o tema, indicando que a comunicação muitas vezes simplifica assuntos complexos e não aprofunda o suficiente a discussão. Além disso, Leff mostrou-se mais 
favorável a uma comunicação mais dialógica, de via dupla, e menos massiva, até para que haja mais troca de conhecimentos antes da implementação de ações unidirecionais.

\begin{abstract}
Depende do que você quer comunicar. Você pode comunicar distintas visões da questão. Então depende o que comunica e como comunica. É uma questão também difícil, porque se há mais comunicação, dentro dessa comunicação também muitas vezes o que fica dentro das cabeças das pessoas é também uma simplificação da complexidade da problemática. $E$ também se difunde um fluxo muitas vezes mais retórico das questões e não um aprofundamento da argumentação, do pensamento crítico sobre o que está jogando esse processo da globalização econômica e dos aspectos negativos da crise ambiental. E eles são muito complexos, então quando você fala de comunicação, a comunicação geralmente tende a simplificar as coisas, sobretudo em divulgações muito massivas, então precisamos também saber que tipo de comunicação. No caso do terceiro setor, ele pode praticar a comunicação com meios massivos de comunicação, transmitir essas informações assim. Outra coisa muito diferente é falar dos diálogos de saberes, dos diálogos mais estratégicos dos grupos, o que é diferente. Então depende que comunicação estamos pensando (LEFF, 2017, entrevista exclusiva).
\end{abstract}

Leonardo Boff também optou por uma argumentação mais crítica, lembrou-se de exemplos feitos para atingir justamente o objetivo oposto, de omitir temas urgentes. Boff também declarou que considera o termo sustentável mal utilizado, muitas vezes agregado às estratégias de marketing para ampliar o consumo, e não como um valor integrado às necessidades da natureza.

Grande parte do debate é feito para ocultar a crise ecológica, seja da escassez dos bens e serviços, seja das ameaças que pesam sobre o nosso futuro. O uso do termo "sustentável" geralmente é apenas marketing, sem corresponder à realidade dos produtos. A sustentabilidade tem a função de um novo paradigma. Ela obriga a uma outra relação com a natureza, não mais de exploração, mas de sinergia. Temos que produzir para atender as demandas humanas, mas dentro dos limites impostos pela Terra que é um planeta velho e com bens e serviços escassos. Um planeta finito não suporta um projeto de crescimento infinito. Ele sucumbe à voracidade humana. $\mathrm{Ou}$ então o sistema-terra criará uma situação em que fará desaparecer esse câncer maligno, capaz de afetar a totalidade do planeta. $O$ antropoceno parte desta constatação, quer dizer, entramos numa nova era geológica onde o meteoro rasante ameaçador não vem de fora, mas é o próprio ser humano que criou o princípio de autodestruição. Ele pode ser o satã da Terra quando é chamado a ser só seu anjo bom e protetor (BOFF, 2016, entrevista exclusiva). 
Na Figura 31, a nuvem de palavras representa as respostas apresentadas pelos entrevistados a esta pergunta e revela as principais expressões utilizadas. Nesse caso, percebe-se a presença da palavra comunicação em destaque, seguida por outras também destacadas nas respostas de todos, como Greenpeace, sustentabilidade, exemplo, pessoas, meio ambiente, ser e ONU.

Figura 31: Nuvem de palavras sobre comunicação para a sustentabilidade

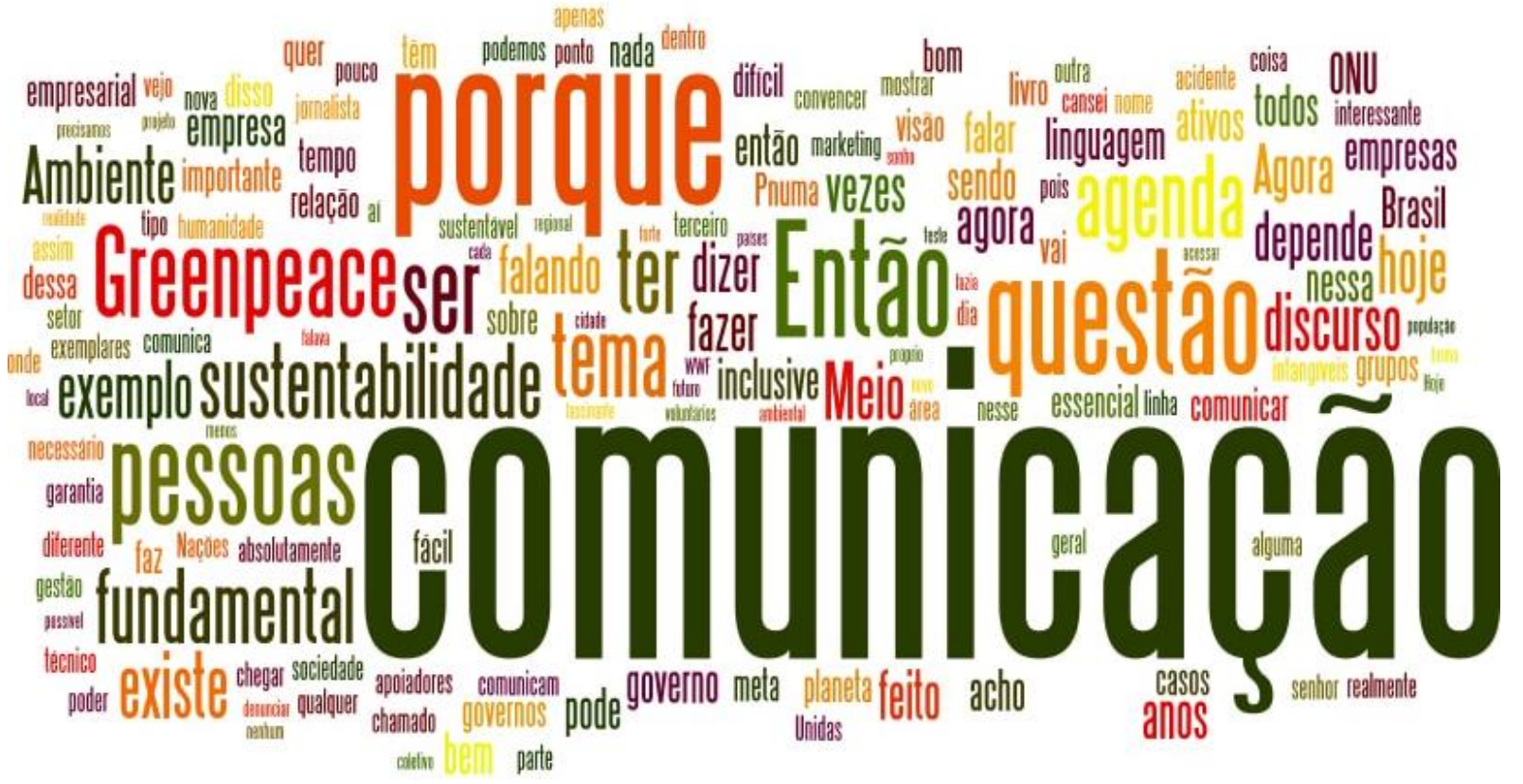

Fonte: Ulsen (2018)

4. Qual é a importância do terceiro setor para liderar pessoas e organizar movimentos e ações para promover a melhoria da sustentabilidade em termos locais, regionais, nacionais e globais?

Pergunta elaborada para apurar qual tem sido a relevância histórica do terceiro setor na criação de mecanismos que promovam a sustentabilidade. A elevada experiência dos entrevistados no âmbito nacional e internacional permite afirmar que as respostas representam um cenário atualizado e confiável sobre o tema.

Para Enrique Leff, apesar de toda a experiência que tem em grupos intergovernamentais em escala mundial, não há como fazer essa avaliação, diante da ausência de mecanismos. Ainda assim Leff citou a desagregação das organizações e 
a necessidade de enxergar um movimento mais expressivo globalmente para analisar esta questão.

\begin{abstract}
Historicamente, não temos mecanismos para avaliar se o terceiro setor tem ganhado força para contribuir para a sustentabilidade. Não temos mecanismos claros de avaliação, fica muito difícil avaliar, mas eu gostaria de ver mais processos de integração e de solidariedade dessa diversidade de movimentos sociais. Não quer dizer que eles não existem, mas eles estão muito desagregados ainda dentro das suas lutas particulares e as pessoas estão muito mais vulneráveis porque cada luta é uma luta mais local, mais particular dentro de condições políticas geralmente muito adversas. Então eu só posso dizer que eu gostaria de ver um processo, um movimento global muito mais amplo do que esse que existe, mas também fica muito difícil porque há diferentes problemáticas locais, diferentes concepções críticas sobre os processos de desenvolvimento, os efeitos negativos sobre o clima, sobre os sistemas e as condições de vida da população (LEFF, 2017, entrevista exclusiva).
\end{abstract}

Leonardo Boff não respondeu diretamente, mas indicou que esta análise pode ser facilitada pela compreensão deste processo a partir de experiências mais regionais que evidenciem os resultados atingidos.

É possível a sustentabilidade dentro do biorregionalismo. Toma-se a região com seus recursos, sua população, sua cultura e sua tecnologia e aí organizar um modo de produção, distribuição e consumo que seja suportável pelos recursos da região, com a capacidade de ser reproduzir e manter a sustentabilidade. Hoje em muitas partes do mundo se fazem experiências nesta área, onde se pode mostrar que é possível as regiões (geralmente definidas pelas bacias hidrográficas) realizar um desenvolvimento humano sustentável. Aqui as comunidades são importantes até no sentido de impedirem grandes conglomerações de riqueza ou de processos produtivos que desequilibram a região. A solução passa pela articulação de todos no terceiro setor que vão assumindo a hegemonia ideológica e prática para essa forma nova de estar sobre a Terra junto com a comunidade de vida (BOFF, 2016, entrevista exclusiva).

Oded Grajew preferiu se basear em exemplos para avaliar a questão. Além disso, novamente Grajew destacou a necessidade de um trabalho integrado entre as organizações e a sociedade civil em um formato cooperativo para impacto em termos locais, nacionais e globais.

Há muitos exemplos ao longo da história de mobilizações locais e nacionais, como o impeachment do Fernando Collor, as 
manifestações no Brasil, os direitos civis nos Estados Unidos. Mas o desafio para a ampliação da mobilização, da pressão, é a sociedade civil conseguir se juntar e atuar em rede. O desafio é a sociedade civil não assumir, nas organizações sociais, a cultura da empresa, que é a cultura da competição. A sociedade civil tem que ter uma cultura da cooperação. Cada organização, individualmente, é muito frágil diante do desafio, mas quando elas se juntam, quando atuam em rede, o impacto é muito maior. Então depende muito da capacidade, da visão e da disponibilidade das lideranças das organizações em não competirem entre si, mas de atuarem conjuntamente em rede cooperando para que o impacto possa ser não só local, não só nacional, não só continental, mas sim global (GRAJEW, 2017, entrevista exclusiva).

Seguindo com Grajew, o sucesso desse trabalho, segundo ele, deve ser oriundo da implementação de políticas públicas e indicadores.

Sobre a necessidade de implementação e controle de políticas públicas, também pode existir a contribuição do terceiro setor nesse sentido. Atualmente, com a maior capacidade de comunicação, 0 amplo acesso à informação, no caso do Brasil por exemplo tem a Lei de Acesso à Informação, a informação é a ferramenta mais importante nas mãos da sociedade civil. Qualquer ditadura, quando se implementa, a primeira coisa que se faz é cortar a informação porque quer a sociedade longe do controle social. $\mathrm{E}$ a informação baseada em indicadores, o que na realidade é a hora da verdade, ela é muito poderosa. Tanto é assim que os governos tentam esconder os indicadores porque o indicador é a hora da verdade. O governo pode dizer que privilegia os pobres, por exemplo, mas quando você analisa os indicadores para checar quanto do orçamento vai para classe rica e quanto do orçamento vai para classe a pobre, aí é a hora da verdade. A verificação do discurso, a hora da verdade do discurso, se ele é verdadeiro ou não, ocorre quando se revelam os indicadores, que é o resultado concreto. Se o governo divulga que está cuidando da saúde da população, e você analisa o indicador e percebe que a mortalidade infantil aumentou, a mortalidade materna aumentou, o tempo de atendimento no posto de saúde aumentou, então não há discurso que resista a isso. O discurso sempre pode ser checado por meio de indicadores (GRAJEW, 2017, entrevista exclusiva).

Denise Hamú lembrou-se de destacar a necessidade de inserir o argumento da urgência nessas ações, até para que as pessoas estejam mais conscientes na necessidade iminente de transformação para a criação de condições favoráveis a uma sociedade mais justa e equilibrada.

Na resposta a seguir, ela fez a analogia de que "estamos querendo ir para a Lua de Fusca" para defender que essa mudança seja mais estrutural e ocorre no 
modelo mental (mindset) das pessoas. Somente assim, afirma, existe a chance de haver uma mudança de patamar na criação de ações mais efetivas e transformadoras.

Essa questão da urgência também é importante. Eu preciso atuar hoje, não é daqui um mês, eu não posso pensar em fazer alguma coisa daqui trinta anos. Eu tenho que atuar hoje na minha casa, na minha comunidade, e por aí vai. Então, caminhamos muito mesmo, mas agora nós precisamos avançar. Eu uso uma figura que eu cito que diz que a nossa ambição é tão grande, e as necessidades que temos de mudanças, de novos padrões de consumo e produção, de uma economia de baixo carbono, que as mudanças estruturais são muito grandes. Então, eu digo que estamos querendo ir para a Lua de Fusca. Porque nós não mudamos o veículo. Mudamos a ambição, mas continuamos com os mesmos desenhos, o mesmo modelo de gestão, os mesmos lugares, a mesma arquitetura. Agora temos que pensar fora da caixa, precisamos ser inovadores, ousar, arriscar. Temos que mudar o nosso modelo de mindset, e isso tudo entra na questão de costumes e valores. Não adianta termos o Acordo de Paris se não mudarmos. Não adianta termos instrumentos legais, obrigações, sobre o que os países e nós dedicamos tanta energia, principalmente as Nações Unidas, se as pessoas que chegam lá para negociar chegam e saem do mesmo jeito. Então temos que atuar nos valores, não vai ser um acordo só. Por isso que eu estou falando que, quando o Donald Trump não vai a um evento desse, acho que temos tantas coisas boas acontecendo lá que eu nem sei se ele vai fazer tanta falta. Os Estados estão comprometidos, as cidades estão comprometidas, as indústrias estão comprometidas, claro que nem todo mundo, mas grande parte. Agora, somos as mesmas pessoas com o nosso modelo mental igual. Temos que fazer mudanças enormes. É nisso que precisamos trabalhar e é por isso que a comunicação é tão importante. Porque não adianta ficarmos só falando entre nós e depois chegarmos à conclusão que nós fracassamos. Não é isso o que nós queremos. Essa é uma mudança de patamar (HAMÚ, 2017, entrevista exclusiva).

Pedro Jacobi preferiu começar com uma visão mais crítica, alinhada com a linha adotada nas publicações e nas respostas apresentadas por Enrique Leff, destacando que o marketing, muitas vezes se sobrepõe, no caso de empresas, ao comprometimento com mudanças estruturais. No entanto, o pesquisador da USP também afirmou que, em termos globais, enxerga uma evolução histórica na atuação das organizações do terceiro setor, o que não ocorre necessariamente no Brasil, onde as iniciativas muitas vezes são intermitentes.

Muitas vezes as ações das empresas são oportunistas, associadas a uma visão de marketing, e menos efetivamente preocupadas em se comprometerem com uma agenda de questionamento mais estrutural, da forma como funciona o sistema produtivo e como funcionam os 
governos. Do ponto de vista mais histórico, de uma análise da evolução dessas organizações do terceiro setor no mundo, não vinculadas a empresas, eu acho que você elas vêm crescendo em importância e o poder de atuarem pela sustentabilidade. Agora, no Brasil, por exemplo, o terceiro setor não vinculado às empresas, sofre altos e baixos. Isso é muito claro justamente pela falta de recursos para poderem viabilizar campanhas, então eu acho que o grande problema está justamente na incapacidade de garantir um número maior de apoiadores e doadores. O Greenpeace é isso, é apoiar uma causa. Quando a Natura tem uma atividade, ela tem uma causa, mas é a causa da empresa e de seus acionistas, que é diferente do Greenpeace. Mas eu acho que, agora, estamos vivendo um momento no qual a sobrevivência de muitas organizações está extremamente fragilizada. Eu mesmo participo de uma organização que, de fato, não tem tido condições de sobreviver. É uma pequena organização totalmente autônoma, que tem um histórico, porque começou em 1997, mas que não tem tido condições de sobreviver e, então existe um componente problemático da própria sociedade brasileira que não se envolve muito em causas comunitárias, em causas mais coletivas (JACOBI, 2016, entrevista exclusiva).

Fernando Almeida optou por uma argumentação mais pragmática e voltou a abordar a importância da liderança para que a transformação para a sustentabilidade ocorra, destacando para isso o conceito que criou de estadista corporativo. Além disso, ele apresentou sua visão como membro de entidades internacionais importantes no mundo para esclarecer como analisa a atuação de empresas no setor e os desafios atuais das ONGs para reverter o quadro em que vivemos.

Liderança é tudo. No meu livro "Os desafios da sustentabilidade", apresento uma expressão que criei: a do estadista corporativo. Seja aonde for, na USP, na Natura, no Ministério do Meio Ambiente, não importa, o ideal é que houvessem milhões de estadistas corporativos liderando processos. O terceiro setor ganha muita importância nessa área de liderança, mas ele atua mais local e, talvez, regionalmente. Nacional e globalmente talvez esteja ainda muito lento. Algumas entidades mundiais, como as preservacionistas, talvez tenham recursos e capacidade de atuar globalmente, mas vou apresentar um dado. Eu fazia um trabalho muito grande junto com o World Business Council for Sustainable Development, o Conselho Empresarial Mundial para o Desenvolvimento Sustentável (WBCSD). Esta é a entidade mundial que congrega todos os CEBDS nacionais e trabalha com produtos, relatórios e ideias fascinantes, porque eles têm muito recurso financeiro. $O$ grupo dos associados dessa entidade tem um PIB só menor que o do Japão. Então eles têm esse poder de transformação caso queiram.

Mas, quando eu conversava, eu observava que, naquele grupo enorme de empresas, mais de 100 , apenas $10 \%$ realmente estavam liderando aquela entidade. As demais estavam lá porque não queria perder o conhecimento ou queriam estar atentas às novas 
informações. As outras associações empresariais, em geral, em vez de serem um vetor de mudança, estão muito mais na defesa. Eu não vou nem citar nenhuma, mas no CEBDS eu tentava fazer completamente diferente. Era um instrumento de pressão e não um instrumento de defesa pura e simplesmente. Óbvio que, em algumas situações, eu as defendia de absurdos do governo, do Congresso, mas, em geral, as entidades são instrumentos de defesa e isso não é o melhor papel.

Acredito também que as ONGs, em geral, têm alguns desafios, porque elas tendem a ser muito mais voltadas para o verde, ligadas à preservação e podem entrar em discussões mais complexas para a sociedade, como o saneamento, por exemplo. O Brasil tem péssimas referências de saneamento, péssimos resultados. Outro tema mais recente, e que envolve a todos, é a segurança. Quem vive no Rio de Janeiro e São Paulo sabe bem o que é isso (ALMEIDA, 2017, entrevista exclusiva).

Denise Hamú abordou a necessidade de reinvenção das próprias organizações do terceiro setor para a continuidade de um plano efetivo. Hamú ainda fez a metáfora de que "somos um Fusca caindo aos pedaços" ao se referir à própria organização e revelou que até o modelo das agências deve ser repensado.

A solução está aí. Agora, isso não é fácil. É fácil pensar e falar, agora,
temos que partir para a ação. Nas Nações Unidas, por exemplo, o
nosso secretário geral, o português António Guterres, começou, e eu
espero que ele continue, um grupo de reforma para pensar as Nações
Unidas. Nós não estamos equipados para isso. Nós somos um Fusca
caindo aos pedaços. Aí cria-se a Agenda 2030 que é um foguete e nós
estamos nos estapeando, porque um entra, o outro sai, e precisamos
de continuidade. Então, as próprias agências terão que ser
repensadas. Será que elas ainda precisam existir? Será que o modelo
agora precisa ter todas essas fragmentações que temos, que um cuida
de agricultura, outro de floresta, um de água, outro de mulher, outro
de HIV? Será que esse é o recorte? Nós já estamos entrando nessa
discussão, vai ser uma guerra, porque você imagina uma mudança de
cultura arraigada, uma cultura onde está todo mundo está forjado em
cima de tantas nacionalidades, isso é mexer com muita zona de
conforto. E sobre a sua pesquisa eu adorei, eu estou falando sério. É
importantíssimo o que você está fazendo. Eu espero que seja
excelente a sua tese, que ela aponte alguns caminhos. Vou adorar
receber a pesquisa concluída (HAMú, 2017 , entrevista exclusiva).

A nuvem de palavras apresentada na Figura 32 refere-se às respostas apresentadas pelos entrevistados a esta questão e ilustra as expressões mais utilizadas. Percebe-se uma multiplicidade de termos, o que representa a diversidade do conteúdo apresentado, com destaque para cultura, sociedade, sustentabilidade, exemplo, indicadores, mundo, ser, organização e Brasil. 
Figura 32: Nuvem de palavras sobre liderança do terceiro setor

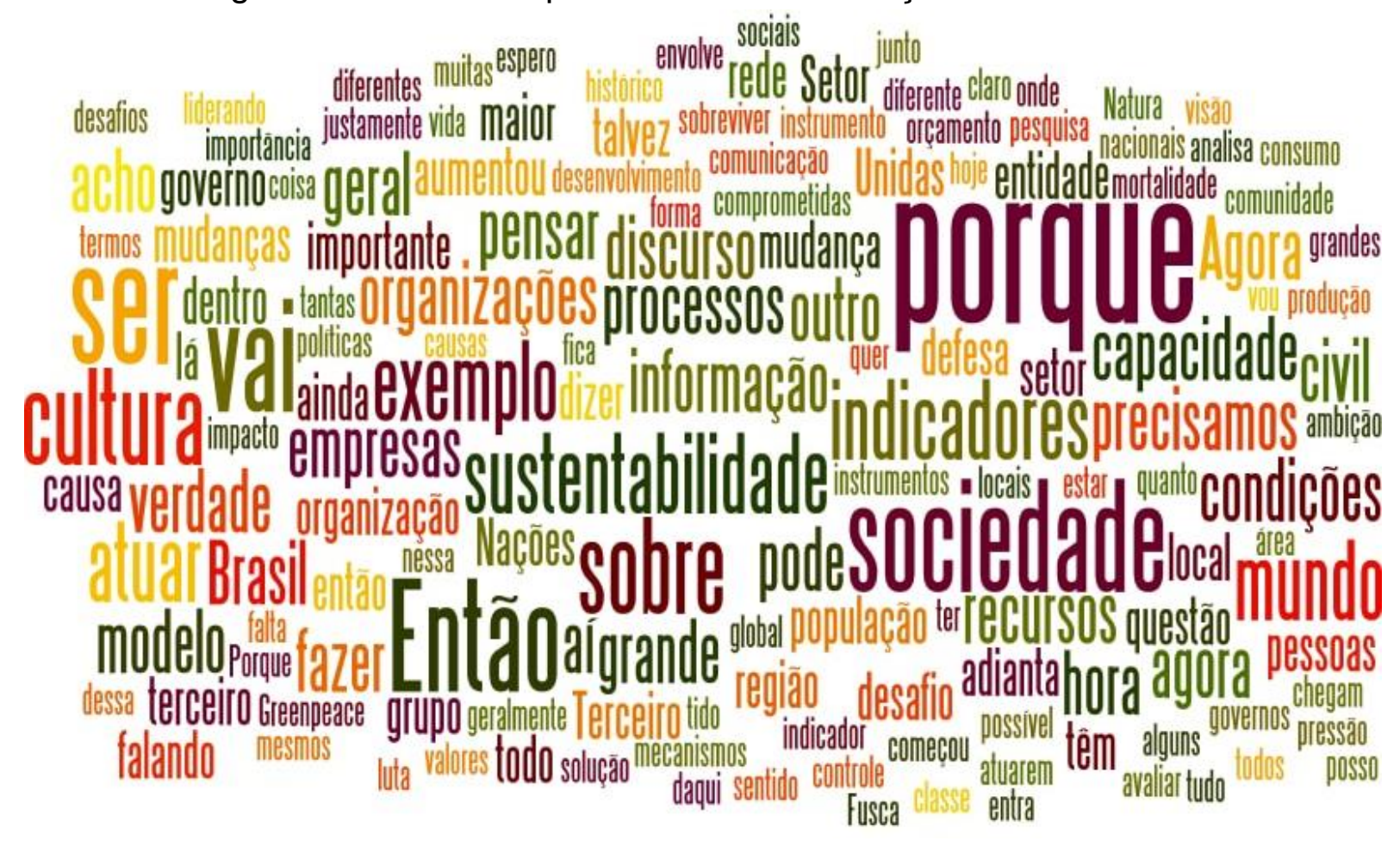

Fonte: Ulsen (2018)

5. Além dos recursos de comunicação, que outras iniciativas são estratégicas para ampliar o debate sobre sustentabilidade e contribuir para uma nova consciência social sobre esta temática?

Como última questão formulada aos especialistas em sustentabilidade e terceiro setor, esta quinta pergunta foi elaborada para apresentar elementos mais conclusivos ao debate com foco nos recursos necessários para estruturar as mudanças sugeridas. Além da atuação da comunicação, com seu potencial e seus limites, há outras áreas de atuação profissional e de conhecimento que, de forma interdisciplinar, podem se integrar nesse desafio.

Para Fernando Almeida, além da liderança, já amplamente apresentada, outro recurso importante é a construção de uma boa relação entre a sociedade civil e as organizações, sobretudo em processos de implementação de projetos que causam impacto socioambiental. 
Em termos de recursos e estratégias, não se consegue isso se não houver sensibilização, se não houver uma liderança dentro da premissa do estadista corporativo. Seja aonde for. Acho que pode ser interessante analisar o trabalho da Fundação Avina, que trabalhava exatamente com terceiro setor. Ela não criava líderes, mas mapeava líderes na sociedade nos mais diversos campos e subvencionava projetos a partir de líderes consagrados. Isso está muito dentro da discussão da comunicação estratégica e da sustentabilidade.

A outra questão que pode ser um vetor na criação de mecanismos que gerem resultados concretos na área de sustentabilidade é a relação biunívoca entre sociedade e empresas durante a implantação de uma usina, por exemplo. Eles se tornam mais sensíveis a uma série de pleitos da sociedade, como, por exemplo, demandas ligadas à saúde e necessidades na educação. Em projetos assim, há exemplos de reconstituição de patrimônio de casas e apoio às pessoas em regiões mais desassistidas de saneamento. Esse é o momento em que se sai do plano teórico e se consegue beneficiar um grupo de pessoas e, também, o próprio sistema ambiental (ALMEIDA, 2017, entrevista exclusiva).

Oded Grajew complementou as atribuições da comunicação a partir de um olhar mais específico da mobilização de pessoas, mas, também, voltou a insistir na temática das políticas públicas, apresentando que esse fator é determinante para qualquer transformação social.

São importantes as manifestações que possam sensibilizar ou constranger os governos, mas também as iniciativas de mobilização. Tudo isso está ligado à comunicação, porque são ações que têm que estar conectadas com a comunicação, que têm que ter visibilidade, porque com a comunicação se ganha e se amplia o alcance. Assim, se produzem os resultados, mas a comunicação tem que ser uma comunicação conectada e relacionada com fatos concretos.

Só para fazer um parêntese, qualquer transformação na sociedade, para o bem ou para o mau, ela se faz por meio de políticas públicas. Isso precisa ficar bem claro. Não é um projeto aqui e outro lá que vai mudar a educação, a saúde, a relação com o meio ambiente as políticas energéticas, as políticas sociais. O que tem poder de transformação pela escala são as políticas públicas. Isso precisa ficar bem claro. Os projetos localizados são bons porque produzem referências, mas o impacto realmente vai ser atingido no momento em que isso ganha escala por meio de políticas públicas. Então, a grande pressão, do meu ponto de vista, deve ser sobre os governos, porque as mudanças vêm com políticas públicas. As empresas já sabem disso e elas aprenderam a usar as políticas públicas a favor delas para que as ações tenham realmente impacto. E aí são várias as estratégias de levantamento de dados, de apurar informações, cobrar promessas, alertar o eleitor, participar das políticas públicas, se envolver com questões de sustentabilidade, participar da vida pública do país, se 
filiar a partidos, se candidatar, estar ativo nas políticas públicas de dentro e de fora (GRAJEW, 2017, entrevista exclusiva).

Enrique Leff também aproveitou a ocasião para reforçar o potencial da comunicação, deixando claro, porém, a relevância do que considera um diálogo de saberes, alinhado com uma comunicação mais horizontal e dialógica, que de fato apure as demandas locais e regionais para gerar transformação.

O diálogo de saberes entre distintos grupos sociais, que fazem refletir e argumentar, dentro da sua visão de mundo, dentro de suas problemáticas ecológicas, existenciais e particulares. E com isso abrir, dentro dessa perspectiva de autoridade os diferentes modos de pensar a questão da sustentabilidade e gerar assim sinergia dentro desse jogo de diferenças (LEFF, 2017, entrevista exclusiva).

Denise Hamú revelou a necessidade de mais acompanhamento de iniciativas tecnológicas, conduzidas pelas novas gerações. Para ela, os jovens também precisam estar envolvidos e engajados a partir de uma linguagem própria direcionada para mudar o modelo mental das pessoas.

Acredito que já falei dos principais. Essa questão de refletir o modelo de governança, de gestão, arquitetura, acho que é por aí. Acho ainda, por exemplo, que precisamos refletir sobre essa questão das startups. Nós precisamos falar a linguagem dos jovens, não podemos nos distanciar deles e não colocar apenas aquele discurso de que estamos preservando hoje para as gerações futuras. Não! Eu estou fazendo isso para que eu possa respirar melhor hoje. Nós ficamos delegando paro o outro e é como se tivessem que nos agradecer daqui algumas décadas. Nós temos que fazer isso para nós. Enquanto nós não nos conscientizarmos muito disso, vai ser difícil. Então é um novo mindset. É por aí mesmo. E a comunicação, como eu disse, ela é fundamental (HAMÚ, 2017, entrevista exclusiva).

Para Fernando Almeida, o fundamental nessa discussão é a clareza a respeito do senso de urgência pelo qual a sociedade está passando. Ele citou pesquisas que revelam a gravidade da atual situação socioambiental e a necessidade, cada vez mais real, de uma mudança drástica nos padrões de consumo. Para Almeida, existem sinais preocupantes e, por outro lado, uma clara ausência de verdadeiros líderes que engajem as pessoas a respeito da sustentabilidade.

Agora, não acho que o senso de urgência tenha perpassado a sociedade. Passa longe disso. Nós não estamos evoluindo de forma 
absolutamente tranquila e garantida nesse tema da sobrevivência. No livro "Os desafios da sustentabilidade", estão algumas tabelas na página 20 do trabalho mais importante que eu participei na minha vida, chamado "Millennium ecosystem assessment", ou "Avaliação ecossistêmica do milênio". A USP participou também. Eu era diretor desse projeto mundial da ONU que reuniu acadêmicos do mundo inteiro para avaliar as condições dos ecossistemas no mundo. Essa tabela é uma referência direta que mostra que a pesca, por exemplo, está condenada a desaparecer possivelmente nos próximos 30 ou 40 anos. Os alimentos silvestres estão decaindo. Combustível de madeira está decaindo. Ou seja, a virada do milênio já foi há algum tempo e realmente não acredito que houve uma mudança nesse cenário claramente apresentado.

Se nós à época tivéssemos o padrão de terrorismo internacional e o padrão de violência nacional atual, nem sei como essa tabela seria colocada, porque essas são duas novas variáveis que, decididamente, só trazem complicação.

Então, ainda tratando de comunicação, não vejo um Nelson Mandela da sustentabilidade nem um Martin Luther King da mudança do clima. Não vejo qualquer grande líder que esteja puxando a sustentabilidade, essa visão da sobrevivência, ou mesmo alguns dos temas, como biodiversidade, por exemplo. Como sustentabilidade tem uma dimensão muito política, eu vejo alguns sinais extremamente preocupantes. Quando existe de um lado do planeta o Donald Trump que se elege do jeito que se elegeu, que fica sozinho no G20 e, mesmo assim, descarta considerações sobre a mudança do clima, e o Vladimir Putin do outro lado do mundo, que nem comenta o assunto, nós estamos em uma situação bem complexa, muito difícil. Mas, eu sou um otimista. Se não fosse, não estaria aqui conversando com você (ALMEIDA, 2017, entrevista exclusiva).

Denise Hamú enxerga essa questão a partir da necessidade de uma visão mais integrada, que de fato resolva os problemas atuais de desenvolvimento com a implementação de soluções mais equilibradas e favoráveis aos atores envolvidos.

A Agenda 2030 é um documento muito inspirador, são tantas as metas, mas também é importante a parte filosófica porque está ali o que a gente precisa. Claro que a gente precisa endereçar os problemas dos Objetivos de Desenvolvimento Sustentável, a gente vê a questão do enfoque mais integrado com o meio ambiente, a geração de emprego e renda, a erradicação da pobreza e toda essa parte social que é fundamental para nós. Isso tudo nós precisamos endereçar. $\mathrm{E}$ acredito que o que nós precisamos é colocar esses pilares de forma complementar. Voltando ao início da minha fala, não adianta nós só preservarmos uma nascente, temos que preservar quem mora lá, quem vai receber a água, então temos que ver que trabalhamos em um sistema vivo, orgânico, com pessoas interagindo com os recursos naturais e por aí vai. $O$ que precisamos é conseguir ter um pouco mais dessa visão mais integrada. E enxergar que uma ação tem consequência na outra (HAMÚ, 2017, entrevista exclusiva). 
Oded Grajew reforçou a importância que credita à comunicação, que seja, na opinião dele, qualificada, com credibilidade e construída a partir de indicadores. $O$ presidente emérito do Instituto Ethos e presidente do Conselho da Oxfam Brasil também destacou conceitos complementares, como políticas públicas, cultura e efeitos.

O alvo são as políticas públicas e a comunicação é fundamental porque é ela que forma a cultura, mobiliza as ações e exerce a pressão. E a comunicação é uma ferramenta, tanto que o Donald Trump, por exemplo, usa bastante a comunicação porque sabe que o poder dele depende disso. Então, pensar na comunicação sob todas as suas formas é fundamental para quem quer defender uma causa, porque na realidade o terceiro setor é formado por pessoas e organizações que defendem causas. Isso depende de se ter adesão dos outros, formar uma cultura e produzir efeitos. Assim, tem que ser uma comunicação qualificada, baseada em indicadores, dados e informações detalhadas. Não pode ser uma comunicação sem credibilidade ou muito superficial (GRAJEW, 2017, entrevista exclusiva).

O pesquisador Pedro Jacobi preferiu analisar a contribuição da educomunicação, com indicação das suas vertentes. Ele destacou ainda ser favorável a diversas iniciativas, que sejam complementares e ampliem o trabalho, bem como ações mais participativas, envolventes e direcionadas para as novas gerações.

A educomunicação é uma forma de se adaptar. Na verdade, não é que seja algo tão diferente. Eu acompanho os trabalhos de educomunicação há mais de vinte anos. Não é que isso seja tão diferente, só que é uma forma mais focada em uma atuação educativa, com foco educativo, no sentido de ser essencialmente baseado em práticas educativas. Eu, por exemplo, trabalho muito com a visão de aprendizagem social. Nós fizemos uma publicação na forma de um manual, intitulada 'Temas atuais em mudanças climáticas'. Esta publicação é um material pedagógico, disponível digitalmente para professores e alunos trabalharem com os temas atuais de mudanças climáticas, conceitos elaborados por professores da USP. Nós reeditamos o material dentro de uma perspectiva educativa. Então, tudo isso são formas de trabalhar com a educomunicação. Essa é uma maneira talvez mais estática por ser um manual, mas aí vai depender muito da dinâmica de como trabalhar. Eu estou totalmente aberto para isso. Para mim, a principal questão é que a educomunicação, assim como outras iniciativas, não tem a receita pronta. Para mim esse é o ponto fundamental. Eu tenho essa visão das coisas. O que eu quero dizer é que ninguém está inventando a roda, mas eu acho que a importância da educomunicação está em sair um pouco do lugar de que, digamos, muitas vezes as iniciativas vêm com receitas prontas e 
que o trabalho das empresas já vem com uma ajuda muito fechada para responder aos interesses das empresas. Nesse sentido, eu acho que é importante todo tipo de iniciativa, mas tem que ampliar muito mais o trabalho com fóruns, com dinâmicas cada vez mais participativas, envolventes, e obviamente buscando uma forma de se comunicar com as gerações mais novas que, hoje, estão todas associadas a iniciativas digitais (JACOBI, 2016, entrevista exclusiva).

Finalmente, Enrique Leff destacou o imediatismo do senso de urgência mandatório para gerar uma mudança estrutural na sociedade atual, a ponto de considerar que todos os recursos são necessários para despertar a consciência das pessoas. Leff ainda defendeu a necessidade de integração da comunicação com a educação na escola e nos ambientes familiares e uma revolução que permita a sobrevivência da espécie humana.

O problema ecológico é tão grave que devemos usar todos os recursos
e meios para despertar a consciência da gravidade da situação em
que nos encontramos. Isso vai desde a educação na família. A escola
deve incorporar a ética da convivência, do cuidado, e da sinergia com
a natureza. Fundamental é mudar a mente e o coração. A mente:
possuir outra visão do universo e da Terra, esta não como um baú de
recursos infindáveis, mas como um super ente vivo que deve ser
cuidado. Um coração: não basta a razão científico-analítica.
Precisamos da razão sensível e cordial que nos anime a defender a
vida e a ter compaixão por todos os seres que sofrem e principalmente
nos leva a respeitar a cada ser porque possui um valor intrínseco,
independentemente do uso humano que fazemos dele. Sem essa
revolução da mente e do coração dificilmente superaremos o atual
drama que pode se transformar numa tragédia. Temos que mudar e
habitar de forma diferente a casa comum se quisermos sobreviver e
continuar nosso ensaio civilizatório. Caso contrário chegou o tempo da
tribulação da desolação, falando em termos bíblicos, quer dizer,
chegou o fim de nossa espécie humana (BOFF, 2016, entrevista
exclusiva).

A nuvem de palavras da Figura 33 representa, de forma visual, as palavras mais utilizadas pelos entrevistados para responder a esta questão. Observa-se a citação de diferentes termos que foram poucos utilizados, como impacto, educação, cultura, saúde e ambiente. Por outro lado, os termos sociedade, educomunicação, políticas públicas, empresas e ser foram os mais utilizados. Além disso, a sustentabilidade também mereceu destaque e o conceito de comunicação visivelmente foi o mais utilizado pelos entrevistados. 
Figura 33: Nuvem de palavras sobre recursos para uma nova consciência social

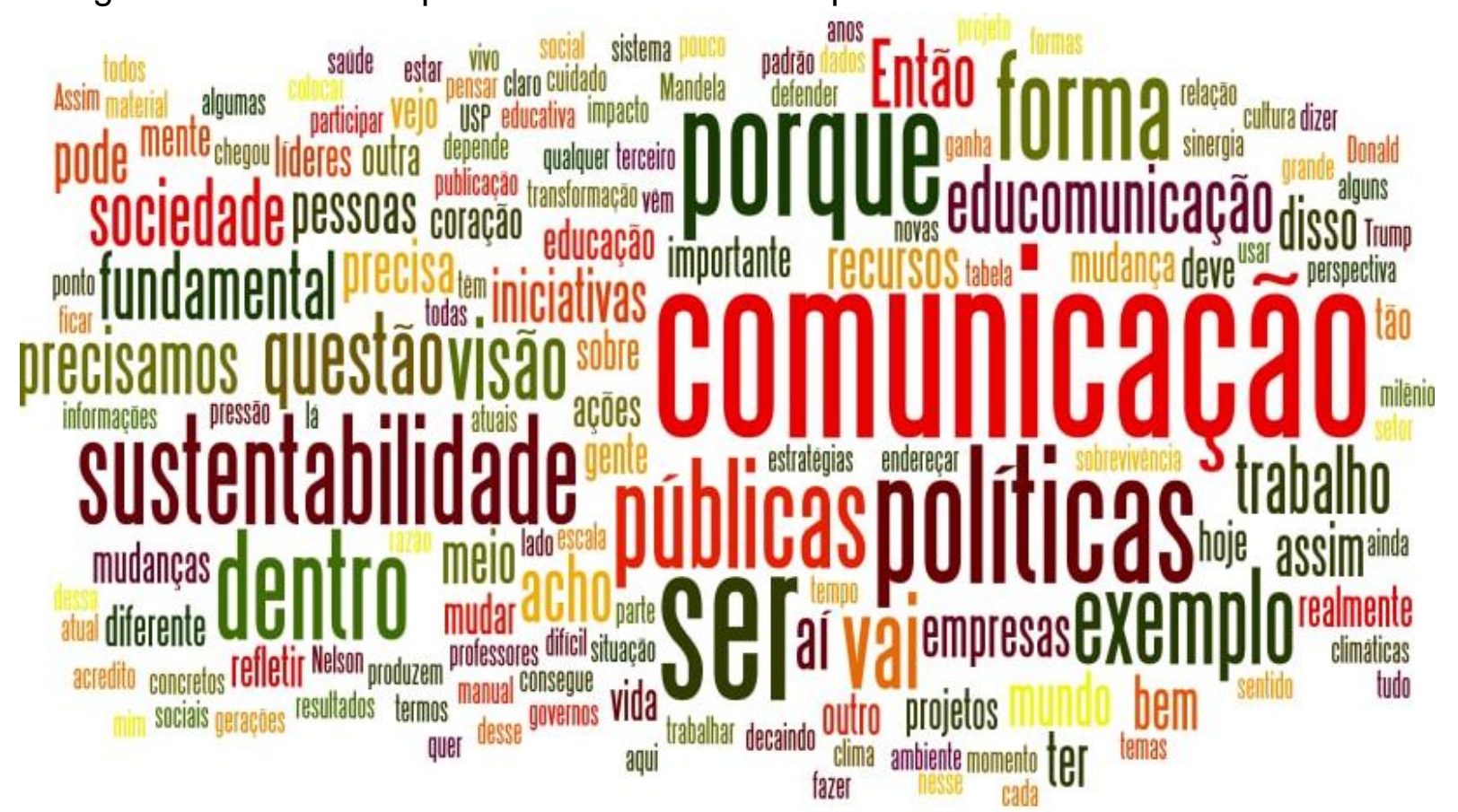

Fonte: Ulsen (2018)

\subsection{Conclusões}

Todas as respostas foram fundamentais para compreender como a sustentabilidade tem sido vista pelos especialistas da área e como a comunicação organizacional está integrada às experiências do terceiro setor. A experiência comprovada na área de cada um deles foi fundamental para compreender o objeto de pesquisa e desenhar um modelo mais efetivo de comunicação focada no desenvolvimento sustentável.

Com relação à questão apresentada aos entrevistados a respeito de qual é o papel dos governos e dos grupos intergovernamentais para o cumprimento dos acordos firmados em conferências sobre o clima no âmbito internacional, o objetivo foi compreender o alcance dessas organizações em políticas públicas de desenvolvimento nacional sustentável. Os entrevistados concordaram que se trata de uma responsabilidade inerente aos governos pois, se assinaram os acordos, devem cumprir, embora há necessidade de que eles avancem e, muitas vezes, esbarrem em campos ambíguos de interpretação sobre a relevância que se dá aos acordos pelo governo em questão. 
Evidenciou-se que existe uma escala de cumprimento dos acordos e que este elemento está também associado à liderança exercida por cada um dos governos e seus representantes no país em que atuam e na região geográfica de sua influência. Sem dúvida, trata-se de um tema complexo e muitas vezes a sociedade civil tem dificuldades de compreender o seu conteúdo, o que reforça a necessidade de organizações do terceiro setor fortes que atuem com uma comunicação mais fluida para transmitir este conteúdo da forma mais simples possível.

Cabe destacar que esta articulação é necessária para a implementação de políticas públicas de transformação da sociedade e que, embora sujeitas às influências e pressões de grandes corporações globais, é responsabilidade dos governos na medida que assinam acordos e participam deste tipo de iniciativa global para criar condições de crescimento sustentável.

Os entrevistados também foram questionados a respeito de como as organizações do terceiro setor podem contribuir para reduzir impactos socioambientais e diminuir os problemas de preservação do planeta, questão formulada para ajudar a delinear a atuação do terceiro setor para disseminar práticas sustentáveis. Necessariamente a sociedade civil precisa atuar exercendo pressão e o terceiro setor nesse sentido é essencial para se contrapor às lógicas corporativistas e governamentais, o que ocorre geralmente por meio de mobilização social e pode ser aperfeiçoado com maior integração entre todos os atores sociais envolvidos.

Quando é fiador de credibilidade para opinar sobre temas de interesse coletivos, o terceiro setor contribui para a criação e a construção de espaços de cidadania, fomentando condições para que a sociedade civil organizada tenha maior poder de atuação e seja protagonista no desenvolvimento de ações mais coletivas e menos individualistas. A respeito de como a comunicação organizacional tem contribuído para incentivar o debate sobre sustentabilidade e sensibilizar as pessoas para criarem ambientes mais sustentáveis, tema da terceira pergunta, a comunicação deve ser mais estratégica e operada dentro da gestão organizacional, trabalhando a favor de causas com uma linguagem assertiva e que sensibilize e engaje novos públicos.

Para tanto é imprescindível que haja um discurso claro e uma fundamentação técnica que embase os argumentos, sendo efetiva para engajar os públicos e incentivar a operacionalização de trabalhos coletivos e avaliando constantemente se 
os resultados atingidos são suficientes. Outros elementos também podem ser complementares nesse sentido, como por exemplo a inovação da comunicação em novos formatos e a utilização de exemplos inspiradores de práticas de sucesso já desenvolvidas em outras iniciativas. Comprovação prática do discurso praticado e mecanismos de transparência também dão visibilidade e controle a respeito dos impactos gerados.

Na sequência também foi considerado avaliar qual é a importância do terceiro setor para liderar pessoas e organizar movimentos para promover a melhoria da sustentabilidade em termos locais regionais nacionais e globais, tema da quarta questão. Diante do cenário de pós-modernidade em que há desagregação das organizações e impactos diretos em transformações de âmbito local, o trabalho integrado entre organizações e sociedade civil pode realmente contribuir para o desenvolvimento de ações mais sustentáveis.

Nesse sentido é oportuno que se aproveite o momento de maior acesso das pessoas a temas socioambientais, sendo necessário importante também considerar a necessidade de contextualização histórica a respeito da evolução dessa situação. Uma reinvenção organizacional nos modelos pensados e implementados também pode ser decisiva, principalmente se associada à implementação de políticas públicas e indicadores de resultados claros, transparentes e constantemente atualizados.

Finalmente, a liderança no terceiro setor para engajar as pessoas pode passar por uma escala que, de alguma forma, avalie a adesão dessas mensagens ao cotidiano de cada um, sendo desta forma importante considerar e prever qual é o impacto esperado das mensagens de sustentabilidade. Isso deve ocorrer sobretudo em um momento de dispersão da atenção coletiva e excesso de canais e informações, com necessidade de mudança de atitudes e comportamentos, mas, sobretudo, de reinvenção do modelo mental do ser humano.

Partindo para a última questão, é evidente que, além de comunicação, existem outras iniciativas e recursos potencialmente estratégicos para ampliar o debate sobre sustentabilidade e contribuir para uma nova consciência social a respeito do tema. $A$ liderança é uma variável essencial nesse processo, pois agrega poder de mobilizar pessoas e facilitar a implementação de políticas públicas. Claro que é necessária uma reflexão a respeito de qual tipo de liderança é adequado para cada situação, ainda assim propõe-se que a comunicação praticada por essas pessoas seja a mais 
horizontal e dialógica possível, já que, enquanto proposta de desenvolvimento, a sustentabilidade não pode oprimir grupos com modelos próprios, mas, ao contrário, praticar uma comunicação de fato comunitária que envolva os atores e implemente soluções coletivamente benéficas.

Conteúdos ligados às relações públicas comunitárias, à comunicação organizacional, à educomunicação e aos estudos de cultura podem contribuir nesse processo. Além disso, o acompanhamento de iniciativas tecnológicas é essencial, inclusive para uma aproximação que sensibilize e engaje as novas gerações. É necessário também esclarecer que a abordagem desse conteúdo precisa ser constantemente refletida e o senso de urgência a respeito dos destinos impostos pelo homem ao planeta deve estar mais claro, sobretudo quando associado a conteúdos produzidos com credibilidade, embasamento técnico, visão analítica e focados em soluções práticas.

A integração do discurso com exemplos e resultados que tragam mudanças estruturais a diferentes ambientes também é fundamental. Da mesma forma, é necessário o apoio na liderança e nos conteúdos fundamentados em pesquisas para integrar à dinâmica um respaldo científico somente observado em pesquisas sérias conduzidas por instituições idôneas direcionadas para iniciativas dessa natureza.

Figura 34: Nuvem de palavras com todas respostas dos especialistas em sustentabilidade

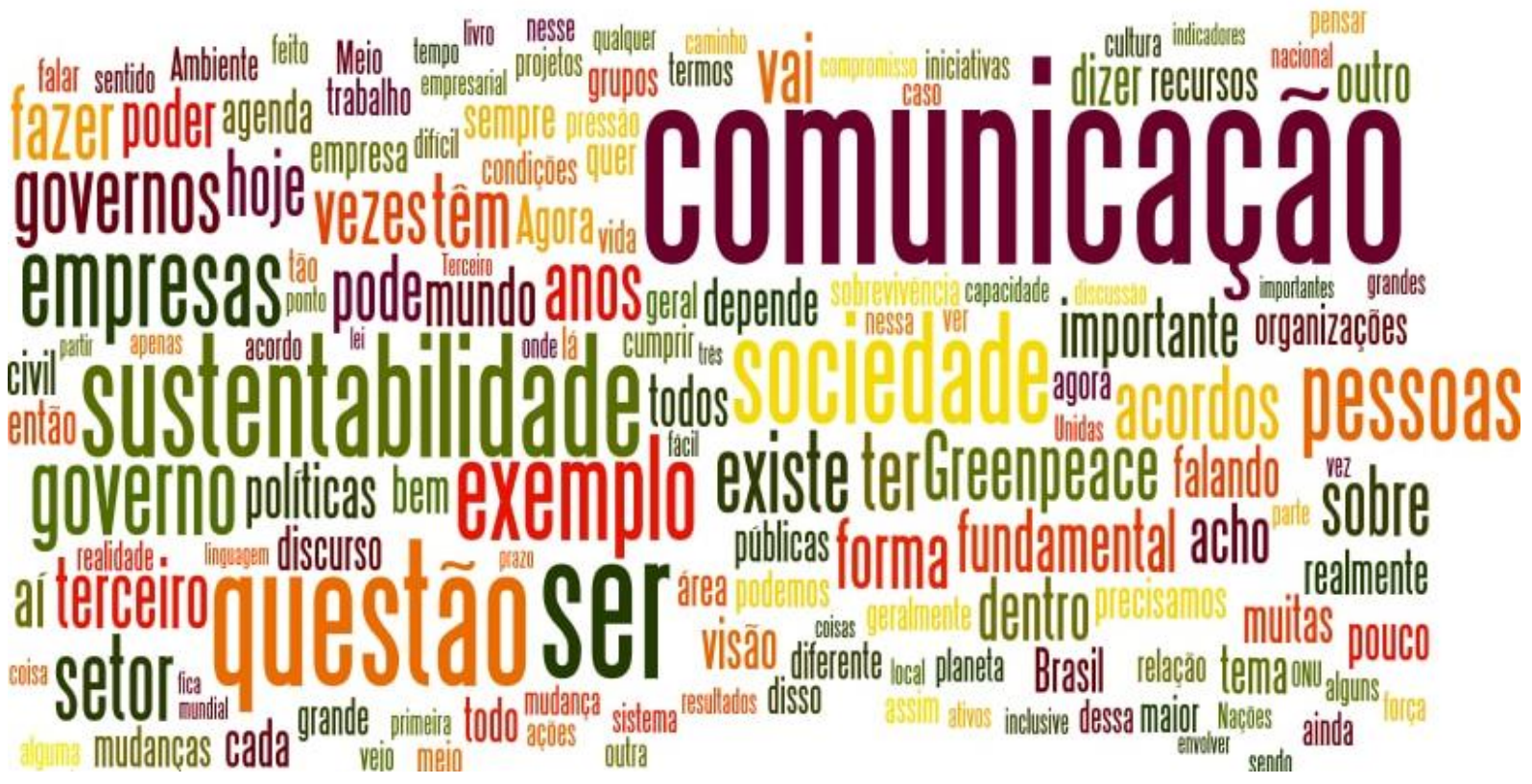

Fonte: Ulsen (2018) 
Figura 35: Nuvem de palavras com respostas de Denise Hamú

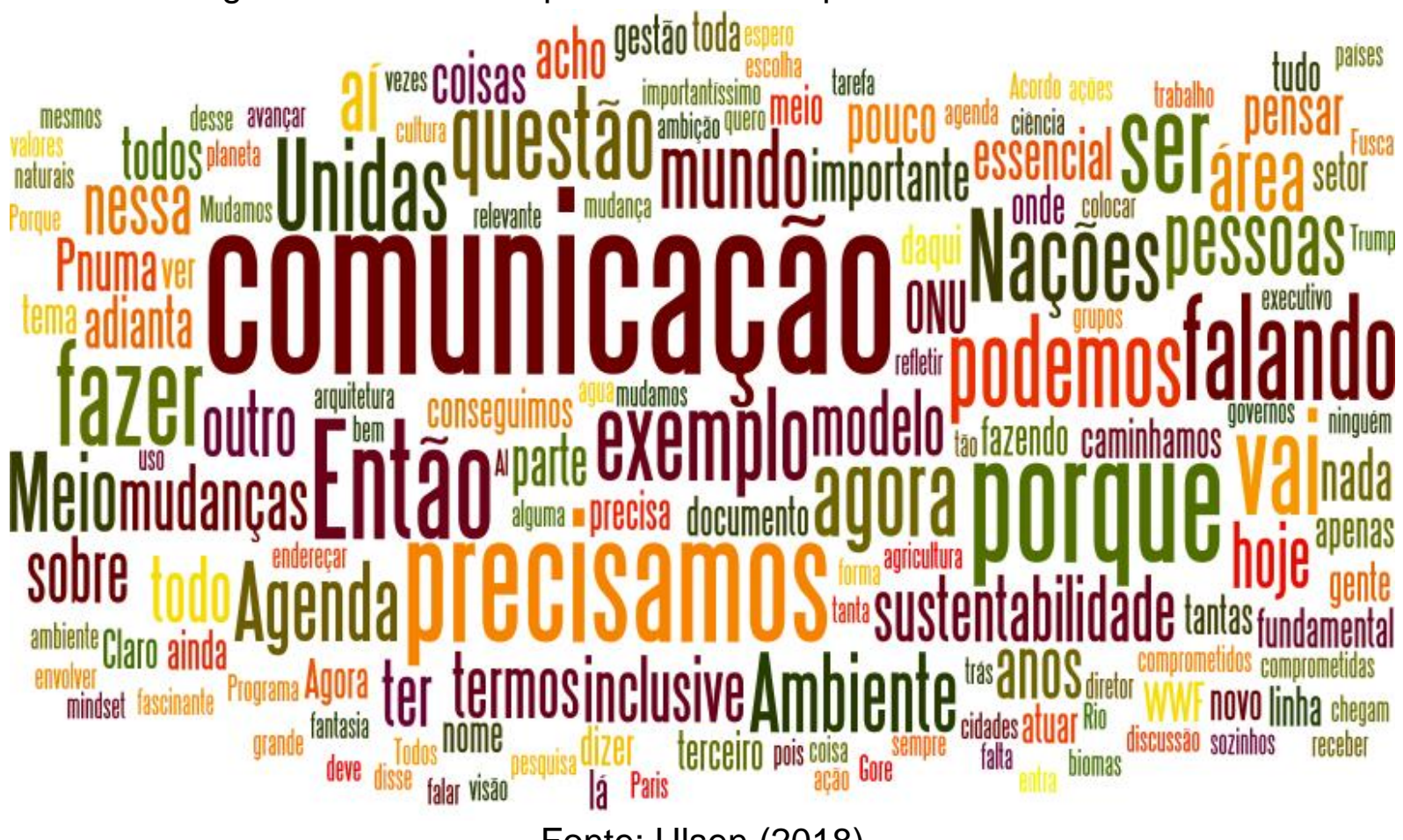

Fonte: Ulsen (2018)

Figura 36: Nuvem de palavras com respostas de Enrique Leff

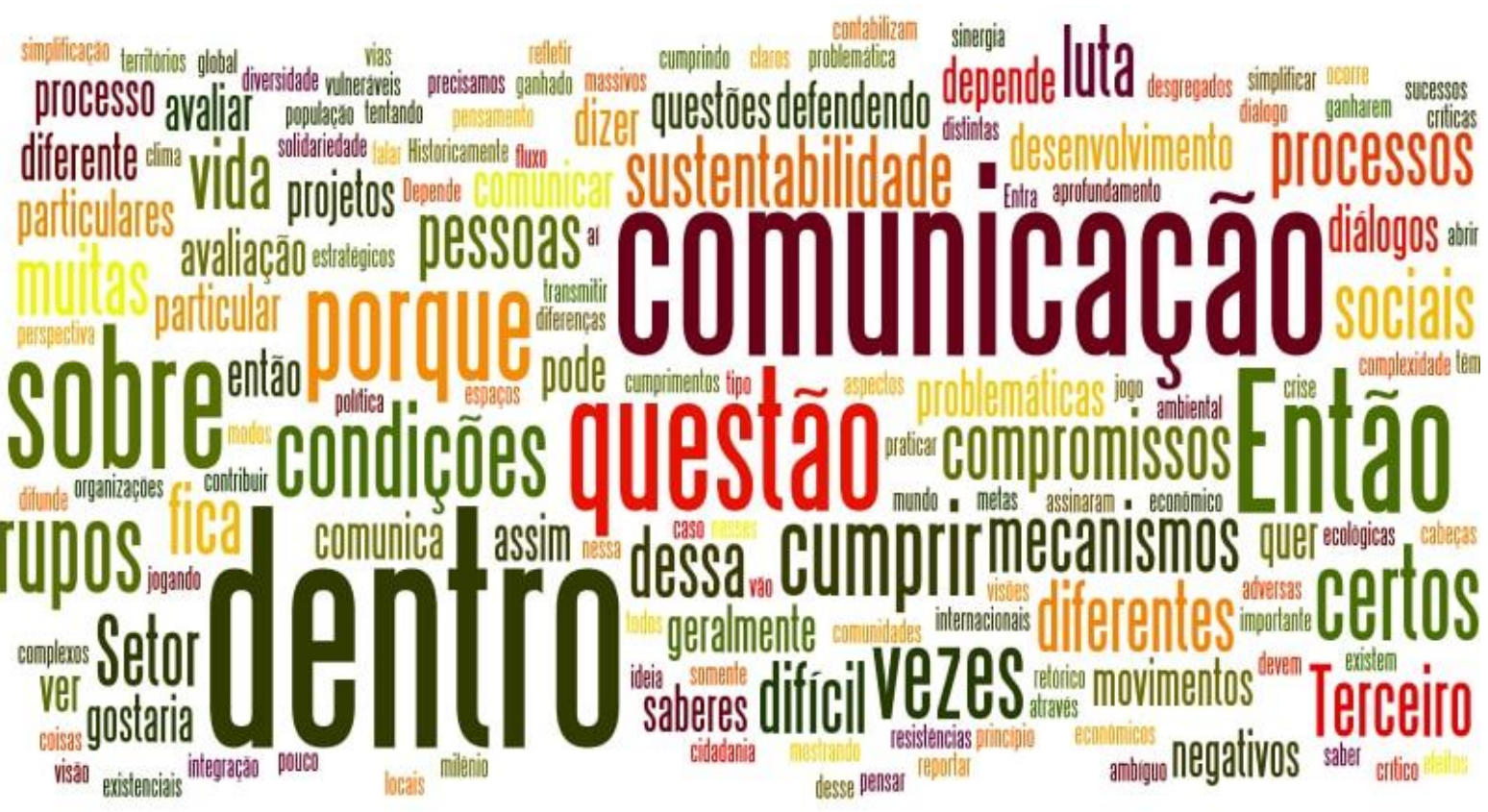

Fonte: Ulsen (2018) 
Figura 37: Nuvem de palavras com respostas de Leonardo Boff

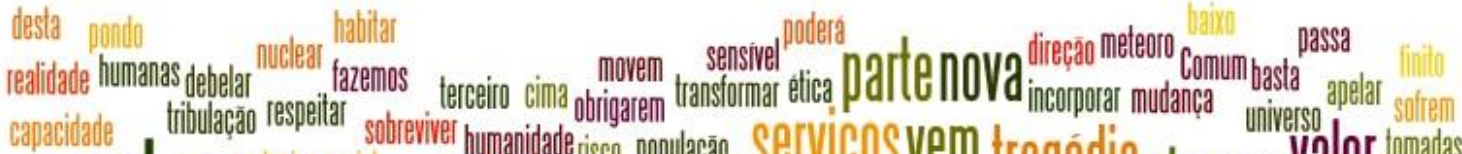
aCOICLS

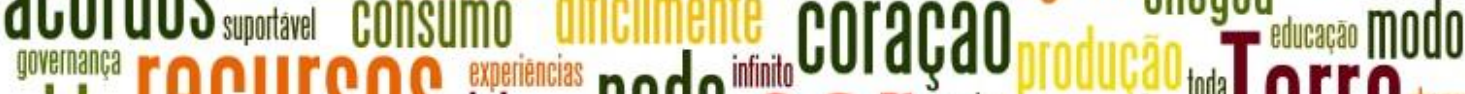

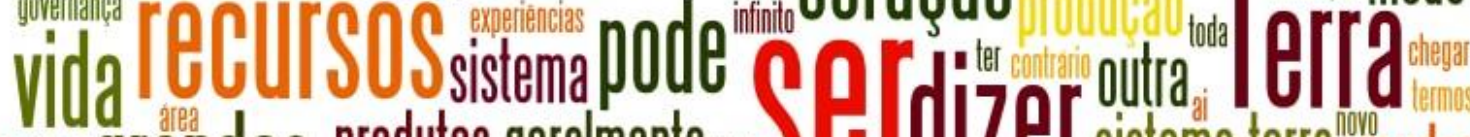

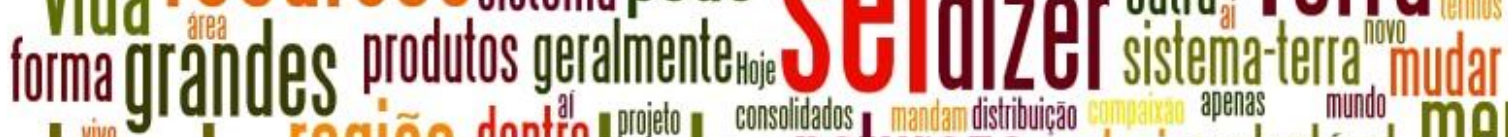

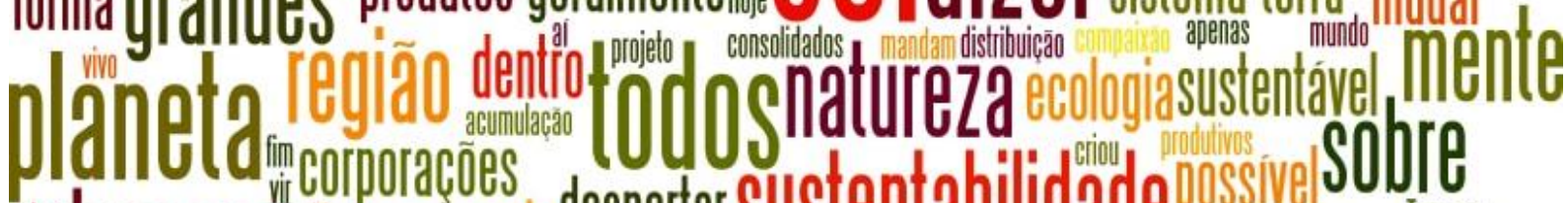

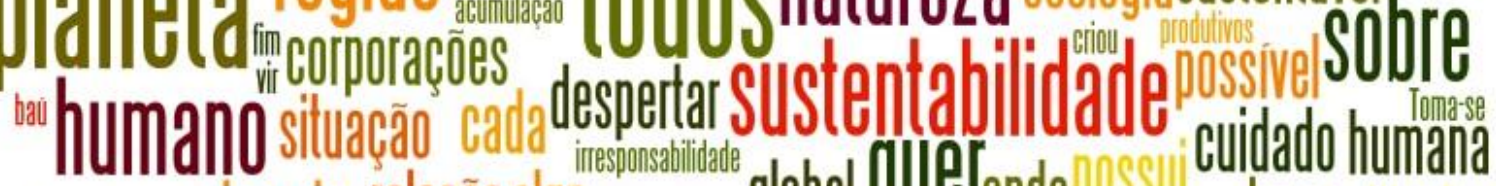

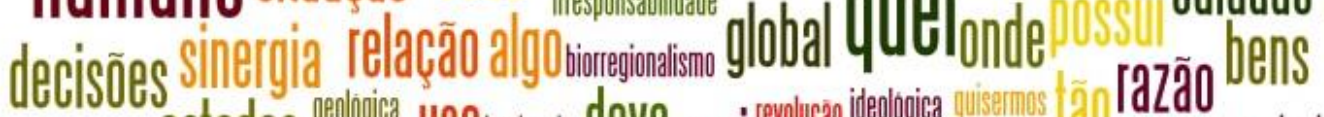

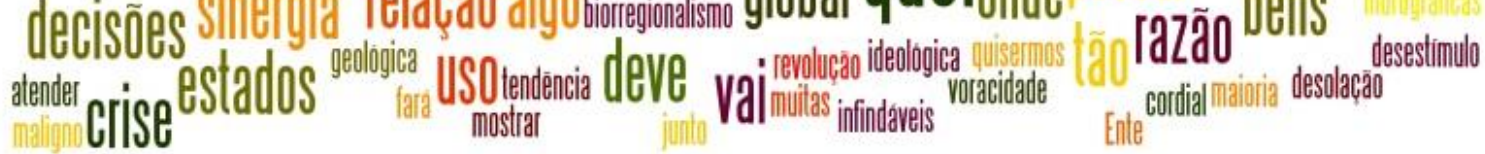

Fonte: Ulsen (2018)

Figura 38: Nuvem de palavras com respostas de Fernando Almeida "

\section{exis (eme} enthe

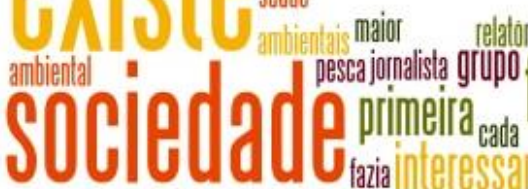

man nuncer Outro local acordos temenices setores tavez

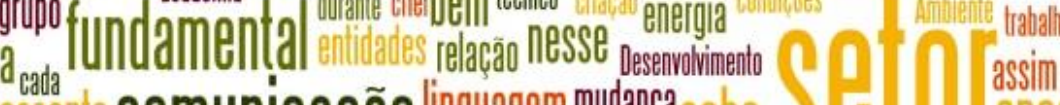

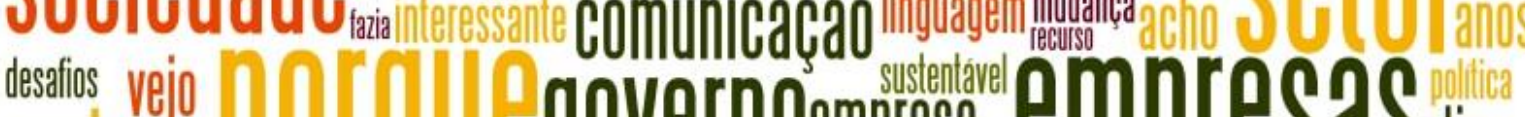

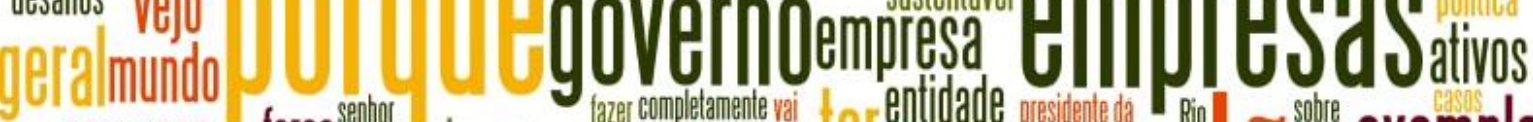

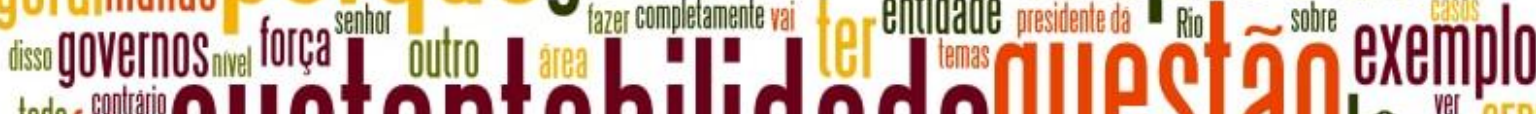

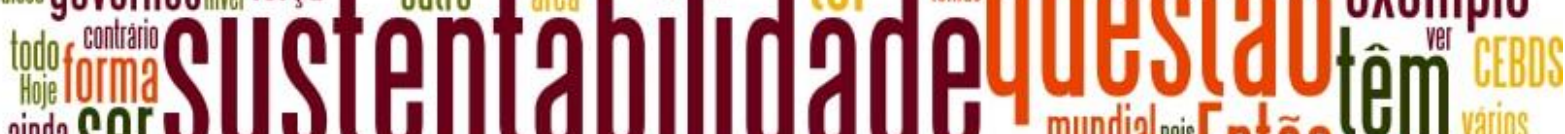

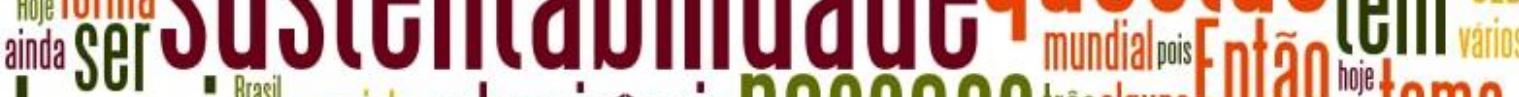

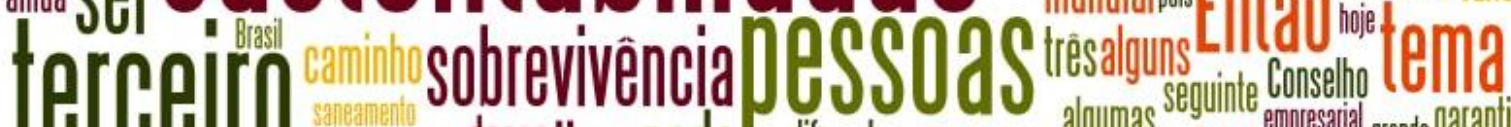

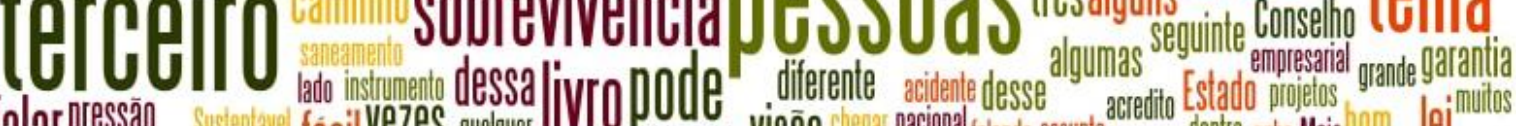

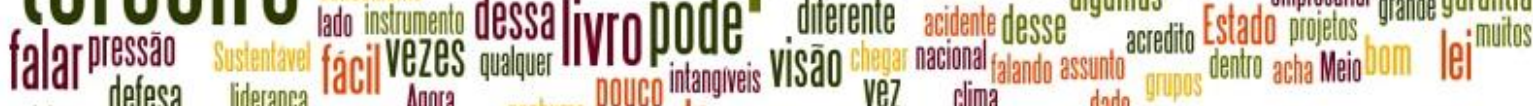
lideres mefesa liderança
muitas

Fonte: Ulsen (2018) 
Figura 39: Nuvem de palavras com respostas de Pedro Jacobi

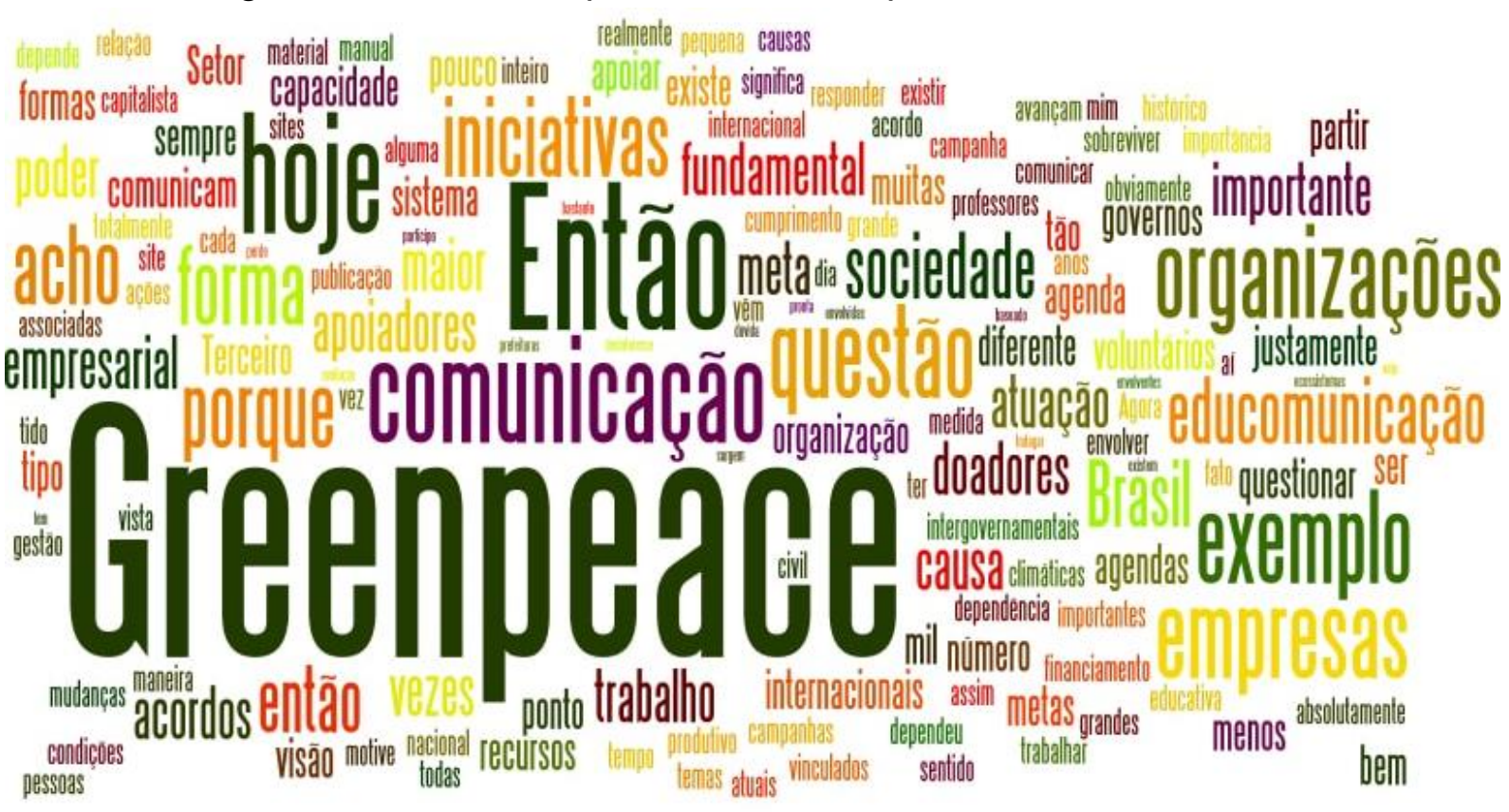

Fonte: Ulsen (2018)

Figura 40: Nuvem de palavras com respostas de Oded Grajew

thoss

Agora forma reglmente reaglidade informaçä̃o

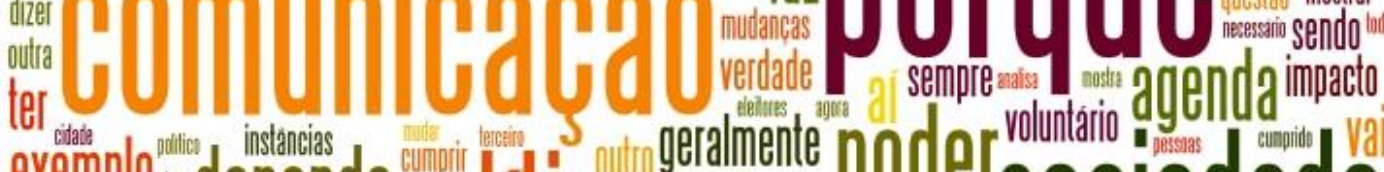

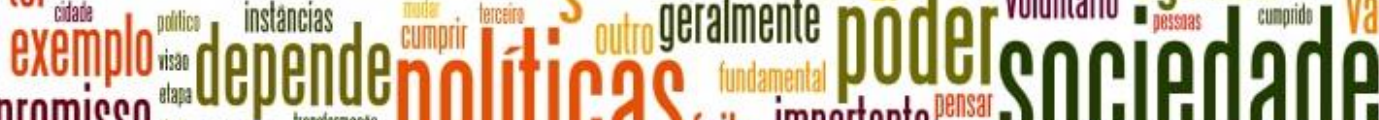

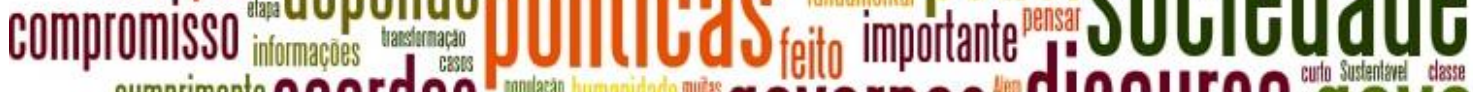

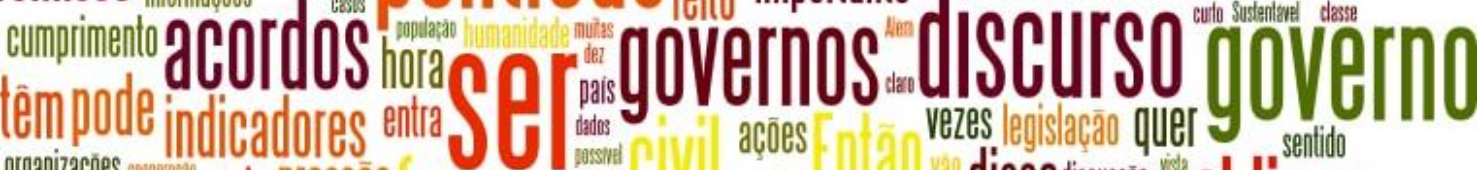

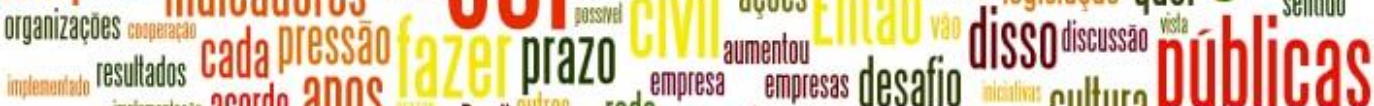

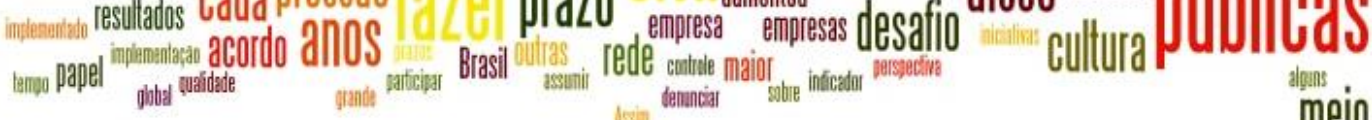

merio

Fonte: Ulsen (2018) 


\section{Considerações finais}

A retrospectiva histórica revela a importância crescente da comunicação organizacional. Nas estruturas mais contemporâneas, a tendência é que a participação das equipes de comunicação seja incentivada com cada vez mais elementos para se tornarem mais produtivas, valorizando a criatividade, desenvolvendo novos recursos e tornando as ações mais ágeis e bem fundamentadas.

A contribuição da comunicação nas organizações também está em participar de situações complexas, já que um bom planejamento da área pode estabelecer relacionamentos entre todos os públicos estratégicos para as organizações, favorecendo a ampliação do diálogo e a criação de canais e meios de comunicação.

É possível ampliar os efeitos da comunicação para a sustentabilidade com métodos, técnicas, linguagens e discursos que podem ser utilizados para esta finalidade. Há uma multiplicidade de públicos e percepções em constante transformação. Nesta pesquisa, a proposta foi compreender os ideais da sustentabilidade e sugerir uma atuação prática das organizações para um mundo mais justo e equilibrado.

Contribuir para que as pessoas acreditem mais no desenvolvimento social somente é possível se as iniciativas do terceiro setor forem planejadas, pois muitos resultados somente serão conseguidos se a discussão for fundamentada em um trabalho responsável de elaboração de materiais e conteúdos bem embasados, formatados em produtos acessíveis aos públicos, criados com uma linguagem que gere significado às pessoas envolvidas.

Nessa perspectiva, esta tese teve como objetivo pesquisar e analisar como a comunicação organizacional é desenvolvida no terceiro setor e quais seriam os impactos das ações dessas organizações direcionadas à sustentabilidade para 0 benefício da sociedade. $\mathrm{E}$, de forma complementar, os objetivos específicos foram analisar as práticas de comunicação e sustentabilidade adotadas pelas organizações no terceiro setor; verificar se a comunicação no terceiro setor tem contribuído para aumentar a consciência sobre a importância da sustentabilidade; buscar aportes teóricos para uma base conceitual da comunicação para a sustentabilidade e fundamentos para ampliar a sustentação da conceituação desse processo; apurar a 
incorporação do conceito de sustentabilidade nas organizações pesquisadas e contribuir para gerar mais consciência social com uma comunicação estratégica.

Esta perspectiva está justificada na proposta de desenvolver pesquisas sobre comunicação em uma perspectiva transformadora, com o resgate da função social da área. Além disso, outra justificativa foi a necessidade de pesquisas que estabelecessem convergências entre comunicação e sustentabilidade para ampliar a qualidade de vida das pessoas e preservar a natureza. Acredita-se que uma formatação planejada da comunicação produz um discurso mais assertivo e a ampliação dos impactos com o devido mapeamento dos públicos e a análise dos indicadores de resultados.

Sendo assim, os procedimentos metodológicos envolveram processos científicos que fundamentaram o percurso da pesquisa com diferentes métodos de coletas de dados em realidades distintas. O trabalho teve início com a pesquisa quantitativa e a aplicação de um questionário disponibilizado para todas as organizações do terceiro setor que atuam com sustentabilidade no Brasil cadastradas em dois bancos de dados. Para complementar a pesquisa quantitativa, a pesquisa qualitativa foi realizada por meio de entrevistas em profundidade com especialistas e gestores de organizações de referência envolvidos diretamente com a temática.

Com relação às hipóteses, elas foram comprovadas ou refutadas, de modo integral ou parcial, conforme detalhado a seguir nas respostas a cada uma das questões de pesquisa. Ainda assim, é possível adiantar que a primeira hipótese foi confirmada, atestando que a comunicação organizacional é estratégica para fomentar o desenvolvimento de práticas sustentáveis na sociedade. Com recursos disponíveis, os comunicadores são essenciais para implementar práticas de gestão que engajem os públicos a favor de causas e envolvam da sociedade em ações de transformação socioambiental.

Em decorrência dessa consideração, a segunda hipótese, que indicava se a comunicação organizacional reúne técnicas para engajar públicos em ações sociais e ambientais, também foi comprovada. Assim, a proposta é compreender a comunicação para a sustentabilidade no terceiro a partir de um processo que transita por diferentes elementos, como níveis, abordagem, transdisciplinaridade, liderança, códigos, meios, linguagem, sentidos, frequência cerebral, públicos de interesse, repertório, perfil do gestor, prazo, escala de mudança, recursos envolvidos, percurso, 
abrangência e frequência. É necessário, também, um gestor que opere uma boa curadoria do conteúdo para oferecê-lo de modo customizado de forma que tenha significado aos públicos.

A terceira hipótese indicada que as organizações do terceiro setor desenvolvem ações de comunicação mais direcionadas para a divulgação das suas atividades e pouco para o desenvolvimento da sustentabilidade, tendo sido parcialmente comprovada e parcialmente refutada. Nesse caso, a pesquisa identificou uma realidade do terceiro setor que evidenciou a necessidade de evolução das estruturas organizacionais. Apesar de ter avançado no Brasil, o terceiro setor precisa ser mais profissionalizado e não tem, na maior parte das iniciativas, os investimentos necessários para contratar equipes qualificadas. Além disso, a pesquisa também identificou pouca fundamentação científica nas experiências relatadas de comunicação.

Partindo para a quarta hipótese, de que o terceiro setor reúne organizações que possuem recursos limitados e uma estrutura pouco desenvolvida de comunicação, esta foi comprovada com algumas observações. Existem organizações de grande porte com equipes mais profissionalizadas que costumam inspirar outras iniciativas envolvidas na disseminação de experiências de transformação. Porém, a pesquisa concluiu que elas convivem com desafios diários, como a recorrente comprovação da relevância da área e a necessidade de atualização decorrente do surgimento de novos formatos de interação com os públicos. A pesquisa comprovou ainda que a ampla predominância é de estruturas pequenas, sendo que mais da metade delas têm até vinte funcionários, colaboradores ou voluntários e quase metade das organizações não têm uma área específica dedicada à comunicação.

As bases conceituais desta pesquisa foram definidas a partir de uma base teórica de pesquisadores que transitam nos eixos temáticos da comunicação organizacional, da sustentabilidade e do terceiro setor. Neste caso, sobre comunicação organizacional foi apresentado um retrato panorâmico sobre a área fundamentado nos estudos de Margarida M. Krohling Kunsch, Gaudêncio Torquato, Wilson da Costa Bueno, Rudimar Baldissera e Cicilia M. Krohling Peruzzo.

A respeito da sustentabilidade, evidenciou-se uma ampla pluralidade conceitual e diversas vertentes de compreensão relacionadas ao tema, tendo sido utilizados, para esta pesquisa, estudiosos brasileiros e estrangeiros que compreendem a 
interface necessária estabelecida com a comunicação e o terceiro setor. Neste caso, a base teórica foi fundamentada em Fernando Almeida, Leonardo Boff, Moacir Gadotti, John Elkington, Ignacy Sachs e Enrique Leff.

Seguindo a questão da base teórica, no terceiro setor foram identificados avanços importantes de pesquisas nos últimos anos, sendo que os autores indicados a seguir embasaram o referencial teórico desta pesquisa. É o caso de Rosa Maria Fischer, Simone de Castro Tavares Coelho, Andrés Pablo Falconer, Rubem César Fernandes, Lester M. Salamon, Helmut K. Anheier, Antônio Carlos Carneiro de Albuquerque, Maria Izilda Santos de Matos, Maiso Dias Alves Júnior, Débora Nacif de Carvalho e Oded Grajew.

Partindo agora para as questões de pesquisa, cada uma delas será respondida com base no trabalho realizado. Com relação à primeira questão de pesquisa, que indagava se a comunicação organizacional pode ser estratégica para fomentar o desenvolvimento de práticas sustentáveis na sociedade, é evidente que sim. Porém, desde que tenha recursos disponíveis para isso, conforme defendido nesta tese, como elementos estruturais, financeiros, profissionais, tecnológicos, humanos e comunicacionais.

Uma equipe altamente profissional e qualificada só consegue ser estruturada a partir de recursos corretamente destinados, sendo as condições financeiras associadas ao engajamento da equipe como um elemento essencial, embora não tire o mérito e a relevância de contribuições voluntárias. Claro que, em situações com escassez de recursos, a dificuldade é maior e a criatividade precisa agir. Ainda assim, é essencial que essa atuação seja feita da forma mais eficaz possível, maximizando os elementos disponíveis, ainda que restritos.

Sendo assim, a comunicação organizacional tem o poder de incentivar o debate sobre sustentabilidade e sensibilizar as pessoas para criarem ambientes mais sustentáveis, sendo mais estratégica quando inserida dentro da gestão e atuando com uma linguagem assertiva que engaje novos parceiros. É essencial que haja um discurso claro e uma fundamentação técnica que embase os argumentos.

Nesse movimento, existem elementos que podem atuar de modo complementar, como a inovação da comunicação em novos formatos e a utilização de exemplos que sejam motivo de inspiração com práticas de sucesso já implementadas. A comprovação prática do discurso praticado e a aplicação de mecanismos de 
transparência são importantes para gerar visibilidade a respeito dos resultados gerados.

Sobre a segunda questão de pesquisa, que indagava se as organizações do terceiro setor desenvolvem ações de comunicação muito mais de divulgação do que de promoção da sustentabilidade, existe uma necessidade claramente identificada de evolução dessas estruturas para a consecução das metas organizacionais. Embora tenha avançado bastante no Brasil, o terceiro setor ainda precisa de mais profissionalização e carece de investimentos que contribuam para a contratação de equipes dedicadas exclusivamente às suas ações. Além disso, foi identificada pouca fundamentação científica nas experiências relatadas de comunicação no terceiro setor.

Ainda assim, foi avaliado qual é a importância do terceiro setor para liderar pessoas e organizar movimentos para promover a sustentabilidade. No contexto de pós-modernidade, com a desagregação das organizações, o trabalho aderente à sociedade civil pode realmente contribuir para o desenvolvimento de ações mais sustentáveis. Assim, é oportuno aproveitar a possibilidade de maior acesso das pessoas às discussões socioambientais para estimular uma reinvenção organizacional nos modelos de gestão. A liderança no terceiro setor para engajar as pessoas pode também ser analisada a partir de uma escala que considere a adesão das mensagens, sendo necessário considerar seus impactos previstos.

Partindo para a terceira questão de pesquisa, que indagava se o terceiro setor possui uma estrutura limitada de comunicação para a sustentabilidade, existem as organizações de grande porte com equipes bem estruturas que desempenham um trabalho mais profissional e costumam ser motivo de inspiração para a disseminação de experiências bem-sucedidas. Ainda assim, a pesquisa identificou que elas também convivem com desafios diários para a execução dos trabalhos, como a constante comprovação da relevância da área e uma necessidade frequente de reconfiguração do posicionamento em decorrência da evolução tecnológica e dos novos formatos de interação com os públicos de interesse.

Além disso, a pesquisa comprovou que, em termos do tamanho das organizações do terceiro setor que atuam com foco em sustentabilidade, a ampla predominância é de estruturas pequenas, já que 61,5\% delas têm até 20 funcionários, colaboradores e/ou voluntários. Mais especificamente sobre a estrutura da 
comunicação, 41,3\% delas não têm uma área específica da área, reforçando que grande parte delas é de pequeno porte e ainda precisa profissionalizar mais as atividades. A respeito do valor investido em comunicação no último ano, 33\% delas investiram até $R \$ 30$ mil.

A quarta questão de pesquisa estava relacionada às razões pelas quais a comunicação deve ser envolvida para desenvolver ações direcionadas para práticas sustentáveis. De acordo com os resultados da pesquisa realizada, a discussão desta temática é relevante para as organizações, mas também interessa à sociedade civil por envolver diretamente temas de interesse público. A reflexão sobre como criar condições mais equilibradas de desenvolvimento será cada vez mais necessária se for considerada a degradação causada pelo ser humano no meio ambiente.

Quando atua de forma articulada, a sociedade civil tem o poder de operar exercendo pressão, sendo o terceiro setor essencial para se contrapor às lógicas corporativistas e governamentais com mobilização social e maior integração entre todos os atores sociais envolvidos. Além disso, o terceiro setor, pelo respaldo civil que tem, pode atuar como um fiador de credibilidade para analisar temas de interesse coletivos, contribuindo para a criação e a manutenção de espaços de cidadania, incentivando a sociedade civil a ter maior poder e ser protagonista no desenvolvimento de ações menos individualistas.

Evoluindo o raciocínio, há também benefícios na integração entre comunicação e a sustentabilidade, sobretudo quando existe participação dessas áreas nas instâncias de tomada de decisão das organizações e quando ela está associada à implementação de um plano prático de ação. Essas áreas são necessariamente identificadas, principalmente no terceiro setor, e disponíveis para serem articuladas com outras instâncias organizacionais importantes.

Nesse sentido, um dos grandes desafios é superar a superficialidade na discussão dos temas e promover a abertura para a ampliação do embasamento técnico com profissionais da área de comunicação como um respaldo complementar para a obtenção de sucesso nas atividades implementadas. A comunicação deve estar a serviço da transparência para tornar as ações mais públicas e valorizar os resultados positivos. Ainda, destaca-se que há a necessidade de melhorias na curadoria de conteúdo com foco na priorização da visibilidade nos impactos gerados pela comunicação. 
Finalmente, a aplicação do questionário com as organizações que atuam em todo o território nacional também revelou que 44\% delas têm como principal definição de sustentabilidade a visão de John Elkington. Embora seja bastante atual, 0 embasamento de sustentabilidade nos pilares econômico, social e ambiental já não responde mais aos novos desafios contemporâneos.

A quinta questão de pesquisa foi criada para responder como direcionar a comunicação para o engajamento do público em ações sustentáveis. A partir disso, é necessário destacar que a pesquisa quantitativa revelou que o envolvimento da comunicação nos processos de tomada de decisão ocorre em 30,7\% dos casos, seguida de $27,1 \%$ que o fazem com frequência intermediária. A respeito dos desafios da comunicação, $43,1 \%$ das organizações indicaram a manutenção do público informado e engajado.

Além disso, dentre as atividades desenvolvidas pela área de comunicação das organizações consultadas, o gerenciamento de mídias sociais foi o mais escolhido, com $63,8 \%$ das respostas. A utilização de redes sociais também ficou evidente na pergunta que tratava sobre o principal recurso de comunicação, com $75,2 \%$ das respostas, demonstrando a consolidação dessa opção para essas organizações.

A esse respeito cabe refletir que o direcionamento da comunicação para o engajamento do público, embora deva utilizar os recursos das novas mídias, precisa ampliar seu foco de atuação e envolver outros recursos mais estratégicos, como a própria gestão da comunicação integrada e a produção de conteúdos institucionais.

A pesquisa também questionou quais são os públicos estratégicos, revelando que o vínculo delas com a comunidades locais é marcante pois correspondeu a 75,7\% das respostas, o que é positivo na medida em que associa essas ações com o desenvolvimento da cidadania e a conscientização dos públicos envolvidos. Mantendo ainda o foco no processo da comunicação para a sustentabilidade, uma profunda reflexão sobre as variáveis apresentadas nesta pesquisa é determinante para gerar clareza a este processo, sendo que o mapeamento delas contribui para o ganho de maior assertividade na comunicação.

A sexta questão de pesquisa indagava quem é o profissional responsável por desenvolver ações e campanhas de comunicação para práticas sustentáveis, temática associada à necessidade de ampliar a profissionalização das equipes e às conclusões da dissertação de mestrado defendida por este autor. Ter, nesses casos, um gestor 
de comunicação é essencial, pois ele é o profissional responsável por discernir o conteúdo para a sustentabilidade e oferecê-lo de modo customizado a fim de ter significado aos públicos. Como responsável pelo significado das informações transmitidas, ele consegue motivar os públicos de interesse das organizações a se engajarem nesta situação de modo que tenham significado e representem uma mudança.

É importante que esse gestor tenha um perfil adequado para compreender e divulgar uma visão conectada dos ideais da sustentabilidade, mas que também saiba construir um planejamento efetivo de comunicação operacionalizado em ações práticas. Desse modo, a sugestão é que o perfil do gestor de comunicação para a sustentabilidade nas organizações contemple formação, compreensão das tendências contemporâneas e mercadológicas, definição das atribuições, compreensão das competências que deve ter, habilidades esperadas, perspectiva de atuação e valores como elemento constituinte do caráter desse profissional.

Além disso, o perfil também envolve a compreensão do posicionamento que este profissional deve ter a clareza dos desafios envolvidos com sua atuação profissional. A difusão da sustentabilidade, portanto, torna-se potencializada e produz mais resultados quando integrada a um trabalho de comunicação com um gestor de comunicação competente e ciente do perfil que ele tem e dos resultados que ele pode gerar para a sociedade.

Partindo para sétima questão de pesquisa, que indagava quais recursos profissionais devem ser utilizados para desenvolver as ações de comunicação para a sustentabilidade, é evidente que, além da comunicação, existem outras áreas potencialmente estratégicas para ampliar o debate sobre sustentabilidade e contribuir para uma nova consciência social sobre o tema.

A liderança, por exemplo, é uma variável essencial, pois tem o poder de mobilizar pessoas e facilitar a implementação de políticas públicas. No caso mais específico da comunicação para a sustentabilidade, é necessário que haja uma reflexão sobre qual é o tipo de liderança mais adequado. A comunicação praticada por essas pessoas deve ser horizontal e dialógica, considerando que, atuando em prol da sustentabilidade, essa liderança deve ter uma atuação comunitária que envolva os atores e implemente soluções coletivas. 
Além disso, em uma perspectiva transdisciplinar, ações fundamentadas nas relações públicas comunitárias, na comunicação organizacional, na educomunicação e nos estudos de cultura também podem contribuir. Ainda, acompanhar iniciativas tecnológicas é essencial para criar novos formatos que aproximem as novas gerações.

Finalmente, a oitava questão de pesquisa indagava quais benefícios sociais e ambientais as ações de comunicação e sustentabilidade podem gerar para a sociedade e como mensurar os resultados. A apuração feita revela que o cenário é complexo e deve ser visto a partir da evolução da própria comunicação no sentido de criação constante e cada vez mais frequente de múltiplas mídias. Elementos complementares também foram evidenciados, como a diversidade dos públicos envolvidos nas mensagens direcionadas, a segmentação dos conteúdos e o aumento das possibilidades de interatividade entre indivíduos e organizações.

Essas questões levam ao entendimento de que a comunicação também vivencia uma dificuldade cotidiana nas organizações de apurar a qualidade na recepção desse conteúdo pelas pessoas. O comunicador que atua no terceiro setor com foco em sustentabilidade vive dilemas profissionais, pois precisa buscar objetividade, planejamento e foco, porém, em muitas situações, se depara com estruturas e recursos escassos ou insuficientes para a operacionalização do trabalho.

Sobre os potenciais e os limites da para ampliar a consciência das pessoas a respeito dos atuais problemas socioambientais, a comunicação, embora estratégica, não resolve todos os problemas, sendo necessário que atue de forma integrada com outras áreas. Uma possibilidade aventada é que a implementação de inovações com a operacionalização de novos formatos e modelos diferentes de transmissão de mensagens para tornar as ações organizacionais mais públicas com conteúdos segmentados aos diferentes públicos.

Outra possibilidade é o alinhamento da comunicação com temas de apelo nacional para que os potenciais sejam ampliados ou, por outro lado, assuntos presentes na grande mídia ou muito próximos da realidade local das pessoas envolvidas também têm maior chance de serem melhor recebidos. O potencial é maior quando há credibilidade da organização e na mensagem direcionada, o que também está relacionado com o desenvolvimento de campanhas seletivas, com discurso claro sobre temas realmente importantes à sociedade. 
A respeito dos métodos de avaliação da comunicação no terceiro setor em ações de sustentabilidade, há dificuldades ainda nesse processo. O questionário aplicado nessa pesquisa revelou $50 \%$ das respostas indicando que isso ocorre a partir da repercussão das ações nas redes sociais. Em seguida, a melhoria da imagem da organização foi selecionada em $49,1 \%$ dos casos.

Permanece o desafio de incorporar um novo olhar sobre as ações desenvolvidas de forma alinhada com a necessidade crescente de compreensão a respeito dos retornos de investimentos na área. Há diferentes formas de mensuração, sendo necessária a incorporação de indicadores de desempenho específicos da área passíveis de compartilhamento e de compreensão por profissionais que atuam em outras áreas.

O alcance do público e a qualidade das metas atingidas são também fontes para possíveis indicadores. Ainda assim, em termos de aderência das mensagens e incorporação do seu conteúdo em processos de mudança de atitude e comportamento, permanece uma margem intangível dificilmente mensurada, o que reforça a necessidade de constante desenvolvimento científico.

Partindo agora paras as recomendações decorrentes da pesquisa para que o processo de comunicação para a sustentabilidade em organizações do terceiro setor seja mais efetivo, a primeira questão a ser considerada é que haja maior clareza quanto aos objetivos estratégicos da organização. Quanto mais evoluído estiver esse aspecto, melhor será a gestão da organização e mais engajado o público interno estará nas causas defendidas. Essa sugestão decorre do fato de muitas organizações do terceiro setor brasileiras, apesar dos avanços observados, ainda precisarem de uma atuação mais profissional.

Um novo papel tem sido exigido das organizações em termos de responsabilidade socioambiental, mas também em termos de gestão. A temática da sustentabilidade cresce de importância e o seu debate se intensifica em todo o mundo, sendo que os impactos da ação humana sobre o planeta exigem uma nova organização do modo de viver, consumir e produzir. Para atrair investimentos e profissionais qualificados, é necessário desenvolver um novo perfil organizacional, com mais transparência e divulgação das demonstrações de desempenho.

Outra recomendação importante está relacionada à definição de objetivos e metas da área de comunicação. Somente com essa delimitação, o gestor da área e 
os demais profissionais envolvidos terão um direcionamento de quais caminhos seguir e para onde direcionar o foco de atuação. A ausência de clareza sobre objetivos e metas é um dos principais fatores que estimula a permanência de organizações com pouco impacto social e ambiental.

Seguindo com a discussão, outro elemento importante nesse processo é investir em alianças institucionais com parceiros e na convergência da comunicação com outras áreas para a mobilização de recursos e o engajamento das pessoas. Redes de relacionamento têm sido criadas em torno de projetos variados para dinamizar as possibilidades de comunicação, sobretudo para a articulação de movimentos sociais, organizações do terceiro setor e entidades de desenvolvimento socioambiental. Dessa forma, muitos avanços têm sido conquistados para garantir legitimidade, resolver problemas financeiros, incentivar ações mais organizadas, aumentar o poder de influência, rever a estrutura organizacional e democratizar a gestão e compartilhar as boas práticas.

Outra recomendação é a atenção à necessidade de recursos para a consecução das metas organizacionais, conforme discutido extensamente nessa tese. É a utilização eficiente de todos os recursos disponíveis que criará as condições necessárias para a realização de um trabalho efetivo. Além do elemento financeiro, são as pessoas que criam as melhores e as piores práticas, então a vontade do ser humano é essencial para obter avanços.

Seguindo com essa discussão, a inovação dos processos e a disponibilidade para mudanças também é uma recomendação essencial, já que, no ritmo atual de mudanças sem precedentes, em que a Internet se torna mais acessível e inclusiva em nível global, as possibilidades de colaborações maciças entre as pessoas estão evidenciadas. Mecanismos de inovação, sejam eles planejados ou feitos com rupturas, estão associados com a expectativa de um novo mundo em que a sustentabilidade é imprescindível para reduzir as desigualdades com as quais convivemos.

Recomenda-se também que a gestão da comunicação seja executada de forma mais estratégica, científica e profissional. Planejamento é essencial, transparência é importante e foco em ações de fato relevantes é necessário. A sugestão é a de uma atuação que promova o engajamento dos públicos e a participação da sociedade civil com o uso de métodos e técnicas de comunicação e assertividade na linguagem. Para 
as pessoas que não aderiram à causa debatida, sugere-se um discurso de sensibilização e engajamento; para aqueles que já são convertidos à causa, a sugestão é de transparência; para as pessoas que já participam do movimento e demais apoiadores, recomenda-se prestação de contas das atividades realizadas.

Assim, a comunicação organizacional, quando é estratégica, agrega valor às organizações e pode contribuir para pautar políticas que considerem os interesses da sociedade. Em se tratando de comunicação para a sustentabilidade, subtende-se também a aplicação das relações públicas comunitárias, com uma atuação interativa em que o profissional atue como um articulador das demandas e aplicador de técnicas profissionais. Repensar a comunicação nesse processo transformador é um desafio, mas, somente assim, será possível implementar as mudanças necessárias.

Outro elemento essencial é a clareza das possibilidades envolvidas nesse processo, sendo que as variáveis indicadas nesta tese foram organizadas da forma mais didática possível para esclarecer que a comunicação, quando compreendida a partir de um fluxo, sofre interferências e sendo que, quando se trata de comunicação para a sustentabilidade, as especificidades aumentam, tornando-se ainda mais complexas com o envolvimento das organizações do terceiro setor.

Deste modo, a comunicação para a sustentabilidade em organizações do terceiro setor deve ser compreendida a partir dos seguintes elementos: níveis; abordagem; transdisciplinaridade; liderança; códigos; meios, canais e formatos; linguagem; sentidos; frequência cerebral; públicos de interesse; repertório; perfil do gestor; prazo; escala de mudança; recursos envolvidos; percurso; abrangência; e frequência.

O respaldo científico também é importante e deve ser considerado como recomendação. Toda ação de comunicação, ou de qualquer outra área do conhecimento, fundamentada em pesquisas científicas, tem uma garantia inerente de que tenha mais sucesso. A ciência de qualidade atende justamente às expectativas de pesquisadores e profissionais que desejam inovar processos com base em experiências previamente testadas a partir de uma metodologia que seja idônea e confiável. Na fundamentação da sustentabilidade, o embasamento técnico também gera credibilidade. Utilizar a ciência é uma forma inteligente de atuar, sobretudo se a causa for de interesse coletivo, como é o caso das organizações que operam com sustentabilidade no terceiro setor. 
Recomenda-se também que haja uma especial atenção aos desafios que se impõem à comunicação, à sustentabilidade e ao terceiro setor. Eles são relevantes pois colocam aos profissionais a necessidade constante de atualização e a oportunidade de produzir uma comunicação mais sofisticada. Entre os desafios mais marcantes no momento estão a profissionalização da comunicação, a customização dos conteúdos, a humanização dos ambientes de trabalho, a mensuração dos resultados gerados e a transformação da sociedade.

Considerando que as mensagens de comunicação para a sustentabilidade geram efeitos nos públicos envolvidos com o tema, compreender a escala de mudança pretendida também é essencial. Nesta pesquisa, chegou-se a uma sugestão que pode ser útil para ser aplicada em situações práticas criadas pelas organizações do terceiro setor, com as seguintes etapas envolvidas: antipatia, apatia, empatia, simpatia, engajamento, atitude, comportamento, advocacia, conduta, mentalidade e existência.

Recomendação complementar é o foco em resultados. Essa é uma das capacidades mais importantes que um profissional de comunicação deve ter pois ela está associada à capacidade de se alcançar as metas definidas, com menor gasto de tempo. A pessoa focada nos resultados, sejam eles quais forem, reconhece seus objetivos e mobiliza todos os recursos necessários. Mesmo que seja necessário rever os métodos usados, e definir novas estratégias, sempre que um planejamento é elaborado, é necessário que haja disciplina e determinação para seguir adiante, mesmo com os obstáculos encontrados no caminho.

Seguindo com a discussão, sugere-se a criação de indicadores de desempenho, com uma gestão que faça o monitoramento da evolução dos resultados da organização e sirva como referência para os processos de tomada de decisão e a atualização das estratégias de melhoria. Esses indicadores ainda precisam ser aperfeiçoados, principalmente no terceiro setor, mas são essenciais para ações de comunicação mais transparentes que demonstrem como as organizações têm atuado para estimular a adesão de novos apoiadores.

Encerrando com as recomendações, todas as ações de comunicação para a sustentabilidade no terceiro setor podem ser fundamentadas na compreensão e na aplicação da cidadania. Quando a exercemos, ampliamos a percepção do mundo e a responsabilidade transformadora que temos. O cidadão é aquele que se identifica com 
determinado território e os costumes ali praticados, usufruindo dos seus direitos e cumprindo com seus deveres.

Lembremos que existe um modelo predominante que determina que nossas experiências são criadas de fora para dentro, com circunstâncias que influenciam nosso humor e nosso destino. No entanto, uma outra abordagem defende que não importa muito o que ocorre conosco, mas como reagimos às situações. Outra perspectiva, mais moderna e arrojada, entende que o externo importa, mas a única maneira de viver em um ambiente melhor é construindo a nossa própria realidade.

Nesse sentido, apenas a transformação mental poderá libertar o ser humano e alterar o destino que a sociedade tem imposto ao mundo. Como o caminho até o sucesso não costuma ser fácil, temos que atravessar os obstáculos e vivenciar situações que nos colocarão à prova. É necessário que haja um motivo especial para vencer. Este motivo precisa ser forte, fonte inesgotável de energia, pois somente assim manteremos o foco na direção correta e não desistiremos dos nossos sonhos.

Afinal, quem somos nós? Adultos ávidos para sobreviver e cumprir metas? Adolescentes irascíveis querendo mudar o mundo? Crianças cheias de sonhos a realizar? Somos tudo isso, e muito mais, neste planeta único chamado Terra. 


\section{Referências}

AGAMBEN, G. O que é o contemporâneo e outros ensaios. Chapecó, SC: Argos, 2009.

ALBUQUERQUE, A. C. C. Terceiro setor: história e gestão de organizações. São Paulo: Summus Editorial, 2006.

ALMEIDA, F. Os desafios da sustentabilidade: uma ruptura urgente. Rio de Janeiro: Elsevier, 2007.

ALVES JUNIOR, M. D. Sustentabilidade na gestão de organizações do terceiro setor: um estudo dos Empreendimentos Sociais apoiados pela Ashoka. 2008. $242 \mathrm{f}$. Dissertação (Mestrado em Administração de Empresas) - Programa de PósGraduação em Administração, Universidade de Fortaleza, Fortaleza, 2008.

BALDISSERA, R. Estratégia, comunicação e relações públicas. Disponível em: <http://www.sinprorp.org.br/clipping/2007/estrategia.pdf>. Acesso em 5 jul. 2017.

BALDISSERA, R. A comunicação (re) tecendo a cultura sustentabilidade em sociedades complexas. In: KUNSCH, M. M. K.; OLIVEIRA I. L. (Orgs.). A comunicação na gestão da sustentabilidade das organizações. São Caetano do Sul: Difusão Editora, 2009a. p. 33-55.

BALDISSERA, R. A teoria da complexidade e novas perspectivas para os estudos de comunicação organizacional. In: KUNSCH, M. M. K. Comunicação organizacional: histórico, fundamentos e processos. São Paulo: Saraiva, 2009b. v.1. p. 135-164.

BAPTISTA, D. M. T. O debate sobre o uso de técnicas qualitativas e quantitativas de pesquisa. In: MARTINELLE, M. L. (Org.). Pesquisa qualitativa: um instigante desafio. Série Núcleo de Pesquisa 1, NEPI/PUC-SP. São Paulo: Veras, 2013.

BATEY, M. O significado da marca: como as marcas ganham vida na mente dos consumidores. Rio de Janeiro: Best Business, 2010.

BIZELLI, J. L. O acesso à banda larga e a sustentabilidade da sociedade digital. In: MELO, J. M.; GONÇALVES, E.; BIZELLI, J. L. (Orgs.). Comunicação para o desenvolvimento: pensamento e ação. Araraquara: Cultura Acadêmica, 2012. p. 182-183.

BOGDAN, R.; BIKLEN, S. Investigação qualitativa em educação: uma introdução à teoria e aos métodos. Porto: Porto Editora, 1994.

BOURDIEU, P. O campo científico. In: Pierre Bourdieu. São Paulo: Ática, 1983, p. 122 a 155. 
BOFF, L. Sustentabilidade: tentativa de definição. Leonardoboff.com, 15 jan. 2012. Disponível em: <http://leonardoboff.wordpress.com/2012/01/15/sustentabilidadetentativa-de-definicao/>. Acesso em: 10 jan. 2017.

BOFF, L. Sustentabilidade - o que é - o que não é. Petrópolis: Vozes, 2013.

BUENO, W. C. Comunicação e sustentabilidade: fontes e recursos. In:

BUENO, W. C. (Org.). Comunicação empresarial e sustentabilidade. Barueri, SP: Manole, 2015.

BUENO, W. C. (Org.). Comunicação empresarial e sustentabilidade. Barueri, SP: Manole, 2015.

BUENO, W. C. Comunicação empresarial: políticas e estratégias. São Paulo: Saraiva, 2009.

CANASSA, D. Capacidade de diálogo, paciência e abertura ao novo. In: VOLTOLINI, R. (Org.). Líderes sustentáveis com a mão na massa: o que aprender com a experiência dos principais executivos de sustentabilidade do Brasil. São Paulo: Ideia Sustentável, 2014.

CAROPRESO, P. Comunicação da sustentabilidade. Ideia sustentável, 16 jun. 2011. Disponível em: <http://www.ideiasustentavel.com.br/comunicacao-dasustentabilidade/>. Acesso em 10 ago. 2013.

CARVALHO, D. N. Gestão e sustentabilidade: um estudo multicasos em ONGs ambientalistas em Minas Gerais. 2006. 157f. Dissertação (Mestrado em Administração de Empresas) - Programa de Pós-Graduação em Administração. Universidade Federal de Minas Gerais: Belo Horizonte, 2006.

CASIMIRO, A. C. Q.; FREITAS, L. S. Modelos de gestão em Organizações não governamentais: da gestão original à gestão estratégia. In: V Simpósio de Excelência em Gestão e Tecnologia - SEGET, 2008, Resende. Anais... Resende: SEGET, 2008.

CASSELL, C.; SYMON, G. Qualitative methods in organizational research. London: Sage Publications, 1994.

CASTELLS, M. A galáxia da internet: reflexões sobre a internet, os negócios e a sociedade. Rio de Janeiro: Jorge Zahar, 2003.

CASTELLS, M. A sociedade em rede. 2 ed. São Paulo: Paz e Terra, 1999.

CENDALES, L.; MARIÑO, G. Educação não formal e educação popular: para uma pedagogia do diálogo cultural. São Paulo: Edições Loyola. 2006.

COELHO, S. C. T. Terceiro setor: um estudo comparado entre Brasil e Estados Unidos. São Paulo: Editora SENAC São Paulo, 2000. 
CORTELLA, M. S. Qual é a tua obra? Inquietações propositivas sobre gestão, liderança e ética. Petropólis, RJ: Vozes, 2007.

CURY, V. B. Comunicação para o desenvolvimento organizacional. In: KUNSCH, M. M. K. (Org.). Comunicação organizacional estratégica: aportes conceituais e aplicados. São Paulo: Summus, 2016. p. 202-203.

DIEHL, A. A. Pesquisa em ciências sociais aplicadas: métodos e técnicas. São Paulo: Prentice Hall, 2004.

DUARTE, J. Entrevista em profundidade. In: BARROS, A.; DUARTE J. (Orgs.).

Métodos e técnicas de pesquisa em comunicação. São Paulo: Atlas, 2011. p. 6283.

ELKINGTON, J. Canibais com garfo e faca. São Paulo: Makron, 2001.

ESCUDERO, R. C. Movimentos sociais, comunidade e cidadania. In: KUNSCH, M. M. K.; KUNSCH, W. L. (Org). Relações públicas comunitárias: a comunicação em uma perspectiva dialogada e transformadora. São Paulo: Summus Editorial, 2007.

FALCONER, A. P. A promessa do terceiro setor: um estudo sobre a construção do papel das organizações sem fins lucrativos e do seu campo de gestão. São Paulo: Centro de Estudos em Administração do Terceiro setor, 1999.

FALCONER, A. P.; FISCHER, R. M. Desafios da parceria governo terceiro setor. Escola de Serviço Social da UFRJ, 1998.

FERNANDES, R. C. Elos de uma cidadania planetária. São Paulo, Brasil, 1995. Disponível em <http://www.anpocs.org.br/portal/publicacoes/rbcs_00_28/rbcs28_02.htm >. Acesso em 15 jan. 2017.

FISCHER, R. M. O desafio da colaboração: práticas de responsabilidade social entre empresas e terceiro setor. São Paulo: Gente, 2002.

FURHAM, A. Linguagem corporal no trabalho. São Paulo: Coleção Você S/A, 2001.

GADOTTI, M. Educar para a sustentabilidade: uma contribuição à década da educação para o desenvolvimento sustentável. $2^{2}$ ed. São Paulo: Instituto Paulo Freire, 2012.

GARBIN, S. M. Inteligência colaborativa: para fazer acontecer um mundo mais colaborativo e em harmonia. Brasília: Thesaurus, 2011.

GONÇALVES, E. M. O conhecimento científico e o exercício da cidadania. In: MELO, J. M.; GONÇALVES, E.; BIZELLI, J. L. (Orgs.). Comunicação para o desenvolvimento: pensamento e ação. Araraquara: FCL-UNESP Laboratório Editorial; São Paulo: Cultura Acadêmica, 2012. p. 115-121. 
GRAJEW, O. A responsabilidade social na construção de um país justo e sustentável. Entrevista concedida a Pedro Ulsen. Disponível em:

<http://www.revistaorganicom.org.br/sistema/index.php/organicom/article/view/1094/ 804>. Acesso em: 15 nov. 2017.

GUIA de comunicação e sustentabilidade. São Paulo: Conselho Empresarial Brasileiro para o Desenvolvimento Sustentável (CEBDS), 2010.

GUTTILLA, R. Comunicação e desenvolvimento sustentável. In: NASSAR, Paulo (Org.). Comunicação empresarial: estratégias de organizações vencedoras. São Paulo: Aberje Editorial, 2005, v.1. p. 137-141.

HARVARD BUSINESS REVIEW. Renovação da estratégia. Rio de Janeiro: Elsevier, 2009.

HARVEY, D. Condição pós-moderna: uma pesquisa sobre as origens da mudança cultural, 19 ed., São Paulo: Loyola, 2010.

HASWANI, M. F. Responsabilidade social: das organizações às instituições. In: KUNSCH, M. M. K. (Org.). Comunicação organizacional estratégica: aportes conceituais e aplicados. São Paulo: Summus, 2016.

HAWKENS, P.; LOVINS, A. e LOVINS, H. Natural Capitalism: creating the next industrial revolution. Little Brown, USA, 1999. Disponível em:

<http://www.natcap.org/>. Acesso em: 15 nov. 2015.

HYMANN, H. Planejamento e análise da pesquisa: princípios, casos e processos. Rio de Janeiro: Lidador, 1967.

Instituto Ethos de Empresas e Responsabilidade Social. Gestão Estratégica para a Sustentabilidade. Disponível em: <http://www.ethos.org.br>. Acesso em 10 set. 2013.

KUNSCH, M. M. K. A comunicação nas organizações: dos fluxos lineares às dimensões humana e estratégica. In: KUNSCH, M. M. K. (Org.). Comunicação organizacional estratégica: aportes conceituais e aplicados. São Paulo: Summus, 2016.

KUNSCH, M. M. K. Comunicação organizacional: contextos, paradigmas e abrangência conceitual. Disponível em: <http://dx.doi.org/10.11606/issn.19828160.v8i2p35-61 >. Acesso em: 10 dez. 2016.

KUNSCH, M. M. K.; SILVA, I. M.; ULSEN, P. A comunicação das organizações para a sustentabilidade. In: XXXVII Congresso Brasileiro de Ciências da Comunicação, 2014, Foz do Iguaçú (PR). Anais... Foz do Iguaçú: Sociedade Brasileira de Estudos Interdisciplinares da Comunicação, 2014, p. 1-15. Disponível em: <http://www.intercom.org.br/papers/nacionais/2014/resumos/R9-2229-4.pdf >. Acesso em: 20 dez. 2016. 
KUNSCH, M. M. K. A dimensão humana da comunicação organizacional. In: $\mathrm{KUNSCH}, \mathrm{M}$. M. K. (Org.). A comunicação como fator de humanização das organizações. 2010. p. 41-60.

KUNSCH, M. M. K. A comunicação para a sustentabilidade das organizações na sociedade global. In: KUNSCH, M. M. K.; OLIVEIRA, I. L. (Orgs.). A comunicação na gestão da sustentabilidade das organizações. 2009a. p. 57-81.

KUNSCH, M. M. K. (Org.). Comunicação organizacional: histórico, fundamentos e processos. São Caetano do Sul, SP: Difusão Editora, v. 1, 2009b.

KUNSCH, M. M. K. Planejamento estratégico de comunicação. In: KUNSCH, M. M. K. (Org.). Gestão estratégica em comunicação organizacional e relações públicas. São Caetano do Sul, SP: Difusão Editora, 2009c, p. 107-123.

KUNSCH, M. M. K. Dimensões e perspectivas das relações públicas comunitárias. In: KUNSCH, M. M. K.; KUNSCH; W. L. (Org.). Relações públicas comunitárias: a comunicação em uma perspectiva dialogada e transformadora. São Paulo: Summus, 2007b, p. 165-180.

KUNSCH, M. M. K. Perspectivas e desafios para as profissões de comunicação no terceiro milênio. In: KUNSCH, M. M. K. (Org.) Ensino de comunicação: qualidade na formação acadêmico-profissional. São Paulo: ECA-USP e Intercom, 2007a, p. 87101.

KUNSCH, M. M. K. Planejamento de relações públicas na comunicação integrada. São Paulo: Summus Editorial, 2003.

LEFF, E. Ecologia, capital e cultura. São Paulo: Vozes, 2009.

LINDSTROM, M. Brandsense: Segredos sensoriais por trás das coisas que compramos. Porto Alegre: Bookman, 2011.

LIU, A. M. M. The framework underpinning conflicting keys in sustainability: harmony-intransit. Property Management, v. 24, 2006. p. 219-231.

LOPES, M. I. V. Pesquisa em comunicação. São Paulo: Edições Loyola, 2012.

LOPES, V. S. C. Avaliação e mensuração em relações públicas e em comunicação organizacional. In: KUNSCH, M. M. K. (Org.). Comunicação organizacional estratégica: aportes conceituais e aplicados. São Paulo: Summus, 2016. p.340.

MARTÍN-BARBERO, J. Dos meios às mediações. Rio de Janeiro: Editora da UFRJ, 2003.

MATOS, M. I. S. Terceiro setor e gênero: trajetórias e perspectivas. São Paulo: Cultura Acadêmica: Instituto Presbiteriano Mackenzie, 2005. 
MATTELART, A.; MATTELART, M. História das teorias da comunicação. 15a ed. São Paulo: Edições Loyola, 2012.

MELO, J. M. Entre o pensamento e a ação: comunicação para o desenvolvimento. In: MELO, J. M.; GONÇALVES, E.; BIZELLI, J. L. (Orgs.). Comunicação para o desenvolvimento: pensamento e ação. Araraquara: FCL-UNESP Laboratório Editorial; São Paulo: Cultura Acadêmica, 2012. p. 9-11.

MORIN, E. A cabeça bem-feita: repensar a reforma, reformar o pensamento. Rio de Janeiro: Bertrand Brasil, 2010.

MORIN, E. Introdução ao pensamento complexo. $3^{\text {a }}$ ed. Lisboa: Instituto Piaget, 2001.

NEILL, M. A revolução do pensamento: a única coisa que você precisa saber para mudar sua vida. $1^{\underline{a}}$ ed. Rio de Janeiro: Agir, 2014.

NESHEIM, J. L. Diferencial competitivo: o segredo para alcançar melhores resultados e vencer a concorrência. Rio de Janeiro: Best Seller, 2007.

NEVES, J. L. Pesquisa qualitativa: características, usos e possibilidades. Cadernos de Pesquisas em Administração, v. 1, n.3, 2ํsem., 1996.

NOVELLI, A. L. R. Pesquisa de opinião. In: BARROS, A.; DUARTE, J. (Orgs.). Métodos e técnicas de pesquisa em comunicação. $2^{a}$. ed. São Paulo: Atlas, 2006. p. 164-179.

OLIVEIRA, M. D. O protagonismo dos cidadãos e de suas organizações: um fenômeno recente, massivo e global. Rede de informações para o terceiro setor. 17 ago. 2001. Disponível em: <http://idac.rits.org.br/prtag/idac_ptrotag_1.html>. Acesso em: 10 jan. 2016.

PARAVENTI, A. C. Ética, compliance e o papel da comunicação. In: KUNSCH, M. M. K. (Org.). Comunicação organizacional estratégica: aportes conceituais e aplicados. São Paulo: Summus, 2016, p. 115-136.

PERUZZO, C. M. K. Observação participante e pesquisa ação. In: BARROS, A.; DUARTE J. (Orgs.). Métodos e técnicas de pesquisa em comunicação. São Paulo: Atlas, 2011. p. 125-145.

PERUZZO, C. M. K. Comunicação comunitária e educação para a cidadania. Revista PCLA - Pensamento Comunicacional Latino Americano. São Bernardo do Campo: Cátedra Unesco Umesp, v.4, n.1, p.1-9, 2002. Disponível em: $<$ www.metodista.br/unesco/pcla $>$.

PIRIE, M. Como vencer todas as argumentações: usando e abusando da lógica. $2^{\mathrm{a}}$ ed. São Paulo: Edições Loyola, 2013.

POPPER, K. A lógica da pesquisa científica. 2. ed. São Paulo: Cultrix, 1972. 
PRADO, E. Desde o começo, movida a causas. In: VOLTOLINI, R. (Org.). Líderes sustentáveis com a mão na massa: o que aprender com a experiência dos principais executivos de sustentabilidade do Brasil. 1ª ed. São Paulo: Ideia Sustentável, 2014. p. 20-27.

REDONDO, J. Resiliência para transformar a cultura de um grupo tradicional. In: VOLTOLINI, R. (Org.). Líderes sustentáveis com a mão na massa: o que aprender com a experiência dos principais executivos de sustentabilidade do Brasil. $1^{a}$ ed. São Paulo: Ideia Sustentável, 2014. p. 84-93.

RICHARDSON, R. J. Pesquisa social: métodos e técnicas. São Paulo: Atlas, 1989.

SACHS, I.; VIEIRA, P. F. (Org.). Rumos à ecossocioeconomia: teoria e prática do desenvolvimento. São Paulo: Cortez, 2007.

SACHS, I. Desenvolvimento includente, sustentável, sustentado. Rio de Janeiro: Garamond, 2004.

SALAMON, L. M.; ANHEIER, H. K. Defining the nonprofit sector: A crossnational analysis. Manchester: Manchester University Press, 1997.

SCHARMER, O.; KAUFER, K. Liderar a partir do futuro que emerge: a evolução do sistema econômico egocêntrico para o ecocêntrico. $1^{\text {a }}$ ed. Rio de Janeiro:

Elsevier, 2014.

SCHARMER, O. Entrevista especial. Ideia sustentável, 18 jul. 2013. Disponível em: < http://www.ideiasustentavel.com.br/entrevista-especial-otto-scharmer/>. Acesso em 20 dez. 2016.

SCHERER-WARREN, I. Redes de movimentos sociais. 3 ed. São Paulo: Loyola, 2005.

SCHIAVONI, J. L. Comunicação corporativa: profissão do futuro. (2007). In:

KUNSCH, M. M. K. (Org.). Ensino de comunicação: qualidade na formação acadêmico-profissional. São Paulo: ECA-USP e Intercom, 2007, p. 113-123.

SILVA, E. L.; MENEZES, E. M. Metodologia da pesquisa e elaboração de dissertação. 4a․ ed. Florianópolis: UFSC, 2005.

SOTO, J. Construindo no dia a dia a visão de ser líder global em química sustentável. In: VOLTOLINI, R. (Org.). Líderes sustentáveis com a mão na massa: o que aprender com a experiência dos principais executivos de sustentabilidade do Brasil. 1a ed. São Paulo: Ideia Sustentável, 2014. p. 48-57.

SOUZA, J. E. O. O gerente comunicador: um guia prático da comunicação gerencial. São Paulo: Aberje Editorial, 2010. 
STEINBERG, H.; HALLQVIST, B.; RODRIGUEZ, F.; DALE, G.; MONFORTE, J.; FALDINI, R. A dimensão humana da governança corporativa: pessoas criam as melhores e as piores práticas. São Paulo: Editora Gente, 2003.

STUMPF, I. R. Pesquisa bibliográfica. In: BARROS, A.; DUARTE J. (Orgs.).

Métodos e técnicas de pesquisa em comunicação. São Paulo: Atlas, 2011. p. 51 61.

TENÓRIO, F. G. (Org.). Gestão de ONGs: principais funções gerenciais. Rio de Janeiro: Fundação Getúlio Vargas, 1997.

TESCH, R. Qualitative research: analysis types and software tools. Basingstoke: The Falmer Press, 1990.

THOMPSON, J. B. Ideologia e cultura moderna: teoria social crítica na era dos meios de comunicação de massa. Petrópolis: Vozes, 1995.

TORQUATO, G. Tratado de comunicação organizacional e política. $2^{\underline{a}}$ ed. revista e ampliada. São Paulo: Cengage Learning, 2011.

TORQUATO, G. Da gênese do jornalismo empresarial e das relações públicas à comunicação organizacional no Brasil. In: KUNSCH, M. M. K. (Org.). Comunicação organizacional: histórico, fundamentos e processos, v.1. São Paulo: Saraiva, 2009. p. 7-28.

TOLSTÓI, L. O que é arte? A polêmica visão do autor de Guerra e Paz. Rio de Janeiro: Editora Nova Fronteira, 2016.

TRIGUEIRO, A. Mundo sustentável: abrindo espaço na mídia para um planeta em transformação. São Paulo: Globo, 2005.

TRIVIÑOS, A. N. S. Introdução à pesquisa em ciências sociais: a pesquisa qualitativa em educação. São Paulo: Atlas, 1987.

ULSEN, P. O perfil do gestor de comunicação: como gerar impacto e promover a sustentabilidade. Jundiaí: Paco Editorial, 2017.

ULSEN, P. Comunicação para a sustentabilidade: variáveis, percepção e recepção. In: XXXIX Congresso Brasileiro de Ciências da Comunicação, 2016, São Paulo.

Anais... São Paulo: Escola de Comunicações e Artes da Universidade de São Paulo, 2016, p. 1-15. Disponível em:

<http://portalintercom.org.br/anais/nacional2016/resumos/R11-2867-1.pdf>. Acesso em: 10 fev. 2017.

ULSEN, P.; KUNSCH, M. M. K. Comunicação organizacional e sustentabilidade: convergência e perfil profissional. In: II Congresso Mundial de Comunicação lberoamericana, 2014, Braga, Portugal. Livro de Atas. Braga: Centro de Estudos de Comunicação e Sociedade (Universidade do Minho), 2014, p. 3529-3539. Disponível 
em: <www.lasics.uminho.pt/ojs/index.php/cecs_ebooks/article/view/1983/1905>. Acesso em: 5 jan. 2017.

ULSEN, P.; SMITH, V. P. B.; FERNANDES, B. R. Comunicação integrada na era digital: convergência, atuação profissional e novos desafios. In: Pens@com Brasil. 2014, São Paulo. Fórum Unescom. Tendências do Pensamento Comunicacional, 2014. Disponível em: <http://www2.metodista.br/unesco/pensacom2014/arquivos/>. ISSN/ISBN: 1806-3500. Acesso em: 15 jun. 2017.

ULSEN, P.; FERNANDES, B. R.; SMITH, V. P. B. Comunicação por um licenciamento ambiental sustentável. In: Pens@com Brasil, 2014, São Paulo. Fórum Unescom. Tendências do Pensamento Comunicacional, 2014. Disponível em: <http://www2.metodista.br/unesco/pensacom2014/arquivos/>. ISSN/ISBN: 18063500. Acesso em: 10 jun. 2017.

ULSEN, P. O perfil do gestor de comunicação para a sustentabilidade nas organizações. 289f. Dissertação (Mestrado em Ciências da Comunicação) - Escola de Comunicações e Artes, Universidade de São Paulo. São Paulo, 2012.

WEIL, P.; TOMPAKOW, R. O corpo fala: a linguagem silenciosa da comunicação não verbal. 2013.

WHITNEY, D. Liderança apreciativa: concentre-se no que funciona para impulsionar um desempenho vencedor e construir uma empresa próspera. São Paulo: Alta Books, 2011.

YANAZE, M. H.; FREIRE, O.; SENISE, D. Retorno dos investimentos em comunicação: avaliação e mensuração. São Caetano do Sul: Difusão Editora, 2010.

\section{Entrevistas com gestores de comunicação}

BALAZINA, A. Comunicação para a sustentabilidade em organizações do terceiro setor [2 fev. 2017]. Entrevista exclusiva concedida a Pedro Ulsen.

BIANCO, M. Comunicação para a sustentabilidade em organizações do terceiro setor [24 mar. 2017]. Entrevista exclusiva concedida a Pedro Ulsen.

GUIMARÃES, R. P. Comunicação para a sustentabilidade em organizações do terceiro setor [30 jan. 2017]. Entrevista exclusiva concedida a Pedro Ulsen.

MORAES, M. Comunicação para a sustentabilidade em organizações do terceiro setor [20 set. 2017]. Entrevista exclusiva concedida a Pedro Ulsen.

ROMANO, R. Comunicação para a sustentabilidade em organizações do terceiro setor [22 mai. 2017]. Entrevista exclusiva concedida a Pedro Ulsen.

WEIS, B. Comunicação para a sustentabilidade em organizações do terceiro setor [23 mai. 2017]. Entrevista exclusiva concedida a Pedro Ulsen. 


\section{Entrevistas com especialistas em sustentabilidade}

ALMEIDA, F. Comunicação para a sustentabilidade em organizações do terceiro setor [10 jul. 2017]. Entrevista exclusiva concedida a Pedro Ulsen.

BOFF, L. Comunicação para a sustentabilidade em organizações do terceiro setor [20 dez. 2016]. Entrevista exclusiva concedida a Pedro Ulsen.

GRAJEW, O. Comunicação para a sustentabilidade em organizações do terceiro setor [28 jun. 2017]. Entrevista exclusiva concedida a Pedro Ulsen.

HAMÚ, D. Comunicação para a sustentabilidade em organizações do terceiro setor [13 jul. 2017]. Entrevista exclusiva concedida a Pedro Ulsen.

JACOBI. P. Comunicação para a sustentabilidade em organizações do terceiro setor [9 dez. 2016]. Entrevista exclusiva concedida a Pedro Ulsen.

LEFF, E. Comunicação para a sustentabilidade em organizações do terceiro setor [1 jun. 2017]. Entrevista exclusiva concedida a Pedro Ulsen. 


\section{Sumário de apêndices}

Apêndice 1. Questionário enviado para organizações do terceiro setor ................309

Apêndice 2. Organizações da Abong acionadas na pesquisa ...............................317

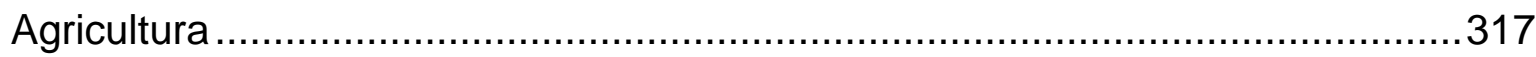

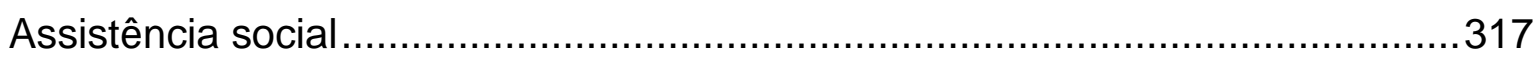

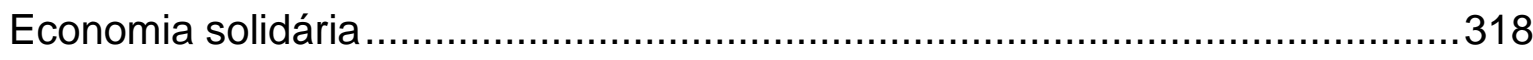

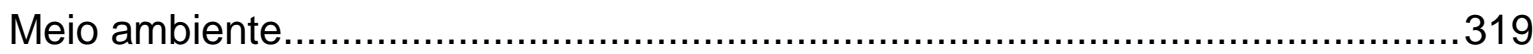

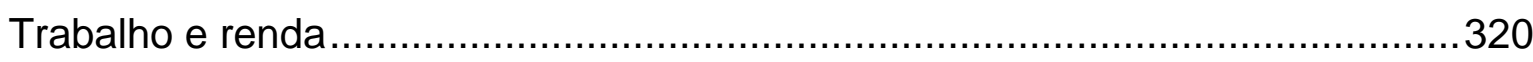

Apêndice 3. Organizações do site ONGs Brasil acionadas na pesquisa ...............323

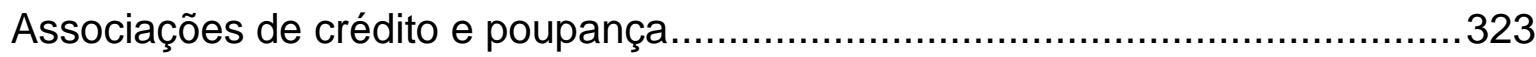

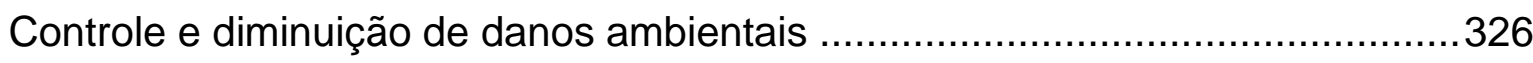

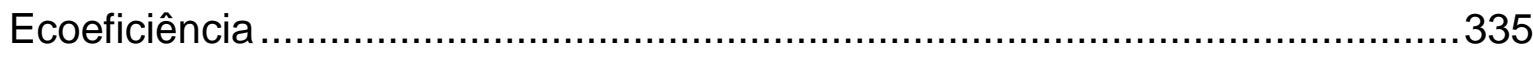

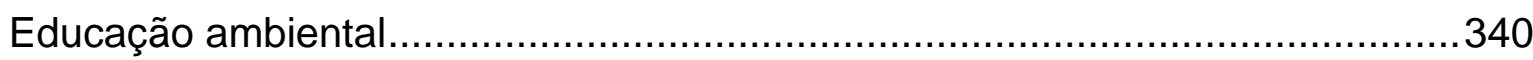

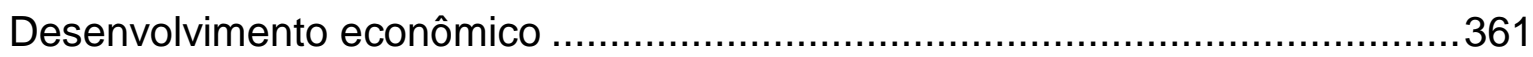

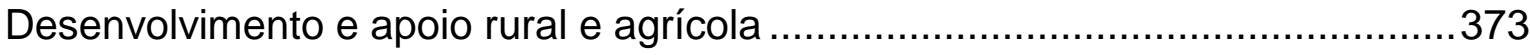

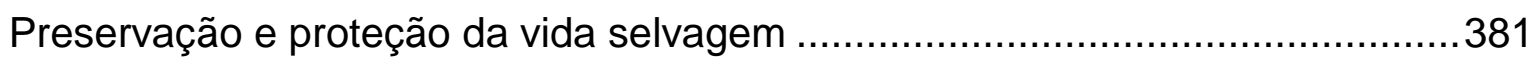

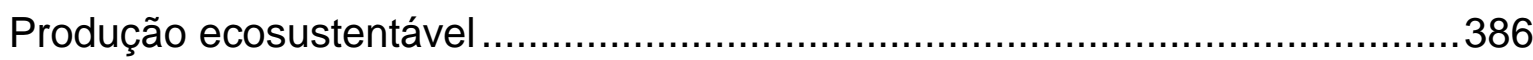

Proteção e conservação do patrimônio natural ....................................................394

Apêndice 4. Nomes das organizações participantes...........................................405

Apêndice 5. Endereços das organizações participantes .....................................411

Apêndice 6. Nomes do respondentes das organizações participantes .................417

Apêndice 7. E-mails das organizações participantes ........................................423

Apêndice 8. Telefones das organizações participantes ........................................429

Apêndice 9. Entrevistas com gestores de comunicação ………….....................435

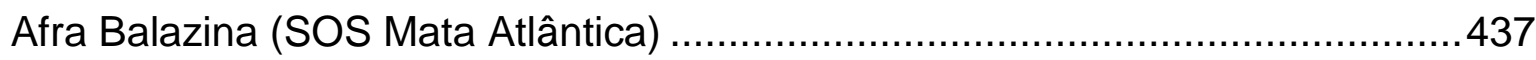

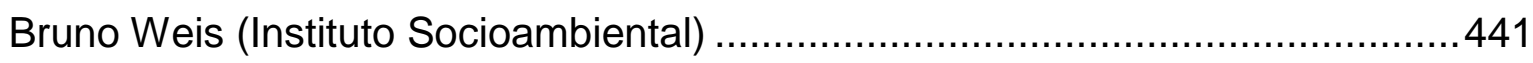

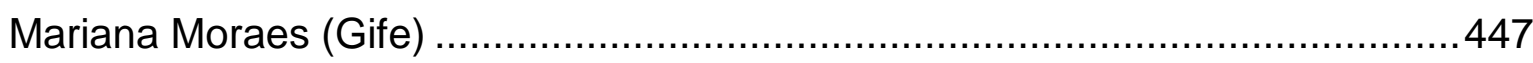

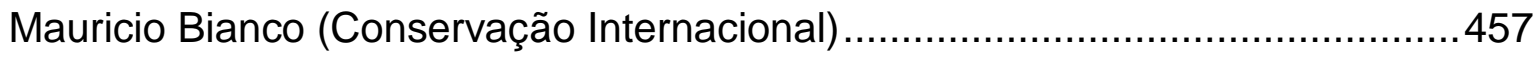

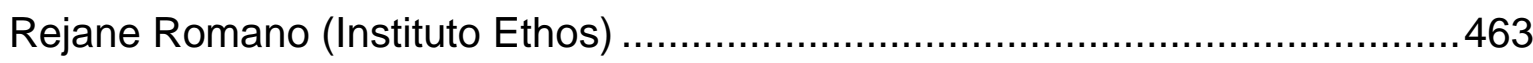

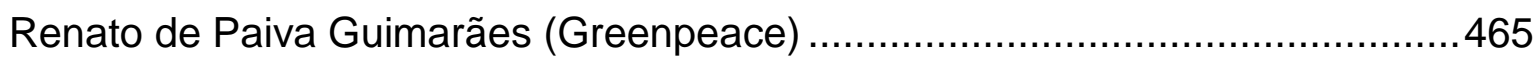

Apêndice 10. Entrevistas com especialistas em sustentabilidade.........................469

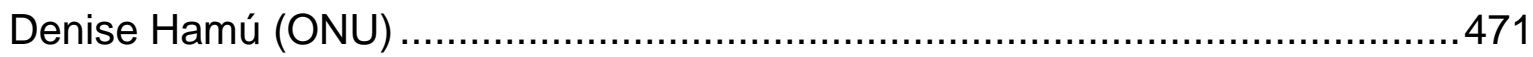

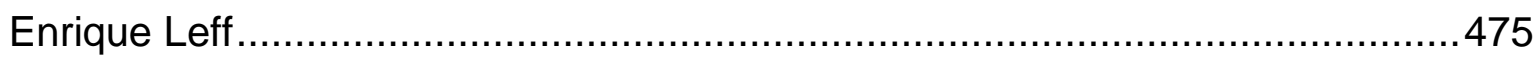

Fernando Almeida

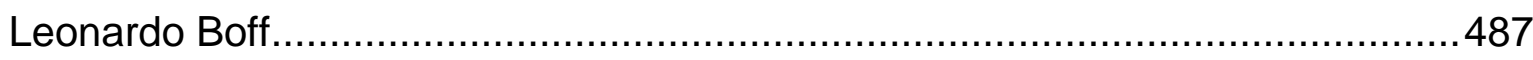

Oded Grajew (Instituto Ethos e Oxfam Brasil)............................................... 491

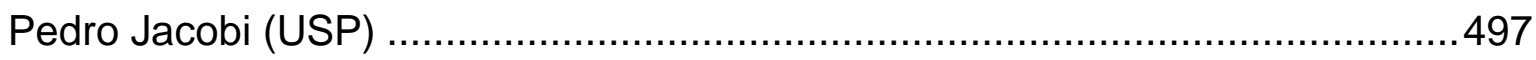


Apêndice 1. Questionário enviado para organizações do terceiro setor

1. Nome da organização

Parte I - Identificação

2. Unidade Federativa

Acre (AC)

Alagoas (AL)

Amapá (AP)

Amazonas (AM)

Bahia (BA)

Ceará (CE)

Distrito Federal (DF)

Espírito Santo (ES)

Goiás (GO)

Maranhão (MA)

Mato Grosso (MT)

Mato Grosso do Sul (MS)

Minas Gerais (MG)

Pará (PA)

Paraíba (PB)

Paraná (PR)

Pernambuco (PE)

Piauí (PI)

Rio de Janeiro (RJ)

Rio Grande do Norte (RN)

Rio Grande do Sul (RS)

Rondônia (RO)

Roraima (RR)

Santa Catarina (SC)

São Paulo (SP)

Sergipe (SE)

Tocantins (TO)

3. Endereço completo

4. Ano de criação

5. Nome do responsável pelas informações

6. E-mail do responsável pelas informações

7. Telefone do responsável pelas informações

8. Cargo do responsável pelas informações

Presidente/Vice-Presidente

Diretor

Gerente

Assessor/Consultor

Coordenador/Supervisor 


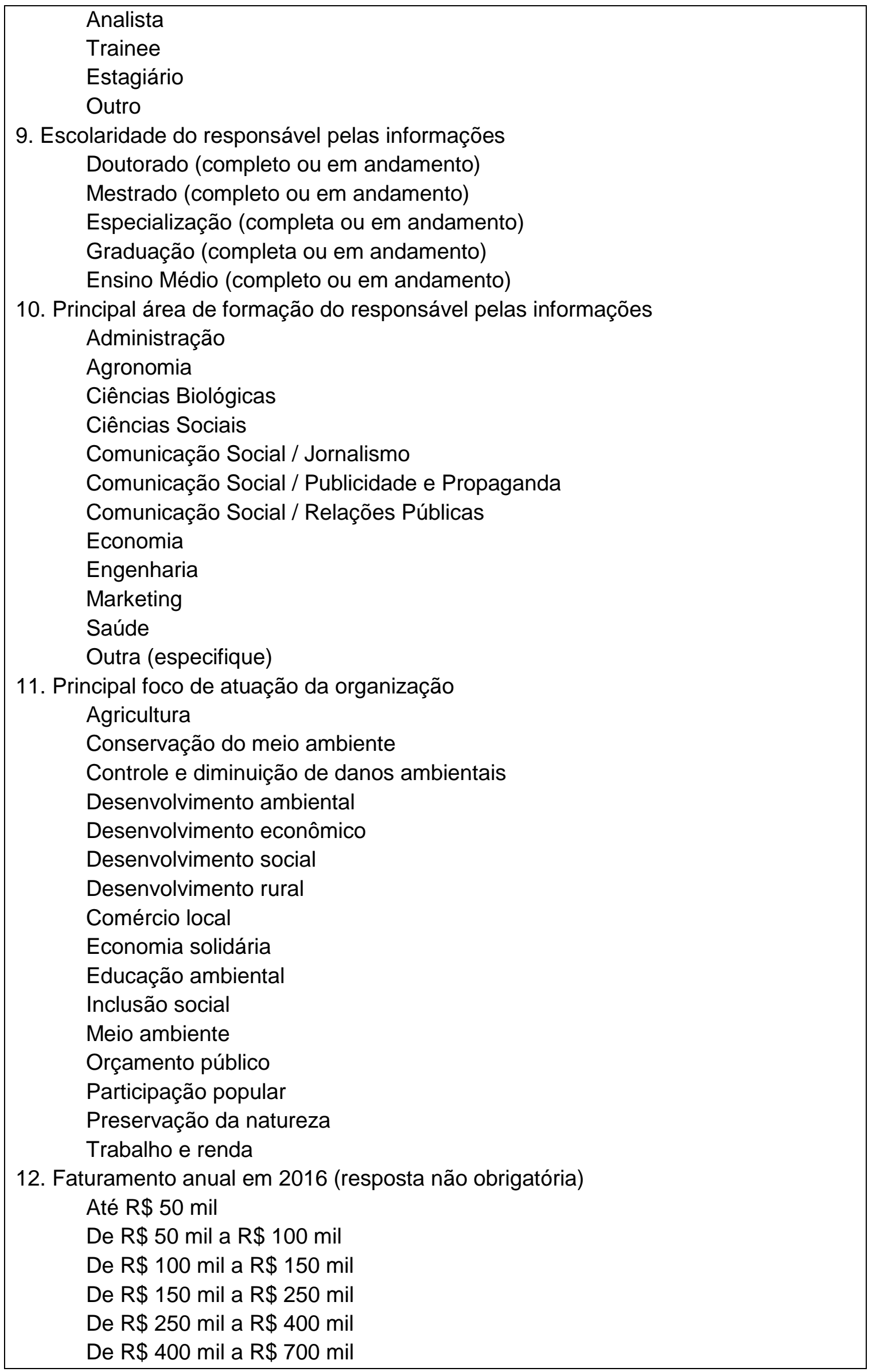


Parte II - Composição

14. Na sua organização, as iniciativas de sustentabilidade são lideradas por qual área? Conselho de Administração

Presidência

Vice-presidência

Diretoria

Comunicação

Financeiro

Marketing

Jurídico

Outra (especifique)

15. Para a sua organização, qual é a melhor definição de sustentabilidade?

"O desenvolvimento sustentável envolve a busca simultânea da prosperidade econômica, da qualidade ambiental e da igualdade social. As empresas que buscam a sustentabilidade precisam empenhar-se não somente na direção de uma única linha de resultados, a financeira, mas sim na linha dos três pilares" "Para a implantação do projeto do ecodesenvolvimento são necessárias reflexões acerca do atual modelo de produção, que gasta mais energia para produzir determinados alimentos em relação à energia resultante no final do processo, e aos efeitos residuais no ambiente. Imaginação, vontade política, o [...] reaparelhamento da economia com tecnologias poupadoras de recursos ou a promoção de sistemas que exigem tempo e investimentos consideráveis também são requisitos"

"A efetivação de um modelo de desenvolvimento ecotecnológico, bem como de uma racionalidade ambiental que o fundamente, deve fazer parte de um projeto histórico mais amplo, conduzido pela sociedade civil, através da conscientização, reivindicação e atuação dos movimentos sociais, sejam de caráter ambiental, étnico, cultural, 'consumerista' ou simplesmente cívico"

"As megamudanças nos ecossistemas que são a base da nossa sobrevivência estão induzindo crescentes alterações no comportamento de diversos atores no setor público, no setor privado e na sociedade civil. Aumentaram a regulamentação por parte dos governos e a pressão exercida sobre as empresas pelos grupos de interesse, sejam eles acionistas, organizações não governamentais ou clientes. A tendência é que esse quadro se torne cada vez mais complexo, à medida que os diversos grupos de interesse vão aferindo a gravidade da situação" 
"Sustentabilidade é toda ação destinada a manter as condições energéticas, informacionais, físico-químicas que sustentam todos os seres, especialmente a Terra viva, a comunidade de vida e a vida humana, visando a sua continuidade e ainda a atender as necessidades da geração presente e das futuras de tal forma que o capital natural seja mantido e enriquecido em sua capacidade de regeneração, reprodução, e coevolução"

"Satisfazer plenamente as necessidades de forma a preservar as condições para que as gerações futuras também o façam. As atividades processadas por agrupamentos humanos não podem interferir prejudicialmente nos ciclos de renovação da natureza e nem destruir esses recursos de forma a privar as gerações futuras de sua assistência"

"Consequência de um complexo padrão de organização que apresenta cinco características básicas: interdependência, reciclagem, parceria, flexibilidade e diversidade. Se estas características, encontradas em ecossistemas, forem "aplicadas" às sociedades humanas, essas sociedades também poderão alcançar a sustentabilidade"

Nenhuma das anteriores

16. Relevância estratégica da Comunicação para disseminar ações sustentáveis

Totalmente relevante

Muito relevante

Relevante

Pouco relevante

Irrelevante

17. Investimento em Comunicação em 2016 (resposta não obrigatória)

Até $\mathrm{R} \$ 30 \mathrm{mil}$

De $R \$ 30$ mil a $R \$ 50$ mil

De $R \$ 50$ mil a $R \$ 75$ mil

De $R \$ 75$ mil a $R \$ 100$ mil

De $R \$ 100$ mil a $R \$ 200$ mil

De $R \$ 200$ mil a $R \$ 500$ mil

De $R \$ 500$ mil a $R \$ 1$ milhão

Mais de $R \$ 1$ milhão

\section{Parte III - Gestão}

18. Estrutura da área de Comunicação na organização

Vice-presidência

Diretoria

Gerência

Coordenação

Analista

Minha organização não tem uma área específica de comunicação

19.A Comunicação mantém que nível de colaboração com a área de Sustentabilidade?

São integradas, compõem a mesma área

As áreas colaboram no nível estratégico e compartilham o processo de tomada de decisões

As áreas colaboram no nível operacional, compartilham informações e dados na formulação e execução dos projetos 


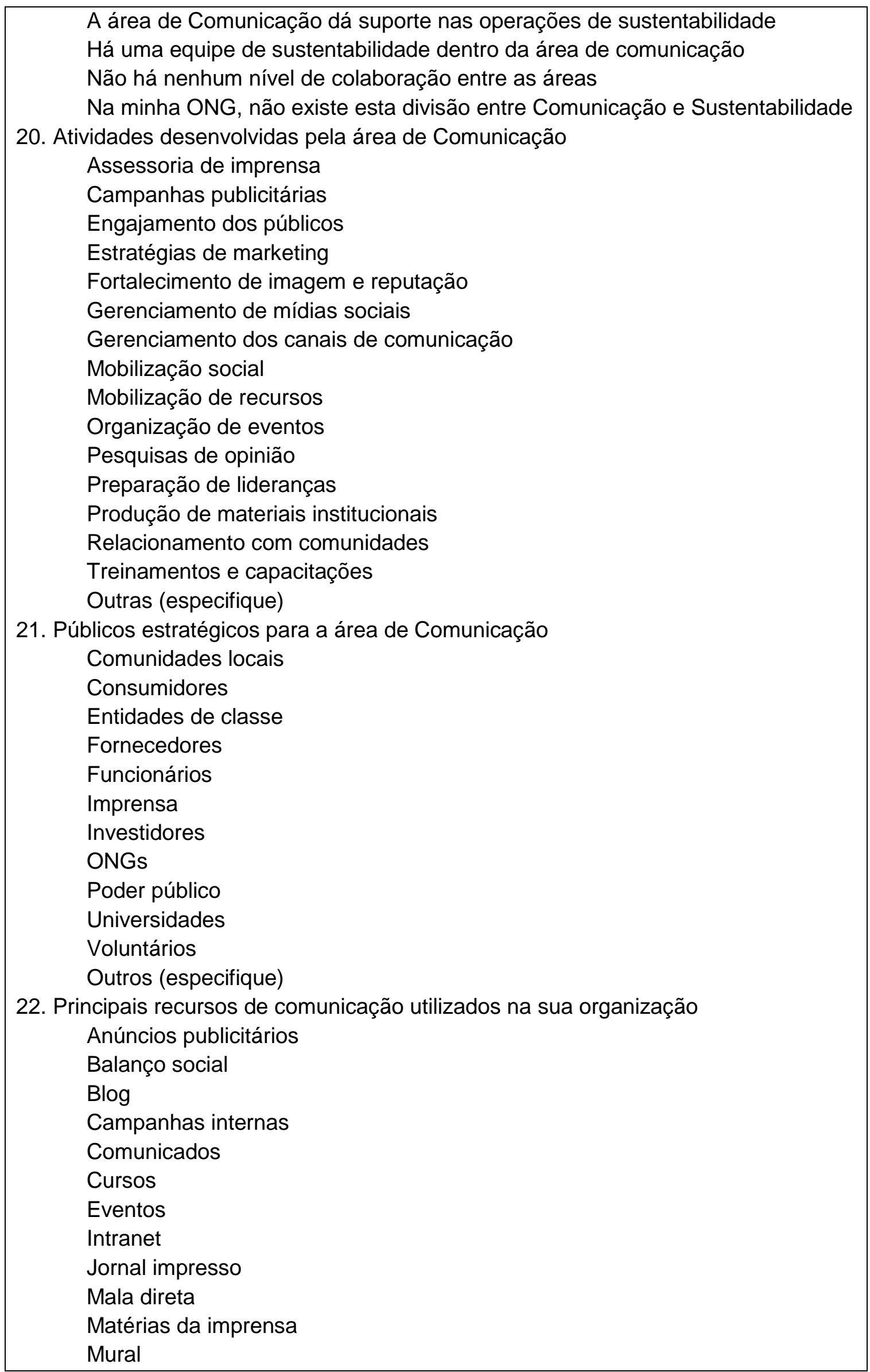




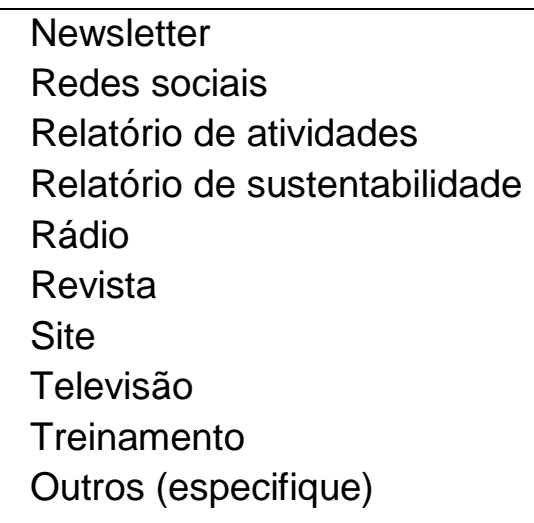

23. Linguagem preferencialmente utilizada em ações de Comunicação

Dramática / Alarmista

Lógica / Racional

Emocional / Indutiva

Envolvente / Sensitiva

Linguagem não determinada

24. Objetivos estratégicos no desenvolvimento de ações de sustentabilidade

Contribuir para transformar a sociedade por meio da ampliação da consciência sobre sustentabilidade

Contribuir para o desenvolvimento social a partir da inclusão de iniciativas práticas de sustentabilidade

Desenvolver novos produtos e processos direcionados para a sustentabilidade Disseminar valores éticos na promoção da sustentabilidade e ser referência no tema

Gerenciar os interesses dos públicos envolvidos para atender suas demandas de forma sustentável

Promover o desenvolvimento, por meio da inclusão ambiental, econômica e social

Zelar para que o atual modelo de produção gere menos impacto para a sociedade e o meio ambiente

\section{Parte IV - Mensuração}

25. Frequência de envolvimento da Comunicação nas tomadas de decisão

Sempre

Na maioria das vezes

Frequência intermediária

Raramente

Nunca

26. Quais são os atuais desafios da área de Comunicação?

Adequar-se à legislação que trata da sustentabilidade

Alcançar mais transparência nos processos

Atingir maior integração com outras áreas

Customizar mensagens para públicos diferentes

Desenvolver uma Comunicação Integrada

Engajar os públicos com os valores da ONG

Empoderar e ampliar a participação das pessoas envolvidas

Estruturar uma equipe qualificada 


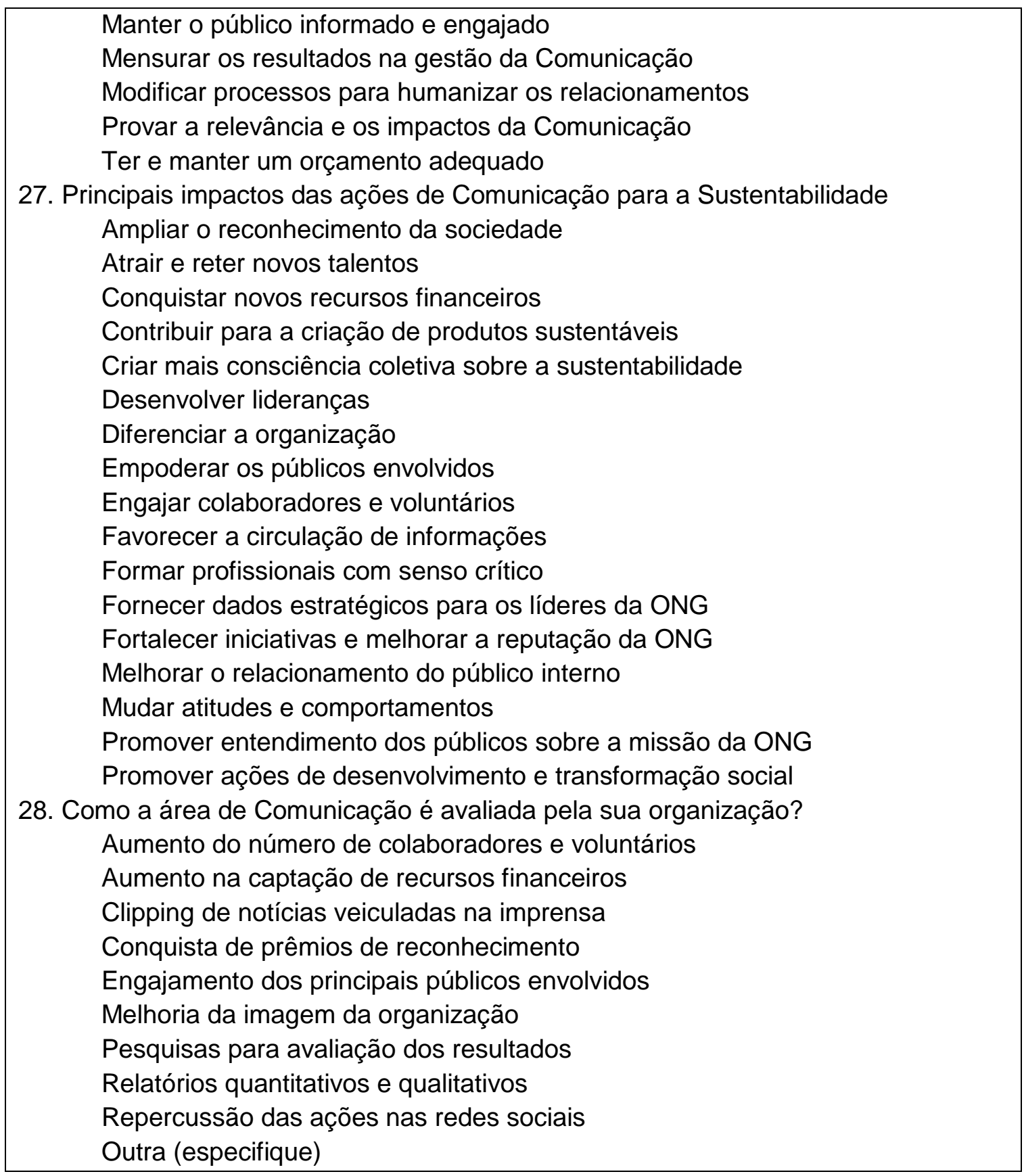




\section{Apêndice 2. Organizações da Abong acionadas na pesquisa}

\section{Agricultura}

AABR - ActionAid Brasil

AGENDHA - Assessoria e Gestão em Estudo da Natureza, Desenvolvimento Humano e Agroecologia APA-TO - Alternativas para a Pequena Agricultura no Tocantins

APACC - Associação Paraense de Apoio às Comunidades Carentes

AS-PTA - Assessoria e Serviços a Projetos em Agricultura Alternativa

ASSEMA - Associação em Áreas de Assentamento no Estado do Maranhão

AVICITECS - AVICITECS - Associação Vianei de Cooperação e Intercâmbio no Trabalho, Educação, Cultura e Saúde

CAATINGA - Centro de Assessoria e Apoio aos Trabalhadores e Instituições não Governamentais

Alternativas

CAPA - Centro de Apoio ao Pequeno Agricultor

CDDH-PETRÓPOLIS - Centro de Defesa dos Direitos Humanos de Petrópolis - Grupo Ação, Justiça e Paz

CDJBC - Centro de Assessoria e Serviço aos/às Trabalhadores/as da Terra Dom José Brandão de

Castro

CEAT - Centro de Estudos e Apoio ao Trabalhador e à Trabalhadora

CECOR - Centro de Educação Comunitária Rural

CEDENPA - Centro de Estudos e Defesa do Negro no Pará

CENTRAC - Centro de Ação Cultural

CENTRO SABIÁ - Centro de Desenvolvimento Agroecológico Sabiá

CESE - Coordenadoria Ecumênica de Serviço

CETAP - Centro de Tecnologias Alternativas Populares

CETRA - Centro de Estudos do Trabalho e de Assessoria ao Trabalhador

CHAPADA - Centro de Habilitação e Apoio ao Pequeno Agricultor do Araripe

CMN - Casa da Mulher do Nordeste

CPCD - Centro Popular de Cultura e Desenvolvimento

DESER - Departamento de Estudos Socioeconômicos Rurais

GACC-CE - Grupo de Apoio às Comunidades Carentes do Ceará

IB - Instituto Braços - Centro de Defesa dos Direitos Humanos em Sergipe

IRT - Instituto de Revitalização para o Trabalho

ISPN - Instituto Sociedade, População e Natureza

MOC - Movimento de Organização Comunitária

PATAC - Programa de Aplicação de Tecnologia Apropriada às Comunidades

RURECO - Fundação para o Desenvolvimento Econômico Rural da Região Centro-Oeste do Paraná

SASOP - Serviço de Assessoria a Organizações Populares Rurais

SERTA - Serviço de Tecnologia Alternativa

SOF - SOF Sempreviva Organização Feminista

TIJUPÁ - Associação Agroecológica Tijupá

\section{Assistência social}

AESOS - Associação Educacional Sons no Silêncio

AMENCAR - Associação de Apoio à Criança e ao Adolescente

APALBA - Associação das Pessoas com Albinismo na Bahia

ASSOCIAÇÃO ABRIGO RAINHA SÍLVIA - Associação Abrigo Rainha Sílvia

ASSOCIAÇÃO EDUCACIONAL LABOR - Associação Educacional Labor

CASA DA CULTURA DA BAIXADA FLUMINENSE - Casa da Cultura Centro de Formação Artística e

Cultural da Baixada Fluminense

CDDH-PETRÓPOLIS - Centro de Defesa dos Direitos Humanos de Petrópolis - Grupo Ação, Justiça e $\mathrm{Paz}$

CDJBC - Centro de Assessoria e Serviço aos/às Trabalhadores/as da Terra Dom José Brandão de

Castro

CEDAP - Centro de Educação e Assessoria Popular 
CEDECA-BA - Centro de Defesa da Criança e do Adolescente Yves de Roussan

CENTRO LUIZ FREIRE - Centro de Cultura Professor Luiz Freire

CETRA - Centro de Estudos do Trabalho e de Assessoria ao Trabalhador

COM CAUSA - Com Causa

CPCD - Centro Popular de Cultura e Desenvolvimento

CVC - Centro de Valorização da Criança

FÉ E ALEGRIA BRASIL - Fundação Fé e Alegria do Brasil

FOAESP - Fórum das ONGs AIDS do Estado de São Paulo

FTM - Fundação Terra Mirim - Centro de Luz

GACC-CE - Grupo de Apoio às Comunidades Carentes do Ceará

GESTOS - Gestos - Soropositividade, Comunicação e Gênero

GMM - Grupo Mulher Maravilha

GTP+ - Grupo de Trabalhos em Prevenção Positivo

IA - Instituto Ambient

IB - Instituto Braços - Centro de Defesa dos Direitos Humanos em Sergipe

ISER - Instituto de Estudos da Religião

MOC - Movimento de Organização Comunitária

MOPROM - Movimento de Promoção da Mulher

OPN - Associação Beneficente O Pequeno Nazareno

PROAME - Programa de Apoio a Meninos e Meninas

REDEH - Rede de Desenvolvimento Humano

VISÃO MUNDIAL - Visão Mundial Brasil

VOCAÇÃO - Ação Comunitária do Brasil - São Paulo

Comércio

ASSEMA - Associação em Áreas de Assentamento no Estado do Maranhão

CAPINA - Cooperação e Apoio a Projetos de Inspiração Alternativa

CDDH-PETRÓPOLIS - Centro de Defesa dos Direitos Humanos de Petrópolis - Grupo Ação, Justiça e Paz

ISPN - Instituto Sociedade, População e Natureza

MOC - Movimento de Organização Comunitária

\section{Economia solidária}

AABR - ActionAid Brasil

AÇÃO COMUNITÁRIA-RJ - Ação Comunitária do Brasil - Rio de Janeiro

ADELCO - Associação para o Desenvolvimento Local Coproduzido

AGENDHA - Assessoria e Gestão em Estudo da Natureza, Desenvolvimento Humano e Agroecologia

APA-TO - Alternativas para a Pequena Agricultura no Tocantins

ASPLANDE - Assessoria \& Planejamento para o Desenvolvimento

AVANTE - Avante - Educação e Mobilização Social

CAMA - Centro de Arte e Meio Ambiente

CAMP - Centro de Assessoria Multiprofissional

CAPINA - Cooperação e Apoio a Projetos de Inspiração Alternativa

CDDH-PETRÓPOLIS - Centro de Defesa dos Direitos Humanos de Petrópolis - Grupo Ação, Justiça e $\mathrm{Paz}$

CDHDMB - Centro de Direitos Humanos Dom Máximo Biennès

CDJBC - Centro de Assessoria e Serviço aos/às Trabalhadores/as da Terra Dom José Brandão de

Castro

CEDAC - Centro de Ação Comunitária

CEDENPA - Centro de Estudos e Defesa do Negro no Pará

CEFURIA - Centro de Formação Urbano Rural Irmã Araújo

CENTRAC - Centro de Ação Cultural

CENTRO SABIÁ - Centro de Desenvolvimento Agroecológico Sabiá

CESE - Coordenadoria Ecumênica de Serviço

CETAP - Centro de Tecnologias Alternativas Populares

CETRA - Centro de Estudos do Trabalho e de Assessoria ao Trabalhador

CF8 - CF8 - Centro Feminista 8 de Março

CHAPADA - Centro de Habilitação e Apoio ao Pequeno Agricultor do Araripe 
CMN - Casa da Mulher do Nordeste

CPCD - Centro Popular de Cultura e Desenvolvimento

CRIAR BRASIL - Centro de Imprensa, Assessoria e Rádio

DESER - Departamento de Estudos Socioeconômicos Rurais

ECOAR - Instituto Ecoar para Cidadania

FÉ E ALEGRIA BRASIL - Fundação Fé e Alegria do Brasil

FTM - Fundação Terra Mirim - Centro de Luz

GERMEN - Grupo de Defesa e Promoção Socioambiental

GMM - Grupo Mulher Maravilha

IB - Instituto Braços - Centro de Defesa dos Direitos Humanos em Sergipe

INSTITUTO KAIRÓS - Instituto Kairós - Ética e Atuação Responsável

IRT - Instituto de Revitalização para o Trabalho

ISPN - Instituto Sociedade, População e Natureza

MOC - Movimento de Organização Comunitária

PACS - Instituto Políticas Alternativas para o Cone Sul

PARRHESIA - Instituto Parrhesia Erga Omnes

PATAC - Programa de Aplicação de Tecnologia Apropriada às Comunidades

PROFEC - Programa de Formação e Educação Comunitária

RAMH - Rede Acreana de Mulheres e Homens

REDEH - Rede de Desenvolvimento Humano

SASOP - Serviço de Assessoria a Organizações Populares Rurais

SERTA - Serviço de Tecnologia Alternativa

SOF - SOF Sempreviva Organização Feminista

TIJUPÁ - Associação Agroecológica Tijupá

VIDA BRASIL - Valorização do Indivíduo e Desenvolvimento Ativo - Brasil (BA)

\section{Meio ambiente}

ABDL - Associação Brasileira para o Desenvolvimento de Lideranças

ADELCO - Associação para o Desenvolvimento Local Co-Produzido

AGENDHA - Assessoria e Gestão em Estudo da Natureza, Desenvolvimento Humano e Agroecologia ASPLANDE - Assessoria \& Planejamento para o Desenvolvimento

Associação Defensores da Terra

AVICITECS - AVICITECS - Associação Vianei de Cooperação e Intercâmbio no Trabalho, Educação,

Cultura e Saúde

CAMA - Centro de Arte e Meio Ambiente

CAPA - Centro de Apoio ao Pequeno Agricultor

CASA DA CULTURA DA BAIXADA FLUMINENSE - Casa da Cultura Centro de Formação Artística e Cultural da Baixada Fluminense

CDDH-PETRÓPOLIS - Centro de Defesa dos Direitos Humanos de Petrópolis - Grupo Ação, Justiça e $\mathrm{Paz}$

CDHMGB - Centro dos Direitos Humanos Maria da Graça Braz

CDJBC - Centro de Assessoria e Serviço aos/às Trabalhadores/as da Terra Dom José Brandão de

Castro

CEBI - Centro de Estudos Bíblicos

CECOR - Centro de Educação Comunitária Rural

CEDAC - Centro de Ação Comunitária

CEDENPA - Centro de Estudos e Defesa do Negro no Pará

CENTRAC - Centro de Ação Cultural

CENTRO SABIÁ - Centro de Desenvolvimento Agroecológico Sabiá

CEPIA - Cidadania, Estudo, Pesquisa, Informação e Ação

CESE - Coordenadoria Ecumênica de Serviço

CETAP - Centro de Tecnologias Alternativas Populares

CETRA - Centro de Estudos do Trabalho e de Assessoria ao Trabalhador

CHAPADA - Centro de Habilitação e Apoio ao Pequeno Agricultor do Araripe

CMN - Casa da Mulher do Nordeste

CNMP - Centro Nordestino de Medicina Popular

COMSAÚDE - Comunidade de Saúde, Desenvolvimento e Educação 
COMUNICAÇÃO E CULTURA - Comunicação e Cultura

CPCD - Centro Popular de Cultura e Desenvolvimento

CRIAR BRASIL - Centro de Imprensa, Assessoria e Rádio

DESER - Departamento de Estudos Socioeconômicos Rurais

ECOAR - Instituto Ecoar para Cidadania

ELO - Elo - Ligação e Organização

ESPAÇO - Espaço Formação Assessoria e Documentação

ESPLAR - Esplar Centro de Pesquisa e Assessoria

FÉ E ALEGRIA BRASIL - Fundação Fé e Alegria do Brasil

FLD - Fundação Luterana de Diaconia

FTM - Fundação Terra Mirim - Centro de Luz

FUNDAÇÃO SOS MATA ATLÂNTICA - Fundação SOS Pró-Mata Atlântica

GAMBA - Grupo Ambientalista da Bahia

GERMEN - Grupo de Defesa e Promoção Socioambiental

GMM - Grupo Mulher Maravilha

GREENPEACE BRASIL - Greenpeace Brasil

IA - Instituto Ambient

IB - Instituto Braços - Centro de Defesa dos Direitos Humanos em Sergipe

IBRACE - Instituto Brasil Central

IDACO - Instituto de Desenvolvimento e Ação Comunitária

IEMA - Instituto de Energia e Meio Ambiente

INESC - Instituto de Estudos Socioeconômicos

INSTITUTO BÚZIOS - Instituto Búzios

INSTITUTO TERRAMAR - Instituto Terramar

IPF - Instituto Paulo Freire

ISA - Instituto Socioambiental

ISER - Instituto de Estudos da Religião

ISER ASSESSORIA - Iser Assessoria

ISPN - Instituto Sociedade, População e Natureza

MENINA FELIZ - ONG Menina Feliz

MOC - Movimento de Organização Comunitária

OPAN - Operação Amazônia Nativa

PARRHESIA - Instituto Parrhesia Erga Omnes

PATAC - Programa de Aplicação de Tecnologia Apropriada às Comunidades

PÓLIS - Pólis Instituto de Estudos, Formação e Assessoria em Políticas Sociais

RAMH - Rede Acreana de Mulheres e Homens

REDEH - Rede de Desenvolvimento Humano

RURECO - Fundação para o Desenvolvimento Econômico Rural da Região Centro-Oeste do Paraná

SASOP - Serviço de Assessoria a Organizações Populares Rurais

SERTA - Serviço de Tecnologia Alternativa

SOF - SOF Sempreviva Organização Feminista

SOMADENA - Sociedade Maranhense de Defesa à Natureza

TIJUPÁ - Associação Agroecológica Tijupá

UCB - União de Ciclistas do Brasil

UNIPOP - Instituto Universidade Popular

\section{Trabalho e renda}

AÇÃO COMUNITÁRIA RJ - Ação Comunitária do Brasil - Rio de Janeiro

ADELCO - Associação para o Desenvolvimento Local Co-Produzido

AESOS - Associação Educacional Sons no Silêncio

AGENDHA - Assessoria e Gestão em Estudo da Natureza, Desenvolvimento Humano e Agroecologia

APACC - Associação Paraense de Apoio às Comunidades Carentes

APALBA - Associação das Pessoas com Albinismo na Bahia

ASPLANDE - Assessoria \& Planejamento para o Desenvolvimento

ASSOCIAÇÃO PROJETO NOVOS HORIZONTES - Associação Projeto Novos Horizontes

AVANTE - Avante - Educação e Mobilização Social

CAMA - Centro de Arte e Meio Ambiente 
CAMP - Centro de Assessoria Multiprofissional

CAMPO - Centro de Assessoria ao Movimento Popular

CAPINA - Cooperação e Apoio a Projetos de Inspiração Alternativa

CASA DA CULTURA DA BAIXADA FLUMINENSE - Casa da Cultura Centro de Formação Artística e

Cultural da Baixada Fluminense

CDDH-PETRÓPOLIS - Centro de Defesa dos Direitos Humanos de Petrópolis - Grupo Ação, Justiça e

$\mathrm{Paz}$

CDI - Comitê para Democratização da Informática

CDJBC - Centro de Assessoria e Serviço aos/às Trabalhadores/as da Terra Dom José Brandão de

Castro

CEAT - Centro de Estudos e Apoio ao Trabalhador e à Trabalhadora

CECOR - Centro de Educação Comunitária Rural

CENTRAC - Centro de Ação Cultural

CEPO - Centro de Educação Popular

CESE - Coordenadoria Ecumênica de Serviço

CETAP - Centro de Tecnologias Alternativas Populares

CETRA - Centro de Estudos do Trabalho e de Assessoria ao Trabalhador

CGGDH - Centro Gaspar Garcia de Direitos Humanos

CMN - Casa da Mulher do Nordeste

CPCD - Centro Popular de Cultura e Desenvolvimento

CRIAR BRASIL - Centro de Imprensa, Assessoria e Rádio

CVI - Centro de Vida Independente do Rio de Janeiro

DESER - Departamento de Estudos Socioeconômicos Rurais

FÉ E ALEGRIA BRASIL - Fundação Fé e Alegria do Brasil

FTM - Fundação Terra Mirim - Centro de Luz

FUNDIFRAN - Fundação de Desenvolvimento Integrado do São Francisco

GACC-CE - Grupo de Apoio às Comunidades Carentes do Ceará

IB - Instituto Braços - Centro de Defesa dos Direitos Humanos em Sergipe

IJC - Instituto de Juventude Contemporânea

IRT - Instituto de Revitalização para o Trabalho

ISPN - Instituto Sociedade, População e Natureza

MOC - Movimento de Organização Comunitária

MRE - Movimento República de Emaús

PARRHESIA - Instituto Parrhesia Erga Omnes

PATAC - Programa de Aplicação de Tecnologia Apropriada às Comunidades

RAMH - Rede Acreana de Mulheres e Homens

SERTA - Serviço de Tecnologia Alternativa

SOF - SOF Sempreviva Organização Feminista

TERRA DOS HOMENS - Associação Brasileira Terra dos Homens 


\section{Apêndice 3. Organizações do site ONGs Brasil acionadas na pesquisa}

\section{Associações de crédito e poupança}

"Instituto Sodetec de Desenvolvimento Social" - "Sodetec"

Abrades Agência Brasileira de Desenvolvimento Econômico e Social

Acreditar

Adesu - Agência de Desenvolvimento Econômico e Social de Ubatuba

Agência Brasileira de Gerenciamento Costeiro

Agência de Crédito do Vale do Itapocu

Agência de Desenvolvimento de Itapecerica da Serra e Região

Agência de Desenvolvimento Econômico e Socioambiental de Canoas - Adescan

Agência de Desenvolvimento Educacional e Social Brasileira

Agência de Desenvolvimento Local e Socioeconômico Excelsior - Fundo Excelsior

Agência de Desenvolvimento Social e Econômico de Guarapari-ES

Agência de Desenvolvimento Sustentável de Boa Esperança

Agência Nacional de Desenvolvimento Microempresarial

Agência Popular de Desenvolvimento da Amazônia

Agência Sul-americana de Desenvolvimento

Alapar - Sistema de Apoio aos Serviços de Saúde

Apoio a Iniciativa Empreendedora

Ass Bras Des da Família - Banco da Família

Associação Aliança Assessoria Financeira de Pessoas Físicas e Jurídicas

Associação Aliança Empreendedora

Associação Amazoncredi

Associação Artístico Cultural Agosto 17

Associação Bem Comum

Associação Civil Pátria Brasil

Associação Comunitária Caiçara

Associação Comunitária de Crédito de João Monlevade - Banco Popular do Pequeno Empreendedor de João Monlevade - Banpope

Associação Comunitária de Crédito do Vale do Aço

Associação Comunitária de Crédito Popular Solidário de João Pinheiro e Três Marias

Associação Comunitária do Sítio Cabaceiras

Associação Comunitária dos Moradores Micro e Pequenos Produtores Rurais do Povoado Olho D'água do Meio

Associação de Apoio às Comunidades do Campo do Mn

Associação de Artesãos Ateliê de Ideias

Associação de Crédito ao Empreendimento Popular

Associação de Crédito Comunidade do Futuro

Associação de Crédito Popular

Associação de Crédito Popular do Amazonas

Associação de Crédito Popular Solidário de Campinas

Associação de Crédito Solidário do Norte e Nordeste de Santa Catarina - Casa do Empreendedor

Associação de Desenvolvimento Econômico, Social e Cultural - Adesc Brasil

Associação de Garantia de Crédito da Serra Gaúcha

Associação de Microcrédito e Desenvolvimento Socioeconômico de Alagoas

Associação do Fórum de Desenvolvimento Local Integrado e Sustentável de Caarapó - Vivacidade

Associação do Povoado Mumbaca

Associação dos Servidores do Poder Judiciário no Estado do Espírito Santo

Associação Guemach Lar da Esperança

Associação Mineira de Crédito Popular

Associação Movimento Amor

Associação Multissocial Pró-Desenvolvimento Nova Era

Associação Objetivo Trabalho 
Associação para o Desenvolvimento da Mulher da Região Sul do Rio Grande do Sul Associação para o Desenvolvimento da Mulher de Caxias do Sul/RS

Associação Primeiros Passos

Associação Pró Emprego e Renda de Barbacena

Associação Rio Minas "Trem Mineiro"

Associação Telecentro de Informação e Negócios

Ativa-Sistema Institucional de Crédito

Banco do Empreendedor

Banco do Povo - Crédito Solidário

Cací - Comitê de Ação pela Cidadania

Cafenas Instituição de Promoção Social

Casa do Microcrédito

Ccrie - Casa de Crédito e Incentivo ao Empreendedor

Centro de Apoio à Economia Popular Solidária

Centro de Apoio a Pequenos Empreendimentos

Centro de Apoio aos Pequenos Empreendimentos de Goiás

Centro de Apoio aos Pequenos Empreendimentos de Pernambuco

Centro de Apoio aos Pequenos Empreendimentos do Estado da Bahia

Centro de Apoio aos Pequenos Empreendimentos do Estado de Sergipe

Centro de Apoio aos Pequenos Empreendimentos do Piauí

Centro de Desenvolvimento Integrado Social e Cultural

Centro de Estudos e Aplicações para as Novas Tecnologias Educacionais

Centro de Estudos e Apoio ao Desenvolvimento do Araripe

Centro de Estudos para o Desenvolvimento Local

Centro de Qualificação e Gestão do Conhecimento - CQG

Centro Ecumênico de Apoio ao Desenvolvimento

Centro Nacional de Apoio aos Pequenos Empreendimentos

Centro Referencial de Estudos e Apoio de Técnicas, Experimentações e Créditos - Createc

Contacred Instituição Mineira de Microcrédito

Creatif - Associação da Igualdade

Crecerto Agência de Microcrédito Solidário do Alto Uruguai Catarinense

Crediamai - Agência de Microcrédito

Credimais Instituição de Crédito Produtivo Popular

Credioeste

Crédito Popular Solidário

Credivale Agência Metropolitana de Microcrédito

Crescer Crédito Solidário

Desenvolvimento Social Humano Tecnológico DSHT

Deutscher Genossenschafts - Und Raiffeisenverband e. V. - Associação Alemã dos Bancos

Cooperativos e das Cooperativas de Crédito Agrícola

E+co Brasil

Educação em Foco

Empregar40

Entidade de Organização e Assistência Social São Brás

Extremo Oeste Agência de Crédito

Fazer - Associação Socioeconômica Fabiano de Cristo

Fundação Brasil Esperança

Fundação para o Desenvolvimento Sustentável do Araripe

Fundo de Apoio ao Empreendedor Joseense

Fundo de Apoio ao Empreendimento Popular

Fundo de Apoio ao Empreendimento Popular de Ariquemes

Grande Vitória Credisol

lagep - Instituto de Apoio à Gestão Pública

Indesus - Instituto Tecnológico para o Desenvolvimento Sustentável

Instituição Comunitária de Crédito

Instituição Comunitária de Crédito Banco do Povo MS

Instituição Comunitária de Crédito Central - RS - ICCC - RS

Instituição Comunitária de Crédito Conquista Solidária

Instituição Comunitária de Crédito da Região Sul - 
Instituição Comunitária de Crédito de Londrina - Casa do Empreendedor Instituição Comunitária de Crédito do Médio Alto Uruguai e Região Celeiro Instituição Comunitária de Crédito Itabuna Solidária Instituição Comunitária de Crédito VLC Rio Grande do Sul Instituição de Crédito Popular do Sudoeste Mineiro Instituição de Crédito Sindcred Instituição para o Desenvolvimento de Empreendimentos Populares Instituto Ambiental Global - IAG Instituto Banco Palmas de Desenvolvimento e Socioeconomia Solidária Instituto Brasil Social Instituto Brasil Solidário Instituto Brasileiro de Administração - IBA Instituto Brasileiro de Desenvolvimento Econômico, Social, Cultural e de Proteção ao Meio Ambiente Inbrades

Instituto Brasileiro de Integração e Desenvolvimento Pró-Cidadão Instituto Brasileiro de Santa Catarina - Ibrasc Instituto Credipaz Instituto de Atitudes Solidárias - lasol Instituto de Defesa da Cidadania Instituto de Desenvolvimento Econômico e Social do Brasil Instituto de Desenvolvimento Social Sustentável Carajás - Idesc Instituto de Economia Solidária Instituto de Estudo do Trabalho e Combate à Pobreza Instituto de Saúde, Educação Bem Estar Social Instituto de Tecnologia \& Gestão - Instituto Alfa Brasil Instituto do Crédito e Cidadania Instituto do Desenvolvimento Social e do Trabalho de Pernambuco Instituto Estrela de Fomento ao Microcrédito Instituto Gente Instituto Nordeste Cidadania Instituto para Cidadania e Implementação da Base Popular - Icibap Instituto para o Desenvolvimento da Administração Social, Saúde, Educação, Emprego e Habitação Idasseeh

Instituto Portas Abertas

Instituto Tecnológico de Administração Municipal Itam Instituto Terra de Santa Cruz Intep - Instituto Nacional Tecnológico de Ensino e Pesquisa Ipef Instituto Pentalfa de Fomento, Promoção, Educação e Desenvolvimento Social Liga Desportiva e Beneficente de Futsal Santamariense Microfenas, Organização de Crédito e Financiamento Movimento de Organização Comunitária Núcleo Verde Amarelo

ONG Dr. Vandick Ponte

Organização de Conservação de Terras do Baixo Sul da Bahia

Organização de Crédito Popular e Solidário do Município de Porto Velho

Organização de Microcrédito Solidário Crediconfiança

Organização Família Legal

Organização Representativa dos Concurseiros e Estudantes do Brasil

Organização, Método, Experiência, Garantia e Ação

Orjure Organização da Juventude Responsável

Oros - Organização Razão Social

Oscip Jovem Sertão - Organização da Sociedade Cível de Interesse Público

Oscip Matas Verde de Rondônia - Omaveron

Oscip Não Me Abandone

Profomento Agência de Crédito Especial

Programa Providência de Elevação da Renda Familiar - Programa Providência

Rede Socioeconômica Popular e Solidária de Desenvolvimento Sustentável Novo Sol

Redes - Rede de Desenvolvimento Social

Serviço de Tecnologia Alternativa 
Sg-coeso 2011

Siai - Sistema de Apoio Institucional

Sociedade de Crédito ao Microempreendedor Divina Providência

Sociedade de Crédito ao Microempreendedor do Planalto Norte

Sociedade de Garantia de Crédito do Noroeste do Paraná

Sociedade de Garantia de Crédito do Sudoeste do Paraná

Sociedade para o Desenvolvimento dos Serviços Públicos

União Brasileira de Desenvolvimento Social

União e Solidariedade para o Desenvolvimento Financeiro da Economia Social - Unisol Finanças

Valer Capacitação e Pesq p Des Local Sustentável

Viva Cred

\section{Controle e diminuição de danos ambientais}

A Mar de Dentro Ambiente e Educação

Academia Taguatinguense de Letras

Ação Brasileira pela Nutrição e Direitos Humanos

Ação Educacional Claretiana

Ação Ética \& Cidadania

Ação Popular Campos Gerais

Ação Social Paroquial São José de Botuverá

Adescan-Agência de Desenvolvimento Econômico e Social de Caldas Novas

Adesu - Agência de Desenvolvimento Econômico e Social de Ubatuba

Adote um Gatinho

Agência Brasileira de Desenvolvimento da Aquicultura

Agência Brasileira de Gerenciamento Costeiro

Agência Brasileira de Meio Ambiente e Tecnologia da Informação

Agência de Desenvolvimento de Guapirama

Agência de Desenvolvimento de Monte Alto e Região

Agência de Desenvolvimento Econômico e Social de Dois Córregos

Agência de Desenvolvimento Econômico e Social de Itanhaém

Agência de Desenvolvimento Econômico e Social de Mandaguari e Região

Agência de Desenvolvimento Econômico e Social de São Miguel do Iguaçu

Agência de Desenvolvimento Econômico e Social de Socorro - Adesso

Agência de Desenvolvimento Econômico e Social do Centro-Oeste - Adesco

Agência de Desenvolvimento Educacional e Social Brasileira

Agência de Desenvolvimento Integrado e Sustentável do Vale do Rio Urucuia

Agência de Desenvolvimento Integrado e Sustentável Sempre Alerta Riachinho

Agência de Desenvolvimento Local de Batayporã

Agência de Desenvolvimento Regional do Extremo Oeste do Paraná

Agência de Desenvolvimento Regional do Maciço de Baturite

Agência de Desenvolvimento Regional do Norte e Noroeste do Estado do Rio de Janeiro

Agência de Desenvolvimento Social de Flexal I e Nova Canaã

Agência de Desenvolvimento Sustentável da Amazônia Maranhense

Agência de Desenvolvimento Sustentável de Rorainópolis

Agência de Desenvolvimento Sustentável do Seridó

Agência do Programa de Desenvolvimento Sustentável do Centro-Oeste Mineiro

Agência Interamericana de Cooperação para o Desenvolvimento Sustentável

Agência Municipal de Desenvolvimento Sustentável

Agência Nacional de Desenvolvimento Eco social

Agência Nacional de Desenvolvimento Social e Ambiental

Agenda Vinte e Um Local de Hortolândia

Ajudanimal, Grupo de Ajuda e Amparo aos Animais do ABC

Ala - Associação Livre dos Aquicultores das Águas do São João

Alavanca

Aliança da Terra

Aliança de Justiça para Uma União Democrática

Aliança Nativa 
Alma - Associação de Moradores da Lauro Muller, Ramon Castilla, Xavier Sigaud e Adjacências Ambiente Brasil Centro de Estudos

Amigo Social

Amigos Associados de Itaberá (Amai)

Amigos da Terra - Amazônia Brasileira

Amigos do Protocolo de Kyoto

Ammatur - Associação Mineira do Meio Ambiente e do Turismo

Ass. Bras. De Infraestrutura e Saneam. Comunitário Social - A.B.I.C.S

Assistencial, Educacional, Beneficente

Assoc dos Usuários da Marina do Saco da Ribeira - Aumar

Associação Águas Claras do Rio Pinheiros

Associação Amazônia Viva

Associação Ambiental Voz da Natureza

Associação Ambientalista do Alto São Francisco

Associação Ambientalista Projeto Copaíba

Associação Ambientalista Roselândia

Associação Amigos do Bairro do Sahy

Associação Amigos do Meio Ambiente

Associação Beneficente Consciência Ecológica do Brasil

Associação Brasil Melhor

Associação Brasileira para a Difusão da Consciência pelo Desenvolvimento Social e Natural

Associação Caatinga

Associação Casa Azul

Associação Casa União pelo Desenvolvimento do Vale do Piranga

Associação Catarinense de Plantas Medicinais

Associação Celeiro do Vale do Rio Pardo

Associação Cellula Mater

Associação Cena Aberta

Associação Central dos Fruticultores do Norte de Minas

Associação Cerrado Nativo

Associação Civil Cidadania Brasil - ACCB

Associação Civil Hoc Tempore

Associação Comercial Industrial Ubaense dos Catadores de Materiais Recicláveis

Associação Comunitária de Desenvolvimento Sustentável São Paulo Apóstolo

Associação Comunitária do Bairro da Felicidade

Associação Comunitária Rural de Baixio e Serrinha

Associação Corpo de Bombeiros Voluntários de Ibirama

Associação da Boa Vontade

Associação de Apoio as Comunidades do Campo do RN

Associação de Bombeiros Comunitários de Videira

Associação de Cultura e Meio Ambiente

Associação de Defesa Ambiental llha Grande

Associação de Defesa Etnoambiental

Associação de Desenvolvimento Sustentável do Jardim Santa Genebra

Associação de Estudos, Orientação e Assistência Rural

Associação de Monitoramento Aéreo Ambiental

Associação de Moradores da Vargem do Forno

Associação de Moradores dos Bairros Rosário, Bicame, Ipanema, Novo Mundo e Novo Rosário

Associação de Preservação da Mata Ciliar do Rio Uruguai

Associação de Preservação do Meio Ambiente e da Vida - Apremavi

Associação de Promoção Humana e Social

Associação de Promoção Social de Campina Grande do Sul - Procamp

Associação de Reciclagem de Vila Velha

Associação do Fórum Ação para o Desenvolvimento de Candido Godoi

Associação do Fórum de Desenvolvimento Local Integrado e Sustentável de Caarapó - Vivacidade

Associação do Verde e Proteção do Meio Ambiente

Associação dos Amigos da Floresta Nacional de Brasília - Flona/BSB

Associação dos Amigos da Pedra da Princesa

Associação dos Amigos de Alto dos Pinheiros 
Associação dos Antigos Alunos da Escola Politécnica da Universidade de São Paulo Associação dos Catadores de Papel de Guarapuava

Associação dos Mineradores de Ouro do Tapajós

Associação dos Moradores da Vila Nova

Associação dos Moradores dos Setores Coimbra e Bela Vista

Associação dos Moradores e Produtores do Núcleo Rural Areia Santa Rita

Associação dos Pequenos Produtores da Fazenda Mata

Associação dos Produtores de Erva Mate de Machadinho

Associação Eco Juréia

Associação Ecológica e Cultural de Integração Fronteira das Artes

Associação Ecológica Tijuco

Associação Ecológica Turismo Sustentável

Associação em Defesa do Meio Ambiente e da Cidadania Caminho Verde

Associação Estadual de Mulheres Camponesas de Santa Catarina

Associação Focinhos Carentes de Toledo - Afocato

Associação Formiga Verde

Associação Fórum de Dlis de Pedro Gomes - ADPEG

Associação Gente Que Faz

Associação Geográfica União das Águas

Associação Gerando Saúde Mental

Associação Global de Desenvolvimento Sustentado

Associação Holística de Participação Comunitária Ecológica - Núcleo da Terra

Associação Humana Povo para Povo Brasil

Associação Instituto de Pesquisas em Energias Renováveis e Meio Ambiente

Associação Instituto de Políticas e Desenvolvimento

Associação Internacional Protetora do Meio Ambiente

Associação Ipê

Associação Latino Americana de Reciclagem e Meio Ambiente

Associação Marca para Promoção de Serviços

Associação Mineira de Defesa do Ambiente

Associação Mineira de Educadores Ambientais

Associação Movimento Ecológico Amigos do Meio Ambiente

Associação Núcleo para Transformações Ambientais e Sociais

Associação Olhos D'Água

Associação Onça D’Água de Apoio à Gestão e ao Manejo das Unidades de Conservação do Estado do Tocantins

Associação Pacto Ambiental

Associação para o Combate à Exclusão Social e Preservação Ambiental - Acespa Chico Mendes

Associação Paranaense de Preservação Ambiental dos Mananciais do Rio Iguaçu e da Serra do Mar Associação Parque Maracá

Associação Paulista de Gestão Pública - APGP

Associação Peixe Vivo Educação Ambiental, Cultura e Lazer

Associação pela Recuperação e Preservação da Mata Atlântica

Associação Polivida

Associação Pró Casa do Pinhal

Associação Projeto 37 Frutágua

Associação Protetora das Montanhas e Araucárias e Seus Valores Sociais, Artísticos, Estéticos, Ambientais, Geológicos, Históricos e Paisagísticos

Associação Reciclar para Construir

Associação Rede Vida de Desenvolvimento Humano Tecnológico e Proteção Social

Associação Regional do Meio Ambiente

Associação Rio_Minas "Trem Mineiro"

Associação Sai da Toca Cultural

Associação Serra da Mantiqueira

Associação Serra do Itapetinga, Movimento pela Biodiversidade e Organização dos Setores Ecológicos

Associação Solidariedade, União e Cidadania - ASUC

Associação Sonhar E Acreditar

Associação SOS Amazônia

Associação Terrabrasil - ONG 
Associação Thalamus

Associação Tuim Proteção e Educação Ambiental

Associação Unida do Bairro Pôr-do-sol

Associação Universitária da Zona Leste

Associação Vianei de C.I.T.E.C.S.

Associação Vida Amiga

Banco de Alimentos do Rio Grande do Sul

Biomavale - Organização da Sociedade Civil de Interesse Público

Brasil - Conscientização e Cidadania

Brasil Ação Solidária

Cací - Comitê de Ação pela Cidadania

Caiapônia Instituto de Saneamento Ambiental

Câmara de Cultura, Comércio e Turismo Brasil - Países Africanos

Camará Saúde Qualidade de Vida e Gestão

Capivari Monos

Caritas Diocesana de Itapipoca

Caritas Diocesana de Januária

Casa da Natureza e de Proteção da Vida

Casa Estrela

Ceadec - Centro de Estudos e Apoio ao Desenvolvimento Emprego e Cidadania

Cempre - Compromisso Empresarial para Reciclagem

Central de Inteligência e Assessoria Brasil

Centro de Aprendizagem e Desenvolvimento Social Sustentável

Centro de Assistência e Desenvolvimento Social

Centro de Desenvolvimento Integrado Social e Cultural

Centro de Desenvolvimento Social

Centro de Desenvolvimento Sustentável e Industrial de Sistemas Florestais do Norte Pioneiro

Centro de Estudos e Aplicações para as Novas Tecnologias Educacionais

Centro de Estudos e Apoio ao Desenvolvimento do Araripe

Centro de Estudos e Pesquisas 28

Centro de Estudos Marinhos do Atlântico Sul

Centro de Estudos para o Desenvolvimento Sustentável e Inclusão Social

Centro de Pastoral do Menor de Itapirapuã

Centro de Pesquisa do Pantanal

Centro de Referência em Cooperativismo e Associativismo

Centro de Referências em Cidadania, Ética e Responsabilidade

Centro de Responsabilidade Socioambiental da Amazônia - CRSAmazônia

Centro de Tecnologia e Tratamento de Resíduos de Maringá e Região, CTR Maringá

Centro de Voluntários em Cooperativismo e Economia Social para as Américas

Centro Educacional Imaculada Conceição

Centro Integrado de Cultura e Meio Ambiente Caburé

Centro Integrado de Promoção Social

Centro Preserv de Promoção do Desenvolvimento Sustentado

Centro Social Shalom

Centro Social Verdadeira Amizade

Ceproser - Centro de Pesquisa Proteína da Serpente

CIT - Centro de Integração do Trabalhador

Cluster de Turismo da Costa dos Coqueiros

Comando do Futuro Entidade Filantrópica

Combina - Companhia dos Bichos e da Natureza

Comitê Sul Brasileiro de Segurança Sócio Ambiental

Companhia de Desenvolvimento Econômico e Social de São Sebastião

Companhia de Desenvolvimento Municipal de Águas Lindas de Goiás

Comunidade Educacional de Pirenópolis

Conselho de Preservação Ambiental Brasileiro

Conserj Conselho Comunitário de Segurança do Rio de Janeiro

Conservation Strategy Fund do Brasil

Consórcio para Proteção Ambiental e Desenvolvimento Sustentável e Sociocultural da Bacia Hidrográfica do Rio das Cinzas 
Copati - Consórcio Intermunicipal para Proteção Ambiental da Bacia do Rio Tibagi

Creatif - Associação da Igualdade

Curuca, Consc. Ecológica c Pers. Curupira e Caapora

Curucutu Parques Ambientais

Desenvolvimento Social Humano Tecnológico DSHT

E.U - Ecologia Urbana

Ecos - Instituto de Pesquisa e Desenvolvimento Socioambiental

Ecovitae Tecnologia Ambiental

Educandário São José

Elo Ambiental - Organização Não Governamental

Elo Social de Gestão Pública

Ema - Conscientização e Recuperação Ambiental

Equipe Cogestora do Parque Estadual Fritz Plaumann

Equipe de Conservação da Amazônia

Escola Viveiro Multiplicadora Artesã

Face a Face Ação Solidária

Fauna \& Flora International

Força Comunitária Nacional

Fórum de Desenvolvimento de Coronel Vivida

Fórum Municipal de Lutas de Itaquaquecetuba

Fórum Permanente de Responsabilidade Social do Rio Grande do Sul

Fundação Abrahma Kasinski

Fundação Brasil Esperança

Fundação Caxias do Sul

Fundação Centro Integrado de Apoio às Vítimas de Violência

Fundação Cepa - Centro de Est e Planif do Ambiente

Fundação Comunitária de Desenvolvimento Integrado do Município de Rio Negro - Fundir

Fundação de Amparo a Pesquisa de Recursos Vivos na Zona Econômica Exclusiva

Fundação de Desenvolvimento da Região da Serra da Mesa

Fundação de Formação, Pesquisa e Difusão Tecnológica Para Uma Convivência Sustentável Com o

Semiárido

Fundação de Salvamento Aquático de Santa Catarina

Fundação Educacional, Assistencial e de Proteção Ao Meio Ambiente

Fundação Emalto

Fundação Espírita Rodolfo Henriques

Fundação Gaúcha dos Bancos Sociais

Fundação Grupo Esquel Brasil

Fundação Movimento Ondazul

Fundação Odebrecht

Fundação para o Desenvolvimento Sustentável do Araripe

Fundação Proamb

Fundação Pro-Defesa Ambiental

Fundação Rio do Leão

Fundação Serviços de Defesa e Tecnologias de Processos

Fundação SOS Pró-Mata Atlântica

Gase Grupo de Apoio ao Serviço Emergencial

Gente Feliz

Gerar Geração de Emprego, Renda e Apoio ao Desenvolvimento Regional

Global Social Impact - GSI

Graf Grupo de Recuperação Ambiental e florestal

Green Cross Brasil

Grupo Ambiental Natureza Bela

Grupo Ambientalista do Rio Iguaçu

Grupo AR - Ação Renovadora

Grupo de Apoio, Estudo e Pesquisa Ambiental e Cultural- Pro Terra

Grupo de Desenvolvimento Humano e Ambiental - Instituto Goiamum

Grupo de Estudos e Promoção do Desenvolvimento Sustentável

Grupo de Estudos Manoa

Grupo de Pesquisas Ufológicas Ufogênesis 
Grupo Ecológico Vida Verde de Cornélio Procópio

Grupo Itápolis Ação e Reintegração Social

Habita Instituto para Desenv das Cidades

Horizonte Promoção Social e Educacional - Oscip

Hospital Dr Pacifico Mascarenhas

Humana Vita - Instituto para Valorização do Ser Humano

lagep - Instituto de Apoio a Gestão Pública

lambra Instituto de Assistência aos Municípios Brasileiros

Ibepoteq - Instituto Brasileiro de Estudos e Pesquisas para Otimização da Tecnologia e Qualidade Aplicadas

Idaq Instituto Dr. Avelino Elias de Queiroga

Ideia Ambiental Sociedade S/C

Idelt - Instituto de Desenvolvimento, Logística, Transporte e Meio Ambiente

Idese - Instituto para o Desenvolvimento Social e Ecológico

Igreja Congregacional Afro-Brasileira de Renovação Espiritual

Inadem Instituto Nacional para o Desenvolvimento Econômico e Preservação do Meio Ambiente

Inderc Instituto de Desenvolvimento Regional do Cintap

Indesus - Instituto Tecnológico para o Desenvolvimento Sustentável

ING - Instituto Os Guardiões Da Natureza

Iniciativa Primus

Inst. de Estudos e Pesq. para Prom. da Educação, Cultura e Desenvolvimento Econômico e Social -

Prosocial

Instituto A Mudança Que Queremos

Instituto Ação Verde

Instituto Acqua - Ação, Cidadania, Qualidade Urbana e Ambiental

Instituto Akaire

Instituto Amar

Instituto Amazônia

Instituto Amazônico de Desenvolvimento Social, Amparo a Pesquisa e a Tecnologia

Instituto Ambiental Aracua

Instituto Ambiental Brasil Sustentável

Instituto Ambiental Ceres

Instituto Ambiental de Desenvolvimento Social Sustentável - Instituto Biocêntrica

Instituto Ambiental Global - IAG

Instituto Ambiental Parque das Perobas

Instituto Ambiental Vale do Iguaçú

Instituto Ambiente Em Foco

Instituto Amea

Instituto Árvore Da Vida

Instituto Assistencial de Atenção a Gestão Médica Hospitalar - Instituto CAV

Instituto Atílio Correia Lima

Instituto Atlantis de Preservação Ambiental

Instituto Ave É Vida

Instituto Barilá

Instituto Bioacqua de Promoção de Desenvolvimento Sustentável e Defesa do Meio Ambiente

Instituto Biológico do Meio Ambiente - Bioma

Instituto Brasil Ambiental

Instituto Brasil Ambiental - Ibra

Instituto Brasil Preservação Ambiental e Desenvolvimento Sustentável

Instituto Brasil Solidário

Instituto Brasileiro de Ações Integradas

Instituto Brasileiro de Administração - IBA

Instituto Brasileiro de Defesa Civil - Ibradec

Instituto Brasileiro de Defesa da Natureza

Instituto Brasileiro de Desenvolvimento da Defesa Civil e do Meio Ambiente IBDM

Instituto Brasileiro de Desenvolvimento Econômico, Social, Cultural e de Proteção ao Meio Ambiente Inbrades

Instituto Brasileiro de Desenvolvimento Social de Planaltina

Instituto Brasileiro de Desenvolvimento Sustentável 
Instituto Brasileiro de Difusão Educacional para o Trânsito

Instituto Brasileiro de Direito Ambiental

Instituto Brasileiro de Engenharia

Instituto Brasileiro de Florestas

Instituto Brasileiro de Integração e Desenvolvimento Pró-Cidadão

Instituto Brasileiro de Irrigação

Instituto Brasileiro de Pesquisas e Estudos Ambientais

Instituto Brasileiro de Responsabilidade Social - IBRS

Instituto Brasileiro de Santa Catarina - IBRASC

Instituto Brasileiro do Crisotila

Instituto Brasileiro para a Inovação Tecnológica Ambiental

Instituto Brasileiro Pró-cidadania

Instituto Bravoli de Desenvolvimento Social

Instituto BS Colway Social

Instituto Câmara Filho

Instituto Çarakura

Instituto Centro De Vida - IVC

Instituto Centro-Brasileiro de Cultura

Instituto Cerrado

Instituto Científico Mauá de Multidesenvolvimento

Instituto Cistema - Cidadania - Saúde - Trabalho - Educação e Meio Ambiente

Instituto Civitas Brasil de Desenv Técnico, Econômico e Social em Saneamento Ambiental

Instituto Coca-Cola Brasil

Instituto Convivência com o Semiárido Brasileiro

Instituto Costa Brasilis - desenvolvimento Socioambiental

Instituto Creatio

Instituto Cultural Soto Delatorre

Instituto da Árvore

Instituto de Ação Social Planejada

Instituto de Apoio a Gestão Pública e social

Instituto de Apoio a Políticas Sociais

Instituto de Apoio a Programa de Ações Sociais - IAPAS

Instituto de Apoio a Tecnologia, Educação, Saúde, Promoção Social, Meio Ambiente e Cultura

Instituto de Apoio e Desenvolvimento Ambiental e Saúde - IADAS

Instituto de Apoio e Proteção Ambiental

Instituto de Apoio Técnico Especializado à Cidadania

Instituto de Cidadania e Estudos Ambientais e Turismo

Instituto de Ciências da Terra e do Mar

Instituto de Cooperação e Tecnologia Socioambiental

Instituto de Desenvolvimento Ambiental e Social

Instituto de Desenvolvimento da Organização Nacional de Excelência Administrativa

Instituto de Desenvolvimento da Região do Sisal

Instituto de Desenvolvimento e Informação em Transporte

Instituto de Desenvolvimento e Integração do Bem-Estar Social e Cidadania de Corbélia

Instituto de Desenvolvimento e Pesquisas do meio ambiente e atividades esportivas

Instituto de Desenvolvimento Econômico e Socioambiental - Idesa

Instituto de Desenvolvimento Integrado

Instituto de Desenvolvimento Integrado para Ações Sociais

Instituto de Desenvolvimento Municipal

Instituto de Desenvolvimento Social, Econômico e Ambiental de Mato Grosso do Sul

Instituto de Desenvolvimento Sócio Ambiental Pantanal Sul

Instituto de Desenvolvimento Socioeconômico dos Trabalhadores de Baixa Renda

Instituto de Desenvolvimento Sustentável de Santa Catarina

Instituto de Desenvolvimento Sustentável do Estado de Santa Catarina

Instituto de Desenvolvimento Tecnológico

Instituto de Desenvolvimento, Educação, Análise e Legislação - Ideal

Instituto de Direito Agrário e Ambiental do Sul - Joaquim Luiz Osorio

Instituto de Ecologia Terrestre

Instituto de Educação Ambiental, Preservação, Conservacionismo e Promoção Social - Patriamada 
Instituto de Educação Pesquisa e Saúde San Julian

Instituto de Ensino Pesquisa e Preservação Ambiental Marcos Daniel - Instituto Marcos Daniel Instituto de Estudos e Projetos de Interesse Social

Instituto de Estudos Socioambientais

Instituto de Estudos Socioculturais e Ambientais Embra Cultural

Instituto de Geração de Tecnologias do Conhecimento

Instituto de Gestão Solidária

Instituto de Integração Social e Ambiental

Instituto de Integração Social, Desenvolvimento Sustentável e Preservação Ambiental

Instituto de Meio Ambiente e Desenvolvimento

Instituto de Meio Ambiente e Desenvolvimento Sustentável - Tramirim

Instituto de Permacultura da Bahia

Instituto de Pesquisa Agropecuária do Nordeste

Instituto de Pesquisa Ambiental Ekos

Instituto de Pesquisa e Conservação da Natureza

Instituto de Pesquisa e Reaproveitamento de Resíduos Sólidos

Instituto de Pesquisas Ambientais e Sociais Aplicadas

Instituto de pesquisas e projetos para o Desenvolvimento Socioeconômico da Amazônia

Instituto de Planejamento Urbano e Gestão Ambiental - IPGA

Instituto de Políticas Públicas e Sociais

Instituto de Políticas Públicas Rio de Janeiro

Instituto de Preservação e Recuperação da Biodiversidade de Jlle e Região - Viva o Cachoeira

Instituto de Promoção e educação em saúde

Instituto de Renovação Social - Família Brasileira

Instituto de Saúde e Meio Ambiente

Instituto de Saúde Preventiva e Ações Sociais Assistidas Meridional

Instituto de Saúde, Educação, Bem-Estar Social

Instituto de Tecnologia \& Gestão - Instituto Alfa Brasil

Instituto de Tecnologia de Prevenção de Desastres Naturais e Industriais

Instituto de Turismo de Itacaré

Instituto Dignidade de Valorização da Vida

Instituto do Cerrado

Instituto Eco Millennium

Instituto Ecoanimal

Instituto Ecoar para a Cidadania

Instituto Eco-empreendedor para a Sustentabilidade Ambiental

Instituto Ecológica Palmas/TO

Instituto Ecos do Brasil

Instituto Ekos Brasil

Instituto Elo

Instituto Espinhaço, Biodiversidade, Cultura e Desenvolvimento Socioambiental

Instituto Eurobase

Instituto Eurofarma

Instituto Excelsa

Instituto Floresta de Pesquisa e Desenvolvimento Sustentável

Instituto Floresta Tropical

Instituto GEA - Ética e Meio Ambiente

Instituto Gênesis

Instituto Germinar Socioambiental

Instituto Gnarus

Instituto Grande Sertão

Instituto Guaicuy - SOS Rio das Velhas

Instituto Hidroambiental Águas do Brasil - Ihab

Instituto Ibá de Desenvolvimento Ambiental e Social

Instituto Ilhabela Sustentável

Instituto Inceri

Instituto Ipsis - Instrumentalização de Projetos Sustentáveis de Interesse Social

Instituto Julieta Araújo

Instituto Justino Carvalho 
Instituto Juventude Ativa

Instituto Labor \& Vita

Instituto Lagoa Prateada

Instituto Litoral Verde

Instituto Mãe Terra de Tecnologia Educacional e Ambiental

Instituto Manicoba

Instituto Maramar Para o Manejo Responsável dos Recursos Naturais

Instituto Marca de Desenvolvimento Ambiental - Imadesa

Instituto Marcia Fraga

Instituto Maria Stella

Instituto Martim Pescador - Movimento de Preservação da Bacia Hidrográfica do Rio dos Sinos

Instituto Missão Urbana - Imur

Instituto Modus Vivendi de Desenvolvimento Social, Cultural e Ambiental

Instituto Montana Ambiental

Instituto Nacional Ações e Metas Integradas

Instituto Nacional de Apoio a Educação, Desenvolvimento, Pesquisa, Ações Assistenciais em Saúde, Meio Ambiente, Turismo e Cultura

Instituto Nacional de Desenvolvimento Agropecuário

Instituto Nacional de Desenvolvimento Sustentável

Instituto Nacional de Fiscalização

Instituto Nacional de Preservação Ambiental

Instituto Nacional de Tecnologia Social

Instituto Nacional para o Desenvolvimento Espacial e Aeronáutico - Idea

Instituto Nascente - Turismo \& Ecologia

Instituto Natureza Viva

Instituto Navega São Paulo

Instituto Novas Fronteiras da Cooperação

Instituto Novos Saberes

Instituto Oca Brasil

Instituto Oikos de Agroecologia

Instituto Oksigeno

Instituto Ondular

Instituto Opab

Instituto Orbis de Proteção e Conservação da Natureza

Instituto para Desenvolvimento Socioambiental e Tecnológico Lótus

Instituto Palavrações

Instituto para Cidadania e Implementação da Base Popular - Icibap

Instituto para Desenvolvimento Ambiental e Tecnológico - Idea Cíclica

Instituto para o Desenvolvimento Ambiental

Instituto para o Desenvolvimento da Administração Social, Saúde, Educação, Emprego e Habitação Idasseeh

Instituto para o Desenvolvimento Social de Ipirá

Instituto para o Desenvolvimento Sociocultural e Ambiental - INDES

Instituto para o Desenvolvimento Sustentável de Joinville

Instituto Parceria

Instituto Patulus

Instituto Peabiru

Instituto Pedro Ludovico

Instituto Physis - Cultura \& Ambiente

Instituto Potiguar de Juventude pela Cidadania

Instituto Prisma de Apoio Administrativo às Micro, às Pequenas, às Médias Empresas e às Entidades da Administração Pública Direta

Instituto Pró Rio Doce

Instituto Profissionalizante de Tecnologia da Informação

Instituto Rodrigo Marcheschi - IRM

Instituto Sadia de Sustentabilidade

Instituto Santa Cruz de Saúde, Meio Ambiente e Tecnologia

Instituto Sergio Escadinha

Instituto SICOOB para o Desenvolvimento Sustentável 
Instituto Sierra de Proteção ao Meio Ambiente e Pequenos Animais

Instituto Social para Edificação da Cidadania

Instituto Social Tecnológico e Econômico do Café - Mais Café

Instituto Social, Educacional e de Pesquisa de Minas Gerais

Instituto Social, Educativo e Beneficente Novo Signo

Instituto Socio Agro Ambiental Campinense - ISAAC

Instituto Socioambiental Guapuruvu

Instituto Socioambiental Latinha da Solidariedade

Instituto Sociocultural Santa Alice Instituto Socioambiental

Instituto Socioambiental Brasil - ISAB

Instituto Socioambiental Brasileiro - ISAB

Instituto Tamanduá Synapse Cultural

Instituto Tempo Bougra - SCTB

Instituto Tempo É Vida

Instituto Terra de Santa Cruz

Instituto Terra, Guardião da Natureza e Assistencial

Instituto Trata Brasil - ITB

Instituto Triunfo

Instituto Verde Brasil

Instituto Verdescola

Instituto Via Viva

Instituto Vida Gestão Ambiental e Municipal

Instituto Vida para o Atendimento à Saúde, Saneamento e Meio Ambiente

Instituto Vitalis Vitalizando a Integração dos Trabalhadores da América Latina na Luta pela Inclusão

Social

Instituto Xopotó de Desenvolvimento Social, Econômico e Ambiental

Interforum Global Intercâmbio e Desenvolvimento Sustentável

Instituto Brasil de Água e Energia - IBRAE

Ipam - Instituto Brasileiro de Pesquisas Ambientais

Itesb - Instituto Técnico Econômico Social Brasileiro

Juventude Sem Fronteiras

Liga Desportiva e Beneficente de Futsal Santamariense

Mana - Mani Círculo Aberto de Comunicação, Educação e Cultura

Mapas - Métodos de Apoio a Práticas Ambientais e Sociais

Mater Natura - Instituto de Estudos Ambientais

Missão Família

Movimento Ambiental Gestão e Organização Social - Magos

Movimento de Cidadania Pelas Águas

Movimento de Organização Comunitária

Movimento Interamericano de Ecologia

Nazaré Universidade da Luz

\section{Ecoeficiência}

A Casa Verde - Cultura e Meio Ambiente

Associação Brasileira ABTCP Associação Brasileira Técnica de Celulose e Papel

Ação Ética \& Cidadania

Ação Popular Campos Gerais

Ação Social Paroquial São José de Botuverá

Adesu - Agência de Desenvolvimento Econômico e Social de Ubatuba

Agência Brasileira de Desenvolvimento da Aquicultura

Agência Brasileira de Gerenciamento Costeiro

Agência Brasileira de Meio Ambiente e Tecnologia da Informação

Agência de Desenvolvimento de Guapirama

Agência de Desenvolvimento de Monte Alto e Região

Agência de Desenvolvimento Econômico e Social do Centro Oeste - ADESCO

Agência de Desenvolvimento Integrado e Sustentável Sempre Alerta Riachinho

Agência de Desenvolvimento Regional da Amurel 
Agência de Desenvolvimento Sustentável da Amazônia Maranhense

Agência de Desenvolvimento Sustentável de Rorainópolis

Agência de Desenvolvimento Sustentável do Seridó

Agência Interamericana de Cooperação Para o Desenvolvimento Sustentável

ALA - Associação Livre dos Aquicultores das Águas do São João

Aliança Nativa

Alma - Associação de Moradores da Lauro Muller, Ramon Castilla, Xavier Sigaud e Adjacências

Ambiente Brasil Centro de Estudos

Amigo Social

Amigos da Terra - Amazônia Brasileira

Ammatur - Associação Mineira do Meio Ambiente e do Turismo

Associação Amazônia Viva

Associação Ambiental Voz da Natureza

Associação Amigos do Bairro do Sahy

Associação Amigos do Futuro

Associação Brasileira Associação Brasileira Água e Energia - ABAE

Associação Brasileira Associação Brasileira de Desenvolvimento Humano

Associação Brasileira Associação Brasileira para a Difusão da Consciência pelo Desenvolvimento

Social e Natural

Associação Caatinga

Associação Casa União pelo Desenvolvimento do Vale do Piranga

Associação Cena Aberta

Associação Civil Instituto Baraeté de Desenvolvimento Social, Ambiental, Desportivo e Cultural - IB

Associação Comercial Industrial Ubaense dos Catadores de Materiais Recicláveis

Associação Comunitária Cidade Viva - "Nossa ONG"

Associação de Reciclagem de Vila Velha

Associação do Fórum de Desenvolvimento Local Integrado e Sustentável de Caarapó - Vivacidade

Associação do Verde e Proteção do Meio Ambiente

Associação dos Amigos da Floresta Nacional de Brasília - Flona/BSB

Associação dos Amigos da Pedra da Princesa

Associação dos Engenheiros da Sabesp

Associação dos Produtores de Erva Mate de Machadinho

Associação Ecológica e Cultural de Integração Fronteira das Artes

Associação em Defesa do Meio Ambiente e da Cidadania Caminho Verde

Associação Formiga Verde

Associação Fórum de Dlis de Pedro Gomes - ADPEG

Associação Geográfica União das Águas

Associação Guardiã da APA do Pratigi

Associação Instituto de Pesquisas em Energias Renováveis e Meio Ambiente

Associação Internacional Protetora do Meio Ambiente

Associação Mineira de Defesa do Ambiente

Associação Núcleo para Transformações Ambientais e Sociais

Associação Pacto Ambiental

Associação para o Combate à Exclusão Social e Preservação Ambiental - ACESPA Chico Mendes

Associação Prato Cheio

Associação Pró Casa do Pinhal

Associação Proeco

Associação Protetora das Montanhas e Araucárias e Seus Valores Sociais, Artísticos, Estéticos, Ambientais, Geológicos, Históricos e Paisagísticos

Associação Sai da Toca Cultural

Associação Serra da Mantiqueira

Associação Terrabrasil - ONG

Associação Thalamus

Associação Tuim Proteção e Educação Ambiental

Associação União llha de Boipeba

Associação Universitária da Zona Leste

Associação Vida Amiga

Brasil Ação Solidária

Brasil Essencial - Resultados Sustentáveis 
Cací - Comitê de Ação pela Cidadania

Casa Estrela

Casativa Centro de Ações Sociais

Central de Inteligência e Assessoria Brasil

Centro de Apoio à Economia Popular Solidária

Centro de Assistência e Desenvolvimento Social

Centro de Desenvolvimento Integrado Social e Cultural

Centro de Desenvolvimento Social

Centro de Desenvolvimento Sustentável e Industrial de Sistemas Florestais do Norte Pioneiro

Centro de Estudos e Aplicações para as Novas Tecnologias Educacionais

Centro de Estudos e Apoio ao Desenvolvimento do Araripe

Centro de Estudos e Pesquisas 28

Centro de Estudos para o Desenvolvimento Local

Centro de Estudos para o Desenvolvimento Sustentável e Inclusão Social

Centro de Estudos Tecnológicos \& Soluções Alternativas

Centro de Gestão de Tecnologia e Inovação - CGTI

Centro de Referências em Cidadania, Ética e Responsabilidade

Centro de Voluntários em Cooperativismo e Economia Social para as Américas

Centro Nacional de Educação Ambiental e Geração de Emprego

Centro Preserv de Promoção do Desenvolvimento Sustentado

Cluster de Turismo da Costa dos Coqueiros

Conselho Brasileiro de Manejo Florestal

Conselho de Preservação Ambiental Brasileiro

Conservation Strategy Fund do Brasil

Consórcio para Proteção Ambiental e Desenvolvimento Sustentável e Sociocultural da Bacia Hidrográfica do Rio das Cinzas

Creatif - Associação da Igualdade

Degraf Instituto Academia de Desenvolvimento Social

Desenvolvimento Social Humano Tecnológico DSHT

E+co Brasil

Eco Atitude - Ações Ambientais

Ecovitae Tecnologia Ambiental

Ema - Conscientização e Recuperação Ambiental

Enfoque Cívico - Organização de Responsabilidade Social

Equipe de Conservação da Amazônia

Escola Viveiro Multiplicadora Artesã

Espaço Múltiplo de Inclusão Social

Fábrica do Futuro

Face a Face Ação Solidária

Fundação Botânica Margaret Mee

Fundação Brasil Esperança

Fundação de Desenvolvimento da Região da Serra da Mesa

Fundação de Salvamento Aquático de Santa Catarina

Fundação Espaço Eco

Fundação Lymington

Fundação Movimento Ondazul

Fundação para o Desenvolvimento Sustentável do Araripe

GRAF Grupo de Recuperação Ambiental e Florestal

Green Cross Brasil

Grupo Ambiental Natureza Bela

Grupo Ambientalista do Rio Iguaçu

Grupo de Pesquisas Ufológicas Ufogênesis

lambra Instituto de Assistência aos Municípios Brasileiros

Idaq Instituto Dr. Avelino Elias de Queiroga

Ideia Ambiental Sociedade S/C

Idese - Instituto para o Desenvolvimento Social e Ecológico

Inceden - Instituto Cultural de Ecodesenvolvimento Nacional

Indesus - Instituto Tecnológico para o Desenvolvimento Sustentável

Instituto Abradee da Energia 
Instituto Ação Ambiente

Instituto Acqua - Ação, Cidadania, Qualidade Urbana e Ambiental

Instituto Amazônia

Instituto Ambiental Aracua

Instituto Ambiental de Desenvolvimento Social Sustentável - Instituto Biocêntrica

Instituto Ambiental Global - IAG

Instituto Ambiental Ratones

Instituto Amigos da Reserva da Biosfera da Mata Atlântica

Instituto Antakarana

Instituto Antrópolis para o Desenvolvimento Sustentável

Instituto Baiano para o Desenvolvimento Social do Nordeste

Instituto Bioacqua de Promoção de Desenvolvimento Sustentável e Defesa do Meio Ambiente

Instituto Bioterra

Instituto Brasil Preservação Ambiental e Desenvolvimento Sustentável

Instituto Brasil Solidário

Instituto Brasil Solidário - IBS

Instituto Brasileiro de Defesa da Natureza

Instituto Brasileiro de Desenvolvimento Econômico, Social, Cultural e de Proteção ao Meio Ambiente Inbrades

Instituto Brasileiro do Crisotila

Instituto Brasileiro do Empreendedor

Instituto Brasileiro para a Inovação Tecnológica Ambiental

Instituto Brasileiro para o Desenvolvimento Econômico, Social e Humano

Instituto BS Colway Social

Instituto Câmara Filho

Instituto Çarakura

Instituto Centro-Brasileiro de Cultura

Instituto Cistema - Cidadania - Saúde - Trabalho - Educação e Meio Ambiente

Instituto Corpore para o Desenvolvimento da Qualidade de Vida

Instituto Cultural Ecoeconômico Espírito Santo

Instituto de Ação Social Planejada

Instituto de Apoio a Tecnologia, Educação, Saúde, Promoção Social, Meio Ambiente e Cultura

Instituto de Cooperação e Tecnologia Socioambiental

Instituto de Desenvolvimento e Pesquisas do Meio Ambiente e Atividades Esportivas

Instituto de Desenvolvimento Integrado para Ações Sociais

Instituto de Desenvolvimento Municipal

Instituto de Desenvolvimento Socioeconômico dos Trabalhadores de Baixa Renda

Instituto de Desenvolvimento Sustentável de Franca e Região da Bacia Hidrográfica do Rio Sapucaí

Mirim Grande

Instituto de Desenvolvimento Sustentável do Estado de Santa Catarina

Instituto de Desenvolvimento Tecnológico

Instituto de Desenvolvimento, Educação, Análise e Legislação - Ideal

Instituto de Direito Agrário e Ambiental do Sul - Joaquim Luiz Osorio

Instituto de Ecologia Terrestre

Instituto de Educação Pesquisa e Saúde San Julian

Instituto de Estudos Socioambientais

Instituto de Geração de Tecnologias do Conhecimento

Instituto de Integração Social, Desenvolvimento Sustentável e Preservação Ambiental

Instituto de Meio Ambiente e Desenvolvimento

Instituto de Meio Ambiente e Desenvolvimento Sustentável - Tramirim

Instituto de Pesquisa e Conservação da Natureza

Instituto de Saúde e Meio Ambiente

Instituto de Saúde, Educação, Bem Estar Social

Instituto de Turismo de Itacaré

Instituto Ecoar para a Cidadania

Instituto Eco-empreendedor para a Sustentabilidade Ambiental

Instituto Ecoengenho de Tecnologia Aplicada ao Desenvolvimento Sustentável

Instituto Eurofarma

Instituto Excelsa 
Instituto Floravida

Instituto Floresta de Pesquisa e Desenvolvimento Sustentável

Instituto GEA - Ética e Meio Ambiente

Instituto Grande Sertão

Instituto Inceri

Instituto Labor \& Vita

Instituto Mãe Terra de Tecnologia Educacional e Ambiental

Instituto Maranata de Pesquisa em Estrutiocultura

Instituto Marca de Desenvolvimento Ambiental - Imadesa

Instituto Nacional de Integração Social

Instituto Nacional para o Desenvolvimento Sustentável - Inades

Instituto Natureza Viva

Instituto Novas Fronteiras da Cooperação

Instituto Novos Saberes

Instituto Oikos de Agroecologia

Instituto para Desenvolvimento Socioambiental e Tecnológico Lótus

Instituto para Cidadania e Implementação da Base Popular - Icibap

Instituto para Desenvolvimento Ambiental e Tecnológico - Idea Cíclica

Instituto para o Desenvolvimento Ambiental

Instituto para o Desenvolvimento Sustentável de Joinville

Instituto Parceria

Instituto Patulus

Instituto Peabiru

Instituto Physis - Cultura \& Ambiente

Instituto Plenojure

Instituto Portas Abertas

Instituto Pró Rio Doce

Instituto Profissionalizante de Tecnologia da Informação

Instituto S.O.S. Sistemas Organizados para Sustentabilidade

Instituto Social Tecnológico e Econômico do Café - Mais Café

Instituto Social, Educacional e de Pesquisa de Minas Gerais

Instituto Socioambiental Latinha da Solidariedade

Instituto Solaris

Instituto Tempo Bougra - SCTB

Instituto Terra de Santa Cruz

Instituto Themys de Pesquisa e Gestão em Desenvolvimento Sustentável Instituto Via Viva

Instituto Vida para o Atendimento à Saúde, Saneamento e Meio Ambiente Interforum Global Intercâmbio e Desenvolvimento Sustentável

Ipam - Instituto Brasileiro de Pesquisas Ambientais

IPD - Instituto de Promoção do Desenvolvimento

Liga Desportiva e Beneficente de Futsal Santamariense

Mapas - Métodos de Apoio a Práticas Ambientais e Sociais

Mediateca Organização para Inclusão Social e Digital

Minasinvest - Aliança de Desenvolvimento

Movimento Interamericano de Ecologia

Núcleo Amigos da Terra/ Brasil

Núcleo de Desenvolvimento em Estudos Socioambientais do Maranhão

Núcleo Verde Amarelo

Nutes - Núcleo de Estudos do Terceiro Setor

Observatório Ambiental

Oca Organizações Cidadania em Ação

ONG Capacidade

ONG Dr. Vandick Ponte

ONG Guaranésia Viva

ONG Me Ensina

Organização Ambientalista Amainan Brasil

Organização Bio-Bras

Organização da Sociedade Civil de Interesse Público Ambientality 
Organização da Sociedade Civil de Interesse Público do Comitê de Defesa da llha Grande Organização de Conservação de Terras do Baixo Sul da Bahia

Organização de Desenvolvimento Cultural e Preservação Ambiental Ama-Brasil

Organização e Apoio a Projetos Ambientais e Sociais - URU

Organização para a Proteção Ambiental S.C.

Organização Ponto Terra

Organização Trajetória Mundial

Organização Verde Brasil

Oscip Pró-Vida Brasil

Projeto Cultural Rio das Ostras

Rede Digital Comunitária Sol

Sertão Verde Vida

Sistema Brasileiro de Tratamento de Resíduos Industriais e Urbanos

Sistema de Apoio e Desenvolvimento - Sisad

Sociedade Ambientalista e Cultural - Angaturama

Sociedade dos Amigos do Cerrado - Socerrado

Sociedade Marinhense de Desenvolvimento Sustentável

Sociedade para o Desenvolvimento dos Serviços Públicos

SOS Povos da Mata Atlântica

Terceiro Setor - Organização Não Governamental - Terset - ONG

The Green Initiative

Tv Vila Imperial Organização das Entidades Usuárias do Canal Comunitário de Petrópolis

União Social Ecológica - USE

Uniciência - União para o Desenvolvimento Social e Cultural Através da Ciência e Tecnologia

Universidade Livre de Idiomas, Sustentabilidade Ambiental \& Corporativa

Universidade Livre do Meio Ambiente

V.O.S - Ver Ouvir e Sorrir, Centro Viver de Otorrinolaringologia e Oftalmologia

\section{Educação ambiental}

Instituto Sodetec de Desenvolvimento Social - Sodetec

5 Elementos Instituto de Educação e Pesquisa Ambiental

A Mar de Dentro Ambiente e Educação

Aapeec - Associação de Apoio a Pais, Educadores, Educandos do Curumim Vila Pérola

Associação Brasileira Abraes - Associação Brasileira de Educação Social

Associação Brasileira ABTCP Associação Brasileira Técnica de Celulose e Papel

Academia Paulista de Magistrados

Academia Taguatinguense de Letras

Ação Comunitária do Espírito Santo

Ação da Cidadania - Comitê lbiúna

Ação Educacional Claretiana

Ação Ética \& Cidadania

Ação Popular Campos Gerais

Ação Social Arquidiocesana Asa

Ação Social Paroquial de Ingleses

Ação Social Paroquial São José de Botuverá

Adesão - Agência de Desenvolvimento Social

Adesu - Agência de Desenvolvimento Econômico e Social de Ubatuba

Adote Um Gatinho

Agência Baiana de Desenvolvimento Social

Agência Brasileira de Desenvolvimento da Aquicultura

Agência Brasileira de Gerenciamento Costeiro

Agência Brasileira de Meio Ambiente e Tecnologia da Informação

Agência de Desenvolvimento Humanitário e Econômico da APA do Igarapé Gelado

Agência de Desenvolvimento Ambiental Capixaba

Agência de Desenvolvimento Cultural de Cariacica

Agência de Desenvolvimento de Guapirama

Agência de Desenvolvimento de Itapecerica da Serra e Região 
Agência de Desenvolvimento de Monte Alto e Região

Agência de Desenvolvimento de São João da Boa Vista

Agência de Desenvolvimento Econômico e Social da Região do Planalto Médio

Agência de Desenvolvimento Econômico e Social de Dois Córregos

Agência de Desenvolvimento Econômico e Social de Mandaguari e Região

Agência de Desenvolvimento Econômico e Social de Ouro Preto

Agência de Desenvolvimento Econômico e Social de Socorro - ADESSO

Agência de Desenvolvimento Econômico e Social do Centro Oeste - ADESCO

Agência de Desenvolvimento Educacional e Social Brasileira

Agência de Desenvolvimento Integrado e Sustentável de Mesorregião dos Vales do Jequitinhonha e do Mucuri

Agência de Desenvolvimento Integrado e Sustentável Sempre Alerta Riachinho

Agência de Desenvolvimento Local de Batayporã

Agência de Desenvolvimento Regional da Amurel

Agência de Desenvolvimento Regional do Extremo Oeste do Paraná

Agência de Desenvolvimento Regional do Maciço de Baturite

Agência de Desenvolvimento Regional Integrado do Planalto Norte Catarinense

Agência de Desenvolvimento Social de Flexal I e Nova Canaã

Agência de Desenvolvimento Social de Flexal II

Agência de Desenvolvimento Social de Piranema

Agência de Desenvolvimento Social de Vasco da Gama

Agência de Desenvolvimento Social e Econômico de Guarapari-ES

Agência de Desenvolvimento Social Vale Esperança

Agência de Desenvolvimento Sustentável da Amazônia Maranhense

Agência de Desenvolvimento Sustentável da Região Lago de Tucuruí

Agência de Desenvolvimento Sustentável de Marechal

Agência de Desenvolvimento Sustentável de Paracatu

Agência de Desenvolvimento Sustentável de Rorainópolis

Agência de Desenvolvimento Sustentável do Seridó

Agência de Desenvolvimento Sustentável do Sul do Estado do Espírito Santo

Agência de Desenvolvimento Urbano e Rural do Município de Guaçuí

Agência de Qualificação e Trabalho para Organizações Associativas

Agência do Instituto Mundial para as Relações Internacionais

Agência do Programa de Desenvolvimento Sustentável do Centro Oeste Mineiro

Agência Interamericana de Cooperação Para o Desenvolvimento Sustentável

Agência Mandalla de Desenvolvimento Holístico Sistêmico e Ambiental

Agência Municipal de Desenvolvimento Sustentável

Agência Nacional de Desenvolvimento Eco-social

Agência Nacional Desenvolvimento Social

Agência para a Promoção do Desenvolvimento, da Educação, Mobilização e Organização

Socioambiental

Agência para o Desenvolvimento Regional

Agência Sul-americana de Desenvolvimento

Agenda Vinte e Um Local de Hortolândia

Água e Cidade

Ajudanimal, Grupo de Ajuda e Amparo aos Animais do ABC

ALA - Associação Livre dos Aquicultores das Águas do São João

Alavanca

Alavancando o Progresso

Aldeia do Futuro Associação para a Melhoria da Condição da População Carente

Alecrim Cultura \& Saúde

Aliança Nativa

Alma - Associação de Moradores da Lauro Muller, Ramon Castilla, Xavier Sigaud e Adjacências

Amatur - Agência de Desenvolvimento do Meio Ambiente e Turismo

Ambiental Litoral Norte

Ambiente Brasil Centro de Estudos

Amigo Social

Amigos Associados de Itaberá (Amai)

Amigos da Mata 
Amigos da Terra - Amazônia Brasileira

Amigos do Protocolo de Kyoto

Amigos Solidários - Instituição Nacional Contra a Pobreza - Organização da Sociedade Civil de Interesse Público - OSCIP

Ammatur - Associação Mineira do Meio Ambiente e do Turismo

APAE Associação de Pais e Amigos dos Excepcionais de Anastácio-MS

Arare - Associação para a Defesa e Recuperação da Fauna Brasileira

Arte Vida

Associação Brasileira de Infraestrutura e Saneamento Comunitário Social - A.B.I.C.C

Assistencial, Educacional, Beneficente

Associação dos Usuários da Marina do Saco da Ribeira - Aumar

Associação Águas Claras do Rio Pinheiros

Associação Aliança Empreendedora

Associação Alto Sustentável

Associação Amazônia Viva

Associação Ambiental do Parque Estadual do Mirador

Associação Ambiental Voz da Natureza

Associação Ambientalista do Alto são Francisco

Associação Ambientalista Projeto Copaíba

Associação Amigos da Criança - Fazenda da Criança

Associação Amigos do Bairro do Sahy

Associação Amigos do Futuro

Associação Amigos do Meio Ambiente

Associação Antonio e Marcos Cavanis

Associação Apóstolas da Sagrada Família

Associação Assistencial Madre Germana II

Associação Barco Escola da Natureza

Associação Beneficente Afro Brasileira

Associação Beneficente dos Filhos e Amigos de São Sebastião

Associação Beneficente Educacional Nova Esperança

Associação Beneficente João Vitor Rodrigues Lima

Associação Brasil

Associação Brasil Melhor

Associação Brasileira Cultural Empresarial - Abrace

Associação Brasileira de Cristãos Evangélicos - Abrace

Associação Brasileira de Inclusão Digital Abrind

Associação Brasileira de Vivências com a Natureza - Instituto Romã

Associação Brasileira Associação Brasileira para a Difusão da Consciência pelo Desenvolvimento

Social e Natural

Associação Brasileira para o Desenvolvimento de Lideranças

Associação Brotar e Crescer

Associação Caatinga

Associação Cairuçu

Associação Caminho Suave Socioambiental

Associação Casa Azul

Associação Casa de Cultura Antonia Ferreira de Souza

Associação Casa União pelo Desenvolvimento do Vale do Piranga

Associação Catarinense de Plantas Medicinais

Associação Celeiro do Vale do Rio Pardo

Associação Cellula Mater

Associação Cena Aberta

Associação Centro Social Comunitário, Assistencial, Cultural, Educacional de Saúde e Recreação de Herculândia

Associação Centrodesignrio

Associação Cerrado Nativo

Associação Cidadela - Arte, Cultura e Cidadania

Associação Circuito Verde-Trilha dos Bandeirantes

Associação Civil Cidadania Brasil - ACCB

Associação Civil Instituto Baraeté de Desenvolvimento Social, Ambiental, Desportivo e Cultural - IB 
Associação Civil Pátria Brasil

Associação Civil Socioambientalista Pedra Que Te Quero Mais

Associação Civil SOS Vale do Jaguari

Associação Comercial Industrial Ubaense dos Catadores de Materiais Recicláveis

Associação Comunitária Caiçara

Associação Comunitária Cidade Viva - "Nossa ONG"

Associação Comunitária Cultural Constelação

Associação Comunitária Cultural Ecológica e Educativa Quatro Bicas

Associação Comunitária de Desenvolvimento Sustentável São Paulo Apóstolo

Associação Comunitária do Bairro da Felicidade

Associação Comunitária do Município de Medina

Associação Comunitária do Sítio Cabaceiras

Associação Comunitária dos Moradores Micro e Pequenos Produtores Rurais do Povoado Olho D’Água do Meio

Associação Comunitária e Agropastoril dos Pequenos Produtores Abandonados da Fazenda Oiteiro e Região

Associação Comunitária Flores Agrícolas de Mundo Novo

Associação Comunitária Itaqui-Bacanga

Associação Comunitária Rural de Baixio e Serrinha

Associação Comunitária Sal da Terra

Associação Comunitária SOS M. S. da Península Itapagipana

Associação Crescer no Campo

Associação Cultural Amigos do Agito

Associação Cultural Artística e Ecológica de Quixadá

Associação cultural de esporte e artes central

Associação cultural e assistencial pequeno paraíso - Ascapp

Associação cultural ecológica sócio econômica do vale do ribeira

Associação cultural educar Brasil-aceb

Associação cultural, esportiva e turística - ascetur

Associação da escola família agrícola de angical

Associação da escola família agrícola de itaquirai

Associação das indústrias de metais sanitários de loanda e região (aimes) - agência de desenvolvimento regional (adr)

Associação de apoio à educação, cultura, esporte e lazer

Associação de apoio ao desenvolvimento social para o agronegócio

Associação de apoio às comunidades do campo do rn

Associação de assistência técnica e extensão rural do estado de rondônia

Associação de cultura e meio ambiente

Associação de defesa ambiental ilha grande

Associação de Defesa Etnoambiental

Associação de Desenvolvimento de Taquari Humanae Vitae

Associação de Desenvolvimento Econômico, Social e Cultural - Adesc Brasil

Associação de Desenvolvimento Sustentável do Jardim Santa Genebra

Associação de fomento a educação e bolsa de projetos Tecnológicos sustentáveis

Associação de moradores da vargem do forno

Associação de Mulheres Empreendedoras de Praia Grande

Associação de Pais e Amigos dos Excepcionais

Associação de Pais e Amigos dos Excepcionais de Açailândia

Associação de Pais e Amigos dos Excepcionais de Constantina

Associação de pequenos produtores de jabuticaba

Associação de preservação da mata ciliar do rio Uruguai

Associação de preservação do meio ambiente e da vida - apremavi

Associação de preservação do meio ambiente natural e melhoria de qualidade de vida - instituto bioma Associação de preservação do meio ambiente, patrimônio histórico e difusão da cultura e educação

Associação de proteção a ecossistemas costeiros

Associação de Reciclagem de Vila Velha

Associação de Reposição Florestal Do Pardo Grande

Associação de Senhoras De Rotarianos De Blumenau

Associação de Senhoras e Assistência Social de Euclides Da Cunha 
Associação do Fórum Ação para o Desenvolvimento de Candido Godoi

Associação do Fórum de Desenvolvimento Local Integrado e Sustentável de Caarapó - Vivacidade

Associação do Núcleo Da Mulher

Associação do Verde e Proteção do Meio Ambiente

Associação Dois De Outubro - Paengaba

Associação dos Amigos da Floresta Nacional de Brasília - Flona/BSB

Associação dos Amigos da Pedra da Princesa

Associação dos catadores de papel de Guarapuava

Associação dos Engenheiros da Sabesp

Associação dos estudantes de ciências

Associação dos funcionários do instituto Brasileiro de integração e Desenvolvimento pró-cidadão

Associação dos mineradores de ouro do tapajós

Associação dos moradores da vila nova

Associação dos moradores do bairro de Henrique Jorge

Associação dos moradores dos setores Coimbra e bela vista

Associação dos Pequenos Agricultores da Região Sítio dos Patos

Associação dos Produtores de Erva Mate de Machadinho

Associação dos Produtores Rurais de Paula Cândido

Associação dos rodonistas de Pernambuco

Associação dos Terapeutas e Alternativos na Saúde, Cultura do Brasil

Associação Eco Juréia

Associação Ecoagente

Associação Ecológica Amigos de Embu

Associação Ecológica e Cultural de Integração Fronteira das Artes

Associação Ecológica Piratingaúna

Associação Ecológica Tijuco

Associação Ecológica Turismo Sustentável

Associação educacional e assistencial shalom

Associação educacional Magnum de Desenvolvimento humano-social

Associação em Defesa do Meio Ambiente e da Cidadania Caminho Verde

Associação esp. Beneficente caminho da paz

Associação estação da arte, cultura e educação

Associação estação de apoio e ofícios "oscip"

Associação Faça Sua Parte

Associação Família Cidadã

Associação Filantrópica Amigos da Esperança

Associação focinhos carentes de Toledo - afocato

Associação Fórum de Dlis de Pedro Gomes - ADPEG

Associação Fórum Pró Cidadania

Associação Gente Do Brasil

Associação Gente Que Faz

Associação Geográfica União das Águas

Associação gera vida de assistência social

Associação Global de Desenvolvimento Sustentado

Associação instituto aquarela

Associação Instituto de Pesquisas em Energias Renováveis e Meio Ambiente

Associação interação rede-social

Associação Internacional Protetora do Meio Ambiente

Associação Ipê

Associação marca para promoção de serviços

Associação Mata Ciliar

Associação metodista de ação social

Associação Mineira de Defesa do Ambiente

Associação mineira de educadores ambientais

Associação movimento ecológico amigos do meio ambiente

Associação mundial de amor e respeito à vida

Associação mundo melhor

Associação municipal de assistência infantil

Associação nacional dos carroceiros e catadores de materiais Recicláveis - ancat 
Associação ninho criança - esperança

Associação novas trilhas

Associação novo encanto Desenvolvimento ecológico

Associação Novolhar

Associação Núcleo para Transformações Ambientais e Sociais

Associação O Eco

Associação Olhos D'Água

Associação onça d'água de apoio à gestão e ao manejo das unidades de conservação do estado do Tocantins

Associação organização da sociedade civil de interesse público mobilidade e ambiente Brasil

Associação organização não governamental solidariedade e vida

Associação Pacto Ambiental

Associação para Desenvolvimento de Ações Públicas

Associação para o Combate à Exclusão Social e Preservação Ambiental - ACESPA Chico Mendes

Associação para o trabalho e inclusão social de Luiz Antônio

Associação parque das águas

Associação parque maracá

Associação paulista de gestão pública - apgp

Associação paulista de serviços comunitários

Associação paulista viva

Associação peixe vivo educação ambiental, cultura e lazer

Associação pela recuperação e preservação da Mata Atlântica

Associação pequeno mundo

Associação plante vida

Associação Polivida

Associação preserva São Paulo

Associação Pró Casa do Pinhal

Associação pró-menor lar padre Jacó

Associação pró-sapiens - logística em Desenvolvimento social

Associação profissionalizante do menor de belo horizonte

Associação programa um milhão de cisternas para o semiárido

Associação pró-menor de Teodoro Sampaio

Associação Protetora das Montanhas e Araucárias e Seus Valores Sociais, Artísticos, Estéticos, Ambientais, Geológicos, Históricos e Paisagísticos

Associação queluz

Associação $r 3$ animal

Associação recicle a vida

Associação rede vida de Desenvolvimento humano tecnológico e proteção social

Associação regional do meio ambiente

Associação Renatinho

Associação Ricardo Gadotti Feldman

Associação Rio Minas "trem mineiro"

Associação Sai da Toca Cultural

Associação santo dias

Associação sarupar do estado do Amazonas - asea

Associação sergipana de Desenvolvimento o Trânsito e o transporte

Associação Serra da Mantiqueira

Associação serra do Itapetinga, movimento pela biodiversidade e organização dos setores ecológicos

Associação sinhana eva

Associação solidariedade, união e cidadania - asuc

Associação sonhar e acreditar

Associação SOS Amazônia

Associação super eco de integração ambiental e Desenvolvimento da criança

Associação terceira via

Associação Terrabrasil - ONG

Associação Thalamus

Associação toto porto de apoio à criança carente

Associação Tuim Proteção e Educação Ambiental

Associação turismo e meio ambiente de Nova Petrópolis 
Associação União llha de Boipeba

Associação unida do bairro pôr-do-sol

Associação Universitária da Zona Leste

Associação Vianei de C.I.T.E.C.S.

Associação Vida Amiga

Associação vida e paz - avip

Associação de saúde dr. Valdenor cordeiro

Ato cidadão

Bambuzeria Cruzeiro do Sul

Banco de alimentos do Rio Grande do Sul

Banco de êxitos s.a - solidariedade e autonomia

Belabrasília preservação do patrimônio arquitetônico de Brasília

Bioética de gestão pública

Biomavale - organização da sociedade civil de interesse público

Biotema ciência e tecnologia

Bioterra - organização para conservação da biodiversidade e meio ambiente

Brasil - conscientização e cidadania

Brasil Ação Solidária

Brasil ambiental

Brasil forte instituto de cidadania e integração ambiental

Brazilian adventure society

Brigada mirim ecológica da ilha grande

Caa-oby

Cací - Comitê de Ação pela Cidadania

Caiapônia instituto de saneamento ambiental

Câmara de cultura, comércio e turismo brasil - países africanos

Câmara de desenvolvimento brasil japão do mato grosso do sul

Camará saúde qualidade de vida e gestão

Casa da amizade das senhoras dos rotarianos

Casa espirita terra de Ismael

Casa espírita tesloo

Casa familiar agroflorestal do baixo sul da Bahia

Casas da convivência familiar

Casativa Centro de Ações Sociais

Catalisa rede de cooperação para sustentabilidade

Ceep- centro de atendimento e educação especial

Cemina - comunicação, educação e informação em gênero

Cenop centro de orientação profissional de saquarema

Central de orientação, Desenvolvimento e apoio da pesca responsável

Central de Inteligência e Assessoria Brasil

Central única das favelas de fortaleza

Centro artístico cultural Belém Amazônia

Centro Brasileiro de Desenvolvimento esportivo e social

Centro cultural e de assist. Social ilso José Webber

Centro de ações de Desenvolvimento social e urbano do nordeste

Centro de Apoio à Economia Popular Solidária

Centro de apoio à educação, meio ambiente e saúde

Centro de apoio e execução de projetos sociais- caeps

Centro de aprendizagem e Desenvolvimento social sustentável

Centro de aprendizagem e inclusão social - cais

Centro de assessoria ao movimento popular-campo

Centro de assessoria e apoio aos trabalhadores e instituições não governamentais alternativas

Centro de assessoria e serviço aos trabalhadores da terra dom José Brandão de castro

Centro de assistência e amparo ao trabalhador - caat

Centro de Assistência e Desenvolvimento Social

Centro de aventura rio do peixe

Centro de capacitação, profissionalização e educação para cidadania

Centro de cultura e aperfeiçoamento de talentos humanos

Centro de cultura e artesanato 
Centro de defesa dos direitos humanos de Petrópolis

Centro de Desenvolvimento agroecológico sabiá

Centro de Desenvolvimento do jovem rural

Centro de Desenvolvimento e pesquisa de tecnologia aplicada organizações ev7

Centro de Desenvolvimento Integrado Social e Cultural

Centro de Desenvolvimento Social

Centro de Desenvolvimento Sustentável e Industrial de Sistemas Florestais do Norte Pioneiro

Centro de educação infantil nossa casinha

Centro de estudo de gestão publica

Centro de Estudos e Aplicações para as Novas Tecnologias Educacionais

Centro de Estudos e Apoio ao Desenvolvimento do Araripe

Centro de Estudos e Pesquisas 28

Centro de estudos integrados e de promoção do ambiente e da cidadania

Centro de estudos marinhos do atlântico sul

Centro de Estudos para o Desenvolvimento Sustentável e Inclusão Social

Centro de estudos, pesquisa e assessoria comunitária

Centro de fomento social e cidadania caminhos de cunha

Centro de formação mandacaru de Pedro II

Centro de pesquisa do pantanal

Centro de Referências em Cidadania, Ética e Responsabilidade

Centro de serviços profissionais e de empreendimentos

Centro de tecnologia e tratamento de resíduos de Maringá e região, ctr Maringá

Centro de tecnologia em ação e Desenvolvimento Sustentável

Centro de tecnologias alternativas da zona da mata

Centro de treinamento da vida

Centro de Voluntários em Cooperativismo e Economia Social para as Américas

Centro educacional imaculada conceição

Centro educacional profissionalizante para o Desenvolvimento socioeconômico de São Paulo

Centro educacional Rebouças

Centro espírita beneficente união do vegetal

Centro nacional de ajuda comunitária

Centro Nacional de Educação Ambiental e Geração de Emprego

Centro organizacional de acompanhamento humano - coach

Centro Preserv de Promoção do Desenvolvimento Sustentado

Centro social shalom

Centro social sopro de vida

Centro social verdadeira amizade

Centro sócio-cultural-educativo casa de "Sophia"

Ceproser - centro de pesquisa proteína da serpente

Circuito de interação de redes sociais

Clube de observadores de aves do vale europeu

Cluster de Turismo da Costa dos Coqueiros

Codenorte - conselho de Desenvolvimento do norte de mato grosso

Colônia de férias Henrique lemle

Combina -companhia dos bichos e da natureza

Comissão XXI de Desenvolvimento Sociocultural

Comitê da Terceira Idade

Comitê Seth de Desenvolvimento social

Comitê Sul Brasileiro de Segurança Socioambiental

Comunicação e Cultura

Comunidade educacional de Pirenópolis

Conexão-serviço de integração social

Congregação das religiosas da assunção de nossa senhora

Congregação holística da Paraíba

Congresso internacional israelita de sociosfera na Amazônia

Connecta

Conselho Brasileiro de Manejo Florestal

Conselho de crianças para a preservação do homem, do ar, das águas, das matas, dos animais e defesa do patrimônio histórico e cultural 
Conselho de Desenvolvimento sustentável da baia da ilha grande

Conselho de Preservação Ambiental Brasileiro

Conservation Strategy Fund do Brasil

Consórcio para Proteção Ambiental e Desenvolvimento Sustentável e Sociocultural da Bacia

Hidrográfica do Rio das Cinzas

Construir Melhor

Construtores Sociais

Coopera Brasil - centro de jogos cooperativos

Copati - Consórcio Intermunicipal para Proteção Ambiental da Bacia do Rio Tibagi

Creatif - Associação da Igualdade

Curucutu Parques Ambientais

Defender - defesa civil do patrimônio histórico

Degraf Instituto Academia de Desenvolvimento Social

Desenvolvimento Social Humano Tecnológico DSHT

E.U - Ecologia Urbana

Eco Atitude - Ações Ambientais

Econsenso

Ecos - instituto de pesquisa e Desenvolvimento socioambiental

Ecovitae Tecnologia Ambiental

Eden - instituto de apoio ao Desenvolvimento humano

Educação em foco

Educandário São José

Ekko Brasil

Elo ambiental - organização não governamental

Elo social de Gestão Pública

Ema - Conscientização e Recuperação Ambiental

Empreende - sistema de empreendedorismo social

Enfoque Cívico - Organização de Responsabilidade Social

Equipe co gestora do parque estadual Fritz plaumann

Equipe de Conservação da Amazônia

Escola da quadra centro de form.educ.cult.art..espor.laze

Escola de formação politica e cidadania

Escola Viveiro Multiplicadora Artesã

Espaço Compartilharte

Espaço cultural pés no chão

Espaço jovem evolução

Estação luz espaço experimental de tecnologias sociais

Ética da terra / Instituto ita weigman do Brasil

Fábrica do Futuro

Face a Face Ação Solidária

Federação das APAES do estado de Rondônia

Federação das associações comunitárias de Felício dos santos

Federação das Associações e Entidades para o Desenvolvimento do Semiárido Baiano

Força Comunitária Nacional

Fórum das Américas

Fórum de Desenvolvimento de Ibaiti

Fórum municipal de lutas de Itaquaquecetuba

Fórum permanente de responsabilidade social do rio grande do sul

Fundação 10 de agosto

Fundação abrahma kasinski

Fundação Ângelo Creta de educação e Desenvolvimento sócio-Econômico-ambiental

Fundação Botânica Margaret Mee

Fundação Brasil cidadão para a educação, cultura e tecnologia - fbc

Fundação Brasil Esperança

Fundação centro Brasileiro de proteção e pesquisa das tartarugas marinhas

Fundação comunitária rio cipó

Fundação Conscienciarte

Fundação cultural exército Brasileiro

Fundação de amparo ao ensino e pesquisa 
Fundação de apoio à vida nos trópicos

Fundação de Desenvolvimento da Região da Serra da Mesa

Fundação de Desenvolvimento educacional e cultural do sistema de crédito cooperativo

Fundação de Desenvolvimento rural

Fundação de estudos e pesquisas aquáticas

Fundação de formação, pesquisa e difusão tecnológica para uma convivência sustentável com o semiárido

Fundação de incentivo à pesquisa

Fundação de Salvamento Aquático de Santa Catarina

Fundação Educacional Guaxupé

Fundação educacional, assistencial e de proteção ao meio ambiente

Fundação Emalto

Fundação Espaço Eco

Fundação Fórmula Cultural

Fundação Gaia

Fundação Gilberto Freyre

Fundação grupo boticário de proteção à natureza

Fundação Heinrich Boll

Fundação herbarium de saúde e pesquisa

Fundação Jose Lazzarini

Fundação Julio Campos

Fundação Lymington

Fundação Maria Cecilia Souto Vidigal

Fundação matutu

Fundação mokiti okada - moa

Fundação Movimento Ondazul

Fundação Nestlé Brasil

Fundação Oswaldo Carlos van leeuwen

Fundação para o Desenvolvimento Sustentável do Araripe

Fundação Pestalozzi do Pará

Fundação Pro Cerrado

Fundação Proamb

Fundação Pró-Defesa Ambiental

Fundação Pró-Natureza

Fundação Pró-Rio Taquari

Fundação Rio Branco

Fundação rio do leão

Fundação Roberto Marinho

Fundação Sistêmica

Fundação SOS Pró-Mata Atlântica

Fundação Turismo para Paz e Desenvolvimento Sustentável

Fundação União

Fundação vida para todos abai

Fundação vovó do mangue

Fundo Brasileiro para a biodiversidade

Gente feliz

Grac - grupo ambientalista do cricare

GRAF Grupo de Recuperação Ambiental e Florestal

Green Cross Brasil

Grin9 - educação e gestão ambiental

Grupo Ambiental Natureza Bela

Grupo Ambientalista do Rio Iguaçu

Grupo ar - ação renovadora

Grupo de apoio à natureza e Desenvolvimento do homem integral

Grupo de apoio, estudo e pesquisa ambiental e cultural- pro terra

Grupo de Desenvolvimento humano e ambiental - instituto goiamum

Grupo de estudos e pesquisas em direito educacional e ação socioambiental - gepede

Grupo de estudos e promoção do Desenvolvimento Sustentável

Grupo de Pesquisas Ufológicas Ufogênesis 
Grupo ecológico vida vede de Cornélio Procópio

Guarda mirim de Colíder MT

Herbário Barbosa Rodrigues

Horizonte promoção social e educacional - oscip

lagep - instituto de apoio à gestão pública

lambra Instituto de Assistência aos Municípios Brasileiros

lav o instituto ambiente vivo

Iberobrasileira de estudos e cooperação

Ibraema - instituto Brasileiro de educação e meio ambiente

Icisec - instituto capixaba de integração socioeconômico dos cidadãos

Idaq Instituto Dr. Avelino Elias de Queiroga

Ideação

Ideia Ambiental Sociedade S/C

Idelt - instituto de Desenvolvimento, logística, transporte e meio ambiente

Identidade de um povo - idp

Idese - Instituto para o Desenvolvimento Social e Ecológico

Igreja congregacional afro-brasileira de renovação espiritual

Inadem Instituto Nacional para o Desenvolvimento Econômico e Preservação do Meio Ambiente

Inceden - Instituto Cultural de Ecodesenvolvimento Nacional

Indesus - Instituto Tecnológico para o Desenvolvimento Sustentável

ING - Instituto Os Guardiões da Natureza

Iniciativa primus

Inmed Brasil

Inst.de estudos e pesq.para prom. da educação, cultura e Desenvolvimento econômico e social prosocial

Instituição de ética e valores humanos estrela da paz

Instituição Filantrópica Sergius Erdelyi

Instituição Regaldo Milbradt

Instituo Bertran Fleury

Instituto Ability Brasil

Instituto abramundo

Instituto abril

Instituto acaiah

Instituto Ação Ambiente

Instituto ação comunitária preventiva de defesa dos direitos da criança, adolescente e idoso

Instituto Ação Saúde e Educação

Instituto Acqua - Ação, Cidadania, Qualidade Urbana e Ambiental

Instituto aequitas para o Desenvolvimento local Sustentável - instituto aequitas

Instituto agua viva de pesq e ext em aquicultura e pesca sustentáveis, meio ambiente e proc de rec pesqueiros

Instituto Akatu

Instituto albatroz

Instituto amar

Instituto Amazônia

Instituto Amazônia de integração e Desenvolvimento

Instituto Amazônico de Desenvolvimento social, amparo a pesquisa e a tecnologia

Instituto Amazônico Rio Pará

Instituto Ambiental Aracua

Instituto ambiental Brasil sustentável

Instituto ambiental ceres

Instituto Ambiental de Desenvolvimento Social Sustentável - Instituto Biocêntrica

Instituto Ambiental Global - IAG

Instituto ambiental parque das perobas

Instituto Ambiental Ratones

Instituto ambiente em foco

Instituto amea

Instituto Amigos da Reserva da Biosfera da Mata Atlântica

Instituto anjos do mar Brasil

Instituto Aquanautas Tocantins 
Instituto arco

Instituto argonauta para a conservação costeira e marinha

Instituto arvore da vida

Instituto Atílio correia lima

Instituto Atlantis de preservação ambiental

Instituto ave é vida

Instituto baía de Guanabara

Instituto baleia jubarte

Instituto barilá

Instituto Barretos de tecnologia - ibt

Instituto benjamim dias - ibd

Instituto Bioacqua de Promoção de Desenvolvimento Sustentável e Defesa do Meio Ambiente

Instituto biobrasil

Instituto bióleo de Desenvolvimento sustentável

Instituto biológico do meio ambiente - bioma

Instituto Bioterra

Instituto Brasil adentro

Instituto Brasil ambiental

Instituto Brasil ambiental - ibra

Instituto Brasil com

Instituto Brasil mãos à obra

Instituto Brasil pnuma s/c Itda

Instituto Brasil Preservação Ambiental e Desenvolvimento Sustentável

Instituto Brasil Solidário

Instituto Brasil Solidário - IBS

Instituto Brasil verdade

Instituto Brasileiro da cidadania

Instituto Brasileiro de ações integradas

Instituto Brasileiro de Defesa da Natureza

Instituto Brasileiro de defesa do consumidor

Instituto Brasileiro de Desenvolvimento " o futuro é hoje"

Instituto Brasileiro de Desenvolvimento da cidadania

Instituto Brasileiro de Desenvolvimento da defesa civil e do meio ambiente ibdm

Instituto Brasileiro de Desenvolvimento Econômico, Social, Cultural e de Proteção ao Meio Ambiente Inbrades

Instituto Brasileiro de Desenvolvimento social de Planaltina

Instituto Brasileiro de difusão educacional para o trânsito

Instituto Brasileiro de direito ambiental

Instituto Brasileiro de educação em negócios sustentáveis

Instituto Brasileiro de florestas

Instituto Brasileiro de inclusão social no turismo

Instituto Brasileiro de integração e Desenvolvimento pró-cidadão

Instituto Brasileiro de pesquisas e estudos ambientais

Instituto Brasileiro de qualidade de vida

Instituto Brasileiro de reciclagem

Instituto Brasileiro de tecnologias sociais

Instituto Brasileiro do Crisólita

Instituto Brasileiro do Empreendedor

Instituto Brasileiro para a Inovação Tecnológica Ambiental

Instituto Brasileiro para o Desenvolvimento Econômico, Social e Humano

Instituto Brasileiro pró-cidadania

Instituto bruno Segalla

Instituto BS Colway Social

Instituto Câmara Filho

Instituto capixaba de Desenvolvimento esportivo e social

Instituto Çarakura

Instituto caranguejo de educação ambiental

Instituto carapebus solidário

Instituto centro de vida - icv 
Instituto Centro-Brasileiro de Cultura

Instituto cidadania ativa

Instituto ciência e arte

Instituto Cistema - Cidadania - Saúde - Trabalho - Educação e Meio Ambiente

Instituto comar - conservação marinha do brasil

Instituto Constâncio pereira dias de responsabilidade socioambiental

Instituto consultor social

Instituto convivência com o semiárido Brasileiro

Instituto convocação para cidadania

Instituto Corpore para o Desenvolvimento da Qualidade de Vida

Instituto corredor Ecológico costa dos coqueiros

Instituto costa brasilis - Desenvolvimento socioambiental

Instituto creatio

Instituto cultural capobianco

Instituto Cultural Ecoeconômico Espírito Santo

Instituto cultural farol do rio doce

Instituto cultural Soto delatorre

Instituto da árvore

Instituto da juventude do baixo sul da Bahia

Instituto da natureza, Desenvolvimento, informação e assistência social

Instituto Darwin - instituto de apoio à evolução da cidadania

Instituto de ação comunitária integração

Instituto de ação cultural e ecológica

Instituto de Ação Social Planejada

Instituto de apoio a Gestão Pública e social

Instituto de apoio a politicas sociais

Instituto de apoio à saúde, educação, meio ambiente, tecnologia, esportes, ciências e habitação iasemtech

Instituto de apoio a saúde, promoção social, educação e meio ambiente

Instituto de Apoio a Tecnologia, Educação, Saúde, Promoção Social, Meio Ambiente e Cultura

Instituto de apoio aos povos do araguaiab - iapa

Instituto de apoio e proteção ambiental

Instituto de apoio técnico especializado à cidadania

Instituto de assessoria para Desenvolvimento humano - iadh

Instituto de assistência, gestão e educação de munícipes - iagm

Instituto de biodiversidade e Desenvolvimento sustentável do oeste da bahiale

Instituto de cidadania e estudos ambientais e turismo

Instituto de ciências da terra e do mar

Instituto de comunicação estudos e consultoria - primeiro plano

Instituto de cooperação Desenvolvimento humano e social

Instituto de Cooperação e Tecnologia Socioambiental

Instituto de desenvol Sustentável e energias renováveis

Instituto de Desenvolvimento a ecologia, saúde e educação

Instituto de Desenvolvimento ambiental e social

Instituto de Desenvolvimento comunitário sustentável

Instituto de Desenvolvimento e integração do bem estar social e cidadania de Corbélia

Instituto de Desenvolvimento e Pesquisas do Meio Ambiente e Atividades Esportivas

Instituto de Desenvolvimento econômico e social do Brasil

Instituto de Desenvolvimento econômico e socioambiental -idesa

Instituto de Desenvolvimento humano

Instituto de Desenvolvimento integrado

Instituto de Desenvolvimento Integrado para Ações Sociais

Instituto de Desenvolvimento Municipal

Instituto de Desenvolvimento Paulo freire

Instituto de Desenvolvimento social e econômico

Instituto de Desenvolvimento social, Econômico e ambiental de mato grosso do sul

Instituto de Desenvolvimento Socioeconômico dos Trabalhadores de Baixa Renda

Instituto de Desenvolvimento socioambiental do vale do javari

Instituto de Desenvolvimento socioeconômico e ambiental 
Instituto de Desenvolvimento socioeconômico, científico, ambiental e tecnológico - parque dos falcões Instituto de Desenvolvimento Sustentável de Franca e Região da Bacia Hidrográfica do Rio Sapucaí Mirim Grande

Instituto de Desenvolvimento Sustentável do baixo sul da Bahia

Instituto de Desenvolvimento Sustentável do Estado de Santa Catarina

Instituto de Desenvolvimento Tecnológico

Instituto de Desenvolvimento Tecnológico e humano

Instituto de Desenvolvimento, Educação, Análise e Legislação - Ideal

Instituto de Direito Agrário e Ambiental do Sul - Joaquim Luiz Osorio

Instituto de eco Desenvolvimento de foz do Iguaçu

Instituto de Ecologia Terrestre

Instituto de educação ambiental, preservação, conservacionismo e promoção social - patriamada

Instituto de educação e pesquisa ambiental planeta verde

Instituto de educação igapó

Instituto de educação integrada garotos de distrito federal

Instituto de Educação Pesquisa e Saúde San Julian

Instituto de ensino pesquisa e preservação ambiental marcos Daniel - instituto marcos Daniel

Instituto de estudo do trabalho e combate a pobreza

Instituto de estudos avançados - iea

Instituto de estudos e projetos de interesse social

Instituto de Estudos Socioambientais

Instituto de estudos socioculturais e ambientais embra cultural

Instituto de estudos técnicos pesquisas e projetos para Desenvolvimento econômico e social

Instituto de Geração de Tecnologias do Conhecimento

Instituto de gestão em políticas públicas

Instituto de gestão solidária

Instituto de manutenção ambiental, ecológico, social e pesquisa - mães da Amazônia

Instituto de Meio Ambiente e Desenvolvimento

Instituto de Meio Ambiente e Desenvolvimento Sustentável - Tramirim

Instituto de pesquisa agropecuária do nordeste

Instituto de pesquisa e assessoria sobre Desenvolvimento e globalização

Instituto de Pesquisa e Conservação da Natureza

Instituto de pesquisa e Desenvolvimento costa do sol

Instituto de pesquisa e reaproveitamento de resíduos sólidos

Instituto de pesquisas agrárias e tecnologia de turismo e meio ambiente

Instituto de pesquisas ambientais e sociais aplicadas

Instituto de pesquisas e estudos aplicados à sociedade - Brasil

Instituto de planejamento e Desenvolvimento holístico - vista

Instituto de políticas públicas rio de janeiro

Instituto de preservação do meio ambiente e dos recursos naturais da Amazônia

Instituto de preservação e recuperação da biodiversidade de jlle e região - viva o cachoeira

Instituto de promoção à educação, bem-estar social e saúde

Instituto de promoção da cidadania - pró-cidadão

Instituto de promoção e Desenvolvimento de estados e municípios

Instituto de promoção e educação em saúde

Instituto de qualidade de vida - iquavi (bucrisgue)

Instituto de Saúde e Meio Ambiente

Instituto de saúde preventiva e ações sociais assistidas meridional

Instituto de Saúde, Educação, Bem Estar Social

Instituto de tecnologia \& gestão - instituto alfa Brasil

Instituto de tecnologia e Desenvolvimento organizacional e social

Instituto de tecnologia socioambiental do baixo sul da Bahia

Instituto de Turismo de Itacaré

Instituto decolar aerodesportivo

Instituto democracia e sustentabilidade

Instituto dharma

Instituto dínamo de inovação e Desenvolvimento sustentável

Instituto do cerrado

Instituto do Desenvolvimento social e do trabalho de Pernambuco 
Instituto dos rodoviários do estado de mato grosso

Instituto eco millennium

Instituto Ecoar para a Cidadania

Instituto Eco-empreendedor para a Sustentabilidade Ambiental

Instituto Ecoengenho de Tecnologia Aplicada ao Desenvolvimento Sustentável

Instituto ecofuturo - futuro p/ Desenvolvimento sustentável

Instituto ecológica palmas/to

Instituto ecos do Brasil

Instituto ekos Brasil

Instituto Elektro

Instituto empreender

Instituto Engevix

Instituto escola ativa

Instituto esperança viva

Instituto espirito santense de consciência antidrogas

Instituto estação Desenvolvimento

Instituto estre de responsabilidade sócio ambiental

Instituto eureka de cidadania

Instituto Eurofarma

Instituto evoluir

Instituto Excelsa

Instituto fauchard

Instituto Fernanda Keller

Instituto festival de inverno - festinver

Instituto Floravida

Instituto Floresta de Pesquisa e Desenvolvimento Sustentável

Instituto floresta tropical

Instituto futuro cidadão

Instituto GEA - Ética e Meio Ambiente

Instituto gen Brasil

Instituto Genaro Krebs

Instituto gênesis

Instituto geração futuro

Instituto germinar socioambiental

Instituto global de marketing social

Instituto Grande Sertão

Instituto guaicuy - sos rio das velhas

Instituto Guararapes de ciência, tecnologia e ação social

Instituto $\mathrm{h} \& \mathrm{~h}$ fauser para o Desenvolvimento Sustentável e a cultura

Instituto harmonia na tera

Instituto hidroambiental aguas do Brasil - ihab

Instituto holcim

Instituto homemterra de educação, meio ambiente e pesquisa científica

Instituto ibá de Desenvolvimento ambiental e social

Instituto ìmer de estudos sociais

Instituto ingo hoffmann

Instituto intercidadania

Instituto international paper

Instituto Jorge Baptista - formação pesquisa e assessoria

Instituto José Ibrahim

Instituto jovem caminhar

Instituto juizforano de pesquisa, elaboração de projetos, planos integrados e praticas esportivas e sociais

Instituto Julieta Araújo

Instituto Justino carvalho

Instituto juventude ativa

Instituto kauli seadi

Instituto Labor \& Vita

Instituto labore de educação profissional e integração ao mercado de trabalho 
Instituto laborearte de capacitação profissional e ética dos socialmente excluídos Instituto lagoa prateada

Instituto lar Instituto Lina Galvani Instituto litoral verde Instituto loja maçônica força e união de porto seguro Instituto madeira da terra Instituto Mãe Terra de Tecnologia Educacional e Ambiental Instituto mangue vivo Instituto manicoba Instituto maniva Instituto maramar para o manejo responsável dos recursos naturais Instituto Maranata de Pesquisa em Estrutiocultura Instituto Marca de Desenvolvimento Ambiental - Imadesa

Instituto Martim pescador-movimento de preservação da bacia hidrográfica do rio dos sinos Instituto mato grossense de Desenvolvimento humano

Instituto mauro Goulart

Instituto maytenus para o Desenvolvimento da agricultura sustentável

Instituto mil povos / macuco

Instituto Montana ambiental

Instituto morro da cutia de agroecologia

Instituto nacional ações e metas integradas

Instituto nacional de Desenvolvimento agropecuário

Instituto nacional de engenharia, arquitetura e agronomia

Instituto Nacional de Integração Social

Instituto nacional de preservação ambiental

Instituto nacional de tecnologia e uso sustentável

Instituto nacional de tecnologia social

Instituto nacional do Desenvolvimento - inde

Instituto nascente - turismo \& ecologia

Instituto Natureza Viva

Instituto náutico Brasileiro - inabra

Instituto navega São Paulo

Instituto noah

Instituto nova agora de cidadania - inac

Instituto Novas Fronteiras da Cooperação

Instituto Novos Saberes

Instituto oca Brasil

Instituto Oikos de Agroecologia

Instituto oksigeno

Instituto opab

Instituto orbis de proteção e conservação da natureza

Instituto Oswaldo ribeiro de Mendonça

Instituto para Desenvolvimento Socioambiental e Tecnológico Lótus

Instituto palavrações

Instituto palmas

Instituto papel Solidário

Instituto para Cidadania e Implementação da Base Popular - Icibap

Instituto para conservação dos carnívoros neotropicais - pró-carnívoros

Instituto para Desenvolvimento Ambiental e Tecnológico - Idea Cíclica

Instituto para Desenvolvimento da criança e do adolescente pela cultura e esporte - idecace.

Instituto para Desenvolvimento de empreendimentos, instalação e aceleração

Instituto para o Desenvolvimento ambiental

Instituto para o Desenvolvimento da administração social, saúde, educação, emprego e habitação idasseeh

Instituto para o Desenvolvimento Sociocultural e Ambiental - INDES

Instituto para o Desenvolvimento Sustentável de Joinville

Instituto parada vital

Instituto Parceria 
Instituto parque das nascentes

Instituto Patulus

Instituto pau Brasil de história natural

Instituto Pe. João Peter

Instituto pé na vila

Instituto pé no chão

Instituto Peabiru

Instituto Phoenix

Instituto Physis - Cultura \& Ambiente

Instituto planeta pantanal

Instituto Plenojure

Instituto Portas Abertas

Instituto Potiguar de Juventude pela Cidadania

Instituto preservarte

Instituto Prisma de Apoio Administrativo às Micro, às Pequenas, às Médias Empresas e às Entidades da Administração Pública Direta

Instituto pro educare

Instituto pró Life

Instituto Pró Rio Doce

Instituto pró-água

Instituto professor Eurípedes barsanulfo

Instituto profissional Laura vicunha

Instituto Profissionalizante de Tecnologia da Informação

Instituto promur- programa multidisciplinar de reabilitação

Instituto proteção ambiental cotia/Tietê oeste

Instituto putzgrila

Instituto recicla Brasil

Instituto recriar

Instituto renovar

Instituto resolver

Instituto rio tiete

Instituto rosamundhi - irm

Instituto rumo náutico

Instituto sacada social - isas

Instituto Sadia de Sustentabilidade

Instituto Samuel murgel branco

Instituto Santa Cruz de Saúde, Meio Ambiente e Tecnologia

Instituto são Cristóvão

Instituto São Paulo de cidadania e política

Instituto sapiens para Desenvolvimento de tecnologias sociais

Instituto saúde Brasil

Instituto seiva Brasil de Desenvolvimento Sustentável

Instituto selvino caramori

Instituto Sergio Escadinha

Instituto Sicoob Para o Desenvolvimento Sustentável

Instituto Sierra de Proteção ao Meio Ambiente e Pequenos Animais

Instituto social integrado e Solidário

Instituto Social Tecnológico e Econômico do Café - Mais Café

Instituto Social, Educacional e de Pesquisa de Minas Gerais

Instituto Social, Educativo e Beneficente Novo Signo

Instituto Socioambiental Guapuruvu

Instituto Socioambiental Latinha da Solidariedade

Instituto Socioambiental Vida Verde

Instituto Sociocultural Santa Alice

Instituto socioambiental

Instituto socioambiental invepar

Instituto socioambiental rio dos peixes

Instituto sociocultural e ambiental do Amapá

Instituto Solaris 
Instituto sollus

Instituto soma Brasil

Instituto sou mais Brasil

Instituto Souza cruz

Instituto sustentar de responsabilidade socioambiental

Instituto Sustentável do meio ambiente - isma pro-humanitate

Instituto Tamboré

Instituto tecendo sonhos

Instituto Tecnológico de Administração municipal itam

Instituto tecnológico latino americano de pesquisas e Desenvolvimento

Instituto Tempo Bougra - SCTB

Instituto Tempo É Vida

Instituto terra

Instituto Terra de Santa Cruz

Instituto terra social

Instituto terra viva

Instituto Themys de Pesquisa e Gestão em Desenvolvimento Sustentável

Instituto Triunfo

Instituto união keralux

Instituto usina social

Instituto utilitarista

Instituto vem ser Sustentável

Instituto veracel

Instituto Verdescola

Instituto Via Viva

Instituto Vida Gestão Ambiental e Municipal

Instituto Vida para o Atendimento à Saúde, Saneamento e Meio Ambiente

Instituto Vitalis Vitalizando a Integração dos Trabalhadores da América Latina na Luta pela Inclusão

Social

Instituto vitória regia para o Desenvolvimento da Amazônia

Instituto viva ourem

Instituto vivo

Instituto Xopotó de Desenvolvimento Social, Econômico e Ambiental

Instituto interamericano de fomento à educação, cultura e ciência

Instituto de economia solidária inclusiva

Instituto Brasileiro de coop.prom.meio amb.e pub.ed.de trans.e transporte

Integração brasileira de educação

Intep - instituto nacional tecnológico de ensino e pesquisa

Interforum Global: Intercâmbio e Desenvolvimento Sustentável

International rivers network

Invisa - instituto vida e saúde

Ipam - Instituto Brasileiro de Pesquisas Ambientais

Ipê - instituto de pesquisas ecológicas

Ipef instituto pentalfa de fomento, promoção, educação e Desenvolvimento social

lua-instituto urbano ambiental

Jean Michel cousteaus ocean futures society do Brasil

Lar espirita Sabina Andrade ribeiro

Lar santa Maria

Liga Desportiva e Beneficente de Futsal Santamariense

Mapas - Métodos de Apoio a Práticas Ambientais e Sociais

Mater Natura - Instituto de Estudos Ambientais

Mediateca Organização para Inclusão Social e Digital

Missão franciscana do mato grosso e mato grosso do sul

Moinho de pedra do Guarapiranga mpg

Movimento ação de inclusão social - mais timburi

Movimento ambiental gestão e organização social - magos

Movimento arte pelo ambiente, sustentabilidade e promoção humana curumim

Movimento de Cidadania Pelas Águas

Movimento de inclusão pela qualificação do especial independente 
Movimento de Organização Comunitária

Movimento dos consumidores pela qualidade de vida do rio grande do sul

Movimento ecológico e cultural do vale do piranga

Movimento familiar cristão

Movimento Interamericano de Ecologia

Movimento nacional de educação no trânsito

Movimento paz espírito santo

Mude o mundo - instituto de promoção da responsabilidade social

Muito especial

Museu a céu aberto - cultura, ecologia e Desenvolvimento

Nazaré Universidade da Luz

Neotropica instituto de educação e ciências aplicadas

Nova sociedade

Instituto de fomento social

Núcleo artevida associação beneficente

Núcleo de apoio ao desenv. De assoc. E ações comunitárias.

Núcleo de cultura e comunicação qualidade \&vida

Núcleo de Desenvolvimento em Estudos Socioambientais do Maranhão

Núcleo de Desenvolvimento social

Núcleo de educação ambiental Francisco de Assis

Núcleo de educação e monitoramento ambiental

Núcleo de educação socioambiental (nesa) "Prof. Leandro Eduardo de Souza"

Núcleo dos colorados de arambare - nca

Núcleo social a fábrica

Núcleo Verde Amarelo

Nutes - Núcleo de Estudos do Terceiro Setor

Oasis-organização de assistência e serviços integrados aos sujeitos com necessidades especiais

Obec - organização beneficente educacional e cultural

Obra social sri sathya sai "verdade e amor"

Obras assistenciais Dr Ismael Alonso y Alonso

Observatório Ambiental

Oca Organizações Cidadania em Ação

Odesc - Organização Desenvolvimento Sustentável

Oficina escola de lutheria da Amazônia - o e I a

Ong - fish - formação, integração e socialização humana

ONG Dr. Vandick Ponte

ONG Guaranésia Viva

ONG Me Ensina

Ong pra frente Brasil

Ong ramudá - ramos que brotam em tempos de mudança

ONG Terra do Seridó

Ong universidade cidadã

Org não governamental canastra do sul

Organização Ambientalista Amainan Brasil

Organização Bio-Bras

Organização brasileira de arte e cultura

Organização brasillinux

Organização caminhando para o futuro

Organização da comunidade ativa

Organização da promoção social e da saúde de Sergipe

Organização da sociedade civil de interesse público pais e filhos

Organização da sociedade civil de interesse público

Organização da Sociedade Civil de Interesse Público Ambientality

Organização da Sociedade Civil de Interesse Público do Comitê de Defesa da llha Grande

Organização da sociedade civil de interesse público ecolmeia

Organização da Sociedade Civil de Interesse Público: Biodiversity Salvation

Organização de Auxílio Fraterno

Organização de Conservação de Terras do Baixo Sul da Bahia

Organização de Desenvolvimento Cultural e Preservação Ambiental Ama-Brasil 
Organização de parcerias para o progresso

Organização de reciclagem ambiental do lixo público

Organização dos protetores dos animais abandonados e maltratados

Organização e Apoio a Projetos Ambientais e Sociais - URU

Organização ecológica cosmopolense o.e.c

Organização em prol da defesa e resgate indígena e meio ambiente

Organização estilo de vida

Organização Família Legal

Organização Kyokushin Oyama

Organização Não Governamental José Amaury Araújo

Organização Não Governamental Monsenhor Antônio Gomes Soares

Organização Palmares Social

Organização para a Proteção Ambiental SC

Organização para educação e extensão da cidadania

Organização para o bem da água, da natureza e da vida - amanhágua

Organização Ponto Terra

Organização Representativa dos Concurseiros e Estudantes do Brasil

Organização social civil de interesse público Brasil euro oscip/be

Organização social do nordeste de estudo e solidariedade

Organização social terra livre

Organização socioambiental para biodiversidade miraterra - omt

Organização Trajetória Mundial

Organização Verde Brasil

Organização, Método, Experiência, Garantia e Ação

Orjure organização da juventude responsável

Oros - organização razão social

Oscip - e.d.m.a.c. - empreendedores e defensores do meio ambiente e da cidadania

Oscip circuito da vida

Oscip jovem sertão - organização da sociedade cível de interesse publico

Oscip lixo e cidade

Oscip Pró-Vida Brasil

Oscip, organização da sociedade civil de interesse público

Pacto - Desenvolvimento social e pesquisa

Pangea centro de estudos socioambientais

Papyrus ambiental

Parceiros do bem - associação nacional pela inclusão social através da cultura, música, arte, turismo e meio ambiente

Parque do Japão - memorial imin 100

Passatempo educativo

Pea - projeto esperança animal

Piracicaba 2010 - realizando o futuro

Prelazia de Cametá do Tocantins

Prestação de serviço social a comunidades carentes

Prima - Mata Atlântica e sustentabilidade

Prime solidária

Programa comunitário da reconciliação

Programa de Desenvolvimento microrregional Sustentável

Programa Social Gotas de Flor com Amor

Projeto Água

Projeto Araras

Projeto Comunitário Sorriso da Criança

Projeto Cultural Rio das Ostras

Projeto gente e para brilhar

Projeto Viva Vida

Projeto Viver Bem

Promoção humana e apoio social

Rc retratando o cerrado - associação pro defesa, preservação do ambiente e promoção do Desenvolvimento Sustentável

Recanto da Fraternidade Plantando Vidas 
Recanto Infanto-Juvenil

Rede Brasileira de Cooperação ao Desenvolvimento

Rede brasileira de cooperativismo

Rede de amigos da holoarte

Rede de Amigos do Igarapé São Francisco do Acre

Rede de sementes do cerrado

Rede de turismo regional - retur

Rede Digital Comunitária Sol

Rede nacional de aprendizagem, promoção social e integração

Redeh rede de Desenvolvimento humano

Redes - rede de Desenvolvimento social

Renctas - Rede Nacional de Combate ao Tráfico de Animais Silvestres

Reserva Brasil

Resgate da vida

Rotary Club São Paulo Oeste

SOS Quatro Patas Centro de Proteção e defesa dos animais de Resende/RJ

SOS Falconiformes

Sagres - Política e Gestão Estratégica Aplicadas

Santa fé - organização da sociedade civil de interesse público

Serra acima - associação de cultura e Educação ambiental

Sertão Verde Vida

Serviço de Apoio Básico a Infância e Adolescência

Serviço de Obras Sociais

Serviço de Tecnologia Alternativa

Siai - sistema de apoio institucional

Sistema Brasileiro de Tratamento de Resíduos Industriais e Urbanos

Sistema de Apoio e Desenvolvimento - Sisad

Socieade Ecoar

Sociedade Ambiental, Educacional e Cultural do Alto Sertão Paraibano

Sociedade Ambientalista e Cultural - Angaturama

Sociedade amigos de barra do una

Sociedade Amigos de Iracambi

Sociedade amigos de Trancoso

Sociedade Brasileira de Cartografia

Sociedade $B$ rasileira de Espeleologia

Sociedade Brasileira de Preservação e Promoção da Vida

Sociedade de Defesa, Preservação e Conservação do Meio Ambiente

Sociedade de Desenvolvimento ambiental do alto acre

Sociedade de Estudos Múltiplos, Ecológica e de Artes - Sociedade Semear

Sociedade de Integração Ambiental álvaro Gayoso

Sociedade de Microcrédito, Pesquisa, Empreendedorismo e Desenvolvimento Sustentável do Norte

Pioneiro

Sociedade de Pesquisa em Vida Selvagem e Educação Ambiental

Sociedade de pesquisa johanna dobereiner

Sociedade dos Amigos do Cerrado - Socerrado

Sociedade educação e caridade

Sociedade humana despertar

Sociedade Marinhense de Desenvolvimento Sustentável

Sociedade para o Desenvolvimento dos Serviços Públicos

Sociedade pró-ar

Sociedade sinha Laurinha

Solidariedade

Solidariedade paz e vida

Sos amigo bicho

SOS animais de rua

SOS Paraíba do sul

SOS Povos da Mata Atlântica

Terra mirim - centro de luz

The Green Initiative 
Thema programas e projetos sociais alterativos assessoria e consultoria

Trama ecológica

Três ecologias instituto ambiental de Desenvolvimento sustentável

Tv Vila Imperial Organização das Entidades Usuárias do Canal Comunitário de Petrópolis

União de mulheres do município de São Paulo

União dos escoteiros do Brasil

União nacional dos dirigentes municipais de educação

Uniciência - União para o Desenvolvimento Social e Cultural Através da Ciência e Tecnologia

Unidade assistencial do núcleo samaúma lar sama

Unigoverno

Universidade Livre de Idiomas, Sustentabilidade Ambiental \& Corporativa

Universidade Livre do Meio Ambiente

V.O.S - Ver Ouvir e Sorrir, Centro Viver de Otorrinolaringologia e Oftalmologia

Vale da Cidadania

Valer capacitação e pesq p des local Sustentável

Veja como ajudar!

Veja como ajudar!

Veja como ajudar!

Vida Brasil

Vitae domini - instituto Brasileiro de Desenvolvimento social

Vivamar

Vivere- estudos em políticas sociais

Voluntários embuense em defesa dos animais

WWF-Brasil

\section{Desenvolvimento econômico}

A p d I - Associação de promoção do Desenvolvimento local

Abcc associação beneficente crista de contagem

Abrades Agência brasileira de Desenvolvimento Econômico e social

Abraso - agência brasileira de Desenvolvimento sustentável e tecnologia social

Ação Comunitária do Espírito Santo

Ação Ética \& Cidadania

Ação social arquidiocesana

Acreditar

Acredite - agência de crédito especial do alto vale do Itajaí

Adesu - Agência de Desenvolvimento Econômico e Social de Ubatuba

Adetec associação do Desenvolvimento tecnológico de londrina e região

Agência Baiana de Desenvolvimento Social

Agência Brasileira de Desenvolvimento da Aquicultura

Agência brasileira de Desenvolvimento sócio econômico - abase

Agência brasileira de planejamento Econômico e social

Agência de cooperação social

Agência de crédito do vale do itapocu

Agência de Desenvolvimento Humanitário e Econômico da APA do Igarapé Gelado

Agência de Desenvolvimento de Araraquara

Agência de Desenvolvimento de Guapirama

Agência de Desenvolvimento de Guarulhos

Agência de Desenvolvimento de Itapecerica da Serra e Região

Agência de Desenvolvimento de Jundiaí e região

Agência de Desenvolvimento de Monte Alto e Região

Agência de Desenvolvimento de ouro branco

Agência de Desenvolvimento de ribeirão do pinhal

Agência de Desenvolvimento de rio pardo

Agência de Desenvolvimento de São João da Boa Vista

Agência de Desenvolvimento do alto vale do rio negro

Agência de Desenvolvimento Econômico de bebedouro e região

Agência de Desenvolvimento Econômico e Social de Dois Córregos 
Agência de Desenvolvimento Econômico e social de Itanhaém

Agência de Desenvolvimento econômico e social de itabirito

Agência de Desenvolvimento Econômico e Social de Mandaguari e Região

Agência de Desenvolvimento Econômico e Social de Ouro Preto

Agência de Desenvolvimento econômico e social de Resende

Agência de Desenvolvimento Econômico e Social de Socorro - ADESSO

Agência de Desenvolvimento Econômico e Social do Centro Oeste - ADESCO

Agência de Desenvolvimento econômico e socioambiental de canoas - adescan

Agência de Desenvolvimento Integrado e Sustentável de Mesorregião dos Vales do Jequitinhonha e do Mucuri

Agência de Desenvolvimento Integrado e Sustentável Sempre Alerta Riachinho

Agência de Desenvolvimento local integrado e Sustentável de João pinheiro

Agência de Desenvolvimento local, integrado e sustentável de Pirapora

Agência de Desenvolvimento regional - unicidades

Agência de Desenvolvimento Regional da Amurel

Agência de Desenvolvimento Regional do Extremo Oeste do Paraná

Agência de Desenvolvimento Regional do Maciço de Baturite

Agência de Desenvolvimento regional do norte e noroeste do estado do rio de janeiro

Agência de Desenvolvimento regional do sudoeste do Paraná

Agência de Desenvolvimento Regional Integrado do Planalto Norte Catarinense

Agência de Desenvolvimento Social de Flexal I e Nova Canaã

Agência de Desenvolvimento Social de Piranema

Agência de Desenvolvimento social e Econômico de Guarapari-ES

Agência de Desenvolvimento Social Vale Esperança

Agência de Desenvolvimento sócio econômico médio norte - adsemn

Agência de Desenvolvimento Sustentável da Amazônia Maranhense

Agência de Desenvolvimento Sustentável da Região Lago de Tucuruí

Agência de Desenvolvimento Sustentável de boa esperança

Agência de Desenvolvimento Sustentável de Paracatu

Agência de Desenvolvimento Sustentável do Seridó

Agência de Desenvolvimento sustentável do sudoeste mineiro

Agência de Desenvolvimento Sustentável do Sul do Estado do Espírito Santo

Agência de Desenvolvimento turístico e cultural da rota dos tropeiros do Paraná

Agência de Desenvolvimento Urbano e Rural do Município de Guaçuí

Agência de Desenvolvimento integrado e sustentável da região do pico da bandeira

Agência do crédito

Agência do Programa de Desenvolvimento Sustentável do Centro Oeste Mineiro

Agência empreender

Agência jacarezinhense de Desenvolvimento e promoção da saúde - ajadps

Agência Mandalla de Desenvolvimento Holístico Sistêmico e Ambiental

Agência nacional de Desenvolvimento microempresarial

Agência nacional de Desenvolvimento social e ambiental

Agência para a promoção do Desenvolvimento sustentado

Agência para o Desenvolvimento de Congonhas

Agência para o Desenvolvimento econômico e social de patos de minas

Agência para o Desenvolvimento Econômico, local, integrado e sustentável de três Marias - MG e região

Agência para o Desenvolvimento para patrocínio

Agência para o Desenvolvimento regional

Agência sul-americana de Desenvolvimento

Agência Tear - Agência para o Desenvolvimento Sustentável e a Inclusão Social

Agnee - associação global nova era

Alavanca

Alavancando o progresso

Alecrim Cultura \& Saúde

Aliança educativa cultural científica e humanística

Aliança Nativa

Amigo social

Amigos Associados de Itaberá (Amai)

Amigos da mata 
Antenados no meio ambiente - AMA

Apec associação promotora de estudos de economia

Apoio à iniciativa empreendedora

Apoio Brasil- sistema de apoio ao trabalhador Brasileiro no exterior

Apoio trabalhador autônomo ata

Ass bras des da família - banco da família

Ass. Dos morad. Da com. De Sta. Amália

Assoc. dos usuários da marina do saco da ribeira - aumar

Associação aliança assessoria financeira de pessoas físicas e jurídicas

Associação Aliança Empreendedora

Associação Amigos do Bairro do Sahy

Associação artístico-cultural de cabedelo

Associação Brasil melhor

Associação Brasileira da infraestrutura e indústrias de base

Associação Brasileira das empresas de tecnologia da informação e comunicação

Associação Brasileira de cimento Portland

Associação Brasileira Associação Brasileira de Desenvolvimento Humano

Associação Brasileira de gestão do conhecimento

Associação Caatinga

Associação catarinense de plantas medicinais

Associação celeiro do vale do rio pardo

Associação Cena Aberta

Associação centrodesignio

Associação circuito verde-trilha dos bandeirantes

Associação civil design Catarina

Associação comercial de porto alegre

Associação comercial, industrial e de serviços de candeias

Associação comercial, industrial, de serviços e agronegócios de formiga

Associação Comunitária Cidade Viva - "Nossa ONG"

Associação comunitária de crédito de João Monlevade - banco popular do pequeno empreendedor de

João Monlevade - banpope

Associação comunitária de crédito do vale do aço

Associação comunitária do bairro da felicidade

Associação Comunitária do sitio cabaceiras

Associação Comunitária dos Moradores Micro e Pequenos Produtores Rurais do Povoado Olho D'Água do Meio

Associação Comunitária flores agrícolas de mundo novo

Associação Comunitária Piracicaba

Associação Comunitária Rural de Baixio e Serrinha

Associação crédito do Brasil

Associação cultural amigos do agito

Associação das organizações de microcrédito e microfinanças de Santa Catarina

Associação de apoio à economia popular da Amazônia

Associação de apoio à educação, cultura, esporte e lazer

Associação de apoio ao Desenvolvimento das comunidades de goianinha-adg

Associação de apoio ao Desenvolvimento social para o agronegócio

Associação de apoio as comunidades do campo do RN

Associação de crédito ao microempreendedor do contestado

Associação de Crédito cidadão de Rondônia - acrecid

Associação de Crédito comunidade do futuro

Associação de Crédito popular

Associação de crédito solidário do norte e nordeste de Santa Catarina - casa do empreendedor

Associação de Desenvolvimento comunitário do bairro novo

Associação de Desenvolvimento de taquari humanae vitae

Associação de Desenvolvimento econômico, social e cultural - adesc Brasil

Associação de garantia de crédito da serra gaúcha

Associação de garantia de crédito do leste de minas gerais

Associação de moradores da Itinga

Associação de moradores da vargem do forno 
Associação de mulheres de negócios e profissionais de esplanda

Associação de mulheres empreendedoras de praia grande

Associação de municípios da região de laguna

Associação de organizadores sociais e serviços

Associação de preservação do meio ambiente natural e melhoria de qualidade de vida - instituto bioma

Associação de profissionais em educação e áreas afins - ceesp

Associação de Reciclagem de Vila Velha

Associação de reposição florestal do pardo grande

Associação de senhoras e assistência social de Euclides da cunha

Associação de usuários dos terminais portuários de salvador - usuport

Associação Desenvolvimento comunitária rural tapera

Associação do Desenvolvimento ao empreendedorismo social

Associação do fórum ação para o Desenvolvimento de Candido Godoi

Associação do Fórum de Desenvolvimento Local Integrado e Sustentável de Caarapó - Vivacidade

Associação do povoado mumbaca

Associação dos amigos da marian

Associação dos Amigos da Pedra da Princesa

Associação dos funcionários do instituto Brasileiro de integração e Desenvolvimento pró-cidadão

Associação dos moradores da vila nova

Associação dos moradores do bairro de Henrique Jorge

Associação dos moradores dos setores Coimbra e bela vista

Associação dos usuários da agua da bacia hidrográfica do rio santa Maria

Associação energia vital

Associação fartura alimentos

Associação fermento na massa

Associação Fórum de Dlis de Pedro Gomes - ADPEG

Associação garantidora de crédito do estado do rio grande do sul

Associação Geográfica União das Águas

Associação instituto da plataforma sinergia

Associação Instituto de Pesquisas em Energias Renováveis e Meio Ambiente

Associação instituto de politicas e Desenvolvimento

Associação Internacional Protetora do Meio Ambiente

Associação Junior achievement de minas gerais

Associação Junior achievement do Piauí

Associação konverto de investimentos sociais

Associação luz do oriente

Associação marca para promoção de serviços

Associação mineira de crédito popular

Associação movimento João de barro

Associação mundaréu

Associação nacional de Desenvolvimento econômico e social

Associação Núcleo para Transformações Ambientais e Sociais

Associação p/promoção da excelência do software Brasileiro- softex

Associação para o Desenvolvimento agro Sustentável do alto Solimões

Associação para o Desenvolvimento da mulher da região sul do rio grande do sul

Associação para o Desenvolvimento da mulher de Caxias do sul/RS

Associação para o Desenvolvimento da mulher do estado da Bahia - bco da mulher

Associação para o Desenvolvimento sustentável - ades

Associação para o Desenvolvimento Tecnológico e industrial do sudoeste do Paraná

Associação pró-emprego e renda de Barbacena

Associação pro melhoramento de são João de viçosa

Associação pró sapiens - logística em Desenvolvimento social

Associação pró-Desenvolvimento do município de soledade - aprosol

Associação programa um milhão de cisternas para o semiárido

Associação projeto bagagem

Associação quintessa

Associação reagir

Associação rede vida de Desenvolvimento humano tecnológico e proteção social

Associação Rio Minas "trem mineiro" 
Associação sul americana de inventores

Associação terraBrasil - ONG

Associação Thalamus

Associação turística e comercial da região de visconde de Mauá - mauatur

Associação União llha de Boipeba

Associação unida do bairro pôr-do-sol

Associação Universitária da Zona Leste

Associação vale para o Desenvolvimento sustentável

Associação Vida Amiga

Banco de projetos em prol do Desenvolvimento do norte do Paraná - banpro

Banco do empreendedor

Bancri-banco de crédito popular da foz do rio Itajaí-açú

Bioética de gestão pública

Biomavale - organização da sociedade civil de interesse público

Brasil Ação Solidária

Brasil Essencial - Resultados Sustentáveis

Brisa-sociedade para o Desenvolvimento da tecnologia da informação

Cací - Comitê de Ação pela Cidadania

Câmara Brasil Israel de comércio e indústria

Câmara de Desenvolvimento Brasil Japão do mato grosso do sul

Camará saúde qualidade de vida e gestão

Cam-centro de apoio aos microempreendedores

Care internacional Brasil

Casa da mulher instituto de capacitação, estudos e integração sociocultural

Casa de apoio à criança carente de contagem

Casa de Daura/agesdh

Casa do microcrédito

Casa familiar agroflorestal do baixo sul da Bahia

Casativa Centro de Ações Sociais

Ccrie - casa de crédito e incentivo ao empreendedor

Ceabra - coletivo de empresários e empreendedores afro-Brasileiros

Central de assessoria social

Central de Inteligência e Assessoria Brasil

Centro assistencial de regeneração dérmica

Centro Brasil trabalho - cbt

Centro de ações de Desenvolvimento social e urbano do nordeste

Centro de alta tecnologia e inovação em software

Centro de Apoio à Economia Popular Solidária

Centro de apoio a pequenos empreendimentos

Centro de apoio aos pequenos empreendimentos de Pernambuco

Centro de apoio aos pequenos empreendimentos do estado da Paraíba

Centro de apoio aos pequenos empreendimentos do estado do maranhão

Centro de apoio aos pequenos empreendimentos do Piauí

Centro de apoio e execução de projetos sociais- caeps

Centro de aprendizagem e Desenvolvimento social sustentável

Centro de assessoria e apoio aos trabalhadores e instituições não governamentais alternativas

Centro de atendimento ao trabalhador - ceat

Centro de aventura rio do peixe

Centro de capacitação, profissionalização e educação para cidadania

Centro de cultura e artesanato

Centro de Desenvolvimento agroecológico sabiá

Centro de Desenvolvimento de empresários e administradores lideres de Tucuruí

Centro de Desenvolvimento Integrado Social e Cultural

Centro de Desenvolvimento Sustentável e Industrial de Sistemas Florestais do Norte Pioneiro

Centro de elaborações assessoria e Desenvolvimento de projetos

Centro de estudo de gestão publica

Centro de estudo pesquisa e empreendedorismo social - cepes

Centro de estudos da cultura e do meio ambiente da Amazônia - rioterra

Centro de Estudos e Aplicações para as Novas Tecnologias Educacionais 
Centro de Estudos e Apoio ao Desenvolvimento do Araripe

Centro de Estudos para o Desenvolvimento Local

Centro de estudos sociais interestadual

Centro de estudos, promoção e Desenvolvimento de mercados

Centro de excelência em tecnologia de software do recife

Centro de inclusão digital e aprendizagem profissional

Centro de integração social e cultural

Centro de promoção do Desenvolvimento sustentável

Centro de qualificação e gestão do conhecimento-cqg

Centro de referencia em cooperativismo e associativismo

Centro ecumênico de apoio ao Desenvolvimento

Centro educacional imaculada conceição

Centro educacional profissionalizante para o Desenvolvimento socioeconômico de São Paulo sertanzinho-sp

Centro integrado de fomento a educação e a tecnologia

Centro Nacional de Educação Ambiental e Geração de Emprego

Centro Preserv de Promoção do Desenvolvimento Sustentado

Centro referencial de estudos e apoio de técnicas, experimentações e créditos - createc

Cerca - centro regional de cultura e arte

Cluster de Turismo da Costa dos Coqueiros

Codenorte - conselho de Desenvolvimento do norte de mato grosso

Comissão xxi de Desenvolvimento sociocultural

Comitê para democratização da informática do Paraná

Companhia de Desenvolvimento econômico e social de são Sebastião

Comunidade kolping frei Tomás

Comunidade semeando o futuro - comsef

Congregação das religiosas da assunção de nossa senhora

Conselho de Desenvolvimento Econômico e social de ponta grossa

Conselho de Desenvolvimento sustentável da baia da ilha grande

Conselho federal parlamentar

Conservation Strategy Fund do Brasil

Consórcio para Proteção Ambiental e Desenvolvimento Sustentável e Sociocultural da Bacia

Hidrográfica do Rio das Cinzas

Contacred instituição mineira de microcrédito

Creatif - Associação da Igualdade

Crecerto Agência de microcrédito solidário do alto Uruguai catarinense

Crediamai - agência de microcrédito

Credioeste

Crédito popular solidário

Credivale Agência metropolitana de microcrédito

Desenvolvimento Social Humano Tecnológico DSHT

Deutscher Genossenschafts und Raiffeisenverband - Associação Alemã dos Bancos Cooperativos e das Cooperativas de Crédito Agrícola

Diocese do alto Solimões

E+co Brasil

Ecos - instituto de pesquisa e Desenvolvimento socioambiental

Ecovitae Tecnologia Ambiental

Empreende - sistema de empreendedorismo social

Escola da quadra centro de form.educ.cult.art..espor.laze

Escola Viveiro Multiplicadora Artesã

Espaço cultural dona Julieta sohn

Extremo oeste agência de crédito

Face a Face Ação Solidária

Federação das associações e entidades para o Desenvolvimento do semiárido baiano

Federação das organizações não governamentais do município de itarema-ce

Força comunitária nacional

Fórum de Desenvolvimento de coronel vivida

Fórum de Desenvolvimento de Ibaiti

Fórum de Desenvolvimento de pato branco 
Fórum de Desenvolvimento de realeza

Fórum municipal de lutas de Itaquaquecetuba

Fórum para o Desenvolvimento do entretenimento, cultura e turismo da Bahia

Fórum permanente de responsabilidade social do rio grande do sul

Fund. Centro neerlandês para promoção comercial

Fundação Brasil Esperança

Fundação centro de estudos do comércio exterior

Fundação centro neerlandês para promoção comercial

Fundação de Desenvolvimento de tecnópolis

Fundação de integração, Desenvolvimento e educação do noroeste do estado

Fundação Gerdau

Fundação Jari

Fundação juazeirense para Desenvolvimento científico, tecnológico, econômico, sociocultural e ambiental

Fundação norte fluminense de Desenvolvimento regional

Fundação para o Desenvolvimento do semiárido Brasileiro - fundesa

Fundação para o Desenvolvimento Sustentável do Araripe

Fundação rio do leão

Fundação serviços de defesa e tecnologias de processos

Fundação stickel

Fundação turismo para paz e Desenvolvimento sustentável

Fundação vovó do mangue

Fundacion avina

Fundo de apoio ao empreendedor joseense

Fundo de apoio ao empreendimento popular

Fundo de apoio ao empreendimento popular de Ariquemes

Fundo para o Desenvolvimento da agricultura familiar

Garantioeste - sociedade de garantia de crédito do oeste do Paraná

Gerar geração de emprego, renda e apoio ao Desenvolvimento regional

Gestão no terceiro milênio

GRAF Grupo de Recuperação Ambiental e Florestal

Grande oeste comunidade solidaria

Grupo de ação social afro reggae - gas

Grupo de apoio nisfram

Grupo de estudos e ações de estimulo ao crédito

Grupo de Pesquisas Ufológicas Ufogênesis

Gruppo di volontariato civile g.v.c. Onlus

Horcap - Desenvolvimento sustentado

lambra Instituto de Assistência aos Municípios Brasileiros

Ibit - instituto Brasileiro de inteligência tecnológica

Ibratec instituto Brasileiro de Desenvolvimento tecnológico

Icde instituto de combate à fraude e defesa da concorrência

Idaq Instituto Dr. Avelino Elias de Queiroga

Idelt - instituto de Desenvolvimento, logística, transporte e meio ambiente

Idess- instituto de Desenvolvimento Econômico setorial Sustentável

Idf - instituto doutor feitosa

Igepas - instituto de gestão pública, ambiental e de assistência social

Inadem instituto nacional para o Desenvolvimento Econômico e preservação do meio ambiente

Incubadora de empresas de base tecnológica tecvitória

Inderc instituto de Desenvolvimento regional do cintap

Indesus - Instituto Tecnológico para o Desenvolvimento Sustentável

Iniciativa primus

Inprefer instituto nacional de preservação e restauração ferroviária

Inst educacional de desenv socio cult e de pesq inst innovare

Inst.de estudos e pesq.para prom.da educação, cultura e Desenvolvimento econômico e social prosocial

Instituição comunitária de crédito Blumenau solidariedade

Instituição comunitária de crédito da região sul -

Instituição comunitária de crédito da serra 
Instituição comunitária de crédito de londrina - casa do empreendedor Instituição comunitária de crédito do médio alto Uruguai e região celeiro Instituição comunitária de crédito Itabuna solidária Instituição comunitária de crédito portosol

Instituição comunitária de crédito vlc rio grande do sul Instituição de crédito solidário - credisol Instituição de crédito solidário de Maringá Instituição para o Desenvolvimento de empreendimentos populares Instituto a mudança que queremos Instituto Abradee da Energia

Instituto acesso

Instituto acil Instituto adote Instituto aequitas para o Desenvolvimento local Sustentável - instituto aequitas Instituto aguativa Instituto alter ego Instituto Amazônia Instituto amazônico de Desenvolvimento social, amparo a pesquisa e a tecnologia Instituto Ambiental de Desenvolvimento Social Sustentável - Instituto Biocêntrica Instituto Ambiental Global - IAG

Instituto amea Instituto amora carambola Instituto Avaí futebol clube Instituto Banco Palmas de Desenvolvimento e Socioeconomia Solidária Instituto barilá Instituto Barretos de tecnologia - ibt Instituto bdoni Instituto Bioacqua de Promoção de Desenvolvimento Sustentável e Defesa do Meio Ambiente Instituto Bioterra Instituto bras de Desenvolvimento da pessoa humana Instituto Brasil 100 Instituto Brasil mãos à obra Instituto Brasil Preservação Ambiental e Desenvolvimento Sustentável Instituto Brasil social Instituto Brasil Solidário Instituto Brasil Solidário - IBS Instituto Brasileiro da cidadania Instituto Brasileiro de administração - iba Instituto Brasileiro de administração municipal Instituto Brasileiro de administração para o Desenvolvimento Instituto Brasileiro de apoio à modernização administrativa Instituto Brasileiro de Desenvolvimento " o futuro é hoje" Instituto Brasileiro de Desenvolvimento de gestão e políticas públicas Instituto Brasileiro de Desenvolvimento Econômico e social - ibdes Instituto Brasileiro de difusão do conhecimento Instituto Brasileiro de difusão educacional para o trânsito Instituto Brasileiro de direito do terceiro setor Instituto Brasileiro de empreendedorismo social - ies Instituto Brasileiro de estudos e pesquisas comunitárias Instituto Brasileiro de ética concorrencial Instituto Brasileiro de executivos de finanças - ibef rio de janeiro Instituto Brasileiro de integração e Desenvolvimento pró-cidadão Instituto Brasileiro de pesquisas e estudos ambientais Instituto Brasileiro de políticas públicas Instituto Brasileiro de Santa Catarina - ibrasc Instituto Brasileiro de tecnologias sociais Instituto Brasileiro do Crisólita Instituto Brasileiro do Empreendedor Instituto Brasileiro para o Desenvolvimento Econômico, Social e Humano 
Instituto Brasileiro para o Desenvolvimento social e econômico Instituto Câmara Filho

Instituto centro de capacitação e apoio ao empreendedor - iccape

Instituto Cia do turismo

Instituto cidadania ativa

Instituto cidadania do nordeste

Instituto civitas Brasil de desenv técnico, econômico e social em saneamento ambiental

Instituto creatio

Instituto cultual batá kotô

Instituto da cultura afr no Brasil

Instituto de Ação Social Planejada

Instituto de Apoio a Tecnologia, Educação, Saúde, Promoção Social, Meio Ambiente e Cultura

Instituto de apoio ao trabalho humano e geração de renda

Instituto de assessoria para Desenvolvimento humano - iadh

Instituto de capacitação profissional Ceará

Instituto de cidadania do noroeste de minas

Instituto de comunicação marketing e empreendedorismo máxima social

Instituto de Cooperação e Tecnologia Socioambiental

Instituto de debates, estudos e alternativas de porto alegre

Instituto de defesa da cidadania

Instituto de desenvol Sustentável e energias renováveis

Instituto de Desenvolvimento científico e tecnológico de xingó

Instituto de Desenvolvimento comunitário sustentável

Instituto de Desenvolvimento corporativo do Paraná

Instituto de Desenvolvimento da região do sisal

Instituto de Desenvolvimento de governador Valadares

Instituto de Desenvolvimento e cidadania - ideci

Instituto de Desenvolvimento econômico e social de Itabira

Instituto de Desenvolvimento econômico e social do Brasil

Instituto de Desenvolvimento econômico e socioambiental - idesa

Instituto de Desenvolvimento humano, econômico e ação social

Instituto de Desenvolvimento Integrado para Ações Sociais

Instituto de Desenvolvimento Laura sciotta

Instituto de Desenvolvimento Municipal nova cidade

Instituto de Desenvolvimento regional do oeste do Paraná

Instituto de Desenvolvimento social do maranhão

Instituto de Desenvolvimento social e econômico

Instituto de Desenvolvimento Socioeconômico dos Trabalhadores de Baixa Renda

Instituto de Desenvolvimento Tecnológico

Instituto de Desenvolvimento Tecnológico e humano

Instituto de Desenvolvimento, Educação, Análise e Legislação - Ideal

Instituto de Direito Agrário e Ambiental do Sul - Joaquim Luiz Osorio

Instituto de Ecologia Terrestre

Instituto de economia e projetos sociais

Instituto de economia solidaria

Instituto de Educação Pesquisa e Saúde San Julian

Instituto de estudo do trabalho e combate a pobreza

Instituto de estudos e pesquisas para o Desenvolvimento com inclusão social

Instituto de estudos e pesquisas, projetos - Project

Instituto de fomento e apoio ao terceiro setor

Instituto de formação empreendedora e educação permanente

Instituto de gestão de projetos da noroeste paulista - gepron

Instituto de gestão social do terceiro setor e responsabilidade empresarial

Instituto de gestão solidária

Instituto de governo eletrônico, inteligência jurídica e sistemas

Instituto de integração e Desenvolvimento da agropecuária Sustentável

Instituto de integração social e ambiental

Instituto de Integração Social, Desenvolvimento Sustentável e Preservação Ambiental

Instituto de Meio Ambiente e Desenvolvimento 
Instituto de pesquisa e Desenvolvimento sustentável via-montes

Instituto de pesquisa e educação (ipe)

Instituto de pesquisas e projetos para o Desenvolvimento socioeconômico da Amazônia

Instituto de planejamento da gestão governamental

Instituto de políticas públicas rio de janeiro

Instituto de renovação social -família brasileira

Instituto de Saúde e Meio Ambiente

Instituto de Saúde, Educação, Bem Estar Social

Instituto de tecnologia \& gestão - instituto alfa Brasil

Instituto de tecnologia aplicada e inovação

Instituto de tecnologia de prevenção de desastres naturais e industriais

Instituto de tecnologia e Desenvolvimento organizacional e social

Instituto de tecnologia e informação social da Amazônia

Instituto de tecnologia social

Instituto de tecnologia, pesquisa e cultura da Amazônia

Instituto democracia e sustentabilidade

Instituto Desenvolvimento Econômico e social do planalto

Instituto dínamo de inovação e Desenvolvimento sustentável

Instituto do conhecimento e ciências aplicadas - icpa

Instituto do Crédito e cidadania

Instituto do Desenvolvimento social e do trabalho de Pernambuco

Instituto Dra. Leda bacci para o Desenvolvimento

Instituto Eco-empreendedor para a Sustentabilidade Ambiental

Instituto educaalma

Instituto educacional carvalho

Instituto eduxxi

Instituto Emerson fittipaldi

Instituto empreender endeavor - Brasil

Instituto estação Desenvolvimento

Instituto estre de responsabilidade sócio ambiental

Instituto ethos de empresas e responsabilidade social

Instituto Eurofarma

Instituto Excelsa

Instituto federal de fiscalização-iff

Instituto finsol if

Instituto Floresta de Pesquisa e Desenvolvimento Sustentável

Instituto fnp

Instituto Frederico markus

Instituto futuro cidadão

Instituto gaúcho de estudos automotivos

Instituto gente

Instituto hábilis

Instituto hartmann regueira

Instituto holcim

Instituto humaniza

Instituto Inceri

Instituto integra para o Desenvolvimento

Instituto Julieta Araújo

Instituto Labor \& Vita

Instituto latino americano de ensino

Instituto madeira da terra

Instituto Mãe Terra de Tecnologia Educacional e Ambiental

Instituto manicoba

Instituto marca Brasil

Instituto Matheus de lima

Instituto mauro Goulart

Instituto meio

Instituto nacional da qualidade judiciária - inqj

Instituto nacional de tecnologia e integração social 
Instituto nacional para o Desenvolvimento espacial e aeronáutico - Idea

Instituto navegamundo

Instituto nova agora de cidadania - inac

Instituto Novas Fronteiras da Cooperação

Instituto Novos Saberes

Instituto oca Brasil

Instituto paju de Desenvolvimento e socioeconomia solidária

Instituto palavrações

Instituto palmas

Instituto papel Solidário

Instituto para Cidadania e Implementação da Base Popular - Icibap

Instituto para Desenvolvimento Ambiental e Tecnológico - Idea Cíclica

Instituto para Desenvolvimento de empreendimentos, instalação e aceleração

Instituto para o Desenvolvimento da administração social, saúde, educação, emprego e habitação idasseeh

Instituto para o Desenvolvimento Econômico auto Sustentável

Instituto para o Desenvolvimento regional

Instituto para o Desenvolvimento Sustentável de Joinville

Instituto para o Desenvolvimento Tecnológico e social

Instituto paradigma

Instituto Parceria

Instituto Patulus

Instituto Peabiru

Instituto Peabirus

Instituto Pedro Ludovico

Instituto pirâmides

Instituto Portas Abertas

Instituto Potiguar de Juventude pela Cidadania

Instituto Prisma de Apoio Administrativo às Micro, às Pequenas, às Médias Empresas e às Entidades

da Administração Pública Direta

Instituto pró-cidadania

Instituto Profissionalizante de Tecnologia da Informação

Instituto qualidade minas

Instituto Roberto Sampaio Ferreira

Instituto Rodrigo Marcheschi - I.R.M.

Instituto S.O.S. Sistemas Organizados para Sustentabilidade

Instituto são Francisco

Instituto sapiens para Desenvolvimento de tecnologias sociais

Instituto senso de avaliação social

Instituto Sergio Escadinha

Instituto Sicoob Para o Desenvolvimento Sustentável

Instituto Social Tecnológico e Econômico do Café - Mais Café

Instituto Social, Educacional e de Pesquisa de Minas Gerais

Instituto sol de Desenvolvimento pesq. Empreed. E Crédito

Instituto Solaris

Instituto soma Brasil

Instituto Tecnológico de Administração municipal itam

Instituto Terra de Santa Cruz

Instituto terra social

Instituto Themys de Pesquisa e Gestão em Desenvolvimento Sustentável

Instituto Triunfo

Instituto utilitarista

Instituto virada beneficente a

Instituto vivarta

Instituto Von Stein

Instituto Wal-Mart

Instituto Xopotó de Desenvolvimento Social, Econômico e Ambiental

Instituto de economia solidária inclusiva

Instrodi - instituto strohalm de Desenvolvimento integral 
Integração brasileira de educação

Integrare ? Centro de integração de negócios

Interforum Global: Intercâmbio e Desenvolvimento Sustentável

IPD - Instituto de Promoção do Desenvolvimento

Ipef instituto pentalfa de fomento, promoção, educação e Desenvolvimento social

Ipep instituto pedagógico de educação profissional do Brasil

Ises - instituto de socioeconomia solidaria

Juriti associação de Crédito ao microempreendedor

Liga carmesiana de assistência social

Liga Desportiva e Beneficente de Futsal Santamariense

Minasinvest - Aliança de Desenvolvimento

Morada norte movimento de empreendedores sociais

Movimento ação de inclusão social - mais timburi

Movimento Brasil competitivo - mbc

Movimento de Organização Comunitária

Movimento Interamericano de Ecologia

Movimento vida nova vila velha

Nea - núcleo de estudos e assessoramento

Nova sociedade

Núcleo de apoio ao desenv. De assoc. E ações comunitárias.

Núcleo de Desenvolvimento econômico do vale do Jequitinhonha

Núcleo de Desenvolvimento humano e Econômico de curiponopolis

Núcleo de Desenvolvimento humano e Econômico de governadores Valadares

Núcleo de Desenvolvimento humano Econômico de Barcarena

Núcleo de Desenvolvimento social

Núcleo de ensino, pesquisa e exploração em tecnologia da informação

Núcleo desenv humano e econ de tucumã

Nutes - Núcleo de Estudos do Terceiro Setor

Obra kolping estadual do Piauí

Obras sociais da comunidade de vinhático

Oca Organizações Cidadania em Ação

Oficina escola de lutheria da Amazônia - o e I a

Ong analise

Ong cidadania em exercício

ONG Terra do Seridó

Ordes - organização para o Desenvolvimento econômico e social

Organização brasileira para o Desenvolvimento científico e tecnológico do controle do espaço aéreo

Organização da sociedade civil de interesse público

Organização da sociedade para a inclusão social - cn 100

Organização de apoio ao Desenvolvimento dos municípios

Organização de apoio ao vale do ribeira

Organização de Conservação de Terras do Baixo Sul da Bahia

Organização de Crédito popular e Solidário do município de porto velho

Organização ecosocial do Araguaia

Organização em prol da defesa e resgate indígena e meio ambiente

Organização família legal

Organização nacional de estudos e projetos

Organização não governamental José Amaury Araújo

Organização para educação e extensão da cidadania

Organização para o Desenvolvimento Sustentável meristema - instituto meristema

Organização Representativa dos Concurseiros e Estudantes do Brasil

Organização Trajetória Mundial

Organização da sociedade civil de interesse publico

Oros - organização razão social

Oscip circuito da vida

Oscip jovem Sertão - organização da sociedade civil de interesse publico

Oscip matas verde de Rondônia - omaveron

Oscip não me abandone

Oscip-projeto sociocultural fabricando empresários 
Pai programa de assistência a infância e adolescência

Planaltina é você

Planet finance Brasil associação civil

Planetapontocom

Polo tecnológico de informação e comunicação da região de Blumenau - blusoft

Ppc - projeto popular de cidadania

Prime solidária

Primeira ordem de socialização do indivíduo em exclusão

Profomento Agência de crédito especial

Programa de Desenvolvimento microregional Sustentável

Programa providência de elevação da renda familiar - programa providência

Programa social gotas de flor com amor

Projeto Cultural Rio das Ostras

Prospectar Brasil associação de estudos prospectivos do Brasil

Rede Digital Comunitária Sol

Rede sócio econômica popular e solidária de Desenvolvimento sustentável novo sol

Redeinternacional de ação comunitária - interação

Redes - rede de Desenvolvimento social

Sentimento sertanejo

Sesbra - sistema de empreendimento orientado da economia popular solidária do Brasil

Siai - sistema de apoio institucional

Sindicato dos professores das escolas particulares de londrina e norte do Paraná

Sistema de transporte ferroviário de passageiros

Sociedade brasileira de biotecnologia

Sociedade brasileira de cartografia

Sociedade de Crédito ao microempreendedor divina providencia

Sociedade de garantia de Crédito do noroeste do Paraná

Sociedade Marinhense de Desenvolvimento Sustentável

Sociedade núcleo de apoio à produção e exportação de software do rio de janeiro

Sociedade para o Desenvolvimento dos Serviços Públicos

Sociedade rural de Sarandi

SOS serviços de obras sociais

Sprite

Terceiro Setor - Organização Não Governamental - Terset - ONG

Terra roxa investimentos agência de Desenvolvimento do norte do Paraná

Transparência Mirassol

Unas união de núcleos associação e sociedade dos moradores de Heliópolis e são João Clímaco

União e solidariedade para o Desenvolvimento financeiro da economia social - unisol finanças

Uniethos - formação e Desenvolvimento da gestão socialmente responsável

Universidade da Inteligência

Universidade Livre do Meio Ambiente

Vale da Cidadania

Valer capacitação e pesq $p$ des local Sustentável

Vértice sociedade civil de profissionais associados

Via pública - instituto para o Desenvolvimento da gestão pública e das organizações de interesse público

Vila Imperial, Cidadania e Ética

Vivere- estudos em políticas sociais

\section{Desenvolvimento e apoio rural e agrícola}

Ação Fome Zero

Ação Popular Campos Gerais

Ação social diocesana de patos

Ação social paróquia palmares

Aefaro - associação das escolas família agrícola de Rondônia

Agência Brasileira de Meio Ambiente e Tecnologia da Informação

Agência de Desenvolvimento Ambiental Capixaba 
Agência de Desenvolvimento de Guapirama

Agência de Desenvolvimento de Monte Alto e Região

Agência de Desenvolvimento de rio pardo

Agência de Desenvolvimento de São João da Boa Vista

Agência de Desenvolvimento Econômico e Social de Dois Córregos

Agência de Desenvolvimento Econômico e Social do Centro Oeste - ADESCO

Agência de Desenvolvimento Educacional e Social Brasileira

Agência de Desenvolvimento Integrado e Sustentável de Mesorregião dos Vales do Jequitinhonha e do

Mucuri

Agência de Desenvolvimento Integrado e Sustentável Sempre Alerta Riachinho

Agência de Desenvolvimento Local de Batayporã

Agência de Desenvolvimento local integrado e Sustentável de João pinheiro

Agência de Desenvolvimento Regional da Amurel

Agência de Desenvolvimento Regional do Extremo Oeste do Paraná

Agência de Desenvolvimento Regional do Maciço de Baturite

Agência de Desenvolvimento regional do sudoeste do Paraná

Agência de Desenvolvimento Social de Flexal I e Nova Canaã

Agência de Desenvolvimento Social de Flexal II

Agência de Desenvolvimento Social de Piranema

Agência de Desenvolvimento Sustentável da Amazônia Maranhense

Agência de Desenvolvimento Sustentável de Marechal

Agência de Desenvolvimento Sustentável de Paracatu

Agência de Desenvolvimento Sustentável de Rorainópolis

Agência de Desenvolvimento Sustentável do Seridó

Agência de Desenvolvimento integrado e sustentável da região do pico da bandeira

Agência do Programa de Desenvolvimento Sustentável do Centro Oeste Mineiro

Agência empreender

Agência Interamericana de Cooperação Para o Desenvolvimento Sustentável

Agência Mandalla de Desenvolvimento Holístico Sistêmico e Ambiental

Agência para a Promoção do Desenvolvimento, da Educação, Mobilização e Organização Socioambiental

Agência popular de Desenvolvimento da Amazônia

Agência sul-americana de Desenvolvimento

Agesba - Agência de Desenvolvimento do sul da Bahia

ALA - Associação Livre dos Aquicultores das Águas do São João

Aliança da terra

Andess Agência nacional de Desenvolvimento sustentável

As-pta assessoria e serviços a projetos em agricultura alternativa

Assistencial, Educacional, Beneficente

Assoc. Prod. Rurais, trab. Trabalhadoras rurais, agr. E agriculturas familiares e artesões

Associação

Associação Amazônia Viva

Associação Antônio vieira

Associação beneficente da comunidade carente de lbicaraí

Associação beneficente dos filhos e amigos de São Sebastião

Associação beneficente João Vicente Ferreira

Associação Brasil melhor

Associação Brasileira Associação Brasileira para a Difusão da Consciência pelo Desenvolvimento

Social e Natural

Associação Caatinga

Associação Casa União pelo Desenvolvimento do Vale do Piranga

Associação Cena Aberta

Associação central dos fruticultores do norte de minas

Associação circuito verde-trilha dos bandeirantes

Associação Comunitária Cidade Viva - "Nossa ONG"

Associação comunitária de campinas

Associação comunitária de Desenvolvimento sustentável São Paulo apóstolo

Associação comunitária do povoado de várzea dos bois e vizinhança

Associação Comunitária do sitio cabaceiras 
Associação Comunitária dos Moradores Micro e Pequenos Produtores Rurais do Povoado Olho D’Água do Meio

Associação Comunitária dos pequenos agricultores da fazenda poço Dantas

Associação Comunitária dos trabalhadores rurais de ciriema

Associação Comunitária e Agropastoril dos Pequenos Produtores Abandonados da Fazenda Oiteiro e Região

Associação Comunitária flores agrícolas de mundo novo

Associação Comunitária Piracicaba

Associação Comunitária Rural de Baixio e Serrinha

Associação da escola família agrícola de capinzal

Associação da escola família agrícola de Itaquirai

Associação das irmãs filhas do sagrado coração de Jesus

Associação de apoio ao Desenvolvimento social para o agronegócio

Associação de apoio às comunidades do campo do RN

Associação de assistência social de castrolanda

Associação de assistência social evangélica de Carambeí

Associação de desenv sust e solid da região sisaleira apaeb

Associação de Desenvolvimento da criança e do adolescente de veredinha

Associação de estudos, orientação e assistência rural

Associação de moradores da vargem do forno

Associação de moradores de água limpa

Associação de moradores e amigos do distrito de jotaesse

Associação de mulheres de negócios e profissionais de esplanda

Associação de promoção ao lavrador e assistência ao menor de turmalina

Associação de reposição florestal do pardo grande

Associação de senhoras e assistência social de Euclides da cunha

Associação do fórum ação para o Desenvolvimento de Candido Godoi

Associação do Fórum de Jacupiranga

Associação do povoado mumbaca

Associação do semiárido da microrregião de livramento

Associação dos fornecedores de cana de Piracicaba

Associação dos moradores da vila nova

Associação dos moradores e amigos do baú

Associação dos moradores e produtores do núcleo rural areia santa Rita

Associação dos Pequenos Agricultores da Região Sítio dos Patos

Associação dos produtores de agricultura e pecuária orgânica de são Miguel do Iguaçu

Associação dos Produtores de Erva Mate de Machadinho

Associação dos produtores e processadores de leite do distrito federal e entorno - aproleite

Associação dos produtores rurais de Paula cândido

Associação dos produtores rurais familiar de foz do Iguaçu

Associação dos rodonistas de Pernambuco

Associação dos usuários da agua da bacia hidrográfica do rio santa Maria

Associação ecológica turismo sustentável

Associação fartura alimentos

Associação gente que faz

Associação Geográfica União das Águas

Associação Guardiã da APA do Pratigi

Associação instituto internacional de ciência

Associação Internacional Protetora do Meio Ambiente

Associação Ipê

Associação marca para promoção de serviços

Associação menonita beneficente - amb

Associação movimento João de barro

Associação mundo melhor

Associação Nobrega de educação e assistência social

Associação para Desenvolvimento de ações públicas

Associação para o Combate à Exclusão Social e Preservação Ambiental - ACESPA Chico Mendes

Associação para o Desenvolvimento agro Sustentável do alto Solimões

Associação para o progresso do agronegócio lácteo 
Associação para um mundo melhor

Associação preparatória de cidadãos do amanhã

Associação pró-emprego e renda de Barbacena

Associação pro melhoramento de são João de viçosa

Associação pró-Desenvolvimento do município de soledade - aprosol

Associação programa um milhão de cisternas para o semiárido

Associação recriar, rede comunitária de aquicultura

Associação regional das casas familiares rurais do sul do Brasil

Associação rural de assistência à infância

Associação sulina de crédito e assistência rural

Associação terceira via

Associação unida do bairro pôr-do-sol

Associação vianei de c.i.t.e.c.s.

Associação Vida Amiga

Associação vox dei

Ativa-sistema institucional de crédito

Banco de projetos em prol do Desenvolvimento do norte do Paraná - banpro

Bem-Estar do Menor

Biotema ciência e tecnologia

Brasil Ação Solidária

Cací - Comitê de Ação pela Cidadania

Cáritas diocesana de Itapipoca

Casa familiar agroflorestal do baixo sul da Bahia

Casa familiar das águas do baixo sul da Bahia - cfa

Casa familiar rural

Casa familiar rural de Igrapiúna

Ccrie - casa de crédito e incentivo ao empreendedor

Cenarium

Central das associações do município de urânia

Centro cultural são Sebastião tem alma

Centro de ações de Desenvolvimento social e urbano do nordeste

Centro de agricultura alternativa do norte de minas

Centro de Apoio à Economia Popular Solidária

Centro de apoio e execução de projetos sociais- caeps

Centro de assessoria e apoio aos trabalhadores e instituições não governamentais alternativas

Centro de cultura e artesanato

Centro de Desenvolvimento agroecológico sabiá

Centro de Desenvolvimento do jovem rural

Centro de Desenvolvimento Integrado Social e Cultural

Centro de Desenvolvimento Sustentável e Industrial de Sistemas Florestais do Norte Pioneiro

Centro de diagnóstico de sanidade animal - cedisa

Centro de elaborações assessoria e Desenvolvimento de projetos

Centro de Estudos e Aplicações para as Novas Tecnologias Educacionais

Centro de Estudos e Apoio ao Desenvolvimento do Araripe

Centro de estudos e assessoria aplicados ao Desenvolvimento - ceaad

Centro de estudos e defesa do negro do Pará

Centro de Estudos para o Desenvolvimento Local

Centro de Estudos para o Desenvolvimento Sustentável e Inclusão Social

Centro de estudos, pesquisa e assessoria comunitária

Centro de estudos, promoção e Desenvolvimento de mercados

Centro de formação e assessoria 25 de julho

Centro de formação mandacaru de Pedro II

Centro de habilitação e apoio ao pequeno agricultor do Araripe

Centro de realizações sociais e ecológicas vida nordeste

Centro de referência e Desenvolvimento de tecnologia bioenergética

Centro de tecnologias alternativas da zona da mata

Centro de tecnologias alternativas populares

Centro de treinamento organização e ação social do cidadão

Centro de Voluntários em Cooperativismo e Economia Social para as Américas 
Centro diocesano de apoio ao pequeno produtor

Centro do comércio de café do rio de janeiro

Centro educacional imaculada conceição

Centro feminista 8 de março

Centro Nacional de Educação Ambiental e Geração de Emprego

Centro social rural de Orizona

Cluster de Turismo da Costa dos Coqueiros

Comissão xxi de Desenvolvimento sociocultural

Congregação das religiosas da assunção de nossa senhora

Conselho de Desenvolvimento comunitário da ilha

Credivale Agência metropolitana de microcrédito

Ctc - centro de tecnologia canavieira

Desenvolvimento Social Humano Tecnológico DSHT

Diaconia

Diocese do alto Solimões

Essor

Federação das associações e entidades para o Desenvolvimento do semiárido baiano

Fundação agrisus

Fundação Brasil Esperança

Fundação de apoio ao Desenvolvimento rural

Fundação de Desenvolvimento de tecnópolis

Fundação de Desenvolvimento rural

Fundação de estudos e pesquisas agrícolas e florestais

Fundação de formação, pesquisa e difusão tecnológica para uma convivência sustentável com o semiárido

Fundação divina pastora

Fundação grupo esquel Brasil

Fundação meridional de apoio à pesquisa agropecuária

Fundação MS para pesquisa e difusão de tecnologias agropecuárias

Fundação norte fluminense de Desenvolvimento regional

Fundação padre Emílio immoos

Fundação para o Desenvolvimento do semiárido Brasileiro - fundesa

Fundação para o Desenvolvimento Sustentável do Araripe

Fundação Pavel

Fundação santa Ângela

Fundação sistêmica

Fundo para o Desenvolvimento da agricultura familiar

Grupo Ambiental Natureza Bela

Grupo de apoio, estudo e pesquisa ambiental e cultural- pro terra

Grupo de estudos e promoção do Desenvolvimento Sustentável

Grupo de Pesquisas Ufológicas Ufogênesis

Grupo de produtores rurais de tomabadouro

Heifer Project international

lagep - instituto de apoio à gestão pública

Ibradepp - instituto de Desenvolvimento em políticas públicas - Zilda Arns

Icisec - instituto capixaba de integração socioeconômico dos cidadãos

Idaq Instituto Dr. Avelino Elias de Queiroga

Identidade de um povo - idp

ING - Instituto Os Guardiões da Natureza

Inst.de estudos e pesq.para prom.da educação, cultura e Desenvolvimento econômico e social prosocial

Instituição adventista nordeste brasileira de educação e assistência social

Instituição comunitária de crédito da região sul -

Instituição sinodal de assistência, educação e cultura

Instituto agua viva de pesq e ext em aquicultura e pesca sustentáveis, meio ambiente e proc de rec pesqueiros

Instituto aliança com o adolescente

Instituto alvorada de agroecologia de sobradinho

Instituto Amazônia 
Instituto amazônico de Desenvolvimento social, amparo a pesquisa e a tecnologia

Instituto ambiental Brasil sustentável

Instituto Ambiental Global - IAG

Instituto amea

Instituto amora carambola

Instituto banco palmas de Desenvolvimento e socioeconomia solidaria

Instituto Barretos de tecnologia - ibt

Instituto bdoni

Instituto Bioacqua de Promoção de Desenvolvimento Sustentável e Defesa do Meio Ambiente

Instituto Brasileiro de ações integradas

Instituto Brasileiro de administração - iba

Instituto Brasileiro de integração e Desenvolvimento pró-cidadão

Instituto Brasileiro de irrigação

Instituto Brasileiro para o Desenvolvimento Econômico, Social e Humano

Instituto Brasileiro para o Desenvolvimento tecnológico do setor energético - ibrate

Instituto Brasileiro pró-cidadania

Instituto Cenibra

Instituto centro de vida - icv

Instituto cidadania do nordeste

Instituto científico Mauá de multidesenvolvimento

Instituto convivência com o semiárido Brasileiro

Instituto corredor Ecológico costa dos coqueiros

Instituto creatio

Instituto da juventude do baixo sul da Bahia

Instituto de Ação Social Planejada

Instituto de Apoio a Tecnologia, Educação, Saúde, Promoção Social, Meio Ambiente e Cultura

Instituto de apoio técnico especializado à cidadania

Instituto de Desenvolvimento ambiental e social

Instituto de Desenvolvimento científico e tecnológico de xingó

Instituto de Desenvolvimento comunitário e participação social

Instituto de Desenvolvimento da região do sisal

Instituto de Desenvolvimento e apoio a aquicultura pesca e empreendedorismo rural

Instituto de Desenvolvimento econômico e social do Brasil

Instituto de Desenvolvimento integrado para o semiárido

Instituto de Desenvolvimento Municipal

Instituto de Desenvolvimento social e econômico

Instituto de Desenvolvimento social, Econômico e ambiental de mato grosso do sul

Instituto de Desenvolvimento sustentável e apoio a agricultura familiar - rede terra

Instituto de Desenvolvimento Tecnológico

Instituto de economia e projetos sociais

Instituto de economia solidaria

Instituto de Geração de Tecnologias do Conhecimento

Instituto de integração e Desenvolvimento da agropecuária Sustentável

Instituto de Integração Social, Desenvolvimento Sustentável e Preservação Ambiental

Instituto de Meio Ambiente e Desenvolvimento

Instituto de Meio Ambiente e Desenvolvimento Sustentável - Tramirim

Instituto de pesquisa agropecuária do nordeste

Instituto de pesquisa ambiental ekos

Instituto de Pesquisa e Conservação da Natureza

Instituto de pesquisa e inovação na agricultura irrigada

Instituto de pesquisas agrárias e tecnologia de turismo e meio ambiente

Instituto de pesquisas ambientais e sociais aplicadas

Instituto de pesquisas e projetos para o Desenvolvimento socioeconômico da Amazônia

Instituto de pesquisas, planejamento e implementação da agricultura familiar na região do Araguaia

Instituto de promoção à educação, bem estar social e saúde

Instituto de Saúde, Educação, Bem Estar Social

Instituto de tecnologia \& gestão - instituto alfa Brasil

Instituto de tecnologia socioambiental do baixo sul da Bahia

Instituto desenvolver 
Instituto direito e cidadania do baixo sul da Bahia

Instituto do Desenvolvimento social e do trabalho de Pernambuco

Instituto Ecoengenho de Tecnologia Aplicada ao Desenvolvimento Sustentável

Instituto ecos do Brasil

Instituto empreender

Instituto espirito santense de consciência antidrogas

Instituto Excelsa

Instituto fazenda tamanduá

Instituto Floresta de Pesquisa e Desenvolvimento Sustentável

Instituto fnp

Instituto Genaro Krebs

Instituto Genesis

Instituto Labor \& Vita

Instituto lambari - arte, cultura e educação

Instituto madeira da terra

Instituto Mãe Terra de Tecnologia Educacional e Ambiental

Instituto Maranata de Pesquisa em Estrutiocultura

Instituto maytenus para o Desenvolvimento da agricultura sustentável

Instituto morro da cutia de agroecologia

Instituto nacional ações e metas integradas

Instituto nacional de Desenvolvimento agropecuário

Instituto Nacional de Integração Social

Instituto nacional de tecnologia e de Desenvolvimento sustentável

Instituto nordeste cidadania

Instituto Novas Fronteiras da Cooperação

Instituto oca Brasil

Instituto Oikos de Agroecologia

Instituto palmas

Instituto para o Desenvolvimento ambiental

Instituto para o Desenvolvimento da administração social, saúde, educação, emprego e habitação idasseeh

Instituto para o Desenvolvimento regional

Instituto para o Desenvolvimento Sustentável de Joinville

Instituto pé no chão

Instituto Peabiru

Instituto potiguar de Desenvolvimento de comunidades

Instituto Potiguar de Juventude pela Cidadania

Instituto Pró Rio Doce

Instituto profissional são José

Instituto regional da pequena agropecuária apropriada

Instituto Sadia de Sustentabilidade

Instituto samaritano de educação e cultura Albert Schweitzer

Instituto seiva Brasil de Desenvolvimento Sustentável

Instituto Social Tecnológico e Econômico do Café - Mais Café

Instituto Social, Educacional e de Pesquisa de Minas Gerais

Instituto socioambiental Brasileiro - isab

Instituto sol de Desenvolvimento pesq. Empreed. E Crédito

Instituto Souza cruz

Instituto Tecnológico de Administração municipal itam

Instituto Tempo Bougra - SCTB

Instituto Terra de Santa Cruz

Instituto Verde Brasil

Instituto Vida para o Atendimento à Saúde, Saneamento e Meio Ambiente

Instituto Xopotó de Desenvolvimento Social, Econômico e Ambiental

Integrar - centro de integração pública e social

Interforum Global: Intercâmbio e Desenvolvimento Sustentável

IPD - Instituto de Promoção do Desenvolvimento

Ipef instituto pentalfa de fomento, promoção, educação e Desenvolvimento social

Lar dos meninos dom orione 
Liga carmesiana de assistência social

Liga Desportiva e Beneficente de Futsal Santamariense

Minasinvest - Aliança de Desenvolvimento

Movimento Ambiental Gestão e Organização Social - Magos

Movimento de Organização Comunitária

Movimento ecológico e cultural do vale do piranga

Movimento Interamericano de Ecologia

Núcleo de Desenvolvimento em Estudos Socioambientais do Maranhão

Núcleo de Desenvolvimento humano e Econômico de Arari

Núcleo de Desenvolvimento social

Núcleo de voluntários sociais de Teixeira de Freitas

Nutes - Núcleo de Estudos do Terceiro Setor

Obra kolping do Brasil

Obra kolping estadual do Piauí

Obras assistenciais Dr Ismael Alonso y Alonso

Obras sociais da diocese de Bragança

Obras sociais da diocese de Goiás

Observatório Ambiental

Oca Organizações Cidadania em Ação

Ong Francisco de Assis de proteção e amparo a criança e ao adolescente

Ong sede de viver

ONG Terra do Seridó

Organização da Sociedade Civil de Interesse Público Ambientality

Organização de apoio ao Desenvolvimento dos municípios

Organização de apoio ao vale do ribeira

Organização de Conservação de Terras do Baixo Sul da Bahia

Organização de reciclagem ambiental do lixo público

Organização e Apoio a Projetos Ambientais e Sociais - URU

Organização em prol da defesa e resgate indígena e meio ambiente

Organização não governamental José Amaury Araújo

Organização para o bem da água, da natureza e da vida - amanhágua

Organização para o Desenvolvimento Sustentável meristema - instituto meristema

Organização Trajetória Mundial

Oscip associação do Desenvolvimento agrícola e comunitário da lagoa da boa vista

Oscip jovem Sertão - organização da sociedade civil de interesse publico

Papyrus ambiental

Polo de proteção da biodiversidade e uso sustentável dos recursos naturais

Prime solidária

Profomento Agência de crédito especial

Projeto beira da estrada

Projeto Cultural Rio das Ostras

Recanto da fraternidade plantando vidas

Rede de amigos do João congo

Rede de intercâmbio de tecnologias alternativas

Rede Digital Comunitária Sol

Redes - rede de Desenvolvimento social

Saga - Instituto de Desenvolvimento regional

Serra acima - associação de cultura e educação ambiental

Serviço de apoio aos projetos alternativos comunitários

Serviço de tecnologia alternativa

Serviço internacional da associação das nações unidas

Serviço internacional da associação das nações unidas

Siai - sistema de apoio institucional

Sociedade Ambiental, Educacional e Cultural do Alto Sertão Paraibano

Sociedade Amigos de Iracambi

Sociedade de pesquisa johanna dobereiner

Sociedade de veterinária do rio grande do sul

Sociedade Marinhense de Desenvolvimento Sustentável

Sociedade nacional de agricultura 
Sociedade para o Desenvolvimento dos Serviços Públicos

Sociedade rural de Sarandi

Sustentec - produtores associados para Desenvolvimento de tecnologias sustentáveis

Terceiro Setor - Organização Não Governamental - Terset - ONG

União das associações das escolas famílias agrícolas do maranhão

Universidade Livre de Idiomas, Sustentabilidade Ambiental \& Corporativa

Vale da Cidadania

Winrock International Institute For Agricultural Development

\section{Preservação e proteção da vida selvagem}

Academia Taguatinguense de Letras

Ação Educacional Claretiana

Ação Popular Campos Gerais

Ação Social Paroquial São José de Botuverá

Agência Brasileira de Desenvolvimento da Aquicultura

Agência Brasileira de Meio Ambiente e Tecnologia da Informação

Agência de Desenvolvimento Ambiental Capixaba

Agência de Desenvolvimento de Itapecerica da Serra e Região

Agência de Desenvolvimento de Monte Alto e Região

Agência de Desenvolvimento Econômico e Social de Dois Córregos

Agência de Desenvolvimento Econômico e Social de Socorro - ADESSO

Agência de Desenvolvimento Econômico e Social do Centro Oeste - ADESCO

Agência de Desenvolvimento Integrado e Sustentável Sempre Alerta Riachinho

Agência de Desenvolvimento Sustentável da Amazônia Maranhense

Agência de Desenvolvimento Sustentável do Seridó

Agência Interamericana de Cooperação Para o Desenvolvimento Sustentável

Agência Tear - Agência para o Desenvolvimento Sustentável e a Inclusão Social

ALA - Associação Livre dos Aquicultores das Águas do São João

Aliança Nativa

Alma - Associação de Moradores da Lauro Muller, Ramon Castilla, Xavier Sigaud e Adjacências

Ambiente Brasil Centro de Estudos

Amigos do Protocolo de Kyoto

Amigos dos Bichos

Ammatur - Associação Mineira do Meio Ambiente e do Turismo

Arare - Associação para a Defesa e Recuperação da Fauna Brasileira

Associação Brasileira de Infraestrutura e Saneamento Comunitário Social - A.B.I.C.C

Assistencial, Educacional, Beneficente

Associação dos Usuários da Marina do Saco da Ribeira - Aumar

Associação Amazônia Viva

Associação Ambiental do Parque Estadual do Mirador

Associação Ambiental Voz da Natureza

Associação Ambientalista Projeto Copaíba

Associação Amigos do Bairro do Sahy

Associação Amigos do Meio Ambiente

Associação Beneficente João Vitor Rodrigues Lima

Associação Brasileira Associação Brasileira para a Difusão da Consciência pelo Desenvolvimento

Social e Natural

Associação Brasileira Associação Brasileira Protetora dos Animais - ABPA Seção Bahia

Associação Caatinga

Associação Cairuçu

Associação Cena Aberta

Associação Civil Pátria Brasil

Associação Civil Socioambientalista Pedra Que Te Quero Mais

Associação Comunitária Rural de Baixio e Serrinha

Associação de Defesa Etnoambiental

Associação do Verde e Proteção do Meio Ambiente

Associação dos Amigos da Floresta Nacional de Brasília - Flona/BSB 
Associação dos Amigos da Pedra da Princesa

Associação dos Pequenos Agricultores da Região Sítio dos Patos

Associação Eco Juréia

Associação Ecológica e Cultural de Integração Fronteira das Artes

Associação Ecológica Piratingaúna

Associação em Prol dos Animais Não Humanos SANAHU

Associação Expedicionários da Saúde

Associação Fórum de Dlis de Pedro Gomes - ADPEG

Associação Geográfica União das Águas

Associação Global de Desenvolvimento Sustentado

Associação Internacional Protetora do Meio Ambiente

Associação Ipê

Associação Mata Ciliar

Associação Mineira de Defesa do Ambiente

Associação Núcleo para Transformações Ambientais e Sociais

Associação o eco

Associação onça d'água de apoio à gestão e ao manejo das unidades de conservação do estado do Tocantins

Associação para proteção da Mata Atlântica do nordeste - amane

Associação pela recuperação e preservação da Mata Atlântica

Associação pelo canino - apelo canino

Associação Pró Casa do Pinhal

Associação Protetora das Montanhas e Araucárias e Seus Valores Sociais, Artísticos, Estéticos,

Ambientais, Geológicos, Históricos e Paisagísticos

Associação $r 3$ animal

Associação Serra da Mantiqueira

Associação Serra do Itapetinga, Movimento pela Biodiversidade e Organização Dos Setores Ecológicos

Associação Sonhar e Acreditar

Associação Terrabrasil - ONG

Associação Tuim Proteção e Educação Ambiental

Associação Universitária da Zona Leste

Biotema ciência e tecnologia

Bioterra - organização para conservação da biodiversidade e meio ambiente

Cací - Comitê de Ação pela Cidadania

Cão sem dono

Casa da natureza e de proteção da vida

Centro de apoio à educação, meio ambiente e saúde

Centro de Assistência e Desenvolvimento Social

Centro de Desenvolvimento Social

Centro de Desenvolvimento Sustentável e Industrial de Sistemas Florestais do Norte Pioneiro

Centro de Estudos e Aplicações para as Novas Tecnologias Educacionais

Centro de Estudos e Pesquisas 28

Centro de estudos marinhos do atlântico sul

Centro de Estudos para o Desenvolvimento Sustentável e Inclusão Social

Centro de Voluntários em Cooperativismo e Economia Social para as Américas

Centro Preserv de Promoção do Desenvolvimento Sustentado

Ceproser - centro de pesquisa proteína da serpente

Clube de observadores de aves do vale europeu

Congresso internacional israelita de sociosfera na Amazônia

Conselho Brasileiro de Manejo Florestal

Conselho de Preservação Ambiental Brasileiro

Conservation International do Brasil

Conservation Strategy Fund do Brasil

Consórcio para Proteção Ambiental e Desenvolvimento Sustentável e Sociocultural da Bacia

Hidrográfica do Rio das Cinzas

Creatif - Associação da Igualdade

Curucutu parques ambientais

Desenvolvimento Social Humano Tecnológico DSHT

Ema - Conscientização e Recuperação Ambiental 
Equipe co gestora do parque estadual Fritz plaumann

Equipe de Conservação da Amazônia

Fábrica do Futuro

Face a Face Ação Solidária

Fauna \& flora international

Fundação Ângelo Creta de educação e Desenvolvimento sócio-Econômico-ambiental

Fundação Brasil Esperança

Fundação de amparo ao ensino e pesquisa

Fundação de apoio à vida nos trópicos

Fundação de Desenvolvimento da Região da Serra da Mesa

Fundação de Salvamento Aquático de Santa Catarina

Fundação grupo boticário de proteção à natureza

Fundação Lymington

Fundação matutu

Fundação Movimento Ondazul

Fundação rio do leão

Fundação SOS pró-Mata Atlântica

Fundo Brasileiro para a biodiversidade

GRAF Grupo de Recuperação Ambiental e Florestal

Green Cross Brasil

Grupo Ambiental Natureza Bela

Grupo Ambientalista do Rio Iguaçu

Grupo de apoio, estudo e pesquisa ambiental e cultural- pro terra

Grupo de Desenvolvimento humano e ambiental - instituto goiamum

Grupo de estudos e promoção do Desenvolvimento Sustentável

Grupo de Pesquisas Ufológicas Ufogênesis

lagep - instituto de apoio a gestão pública

lambra Instituto de Assistência aos Municípios Brasileiros

Idaq Instituto Dr. Avelino Elias de Queiroga

Ideia Ambiental Sociedade S/C

Idese - Instituto para o Desenvolvimento Social e Ecológico

ING - Instituto Os Guardiões da Natureza

Iniciativa primus

Instituição comunitária de crédito da região sul -

Instituto Abradee da Energia

Instituto acaiah

Instituto Albatroz

Instituto alvorada de agroecologia de sobradinho

Instituto Amazônia

Instituto amazônico de Desenvolvimento social, amparo a pesquisa e a tecnologia

Instituto Ambiental Aracua

Instituto Ambiental de Desenvolvimento Social Sustentável - Instituto Biocêntrica

Instituto Ambiental Global - IAG

Instituto ambiental parque das perobas

Instituto Amigos da Reserva da Biosfera da Mata Atlântica

Instituto aquanautas Tocantins

Instituto argonauta para a conservação costeira e marinha

Instituto Atlantis de preservação ambiental

Instituto baleia jubarte

Instituto Bioacqua de Promoção de Desenvolvimento Sustentável e Defesa do Meio Ambiente

Instituto biológico do meio ambiente - bioma

Instituto Brasil ambiental

Instituto Brasileiro de Desenvolvimento da defesa civil e do meio ambiente ibdm

Instituto Brasileiro de Desenvolvimento Econômico, Social, Cultural e de Proteção ao Meio Ambiente Inbrades

Instituto Brasileiro de florestas

Instituto Brasileiro do Crisotila

Instituto comar - conservação marinha do brasil

Instituto convocação para cidadania 
Instituto Corpore para o Desenvolvimento da Qualidade de Vida

Instituto costa brasilis - Desenvolvimento socioambiental

Instituto de Apoio a Tecnologia, Educação, Saúde, Promoção Social, Meio Ambiente e Cultura

Instituto de apoio e proteção ambiental

Instituto de Desenvolvimento e Pesquisas do Meio Ambiente e Atividades Esportivas

Instituto de Desenvolvimento econômico e social do Brasil

Instituto de Desenvolvimento econômico e socioambiental -idesa

Instituto de Desenvolvimento integrado

Instituto de Desenvolvimento Municipal

Instituto de Desenvolvimento social, Econômico e ambiental de mato grosso do sul

Instituto de Desenvolvimento socioambiental, saúde e bem estar

Instituto de Desenvolvimento socioeconômico, científico, ambiental e tecnológico - parque dos falcões

Instituto de Desenvolvimento Sustentável do Estado de Santa Catarina

Instituto de Desenvolvimento Tecnológico

Instituto de Direito Agrário e Ambiental do Sul - Joaquim Luiz Osorio

Instituto de Ecologia Terrestre

Instituto de Educação Pesquisa e Saúde San Julian

Instituto de ensino pesquisa e preservação ambiental marcos Daniel - instituto marcos Daniel

Instituto de estudos socioculturais e ambientais embra cultural

Instituto de Integração Social, Desenvolvimento Sustentável e Preservação Ambiental

Instituto de manutenção ambiental, ecológico, social e pesquisa - mães da Amazônia

Instituto de Meio Ambiente e Desenvolvimento

Instituto de Meio Ambiente e Desenvolvimento Sustentável - Tramirim

Instituto de Pesquisa e Conservação da Natureza

Instituto de promoção e educação em saúde

Instituto de Renovação Social - Família Brasileira

Instituto de Saúde e Meio Ambiente

Instituto de Saúde, Educação, Bem Estar Social

Instituto de Turismo de Itacaré

Instituto de valorização da vida animal ivva

Instituto do cerrado

Instituto do parque do pantanal

Instituto Ecoanimal

Instituto Ecoar para a Cidadania

Instituto ecológica palmas/to

Instituto ecos do Brasil

Instituto Eurofarma

Instituto Floravida

Instituto gente

Instituto harmonia na tera

Instituto Juventude Ativa

Instituto Labor \& Vita

Instituto lagoa prateada

Instituto Mãe Terra de Tecnologia Educacional e Ambiental

Instituto nacional de apoio à educação, Desenvolvimento, pesquisa, ações assistenciais em saúde, meio ambiente, turismo e cultura

Instituto Nacional de Integração Social

Instituto Natureza Viva

Instituto Novos Saberes

Instituto oca Brasil

Instituto Oikos de Agroecologia

Instituto onça-pintada

Instituto orbis de proteção e conservação da natureza

Instituto para Desenvolvimento Socioambiental e Tecnológico Lótus

Instituto para Cidadania e Implementação da Base Popular - Icibap

Instituto para conservação dos carnívoros neotropicais - pró-carnívoros

Instituto para o Desenvolvimento ambiental

Instituto para o Desenvolvimento Sustentável de Joinville

Instituto Parceria 
Instituto parque das nascentes

Instituto Patulus

Instituto Pé no Chão

Instituto Physis - Cultura \& Ambiente

Instituto Pró Rio Doce

Instituto pró-água

Instituto são Francisco

Instituto Sergio Escadinha

Instituto Social, Educacional e de Pesquisa de Minas Gerais

Instituto Socioambiental Guapuruvu

Instituto Tamboré

Instituto Tempo Bougra - SCTB

Instituto Xopotó de Desenvolvimento Social, Econômico e Ambiental

Integração brasileira de educação

International Rivers network

Instituto Brasil de agua e energia - ibrae

Ipam - Instituto Brasileiro de Pesquisas Ambientais

Liga Desportiva e Beneficente de Futsal Santamariense

Mandala

Mapas - Métodos de Apoio a Práticas Ambientais e Sociais

Mater Natura - Instituto de Estudos Ambientais

Movimento Ambiental Gestão e Organização Social - Magos

Movimento ecológico e cultural do vale do piranga

Movimento Pernambuco contra o crime

Museu a céu aberto - cultura, ecologia e Desenvolvimento

Instituto Maranata de pesquisa em estrutiocultura

Instituto Peabiru

Instituto social tecnológico e econômico do café - mais café

Núcleo de Desenvolvimento em Estudos Socioambientais do Maranhão

Núcleo de educação e monitoramento ambiental

Núcleo Verde Amarelo

Obec - organização beneficente educacional e cultural

Observatório Ambiental

ONG Guaranésia Viva

ONG Me Ensina

ONG Terra do Seridó

Organização Ambientalista Amainan Brasil

Organização Bio-Bras

Organização da Sociedade Civil de Interesse Público Ambientality

Organização da Sociedade Civil de Interesse Público do Comitê de Defesa da llha Grande

Organização da Sociedade Civil de Interesse Público: Biodiversity Salvation

Organização de Conservação de Terras do Baixo Sul da Bahia

Organização de Desenvolvimento Cultural e Preservação Ambiental Ama-Brasil

Organização dos protetores dos animais abandonados e maltratados

Organização e Apoio a Projetos Ambientais e Sociais - URU

Organização em prol da defesa e resgate indígena e meio ambiente

Organização estilo de vida

Organização nacional de estudos e projetos

Organização para a Proteção Ambiental S.C.

Organização para educação e extensão da cidadania

Organização Representativa dos Concurseiros e Estudantes do Brasil

Organização Social Civil De Interesse Público Brasil Euro Oscip/BE

Organização Socioambiental Para Biodiversidade Miraterra - OMT

Organização Verde Brasil

Organização, Método, Experiência, Garantia e Ação

Oscip matas verde de Rondônia - omaveron

Oscip Pró-Vida Brasil

Pea - Projeto Esperança Animal

Petpe - Espaço Liberdade Para Animais Carentes 
Projeto Araras

Projeto Cultural Rio das Ostras

Rede Brasileira de Cooperação ao Desenvolvimento

Rede de Amigos do Igarapé São Francisco do Acre

Rede Digital Comunitária Sol

Renctas - Rede Nacional de Combate ao Tráfico de Animais Silvestres

Reserva Brasil

S.O.S Falconiformes

Sagres - Política e Gestão Estratégica Aplicadas

Sociedade Ambiental, Educacional e Cultural do Alto Sertão Paraibano

Sociedade Amigos de Iracambi

Sociedade Brasileira de Ictiologia

Sociedade Civil Corpo Bombeiros Voluntários de Rolante

Sociedade de Defesa, Preservação e Conservação do Meio Ambiente

Sociedade de Pesquisa em Vida Selvagem e Educação Ambiental

Sociedade dos Amigos do Cerrado - Socerrado

Sociedade para o Desenvolvimento dos Serviços Públicos

Sociedade Pró Ar

Sociedade Sinha Laurinha

Sociedade União Internacional Protetora dos Animais - Suipa

SOS Povos da Mata Atlântica

Universidade Livre do Meio Ambiente

V.O.S - Ver Ouvir e Sorrir, Centro Viver de Otorrinolaringologia e Oftalmologia

WWF-Brasil

\section{Produção ecosustentável}

Associação Brasileira ABTCP Associação Brasileira Técnica de Celulose e Papel

Academia Taguatinguense de Letras

Ação Educacional Claretiana

Ação Ética \& Cidadania

Ação Popular Campos Gerais

Ação Social Paroquial São José de Botuverá

Adesu - Agência de Desenvolvimento Econômico e social de Ubatuba

Agência Brasileira de Desenvolvimento da Aquicultura

Agência Brasileira de Meio Ambiente e Tecnologia da Informação

Agência de Desenvolvimento Ambiental Capixaba

Agência de Desenvolvimento de Guapirama

Agência de Desenvolvimento de Monte Alto e Região

Agência de Desenvolvimento Econômico e Social de Dois Córregos

Agência de Desenvolvimento Econômico e social de Mandaguari e Região

Agência de Desenvolvimento Econômico e Social de Resende

Agência de Desenvolvimento Econômico e Social de Socorro - Adesso

Agência de Desenvolvimento Econômico e Social do Centro-Oeste - Adesco

Agência de Desenvolvimento Integrado e Sustentável Sempre Alerta Riachinho

Agência de Desenvolvimento Regional da Amurel

Agência de Desenvolvimento Regional do Maciço de Baturite

Agência de Desenvolvimento Sustentável de Rorainópolis

Agência de Desenvolvimento Sustentável do Seridó

Agência de Desenvolvimento Sustentável do Sul do Estado do Espírito Santo

Agência do Programa de Desenvolvimento Sustentável do Centro Oeste Mineiro

Agência Interamericana de Cooperação para o Desenvolvimento Sustentável

Agência Nacional de Desenvolvimento Eco-social

Agência Sul-americana de Desenvolvimento

Agenda Vinte e Um Local de Hortolândia

Agesba - Agência de Desenvolvimento do Sul da Bahia

Ala- Associação Livre dos Aquicultores das Águas do São João

Alavanca 
Aliança de Justiça Para Uma União Democrática

Alma - Associação de Moradores da Lauro Muller, Ramon Castilla, Xavier Sigaud e Adjacências

Ambiente Brasil Centro de Estudos

Amigo Social

Amigos da Terra - Amazônia Brasileira

Ammatur - Associação Mineira do Meio Ambiente e do Turismo

Assistencial, Educacional, Beneficente

Associação Abaporu

Associação Amazônia Viva

Associação Ambiental Voz da Natureza

Associação Amigos do Bairro do Sahy

Associação Amigos do Futuro

Associação Beneficente dos Filhos e Amigos de São Sebastião

Associação Brasil Melhor

Associação Brasileira para a Difusão da Consciência pelo Desenvolvimento Social e Natural

Associação Caatinga

Associação Cairuçu

Associação Caminho Suave Socioambiental

Associação Capixaba de Arte Sociocultural

Associação Casa Azul

Associação Casa União pelo Desenvolvimento do Vale do Piranga

Associação Celeiro do Vale do Rio Pardo

Associação Cena Aberta

Associação Central dos Fruticultores do Norte de Minas

Associação Centrodesignrio

Associação Cerrado Nativo

Associação Circuito Verde-trilha dos Bandeirantes

Associação Civil Pátria Brasil

Associação Cluster São Carlos de Alta Tecnologia

Associação Comercial Industrial Ubaense dos Catadores de Materiais Recicláveis

Associação Comunitária dos Pequenos Agricultores da Fazenda Poço Dantas

Associação Cultural e Assistencial Pequeno Paraíso - ASCAPP

Associação de Apoio ao Desenvolvimento Social para o Agronegócio

Associação de Apoio as Comunidades do Campo do RN

Associação de Crédito Cidadão de Rondônia - ACRECID

Associação de Defesa Etnoambiental

Associação de Desenvolvimento de Taquari Humanae Vitae

Associação de Moradores da Vargem do Forno

Associação de Preservação do Meio Ambiente e da Vida - Apremavi

Associação de Programas Transdisciplinares Apta Ação

Associação de Reciclagem de Vila Velha

Associação do Fórum Ação para o Desenvolvimento de Candido Godoi

Associação do Fórum de Desenvolvimento Local Integrado e Sustentável de Caarapó - Vivacidade

Associação do Fórum de Dlis de Bom Jesus do Itabapoana

Associação do Fórum de Jacupiranga

Associação do Verde e Proteção do Meio Ambiente

Associação dos Amigos da Floresta Nacional de Brasília - Flona/BSB

Associação dos Amigos da Pedra da Princesa

Associação dos Inventores do Paraná

Associação dos Mineradores de Ouro do Tapajós

Associação dos Moradores da Vila Nova

Associação dos Moradores dos Setores Coimbra e Bela Vista

Associação dos Produtores de Erva Mate de Machadinho

Associação dos Produtores Rurais Familiar de Foz do Iguaçu

Associação dos Usuários da Água da Bacia Hidrográfica do Rio Santa Maria

Associação Ecológica e Cultural de Integração Fronteira das Artes

Associação Fartura Alimentos

Associação Fórum de Dlis de Pedro Gomes - ADPEG

Associação Gente do Brasil 
Associação Geográfica União das Águas

Associação Global de Desenvolvimento Sustentado

Associação Holística de Participação Comunitária Ecológica - Núcleo da Terra

Associação Instituto da Plataforma Sinergia

Associação Instituto de Pesquisas em Energias Renováveis e Meio Ambiente

Associação Internacional Protetora do Meio Ambiente

Associação Marca para Promoção de Serviços

Associação Movimento João de Barro

Associação Mundaréu

Associação Núcleo para Transformações Ambientais e Sociais

Associação Olhos D'Água

Associação Onça D'água de Apoio à Gestão e ao Manejo das Unidades de Conservação do Estado do Tocantins

Associação Organização da Sociedade Civil de Interesse Público Mobilidade e Ambiente Brasil

Associação para o Combate à Exclusão Social e Preservação Ambiental - ACESPA Chico Mendes

Associação Paulista de Gestão Pública - APGP

Associação pela Recuperação e Preservação da Mata Atlântica

Associação Pró Casa do Pinhal

Associação Proeco

Associação Protetora das Montanhas E Araucárias e Seus Valores Sociais, Artísticos, Estéticos,

Ambientais, Geológicos, Históricos e Paisagísticos

Associação Recriar, Rede Comunitária de Aquicultura

Associação Rio_Minas "Trem Mineiro"

Associação Rondon Brasil

Associação Sai da Toca Cultural

Associação Ser Cidadão

Associação Serra da Mantiqueira

Associação Terrabrasil - ONG

Associação Thalamus

Associação União llha de Boipeba

Associação Unida do Bairro Pôr-do-sol

Associação Universitária da Zona Leste

Associação Vida Amiga

Associação Vida Verde da Amazônia

Biomavale - Organização da Sociedade Civil de Interesse Público

Biotema Ciência e Tecnologia

Bioterra - Organização Para Conservação Da Biodiversidade E Meio Ambiente

Brasil Ação Solidária

Cací - Comitê de Ação pela Cidadania

Caiapônia Instituto De Saneamento Ambiental

Câmara de Desenvolvimento Brasil Japão do Mato Grosso do Sul

Camará Saúde Qualidade De Vida E Gestão

Caritas Diocesana de Itapipoca

Casa Familiar Agroflorestal do Baixo Sul da Bahia

Casativa Centro de Ações Sociais

Catalisa Rede de Cooperação Para Sustentabilidade

Ccrie - Casa De Crédito E Incentivo Ao Empreendedor

Central de Inteligência e Assessoria Brasil

Centro de Apoio à Economia Popular Solidária

Centro de Apoio E Execução De Projetos Sociais- Caeps

Centro de Assessoria e Serviço Aos Trabalhadores da Terra Dom José Brandão de Castro

Centro de Assistência e Desenvolvimento Social

Centro de Aventura Rio Do Peixe

Centro de Capacitação, Profissionalização e Educação Para Cidadania

Centro de Desenvolvimento Agroecológico Sabiá

Centro de Desenvolvimento Integrado Social e Cultural

Centro de Desenvolvimento Social

Centro de Desenvolvimento Sustentável e Industrial de Sistemas Florestais do Norte Pioneiro

Centro de Estudo de Gestão Pública 
Centro de Estudos do Trabalho e de Assessoria ao Trabalhador

Centro de Estudos e Aplicações para as Novas Tecnologias Educacionais

Centro de Estudos e Apoio ao Desenvolvimento do Araripe

Centro de Estudos e Pesquisas 28

Centro de Estudos para o Desenvolvimento Local

Centro de Estudos para o Desenvolvimento Sustentável e Inclusão Social

Centro de Referência em Cooperativismo e Associativismo

Centro de Referências em Cidadania, Ética e Responsabilidade

Centro de Tecnologias Alternativas da Zona da Mata

Centro de Tecnologias Alternativas Populares

Centro de Voluntários em Cooperativismo e Economia Social para as Américas

Centro Educacional Imaculada Conceição

Centro Nacional de Educação Ambiental e Geração de Emprego

Centro Preserv de Promoção do Desenvolvimento Sustentado

Cluster de Turismo da Costa dos Coqueiros

Combina - Companhia dos Bichos e da Natureza

Comissão XXI de Desenvolvimento Sociocultural

Comunidade Educacional de Pirenópolis

Congresso Internacional Israelita de Sociosfera na Amazônia

Conselho de Preservação Ambiental Brasileiro

Conservation Strategy Fund do Brasil

Consórcio para Proteção Ambiental e Desenvolvimento Sustentável e Sociocultural da Bacia Hidrográfica do Rio das Cinzas

Creatif - Associação da Igualdade

Desenvolvimento Social Humano Tecnológico DSHT

E.U - Ecologia Urbana

E+co Brasil

Ecovitae Tecnologia Ambiental

Educação em Foco

Educandário São José

Elo Social de Gestão Pública

Ema - Conscientização e Recuperação Ambiental

Empreende - Sistema de Empreendedorismo Social

Escola Viveiro Multiplicadora Artesã

Ética da Terra / Instituto Ita Weigman do Brasil

Fábrica do Futuro

Face a Face Ação Solidária

Federação Brasileira de Plantio Direto Na Palha

Federação das Associações e Entidades para o Desenvolvimento do Semiárido Baiano

Fórum para o Desenvolvimento do Entretenimento, Cultura e Turismo da Bahia

Fórum Permanente de Responsabilidade Social do Rio Grande do Sul

Fundação Brasil Esperança

Fundação de Desenvolvimento da Região da Serra da Mesa

Fundação de Formação, Pesquisa e Difusão Tecnológica Para Uma Convivência Sustentável Com o

Semiárido

Fundação Educacional, Assistencial e de Proteção Ao Meio Ambiente

Fundação Grupo Esquel Brasil

Fundação Instituto De Hospitalidade

Fundação Lymington

Fundação Matutu

Fundação Movimento Ondazul

Fundação Proamb

Fundação Pró-Natureza

Fundação Turismo Para Paz e Desenvolvimento Sustentável

Fundo de Desenvolvimento Florestal Florestar São Paulo

Gente Feliz

GRAF Grupo de Recuperação Ambiental e Florestal

Green Cross Brasil

Grin9 - Educação e Gestão Ambiental 
Grupo Ambiental Natureza Bela

Grupo Ambientalista do Rio Iguaçu

Grupo de Apoio, Estudo e Pesquisa Ambiental e Cultural- Pró-Terra

Grupo de Desenvolvimento Humano e Ambiental - Instituto Goiamum

Grupo de Estudos e Promoção do Desenvolvimento Sustentável

Grupo de Estudos Manoa

Grupo de Pesquisas Ufológicas Ufogênesis

Horizonte Promoção Social e Educacional - Oscip

lagep - Instituto de Apoio a Gestão Pública

lambra Instituto de Assistência aos Municípios Brasileiros

Iberobrasileira de Estudos e Cooperação

Ibit - Instituto Brasileiro de Inteligência Tecnológica

Idaq Instituto Dr. Avelino Elias de Queiroga

Ideia Ambiental Sociedade S/C

Idese - Instituto para o Desenvolvimento Social e Ecológico

Indesus - Instituto Tecnológico para o Desenvolvimento Sustentável

Inri - Instituto Nacional De Renovação Integrado

Inst. de Estudos e Pesq. para Prom. da Educação, Cultura e Desenvolvimento Econômico e Social -

Prosocial

Instituição Comunitária de Crédito da Região Sul -

Instituto Abradee da Energia

Instituto Ação Ambiente

Instituto Ação Comunitária Preventiva de Defesa dos Direitos da Criança, Adolescente e Idoso

Instituto Acqua - Ação, Cidadania, Qualidade Urbana e Ambiental

Instituto Alvorada de Agroecologia de Sobradinho

Instituto Amazônia

Instituto Ambiental Brasil Sustentável

Instituto Ambiental de Desenvolvimento Social Sustentável - Instituto Biocêntrica

Instituto Ambiental Global - IAG

Instituto Ambiente \& Urbano de Planos Desenvolvimento e Inclusão Social

Instituto Amigos da Reserva da Biosfera da Mata Atlântica

Instituto Amora Carambola

Instituto Antrópolis para o Desenvolvimento Sustentável

Instituto Arapoty

Instituto Árvore da Vida

Instituto Bdoni

Instituto Bioacqua de Promoção de Desenvolvimento Sustentável e Defesa do Meio Ambiente

Instituto Brasil Preservação Ambiental e Desenvolvimento Sustentável

Instituto Brasil Solidário - Instituto Brasil Solidário - IBSIBS

Instituto Brasileiro de Administração - IBA

Instituto Brasileiro de Desenvolvimento Econômico, Social, Cultural e de Proteção ao Meio Ambiente Inbrades

Instituto Brasileiro de Direito Ambiental

Instituto Brasileiro de Educação Em Negócios Sustentáveis

Instituto Brasileiro de Estudos e Pesquisas Comunitárias

Instituto Brasileiro de Florestas

Instituto Brasileiro de Pesquisa e Desenvolvimento Social Sustentável - Ibrapeds

Instituto Brasileiro de Pesquisas e Estudos Ambientais

Instituto Brasileiro de Reciclagem

Instituto Brasileiro do Crisólita

Instituto Brasileiro do Empreendedor

Instituto Brasileiro para a Inovação Tecnológica Ambiental

Instituto Brasileiro para o Desenvolvimento Econômico, Social e Humano

Instituto BS Colway Social

Instituto Centro de Vida - ICV

Instituto Centro-Brasileiro de Cultura

Instituto Cerrado

Instituto Cistema - Cidadania - Saúde - Trabalho - Educação e Meio Ambiente

Instituto Corpore para o Desenvolvimento da Qualidade de Vida 
Instituto Corredor Ecológico Costa dos Coqueiros

Instituto Costa Brasilis - Desenvolvimento Socioambiental

Instituto Cultural Eco Econômico Espírito Santo

Instituto Cultural Farol do Rio Doce

Instituto da Árvore

Instituto de Ação Cultural e Ecológica

Instituto de Ação Social Planejada

Instituto de Apoio a Políticas Sociais

Instituto de Apoio a Tecnologia, Educação, Saúde, Promoção Social, Meio Ambiente e Cultura

Instituto de Apoio Técnico Especializado à Cidadania

Instituto de Biodiversidade e Desenvolvimento Sustentável do Oeste da Bahia

Instituto de Cidadania e Estudos Ambientais e Turismo

Instituto de Cooperação e Tecnologia Socioambiental

Instituto de Desenvolvimento Sustentável e Energias Renováveis

Instituto de Desenvolvimento Comunitário Sustentável

Instituto de Desenvolvimento e Pesquisas do Meio Ambiente e Atividades Esportivas

Instituto de Desenvolvimento Integrado

Instituto de Desenvolvimento Integrado para Ações Sociais

Instituto de Desenvolvimento Integrado para o Semiárido

Instituto de Desenvolvimento Municipal

Instituto de Desenvolvimento Socioambiental Pantanal Sul

Instituto de Desenvolvimento Socioeconômico dos Trabalhadores de Baixa Renda

Instituto de Desenvolvimento Socioambiental do Vale do Javari

Instituto de Desenvolvimento Sustentável de Franca e Região da Bacia Hidrográfica do Rio Sapucaí

Mirim Grande

Instituto de Desenvolvimento Sustentável de Santa Catarina

Instituto de Desenvolvimento Sustentável do Estado de Santa Catarina

Instituto de Desenvolvimento Tecnológico

Instituto de Desenvolvimento, Educação, Análise e Legislação - Ideal

Instituto de Direito Agrário e Ambiental do Sul - Joaquim Luiz Osorio

Instituto de Ecologia Terrestre

Instituto de Educação Pesquisa e Saúde San Julian

Instituto de Estudo do Trabalho e Combate a Pobreza

Instituto de Estudos e Projetos de Interesse Social

Instituto de Estudos Socioambientais

Instituto de Estudos Socioculturais e Ambientais Embra Cultural

Instituto de Geração de Tecnologias do Conhecimento

Instituto de Gestão Solidária

Instituto de Integração Social, Desenvolvimento Sustentável e Preservação Ambiental

Instituto de Manutenção Ambiental, Ecológico, Social e Pesquisa - Mães da Amazônia

Instituto de Meio Ambiente e Desenvolvimento

Instituto de Meio Ambiente e Desenvolvimento Sustentável - Tramirim

Instituto de Permacultura da Bahia

Instituto de Pesquisa e Conservação da Natureza

Instituto de Pesquisa e Educação (Ipe)

Instituto de Pesquisa e Educação em Telecomunicações - IPET

Instituto de Preservação do Meio Ambiente e dos Recursos Naturais da Amazônia

Instituto de Saúde e Meio Ambiente

Instituto de Saúde, Educação, Bem Estar Social

Instituto de Tecnologia \& Gestão - Instituto Alfa Brasil

Instituto de Turismo de Itacaré

Instituto Desafio Jovem Salmo 23 de Apoio Social

Instituto do Cerrado

Instituto do Parque do Pantanal

Instituto Eco Ambiental e Social

Instituto Ecoar para a Cidadania

Instituto Eco-empreendedor para a Sustentabilidade Ambiental

Instituto Ecoengenho de Tecnologia Aplicada ao Desenvolvimento Sustentável

Instituto Ecológica Palmas/TO 
Instituto Ecos do Brasil

Instituto Estação Desenvolvimento

Instituto Eurofarma

Instituto Excelsa

Instituto Festival De Inverno - Festinver

Instituto Floravida

Instituto Floresta de Pesquisa e Desenvolvimento Sustentável

Instituto GEA - Ética e Meio Ambiente

Instituto Gênesis

Instituto Guaicuy - SOS Rio das Velhas

Instituto H \& H Fauser para o Desenvolvimento Sustentável e a Cultura

Instituto Harmonia na Terra

Instituto Horizontes

Instituto International Paper

Instituto Justino Carvalho

Instituto Kauli Seadi

Instituto Labor \& Vita

Instituto Laborearte de Capacitação Profissional e Ética dos Socialmente Excluídos

Instituto Lar

Instituto Mãe Terra de Tecnologia Educacional e Ambiental

Instituto Mangue Vivo

Instituto Maranata de Pesquisa em Estrutiocultura

Instituto Mauro Goulart

Instituto Maytenus para o Desenvolvimento da Agricultura Sustentável

Instituto Morada da Floresta

Instituto Nacional de Integração Social

Instituto Nacional de Preservação Ambiental

Instituto Nacional de Tecnologia e Uso Sustentável

Instituto Natureza Viva

Instituto Novas Fronteiras da Cooperação

Instituto Novos Saberes

Instituto Oca Brasil

Instituto Oikos de Agroecologia

Instituto Opab

Instituto Orbis de proteção e conservação da natureza

Instituto para Desenvolvimento Socioambiental e Tecnológico Lótus

Instituto Palavrações

Instituto Palmas

Instituto para Cidadania e Implementação da Base Popular - Icibap

Instituto para Desenvolvimento Ambiental e Tecnológico - Idea Ciclica

Instituto para o Desenvolvimento Ambiental

Instituto para o Desenvolvimento Sociocultural e Ambiental - INDES

Instituto para o Desenvolvimento Sustentável de Joinville

Instituto Parceria

Instituto Parque das Nascentes

Instituto Patulus

Instituto Pé no Chão

Instituto Peabiru

Instituto Physis - Cultura \& Ambiente

Instituto Portas Abertas

Instituto Prisma de Apoio Administrativo às Micro, às Pequenas, às Médias Empresas e às Entidades da Administração Pública Direta

Instituto Pró Rio Doce

Instituto regional da pequena agropecuária apropriada

Instituto S.O.S. Sistemas Organizados para Sustentabilidade

Instituto Sadia de Sustentabilidade

Instituto São Francisco

Instituto Sapiens para Desenvolvimento de Tecnologias Sociais

Instituto Sarah Bernhardt - ISB 
Instituto Sergio Escadinha

Instituto Social para Edificação da Cidadania

Instituto Social Tecnológico e Econômico do Café - Mais Café

Instituto Social, Educacional e de Pesquisa de Minas Gerais

Instituto Socio Agro Ambiental Campinense - ISAAC

Instituto Socioambiental Guapuruvu

Instituto Socioambiental Latinha da Solidariedade

Instituto Socioambiental

Instituto Tecnológico de Administração Municipal Itam

Instituto Tempo Bougra - SCTB

Instituto Terra de Santa Cruz

Instituto Terra, Guardião da Natureza e Assistencial

Instituto Triângulo de Desenvolvimento Sustentável

Instituto Triunfo

Instituto Verdescola

Instituto Via Viva

Instituto Vitalis Vitalizando a Integração dos Trabalhadores da América Latina na Luta pela Inclusão

Social

Instituto Viva Ourem

Instituto Xopotó de Desenvolvimento Social, Econômico e Ambiental

Interforum Global: Intercâmbio e Desenvolvimento Sustentável

Ipam - Instituto Brasileiro de Pesquisas Ambientais

Ipd - Instituto de Promoção do Desenvolvimento

Ipef Instituto Pentalfa de Fomento, Promoção, Educação e Desenvolvimento Social

Liga Desportiva e Beneficente de Futsal Santamariense

Mapas - Métodos de Apoio a Práticas Ambientais e Sociais

Mediateca Organização para Inclusão Social e Digital

Minasinvest - Aliança de Desenvolvimento

Movimento Ambiental Gestão e Organização Social - Magos

Movimento de Organização Comunitária

Movimento Interamericano de Ecologia

Nazaré Universidade da Luz

Nova Sociedade

Instituto da Natureza, Desenvolvimento, Informação e Assistência Social

Instituto Giramundo Mutuando

Instituto Ibá de Desenvolvimento Ambiental e Social

Instituto Julieta Araújo

Núcleo de Desenvolvimento em Estudos Socioambientais do Maranhão

Núcleo de Educação e Monitoramento Ambiental

Núcleo Verde Amarelo

Obef - Organização Beija-Flor

Observatório Ambiental

Oca Organizações Cidadania em Ação

Odesc - Organização Desenvolvimento Sustentável

ONG Dr. Vandick Ponte

ONG Guaranésia Viva

ONG Me Ensina

ONG Sede de Viver

ONG Terra do Seridó

Organização Ambientalista Amainan Brasil

Organização Bio-bras

Organização da Sociedade Civil de Interesse Público Ambientality

Organização da Sociedade Civil de Interesse Público: Biodiversity Salvation

Organização de Apoio ao Desenvolvimento dos Municípios

Organização de Apoio ao Vale do Ribeira

Organização de Conservação de Terras do Baixo Sul da Bahia

Organização de Desenvolvimento Cultural e Preservação Ambiental Ama-Brasil

Organização e Apoio a Projetos Ambientais e Sociais - URU

Organização Família Legal 
Organização para Educação e Extensão da Cidadania

Organização Representativa dos Concurseiros e Estudantes do Brasil

Organização Social do Nordeste de Estudo e Solidariedade

Organização Trajetória Mundial

Organização Verde Brasil

Organização Vida Nova/ Escola Experimental Casa das Mangueiras

Organização, Método, Experiência, Garantia e Ação

Oscip Jovem Sertão - Organização da Sociedade Cível de Interesse Público

Oscip Pró-vida Brasil

Polo de Proteção da Biodiversidade e Uso Sustentável dos Recursos Naturais

Prime Solidária

Projeto Cultural Rio das Ostras

RC Retratando o Cerrado - Associação Pró Defesa, Preservação do Ambiente e Promoção do Desenvolvimento Sustentável

Rede de Amigos do Igarapé São Francisco do Acre

Rede de Profissionais em Gestão

Rede de Sementes do Cerrado

Rede de Turismo Regional - Retur

Rede Digital Comunitária Sol

Redes - Rede de Desenvolvimento Social

Sagres - Política e Gestão Estratégica Aplicadas

Serra Acima - Associação de Cultura e Educação Ambiental

Sertão Verde Vida

Serviço de Tecnologia Alternativa

Sistema de Apoio e Desenvolvimento - Sisad

Sistema integrado de Apoio, Gestão e Assistência Social - Sinaga Social

Sociedade Ambiental, Educacional e Cultural do Alto Sertão Paraibano

Sociedade Ambientalista e Cultural - Angaturama

Sociedade Amigos de Iracambi

Sociedade Brasileira de Preservação e Promoção da Vida

Sociedade de Microcrédito, Pesquisa, Empreendedorismo e Desenvolvimento Sustentável do Norte Pioneiro

Sociedade de Pesquisa em Vida Selvagem e Educação Ambiental

Sociedade dos Amigos do Cerrado - Socerrado

Sociedade Marinhense de Desenvolvimento Sustentável

Sociedade para o Desenvolvimento dos Serviços Públicos

SOS Povos da Mata Atlântica

Sustentec - Produtores Associados para Desenvolvimento de Tecnologias Sustentáveis

Terceiro Setor - Organização Não Governamental - Terset - ONG

Terra Nova Sociedade Beneficente do Vale do Pirapocu

Três Ecologias Instituto Ambiental de Desenvolvimento Sustentável

Tv Vila Imperial Organização das Entidades Usuárias do Canal Comunitário de Petrópolis

Uniciência - União para o Desenvolvimento Social e Cultural Através da Ciência e Tecnologia

Uniethos - Formação e Desenvolvimento da Gestão Socialmente Responsável

Universidade Livre do Meio Ambiente

Vale da Cidadania

Vivere - Estudos em Políticas Sociais

\section{Proteção e conservação do patrimônio natural}

A Mar de Dentro Ambiente e Educação

Academia Brasileira de Ciências

Academia Taguatinguense de Letras

Ação Educacional Claretiana

Ação Ética \& Cidadania

Ação Popular Campos Gerais

Ação Social Paroquial São José de Botuverá

Adesu - Agência de Desenvolvimento Econômico e Social de Ubatuba 
Agência Baiana de Desenvolvimento Social

Agência Brasileira de Desenvolvimento da Aquicultura

Agência Brasileira de Gerenciamento Costeiro

Agência Brasileira de Meio Ambiente e Tecnologia da Informação

Agência de Desenvolvimento Ambiental Capixaba

Agência de Desenvolvimento de Guapirama

Agência de Desenvolvimento de Monte Alto e Região

Agência de Desenvolvimento de São João da Boa Vista

Agência de Desenvolvimento Econômico e Social da Região do Planalto Médio

Agência de Desenvolvimento Econômico e Social de Dois Córregos

Agência de Desenvolvimento Econômico e Social de Mandaguari e Região

Agência de Desenvolvimento Econômico e Social de São Miguel do Iguaçu

Agência de Desenvolvimento Econômico e Social de Socorro - Adesso

Agência de Desenvolvimento Econômico e Social do Centro Oeste - Adesco

Agência de Desenvolvimento Educacional e Social Brasileira

Agência de Desenvolvimento Integrado e Sustentável Sempre Alerta Riachinho

Agência de Desenvolvimento Social de Flexal I e Nova Canaã

Agência de Desenvolvimento Social e Econômico de GGuarapari-ES

Agência de Desenvolvimento Sustentável da Amazônia Maranhense

Agência de Desenvolvimento Sustentável de Paracatu

Agência de Desenvolvimento Sustentável de Rorainópolis

Agência de Desenvolvimento Sustentável do Sul do Estado do Espírito Santo

Agência de Desenvolvimento Turístico e Cultural da Rota dos Tropeiros do Paraná

Agência do Programa de Desenvolvimento Sustentável do Centro Oeste Mineiro

Agência Interamericana de Cooperação para o Desenvolvimento Sustentável

Agência Jacarezinhense de Desenvolvimento e Promoção da Saúde - Ajadps

Akarui

Ala - Associação Livre dos Aquicultores das Águas do São João

Alavancando o Progresso

Aliança de Justiça para Uma União Democrática

Aliança Nativa

Alma - Associação de Moradores da Lauro Muller, Ramon Castilla, Xavier Sigaud e Adjacências

Ambiental Litoral Norte

Ambiente Brasil Centro de Estudos

Amigo Social

Amigos Associados de Itaberá (AMAI)

Amigos da Mata

Amigos da Terra - Amazônia Brasileira

Amigos do Protocolo de Kyoto

Ammatur - Associação Mineira do Meio Ambiente e do Turismo

Apiz Associação do Povo Indígena Zoro Pangyjej

Arte Vida

Assistencial, Educacional, Beneficente

Associação dos Usuários da Marina do Saco da Ribeira - Aumar

Associação Águas Claras do Rio Pinheiros

Associação Amazônia Viva

Associação Ambiental do Parque Estadual do Mirador

Associação Ambiental Voz da Natureza

Associação Ambientalista do Alto São Francisco

Associação Ambientalista Projeto Copaíba

Associação Amigos da Amazônia Viva

Associação Amigos do Bairro do Sahy

Associação Amigos do Meio Ambiente

Associação Amigos do Meio Ambiente

Associação Barco Escola da Natureza

Associação Beneficente Consciência Ecológica do Brasil

Associação Brasil Melhor

Associação Brasileira Cultural Empresarial - Abrace

Associação Brasileira de Desenvolvimento Humano 
Associação Brasileira de Vivências com a Natureza - Instituto Romã

Associação Brasileira para a Difusão da Consciência pelo Desenvolvimento Social e Natural

Associação Caatinga

Associação Cairuçu

Associação Casa Azul

Associação Casa União pelo Desenvolvimento do Vale do Piranga

Associação Cellula Mater

Associação Cena Aberta

Associação Cerrado Nativo

Associação Civil Pátria Brasil

Associação Civil Socio Ambientalista Pedra Que Te Quero Mais

Associação Comunitária Cidade Viva - "Nossa ONG"

Associação Comunitária do Sítio Cabaceiras

Associação Comunitária e Produtiva São José

Associação Comunitária Flores Agrícolas de Mundo Novo

Associação Corpo de Bombeiros Voluntários de Indaial

Associação Cultural do Sítio Histórico da Fortaleza de São João

Associação Dan Brasil

Associação de Apoio as Comunidades do Campo do RN

Associação de Cultura e Meio Ambiente

Associação de Defesa Ambiental llha Grande

Associação de Defesa Etnoambiental

Associação de Moradores da Vargem do Forno

Associação de Preservação da Mata Ciliar do Rio Uruguai

Associação de Preservação do Meio Ambiente e da Vida - Apremavi

Associação de Preservação do Meio Ambiente, Patrimônio Histórico e Difusão da Cultura e Educação

Associação de Programas Transdisciplinares Apta Ação

Associação de Promoção Humana e Social

Associação de Proteção a Ecossistemas Costeiros

Associação de Reciclagem de Vila Velha

Associação de Senhoras de Rotarianos de Blumenau

Associação do Fórum Ação para o Desenvolvimento de Candido Godoi

Associação do Fórum de Desenvolvimento Local Integrado e Sustentável de Caarapó - Vivacidade

Associação Dois de Outubro - Paengaba

Associação dos Amigos da Floresta Nacional de Brasília - Flona/BSB

Associação dos Amigos da Pedra da Princesa

Associação dos Moradores dos Setores Coimbra e Bela Vista

Associação dos Pequenos Agricultores da Região Sítio dos Patos

Associação dos Produtores de Erva Mate de Machadinho

Associação Ecológica e Cultural de Integração Fronteira das Artes

Associação Ecológica Turismo Sustentável

Associação Estação de Apoio e Ofícios "OSCIP"

Associação Faça Sua Parte

Associação Floripamanhã

Associação Fórum de Dlis de Pedro Gomes - ADPEG

Associação Gente Que Faz

Associação Geográfica União das Águas

Associação Gera Vida de Assistência Social

Associação Global de Desenvolvimento Sustentado

Associação Guardiã da APA do Pratigi

Associação Holística de Participação Comunitária Ecológica - Núcleo da Terra

Associação Internacional Protetora do Meio Ambiente

Associação Ipê

Associação Marca para Promoção de Serviços

Associação Mineira de Defesa do Ambiente

Associação Movimento Ecológico Amigos do Meio Ambiente

Associação Novo Encanto Desenvolvimento Ecológico

Associação Núcleo para Transformações Ambientais e Sociais

Associação Olhos D'Água 
Associação Onça D'Água de Apoio à Gestão e ao Manejo das Unidades de Conservação do Estado do Tocantins

Associação Organização Não Governamental Solidariedade e Vida

Associação para Desenvolvimento de Ações Públicas

Associação para o Combate à Exclusão Social e Preservação Ambiental - Acespa Chico Mendes

Associação para o Desenvolvimento e Pesquisa da Saúde e Educação

Associação Parque das Águas

Associação Parque do Povo

Associação Parque Maracá

Associação Paulista de Serviços Comunitários

Associação pela Recuperação e Preservação da Mata Atlântica

Associação Planejar

Associação Pró Casa do Pinhal

Associação Pró Sapiens - Logística em Desenvolvimento Social

Associação Projeto Bagagem

Associação Protetora das Montanhas e Araucárias e Seus Valores Sociais, Artísticos, Estéticos,

Ambientais, Geológicos, Históricos e Paisagísticos

Associação Rio_Minas "Trem Mineiro"

Associação Sai da Toca Cultural

Associação Ser Cidadão

Associação Serra da Mantiqueira

Associação Serra do Itapetinga, Movimento pela Biodiversidade e Organização dos Setores Ecológicos

Associação Sonhar e Acreditar

Associação SOS Amazônia

Associação Super Eco de Integração Ambiental e Desenvolvimento da Criança

Associação TerraBrasil - ONG

Associação Thalamus

Associação Tuim Proteção e Educação Ambiental

Associação Unida do Bairro Pôr-do-sol

Associação Universitária da Zona Leste

Associação Vida Verde da Amazônia

Belabrasília Preservação do Patrimônio Arquitetônico de Brasília

Biomavale - Organização da Sociedade Civil de Interesse Público

Biotema Ciência e Tecnologia

Bioterra - Organização para Conservação da Biodiversidade e Meio Ambiente

Brasil Ação Solidária

Cací - Comitê de Ação pela Cidadania

Caiapônia Instituto de Saneamento Ambiental

Catalisa Rede de Cooperação para Sustentabilidade

Cenarium

Centro de Apoio à Economia Popular Solidária

Centro de Apoio à Educação, Meio Ambiente e Saúde

Centro de Assistência e Desenvolvimento Social

Centro de Aventura Rio do Peixe

Centro de Desenvolvimento Integrado Social e Cultural

Centro de Desenvolvimento Social

Centro de Desenvolvimento Sustentável e Industrial de Sistemas Florestais do Norte Pioneiro

Centro de Estudos e Aplicações para as Novas Tecnologias Educacionais

Centro de Estudos e Apoio ao Desenvolvimento do Araripe

Centro de Estudos e Pesquisas 28

Centro de Estudos Marinhos do Atlântico Sul

Centro de Estudos para o Desenvolvimento local

Centro de Estudos para o Desenvolvimento Sustentável e Inclusão Social

Centro de Gestão de Tecnologia e Inovação - CGTI

Centro de Realizações Sociais e Ecológicas Vida Nordeste

Centro de Voluntários em Cooperativismo e Economia Social para as Américas

Centro Educacional Imaculada Conceição

Centro Preserv de Promoção do Desenvolvimento Sustentado

Centro Social Verdadeira Amizade 
Centro Socio-cultural-educativo Casa de "Sophía"

Cerca - Centro Regional de Cultura e Arte

Clube de Observadores de Aves do Vale Europeu

Cluster de Turismo da Costa dos Coqueiros

Comitê sul Brasileiro de Qualidade dos Combustíveis

Comunidade Educacional de Pirenópolis

Congresso Internacional Israelita de Sociosfera na Amazônia

Connecta

Conselho Brasileiro de Manejo Florestal

Conselho Comunitário de Segurança Preventiva de Patrocínio

Conselho de Crianças para a Preservação do Homem, do Ar, das Águas, das Matas, dos Animais e

Defesa do Patrimônio Histórico e Cultural

Conselho de Preservação Ambiental Brasileiro

Conservation International do Brasil

Conservation Strategy Fund do Brasil

Consórcio para Proteção Ambiental e Desenvolvimento Sustentável e Sociocultural da Bacia

Hidrográfica do Rio das Cinzas

Copati - Consórcio Intermunicipal para Proteção Ambiental da Bacia do Rio Tibagi

Creatif - Associação da Igualdade

Curucutu Parques Ambientais

Defender - Defesa Civil do Patrimônio Histórico

Dese - Instituto para o Desenvolvimento Social e Ecológico

Desenvolvimento Social Humano Tecnológico DSHT

E.U - Ecologia Urbana

Eco Atitude - Ações Ambientais

Econsenso

Ecovitae Tecnologia Ambiental

Ekko Brasil

Ema - Conscientização e Recuperação Ambiental

Equipe Cogestora do Parque Estadual Fritz Plaumann

Equipe de Conservação da Amazônia

Escola Viveiro Multiplicadora Artesã

Fábrica do Futuro

Face a Face Ação Solidária

Federação Brasileira de Plantio Direto na Palha

Federação das Associações e Entidades para o Desenvolvimento do Semiárido Baiano

Força Comunitária Nacional

Fórum Municipal de Lutas de Itaquaquecetuba

Fórum para o Desenvolvimento do Entretenimento, Cultura e Turismo da Bahia

Fórum Permanente de Responsabilidade Social do Rio Grande do Sul

Fundação Angelo Creta de Educação e Desenvolvimento Socioeconômico Ambiental

Fundação Aron Birmann

Fundação Botânica Margaret Mee

Fundação Brasil Cidadão para a Educação, Cultura e Tecnologia - FBC

Fundação Brasil Esperança

Fundação Cepa - Centro de Est e Planif do Ambiente

Fundação de Apoio à Vida nos Trópicos

Fundação de Desenvolvimento da Região da Serra da Mesa

Fundação de Formação, Pesquisa e Difusão Tecnológica para uma Convivência Sustentável com o Semiárido

Fundação de Salvamento Aquático de Santa Catarina

Fundação Educacional, Assistencial e de Proteção ao Meio Ambiente

Fundação Emalto

Fundação Espaço Eco

Fundação Grupo Esquel Brasil

Fundação Lymington

Fundação Matutu

Fundação Movimento Ondazul

Fundação Museu do Homem Americano 
Fundação para o Desenvolvimento Sustentável do Araripe

Fundação Patrimônio Histórico da Energia e Saneamento

Fundação Pró-defesa Ambiental

Fundação Pró-natureza

Fundação Rio do Leão

Fundação SOS Pró-Mata Atlântica

Fundação Turismo para Paz e Desenvolvimento Sustentável

Fundação Vovó do Mangue

Fundacion Avina

Fundo Brasileiro para a Biodiversidade

Graf Grupo de Recuperação Ambiental e Florestal

Green Cross Brasil

Grupo Ambiental Natureza Bela

Grupo Ambientalista do Rio Iguaçu

Grupo AR - Ação Renovadora

Grupo de Apoio, Estudo e Pesquisa Ambiental e Cultural - Pró-Terra

Grupo de Desenvolvimento Humano e Ambiental - Instituto Goiamum

Grupo de Estudos e Promoção do Desenvolvimento Sustentável

Grupo de Pesquisas Ufológicas Ufogênesis

Guarda Mirim de Colider MT

Hospital São Vicente de Paulo de Piranga

lagep - Instituto de Apoio a Gestão Pública

lambra Instituto de Assistência aos Municípios Brasileiros

Iberobrasileira de Estudos e Cooperação

Icult - Instituto de Cultura e Cidadania

Idaq Instituto Dr. Avelino Elias de Queiroga

Ideia Ambiental Sociedade S/C

Igreja Congregacional Afro-brasileira de Renovação Espiritual

Indesus - Instituto Tecnológico para o Desenvolvimento Sustentável

ING - Instituto Os Guardiões da Natureza

Iniciativa Primus

Inprefer Instituto Nacional de Preservação e Restauração Ferroviária

Inri - Instituto Nacional de Renovação Integrado

Inst. de Estudos e Pesq. para Prom. da Educação, Cultura e Desenvolvimento Econômico e Social -

Prosocial

Instituto Abradee da Energia

Instituto Abramundo

Instituto Acaiah

Instituto Ação Ambiente

Instituto Ação Verde

Instituto Acqua - Ação, Cidadania, Qualidade Urbana e Ambiental

Instituto Adriana Colares Nelson de Senna

Instituto Akaire

Instituto Akatu

Instituto Amar

Instituto Amazônia

Instituto Ambiental Aracua

Instituto Ambiental de Desenvolvimento Social Sustentável - Instituto Biocêntrica

Instituto Ambiental Global - IAG

Instituto Ambiental Parque das Perobas

Instituto Ambiental Ratones

Instituto Amea

Instituto Amigos da Reserva da Biosfera da Mata Atlântica

Instituto Antrópolis para o Desenvolvimento Sustentável

Instituto Arapoty

Instituto Argonauta para a Conservação Costeira e Marinha

Instituto Árvore da Vida

Instituto Atlantis de Preservação Ambiental

Instituto Ave é Vida 
Instituto Baía de Guanabara

Instituto Bioacqua de Promoção de Desenvolvimento Sustentável e Defesa do Meio Ambiente

Instituto Brasil Preservação Ambiental e Desenvolvimento Sustentável

Instituto Brasileiro da Cidadania

Instituto Brasileiro da Ecologia e da Cultura

Instituto Brasileiro de Administração - IBA

Instituto Brasileiro de Defesa da Natureza

Instituto Brasileiro de Desenvolvimento "O futuro é hoje"

Instituto Brasileiro de Desenvolvimento da Defesa Civil e do Meio Ambiente IBDM

Instituto Brasileiro de Desenvolvimento Econômico, Social, Cultural e de Proteção ao Meio Ambiente Inbrades

Instituto Brasileiro de Direito do Terceiro Setor

Instituto Brasileiro de Engenharia

Instituto Brasileiro de Florestas

Instituto Brasileiro de Integração e Desenvolvimento Pró-Cidadão

Instituto Brasileiro de Pesquisa e Desenvolvimento Social Sustentável - Ibrapeds

Instituto Brasileiro de Responsabilidade Social - IBRS

Instituto Brasileiro do Crisotila

Instituto Câmara Filho

Instituto Centro de Vida - ICV

Instituto Centro-Brasileiro de Cultura

Instituto Chão Caipira "Malvina Borges de Faria"

Instituto Cistema - Cidadania - Saúde - Trabalho - Educação e Meio Ambiente

Instituto Convocação para Cidadania

Instituto Corpore para o Desenvolvimento da Qualidade de Vida

Instituto Costa Brasilis - Desenvolvimento Socioambiental

Instituto Creatio

Instituto Cruzeiro do Sul

Instituto Cultual Batá Kotô

Instituto Cultural Capobianco

Instituto Cultural e Educacional - Museu do Aço

Instituto Cultural Eco Econômico Espírito Santo

Instituto Cultural Farol do Rio Doce

Instituto Cultural Leopoldina Geovana de Araújo

Instituto da Economia Criativa

Instituto de Ação Cultural e Ecológica

Instituto de Ação Social Planejada

Instituto de Apoio a Saúde, Educação, Meio Ambiente, Tecnologia, Esportes, Ciências e Habitação lasemtech

Instituto de Apoio a Tecnologia, Educação, Saúde, Promoção Social, Meio Ambiente e Cultura

Instituto de Apoio e Proteção Ambiental

Instituto de Assistência, Gestão e Educação de Munícipes - IAGM

Instituto de Cidadania e Estudos Ambientais e Turismo

Instituto de Cooperação e Tecnologia Socioambiental

Instituto de Desenvolvimento a Ecologia, Saúde e Educação

Instituto de Desenvolvimento ao Ensino e Pesquisa

Instituto de Desenvolvimento da Região do Sisal

Instituto de Desenvolvimento Econômico e Social do Brasil

Instituto de Desenvolvimento Econômico e Socioambiental Idesa

Instituto de Desenvolvimento Integrado

Instituto de Desenvolvimento Municipal

Instituto de Desenvolvimento Social do Maranhão

Instituto de Desenvolvimento Social, Econômico e Ambiental de Mato Grosso do Sul

Instituto de Desenvolvimento Socioeconômico dos Trabalhadores de Baixa Renda

Instituto de Desenvolvimento Socioambiental, Saúde e Bem Estar

Instituto de Desenvolvimento Sustentável do Baixo Sul da Bahia

Instituto de Desenvolvimento Sustentável do Estado de Santa Catarina

Instituto de Desenvolvimento Sustentável Terra Boa

Instituto de Desenvolvimento Tecnológico 
Instituto de Desenvolvimento Tecnológico e Humano

Instituto de Direito Agrário e Ambiental do Sul - Joaquim Luiz Osorio

Instituto de Ecologia Terrestre

Instituto de Educação Igapó

Instituto de Educação para Pesquisa, Desenvolvimento e Inovação Tecnológica - Royal

Instituto de Educação Pesquisa e Saúde San Julian

Instituto de Ensino Pesquisa e Preservação Ambiental Marcos Daniel - Instituto Marcos Daniel

Instituto de Estudos Socioculturais e Ambientais Embra Cultural

Instituto de Gestão Solidária

Instituto de Integração Social, Desenvolvimento Sustentável e Preservação Ambiental

Instituto de Manutenção Ambiental, Ecológico, Social e Pesquisa - Mães da Amazônia

Instituto de Meio Ambiente e Desenvolvimento

Instituto de Meio Ambiente e Desenvolvimento Sustentável - Tramirim

Instituto de Organização Nacional Socioambiental - Onsa

Instituto de Pesquisa e Conservação da Natureza

Instituto de Pesquisa e Desenvolvimento Sustentável Via-montes

Instituto de Pesquisas Ambientais e Sociais Aplicadas

Instituto de Preservação do Meio Ambiente e dos Recursos Naturais da Amazônia

Instituto de Promoção a Educação, Bem-estar Social e Saúde

Instituto de Promoção e Educação em Saúde

Instituto de Recuperação do Patrimônio Histórico no Estado de São Paulo

Instituto de Saúde e Meio Ambiente

Instituto de Saúde, Educação Bem-Estar Social

Instituto de Tecnologia \& Gestão - Instituto Alfa Brasil

Instituto de Tecnologia de Prevenção de Desastres Naturais e Industriais

Instituto de Turismo de Itacaré

Instituto Decolar Aerodesportivo

Instituto Dignidade de Valorização da Vida

Instituto do Homem e Meio Ambiente da Amazônia

Instituto do Parque do Pantanal

Instituto Eco Millennium

Instituto Ecoar para a Cidadania

Instituto Eco-empreendedor para a Sustentabilidade Ambiental

Instituto Ecofuturo - Futuro para Desenvolvimento Sustentável

Instituto Ecológica Palmas/TO

Instituto Esperança Viva

Instituto Estação Desenvolvimento

Instituto Eureka de Cidadania

Instituto Eurofarma

Instituto Excelsa

Instituto Família Legal

Instituto Fazenda Tamanduá

Instituto Festival de Inverno - Festinver

Instituto Floravida

Instituto Floresta de Pesquisa e Desenvolvimento Sustentável

Instituto Gea - Ética e Meio Ambiente

Instituto Gênesis

Instituto Germinar Socioambiental

Instituto Global de Marketing Social

Instituto Grande Sertão

Instituto Guaicuy - SOS Rio das Velhas

Instituto Harmonia na Terra

Instituto Histórico e Geográfico de Paranaguá

Instituto Ilhabela Sustentável

Instituto Intercidadania

Instituto Jorge Baptista - Formação Pesquisa e Assessoria

Instituto Jovem Caminhar

Instituto Justino Carvalho

Instituto Juventude Ativa 
Instituto Labor \& Vita

Instituto Lagoa Prateada

Instituto Lar

Instituto Latino Americano de Saúde e Meio Ambiente

Instituto Litoral Verde

Instituto Luminar

Instituto Mãe Terra de Tecnologia Educacional e Ambiental

Instituto Maranata de Pesquisa em Estrutiocultura

Instituto Martim Pescador - Movimento de Preservação da Bacia Hidrográfica do Rio dos Sinos

Instituto Mil Povos / Macuco

Instituto Modus Vivendi de Desenvolvimento Social, Cultural e Ambiental

Instituto Montana Ambiental

Instituto Nacional de Apoio a Educação, Desenvolvimento, Pesquisa, Ações assistenciais em Saúde,

Meio Ambiente, Turismo e Cultura

Instituto Nacional de Integração Social

Instituto Nacional de Preservação Ambiental

Instituto Nacional de Tecnologia e Uso Sustentável

Instituto Nascente - Turismo \& Ecologia

Instituto Natureza Viva

Instituto Navegamundo

Instituto Novas Fronteiras da Cooperação

Instituto Novos Saberes

Instituto Oca Brasil

Instituto Oikos de Agroecologia

Instituto Oksigeno

Instituto Orbis de Proteção e Conservação da Natureza

Instituto para Desenvolvimento Socioambiental e Tecnológico Lótus

Instituto para Cidadania e Implementação da Base Popular - Icibap

Instituto para Conservação dos Carnívoros Neotropicais - Pró-carnívoros

Instituto para Desenvolvimento Ambiental e Tecnológico - Idea Cíclica

Instituto para Desenvolvimento da Criança e do Adolescente pela Cultura e Esporte - Idecace

Instituto para o Desenvolvimento Ambiental

Instituto para o Desenvolvimento Sustentável de Joinville

Instituto Parceria

Instituto Parque das Nascentes

Instituto Patulus

Instituto Pé no Chão

Instituto Peabiru

Instituto Physis - Cultura \& Ambiente

Instituto Portas Abertas

Instituto Porto Seguro

Instituto Potiguar de Juventude pela Cidadania

Instituto Pró Rio Doce

Instituto Pró-água

Instituto Proteção Ambiental Cotia/ Tietê Oeste

Instituto Putzgrila

Instituto Rio Tietê

Instituto Rodrigo Marcheschi - I.R.M.

Instituto Roerich da Paz e Cultura do Brasil

Instituto Sadia de Sustentabilidade

Instituto Samuel Murgel Branco

Instituto São Cristóvão

Instituto São Francisco

Instituto Social Tecnológico e Econômico do Café - Mais Café

Instituto Social, Educacional e de Pesquisa de Minas Gerais

Instituto Socioambiental Guapuruvu

Instituto Socioambiental

Instituto Tamboré

Instituto Tempo Bougra - SCTB 


\author{
Instituto Terra \\ Instituto Terra de Santa Cruz \\ Instituto Verdescola \\ Instituto Vida Mar \\ Instituto Vida para o Atendimento à Saúde, Saneamento e Meio Ambiente \\ Instituto Vitalis Vitalizando a Integração dos Trabalhadores da América Latina na Luta pela Inclusão \\ Social \\ Instituto Viva Ourem \\ Instituto Xopotó de Desenvolvimento Social, Econômico e Ambiental \\ Integração Brasileira de Educação \\ Interforum Global: Intercâmbio e Desenvolvimento Sustentável \\ Ipam - Instituto Brasileiro de Pesquisas Ambientais \\ Ipê - Instituto de Pesquisas Ecológicas \\ Liga Carmesiana de Assistência Social \\ Liga Desportiva e Beneficente de Futsal Santamariense \\ Lista de ONGs \\ Mana - Mani Círculo Aberto de Comunicação, Educação e Cultura \\ Mandala \\ Mapas - Métodos de Apoio a Práticas Ambientais e Sociais \\ Mater Natura - Instituto de Estudos Ambientais \\ Memorial Chico Mendes Embaixada dos Povos da Floresta \\ Moinho de Pedra do Guarapiranga MPG \\ Movimento Ação de Inclusão Social - Mais Timburi \\ Movimento Ambiental Gestão e Organização Social - Magos \\ Movimento Ecológico e Cultural do Vale do Piranga \\ Movimento Interamericano de Ecologia \\ Movimento Pernambuco Contra o Crime \\ Museu a Céu Aberto - Cultura, Ecologia e Desenvolvimento \\ Nazaré Universidade da Luz
}




\section{Apêndice 4. Nomes das organizações participantes}

\begin{tabular}{|c|c|c|}
\hline 1 & 28/6/2017; $12 \mathrm{~h} 41$ & Projeto Tamar \\
\hline 2 & 23/6/2017; 20h06 & Instituto Ecológico de Palmas \\
\hline 3 & 22/6/2017; 16h07 & Instituto Pólis \\
\hline 4 & 20/6/2017; 15h23 & Associação Bem Comum \\
\hline 5 & 19/6/2017; 13h23 & $\begin{array}{l}\text { Associação de Moradores da Lauro Muller, Ramon Castilla, } \\
\text { Xavier Sigaud e Adjacências (Alma) }\end{array}$ \\
\hline 6 & 19/6/2017; 13h10 & Quintessa \\
\hline 7 & 13/6/2017; 19h15 & Instituto Brasileiro de Defesa da Natureza \\
\hline 8 & 13/6/2017; $18 h 40$ & Instituto IPET \\
\hline 9 & 13/6/2017; $16 h 16$ & Instituto Nacional de Tecnologia e Uso Sustentável (INNATUS) \\
\hline 10 & 13/6/2017; $13 \mathrm{~h} 12$ & Degraf Instituto Academia de Desenvolvimento Social \\
\hline 11 & 13/6/2017; $12 h 32$ & $\begin{array}{l}\text { Centro de Assessoria e Apoio aos Trabalhadores e Instituições } \\
\text { Não Governamentais Alternativas (Caatinga) }\end{array}$ \\
\hline 12 & 13/6/2017; 09h48 & FAEP \\
\hline 13 & 13/6/2017; 08h28 & IDR-Oeste \\
\hline 14 & 12/6/2017; 13h12 & Associação SOS Amazônia \\
\hline 15 & 12/6/2017; $12 \mathrm{~h} 54$ & COPATI \\
\hline 16 & $12 / 6 / 2017 ; 12 h 28$ & $\begin{array}{l}\text { Instituto Maramar para Gestão Responsável dos Ambientes } \\
\text { Costeiros e Marinhos }\end{array}$ \\
\hline 17 & 12/6/2017; $11 \mathrm{~h} 40$ & Associação Comunitária Itaqui Bacanga \\
\hline 18 & 12/6/2017; $10 h 23$ & CAPA \\
\hline 19 & 12/6/2017; $10 h 17$ & $\begin{array}{l}\text { Centro de Estudos da Cultura e do Meio Ambiente da Amazônia } \\
\text { (Rioterra) }\end{array}$ \\
\hline 20 & 12/6/2017; 09h12 & Instituto Holcim \\
\hline 21 & 09/6/2017; $10 h 56$ & Instituto Brasileiro do Crisotila \\
\hline 22 & 09/6/2017; 09h08 & Instituto Dínamo de Desenvolvimento Sustentável \\
\hline 23 & 08/6/2017; 22h17 & Associação Pelo Canino - Apelo Canino \\
\hline 24 & 08/6/2017; 20h23 & Elo Ambiental \\
\hline 25 & 08/6/2017; $18 h 45$ & Associação Ambiental Voz da Natureza \\
\hline 26 & 08/6/2017; 18h11 & Instituto Sicoob \\
\hline 27 & 08/6/2017; 14h38 & Associação Circuito Verde \\
\hline 28 & 08/6/2017; 14h37 & Conservação Estratégica (CSF) \\
\hline 29 & 08/6/2017; 14h29 & Brigada Mirim Ecológica da Ilha Grande \\
\hline 30 & 08/6/2017; $13 \mathrm{~h} 46$ & Associação da Escola Família Agrícola de Angical \\
\hline 31 & 08/6/2017; $12 \mathrm{~h} 29$ & Fundação Grupo Esquel Brasil \\
\hline 32 & 08/6/2017; $12 \mathrm{h02}$ & Instituto Baía de Guanabara (IBG) \\
\hline 33 & 08/6/2017; $10 h 51$ & Agência de Desenvolvimento Sustentável do Seridó (Adese) \\
\hline 34 & 08/6/2017; $10 h 42$ & Associação Mineira de Defesa do Ambiente (Amda) \\
\hline 35 & 07/6/2017; $14 \mathrm{~h} 30$ & $\begin{array}{l}\text { Instituto Bioterra - Organização para Conservação da } \\
\text { Biodiversidade e Meio Ambiente }\end{array}$ \\
\hline 36 & 07/6/2017; 14h03 & Fundação Gilberto Freyre \\
\hline
\end{tabular}




\begin{tabular}{|c|c|c|}
\hline 37 & 07/6/2017; $12 \mathrm{h04}$ & $\begin{array}{l}\text { União de Núcleos, Associações dos Moradores de Heliópolis e } \\
\text { Região }\end{array}$ \\
\hline 38 & 07/6/2017; $11 \mathrm{h01}$ & Associação de Defesa Etnoambiental Kanindé \\
\hline 39 & 07/6/2017; 08h19 & Associação de Pequenos Produtores de Jaboticaba (APPJ) \\
\hline 40 & 07/6/2017; 07h40 & Núcleo de Desenvolvimento Social \\
\hline 41 & 06/6/2017; 19h41 & Aliança da Terra \\
\hline 42 & 06/6/2017; $15 h 45$ & Fundação SOS Mata Atlântica \\
\hline 43 & 06/6/2017; $10 h 39$ & Idese \\
\hline 44 & 06/6/2017; $10 h 09$ & Instituto Projeto Rondon PE \\
\hline 45 & 05/6/2017; $18 \mathrm{~h} 04$ & Agência de Desenvolvimento de Jundiaí e Região \\
\hline 46 & 05/6/2017; 17h49 & Instituto Brasileiro de Florestas \\
\hline 47 & 05/6/2017; 14h02 & $\begin{array}{l}\text { Agencia de Desenvolvimento Integrado e Sustentável do Vale do } \\
\text { Rio Urucuia }\end{array}$ \\
\hline 48 & 02/6/2017; 11h55 & Associação FloripAmanhã \\
\hline 49 & 01/6/2017; 20h46 & Instituto Amazônia Viva \\
\hline 50 & 01/6/2017; 18h10 & Centro de Estudos Bíblicos (Cebi) \\
\hline 51 & 01/6/2017; 15h26 & Bioética de Gestão Publica \\
\hline 52 & 01/6/2017; 09h51 & Núcleo de Desenvolvimento em Estudos Socioambientais \\
\hline 53 & 01/6/2017; 00h28 & Núcleo de Educação Ambiental Francisco de Assis \\
\hline 54 & $31 / 5 / 2017 ; 18 h 22$ & Instituto Ekko Brasil \\
\hline 55 & 31/5/2017; 16h11 & Fundação Museu do Homem Americano \\
\hline 56 & 31/5/2017; $12 \mathrm{~h} 44$ & Defender Defesa Civil do Patrimônio Histórico \\
\hline 57 & 31/5/2017; 11h52 & Associação Global de Desenvolvimento Sustentado \\
\hline 58 & 31/5/2017; 09h28 & Emater \\
\hline 59 & 30/5/2017; 15h08 & Capivari Monos \\
\hline 60 & $30 / 5 / 2017 ; 14 h 38$ & Centro de Desenvolvimento Agroecológico Sabiá \\
\hline 61 & 30/5/2017; 13h52 & Associação R3 Animal \\
\hline 62 & $30 / 5 / 2017 ; 11 \mathrm{~h} 34$ & Associação dos Amigos de Alto dos Pinheiros (SAAP) \\
\hline 63 & $30 / 5 / 2017 ; 11 \mathrm{~h} 15$ & Rede Vale de Comunicação Ltda \\
\hline 64 & 30/5/2017; $10 h 58$ & Associação dos Catadores de Materiais Recicláveis de Lavras \\
\hline 65 & 30/5/2017; 10h27 & AGEPLAN \\
\hline 66 & 30/5/2017; 08h52 & Associação Ambientalista Copaíba \\
\hline 67 & 29/5/2017; 17h21 & Associação Menonita Beneficente (AMB) \\
\hline 68 & 29/5/2017; 16h14 & Associação Paranaense de Pesquisas Ambientais (APPAM) \\
\hline 69 & 29/5/2017; $16 h 08$ & Instituto Peabiru \\
\hline 70 & 29/5/2017; 14h54 & Associação Caatinga \\
\hline 71 & 29/5/2017; 11h54 & Caatinga \\
\hline 72 & 29/5/2017; $11 \mathrm{~h} 53$ & $\begin{array}{l}\text { Centro Preservação de Promoção do Desenvolvimento } \\
\text { Sustentado }\end{array}$ \\
\hline 73 & 29/5/2017; $11 \mathrm{~h} 16$ & $\begin{array}{l}\text { Associação San Julian, Amigos e Colaboradores (Hospital San } \\
\text { Julian) }\end{array}$ \\
\hline 74 & 29/5/2017; 10 h09 & ACREVI \\
\hline 75 & 29/5/2017; 08h50 & Instituição de Crédito Solidário (Credisol) \\
\hline
\end{tabular}




\begin{tabular}{|c|c|c|}
\hline 76 & 28/5/2017; 23h11 & Associação Amigos do Meio Ambiente (AMA) \\
\hline 77 & 27/5/2017; 20h01 & $\begin{array}{l}\text { Agência de Desenvolvimento Econômico e Social da Região do } \\
\text { Planalto Médio (Programa Yacamim) }\end{array}$ \\
\hline 78 & 27/5/2017; 11h24 & Instituto Goiamum \\
\hline 79 & 27/5/2017; 08h45 & Instituto Social Integrado e Solidário (Isis) \\
\hline 80 & 26/5/2017; 16h32 & Mater Natura-Instituto de Estudos Ambientais \\
\hline 81 & 26/5/2017; $16 h 29$ & CEMPRE \\
\hline 82 & 26/5/2017; 14h56 & Instituto Mangue Vivo \\
\hline 83 & 26/5/2017; 09h49 & Fundação para o Desenvolvimento do Araripe \\
\hline 84 & 25/5/2017; $10 h 14$ & Oscip Jovem Sertão \\
\hline 85 & 24/5/2017; 18 h08 & Fundação Grupo Boticário de Proteção à natureza \\
\hline 86 & 24/5/2017; 15h31 & Instituto Lotus \\
\hline 87 & 23/5/2017; 17h29 & Instituto de Cidadania Empresarial do Maranhão \\
\hline 88 & 23/5/2017; 17h05 & Sociedade Angrense de Proteção Ecológica (Sapê) \\
\hline 89 & 23/5/2017; 08h45 & Movimento de Organização Comunitária (MOC) \\
\hline 90 & 22/5/2017; 23h04 & Verde vida \\
\hline 91 & 22/5/2017; $16 h 39$ & Instituto de Meio Ambiente e Desenvolvimento (IMAD) \\
\hline 92 & 22/5/2017; 15h55 & Instituto Biológico do Meio Ambiente (Bioma) \\
\hline 93 & 22/5/2017; $10 \mathrm{~h} 07$ & $\begin{array}{l}\text { Associação Vianei de Cooperação e Intercâmbio no Trabalho, } \\
\text { Educação, Cultura e Saúde (AVICITECS) }\end{array}$ \\
\hline 94 & 20/5/2017; 22h57 & Instituto Terra \\
\hline 95 & 20/5/2017; $12 \mathrm{~h} 36$ & Catalisa - Rede de Cooperação para Sustentabilidade \\
\hline 96 & 19/5/2017; $16 h 04$ & $\begin{array}{l}\text { Assessoria e Serviços a Projetos em Agricultura Alternativa (AS- } \\
\text { PTA) }\end{array}$ \\
\hline 97 & 19/5/2017; 15 h00 & $\begin{array}{l}\text { Associação de Apoio as Comunidades do Campo do RN (AACC- } \\
\text { RN) }\end{array}$ \\
\hline 98 & 19/5/2017; $14 h 42$ & Ecopef \\
\hline 99 & 18/5/2017; $16 h 43$ & Instituto Ação Verde \\
\hline 100 & $18 / 5 / 2017 ; 15 h 28$ & Grupo Ambiental Natureza Bela \\
\hline 101 & 18/5/2017; 14h26 & Fundação Emalto \\
\hline 102 & 18/5/2017; 11h59 & Organização Social Ambiental da Fauna e Flora do Brasil \\
\hline 103 & 18/5/2017; $10 h 51$ & Instituto Verde Brasil \\
\hline 104 & 18/5/2017; 02h30 & Amigos da Terra - Amazônia Brasileira \\
\hline 105 & 17/5/2017; 16h41 & Centro Dom José Brandão de Castro \\
\hline 106 & 17/5/2017; $16 h 27$ & Instituto Banco Palmas \\
\hline 107 & $17 / 5 / 2017 ; 16 h 19$ & $\begin{array}{l}\begin{array}{l}\text { Instituto de Desenvolvimento Econômico e Socioambiental } \\
\text { (Idesa) }\end{array} \\
\end{array}$ \\
\hline 108 & 17/5/2017; $12 \mathrm{~h} 52$ & Instituto de Assessoria para o Desenvolvimento Humano \\
\hline 109 & 16/5/2017; 17h22 & Fundação Stickel \\
\hline 110 & 16/5/2017; $16 h 25$ & Movive \\
\hline 111 & 16/5/2017; $16 h 12$ & Instituto-E \\
\hline 112 & 16/5/2017; 14h02 & Cooperativa de Reciclagem de Ituiutaba (Copercicla) \\
\hline 113 & 16/5/2017; $10 h 03$ & Instituto Os Guardiões da Natureza (ING) \\
\hline
\end{tabular}




\begin{tabular}{|c|c|c|}
\hline 114 & 16/5/2017; $01 \mathrm{~h} 03$ & Centro de Estudos Marinhos do Atlântico Sul \\
\hline 115 & 15/5/2017; 20h42 & Agência Brasileira de Desenvolvimento Socioambiental \\
\hline 116 & 15/5/2017; 17h49 & Grupo de Trabalhos em Prevenção Posithivo (GTP+) \\
\hline 117 & 15/5/2017; 14h59 & Instituto Atlantis de Preservação Ambiental \\
\hline 118 & 12/5/2017; $19 h 02$ & Instituto Ilhabela Sustentável \\
\hline 119 & $11 / 5 / 2017 ; 18 h 44$ & Instituto Ethos \\
\hline 120 & 11/5/2017; 13h22 & ASF \\
\hline 121 & 09/5/2017; 15h05 & José Ventura Sobrinho \\
\hline 122 & 09/5/2017; 14h50 & Banco do Empreendedor \\
\hline 123 & 09/5/2017; $10 h 33$ & Movimento de Organização Comunitária (MOC) \\
\hline 124 & 08/5/2017; 21h04 & Organização Maria Otilia Neix \\
\hline 125 & 06/5/2017; 22h30 & OSCIP Ecolmeia \\
\hline 126 & 05/5/2017; $15 h 30$ & Iniciativa Verde \\
\hline 127 & 04/5/2017; $19 \mathrm{~h} 26$ & Ação Social Arquidiocesana (ASA) \\
\hline 128 & 04/5/2017; $14 h 58$ & Aumar \\
\hline 129 & 04/5/2017; $12 \mathrm{~h} 13$ & Instituto Ekos Brasil \\
\hline 130 & 03/5/2017; 22h38 & Pro Natura Internacional \\
\hline 131 & 03/5/2017; 17h31 & $\begin{array}{l}\text { Serra do Itapetinga, Movimento pela Biodiversidade e } \\
\text { Organização dos Setores Ecológicos (Simbiose) }\end{array}$ \\
\hline 132 & 03/5/2017; $10 h 41$ & $\begin{array}{l}\text { Instituto Social Educacional e de Pesquisa de Minas Gerais } \\
\text { (Isepem) }\end{array}$ \\
\hline 133 & 03/5/2017; 09h24 & Adesita \\
\hline 134 & 03/5/2017; 09h03 & $\begin{array}{l}\text { Instituição Comunitária de Crédito de Londrina Casa do } \\
\text { Empreendedor }\end{array}$ \\
\hline 135 & 03/5/2017; 08h34 & Garantioeste \\
\hline 136 & 03/5/2017; $15 h 49$ & Hotel Esmig \\
\hline 137 & 02/5/2017; $12 \mathrm{~h} 13$ & Instituto Rumo Náutico \\
\hline 138 & 28/4/2017; $10 h 38$ & Associação Comercial, Industrial e Agropecuária de Horizontina \\
\hline 139 & 27/4/2017; 14h45 & Apremavi \\
\hline 140 & 26/4/2017; 17h18 & Instituto Brasil Solidário - IBS \\
\hline 141 & 26/4/2017; $10 h 49$ & Instituto Brasileiro de Ética Concorrencial (Etco) \\
\hline 142 & 25/4/2017; $16: 08$ & Associação Mineira de Crédito Popular \\
\hline 143 & 21/4/2017; 17:02 & Instituto Socioambiental \\
\hline 144 & 20/4/2017; $15: 33$ & Associação Eco Juréia \\
\hline 145 & 20/4/2017; 13:54 & $\begin{array}{l}\text { Associação de Reposição Florestal do Pardo Grande Verde } \\
\text { Tambaú }\end{array}$ \\
\hline 146 & 20/4/2017; $12 \mathrm{~h} 12$ & AEP \\
\hline 147 & 20/4/2017; $10 h 52$ & Associação dos Engenheiros Politécnicos (AEP) \\
\hline 148 & 19/4/2017; 17h33 & Centro Artístico Cultural Belém Amazônia/ Rádio Margarida \\
\hline 149 & 19/4/2017; 16h42 & Terra Roxa Agência de Desenvolvimento do Norte do Paraná \\
\hline 150 & 19/4/2017; 15h18 & Núcleo de Educação e Monitoramento Ambiental (Nema) \\
\hline 151 & 19/4/2017; 10h44 & Instituto Acqua \\
\hline 152 & 19/4/2017; $10 h 28$ & Aliança Empreendedora \\
\hline
\end{tabular}




\begin{tabular}{|c|c|c|}
\hline 153 & 19/4/2017; 08h31 & Instituto Regional de Desenvolvimento Econômico e Social \\
\hline 154 & 18/4/2017; $16 h 09$ & Instituto de Cidadania e Integração Ambiental \\
\hline 155 & 18/4/2017; 15h32 & Noroeste Garantias Sociedade de Garantias de Crédito \\
\hline 156 & $18 / 4 / 2017 ; 11 \mathrm{~h} 25$ & Instituto Omolara Brasil \\
\hline 157 & 18/4/2017; $10 h 30$ & $\begin{array}{l}\text { Serviço de Assessoria a Organizações Populares Rurais } \\
\text { (Sasop) }\end{array}$ \\
\hline 158 & 17/4/2017; 16h29 & Instituto Floresta Tropical \\
\hline 159 & 17/4/2017; 10h32 & Fundação Proamb \\
\hline 160 & 13/4/2017; 17h22 & Oscip SOS Animais de Rua \\
\hline 161 & 12/4/2017; $16 h 48$ & Instituto de Pesquisas Ecológicas (IPÊ) \\
\hline 162 & 12/4/2017; $16 h 35$ & Instituto Centro de Vida (ICV) \\
\hline 163 & 12/4/2017; $13 \mathrm{~h} 48$ & Verde Vida Programa Oficina Educativa \\
\hline 164 & 12/4/2017; $10 h 29$ & $\begin{array}{l}\text { Associação de Educação e Assistência Social Nossa Senhora } \\
\text { da Assunção (ANSA) }\end{array}$ \\
\hline 165 & 12/4/2017; $10 h 10$ & Instituto Labor \& Vita \\
\hline 166 & 11/4/2017; 17h27 & Instituto Oca Brasil \\
\hline 167 & 11/4/2017; 16h19 & FUNTEC \\
\hline 168 & 11/4/2017; $11 \mathrm{~h} 18$ & Serra Acima Associação de Cultura e Educação Ambiental \\
\hline 169 & $11 / 4 / 2017 ; 10 h 13$ & Instituto Excelsa \\
\hline 170 & 11/4/2017; 08h58 & Microfenas Organização de Crédito e Financiamento \\
\hline 171 & 10/4/2017; 09h24 & Oficina Escola de Lutheria da Amazônia \\
\hline 172 & 09/4/2017; 23h10 & Formiga Verde \\
\hline 173 & 09/4/2017; $12 \mathrm{~h} 25$ & LDBFSS/Oscip/Bahia/Brasil \\
\hline 174 & 08/4/2017; 20h06 & Café Igarai \\
\hline 175 & 07/4/2017; $18 h 18$ & Associação de Defesa Etnoambiental Kanindé \\
\hline 176 & 07/4/2017; $11 \mathrm{~h} 24$ & Cáritas Diocesana de Januária \\
\hline 177 & 07/4/2017; $10 h 53$ & Boma Vale \\
\hline 178 & 06/4/2017; $12 \mathrm{h08}$ & Instituto Meio \\
\hline 179 & 05/4/2017; 14h53 & Instituto Goiamum \\
\hline 180 & 05/4/2017; $14 h 12$ & Nazaré Uniluz \\
\hline 181 & 05/4/2017; 03h03 & Cão Sem Dono de Proteção Animal \\
\hline 182 & 30/3/2017; 10 h34 & $\begin{array}{l}\text { Associação Núcleo para Transformações Ambientais e Sociais } \\
\text { (ANTAS) }\end{array}$ \\
\hline 183 & 29/3/2017; $12 h 16$ & $\begin{array}{l}\text { Instituto Brasileiro de Desenvolvimento e Sustentabilidade } \\
\text { (IABS) }\end{array}$ \\
\hline 184 & 28/3/2017; 14 h08 & Instituto Ambiente em Foco (IAF) \\
\hline 185 & 28/3/2017; 14h02 & Projeto Comunitário Sorriso da Criança \\
\hline 186 & 28/3/2017; $12 \mathrm{~h} 37$ & Instituto Çarakura \\
\hline 187 & 28/3/2017; $12 \mathrm{~h} 21$ & Instituto de Tecnologia e Informação Social da Amazônia (ITEIA) \\
\hline 188 & 28/3/2017; 09h41 & Caiapônia Instituto de Saneamento Ambiental \\
\hline 189 & 28/3/2017; 09h08 & The Forest Trust - TFT \\
\hline 190 & 28/3/2017; 08h58 & $\begin{array}{l}\text { Agência para o Desenvolvimento Econômico e Social de Patos } \\
\text { de Minas (ADESP) }\end{array}$ \\
\hline 191 & 23/3/2017; $11 \mathrm{~h} 53$ & Profomento Agência de Crédito Especial \\
\hline
\end{tabular}




\begin{tabular}{|c|c|c|}
\hline 192 & 22/3/2017; 17h56 & Inmed Brasil \\
\hline 193 & 22/3/2017; 17h14 & Themis Gênero, Justiça e Direitos Humanos \\
\hline 194 & 21/3/2017; 17h25 & Agência Brasileira de Desenvolvimento Regional (ADRAM) \\
\hline 195 & 21/3/2017; 08:20 & Passatempo Educativo \\
\hline 196 & 20/3/2017; $11 \mathrm{~h} 07$ & Gerar \\
\hline 197 & 20/3/2017; $10 h 20$ & Espaço Cultural Pés no Chão \\
\hline 198 & 20/3/2017; 09h58 & Centro de Educação Comunitária Rural (CECOR) \\
\hline 199 & 20/3/2017; 08h59 & $\begin{array}{l}\text { Fundação Brasil Cidadão para Educação, Cultura, Tecnologia e } \\
\text { Meio Ambiente }\end{array}$ \\
\hline 200 & 20/3/2017; 08h53 & Vocação \\
\hline 201 & 20/3/2017; 08h49 & Programa Providência de Elevação da Renda Familiar \\
\hline 202 & 20/3/2017; 08h46 & Essor Brasil \\
\hline 203 & 20/3/2017; 06h02 & Instituto Convivência Com o Semiárido Brasileiro \\
\hline 204 & 19/3/2017; 23h13 & Instituto Pró Cidadania de Curitiba \\
\hline 205 & 19/3/2017; 20h39 & Instituto de Geração de Tecnologias do Conhecimento Kw \\
\hline 206 & 18/3/2017; 09h21 & Abrigo Rainha Sílvia \\
\hline 207 & 17/3/2017; 17h54 & Orbe Trabalho Terra Ambiente Gente \\
\hline 208 & 17/3/2017; 11h45 & Fundação Terra Mirim \\
\hline 209 & 17/3/2017; 07h58 & Instituto Costa Brasilis Desenvolvimento Socioambiental \\
\hline 210 & 16/3/2017; 11h52 & Associação Sinhana Eva \\
\hline 211 & 16/3/2017; $10 h 18$ & Instituto Tempo é Vida (ITEV) \\
\hline 212 & 14/3/2017; $14 h 48$ & Instituto Gea Ética e Meio Ambiente \\
\hline 213 & 14/3/2017; 14h39 & Instituto Marcos Daniel \\
\hline 214 & 14/3/2017; $10 h 33$ & Fundação de Apoio a Vida nos Trópicos Ecotrópica \\
\hline 215 & 13/3/2017; 09h00 & $\begin{array}{l}\text { Sociedade Brasileira de Cultura Japonesa e de Assistência } \\
\text { Social }\end{array}$ \\
\hline 216 & 13/3/2017; 08h30 & Associação Habitacional de Interesse Social (AMASMI) \\
\hline 217 & 12/3/2017; 22h12 & União Social Ecológica (USE) \\
\hline 218 & 12/3/2017; 22h04 & Instituto Usina Social \\
\hline
\end{tabular}




\section{Apêndice 5. Endereços das organizações participantes}

\begin{tabular}{|c|c|}
\hline 1 & Av. Farol Garcia D'Ávila, s/n, Mata de São João, BA \\
\hline 2 & Quadra 103 Sul, Rua SO1, Lote 01, sala 603, Palmas, TO \\
\hline 3 & Rua Araújo, 124, São Paulo, SP \\
\hline 4 & Rua Nossa Senhora de Nazaré, 111, São Paulo, SP \\
\hline 5 & Rua Lauro Muller, 66 / 1405, Rio de Janeiro, RJ \\
\hline 6 & Rua Dr. Virgílio de Carvalho Pinto, 433, São Paulo, SP \\
\hline 7 & Rua Herval, 488, São Paulo, SP \\
\hline 8 & Rua Francisco Negrão, 175, Curitiba, PR \\
\hline 9 & Rua Paulo Barbosa, 180, sala 202, Petrópolis, RJ \\
\hline 10 & Av. João Severiano Rodrigues da Cunha, 120, Uberaba, MG \\
\hline 11 & Av. Engenheiro Camacho, 475, Ouricuri, PE \\
\hline 12 & Av. Dr. Cândido Xavier de Almeida e Souza, 200, Mogi das Cruzes, SP \\
\hline 13 & Largo São Vicente de Paulo, 1333, Toledo, PR \\
\hline 14 & Rua Pará, 61, Rio Branco, AC \\
\hline 15 & Rua Mato Grosso, 927, sala 301, Londrina, PR \\
\hline 16 & Rua República do Equador, 100, sala 22, Santos, SP \\
\hline 17 & Av. Vaticano, Quadra 57, 09, São Luís, MA \\
\hline 18 & Rua Gaurama, 470, Erexim, RS \\
\hline 19 & Rua Padre Chiquinho, 1651, Porto Velho, RO \\
\hline 20 & Av. Almirante Barroso, 52, Rio de Janeiro, RJ \\
\hline 21 & Av. Laurício Pedro Rasmussen, 2535, Goiânia, GO \\
\hline 22 & Rua Prudente de Moraes Neto, 38, sala 02, São Paulo, SP \\
\hline 23 & Rua A, 3000, Montes Claros, MG \\
\hline 24 & Rua 24 de outubro, 390, sala 6, São Paulo, SP \\
\hline 25 & Rua Coronel Schwab Filho, 104, Vitória, ES \\
\hline 26 & Av. Duque de Caxias, 882, Maringá, PR \\
\hline 27 & [Não respondeu] \\
\hline 28 & Estrada Dona Castorina, 124, Rio de Janeiro, RJ \\
\hline 29 & Av. Beira Mar, 13, Angra dos Reis, RJ \\
\hline 30 & Povoado Covas, Angical, BA \\
\hline 31 & SCS Quadra 1 Ed. Central, Brasília, DF \\
\hline 32 & Alameda São Boaventura, 770, Niterói, RJ \\
\hline 33 & Praça Dom José Delgado, 51-A, 1a andar, Caicó, RN \\
\hline 34 & Rua Costa Pinto, 258, Belo Horizonte, MG \\
\hline 35 & Av. Enos Sadock de Sá, 216-B, Aracaju, SE \\
\hline 36 & Rua Dois Irmãos, 320, Recife, PE \\
\hline 37 & Rua da Mina, 38, São Paulo, SP \\
\hline 38 & Rua Dom Pedro II, 1892, sala 7, Porto Velho, RO \\
\hline 39 & Rua Alto Alegre, s/n, Povoado de Jaboticaba, Quixabeira, BA \\
\hline 40 & Rua José Farache, 1420, Natal, RN \\
\hline
\end{tabular}




\begin{tabular}{|c|c|}
\hline 41 & Av. das Indústrias, 601, sala 301 e 302, Goiânia, GO \\
\hline 42 & Av. Paulista, 2073, cj. 1318, São Paulo, SP \\
\hline 43 & Fazenda Triunfo, s/n, Zona Rural, Coruripe, AL \\
\hline 44 & Av. Dom Manoel de Medeiros, s/n, Campus de Dois Irmãos, Recife, PE \\
\hline 45 & Rua Doroty Nano Martinasso, 150, Jundiaí, SP \\
\hline 46 & Av. Ayrton Senna, s/n, Apucarana, PR \\
\hline 47 & Rua Benevides Borges Carneiro, 163, Arinos, MG \\
\hline 48 & Rua Feliciano Nunes Pires, 35, Florianópolis, SC \\
\hline 49 & Av. Carlos Pereira de Melo, 4422, Boa Vista, RR \\
\hline 50 & Rua João Batista de M. Freitas, 558, São Leopoldo, RS \\
\hline 51 & Av. Dr. Antonio Gomes de Barros, 1216, Maceió, AL \\
\hline 52 & Rua 15 DE Novembro, 12, São Luís, MA \\
\hline 53 & Rua dos Bandeirantes, 504, Maceió, AL \\
\hline 54 & Servidão Euclides João Alves, s/n, Florianópolis, SC \\
\hline 55 & Av. Dep. João Batista Dias, s/n, São Raimundo Nonato, PI \\
\hline 56 & Rua Andrade Neves, 1510, cj. 12/14, Cachoeira do Sul, RS \\
\hline 57 & Avenida Vivaldi, 1421, São Paulo, SP \\
\hline 58 & Palacio Rio Madeira, Ed. Rio Jamari, $1^{\circ}$ piso, Porto Velho, RO \\
\hline 59 & Av. Adilia Barbosa Neves, 2340, São Paulo, SP \\
\hline 60 & Rua do Sossego, 355, Recife, PE \\
\hline 61 & Rodovia João Gualberto Soares, s/n, Km 11, Florianópolis, SC \\
\hline 62 & Av. Pedroso de Morais, 631, cj. 16, São Paulo, SP \\
\hline 63 & Av. Benjamin Constant, 2197, Lajeado, RS \\
\hline 64 & Rua Silvio Modesto de Souza, 540, Nova Lavras, MG \\
\hline 65 & Av. Paulista, 807, 15a andar, cj. 1521, São Paulo, SP \\
\hline 66 & Estrada Municipal da Pedra Branca, s/n, Socorro, SP \\
\hline 67 & Col. Witmarsum, s/n, Palmeira, PR \\
\hline 68 & Av. Pineville, 450, Pinhais, PR \\
\hline 69 & Rua Ó de Almeida, 1083, Belém, PA \\
\hline 70 & Rua Cláudio Manuel Dias Leite, 50, Fortaleza, Ceará \\
\hline 71 & Av. Engenheiro Camacho, 475, Ouricuri, PE \\
\hline 72 & AV. Rio Branco, 257, sala 508, Rio de Janeiro, RJ \\
\hline 73 & Av. Getulio Vargas, 1900, Piraquara, $\mathrm{Pr}$ \\
\hline 74 & Av. Marechal Deodoro da Fonseca, 776, sala 01, Jaraguá do Sul, SC \\
\hline 75 & Av. Centenário, 4243, Criciúma, SC \\
\hline 76 & Rua Quatorze de Outubro, 370, Guaíba, RS \\
\hline 77 & Rua Itararé, 712, Carazinho, RS \\
\hline 78 & Av. Augusto Ruschi, 1871, Serra, ES \\
\hline 79 & Av. Belo Horizonte, 195, Itu, SP \\
\hline 80 & Rua Lamenha Lins, 1080, Curitiba, PR \\
\hline 81 & Rua Bento de Andrade, 126, São Paulo, SP \\
\hline 82 & Rua Isaltina Paula Cidade, 44, São José, SC \\
\hline
\end{tabular}




\begin{tabular}{|c|c|}
\hline 83 & Rua Leandro Bezerra, 338, Crato, CE \\
\hline 84 & Rua do Cajueiro, 53, Petrolina, PE \\
\hline 85 & Rua Gonçalves Dias, 225, Curitiba, PR \\
\hline 86 & Rua Conego Ladeira, 437, São Paulo, SP \\
\hline 87 & Av. Jerônimo de Albuquerque, 25, São Luís, MA \\
\hline 88 & Rua José Cândido de Oliveira, 865, Angra dos Reis, RJ \\
\hline 89 & Rua Pontal, 61, Feira de Santana, BA \\
\hline 90 & Rua Santo Soriani, 11 \\
\hline 91 & Rua Iguassu, 1105, Dourados, MS \\
\hline 92 & Rua Anita Ribas, 753, Curitiba, PR \\
\hline 93 & Av. Papa João XXIII, 1565, Lages, SC \\
\hline 94 & Fazenda Bulcão, s/n, Aimorés, MG \\
\hline 95 & [Em mudança de endereço da sede social] \\
\hline 96 & Rua das Palmeiras, 90, Rio de Janeiro, RJ \\
\hline 97 & Rua Dr. Múcio Galvão, 449, Natal, RN \\
\hline 98 & Parque Estadual Fritz Plaumann, Concordia, SC \\
\hline 99 & Av. Historiador Rubens de Mendonça, 4193, Cuiabá, MT \\
\hline 100 & Rua Castro Alves, 20, 1ํandar, sala 01, Itabela, BA \\
\hline 101 & Av. Alexandre Torquetti, 151, Timóteo, MG \\
\hline 102 & Quadra 05, Lote 03, sala 207, Valparaíso de Goiás, GO \\
\hline 103 & Rua Princesa Isabel, 25, Domingos Martins, ES \\
\hline 104 & Rua Cônego Roque Viggiano, 44, São Paulo, SP \\
\hline 105 & Rua Rondônia, 616, Aracaju, SE \\
\hline 106 & Av. Val Paraiso, 620, cj. Palmeira, Fortaleza, CE \\
\hline 107 & Av. 85, 1760, Quadra 20 Lote 11E, sala 105, Goiânia, GO \\
\hline 108 & Rua Padre Carapuceiro, 968, sala 1406, Recife, PE \\
\hline 109 & Rua Nova Cidade, 193, São Paulo, SP \\
\hline 110 & Rua Afonso Pena, 10, Vila Velha, ES \\
\hline 111 & Rua General Rabelo, 43, Rio de Janeiro, RJ \\
\hline 112 & Av. Sete, 634, Ituiutaba, MG \\
\hline 113 & Rua Capitão Francisco Durski Silva, 1520, Prudentópolis, PR \\
\hline 114 & Rua Duque de Caxias, 671, ap. 504, Porto Alegre, RS \\
\hline 115 & Av. dos Pinheirais, 684, Natal, RN \\
\hline 116 & Av. Manoel Borba, 545, 1ํandar, Recife, PE \\
\hline 117 & Rua Mena Barreto, 9, sala 204, Rio de Janeiro, RJ \\
\hline 118 & Rua Olimpio Leite da Silva, 77, Ilhabela, SP \\
\hline 119 & Rua Bela Cintra, 952, São Paulo, SP \\
\hline 120 & Rua São Paulo, 165, Lagoa da Prata, MG \\
\hline 121 & Av. Visconde de Suassuna, 607, Recife, PE \\
\hline 122 & Rua Fulvio Aducci, 710, Florianópolis, SC \\
\hline 123 & Rua Pontal, 61, Feira de Santana, BA \\
\hline 124 & Rua Floriano Peixoto, 480, Ribeirão Preto, SP \\
\hline
\end{tabular}




\begin{tabular}{|c|c|}
\hline 125 & Rua Vicente Galafassi, 275, compl. 20, São Bernardo do Campo, SP \\
\hline 126 & Rua João Elias Saada, 46, São Paulo, SP \\
\hline 127 & Rua Esteves Júnior, 447, Florianópolis, SC \\
\hline 128 & Rua Flamenguinho, 65, Ubatuba, SP \\
\hline 129 & Av. Dr. Chucri Zaidan, 1550, cj. 1208, São Paulo, SP \\
\hline 130 & Estrada das Furnas, s/n, Rio de Janeiro, RJ \\
\hline 131 & Rua Joao Pires, 947, Atibaia, SP \\
\hline 132 & Rua João Pinheiro, 350, Passos, MG \\
\hline 133 & Rua Dr. Guilherme, 44, Itabirito, MG \\
\hline 134 & Rua Mato Grosso, 77, loja 02, Londrina, PR \\
\hline 135 & Rua Largo São Vicente de Paulo, 1333, Toledo, PR \\
\hline 136 & Av. Ângelo Altoé, 920, Venda Nova do Imigrante, ES \\
\hline 137 & Av. Carlos Ermelindo Marins, 494, Niterói, RJ \\
\hline 138 & Rua Duque de Caxias, 304, Horizontina, RS \\
\hline 139 & Estrada Geral Alto Dona Luiza, Atalanta, SC \\
\hline 140 & Av. Jorge João Saad, 241, 1ํandar, São Paulo, SP \\
\hline 141 & Rua Viradouro, 63, São Paulo, SP \\
\hline 142 & Rua Dores do Indaiá, 17, Patos de Minas, MG \\
\hline 143 & Av. Higienópolis, 901, São Paulo, SP \\
\hline 144 & Rua Iperoig, 742, São Paulo, SP \\
\hline 145 & Av. Alcindo Morndim fundos, Tambaú, SP \\
\hline 146 & Cidade Universitária USP, São Paulo, SP \\
\hline 147 & Av. Prof. Luciano Gualberto, trav. 3, 380, Cidade Universitária, São Paulo, SP \\
\hline 148 & Av. Gov. José Malcher, 189, Belém, PA \\
\hline 149 & Av. dos Expedicionários, 342, sala 72, Rolândia, PR \\
\hline 150 & Rua Maria Araújo, 450, Rio Grande, RS \\
\hline 151 & Av. Lino Jardim, 905, Santo André, SP \\
\hline 152 & Alameda Júlia da Costa, 362, Curitiba, PR \\
\hline 153 & Rua Xingú, 833, Pato Branco, PR \\
\hline 154 & SCS Quadra 06, Ed. José Severo, $6^{\circ}$ andar, sala 620, Asa Sul, Brasilia, DF \\
\hline 155 & Av. Basílio Sautchuk, 368, Maringá, PR \\
\hline 156 & [Não respondeu] \\
\hline 157 & Rua Aristides Novis, 101, Salvador, BA \\
\hline 158 & Rua dos Mundurucus, 1613, Belém, PA \\
\hline 159 & Av. São Paulo, 1068, Bento Gonçalves, RS \\
\hline 160 & Rua Rio Grande do Norte, 66/54, Santos, SP \\
\hline 161 & Rod. D. Pedro I, km 47, Nazaré Paulista, SP \\
\hline 162 & Rua Ariosto da Riva, 3473, Alta Floresta, MT \\
\hline 163 & Rua Mal. Floriano Peixoto, 2151L, Chapecó, SC \\
\hline 164 & Av. Gov. José Fragelli, 1050, São Félix do Araguaia, MT \\
\hline 165 & Rua Amador Bueno, 811, São Paulo, SP \\
\hline 166 & Rod. GO 239, s/n, Alto Paraíso de Goiás, GO \\
\hline
\end{tabular}




\begin{tabular}{|c|c|}
\hline 167 & Av. Anhanguera, 5440, Goiânia, GO \\
\hline 168 & Rua José Flamino Barbosa, 142, Cunha, SP \\
\hline 169 & Rua General Carneiro, 270, Itacoatiara, AM \\
\hline 170 & Rod. MG 179 KM 0, Alfenas, MG \\
\hline 171 & Rua 22, Casa 8, São Cristóvão, Zumbi dos Palmares, Manaus, AM \\
\hline 172 & Rua Montalvania, 1357, Bom Despacho, MG \\
\hline 173 & Rua Alto do Menino Deus, casa 22, Santa Maria da Vitória, BA \\
\hline 174 & Rua Julio Cesar Boechat, 126, Mococa, SP \\
\hline 175 & Rua Dom Pedro II, 1892, sala7, Porto Velho, RO \\
\hline 176 & Rua E, 230, Januária, MG \\
\hline 177 & Rua Geraldo Nogueira Leite, 1735, Assis, SP \\
\hline 178 & Rua Mário de Alencar, 239, São Paulo, SP \\
\hline 179 & Av. Augusto Ruschi, 1871, Serra, ES \\
\hline 180 & Estrada do Ribeirão Acima, km01, Nazaré Paulista, SP \\
\hline 181 & Estrada do Borba Gato, 56, Itapecerica da Serra, SP \\
\hline 182 & Rua Eliseu Guilherme, 267, sala 10, Ribeirão Preto, SP \\
\hline 183 & SHIS QI 05, cj. 10, Casa 1, Brasília, DF \\
\hline 184 & Rod. Péricles Belini, km 122, Votuporanga, SP \\
\hline 185 & Rua Planalto, 167, Fortaleza, CE \\
\hline 186 & Servidão Caminho da Costa, 333, Florianópolis, SC \\
\hline 187 & Rua Salvador, $120,12^{\circ}$ andar, sala 1201 , Manaus, AM \\
\hline 188 & Av. 21, 1095, Ituiutaba, MG \\
\hline 189 & Rua Eng. Carlos Stevenson, 1076, Campinas, SP \\
\hline 190 & Rua Dores do Indaiá, 17, 5 andar, Patos de Minas, MG \\
\hline 191 & Rua Adriano Schaefer, 182, Brusque, SC \\
\hline 192 & Rua Jericó, 255, cj. 81, São Paulo, SP \\
\hline 193 & Rua dos Andradas, 1137 , sala 2205, Porto Alegre, RS \\
\hline 194 & Av. Marcolino Martins Cabral, $1788,2^{\circ}$ andar, Tubarão, SC \\
\hline 195 & Rua dos Democratas, 975, São Paulo, SP \\
\hline 196 & Rua Visconde de Guarapuava, 3410, Curitiba, PR \\
\hline 197 & Rua Macapá, 72, Ilhabela, SP \\
\hline 198 & Rua Comandante Superior, 1349, Serra Talhada, PE \\
\hline 199 & Rua Oswaldo Cruz, 01, sala 1508, Fortaleza, CE \\
\hline 200 & Rua Amacás, 243, Campo Limpo Paulista, SP \\
\hline 201 & SGAS Quadra 601, cj. B, Ed. Providência, 1ํandar, Brasília, DF \\
\hline 202 & Rua José Serrano Navarro, 240, João Pessoa, PB \\
\hline 203 & Alameda do Açude do Cedro, s/n, Quixadá, CE \\
\hline 204 & Rua Eduardo Sprada, 4520, Curitiba, PR \\
\hline 205 & Rua Joaquim José Antunes, 403, Florianópolis, SC \\
\hline 206 & Av. Vereador Hermínio Moreira, 178, Itaboraí, RJ \\
\hline 207 & Av. Diógenes Ribeiro de Lima, 1132, São Paulo, SP \\
\hline 208 & Rodovia BA 093, Km 7. Simões Filho, Bahia \\
\hline
\end{tabular}




\begin{tabular}{|l|l|}
209 & Rua Emiliano Cardoso de Mello, 46, São Paulo, SP \\
\hline 210 & Avenida J.K., 220, Piumhi, MG \\
\hline 211 & Av. Custodio Silva, 1022/102, Ponte Nova, MG \\
\hline 212 & Rua Sampaio Viana, 190, 3o andar, São Paulo, SP \\
\hline 213 & Rua Fortunato Ramos, 123, Vitória, ES \\
\hline 214 & Rua 03, 391, Cuiabá, MT \\
\hline 215 & Rua São Joaquim, 381, São Paulo, SP \\
\hline 216 & Rua Vanio Ghellere, 64, São Miguel do Iguaçú, PR \\
\hline 217 & Rua da Moeda, 1646, Três Lagoas, MS \\
\hline 218 & Rua Américo Rodrigues, 77, São Gonçalo, RJ \\
\hline
\end{tabular}




\section{Apêndice 6. Nomes dos respondentes das organizações}

\section{participantes}

\begin{tabular}{|c|l|}
\hline 1 & Beatriz Ribas \\
\hline 2 & Stefano Merlin \\
\hline 3 & Emmanuel Ponte \\
\hline 4 & Roberto Campos Junior \\
\hline 5 & Abilio Valério Tozini \\
\hline 6 & Maércio Diogo \\
\hline 7 & Rogério lório \\
\hline 8 & Jefferson Schreiber \\
\hline 9 & José Carlos Marques \\
\hline 10 & Geise Terra \\
\hline 11 & Francisca Cristina Lopes Ferreira \\
\hline 12 & Luiz Carlos \\
\hline 13 & Jale Pedroso da Silva \\
\hline 14 & Eliz Tessinari \\
\hline 15 & Lucia Helena Batista Gratão \\
\hline 16 & Fabrício Gandini \\
\hline 17 & Suelen da Costa Chaves \\
\hline 18 & Vitor Hugo Hollas \\
\hline 19 & Fabiana Barbosa Gomes \\
\hline 20 & Marcelle Dias Faria \\
\hline 21 & Marcondes Braga de Moraes \\
\hline 22 & Lucas Pizzol \\
\hline 23 & Ivana Lima \\
\hline 24 & Vittorio Gilberto Zottino \\
\hline 25 & Hudson Tercio Pinheiro \\
\hline 26 & Júlia Fagan \\
\hline 27 & Eli \\
\hline 28 & Camila Jericó-Daminello \\
\hline 29 & Ulisses Mansur \\
\hline 30 & José Alves \\
\hline 31 & Silvio R. Sant'Ana \\
\hline 32 & Adauri Souza \\
\hline 33 & Emídio Gonçalves de Medeiros \\
\hline 34 & Elizabete Lino de Oliveira \\
\hline 35 & Geisi Azevedo \\
\hline 36 & Gabriela Bispo da Silva \\
\hline 37 & Bárbara Bethânia de Paula Pinto \\
\hline 38 & Ivaneide Bandeira Cardozo \\
\hline & \\
\hline
\end{tabular}




\begin{tabular}{|l|l|}
\hline 39 & lolânda Almeida Santos Matos \\
\hline 40 & Gustavo Alberto \\
\hline 41 & Aline Locks \\
\hline 42 & Andrea Godoy Herrea \\
\hline 43 & Alex Ramalho \\
\hline 44 & Dário Ferreira Emerenciano \\
\hline 45 & Lurdes Dorta \\
\hline 46 & Lucimara \\
\hline 47 & Irene Gomes Guedes \\
\hline 48 & Márcia R. Teschner \\
\hline 49 & Onofre Moreira dos Santos \\
\hline 50 & Maribel Rodrigues \\
\hline 51 & Marcio Lessa \\
\hline 52 & Jadirson Alves da Silva \\
\hline 53 & Deisy Nascimento \\
\hline 54 & Alesandra Bez Birolo \\
\hline 55 & Niéde Guidon \\
\hline 56 & Telmo Padilha Cesar \\
\hline 57 & Nelson Reis Claudino Pedroso \\
\hline 58 & Enoque Gonçalves de Oliveira \\
\hline 59 & Cassio Benatti \\
\hline 60 & Maria Cristina Aureliano de Melo \\
\hline 61 & Cristiane K. M. Kolesnikovas \\
\hline 62 & Marcia Kalvon Woods \\
\hline 63 & Miriam Teresinha volkmer Destefani \\
\hline 64 & Evaldo Cristiano Garcia \\
\hline 65 & Bergman Santos \\
\hline 66 & Flávia Balderi \\
\hline 67 & Erhard Friesen \\
\hline 68 & Arilton Portella \\
\hline 69 & Swellen Barbosa \\
\hline 70 & Daniel Fernandes \\
\hline 71 & Kátia Rejane Holanda Lopes \\
\hline 72 & Maria Cristina Moreira \\
\hline 73 & Sandro Leão Sávio \\
\hline 74 & Mariane Pedrelli Demarchi \\
\hline 75 & Eduardo R Manenti \\
\hline 76 & Guilherme Lessa Bica Machado \\
\hline 77 & Vera Anita Suckau \\
\hline 78 & Iberê Sassi \\
\hline 79 & Celia Maria Gardino Barbin \\
\hline 80 & Helena Zarantonielli da Costa \\
\hline & \\
\hline
\end{tabular}




\begin{tabular}{|c|c|}
\hline 81 & Aline F. Paschoalino \\
\hline 82 & Paulo Douglas \\
\hline 83 & Perre Maurice Gervaiseau \\
\hline 84 & Aluisio Ferreira Gomes \\
\hline 85 & Bianca Brasil \\
\hline 86 & Nabil Onaissi \\
\hline 87 & Maurício Vieira de Paula \\
\hline 88 & Irene Chada Ribeiro \\
\hline 89 & Maria José Esteves \\
\hline 90 & Izaias parreira \\
\hline 91 & Mario Vito Comar \\
\hline 92 & Priscilla Arruda \\
\hline 93 & Natal João Magnanti \\
\hline 94 & Paulo Henrique Ribeiro \\
\hline 95 & Gilson Barbosa de Lima \\
\hline 96 & Marcio Mattos de Mendonça \\
\hline 97 & Conceição Bezerra \\
\hline 98 & Rafael Leão \\
\hline 99 & Francielly de Almeida Mendanha \\
\hline 100 & Jeane D. Ajuda Apelfeler O. dos Santos \\
\hline 101 & Grazielle Araujo Martins Torres Torqueti \\
\hline 102 & Carlos Roberto Silva \\
\hline 103 & [Não respondeu] \\
\hline 104 & Aldrey Riechel \\
\hline 105 & Alex Federle do Nascimento \\
\hline 106 & João Joaquim de Melo Neto Segundo \\
\hline 107 & Paulo D'Ávila Ferreira \\
\hline 108 & Juliana da Paz \\
\hline 109 & Igor Leme Damianof \\
\hline 110 & Tamara \\
\hline 111 & Nina Almeida Braga \\
\hline 112 & Odeon Nunes Barcelos \\
\hline 113 & Vânia Mara Moreira dos Santos \\
\hline 114 & José Carlos Tarasconi \\
\hline 115 & José Salim \\
\hline 116 & Wladimir Cardoso Reis \\
\hline 117 & Leandro Guerise \\
\hline 118 & Carlos Roberto Nunes \\
\hline 119 & Rejane Romano Silveira \\
\hline 120 & Ricardo Oliveira \\
\hline 121 & José Ventura Sobrinho \\
\hline 122 & Wilson Vamerlati Dutra \\
\hline
\end{tabular}




\begin{tabular}{|c|c|}
\hline 123 & Maria Neuza Rios \\
\hline 124 & Diva Garcia Reis \\
\hline 125 & Elaine Santos \\
\hline 126 & Isis Nóbile Diniz \\
\hline 127 & Fernando Anisio Batista \\
\hline 128 & José Marcelo da Silva \\
\hline 129 & lago Rangel \\
\hline 130 & Fabiane Luisi Turisco \\
\hline 131 & Vinícius Gaburro De Zorzi \\
\hline 132 & Davi de Oliveira \\
\hline 133 & Elizabeth Lima \\
\hline 134 & Andresa de Lima Rossato \\
\hline 135 & Marco Rothe \\
\hline 136 & Loreda Venturim \\
\hline 137 & Joanna Dutra \\
\hline 138 & Tiago Dotto de Almeida \\
\hline 139 & Grasiela Hoffmann \\
\hline 140 & Luis Eduardo Cardoso de Almeida Salvatore \\
\hline 141 & Andrea Lopes \\
\hline 142 & Regina Aparecida Nunes e Silva \\
\hline 143 & Bruno Weis \\
\hline 144 & Cybele da Silva \\
\hline 145 & Gustavo do Valle Silvestre \\
\hline 146 & Sokan Kato Young \\
\hline 147 & Guilherme Turra \\
\hline 148 & Maria Eugenia Melo \\
\hline 149 & Alexandre Farina \\
\hline 150 & Sérgio Curi Estima \\
\hline 151 & Samir Rezende Siviero \\
\hline 152 & Adriano Luiz dos Santos \\
\hline 153 & Angelo Silva \\
\hline 154 & Cleudison de Araujo \\
\hline 155 & Jean Flávio Zanchetti \\
\hline 156 & Silvia Regina de Almeida \\
\hline 157 & Luciana Rios \\
\hline 158 & Iran Paz Pires \\
\hline 159 & Caroline de Lima Frare \\
\hline 160 & Luciene Borges das Neves \\
\hline 161 & Paula Piccin \\
\hline 162 & Raissa \\
\hline 163 & Odair Balen \\
\hline 164 & Vania Costa Aguiar \\
\hline
\end{tabular}




\begin{tabular}{|l|l|}
\hline 165 & Clovis Moura \\
\hline 166 & Andreza Girardi \\
\hline 167 & Cintia Amorim \\
\hline 168 & Alketa Bestaku \\
\hline 169 & Ana Luiza Pellegrini Vergueiro \\
\hline 170 & Brassilda Aparecida Dias \\
\hline 171 & Rosemeri \\
\hline 172 & Ricardo Medeiros \\
\hline 173 & Josenildo de S. Barbosa \\
\hline 174 & Eliana de Fátima Santana \\
\hline 175 & Gabriel Fleming \\
\hline 176 & Tatiane Mendes da Rocha \\
\hline 177 & Robinson Domingues \\
\hline 178 & Eduardo \\
\hline 179 & Iberê Sassi \\
\hline 180 & David Arnaldo Silveira Ferreira \\
\hline 181 & Vicente Define Neto \\
\hline 182 & Guilherme Duarte Martins \\
\hline 183 & Luis Tadeu Assad \\
\hline 184 & André Luiz Sanchez Navarro \\
\hline 185 & Alilian Gradela \\
\hline 186 & Eduardo Schnitzler Moure \\
\hline 187 & Adriann Sahdo \\
\hline 188 & Ana Cristina Marquez Gouveia \\
\hline 189 & Tatiana Yoshida \\
\hline 190 & Sílvia \\
\hline 191 & Larissa Fachini \\
\hline 192 & Joyce Capelli \\
\hline 193 & Lívia Zanatta \\
\hline 194 & Ruben Cesar Reinoso \\
\hline 195 & Carlos Chinen \\
\hline 196 & Francisco R. Essert \\
\hline 197 & Inês Bianchi \\
\hline 198 & Espedito Brito Brasil \\
\hline 199 & João Bosco Priamo Carbognin \\
\hline 200 & Anadelli Soares Braz \\
\hline 201 & Marcia Villas Boas Ramos \\
\hline 202 & [Não respondeu] \\
\hline 203 & Osvaldo Alves de Andrade filho \\
\hline 204 & Renê Galiciolli \\
\hline 205 & Harrysson Luiz da Silva \\
\hline 206 & Washington Carlos Silva \\
\hline & \\
\hline
\end{tabular}




\begin{tabular}{|c|l|}
\hline 207 & Milton Diniz Junior \\
\hline 208 & Anne Brito \\
\hline 209 & Márcia Regina Denadai \\
\hline 210 & Helder Antonio de Oliveira \\
\hline 211 & Rafael Esteban Armas \\
\hline 212 & Ana Maria Domingues Luz \\
\hline 213 & Marcelo Renan \\
\hline 214 & Karen Regina Domingo Sobreira \\
\hline 215 & Ana Aoki \\
\hline 216 & Luciano Aparecido Neris \\
\hline 217 & Valdei José Santos da Silva \\
\hline 218 & Simone Monteiro \\
\hline
\end{tabular}




\section{Apêndice 7. E-mails das organizações participantes}

\begin{tabular}{|c|c|}
\hline 1 & biaribas@tamar.org.br \\
\hline 2 & stefano@ecologica.org.br \\
\hline 3 & esponte@gmail.com \\
\hline 4 & becamposjr@bemcomum.org.br \\
\hline 5 & alma@centroin.com.br \\
\hline 6 & maercio.diogo@quintessa.org.br \\
\hline 7 & presidente@ibdn.org.br \\
\hline 8 & jefferson@ipeptr.org.br \\
\hline 9 & josemarques@innatus.org.br \\
\hline 10 & degrafdegraf@mednet.com.br \\
\hline 11 & cristina@caatinga.org.br \\
\hline 12 & faep@faep.org.br \\
\hline 13 & jale.fsa@hotmail.com \\
\hline 14 & eliztessinari@sosamazonia.org.br \\
\hline 15 & ana@copati.org.br \\
\hline 16 & fabricio@maramar.org.br \\
\hline 17 & acib-ma@hotmail.com \\
\hline 18 & vitor@capa.org.br \\
\hline 19 & fabiana@rioterra.org.br \\
\hline 20 & marcelle.faria@lafargeholcim.com \\
\hline 21 & marcondes@ibcbrasil.org.br \\
\hline 22 & lucas@pizzolcontabil.com.br \\
\hline 23 & ivanalimaesilva@gmail.com \\
\hline 24 & zottinogv@gmail.com \\
\hline 25 & htpinheiro@gmail.com \\
\hline 26 & julia@institutosiccob.org.br \\
\hline 27 & elicircuitoverde@gmail.com \\
\hline 28 & camila@conservation-strategy.org \\
\hline 29 & ulisses@brigadamirim.org.br \\
\hline 30 & josealvesom6@gmail.com \\
\hline 31 & silvio@esquel.org.br \\
\hline 32 & adauri@baiadeguanabara.org.br \\
\hline 33 & emidioserido@hotmail.com \\
\hline 34 & elizabete@amda.org.br \\
\hline 35 & azevedogeisi@yahoo.com.br \\
\hline 36 & bispogabriela03@gmail.com \\
\hline 37 & projetos@unas.org.br \\
\hline 38 & neidinhasurui@gmail.com \\
\hline 39 & appjconviver@yahoo.com.br \\
\hline 40 & nucon@uol.com.br \\
\hline
\end{tabular}




\begin{tabular}{|c|c|}
\hline 41 & aline.locks@aliancadaterra.org \\
\hline 42 & andrea@sosma.org.br \\
\hline 43 & alex.ramalho@usinacoruripe.com.br \\
\hline 44 & darioemerenciano@terra.com.br \\
\hline 45 & lurdesdorta@adej.org.br \\
\hline 46 & lucimara@ibflorestas.org.br \\
\hline 47 & irenegguedes@gmail.com \\
\hline 48 & marcia.teschner@floripamanha.org \\
\hline 49 & onofresantos42@gmail.com \\
\hline 50 & publicacoes@cebi.org.br \\
\hline 51 & oscipbioetica@gmail.com \\
\hline 52 & fazedterranova@gmail.com \\
\hline 53 & deisynascimento83@gmail.com \\
\hline 54 & ale@ekkobrasil.org.br \\
\hline 55 & guidon@fumdham.org.br \\
\hline 56 & padilha@defender.org.br \\
\hline 57 & nelsonpedroso@agds.org.br \\
\hline 58 & ascom@emater-ro.com.br \\
\hline 59 & ong@capivarimonos.org.br \\
\hline 60 & maria@centrosabia.org.br \\
\hline 61 & cristiane@r3animal.org \\
\hline 62 & saap@saap.org.br \\
\hline 63 & miriam@informativo.com.br \\
\hline 64 & evaldoacamar@gmail.com \\
\hline 65 & ageplan@ageplan.org.br \\
\hline 66 & flavia.balderi@copaiba.org.br \\
\hline 67 & erhard.friesen@missaoamb.org \\
\hline 68 & aportella@ara-atualiza.com \\
\hline 69 & peabiru@peabiru.org.br \\
\hline 70 & daniel@acaatinga.org.br \\
\hline 71 & jane@caatinga.org.br \\
\hline 72 & preserv@preserv.org.br \\
\hline 73 & sandro@sanjulian.com.br \\
\hline 74 & administrativo@acrevi.com \\
\hline 75 & eduardo@credisol.org.br \\
\hline 76 & amaguaiba@gmail.com \\
\hline 77 & programayacamim@globo.com \\
\hline 78 & ibere@goiamum.org.br \\
\hline 79 & celiabarbin@hotmail.com \\
\hline 80 & helena@maternatura.org.br \\
\hline 81 & projeto@cempre.org.br \\
\hline 82 & Paulo@manguevivo.org.br \\
\hline
\end{tabular}




\begin{tabular}{|c|c|}
\hline 83 & pierre2013gervaiseau@gmail.com \\
\hline 84 & aluisiogomes.aluisio@gmail.com \\
\hline 85 & brasil@fundacaogrupoboticario.org.br \\
\hline 86 & nabil@institutolotus.org.br \\
\hline 87 & comunicacao@icema.org.br \\
\hline 88 & irere.ribe@gmail.com \\
\hline 89 & mariajose@moc.org.br \\
\hline 90 & parreiraizaias@gmail.com \\
\hline 91 & vitocomar@gmail.com \\
\hline 92 & ibioma@hotmail.com \\
\hline 93 & natalmagnanti@gmail.com \\
\hline 94 & paulohenrique@institutoterra.org \\
\hline 95 & catalisa@catalisa.org.br \\
\hline 96 & urbana@aspta.org.br \\
\hline 97 & ceicabsilva@gmail.com \\
\hline 98 & administrativo@ecopef.org.br \\
\hline 99 & francielly@acaoverde.org.br \\
\hline 100 & jeanenaturezabela@gmail.com \\
\hline 101 & grazielle@fundacaoemalto.com.br \\
\hline 102 & carlosrobertosaff@gmail.com \\
\hline 103 & info@institutoverdebrasil.org \\
\hline 104 & aldrey@amazonia.org.br \\
\hline 105 & cdjbc@cdjbc.org.br \\
\hline 106 & joaquim@bancopalmas.org.br \\
\hline 107 & paulodavilaboxexa@gmail.com \\
\hline 108 & juliana.paz@iadh.org.br \\
\hline 109 & igor@fundacaostickel.org.br \\
\hline 110 & adm@movive.org.br \\
\hline 111 & nina@institutoe.org.br \\
\hline 112 & coperciclaitba@hotmail.com \\
\hline 113 & vaniaing@uol.com.br \\
\hline 114 & cenemar@terra.com.br \\
\hline 115 & salimarte@gmail.com \\
\hline 116 & wladimirreisgtp@yahoo.com.br \\
\hline 117 & leandro@atlantis.eco.br \\
\hline 118 & carlos.nunes@iis.org.br \\
\hline 119 & rromano@ethos.org.br \\
\hline 120 & cbhsf1@yahoo.com.br \\
\hline 121 & joseventura@ceape-pe.org.br \\
\hline 122 & wilson@bancodoempreendedor.org.br \\
\hline 123 & moc@moc.org.br \\
\hline 124 & divagarciareis@hotmail.com \\
\hline
\end{tabular}




\begin{tabular}{|c|c|}
\hline 125 & contato@ecolmeia.org.br \\
\hline 126 & isis@iniciativaverde.org.br \\
\hline 127 & fernando@arquifln.org.br \\
\hline 128 & aumar.ubatuba@gmail.com \\
\hline 129 & iago.rangel@ekosbrasil.org \\
\hline 130 & fabiane.turisco@pronatura.org.br \\
\hline 131 & viniciuszorzi@gmail.com \\
\hline 132 & daviisepem@gmail.com \\
\hline 133 & beth.lima@adesita.org.br \\
\hline 134 & icclon@sercomtel.com.br \\
\hline 135 & marco.rothe@garantioeste.org.br \\
\hline 136 & loreda@hotelesmig.com.br \\
\hline 137 & joannadutra@rumonautico.org.br \\
\hline 138 & tiago@aciaphz.com.br \\
\hline 139 & grasiela@apremavi.org.br \\
\hline 140 & luis@brasilsolidario.org.br \\
\hline 141 & andrealopes@etco.org.br \\
\hline 142 & regina@bancodagente.com.br \\
\hline 143 & bruno@socioambiental.org \\
\hline 144 & ecojureia@ecojureia.org.br \\
\hline 145 & verdetambau@verdetambau.com.br \\
\hline 146 & sokan@uol.com.br \\
\hline 147 & guiturra@yahoo.com.br \\
\hline 148 & radiomargarida@radiomargarida.org.br \\
\hline 149 & alexandre@terraroxa.org.br \\
\hline 150 & nema@nema-rs.org.br \\
\hline 151 & samir@acqua.org.br \\
\hline 152 & adriano@aliancaempreendedora.org.br \\
\hline 153 & institutoregional@irdes.org.br \\
\hline 154 & brasilforte.oscip@bol.com.br \\
\hline 155 & jean@noroestegarantias.com.br \\
\hline 156 & sralmeida.omolara@gmail.com \\
\hline 157 & comunicacao@sasop.org.br \\
\hline 158 & elias@ift.org.br \\
\hline 159 & caroline.lima@proamb.com.br \\
\hline 160 & borgeslucky@gmail.com \\
\hline 161 & paula@ipe.org.br \\
\hline 162 & raissa.genro@icv.org.br \\
\hline 163 & obalen@verdevida.org.br \\
\hline 164 & ansaraguaia@ansaraguaia.org.br \\
\hline 165 & diretoria@laborevita.org.br \\
\hline 166 & diretoria@ocabrasil.org \\
\hline
\end{tabular}




\begin{tabular}{|c|c|}
\hline 167 & cintiaamorim@sistemafieg.org.br \\
\hline 168 & serracima@serracima.org.br \\
\hline 169 & analuiza@institutoexcelsa.org \\
\hline 170 & microfenas@unifenas.br \\
\hline 171 & financeiro2@oela.org.br \\
\hline 172 & ricardombc10@gmail.com \\
\hline 173 & jsbbahiabrasil@yahoo.com.br \\
\hline 174 & contato@cafeigarai.com.br \\
\hline 175 & foto@gabrieluchida.com \\
\hline 176 & caritasjanuaria@gmail.com.br \\
\hline 177 & robinsondomingues@gmail.com \\
\hline 178 & eduardo@institutomeio.org \\
\hline 179 & ibere@goiamum.org.br \\
\hline 180 & wayandavi@gmail.com \\
\hline 181 & vicente@caosemdono.com.br \\
\hline 182 & guilherme@antas.org.br \\
\hline 183 & assadmar@iabs.org.br \\
\hline 184 & alsnavarro@gmail.com \\
\hline 185 & aagradela@yahoo.com.br \\
\hline 186 & eduardosmoure@gmail.com \\
\hline 187 & adriann@iteiamazon.org \\
\hline 188 & caiaponiainstituto@gmail.com \\
\hline 189 & t.yoshida@tft-earth.org \\
\hline 190 & adesp@adesppatos.org.br \\
\hline 191 & larissa@profomento.com.br \\
\hline 192 & jcapelli@inmed.org.br \\
\hline 193 & livia@themis.org.br \\
\hline 194 & adram@adram.org \\
\hline 195 & passatempo@passatempoeducativo.org.br \\
\hline 196 & francisco@gerar.org.br \\
\hline 197 & ines@pesnochao.org.br \\
\hline 198 & brasil@cecor.org.br \\
\hline 199 & bosco@promosell.com.br \\
\hline 200 & anadelli@vocacao.org.br \\
\hline 201 & marcia.ramos@programaprovidencia.org.br \\
\hline 202 & essor@essorbrasil.org \\
\hline 203 & osandrade61@gmail.com \\
\hline 204 & rgaliciolli@ipcc.org.br \\
\hline 205 & [Não respondeu] \\
\hline 206 & abrigo@abrigo.se \\
\hline 207 & miltondiniz.jr@orbesfx.org.br \\
\hline 208 & comunicar@terramirim.org.br \\
\hline
\end{tabular}




\begin{tabular}{|l|l|}
\hline 209 & denadai@costabrasilis.org.br \\
\hline 210 & sinhanaeva@gmail.com \\
\hline 211 & presidente.rafaelesteban@itev.org.br \\
\hline 212 & contato@institutogea.org.br \\
\hline 213 & mrenansantos@gmail.com \\
\hline 214 & karendomingo@gmail.com \\
\hline 215 & secadm@bunkyo.org.br \\
\hline 216 & neris@innet.com.br \\
\hline 217 & valdei@use.org.br \\
\hline 218 & simone.ius@gmail.com \\
\hline
\end{tabular}




\section{Apêndice 8. Telefones das organizações participantes}

\begin{tabular}{|l|l|}
\hline 1 & $(71) 99979-6661$ \\
\hline 2 & $(11) 99400-1232$ \\
\hline 3 & $(11) 95485-5545$ \\
\hline 4 & $(11) 5666-6893$ \\
\hline 5 & $(21) 9965-1898$ \\
\hline 6 & $(11) 98828-9442$ \\
\hline 7 & $(11) 3532-0163$ \\
\hline 8 & $(41) 98401-3666$ \\
\hline 9 & $(24) 98868-1057$ \\
\hline 10 & $(34) 3317-0402$ \\
\hline 11 & $(87) 3874-1258$ \\
\hline 12 & $(11) 4798-7083$ \\
\hline 13 & $(44) 99708-0978$ \\
\hline 14 & $(68) 98422-1284$ \\
\hline 15 & $(43) 99618-3661$ \\
\hline 16 & $(13) 2202-8506$ \\
\hline 17 & $(98) 3228-5427$ \\
\hline 18 & $(54) 3321-5951$ \\
\hline 19 & $(69) 9996-1181$ \\
\hline 20 & $(22) 2555-0405$ \\
\hline 21 & $(62) 3604-0750$ \\
\hline 22 & $(11) 5585-9585$ \\
\hline 23 & $(38) 99123-3300$ \\
\hline 24 & $(19) 99258-4185$ \\
\hline 25 & $(27) 3324-0114$ \\
\hline 26 & $(44) 3032-7785$ \\
\hline 27 & $(31) 9922-5014$ \\
\hline 28 & $(21) 3875-8235$ \\
\hline 29 & $(24) 3361-5301$ \\
\hline 30 & $(77) 3622-2329$ \\
\hline 31 & $(61) 3322-2062$ \\
\hline 32 & $(21) 2625-4311$ \\
\hline 33 & $(84) 3417-2948$ \\
\hline 34 & $(31) 3291-0661$ \\
\hline 35 & $(79) 98107-9232$ \\
\hline 36 & $(81) 98723-9572$ \\
\hline 37 & $(11) 2272-0140$ \\
\hline 38 & $(69) 3229-2826$ \\
\hline 39 & $(74) 3676-6021$ \\
\hline 40 & $(84) 3613-1754$ \\
\hline & \\
\hline
\end{tabular}




\begin{tabular}{|l|l|}
\hline 41 & $(62) 98136-6672$ \\
\hline 42 & $(11) 3262-4088$ \\
\hline 43 & $(82) 99127-5787$ \\
\hline 44 & $(81) 3432-1807$ \\
\hline 45 & $(11) 4582-1584$ \\
\hline 46 & $(43) 3324-7551$ \\
\hline 47 & $(38) 99957-2671$ \\
\hline 48 & $(48) 99987-0097$ \\
\hline 49 & $(95) 99164-7026$ \\
\hline 50 & $(51) 3568-2560$ \\
\hline 51 & $(82) 99928-3943$ \\
\hline 52 & $(98) 98197-0545$ \\
\hline 53 & $(82) 99910-4592$ \\
\hline 54 & $(48) 3237-5071$ \\
\hline 55 & $(89) 3582-1717$ \\
\hline 56 & $(51) 98577-1637$ \\
\hline 57 & $(11) 97080-8817$ \\
\hline 58 & $(69) 99981-9644$ \\
\hline 59 & $(11) 4652-2020$ \\
\hline 60 & $(81) 3223-7026$ \\
\hline 61 & $(48) 3665-0492$ \\
\hline 62 & $(11) 3814-9206$ \\
\hline 63 & $(51) 3726-6700$ \\
\hline 64 & $(35) 99963-8663$ \\
\hline 65 & $(11) 3825-0510$ \\
\hline 66 & $(19) 99953-8382$ \\
\hline 67 & {$[$ Não respondeu] } \\
\hline 68 & $(41) 3335-3437$ \\
\hline 69 & $(91) 3222-6000$ \\
\hline 70 & $(85) 3241-0759$ \\
\hline 71 & $(87) 99937-0052$ \\
\hline 72 & $(21) 2210-1343$ \\
\hline 73 & $(041) 3673-8393$ \\
\hline 74 & $(47) 3275-0020$ \\
\hline 75 & $(48) 99616-2366$ \\
\hline 76 & $(51) 98422-0193$ \\
\hline 77 & $(54) 3330-2951$ \\
\hline 78 & $(27) 3238-9301$ \\
\hline 79 & $(11) 97183-9588$ \\
\hline 80 & $(41) 3013-7185$ \\
\hline 81 & $(11) 3889-7806$ \\
\hline 82 & $(48) 3248-3030$ \\
\hline & \\
\hline
\end{tabular}




\begin{tabular}{|c|c|}
\hline 83 & (88) 3523-1605 \\
\hline 84 & (87) 98806-0620 \\
\hline 85 & (41) 3318-2672 \\
\hline 86 & [Não respondeu] \\
\hline 87 & (98) 3303-1976 \\
\hline 88 & (21) $97199-7015$ \\
\hline 89 & (75) 3322-4428 \\
\hline 90 & (43) 99630-0040 \\
\hline 91 & [Não respondeu] \\
\hline 92 & (41) 99961-0992 \\
\hline 93 & (49) 3222-4255 \\
\hline 94 & (33) $3267-2025$ \\
\hline 95 & (11) 4249-1602 \\
\hline 96 & (21) 2253-8317 \\
\hline 97 & (84) 99608-7272 \\
\hline 98 & (49) 98839-1493 \\
\hline 99 & (65) 3611-1606 \\
\hline 100 & (73) 3270-2215 \\
\hline 101 & (31) 3845-4910 \\
\hline 102 & (61) $99217-5254$ \\
\hline 103 & (27) 3268-2068 \\
\hline 104 & (11) $3887-9369$ \\
\hline 105 & (79) 3259-6971 \\
\hline 106 & (85) 98724-2386 \\
\hline 107 & (62) 99972-7953 \\
\hline 108 & (81) 3425-4292 \\
\hline 109 & (11) $3083-2811$ \\
\hline 110 & (27) 3229-8822 \\
\hline 111 & (21) 98874-8183 \\
\hline 112 & (34) 3261-1171 \\
\hline 113 & (42) $99974-0680$ \\
\hline 114 & (51) 3221-4486 \\
\hline 115 & (84) 3217-8511 \\
\hline 116 & (81) 3231-0905 \\
\hline 117 & (21) 2225-7510 \\
\hline 118 & (12) 99793-7853 \\
\hline 119 & (11) 3897-2416 \\
\hline 120 & (37) 3261-9727 \\
\hline 121 & (81) 3231-4259 \\
\hline 122 & (48) 3348-0300 \\
\hline 123 & (75) 3322-4444 \\
\hline 124 & (16) 3877-7327 \\
\hline
\end{tabular}




\begin{tabular}{|l|l|}
\hline 125 & $(11) 98755-4533$ \\
\hline 126 & $(11) 3647-9293$ \\
\hline 127 & $(48) 3224-8776$ \\
\hline 128 & $(12) 3842-0304$ \\
\hline 129 & $(11) 5505-6371$ \\
\hline 130 & $(21) 2484-8323$ \\
\hline 131 & $(11) 96425-3931$ \\
\hline 132 & $(35) 98855-5191$ \\
\hline 133 & $(31) 3563-1958$ \\
\hline 134 & $(43) 3339-0065$ \\
\hline 135 & $(45) 3055-2604$ \\
\hline 136 & $(28) 3546-1213$ \\
\hline 137 & $(21) 2711-9875$ \\
\hline 138 & $(55) 3537-1868$ \\
\hline 139 & $(47) 98843-3035$ \\
\hline 140 & $(11) 98275-2727$ \\
\hline 141 & $(11) 3078-1716$ \\
\hline 142 & $(34) 99926-0322$ \\
\hline 143 & $(11) 3515-8965$ \\
\hline 144 & $(11) 3801-2667$ \\
\hline 145 & $(19) 3673-1179$ \\
\hline 146 & $(11) 98149-5847$ \\
\hline 147 & $(11) 98944-8227$ \\
\hline 148 & $(91) 99144-1156$ \\
\hline 149 & $(43) 99139-8738$ \\
\hline 150 & $(53) 3236-2420$ \\
\hline 151 & $(11) 4823-1800$ \\
\hline 152 & $(41) 9955-7242$ \\
\hline 153 & $(46) 3225-9256$ \\
\hline 154 & $(61) 99120-6555$ \\
\hline 155 & $(44) 3023-2283$ \\
\hline 156 & $(21) 97007-3989$ \\
\hline 157 & $(71) 3335-6049$ \\
\hline 158 & $(91) 99166-8455$ \\
\hline 159 & $(54) 3055-8728$ \\
\hline 160 & $(13) 9911-6200$ \\
\hline 161 & $(11) 97144-1103$ \\
\hline 162 & $(66) 3521-8555$ \\
\hline 163 & $(49) 3322-2776$ \\
\hline 164 & $(66) 3522-1638$ \\
\hline 165 & $(11) 5548-8613$ \\
\hline 166 & $(62) 3446-1166$ \\
\hline & \\
\hline
\end{tabular}




\begin{tabular}{|l|l|}
\hline 167 & $(62) 3225-8735$ \\
\hline 168 & $(12) 3111-1744$ \\
\hline 169 & $(11) 98145-3439$ \\
\hline 170 & $(35) 3299-3045$ \\
\hline 171 & $(92) 3638-2667$ \\
\hline 172 & $(37) 99861-1313$ \\
\hline 173 & $(61) 98266-3959$ \\
\hline 174 & $(19) 99757-5797$ \\
\hline 175 & $(69) 99926-1526$ \\
\hline 176 & $(38) 3621-3102$ \\
\hline 177 & $(18) 3323-3912$ \\
\hline 178 & $(11) 3813-6286$ \\
\hline 179 & $(27) 3238-9301$ \\
\hline 180 & $(11) 99604-4220$ \\
\hline 181 & $(35) 99144-9744$ \\
\hline 182 & $(16) 99766-7719$ \\
\hline 183 & $(61) 3364-6005$ \\
\hline 184 & $(17) 98203-0008$ \\
\hline 185 & $(85) 98810-5786$ \\
\hline 186 & $(48) 99632-4778$ \\
\hline 187 & $(92) 98427-2595$ \\
\hline 188 & $(34) 3261-6531$ \\
\hline 189 & $(19) 3251-1078$ \\
\hline 190 & $(34) 3823-3991$ \\
\hline 191 & $(47) 99984-8086$ \\
\hline 192 & $(11) 3815-9079$ \\
\hline 193 & $(51) 3212-0104$ \\
\hline 194 & $(48) 98834-4983$ \\
\hline 195 & $(11) 99757-9540$ \\
\hline 196 & $(41) 3039-6599$ \\
\hline 197 & $(12) 3894-9237$ \\
\hline 198 & $(87) 9992-3478$ \\
\hline 199 & $(85) 3089-5756$ \\
\hline 200 & $(11) 5843-2948$ \\
\hline 201 & $(61) 3321-1762$ \\
\hline 202 & $(83) 3235-8574$ \\
\hline 203 & $(88) 99984-3794$ \\
\hline 204 & $(41) 3040-1500$ \\
\hline 205 & {$[$ Não respondeu} \\
\hline 206 & $(21) 2632-1215$ \\
\hline 207 & $(12) 99795-1512$ \\
\hline 208 & {$[$ Não respondeu} \\
\hline & \\
\hline
\end{tabular}




\begin{tabular}{|l|l|}
\hline 209 & (11) $99881-6584$ \\
\hline 210 & (37) 33371-2111 \\
\hline 211 & [Não respondeu] \\
\hline 212 & $(11) 99121-5826$ \\
\hline 213 & (27) $98827-2334$ \\
\hline 214 & (65) $99973-8598$ \\
\hline 215 & {$[$ Não respondeu] } \\
\hline 216 & (45) $9907-2665$ \\
\hline 217 & (67) $99283-4255$ \\
\hline 218 & (21) $96419-6415$ \\
\hline
\end{tabular}




\title{
Apêndice 9. Entrevistas com gestores de comunicação
}

\author{
Afra Balazina (SOS Mata Atlântica) \\ Bruno Weis (Instituto Socioambiental) \\ Mariana Moraes (Grupo de Institutos Fundações e Empresas) \\ Mauricio Bianco (Conservação Internacional) \\ Rejane Romano (Instituto Ethos) \\ Renato de Paiva Guimarães (Greenpeace)
}


Afra Balazina (SOS Mata Atlântica)

Atuacão profissional: Diretora de Comunicação da Fundação SOS Mata Atlântica

Breve currículo: Nascida em Holambra, interior de São Paulo, graduou-se em Jornalismo pela Faculdade Cásper Líbero, em 2002, em São Paulo e especializou-se em cobrir, na imprensa, a área de meio ambiente. Fellow da Convenção do Clima da ONU, esteve em conferências sobre mudanças climáticas em Poznan (COP-14), em Copenhague (COP-15), em Cancún (COP16) e em Durban (COP-17). Trabalhou no jornal Folha de S. Paulo nas editorias de Cotidiano e Ciência. No jornal O Estado de S. Paulo foi repórter de meio ambiente e responsável pela coluna Planeta.

1. Na sua avaliação, como a comunicação tem contribuído para criar mensagens que engajem públicos para a prática da sustentabilidade nas organizações?

Hoje existem muitas causas, e isso gera até concorrência entre as organizações que atuam com sustentabilidade. Nesse cenário, precisamos engajar as pessoas e minha experiência com o terceiro setor e na SOS Mata Atlântica é de que precisamos muito da comunicação digital para chegar em todo o País, até mesmo por não termos recursos financeiros suficientes para realizar campanhas em mídias mais caras, como a televisão. Para nós, a comunicação está muito alinhada com o engajamento. Antes, atuávamos mais em São Paulo, e o trabalho sempre foi muito bom, hoje as demandas são muito maiores e precisamos ir além, até o detalhe de pensamos sobre dicas para postagens nas redes sociais. Tudo isso tem ajudado a conscientizar mais as pessoas quando fazemos parte do dia a dia delas. Com o nosso estímulo, ela pode fazer um abaixo assinado exercendo a cidadania e fazendo pressão nos órgãos competentes pela comunicação, e liderar campanhas de petições pela Internet. Não adianta criar petições em pensar a comunicação. Temos muita concorrência e são muitos os problemas, são muitas as causas e fazer com que as pessoas se interessem é um desafio. Atualmente 145 milhões de pessoas vivem na Mata Atlântica, mas elas não sabem falar sobre isso. Existe ainda uma questão educacional e nosso desafio é comunicar educando, mas sem um tom muito professoral. Temos que ser divertidos para que as pessoas assimilem. É importante realizarmos a comunicação aliada a uma estratégia eficiente para trazermos as pessoas e o engajamento é muito importante para nos ajudar a desenvolver políticas para o meio ambiente.

\section{Você consegue delimitar os potenciais e os limites da comunicação para ampliar a consciência das pessoas sobre os atuais problemas sociais e ambientais?}

A comunicação é muito estratégica, mas não resolve todas as questões. É importante para as ações de apresentação, relacionamento e acompanhamento dos públicos. Na SOS Mata Atlântica, temos um modelo que é o de uma pirâmide em que, na base, estão as pessoas que nos conhecem. Um nível acima, as pessoas um pouco mais engajadas, no terceiro nível a pessoa mais atuante, aquelas que são voluntárias ou filiadas e tem uma atuação mais efetiva.

Em nossas ações de comunicação, falamos muito com o primeiro e o segundo nível. No terceiro nível, temos que ir além, e precisamos de mais conteúdo para 
gerar oportunidades, por exemplo, para os voluntários. Então, com a comunicação apenas, conseguimos ir até um limite. Para conseguirmos ter uma pessoa engajada, é necessário ir além da comunicação, e integrar outras áreas, como eventos e administração.

O planejamento é muito importante. Queremos agilidade, mas temos também objetivos a perseguir. Esse dilema nós vivemos todos os dias. Então, na SOS Mata Atlântica, temos, na área de Comunicação, pessoas focadas em determinadas atribuições. Todos os profissionais hoje estão alinhados para chegar aos jovens e cada vez mais ampliar o público que nos conhece. E existe uma meta para a área como um todo. Isso ajuda muito a instituição a entender e a comunicação tem que estar integrada, pois assim realizamos nossas ações.

O planejamento também tem que existir já que não podemos apenas reagir aos acontecimentos, e a comunicação é cada vez mais importante. A comunicação às vezes é vista como um meio, mas ela também é um fim, então precisa ser muito planejada.

\section{Quais são os benefícios que a integração entre comunicação e sustentabilidade podem gerar para a sociedade?}

Os benefícios da integração entre comunicação e sustentabilidade são muito importantes para a sociedade. Cada vez mais as empresas levam isso em consideração, mas ainda de forma superficial. O desafio é sair do discurso é ir mais a fundo. Muita gente ainda usa materiais impressos em divulgações, por exemplo. Recentemente, em uma ação de Carnaval, tivemos uma ideia de fazer máscaras com imagens de animais da Mata Atlântica para chamar a atenção para a necessidade de preservação deles. Mas, depois, avaliamos que isso poderia gerar um lixo desnecessário e que poderíamos acabar poluindo as ruas, e repensamos a estratégia. Atualmente, se a organização não tem a sustentabilidade no centro do negócio, é a primeira área a ser cortada. Além disso, muitas vezes, nas empresas, comunicação e sustentabilidade estão em áreas separadas, e não há a sinergia que deveria, pois a sustentabilidade não permeia toda a organização. A missão atual da SOS Mata Atlântica, depois de trinta anos de história, é inspirar a sociedade na defesa da Mata Atlântica. Nós não queremos só beneficiar animais e florestas. Ao contrário, queremos também incluir o ser humano. Na crise hídrica ocorrida no Estado de São Paulo, observamos que houve uma redução da qualidade da água. Todos têm que pensar sobre isso. Nesse período, muitas empresas pararam as atividades, pois não tinham água para operar. O desafio é as pessoas entenderem essa relação. Se você quiser discutir mudanças climáticas, por exemplo, todos acham que isso é muito distante. $\mathrm{E}$, apesar das pessoas saberem mais sobre o meio ambiente, elas também se interessam cada vez menos pelo tema. Então, a comunicação não pode ser chata. Nós falamos muito "não". Por exemplo, "não lave seu carro", "não demore no banho". Esse é o desafio da comunicação. Temos que pensar em como atingir as pessoas.

\section{Quais recursos são necessários e como devem ser planejadas as ações} de comunicação no Terceiro setor? 
Na SOS Mata Atlântica temos uma equipe grande e uma assessoria de imprensa terceirizada, e isso tem funcionado bem e nos permite pensar também em produção de conteúdos, como artigos e pesquisas. Sobre os recursos financeiros, não investimos em anúncios. O gasto extra é para produção de conteúdo e assessoria de imprensa. Antigamente tínhamos muitas ações para o Bono, em benefício do público, que não eram de necessariamente com temas do nosso interesse. Por exemplo, a campanha de xixi no banho que a agência F/Nazca Saatchi \& Saatchi fez, ganhou inúmeros prêmios, até em no Festival de Publicidade de Cannes, na França. A campanha ficou muito famosa. Nós adoramos esta campanha, mas não necessariamente as pessoas a associam com a SOS Mata Atlântica. Então, repensamos isso. Queremos um trabalho sério, um compromisso de longo prazo, então precisa haver esse planejamento e tem que ser algo constante. Precisamos investir em recursos. Profissionalizar a nossa atuação traz retorno de mídia e faz diferença. Atualmente, os projetos que são da instituição têm que reservar recursos para as ações de comunicação. Se eu vou falar daquele projeto, preciso de recursos daquela área. Temos muitas necessidades, salários das pessoas, custos previstos, então nós temos realizado esse trabalho. Existem projetos que alocam mais verba e outros feitos de forma voluntária. $\mathrm{E}$ os coordenadores dos projetos institucionais da SOS Mata Atlântica, desenvolvidos com apoio das empresas, têm que entender isso e passam a valorizar mais o nosso trabalho.

\begin{tabular}{l} 
5. Você pode descrever como é possível avaliar a comunicação no \\
Terceiro setor em ações de sustentabilidade e quais são os principais \\
desafios para isso? \\
\hline Na SOS Mata Atlântica, nós temos formas de mensurar. Utilizamos o clipping \\
da assessoria de imprensa, controle da quantidade de e-mails que foram \\
abertos nas campanhas que fazemos, quantidade de pessoas em nossa base \\
de dados, avaliamos a qualidade das informações, o alcance, a quantidade de \\
fãs, o nível de engajamento das pessoas. Temos relatórios mensais com esses \\
dados e, anualmente, centimetragem da nossa presença na imprensa, com \\
média de equivalência comercial de até $R \$ 60$ milhões por ano. Mesmo com o \\
crescimento das redes sociais, o investimento em assessoria de imprensa \\
continua importante.
\end{tabular}




\section{Bruno Weis (Instituto Socioambiental)}

Atuacão profissional: Coordenador de Comunicação no Instituto Socioambiental (ISA)

Breve currículo: Coordenador de Comunicação na Instituto Socioambiental (ISA) desde maio de 2016, sendo responsável pela gestão da equipe e de ações de planejamento, produção, edição e divulgação de conteúdos em diversas plataformas de mídia para fortalecer a missão da organização. Por mais de três anos foi coordenador de comunicação do Greenpeace Brasil e também editor da Revista Status, quando foi responsável pelas entrevistas, reportagens sobre comportamento, estilo de vida, assuntos internacionais, meio ambiente, política, polícia, entre outros. Na campanha da candidata Marina Silva à presidência, foi integrante da equipe de conteúdo e preparação de debates. Atuou como editor da publicação trimestral da revista Natura, sendo responsável pela produção de conteúdo, definição de pautas e edição de textos sobre sustentabilidade, ética e qualidade de vida. Foi jornalista no Instituto Democracia e Sustentabilidade (IDS), editor e autor de reportagens da revista Pororoca, quando teve a oportunidade de publicar uma reportagem sobre o Alto Rio Negro (AM), a cultura e a culinária indígena na Amazônia. Também foi editor da revista Sustenta, publicação lançada em 2008 pela Carta Capital com foco em temas ligados à sustentabilidade ambiental, social e econômica, sendo responsável pela criação de colunas, pautas, edição de textos e produção de reportagens. É bacharel em Jornalismo pela Pontifícia Universidade Católica de São Paulo (PUC-SP).

1. Na sua avaliação, como a comunicação tem contribuído para criar mensagens que engajem públicos para a prática da sustentabilidade nas organizações?

Nós temos na verdade um momento bastante interessante para comunicação das organizações do Terceiro setor que é o uso das redes sociais, que abriram diversos canais de comunicação com públicos segmentados e públicos específicos que têm assim uma escolha de consumo de informação mais autônoma e menos focada no que os grandes veículos de comunicação escolhem como notícia. Então eu posso simplesmente abrir mão de me informar pela grande imprensa e posso assinar canais do YouTube, posso seguir perfis no Twitter, posso seguir perfis no Facebook e assim por diante. Dessa forma, existe outra lógica de consumo e produção da informação que não deixa de ser uma grande oportunidade para as organizações não governamentais serem produtoras de conteúdo com um custo inclusive bem mais baixo. Eu lembro que, antigamente, quando você queria produzir e publicar um anúncio no jornal, os custos eram inviáveis para uma ONG. Com todas essas redes se ampliando, é possível acessar o público em uma escala bastante interessante com um custo relativamente pagável, viável. Eu trabalhei muitos anos em revistas e jornais e você tinha uma circulação média de dez, vinte, trinta, quarenta, cinquenta mil exemplares de uma revista. Então, digamos que a revista chegava em cem mil pessoas. Hoje um bom vídeo que tenha conseguido atingir a sua base no Facebook, por exemplo, você tem um alcance de meio milhão de pessoas. Então você tem um acesso à opinião pública muito mais democratizado em função da Internet e das redes sociais. O fator da interatividade das redes sociais também facilita que o debate seja mais expandido e as pessoas participem mais e que esses conceitos avancem mais. O papel de produtor de 
conteúdo e consumidor de conteúdo hoje em dia ele está difuso. Os papéis não são estanques. Hoje você é um produtor e, ao mesmo tempo, consumidor de informação como usuário da rede. Nós estamos consumindo e produzindo informação. Isso vale para as ONGs também. A interatividade é a marca das redes sociais, tem muita gente que estuda esse assunto e diz que, hoje, na rede social, você não tem que se preocupar só com o que você vai dizer, mas, sobretudo, como você vai escutar o que está sendo dito no esteio da sua comunicação e como você vai se posicionar em relação a isso. Isso envolve desde uma capacidade de interlocução com públicos que não necessariamente estão aderindo aos seus valores, e também políticas de lidar com haters, com discurso de ódio, de racismo. Tudo isso é um desafio para quem está nessa fronteira da comunicação. É bem interessante.

\section{Você consegue delimitar os potenciais e os limites da comunicação para ampliar a consciência das pessoas sobre os atuais problemas sociais e ambientais?}

Vou falar do ponto de vista do Instituto Socioambiental. Eu acho que tem alguns valores nossos que nunca podem sofrer arranhões, ainda que o nosso objetivo de ampliação de alcance seja crescente. Nós temos uma credibilidade, o que é fundamental quando a gente tem um assunto que merece uma comunicação. Então nesse momento, por exemplo, o Senado Federal está votando duas provisórias que vão reduzir o limite das unidades de conservação de proteção integral no estado do Pará. Elas estão tendo os limites revistos no Senado, já passou pela Câmara e agora está no Senado. Este é um assunto de uma gravidade tremenda que merece todo o esforço de comunicação das organizações como o ISA, mas não só, para alertar a população para que todos possam fazer pressão em relação aos políticos em que elas votaram, avisar a imprensa, tentar fazer uma pressão para que essa votação não aconteça ou que não sejam aprovadas as Medidas Provisórias. O ponto é que, quando o assunto não tem essa importância toda, e você vira refém dos likes, de algo assim, você acaba gerando um alarmismo, ou há o risco de gerar um alarmismo excessivo para você ganhar uma evidência uma disputa no feed das pessoas. Porque, no fundo, estamos em uma disputa que é o seguinte: você tem diversas causas competindo pela atenção e pelo engajamento das pessoas. Há a causa ambiental, a causa indígena, a causa dos direitos humanos, a urbana, o direito à moradia, o direito de legalização das drogas. Tem várias causas e todas elas estão disputando um público relativamente parecido, existe uma convergência de um olhar progressista de pessoas que comungam de valores ligados a uma visão do mundo de esquerda, de que as minorias devem ter seus direitos respeitados. Se você entra numa disputa fraticida com os seus pares para ganhar mais espaço há um risco da sua credibilidade sofrer danos, ou seja, tem que ter muita calma na hora de você fazer uma imagem no Facebook dizendo que é urgente, aqui, agora. É como aquela coisa, você conta dez vezes uma mentira e, na hora que vai contar uma verdade, ninguém vai te ouvir. Tem que ter um certo cuidado para você dosar de fato a comunicação no calibre do que o assunto em si merece. Tem momentos em que você tem que fazer uma comunicação um pouco mais austera, um pouco mais sóbria porque o assunto talvez não mereça ou você não tem nem informação suficiente pra cravar um posicionamento institucional. A busca pelo engajamento nunca deve colocar a sua credibilidade enquanto organização em risco. 


\section{Quais são os benefícios que a integração entre comunicação e sustentabilidade podem gerar para a sociedade?}

Eu acho que há um lado negativo que é importante ser ressaltado que é o famoso greenwashing. A comunicação, como muitas ferramentas do establishment, se apropria de conceitos que nascem revolucionários, mas logo são totalmente incorporados pelo sistema dominante. Então, tendo um discurso de sustentabilidade pelas empresas, com departamentos de responsabilidade socioambiental, nisso a comunicação acaba sendo a protagonista nas empresas desse tipo de discurso, mas isso não se reflete nas práticas dos negócios das empresas, nas cadeias produtivas que são envolvidas. Então eu acho que na verdade tem um lado $B$ aí bastante importante de ser observado. A comunicação promove a consciência das pessoas, promove a sustentabilidade, mas ela promove muito mais hoje o greenwashing, sobretudo no segundo setor, nas empresas. Vamos pegar o caso de Belo Monte. Acho que - Belo Monte é um caso fantástico para olhar como o Governo Federal se apropriou de um discurso para dizer que ali foi tudo resolvido, que a hidrelétrica era moderna, não geraria passivo ambiental, não geraria passivo social. $E$ isso, inclusive para quem visitou as obras durante sua execução, eu fui uma dessas pessoas, dentro de um ônibus da empresa Norte Energia, você estava ali ouvindo discurso onde pensava que aquilo era uma maravilha do mundo, tudo perfeito, tudo equacionado, não vai ter mais problema nenhum. Hoje, a usina só funciona porque ela tem um mecanismo de suspensão de segurança que impede que a justiça interrompa o seu funcionamento em função das multas que foram aplicadas pelo lbama e nunca foram pagas, dada a quantidade de passivos e pendências socioambientais. Então eu acho que tem exemplos no governo e nas empresas que recorrentemente falam de sustentabilidade da boca para fora, um discurso vazio, e isso é uma coisa que a cultura brasileira ainda vai ter que amadurecer muito para separar o joio do trigo mesmo.

4. Quais recursos são necessários e como devem ser planejadas as ações de comunicação no Terceiro setor?

Eu acho que recursos financeiros, tecnológicos e humanos são fundamentais. Mas eu acrescentaria uma coisa chamada capital social, que é o acúmulo de relações que o profissional gera ao longo da sua carreira, da sua performance profissional, da sua trajetória. Capital social é o conhecimento de redes, coletivos, são profissionais que podem contribuir com o seu projeto e a sua estratégia. Dinheiro é um recurso importante, uma equipe interna também é um recurso humano fundamental, assim como uma infraestrutura de tecnologia. Agora, o capital social, estar em contato com o mundo lá fora, saber quem está fazendo as coisas com inovação com criatividade, quebrando paradigmas, isso é um valor subestimado. É bem importante acumular relações em que você consiga com isso ativar talentos de maneira estratégica.

\section{Você pode descrever como é possível avaliar a comunicação no Terceiro setor em ações de sustentabilidade e quais são os principais desafios para isso?}

O nosso grande desafio, no ISA, no Akatu, no Greenpeace, é fazer com que as pessoas incorporem no seu dia a dia o valor delas em relação ao que elas consomem e aos hábitos delas dia. Se as pessoas incorporarem que o impacto 
de cada escolha feita, seja de consumo, seja de hábito de vida, tem um elo muitas vezes invisível com questões muito maiores. Por exemplo, com a questão da Amazônia, a questão climática, a questão hídrica. Facilitar esse entendimento, aproximar o microcosmo do dia a dia do indivíduo com as grandes questões planetárias é a nossa missão diária numa organização como o ISA e outras parecidas. Traduzir e simplificar os caminhos para as pessoas entenderem que nada está descolado, tudo está relacionado e que, por maior que as causas aparentam ser, o que eu posso fazer pelo degelo do Ártico, isso é bastante desmobilizador. Então eu acho que não pode ter um discurso vazio de que você vai salvar o Ártico, você José da Silva que mora em Pindamonhangaba. Não é isso. Mas ele tem uma série de decisões diárias que ele pode fazer que, somadas às decisões diárias de seus colegas contemporâneos, vai gerando um caldo de cultura para quem sabe um dia os desafios não sejam mais tão insuperáveis. Acho que esse é um desafio da comunicação como um todo para quem trabalha nessa pauta.

Tem uma questão que sempre aparece em nosso dia a dia de alguns indicadores de resultados que são aferidos e os que não são aferidos. Então vou pegar o exemplo de uma campanha nossa que deu muita repercussão e era um filme chamado 'Menos preconceito e mais índio'. Não sei se você chegou a ver, era um filme de noventa segundos e conseguimos veiculação em TV aberta, TV fechada, cinema, todos os meios digitais. Chegamos a uma conta de vinte e dois milhões de brasileiros que viram esse filme Somando todas as plataformas e mídias. Em um cálculo conservador nosso, vinte e dois milhões de brasileiros viram o filme. Isso já é indicador de resultado. Conseguir passar no horário nobre da Rede Globo também é um indicador de resultado. Agora, esse filme tinha uma proposta que era discutir um preconceito entranhado em muita gente no Brasil sobre os índios que usam aparatos tecnológicos, usam bens e hábitos da sociedade branca. $O$ fato de o indivíduo ver esse filme não significa que ele mudou a cabeça dele necessariamente. Então eu tenho sempre uma margem que eu não consigo aferir de resultado, que é a mudança do pensamento das pessoas. Eu cheguei em vinte e dois milhões de pessoas, consegui entrar na Rede Globo, tudo isso é indicador. A minha página no Facebook aumentou em 30\% em um mês, eu consegui tantos doadores para o ISA. Tudo isso é objetivo concreto aferido. Mas tem uma fatia de mudança de pensamento. Vamos pegar esse exemplo. A pessoa viu a campanha e concluiu que não precisa ter esse preconceito. Só que, digamos que ele mudou a cabeça dele, mas não se tornou filiado ao ISA, não começou a assinar a minha newsletter. Então eu não tenho um indicador concreto de que essa pessoa entrou para minha base de apoiador. Mas ele mudou a cabeça dele, ele vai parar de falar para os amigos dele que índio que usa celular não é mais índio. Então o meu macro objetivo foi atingido. Ele mudou, ele não tem mais o preconceito. Mas como é que eu vou aferir isso? Eu tenho que conhecer essa pessoa. São vinte e dois milhões de brasileiros. Então, tem sempre uma margem de resultado que é intangível e isso não impede que eu tenha uma série de outros indicadores possíveis de mensurar, mas quando estamos falando de incidência política, de mudança de pensamento, existe uma margem. Temos que fazer o máximo para que o conteúdo seja efetivo, ele tem que ser veiculado no máximo de lugares possíveis e desejar que as pessoas façam sua reflexão. 
Agora, o que essa reflexão vai ensejar na pessoa, muitas vezes eu perco aí o fio da meada. Até onde essa mudança gerar um convertido à causa ou apenas uma pessoa que vai parar de propagar preconceito. É uma questão para a gente isso. Talvez na próxima eleição ele vote em um candidato que esteja um pouco menos alinhado com uma pauta preconceituosa. Não dá pra aferir tudo. Tem muita coisa subjetiva também. 
Mariana Moraes (Gife)

Atuacão profissional: Gerente de Comunicação do Gife.

Breve currículo: Formada em comunicação social pela Escola Superior de Propaganda e Marketing (ESPM), cursou pós-graduação em jornalismo na Faculdade Cásper Libero e em comunicação digital na Universidade de Sydney (Austrália). Trabalhou na área de responsabilidade social da Repense Comunicação e em ONGs como Oxfam e Action Aid Austrália. É voluntária do Sou da Paz e TETO, professora de psicologia social e terceiro setor na Universidade de Santo Amaro (Unisa) e conselheira do Minha Sampa.

\section{Na sua avaliação, como a comunicação tem contribuído para criar mensagens que engajem públicos para a prática da sustentabilidade nas organizações?}

É importante primeiro dizer que engajamento é uma das curvas da comunicação. É muito difícil conseguir o engajamento de qualquer causa sem que as pessoas saibam que essa causa existe, sem que as pessoas recebam a explicação do porquê da causa ou sejam impactadas de alguma forma com a causa, com a organização. Então não existe engajamento, é muito difícil, eu não conheço nenhum caso, em que o engajamento aconteça sem o papel fundamental da comunicação envolvida no processo. E ela precisa estar envolvida desde o começo, desde o marco zero, desde o momento em se decide fazer alguma coisa ou que tenha uma organização com um determinado projeto. É a comunicação que provoca o projeto e a organização a pensarem com quem se quer falar, por que, como, quando, onde. É a comunicação que ajuda a fazer um diagnóstico do cenário antes de se colocar o carro na rua. $\mathrm{E}$ a comunicação, para ser engajadora, tem que ter, primeiro, muita clareza de qual é a causa sobre o que se quer dizer, muita simplicidade na mensagem. Não pode ser uma mensagem simplista, mas para se falar com as pessoas tem que haver uma mensagem simples, é necessário falar uma linguagem que qualquer pessoa entenda e, principalmente, tocar o coração. Para se tocar o coração das pessoas, normalmente existe uma combinação da mensagem bem clara, relevante, interessante e que, de algum jeito, toque o outro, porque é uma causa que o outro já se interessa, somado ao momento da sociedade, a uma oportunidade que se coloca alguma situação em que seja o momento perfeito para a coisa acontecer.

Então, por exemplo, quando nós tivemos as manifestações de 2013, não é que as pessoas acordaram e perceberam que subiu a tarifa dos transportes públicos e todos decidiram ir para a rua. Calhou o momento em que o movimento se sentia maduro para brigar pelo que queria com o momento em que as pessoas estavam cansadas e precisando gritar com um momento em que a tarifa ia subir, mas poderíamos pedir para não subir. Enfim, foi uma vontade da organização de colocar um ponto de vista somado a um momento ideal. Isso ajuda muito nessa curva de engajamento. Se não se dá à comunicação a oportunidade de entrar logo no começo do processo para pensar junto com o projeto, é muito mais difícil que o engajamento aconteça porque a comunicação ajuda a pensar o público também. Não se engaja uma pessoa que não tenha absolutamente nenhuma sinergia com o que se quer, principalmente no curto prazo. Se não há clareza de com quem se quer falar, não se fala com ninguém. Por exemplo, na 
Fundação Maria Cecília Souto Vidigal, quando eles fizeram a campanha para mudar o marco regulatório das organizações, o marco civil da primeira infância, que agora é lei, eles sabiam quem era o público com quem eles precisavam falar. Então eles sabiam que, primeiro, tinham que falar com o formador de opinião, depois eles precisavam falar com os legisladores e, por fim, precisavam dar uma mensagem geral para a sociedade. Aí eles colocaram um vídeo do começo da vida para que mais gente conhecesse a causa. Mas o começo da vida é o estopim, é um passo depois de cinco anos de campanha falando com muitas pessoas que precisavam ouvir essa mensagem.

Então, engajamento tem muito a ver com a construção de mensagem ao longo do tempo, dar tempo ao tempo para que as coisas aconteçam. As pessoas querem muito que as coisas sejam para amanhã, mas mudança de cultura, mudança de comportamento, mudança de valores, todas essas mudanças que uma grande causa mexe, elas levam muito tempo. As pessoas agora estão começando a falar de resíduos sólidos. Quanto tempo isso existe, quanto tempo isso está sendo gritado, quanto tempo muitos ambientalistas estão falando sobre o lixo e tantas outras questões? Quanto tempo as pessoas estão falando sobre a importância de um espaço público em São Paulo para que a ONG Minha Sampa conseguisse abrir a avenida Paulista? É a ONG querendo abrir a avenida Paulista com um momento em que a sociedade precisa de um espaço que público, então é a construção de mais um espaço para as pessoas se divertirem no domingo. Em relação a essa questão do momento, posso complementar com uma fala do Marcelo Furtado, que era do Instituto Arapyaú, quando afirma que a causa comunica bem quando está sintonizada com o desejo, o espírito e o rumo do tempo que está no ar. Assim é possível casar o desejo da organização com o rumo do tempo que está no ar. Isso faz muito sentido. Tem um case que assistimos no ComNet, que é Congresso de Comunicação de Causas para o Terceiro setor que me marcou muito. Uma organização dos Estados Unidos estava lutando pelo casamento gay e eles passaram anos batendo na tecla da importância do casamento gay e repetiam sempre o mesmo discurso, mas esse discurso não ressoava. Havia um certo público que acreditava, mas os outros eram muito reativos. Eles conseguiram reverter a situação e aprovar o casamento gay nos Estados Unidos quando entenderam que a causa deles não era o casamento gay, a causa era o direito de amar. A partir do momento que eles começaram a trabalhar o direito de amar com as pessoas, foi o momento em que o casamento gay foi aprovado porque aí você entende que a comunicação vai para a frente quando ela realmente toca o coração das pessoas. Por isso é necessário procurar uma causa que dialogue com o que as pessoas acreditam e, nesse caso, foi muito bem amarrado. Outro caso muito bom que nós estamos querendo trazer para o Brasil para o Congresso do Gife no ano que vem é sobre o Aaron Belkin, que fez uma campanha nos Estados Unidos chamada Don't Ask Don't Tell para a ONG Palm Center. Ele percebeu que, nos Estados Unidos, queriam proibir gays no serviço militar a ONG achava isso um absurdo. Então ele passou muitos anos comprovando de diversas formas como os gays no serviço militar não prejudicavam o serviço militar, muito pelo contrário. Os pilares em que ele se apoiou muito, para a sua comunicação ter mais impacto, para a causa ter mais impacto, foram de public education, educar o público no sentido de explicar para 
as pessoas o que você está falando, advocacy, levantamento de muitos dados e a própria comunicação. É esse conjunto que faz com que haja sucesso em uma mudança de cultura e no engajamento.

Em relação ao Gife, a comunicação tem nos ajudado, primeiro, a disseminar as nossas causas para mais gente e, segundo, o que eu destaco muito e continuarei destacando, é sobre a importância de começarmos a traduzir essa linguagem de nicho, que é a linguagem do terceiro setor, a linguagem do investimento social, para a sociedade civil. $O$ que é que nós estamos falando quando abordamos recursos privados para o bem público? Estamos falando de grandes famílias, de grandes fortunas que pegam o dinheiro delas e querem desenvolver uma sociedade. Quais são as implicações disso? Quais são as problematizações disso? É muito importante traduzir sempre o que a organização está fazendo. Para mim, uma forma da comunicação engajar é quando ela consegue realmente traduzir uma mensagem de uma forma que toque o outro.

\section{Você consegue delimitar os potenciais e os limites da comunicação para ampliar a consciência das pessoas sobre os atuais problemas sociais e ambientais?}

Acredito que, no fundo, o acesso é um potencial e o excesso é um limite. Estamos vivendo um novo paradigma da comunicação. Hoje em dia existe uma hiperconectividade, todas as barreiras de se comunicar caíram, as estruturas de poder estão mudando muito. Então todos têm acesso, são muitos emissores e muitos receptores. Antigamente existiam poucos emissores para muitos receptores, era como se fosse uma igreja e, hoje em dia, é como se fosse uma feira, são muitos emissores para muitos receptores e esse novo cenário implica diretamente na forma como as pessoas se comunicam, porque ter acesso é poder ter abertura para se comunicar. Mas, com o excesso, existe o risco de se perder em um oceano de informações que temos hoje em dia. Eu acredito que existem dois problemas decorrentes desse oceano de informações. Por um lado, os negacionistas, os pessimistas, aqueles que negavam a mudança climática, por exemplo, que negavam a desigualdade, que negavam todos os temas que são relevantes para a sociedade civil, eles tinham um certo espaço para se comunicarem, um certo limite naquilo que ele comunicava e um pouco de barreira para estar na mídia, para falar o que ele pensa. Isso porque, querendo ou não, os grandes veículos eram imparciais e seguravam um pouco esse tipo de reação. Hoje em dia, como nós não temos mais as barreiras de entrada e todo mundo pode se comunicar, essas pessoas que antes tinham um pouco de limite, agora eles têm o mesmo peso e a mesma influência que um The New York Times. Essa pessoa pode acabar influenciando a eleição do Donald Trump e pode acabar influenciando pessoas a negarem a mudança climática. Então, excesso de informação é um limite da comunicação. O outro é o fake news, isso é muito claro, hoje em dia as pessoas criam a verdade que elas quiserem, e estamos vivemos a pós-verdade. Como as notícias são criadas o tempo inteiro do jeito que as pessoas querem, sem investigar, sem muita apuração, fica muito mais difícil para as organizações conseguirem se colocar, porque é tanta informação e são tantas mentiras brigando com as verdadeiras, que as organizações acabam se perdendo porque não têm tanta estrutura para se colocar. 
Tem dois potenciais muito grandes do terceiro setor. Um deles é que o terceiro setor sempre foi e é peça-chave como uma organização de denúncia. Então, o Greenpeace é quem vai dizer que $60 \%$ da Amazônia é desmatada por gado, que os supermercados estão vendendo carnes sem rastrear a origem, e indicar para Pão de Açúcar, Walmart, Carrefour que é responsabilidade deles criar critérios para que a compra de carne que não seja oriunda de desmatamento da Amazônia e questionar o que eles vão fazer em relação a isso. Esse é só um exemplo, e eu realmente acho que as organizações têm como potencial ser um elemento de denúncia, de controle social, uma organização que fica o tempo inteiro investigando, determinando e pressionando para que as coisas sejam denunciadas. Isso é muito importante, é um papel que o terceiro setor tem de mais precioso e que, somado a isso, principalmente com essa crise da mídia, com a forma como os grandes veículos estão vivendo hoje, sempre com muita dificuldade de averiguar, apurar, buscar dados, eu acredito que um potencial do terceiro setor é aproveitar para comunicar seus dados. Porque o terceiro setor é que tem os dados, tem o olhar na ponta, que conseguiu apurar exatamente como está uma região. Se for perguntar para o Instituto Alana, eles sabem exatamente dizer como está a região do Pantanal Paulista. Se falar com o projeto Arrastão, eles sabem como está o Campo Limpo. Eles têm como apurar os problemas e as soluções para a região em que estão atuando. Se quiser conversar sobre saúde da criança, a Vera Cordeiro vai falar que sabe exatamente o grande problema das crianças que vão para o hospital. Ela diz que as crianças moram em casas úmidas, insalubres, as famílias não sabem lidar com uma criança recém curada e as crianças acabam voltando para o hospital ainda mais doentes.

Então não tem ninguém que entenda mais daquele assunto do que a própria organização e isso é uma super oportunidade, um super potencial de comunicação mesmo, de ser a organização que se coloca e que tem os dados e as informações que nenhum outro veículo de comunicação teriam. São os dados que as organizações do terceiro setor têm. Todas as pesquisas que 0 Instituto Ayrton Senna, por exemplo, faz sobre comunicação e educação são muito importantes para que se consiga ter assuntos mais em profundidade. Se essas organizações aproveitarem esse potencial de serem provedores de dados, o terceiro setor vai começar a ser muito mais reconhecido. Então, mais um exemplo. Nós fizemos um evento no Gife em que chamamos o jornal Nexo, a revista Época e os associados das áreas de comunicação. Colocamos eles para conversar, para entender por que o terceiro setor não sai na mídia e a Paula Miraglia, do jornal Nexo, falou várias vezes que precisa muito de nós, dos dados do terceiro setor, que acredita realmente que o terceiro setor tem muito potencial, muita pesquisa, muito dado que nenhum outro setor tem com tanta precisão, que eles não entendem dos assuntos que nós entendemos então pediu, por favor, para sentarmos com ela, traduzirmos, ajudarmos a fazer matérias mais completas, notícias mais apuradas, a fazer uma comunicação mais poderosa para a sociedade. Então, usar o terceiro setor para dar suporte para a mídia é um potencial muito importante. 
Outro potencial da comunicação, ou limite, depende do jeito que se observa, é a ideia do tempo. Para ampliar a consciência das pessoas sobre problemas, é necessário tempo, precisa haver paciência, muita perseverança para que se entre em uma curva, em um processo, em uma linha em que se consiga aos poucos transformar as pessoas. Mudar a cultura já é muito difícil quando é um tema muito óbvio, imagina quando é um assunto que as pessoas às vezes precisam conhecer para depois mudar. Ser mais transparente, entender a importância. Até quando o tema é óbvio, por exemplo de não fazer propaganda na televisão para crianças, como é o caso do Instituto Alana, eles precisaram de uma curva de compreensão das pessoas sobre os riscos de propagandas para crianças, eles precisaram de muita persistência na mensagem para que eles conseguissem essa curva. Eu realmente acho que um limite da comunicação é a pressa e um potencial é o timing, é entender que se vai ficar anos naquela mensagem, mas que, depois, pode-se conseguir uma mudança muito grande.

\section{Quais são os benefícios que a integração entre comunicação e sustentabilidade podem gerar para a sociedade?}

Fazendo um resumo de tudo em relação a comunicação para a sustentabilidade, acredito que comunicar para o terceiro setor, comunicar a sustentabilidade, comunicar causas é algo sobre o que é preciso ter muita clareza da causa, precisa ter muita paciência porque requer muito tempo, então não atravesse, não corra, precisa não perder o timing. Então, identificar o que a sociedade está pedindo e se adequa e precisa avaliar depois. Eu diria que comunicação é uma peça-chave para qualquer organização porque a comunicação é a forma como nos colocamos no mundo. Sem comunicação não há disseminação, então assim estabelecemos diálogos, criamos vínculos, avisamos, denunciamos, nos colocamos, fiscalizamos. A organização que não se comunica está, por si só, errando, perdendo uma oportunidade. Comunicação é um requisito fundamental para a transformação, quem não se comunica não está dialogando com ninguém e a mudança de valor requer comunicação.

Por fim eu acredito que é importante falar que os tempos são outros, nós estamos vivendo a hiperconectividade, a falta de tempo, a comunicação mudou de paradigma completamente. Qualquer pessoa é produtora de conteúdo, são muitos emissores para muitos receptores, comunicar ganhou uma relevância muito grande porque, como é que se faz para se destacar em um oceano de informações? Então é necessário nos adequarmos à comunicação que existe hoje e nunca esquecermos de tocar o coração das pessoas, porque, no fundo, quando estamos falando de causa, estamos falando: Ei, você aí!

Existe um elemento que eu considero importante e eu gostaria que você também achasse importante, que você também se desse conta. Tem uma questão de, a partir da comunicação, principalmente no terceiro setor, ajudar as pessoas a sonharem também com um mundo melhor. Então, quando estamos querendo comunicar uma causa, querendo comunicar ações do terceiro setor, estamos falando que queremos nos comunicar com o outro para que ele 
entenda que o tema é importante e esse outro também pode ser parte dessa solução se ele tiver consciência de que esse problema existe. $\mathrm{E}$, para que ele tenha consciência, é preciso contar que esse problema existe. Então no fundo é isso, é alguém dizendo que percebeu que existe uma questão que não está sendo atendida, que quer comunicar, quer tocar o outro para que ele entenda que essa questão, que ele existe incorpore para dentro do coração e também se sinta capaz de ajudar nessa transformação.

Falando agora sobre como são planejadas as ações de comunicação no terceiro setor, eu posso contar como elas são planejadas no Gife. Em todas as ações, a comunicação tem que ser acionada desde o marco zero, sempre, então quem está pensando em fazer alguma ação já nos avisa porque é a comunicação que vai provocar com quem se quer falar, porque se quer falar, quando se quer falar, como se quer falar, qual é a mensagem que se quer tirar daquilo, qual é a real causa por trás, que é sempre o que causa ruído quando não está muito claro o que se quer comunicar. Então nós sempre envolvemos redes sociais, assessoria de imprensa, matérias no próprio site do Gife, o nosso boletim e, depois, a gente continua replicando tudo nos nossos veículos. Nós sempre repetimos que existe uma estratégia que eu vi uma vez naquele ComNet chamada 4060 que é, quando se está pensando na comunicação de um projeto, de um produto, de qualquer ação, o quanto que se tem que pensar que foi gasto em relação à comunicação. É necessário $40 \%$ de esforço para fazer o material e $60 \%$ para divulgar. Isso faz sabermos que temos que precisamos sempre continuar "picando em bifinhos" o nosso grande produto. Então, por exemplo, uma ação de comunicação que fizemos no Gife. Precisávamos divulgar uma publicação de investidores sociais independentes. Quando descobrimos que teríamos essa publicação, fomos acionados e fomos fazendo teasers levantando alguns dados e soltando esses dados para a população até o dia em que a publicação ia ser lançada. Assim já tínhamos amarrado todos os envolvidos e, ao mesmo tempo, a publicação saiu no site, saiu no boletim do Gife, a assessoria de imprensa foi acionada e disparou o release para todos os veículos e colocamos nas nossas redes sociais. Passado esse primeiro momento de euforia, transformamos a publicação em infográfico, transformamos a publicação em vídeo, em posts no Facebook, em posts no Twitter, recortamos em artigos para o site, recortamos em notícias para a nossa newsletter. Enfim, ficamos trabalhando a publicação quase até o final do ano, então eu acho que, se se faz uma ação de comunicação bem planejada antes, é possível recortá-la sem deixá-la cansativa por vários ângulos diferentes, em um período mais longo de tempo. Isso é muito importante. Então essa questão do marco zero é importante e sempre entender com quem se quer falar, como se quer falar, porque se quer falar, qual é a causa por trás e qual é a mensagem que será utilizada de forma fixa e repetitiva ao longo do projeto.

4. Quais recursos são necessários e como devem ser planejadas as ações de comunicação no Terceiro setor?

Em relação aos recursos, tenho um frame de uma área de comunicação que seria um sonho que eu montei para ver se um dia nós temos aqui no Gife. Claro que teriam mudanças, a equipe poderia até ser maior, mas é uma estrutura do que seria o básico de uma estrutura de comunicação que considero que seria boa de se trabalhar. Sobre as áreas de comunicação dos institutos e fundações 
associados ao Gife, no Censo Gife, que é a nossa pesquisa produzida a cada dois anos, existem algumas poucas perguntas relacionadas à comunicação. Posso te adiantar alguns resultados. Foram 100 respondentes, o que equivale a mais de $90 \%$ dos associados. A pesquisa revelou que $50 \%$ dos respondentes têm equipe interna destinada à comunicação, 33\% possuem equipe de comunicação terceirizada contratada diretamente pelo associado. Parece que uma se sobrepõe a outra isso, e isso é meio curioso. $45 \%$ dividem estrutura de comunicação com a empresa mantenedora e isso é um grande conflito porque a estrutura de comunicação da mantenedora, dos empresariais, por exemplo, normalmente é incrível, mas a comunicação do instituto, da fundação, fica à mercê de um tempo livre da equipe que está envolvida com as ações deles, e é difícil fazer com que elas se envolvam. Tem uma observação no censo que diz que, neste último caso, ressalta-se o quanto o compartilhamento da estrutura de comunicação com a mantenedora pode prejudicar a comunicação da atuação social da organização dada a dificuldade de encontrar comunicadores que compreendam o setor e possam evidenciar práticas sem cair nas leituras mais restritas como as de cunho assistencialista, por exemplo. Não há ninguém que esteja superpreparado para dialogar sobre os conflitos do setor. Fica aquela coisa do profissional do marketing querendo falar sobre os projetos sociais com aquele olhar de que estão fazendo assistencialismo mesmo. A pesquisa também revelou que $5 \%$ dos respondentes não possuem nenhuma estrutura de comunicação e 3\% afirmam que nem fazem nenhum tipo de comunicação.

Entre os canais mais utilizados pelos respondentes, sites, blogs, redes sociais ou outros espaços virtuais abertos são os mais recorrentes ( $86 \%)$, seguidos de boletim online ou newsletter (64\%), em geral voltados a públicos específicos ou pré-selecionados. E-mail marketing foi indicado por $59 \%$ dos respondentes. Vou fazer uma observação aqui sobre a newsletter, que considerávamos uma ferramenta velha, só que temos uma pesquisa internacional sobre tendências de comunicação, sobre redes sociais e comunicação no terceiro setor nos Estados Unidos, e percebemos que a newsletter teve uma curva de queda, mas voltou a funcionar porque as pessoas estão com muita informação, muito overwell, muito cansadas e procurando alguém que lhes forneça curadoria. E a newsletter é assim. As pessoas confiam no Gife e sabem que as matérias que vamos mandar são boas, então apostamos na newsletter. Chama a atenção que $45 \%$ dos respondentes também fazem ações de comunicação utilizando meios de comunicação de massa, como TV, rádio, jornal e revista. O último dado talvez explique porque quando perguntado sobre o público que procuram atingir com suas ações, $74 \%$ dos respondentes têm como seus públicos-alvo a sociedade em geral.

Eu acredito muito que comunicar para a sociedade em geral não funciona, não existe, não existe mais comunicação de massa, ela não é mais muito eficaz, de forma nenhuma, principalmente porque as pessoas estão se comunicando de forma muito mais fragmentada. Quando se decide comunicar para a sociedade em geral, não se está comunicando para ninguém. As pessoas hoje em dia podem ter acesso só ao que querem ver, esse é um dos grandes problemas das redes sociais. Então se achar que vai comunicar para um público enorme com a mesma mensagem é difícil, não sei se funciona nesse caso das ONGs. 
Ainda sobre recursos, este é um tema recorrente, ele consta muito nos encontros que fazemos no Gife. Certa vez fomos discutir a estrutura do site do Gife e as equipes de comunicação dos associados vieram porque queriam falar sobre o quanto eles não têm recursos, não tem equipe, e o quanto que isso é prejudicial para eles. Então esse é um tema que é recorrente, eles se sentem sempre carentes de conversar. Então existe um pacote mínimo de recursos, cada vez que se se comunicar, é necessário ter dinheiro e equipe, que são os básicos, mas é preciso ter uma estrutura de comunicação.

\section{Você pode descrever como é possível avaliar a comunicação no Terceiro setor em ações de sustentabilidade e quais são os principais desafios para isso?}

Os desafios são muitos porque quando estamos falando sobre temas complexos, como uma mudança de cultura, sobre organizações se tornarem mais transparentes, no caso do Painel de Transparência do Gife, estamos falando sobre os pais terem uma licença paternidade mais longa no caso da Fundação Maria Cecília, estamos falando sobre as crianças não poderem mais assistir propaganda de produtos na televisão, estamos falando sobre abrir a avenida Paulista, estamos falando sobre projetos que são muito intangíveis e complexos. Estamos falando sobre crianças que estão aprendendo mais em uma escola, no caso da Fundação Itaú Social. São sempre projetos que requerem um longo prazo, requerem um olhar muito mais sensível, muito mais qualitativo do que quantitativo no sentido de que, se a intenção é que as crianças saiam da escola sabendo ler e escrever, às vezes a criança não sabe ler e escrever exatamente, mas ela aprendeu muito, ela impactou a família inteira, a comunidade inteira está se esforçando. Então não se pode falar que o projeto não deu certo, é muito delicado. Então é muito importante que quando se vai avaliar a comunicação, como se está falando de um intangível, o peso da relatividade que se vai colocar para os números tem que ter um olhar muito mais crítico, muito mais leve. É possível escolher os indicadores, mas eles nunca serão uma resposta precisa. Você pode usar as técnicas de publicidade, usar as técnicas de assessoria de imprensa, mas, mesmo assim, eu não acredito tanto nelas porque os indicadores podem acabar atrapalhando em vez de ajudar, trazer números que mostrem que a sua comunicação não funcionou, mas no fundo ela funcionou sim, funcionou de outra forma.

Então eu volto de novo em 2013 nas manifestações, aquele foi um estopim de um processo. Se forem avaliadas algumas ações do movimento tempos atrás talvez eles não tivessem tido um bom resultado, mas no fundo eles já estavam jogando uma semente que depois iria germinar dez anos depois. Então se formos muito com uma lógica de produto, como é feito com as empresas, não se avalia com muita precisão, acaba se perdendo a complexidade que é avaliar o terceiro setor.

Nós temos uma matéria do Gife abordando o quanto que a comunicação é parte intrínseca no processo de avaliação de projetos, só que não é avaliando a comunicação, é avaliando o projeto em si, porque, quando se está fazendo um projeto, primeiro é necessário nos perguntarmos sobre avaliar para quem. Se perguntamos depois para que é preciso avaliar, vamos saber que tipo de 
produto que se quer tirar dali. Então, por exemplo, se é fundamental que se esteja pensando no seu público e a pergunta for avaliar para que, e a reposta for que é preciso avisar os financiadores sobre o seu projeto, então é melhor que se faça um relatório. Agora, se ser avaliado o seu projeto, porque você quer que a sociedade civil utilize esse projeto, é mais fácil você fazer um vídeo ou um infográfico para ensinar a população. Então, é necessário ter muita clareza para o que se quer avaliar e para o que se quer comunicar.

Em relação à avaliação e aos recursos, aqui no Gife o que fazemos é que temos algumas metas para apresentar ao Conselho, mas elas não são perfeitas. Elas são relacionadas a compartilhamentos no Facebook, número de seguidores, número de pessoas que se cadastram para receber a newsletter do Gife, número de matérias que são publicadas, então consideramos importante acompanhar a assessoria de imprensa, a mídia é muito importante. Então, é relacionado às redes sociais, ao número de visualizações do site e à imprensa. São esses três macro indicadores com pequenos indicadores dentro de cada um desses. Então eu acredito que isso seja referência, já fizemos algumas conversas com os associados e eles também não tem certeza, não têm essa resposta. Eles têm muita dificuldade de saber o que medir, têm muita dificuldade em relação à comunicação. Um dia eu falei em um evento de finanças sociais em uma mesa com nomes muito bons, como o presidente da agência de publicidade Lew'LaralTBWA, que estava na mesa, e ele falou que não tem resposta para essa pergunta, disse que eles continuam andando um pouco às cegas.

Então as organizações da sociedade civil não têm muita clareza ainda de como medir, assim como as empresas também não têm, porque o tempo é outro e a comunicação é muito dinâmica, muito rápida, e as ações vão tendo impacto ao longo do tempo. Mas não pode desistir de avaliar, acredito que isso é o mais importante, sempre se preocupar em avaliar independente se está certo ou está errado, você vai acertando no caminho. A avaliação, mais do que servir para saber se deu certo ou não deu certo, ela serve para ter um retorno sobre a iniciativa do que se está fazendo. Ela é mais para alinhar a carruagem e continuar seguindo do que para ver o sucesso que fez. Os retornos de congressos para nós são muito fundamentais, nós avaliamos todos os encontros com feitas com os associados. Todos os congressos e os retornos são sempre fundamentais para podermos redirecionar caminhos. $O$ importante da avaliação não é saber se houve sucesso ou não, mas sim aproveitar a avaliação para repensar os projetos e a organização. 


\begin{abstract}
Mauricio Bianco (Conservação Internacional)
Atuacão profissional: Diretor de Desenvolvimento e Comunicação na Conservação Internacional Brasil

Breve currículo: Trabalhou mais de 12 anos na TIM como gerente de Comunicação Corporativa, onde construiu a carreira na área de comunicação por meio das estratégias desenvolvidas em dez estados da federação. Tem habilidades de comunicação integrada no terceiro setor, do ponto de vista estratégico e operacional, bem como em fundraising. Durante dois anos e meio trabalhou no ChildFund Brasil como responsável pela área de comunicação e mobilização de recursos no país, atingindo resultados expressivos, como o aumento de visibilidade e da receita da organização por meio de doadores nacionais. Atualmente é Diretor de Desenvolvimento e Comunicação na Conservação Internacional.
\end{abstract}

1. Na sua avaliação, como a comunicação tem contribuído para criar mensagens que engajem públicos para a prática da sustentabilidade nas organizações?

Eu vejo a comunicação como um meio, eu não estou olhando a comunicação como um fim. Nesse caso aqui ela é bem meio mesmo e, com relação a isso, sabe-se que, por mais que a atuação do Terceiro setor seja na área social, ambiental, de desenvolvimento, direitos humanos, em todas as áreas em que tenham sido trabalhadas há muito tempo, não só no Brasil, mas globalmente, a comunicação, na maioria das vezes, nunca foi um objeto a ser considerado estratégico até, digamos assim, 20, talvez 25 anos. Então era 'vamos fazer o que a gente precisa fazer e não precisa contar para ninguém'. E na perspectiva que só o fazer já seria suficiente para entregar o que a missão e que a organização se propunha. Na medida em que você tem novos meios de comunicar com as pessoas e as pessoas têm acesso às informações com muito mais frequência e em um patamar muito maior, é importante você começar a dar uma mensagem clara não só no que você se propõe em termos de projetos e programas que você vai desenvolvendo, mas principalmente no que você se propõe a fazer institucionalmente, como que é a sua participação e a sua missão dentro da sociedade. E aí eu vejo a comunicação como um meio extremamente importante para dar vazão a essa necessidade que, para algumas organizações, ela é muito maior porque entendeu que é essa missão faz a gente chegar no público mais amplo, e algumas que estão já começando a entender isso de forma mais recente. Posso dizer que a Conservação Internacional, onde eu trabalho hoje, acordou entre aspas para essa questão recentemente, talvez em menos de dez anos para cá. Ela tinha garantido fundos por determinadas fontes então teoricamente não precisava envolver muita gente e contar o que ela estava fazendo para captar mais recurso ou mesmo para envolver uma audiência maior, os stakeholders de forma geral. Então não nenhuma necessidade de comunicação e, se fazia, fazia de forma muito tímida. $\mathrm{Na}$ medida em que você sabe que, para ter uma transformação efetiva, você precisa efetivamente envolver uma quantidade maior de audiência, e aí vamos ser bem sinceros, de um público que normalmente não está diretamente relacionado com você, não é seu público que vai ter interesse direto contigo, mas que você precisa se comunicar, que é que chamamos de convertidos, se eu preciso ir para um público mais amplo, então a comunicação passa a ser 
importante. E aí quando eu falo de comunicação eu não falo só da necessidade dela, mas a forma como você faz ela, os meios que você utiliza para fazer. Tudo isso passa a ser extremamente importante para você dar o seu recado para um público que normalmente não te conhecia. Eu acredito piamente no que é necessário e isso não só é verdade porque eu acredito, mas se percebe claramente que o papel da comunicação na estratégia organizacional dessas organizações do Terceiro setor é cada vez mais estratégico. Ela não está só na comunicação para fazer o folder, fazer o site e o vídeo. Ela está hoje em um papel mais estratégico para posicionar a organização, por meio da sua mensagem, para uma reputação e o que se refere se branding. Imagina, branding era uma coisa que nem se falava em organizações do Terceiro setor alguns anos atrás. Então esse tipo de coisa eu acho que está de fato evoluindo muito.

\section{Você consegue delimitar os potenciais e os limites da comunicação para ampliar a consciência das pessoas sobre os atuais problemas sociais e ambientais?}

Eu parto do princípio de que se você não der conta de mostrar que esses problemas e essas situações existem, teoricamente você vai ter um grupo muito pequeno de ajuda. E se você está buscando envolver um público mais amplo para poder gerar uma discussão maior, sem a comunicação você vai estar extremamente limitado no que se refere ao poder de transformação que você tende a fazer, seja na área social, seja na área ambiental. Então existe a limitação sim, ela é muito mais ligada a recursos humanos e financeiros, mas não existe uma limitação em termos do que pode ser feito em comunicação. Existem hoje iniciativas de comunicação espalhadas no Terceiro setor em vários países que são de uma criatividade e de um alcance tamanho que isso, para mim, é o potencial da comunicação. Ele é enorme e acaba não tendo limites de fato, porque você de fato consegue ter um impacto muito grande. Agora, o que se vê hoje, e não é uma verdade só para a sustentabilidade das organizações, é que cada vez mais estamos falando em nichos. Nós antes podíamos usar, por mais ruim que pareça essa expressão, uma bala de canhão e acabava atingindo muitas pessoas. Hoje não adianta mais. Se você não trabalhar com nichos e com mensagens para o nicho, na forma para o nicho, você pode estar usando uma bala de canhão à toa, que vai voltar vai voltar para você. Então isso torna ainda mais complexo esse caminho que a comunicação percorre no Terceiro setor. Porque, se uma forma estamos falando que a comunicação é relativamente nova no Terceiro setor, e que no geral ela tem certa inovação, quando você começa a trabalhar a comunicação no Terceiro setor, já começa a se deparar com uma ferramenta que não é uma única mensagem para todos, como já foi no passado no primeiro e no segundo setor. Ou seja, você precisa trabalhar de forma focada no público-alvo, então se torna uma coisa ainda mais complexa. E tudo o que está tarelado a isso, o sistema de pesquisa do seu público-alvo que você precisa, que tipo de informação e por que meio que vai público, aí fica bem mais complexo mesmo para um conjunto de organização que têm limitação de recursos e pessoas para fazer, isso então é um desafio muito maior. Hoje estamos falando de microtarget hoje, ir no target bem específico para você dar o recado para a pessoa certa. Isso para o Terceiro setor é extremamente importante, porque ninguém mais que o Terceiro setor olha para o ROI, o retorno sobre investimentos da comunicação, do que o 
próprio Terceiro setor, porque os recursos são limitados, normalmente de origem de doadores, sejam eles de empresas privadas, do governo, ou de organizações multilaterais, mas, enfim, é um dinheiro que é muito mais vigiado, e tem que ser mesmo, então é necessário que a atuação seja muito mais certeira e muitas vezes não vai ter perdão de você não fazer um negócio bem feito. Isso pode custar uma grande ferida na organização se você investir em recursos que não vão ter um resultado tão significativo.

\section{Quais são os benefícios que a integração entre comunicação e sustentabilidade podem gerar para a sociedade?}

Para mim o mais importante, a primeira coisa, é ter conhecimento e transparência. Ou seja, você ter a comunicação em um espírito de tornar público o que você faz, na medida em que isso traz transparência e conhecimento para as pessoas. Só por isso entendo que já é benefício extremamente bem pago. Ou seja, fazer uma comunicação para mostrar o que você faz, que é normalmente de impacto coletivo, então você precisa de fato olhar para isso. Depois tem a questão que, ao fazer uma comunicação devida, você está gerando um awareness para a sua organização, para a sua causa, para o seu projeto e, consequentemente, está alavancando possibilidades de novos recursos para gerar uma transformação ainda maior. Então tem esse lado de comunicação para a captação de recursos, que é extremamente importante. É pouco provável que você consiga ter investimento na sua causa, na sua organização, se você não for conhecido ou for pouquíssimo conhecido, então é a sustentabilidade financeira da própria organização. Ainda tem esse outro ponto. Então eu considero que são benefícios extremamente importantes para se investir em comunicação ligada à sustentabilidade. E eu vejo a comunicação cada vez mais estratégica para o desenvolvimento da sustentabilidade. Se você fizer com profissionais da comunicação, e der para esses profissionais recursos e equipamentos para fazerem alguma coisa bem-feita, e tem um retorno com isso. O que é interessante olhar, e eu vivencio isso de forma cotidiana, é que parece que de medicina e comunicação todo mundo entende um pouco. Sempre tem um remédio que alguém quer receitar, assim como sempre tem alguma sugestão que alguém acha que isso é importante em termos de comunicação. $\mathrm{E}$ não estou dizendo que não deva ser feito. Gosto muito de decisões colegiadas, mas existe um técnico, uma pessoa que estudou e, teoricamente, tem condições de dar opiniões estratégicas sobre isso. $E$ muitas vezes não é assim que funciona. Então, colocar na comunicação pessoas que foram capacitadas para isso, e dar oportunidade, entenda-se recursos para ela desenvolver a estratégia, me parece importante para você avaliar se essa comunicação foi bem-feita ou não. Porque, se não for assim, você mata a comunicação antes. Alguém que não tenha o perfil não vai conseguir fazer o trabalho para você. Basta a gente convencer os outros que eles têm que olhar por esse lado também.

4. Quais recursos são necessários e como devem ser planejadas as ações de comunicação no Terceiro setor?

O primeiro ponto é o recurso humano. Pode até parecer clichê, mas se você não tiver um profissional minimamente capacitado da área para fazer esse tipo de ação, você não pode esperar um resultado positivo. Se for positivo, vai ser uma 
consequência ótima, mas vai ser coincidência. Se você de fato entende que a comunicação tende a aportar, invista em mão de obra capacitada. Tem um monte de gente saindo da faculdade hoje, e existe um mercado no Terceiro setor, então que o Terceiro setor também olhe para investimentos em comunicação primeiramente contratando pessoas da área. Isso seria a principal. Segundo, que é mais complicado, mas que devemos brigar por isso, é ter orçamentos, entenda-se dinheiro, investimento, para poder fazer uma boa ação. Porque também não adianta colocar um profissional da comunicação para fazer o trabalho e, se você não tiver dinheiro, ele vai conseguir fazer muito pouco e aí, logicamente, os resultados vão ser igualmente pequenos. Então eu tenho um mantra que é bem básico, eu acredito muito nele e diz que 'what you pay is what you get'. Então, o que você paga é o que você tem. Se você não paga, você não tem. Se tiver, é uma coisa muito marginal. Isso é verdade não só na comunicação, mas em qualquer outra coisa. Isso me remete a outra questão. No terceiro setor é comum que se façam muitas parcerias. E quando eu falo parcerias, eu falo de troca de conhecimentos que não envolvem recursos financeiros. Isso é muito importante acontecer, deve acontecer, sou muito partidário a essa estratégia, mas existem coisas que a gente sabe são limitantes também. Se você tem uma agência de publicidade que vai te ajudar, em forma de parceria para alguma estratégia, é bem provável que, no começo ela dê um gás bacana, no meio prazo você continue tendo um parceiro, mas eu vou ser bem sincero. Se ela tiver que optar em escolher você, ou atender alguém que está remunerando, ela vai escolher a remuneração. E está certo. Ela tem de pagar custos, pessoas, equipamento, infraestrutura e tudo mais. Então, se você tem uma parceria que te ofereça voluntariamente esses serviços, saiba que esses serviços vão ser condizentes com o que você está pagando, que é nada. Eu não estou generalizando, mas na média é isso basicamente o que acontece. Isso está totalmente ligado à necessidade de profissionalização do setor. Eu acredito de verdade que as parcerias podem acontecer. Acredito mesmo. Agora, vou ser bem sincero. Na medida em que uma empresa abre mão de ganhar dinheiro com o serviço que ela está oferecendo, ela está vendendo a galinha dos ovos de ouro. Então você tem que estar bem certo que alguém está pagando o tempo dessa pessoa. Então, se você puder remunerar pelo serviço, você também está valorizando o profissional de comunicação que está do outro lado. Então eu acho isso importante que isso, na medida do possível, aconteça. Com isso eu quero dizer que, quando você prevê orçamentos para projetos, para grandes iniciativas, ou mesmo para uma organização, você tem que prever orçamento para remunerar a comunicação também. Porque ela é igualmente importante como outros meios. Então em termos de recursos necessários é pessoal capacitado e recursos financeiros, e aí estou incluindo equipamentos, software, computadores, filmadoras, vai depender da sua estratégia de comunicação.

\section{Você pode descrever como é possível avaliar a comunicação no Terceiro setor em ações de sustentabilidade e quais são os principais desafios para isso?}

Primeiro que acho que a comunicação e o Terceiro setor, quando se fala em como avaliar, não difere em nada de qualquer outro tipo de avaliação que se faz em uma empresa, ou que se faz no governo. Ou seja, se você está fazendo um trabalho de assessoria de imprensa, vai medir com análise de mídia. Se você 
está fazendo publicidade, vai fazer retorno sobre investimento mesmo, o que está vindo para você em função do que você investiu. Não pode abrir mão pelo fato de ser uma organização do Terceiro setor. Não pode abrir mão de usar as ferramentas de avaliação que estão disponíveis hoje no governo e na empresa privada. Esse é o primeiro ponto. E em termos de desafios, eu acho que são muitos, porque buscar grandes resultados com, normalmente, poucos recursos, é sempre um grande desafio. Pode ser muito bom, porque te exige buscar caminhos alternativos. Então, o advento da comunicação online é muito propício para quem está trabalhando no Terceiro setor. Então você faz Facebook Ads, Google Ads, qualquer coisa do tipo, você está pagando o que tem de retorno. Se a pessoa acessa, você paga, se a pessoa não acessa você não paga. Isso é muito mais, entre aspas, justo, do que uma mídia tradicional, como jornal ou televisão. Isso é um potencial muito grande de como usar as novas mídias para fortalecer a comunicação do Terceiro setor. Parece-me mais interessante. $E$ também procurar novas mídias para usar no Terceiro setor, e isso é um desafio muito maior. Vou te dar um exemplo. Se eu não me engano foi a organização Save the Children, que é uma organização internacional, que buscou uma forma nova de mídia. Por exemplo, você deve ter na sua área de trabalho do seu computador um monte de ícones com seus arquivos. É um exemplo bem específico para chegar ao ponto que quero destacar. Essa organização, Save the Children, buscou em usuários de computador, que têm esses ícones, vender o ícone para que empresas privadas consigam colocar as suas marcas e as suas mensagens no ícone do seu computador. O que é isso? Sabe aquele ícone do Word, do Excel que você tem ali por acaso, vai estar escrito Off, que é a marca do repelente de mosquito. Basta baixar um programa que faz com que, automaticamente, todos os ícones da sua área de trabalho tenham alguma uma marca. Ou seja, o recurso dessa mídia, a venda dessa mídia, é revertida na causa da Save the Children. Então eu estou dando um exemplo de uma coisa que não é mídia. É o ícone de computador, então foi inventado isso como mídia, transformou isso em mídia. Tem também uma experiência que a Médicos sem Fronteiras fez na Espanha, que é vender remédio para a dor alheia. Eles estavam vendendo chiclete e, ao você comprar esse chiclete dos Médicos sem Fronteiras, o recurso era revertido para comprar equipamento para quem estava precisando em algum lugar do mundo. Então você está comprando remédio para a dor do outro. Então você adquire um produto que compraria de qualquer forma para mascar, mas que está ajudando o outro. Então você achou um elemento que não existia e passou a ser um veículo de comunicação para ajudar a causa que você está defendendo. Então, quando eu falo de achar outras mídias, é um desafio enorme você poder chegar nesse tipo de estratégia. $\mathrm{O}$ online já não dá para não mais para desconsiderar. Mas, achar mídia nova para o seu produto, entenda-se a causa da sua própria organização, para que você seja conhecido, seja apoiado, é uma coisa fantástica. Então eu só dei esses exemplos para fortalecer esse ponto de que é um desafio enorme e não tem fronteira, não tem limite. O limite mesmo é a criatividade. Enfim, é o que eu venho recolhendo de experiências dos últimos anos em que eu tenho atuado no terceiro setor. 


\section{Rejane Romano (Instituto Ethos)}

Atuacão profissional: Coordenadora de Comunicação do Instituto Ethos Breve currículo: Graduada em Jornalismo e pós-graduada em Mídia, Informação e Cultura pela Universidade de São Paulo (USP). Iniciou na área em 2003 como repórter do jornal Tribuna, em Ribeirão Preto. Prestou trabalhos em assessora de imprensa e edição da revista da ONG Liga dos Amigos e Estudantes Africanos (LAEA), sediada na capital paulista, com ações para assegurar a inclusão do negro na sociedade. Entre 2009 e 2016 trabalhou para a ONG Afrobras (Sociedade Afro Brasileira de Desenvolvimento Sociocultural), entidade que trata de temas relacionados à cidadania, inclusão e valorização do negro brasileiro e que atua juntamente com a Faculdade Zumbi dos Palmares. $\mathrm{Na}$ ocasião, atuou como gerente do departamento de comunicação da faculdade, editora da Revista Afirmativa Plural, editora de conteúdo do Portal Afrobrasileiros e apresentadora do programa Negros em Foco.

1. Na sua avaliação, como a comunicação tem contribuído para criar mensagens que engajem públicos para a prática da sustentabilidade nas organizações?

No Instituto Ethos trabalhamos com Twitter, Linkedln e Facebook, cada um com uma linguagem própria de acordo com o perfil. No Linkedln, por exemplo, o foco é na empresa e por isso usamos uma linguagem que busca a sensibilização das pessoas que estão no mercado. Já no Facebook trabalhamos com a pessoa física, pontuando nossas ações de forma a tornarmos conhecidas as iniciativas que o Ethos abarca.

2. Você consegue delimitar os potenciais e os limites da comunicação para ampliar a consciência das pessoas sobre os atuais problemas sociais e ambientais?

Não há como delimitar, mas existe uma percepção de quais temas têm maior ou menor aceitação, levando-se em consideração ainda o momento da sociedade, que muda ao soprar dos ventos. Atualmente, é perceptível uma comoção nacional com assuntos que estejam relacionados à ética.

\section{Quais são os benefícios que a integração entre comunicação e sustentabilidade podem gerar para a sociedade?}

Ambas estão intrínsecas e a grande sacada é trabalhar a transversalidade das questões. A começar por evidenciar o quanto sustentabilidade não se refere apenas a questões de meio ambiente, mas sim todo escopo abrangido pela responsabilidade social.

4. Quais recursos são necessários e como devem ser planejadas as ações de comunicação no Terceiro setor?

Uma boa estratégia requer investimento financeiro e, como esta é uma questão delicada para muitas organizações do Terceiro setor, a criatividade se torna 
preponderante. O engajamento é um recurso imprescindível e neste ponto as redes sociais são fortes meios de disseminação e atração de pessoas.

5. Você pode descrever como é possível avaliar a comunicação no Terceiro setor em ações de sustentabilidade e quais são os principais desafios para isso?

O desafio é que esta comunicação não se torne apenas de nicho, mas sim que se entenda a relevância das ações. Desde as mais simples, como posts que pontuem datas, até a divulgação de eventos. Questões que podem ser consolidadas com um plano de comunicação que alinhe redes sociais e site institucional, além de influenciadores e articulistas que possam embasar o plano de ação. 


\section{Renato de Paiva Guimarães (Greenpeace)}

Atuação profissional: Diretor de Mobilização do Greenpeace Brasil

Breve currículo: Jornalista com pós-graduação em Comunicação Corporativa e Gestão de Marcas. Fellow do Center on Civil Society da City University de Nova York. Possui ampla experiência em comunicação estratégica, relações públicas, responsabilidade social e sustentabilidade acumulada após mais de 15 anos de experiência, incluindo experiências internacionais, quando morou em New York (Estados Unidos) e Lima (Peru), além de ter feito várias viagens de negócios. Focado em resultados de alto impacto em aspectos-chave da comunicação estratégica: assuntos corporativos, gestão da marca, comunicação interna e externa, reputação, equipes interculturais, endomarketing, estratégia, planejamento de eventos, sustentabilidade, responsabilidade social corporativa, análise de ROI, Relações Públicas, planejamento de mídia e advocacy. Além disso, atua com relações com a imprensa, gerenciamento de crises de imagem, relações públicas, planejamento de mídia, storytelling, planejamento de mídia social, gerenciamento da marca (brand management), edição e desenvolvimento de conteúdo de publicações, engajamento de partes interessadas (stakeholder engagement), redação de discursos e artigos, relações governamentais e outros públicos-chave (advocacy), planejamento e desenvolvimento de eventos, projetos de responsabilidade social corporativa e sustentabilidade. Tem experiência no gerenciamento de equipes altamente eficientes e atuação no desenvolvimento de um ótimo ambiente de trabalho, baseado no respeito às capacidades de cada um, no valor da diversidade, em processos de diálogo claros e transparentes e na transparência no processo decisório. No Greenpeace é Diretor de Mobilização desde setembro de 2015, sendo responsável por uma equipe de comunicadores, designers, especialistas em vídeo e foto, mobilização de voluntários e especialistas no mundo digital para mobilizar e engajar os cidadãos para lutar contra as causas da crise ambiental no Brasil, com um foco em florestas, mudança climática, energia e temas urbanos.

\section{Na sua avaliação, como a comunicação tem contribuído para criar mensagens que engajem públicos para a prática da sustentabilidade nas organizações?}

O mundo lá fora eu tenho dificuldades de entender como isso chega até por falta de recursos. A comunicação não se dá na emissão, mas quando a pessoa do outro lado a recebe. Como é mais fácil compreender a emissão, muitas pessoas param aí. A comunicação tem muita dificuldade de chegar e como avaliar o que ela recebe, o impacto que ela recebe. Esse aspecto é o mais complexo, pois o processo de típico da comunicação era mais ou menos estável. Os meios eram mais ou menos conhecidos. Com as mídias sociais prevalentes, as pessoas se tornaram emissoras de comunicação de forma fluida, e isso ficou mais complicado ainda, pois depende da interpretação e da reinterpretação das pessoas. Este é o mundo fragmentado das mídias. Existem várias tentativas de trazer sustentabilidade para o cotidiano das pessoas.

\section{Você consegue delimitar os potenciais e os limites da comunicação para ampliar a consciência das pessoas sobre os atuais problemas sociais e ambientais?}


No Greenpeace, temos tentado muito pensar e testar formas de conteúdos com pessoas antes de torná-los públicos. Por exemplo, o tema da luta contra a implantação de projetos na Amazônia e os impactos sobre o meio ambiente. Como as pessoas percebem que o tema da Amazônia tem a ver com a vida dela em São Paulo? Fazemos testes de como isso impacta cada público. Usamos muito mídias sociais, criamos postagens com diferentes aspectos, testes com pessoas diferentes, e aplicamos. Dependendo do retorno, avaliamos qual frase e qual foto traz mais engajamento. Isso deu muito certo na campanha Tapajós. Esse teste ajuda muito a posicionar melhor a comunicação. Parte dos conteúdos das organizações não faz isso. Essa capacidade de segmentar os conteúdos será absolutamente fundamental.

\section{Quais são os benefícios que a integração entre comunicação e sustentabilidade podem gerar para a sociedade?}

Hoje em dia observamos, por um lado, as pessoas sendo produtoras e reprodutoras de conteúdo, uma democratização massiva da comunicação. Por outro lado, com as margens para pós-verdades e interpretações negativas, isso aumenta a relevância da curadoria. Hoje isso é uma oportunidade importante para a comunicação, serve para separar o joio do trigo. Comunicação é fundamental, é fluida, assim começamos a atingir as pessoas. A curadoria se tornará mais importante na sustentabilidade, é como se tangibiliza isso. Comunicação mais fragmentada, diluída, ela força isso. As pessoas querem saber como isso impacta na vida. Conteúdos genéricos, muito profundos, técnicos demais, não conseguem comunicação para as pessoas. Os conteúdos que mostram os problemas, como eles impactam, que chamam para a ação, com boa formatação visual são os que têm mais impacto.

\section{Quais recursos são necessários e como devem ser planejadas as ações de comunicação no Terceiro setor?}

Com a utilização de recursos de economia criativa, conseguimos diluir custos, mas a questão principal é que este aspecto é fundamental. As pessoas devem incluir recursos para a comunicação, para profissionais que pensem a comunicação além da produção de conteúdo, focada em engajamento. Às vezes, um relatório tem menor impacto que uma campanha bem construída. Pensar a estratégia é o que mais faz falta para as organizações que atuam com sustentabilidade atualmente. A visão estratégica deveria estar no centro da organização, que deve ter um profissional que não tenha o um perfil de um assessor de imprensa tradicional, mas que seja um gestor de engajamento e mobilização.
5. Você pode descrever como é possível avaliar a comunicação no Terceiro setor em ações de sustentabilidade e quais são os principais desafios para isso?
A mensuração deve ser feita sempre em comparação com alguma coisa. $\mathrm{O}$ setor privado tem este conceito muito forte do plano, objetivo, ação e indicadores de performance. Qualquer processo de mensuração só faz sentido se antes foi realizado um indicador de desempenho. Esse indicador é o princípio da coisa. Assim, eu consigo implementar a mensuração, e é muito difícil. Esse processo tem que estar muito claro e alinhado com os objetivos da organização. Hoje já existem muitas opções disponíveis e isso é um processo de descoberta. 
Com relação aos desafios, a educação tem que estar muito relacionada à comunicação, por exemplo, pensando sobre como entregar as mensagens chegar nas novas gerações, pois é muito difícil mudar quem está no poder. É um desafio muito grande nos comunicarmos, utilizando não somente a educação formal, mas, com as novas gerações, outros formatos são importantes. No caso da comunicação integrada à sustentabilidade, essa fragmentação traz o desafio que há cada vez menos especialistas e potenciais curadores confiáveis. É importante refletir sobre como estão sendo formados os curadores, oferecendo informações confiáveis e qualificadas, com conteúdos relevantes. Os curadores que têm credibilidade junto às suas comunidades $e$ outros públicos, mas que falem com propriedade e levem mensagens aos públicos. Assim, como geradoras publicações, as organizações se tornam parte do processo de transferência de conteúdo para as pessoas. 
Apêndice 10. Entrevistas com especialistas em sustentabilidade

Denise Hamú (ONU)

Enrique Leff

Fernando Almeida

Leonardo Boff

Oded Grajew (Ethos)

Pedro Jacobi (USP) 


\section{Denise Hamú (ONU)}

Atuação profissional: Representante, no Brasil, do Programa das Nações Unidas para o Meio Ambiente (Pnuma) da Organização das Nações Unidas (ONU)

Breve currículo: Mais de 25 anos de experiência na área de conservação ambiental, dos quais uma década inteira de carreira exercida na Amazônia. Formada em relações internacionais e em história pela Universidade de Brasília (UnB) e mestre em museologia pela George Washington University (EUA), com ênfase em história natural e antropologia cultural, Denise Hamú foi secretáriageral da WWF-Brasil durante oito anos. Denise Hamú também tem experiência com questões de desenvolvimento nacional, regional e internacional e presidiu a Comissão de Educação e Comunicação da União Internacional para a Conservação da Natureza (IUCN) de 2000 a 2006. Além disso, ela foi funcionária do Conselho Nacional de Desenvolvimento Científico e Tecnológico (CNPq) do Ministério da Ciência e Tecnologia, tendo trabalhado também no Ministério do Meio Ambiente e representado o Brasil em vários fóruns ambientais internacionais.

1. Qual é o papel dos governos e dos grupos intergovernamentais para o cumprimento dos acordos firmados em conferências sobre o clima no âmbito internacional?

Os governos e os grupos intergovernamentais podem desenvolver ações muito importantes, mas só o governo não resolve. A sustentabilidade é uma tarefa de todo mundo, de todos os habitantes desse planeta. Claro que não podemos ser John Lennon e cantar Imagine. Nós temos que ser bem objetivos, mas sem o terceiro setor nós não conseguimos implementar a Agenda 2030. Ela é realmente o nosso caminho, o que foi acordado inclusive pelo terceiro setor por meio do Pacto Global, dos stakeholders, e dos major groups. Pela Agenda 2030 houve um processo de consulta extremamente importante e relevante. As Nações Unidas implementaram esse processo que culminou com a adoção do documento da Agenda 2030 e nela está escrito que, primeiro, nós não podemos deixar ninguém para trás, ou seja, envolver as pessoas do norte, sul leste e oeste, e temos que envolver todos os setores. Tanto é que tem um dos "Ps" do documento é de parceria. Nós não podemos fazer nada sozinhos.

2. Como as organizações, especialmente as do Terceiro setor, têm possibilidade de contribuir para reduzir os impactos sociais e ambientais e diminuir os problemas de preservação do planeta?

Nós organizamos recentemente um simpósio no Museu do Amanhã, no Rio de Janeiro, em que nós discutimos o que avançamos da Rio 92 até hoje. Realmente nós caminhamos muito, mas sempre temos a sensação, na área ambiental em particular, que estamos sempre chegando atrasados. Nós acordamos de manhã e percebemos que nunca conseguimos nos antecipar. Nós somos péssimos de visão, mas temos conseguido, se olharmos para trás de 1992 para cá, a quantidade de ações que foram construídas. Nós já conseguimos muitas coisas. Então, por exemplo, há 15 anos não existia nenhum lugar em que você trabalhava uma área de mudanças climáticas. Por exemplo, quando eu cheguei no WWF, em 2003, nós não tínhamos nem uma área de agricultura. Nós falávamos só de biomas, Mata Atlântica, Amazônia, Pantanal. 
Então, nós começamos a ver que não adiantava só localizar as coisas, mas precisávamos tratar daqueles assuntos que permeavam todos os biomas e toda essa questão de não ter fronteira, pois estamos falando de um só planeta. Ponto. Todos nós dependemos uns dos outros, seja em termos de recursos naturais, em termos de áreas agriculturáveis, em termos de ar de qualidade para respirarmos, de saneamento. A discussão sobre cidades, por exemplo, não estava no contexto. A Agenda 21 trouxe essa contribuição, mas pouco se falava. Então, fomos evoluindo. Os últimos dez anos foram incríveis. Se você olhar o conhecimento novo que foi gerado na área de mudanças climáticas é uma grandeza. Há vinte anos tínhamos muito pouco. Isso porque ainda temos um Donald Trump questionando a ciência. Mas, de qualquer forma, sabemos que caminhamos demais. Temos 0 trabalho maravilhoso do Painel Intergovernamental sobre Mudanças Climáticas (IPCC), que tem congregado a ciência toda e tentado traduzir isso de uma maneira mais palatável, onde falta muito a comunicação. Mas temos também o Al Gore que tem feito um trabalho importantíssimo de sensibilização e de conscientização pública no mundo todo. E ele tem esse poder da comunicação. O Al Gore chega e encanta todo mundo por onde ele passa.

\section{Na sua avaliação, a comunicação praticada pelas organizações tem contribuído para incentivar o debate sobre sustentabilidade e sensibilizar as pessoas para criarem ambientes mais sustentáveis?}

Antes de mais nada, eu quero dizer que a comunicação é fundamental. Você selecionou um tema fascinante e necessário, mesmo porque, e você já deve ter percebido pela sua escolha, que a comunicação para a área de sustentabilidade e o meio ambiente, especialmente, é um instrumento de gestão. Ela é parte de um projeto, não é apenas para comunicar os resultados. Não. Ela é essencial, inclusive no terceiro setor, e eu fui CEO do WWF Brasil por quase nove anos, uma organização muito relevante no mundo, presente em 120 países. Todos os projetos do WWF têm um comunicador. Eu não precisava convencer ninguém. Era o sonho porque a comunicação, e os modelos de comunicação eram muito utilizados com grupos focais, por exemplo, atuavam em tudo até na preparação para as reuniões. Tudo isso é comunicação e, normalmente, as pessoas confundem com Relações Públicas. Então, a comunicação é um tema fascinante, eu vejo como um ingrediente essencial e quero te dar os parabéns pela escolha do tema.

Eu acho a comunicação essencial. Ela é essencial, inclusive a sustentabilidade deve ser conjugada no plural. A sustentabilidade é a essência do coletivo. Nós não podemos fazer nada sozinhos. A comunicação é a cola. Muitas vezes nós tendemos a fazer a comunicação exposed. Ou seja, quando temos algum material, pensamos em fazer um release, e às vezes não tem nada a ver com determinadas estratégias, pois precisamos ouvir as opiniões. Eu acho que, por exemplo, nós das Nações Unidas temos um papel nessa agenda que é servir de plataforma de diálogo, promover encontros desses mundos. Não estamos falando só com governos. Claro que, aqui, eu represento a ONU Meio Ambiente, nós inclusive mudamos de nome do Pnuma inclusive nessa linha que você está falando. O nosso nome fantasia agora é ONU Meio Ambiente, porque já existe 
o Programa das Nações Unidas para o Meio Ambiente. O nosso nome fantasia agora é ONU Meio Ambiente, o que está absolutamente na sua linha porque Programa das Nações Unidas para o Meio Ambiente (Pnuma) não quer dizer muita coisa. O nosso novo diretor executivo determinou uma ordem interna que baniu Pnuma e Unep. Todas as divisões do Pnuma, os departamentos, tinham nomes muito extensos. Mudamos todos.

Isso porque nós estamos percebendo que, na área de sustentabilidade, estamos falando para os convertidos. Nós temos que romper esses silos. Estamos um pouco inebriados, até por essa agenda ter tomado alguma relevância, e por conta da importância do Acordo de Paris, que estamos falando apenas para os nossos pares. E aí não estávamos alcançando os de fora. Nosso diretor executivo mudou isso agora e nós não podemos seguir fazendo o que fazíamos. Temos que avançar nessa questão. A comunicação agora é o não uso de acrônimos, não podemos dizer sigla nenhuma porque ele disse que se as pessoas não identificam a ONU Meio Ambiente como um espaço aberto de aprendizado, de idas e vindas, de mão dupla, como é que que nós queremos achar que vamos realizar o nosso mandato? Estamos caminhando muito nessa linha. E uma tarefa enorme, mas estamos bem comprometidos para que as coisas aconteçam.

4. Qual é a importância do Terceiro setor para liderar pessoas e organizar movimentos e ações para promover a melhoria da sustentabilidade em termos locais, regionais, nacionais e globais?

Essa questão da urgência também é importante. Eu preciso atuar hoje, não é daqui um mês, eu não posso pensar em fazer alguma coisa daqui trinta anos. Eu tenho que atuar hoje na minha casa, na minha comunidade, e por aí vai. Então, caminhamos muito mesmo, mas agora nós precisamos avançar. Eu uso uma figura que eu cito que diz que a nossa ambição é tão grande, e as necessidades que temos de mudanças, de novos padrões de consumo e produção, de uma economia de baixo carbono, que as mudanças estruturais são muito grandes. Então, eu digo estamos querendo ir para a Lua de Fusca. Porque nós não mudamos o veículo. Mudamos a ambição, mas continuamos com os mesmos desenhos, o mesmo modelo de gestão, os mesmos lugares, a mesma arquitetura. Agora temos que pensar fora da caixa, precisamos ser inovadores, ousar, arriscar. Temos que mudar o nosso modelo de mindset, e isso tudo entra na questão de costumes e valores. Não adianta termos o Acordo de Paris se não mudarmos. Não adianta termos instrumentos legais, obrigações, sobre o que os países e nós dedicamos tanta energia, principalmente as Nações Unidas, se as pessoas que chegam lá para negociar chegam e saem do mesmo jeito. Então temos que atuar nos valores, não vai ser um acordo só. Por isso que eu estou falando que, quando o Donald Trump não vai a um evento desse, acho que temos tantas coisas boas acontecendo lá que eu nem sei se ele vai fazer tanta falta. Os Estados estão comprometidos, as cidades estão comprometidas, as indústrias estão comprometidas, claro que nem todo mundo, mas grande parte. Agora, somos as mesmas pessoas com o nosso modelo mental igual. Temos que fazer mudanças enormes. É nisso que precisamos trabalhar e é por isso que a comunicação é tão importante. Porque não adianta ficarmos só falando entre nós e depois chegarmos à conclusão que 
nós fracassamos. Não é isso o que nós queremos. Essa é uma mudança de patamar.

A solução está aí. Agora, isso não é fácil. É fácil pensar e falar, agora, temos que partir para a ação. Nas Nações Unidas, por exemplo, o nosso secretário geral, o português António Guterres, começou, e eu espero que ele continue, um grupo de reforma para pensar as Nações Unidas. Nós não estamos equipados para isso. Nós somos um Fusca caindo aos pedaços. Aí cria-se a Agenda 2030 que é um foguete e nós estamos nos estapeando, porque um entra, o outro sai, e precisamos de continuidade. Então, as próprias agências terão que ser repensadas. Será que elas ainda precisam existir? Será que o modelo agora precisa ter todas essas fragmentações que temos, que um cuida de agricultura, outro de floresta, um de água, outro de mulher, outro de HIV? Será que esse é o recorte? Nós já estamos entrando nessa discussão, vai ser uma guerra, porque você imagina uma mudança de cultura arraigada, uma cultura onde está todo mundo está forjado em cima de tantas nacionalidades, isso é mexer com muita zona de conforto. E sobre a sua pesquisa eu adorei, eu estou falando sério. É importantíssimo o que você está fazendo. Eu espero que seja excelente a sua tese, que ela aponte alguns caminhos. Vou adorar receber a pesquisa concluída.

5. Além dos recursos de comunicação, que outras iniciativas são estratégicas para ampliar o debate sobre sustentabilidade e contribuir para uma nova consciência social sobre esta temática?

Eu já falei dos principais. Essa questão de refletir o modelo de governança, de gestão, arquitetura, acho que é por aí. Acho ainda, por exemplo, que precisamos refletir sobre essa questão das startups. Nós precisamos falar a linguagem dos jovens, não podemos nos distanciar deles e não colocar apenas aquele discurso de que estamos preservando hoje para as gerações futuras. Não! Eu estou fazendo isso para que eu possa respirar melhor hoje. Nós ficamos delegando paro o outro e é como se tivessem que nos agradecer daqui algumas décadas. Nós temos que fazer isso para nós. Enquanto nós não nos conscientizarmos muito disso, vai ser difícil. Então é um novo mindset. É por aí mesmo. E a comunicação, como eu disse, ela é fundamental.

A Agenda 2030 é um documento muito inspirador, são tantas as metas, mas também é importante a parte filosófica porque está ali o que a gente precisa. Claro que a gente precisa endereçar os problemas dos Objetivos de Desenvolvimento Sustentável, a gente vê a questão do enfoque mais integrado com o meio ambiente, a geração de emprego e renda, a erradicação da pobreza e toda essa parte social que é fundamental para nós. Isso tudo nós precisamos endereçar. $E$ acredito que o que nós precisamos é colocar esses pilares de forma complementar. Voltando ao início da minha fala, não adianta nós só preservarmos uma nascente, temos que preservar quem mora lá, quem vai receber a água, então temos que ver que trabalhamos em um sistema vivo, orgânico, com pessoas interagindo com os recursos naturais e por aí vai. O que precisamos é conseguir ter um pouco mais dessa visão mais integrada. $E$ enxergar que uma ação tem consequência na outra. 


\section{Enrique Leff}

Atuacão profissional: Ex-coordenador da Rede de Formação Ambiental para a América Latina e o Caribe, do Programa das Nações Unidas para o Meio Ambiente (ONU)

Breve currículo: Enrique Leff é um dos principais intelectuais latino-americanos no âmbito da problemática ambiental. Foi coordenador da Rede de Formação Ambiental da América Latina e Caribe, do Programa das Nações Unidas para o Meio Ambiente (Pnuma) e, também, professor da Universidade Autônoma do México (Unam). Durante as décadas de 1970 e 1980, Leff já era amplamente conhecido nos países hispânicos por sua posição teórica marxista. Doutor em Economia do Desenvolvimento, Enrique Leff é um dos maiores defensores do diálogo entre os saberes como forma de resolver os problemas ambientais para a construção de uma racionalidade ambiental que supere a crise ambiental resultante do modelo capitalista de desenvolvimento. As proposições de Leff são consideradas postulados que têm auxiliado pesquisadores de todo o mundo na melhora da qualidade do meio ambiente, transformando o contexto socioambiental para a sustentabilidade. Enrique Leff é convidado como professor, palestrante e panelista em várias universidades e nos principais convites internacionais sobre temas de economia ecológica, ecologia política e educação ambiental, na América Latina, nos Estados Unidos e na Europa. Ele é o autor de mais de 20 livros e 200 artigos publicados no México, Alemanha, Argentina, Bélgica, Brasil, Canadá, Colômbia, Costa Rica, Chile, Espanha, EUA, Inglaterra, Itália, Alemanha, Holanda, Venezuela. Membro dos conselhos editoriais e/ou científicos das revistas: Revista Mexicana de Sociologia, Revista Etnobiología, Estudios Sociales, Gaceta Ecológica e Quivera (México); Capitalismo, Natureza, Socialismo (EUA); Ecologia Política, Coleção Periferias (Universidade de Granada) e AmbientalMente Sustentável, Revista GalegaLusófona de Educação Ambiental (Espanha); Revista Theomai, Habitat e Meio Ambiente, Instituto de Habitat e Meio Ambiente, Universidade de Mar del Plata (Argentina); Desenvolvimento e Meio Ambiente, Universidade \& Sociedade, Revista Científica Meio Ambiente e Sustentabilidade; Revista Polis Amazônica, Linhas Criticas, Gaia Scientia e Sociedade em Debate (Brasil); Idéias ambientais e gestão e meio ambiente (Colômbia); Ambiental (Costa Rica); Polis, Leading Magazine e Sustainability Magazine (Chile); Revista Ibero-Americana de Economia Ecológica (Equador); Revista Latino-Americana de Pesquisa em Organização, Meio Ambiente e Sociedade Teuken Bidikay (Argentina-Colômbia, México); Ambien-Iberoamericana University Journal on Environment, Society and Sustainability.

\section{Qual é o papel dos governos e dos grupos intergovernamentais para o cumprimento dos acordos firmados em conferências sobre o clima no âmbito internacional?}

Em princípio, se eles assinaram, devem cumprir. Mas eles têm diversas vias para cumprir ou não cumprir. Isso ocorre quando estão tentando cumprir através de certos mecanismos e projetos econômicos e como contabilizam essa questão para reportar os sucessos desses compromissos. Então aí é um campo um pouco ambíguo também de como eles estão cumprindo com esses compromissos. Entra dentro de certas lógicas de avaliação dos cumprimentos 
dos compromissos dos acordos, das metas do milênio e de todos os grupos internacionais.

2. Como as organizações, especialmente as do Terceiro setor, têm possibilidade de contribuir para reduzir os impactos sociais e ambientais e diminuir os problemas de preservação do planeta?

As organizações do Terceiro setor são muito importantes porque estão mobilizando a inquietude social sobre essa questão da sustentabilidade e às vezes esses movimentos são de pessoas de comunidades que estão defendendo uma questão mais particular, mais pontual, dentro das suas condições de vida, não somente uma ideia geral. Então estão se defendendo contra muitas vezes certos empreendimentos que afetam diretamente essas condições de vida. Então seria importante para eles ganharem, nessa luta política, seus direitos para resolverem essas questões a seu favor. Mas, também, porque nesses processos vão se mostrando também as resistências da cidadania e dos grupos sociais sobre o direito de o capital desapropriar certos territórios e certos espaços para seus projetos de desenvolvimento econômico.

3. Na sua avaliação, a comunicação praticada pelas organizações tem contribuído para incentivar o debate sobre sustentabilidade e sensibilizar as pessoas para criarem ambientes mais sustentáveis?

Depende do que você quer comunicar. Você pode comunicar distintas visões da questão. Então depende o que comunica e como comunica. É uma questão também difícil, porque se há mais comunicação, dentro dessa comunicação também muitas vezes o que fica dentro das cabeças das pessoas é também uma simplificação da complexidade da problemática. $E$ também se difunde um fluxo muitas vezes mais retórico das questões e não um aprofundamento da argumentação, do pensamento crítico sobre o que está jogando esse processo da globalização econômica e dos aspectos negativos da crise ambiental. E eles são muito complexos, então quando você fala de comunicação, a comunicação geralmente tende a simplificar as coisas, sobretudo em divulgações muito massivas, então precisamos também saber que tipo de comunicação. No caso do Terceiro setor, ele pode praticar a comunicação com meios massivos de comunicação, transmitir essas informações assim. Outra coisa muito diferente é falar dos diálogos de saberes, dos diálogos mais estratégicos dos grupos, o que é diferente. Então depende que comunicação estamos pensando.

4. Qual é a importância do Terceiro setor para liderar pessoas e organizar movimentos e ações para promover a melhoria da sustentabilidade em termos locais, regionais, nacionais e globais?

Historicamente, não temos mecanismos para avaliar se o Terceiro setor tem ganhado força para contribuir para a sustentabilidade. Não temos mecanismos claros de avaliação, fica muito difícil avaliar, mas eu gostaria de ver mais processos de integração e de solidariedade dessa diversidade de movimentos sociais. Não quer dizer que eles não existem, mas eles estão muito desagregados ainda dentro das suas lutas particulares e as pessoas estão muito mais vulneráveis porque cada luta é uma luta mais local, mais particular 
dentro de condições políticas geralmente muito adversas. Então eu só posso dizer que eu gostaria de ver um processo, um movimento global muito mais amplo do que esse que existe, mas também fica muito difícil porque há diferentes problemáticas locais, diferentes concepções críticas sobre os processos de desenvolvimento, os efeitos negativos sobre o clima, sobre os sistemas e as condições de vida da população.

5. Além dos recursos de comunicação, que outras iniciativas são estratégicas para ampliar o debate sobre sustentabilidade e contribuir para uma nova consciência social sobre esta temática?

O diálogo de saberes entre distintos grupos sociais, que fazem refletir e argumentar, dentro da sua visão de mundo, dentro de suas problemáticas ecológicas, existenciais e particulares. E com isso abrir, dentro dessa perspectiva de autoridade os diferentes modos de pensar a questão da sustentabilidade e gerar assim sinergia dentro desse jogo de diferenças. 


\section{Fernando Almeida}

Atuaç̃o profissional: Consultor, escritor e conferencista de sustentabilidade Breve currículo: Com mais de 30 anos de experiência profissional nos setores empresarial, governamental e acadêmico, o engenheiro Fernando Almeida tornou-se uma das maiores referências em sustentabilidade no país. Como escritor, conferencista e estrategista, Fernando Almeida tem ajudado empresas a alinhar a responsabilidade socioambiental com o sucesso do negócio. Como comunicador, desenvolveu a capacidade de expor os problemas de forma equilibrada, realística, criando caminhos estratégicos seguros para moldar uma visão interna consistente na instituição e produzir parcerias produtivas. Atualmente, Fernando Almeida é um dos mais qualificados porta-vozes da visão das tendências internacional, nacional e local, tanto na abordagem dos ecossistemas (mudança do clima, escassez de água, biodiversidade), como em relação aos aspectos sociais revelados nas necessidades dos stakeholders. Tem atuado na formulação de políticas empresariais e públicas, com foco na visão de longo prazo, definindo com clareza desafios e oportunidades. Esteve à frente do Conselho Empresarial Brasileiro para o Desenvolvimento Sustentável (CEBDS) e, ultimamente tem se dedicado mais à atividade empresarial. Após se formar em Engenharia Civil pela Universidade do Estado do Rio de Janeiro (UERJ), nos anos 1970, Fernando Almeida foi estudar um pouco mais e fez Mestrado em Engenharia Ambiental nos Estados Unidos. De volta ao Brasil, ingressou na recém-criada Feema (agência estadual pioneira no país na área ambiental). Paralelamente ao serviço público e demais atividades que assumiria depois, Fernando Almeida exerceu também a carreira de professor de graduação e pós-graduação. O salto qualitativo de sua carreira poderia ocorreu com a realização da Rio-92, quando acompanhou o discurso do empresário suíço Stephan Schmidheiny, que apresentou o conceito de ecoeficiência e estabeleceu a ligação entre o conceito de desenvolvimento sustentável e a atividade empresarial. A experiência acumulada como gestor público, professor e pequeno empresário foi a base de conhecimento para perceber que, isoladamente, os três setores da sociedade não seriam capazes de imprimir mudanças de rumo do modelo de desenvolvimento tradicional, baseado no lucro a qualquer preço, na destruição dos recursos naturais e na exclusão social. Apesar da disseminação do conceito de sustentabilidade, Fernando Almeida ainda é visto por alguns como "um capitalista disfarçado de ambientalista" e por outros como "ambientalista inconsequente". Foi convidado pelo Conselho Empresarial Mundial para o Desenvolvimento Sustentável (WBCSD) para representá-lo no Comitê Executivo do programa da ONU Avaliação Sistêmica do Milênio, o mais importante inventário ambiental global realizado até agora. Participou como principal orientador na criação de conselhos da rede do WBCSD de outros países, como China, Chile e Angola. Hoje, integra o Conselho Diretor do Instituto de Estudos Avançados da Universidade das Nações Unidas, sediado no Japão.

1. Qual é o papel dos governos e dos grupos intergovernamentais para o cumprimento dos acordos firmados em conferências sobre o clima no âmbito internacional? 
A primeira questão é que este é um dos temas mais difíceis da atualidade, pois o primeiro problema é que a sustentabilidade é um termo extremamente hermético para a sociedade em geral. Eu sempre expliquei sustentabilidade da seguinte forma: é sobrevivência. Mas, sobrevivência de quem? Sobrevivência dos ativos ambientais para uma sociedade mais justa e sobrevivência das empresas, naturalmente. Sustentabilidade é sinônimo de sobrevivência.

Existem vários acordos, o do clima é o mais badalado. Os acordos feitos no âmbito da ONU têm força de lei. Uma vez assinados, têm força de lei dentro dos países que estão ratificando. Se ratificou, tem força de lei. No Brasil, sabemos que há algumas leis que são aceitas, outras que não são aceitas e fica por isso mesmo. Mas ele tem força de lei. Essa é uma primeira questão. O que eu tenho visto é uma participação do governo cada vez menor. Eu vejo os governos, nos últimos dez anos, cada vez mais afastados desses temas, sendo que o Brasil já teve maior liderança nisso na América do Sul e mesmo a nível mundial em alguns aspectos. Hoje isso não acontece.

Os grupos intergovernamentais e as entidades governamentais até tentam fazer um certo tipo de pressão, mas muitas vezes a maior pressão que se pode conseguir é a da sociedade como um todo, não apenas da sociedade civil organizada e das ONGs. Eu não quero politizar a discussão, porque a sustentabilidade não é uma questão de natureza intrinsecamente política. Como ela atinge todo mundo, deveríamos caminhar juntos nesse sentido, mas não é a realidade.

Sobre políticas públicas, podemos exemplificar com diferenças estaduais. O governo de Minas Gerais, de uma forma ou de outra, deu incentivo à adoção de energia solar e neste Estado existe hoje o parque solar mais desenvolvido do País e a forma mais fácil e mais barata de gerar energia, sem burocracia, com possibilidade ainda de vendê-la para empresas de energia elétrica. No Estado do Rio de Janeiro foi o contrário. Impostos foram mantidos em nível tão elevado que praticamente nãos se encontra geração domiciliar de energia a partir de células fotovoltaicas. Então existe a política pública, que facilita a aplicação das mesmas ideias de algumas decisões acertadas de criação de unidades ambientais e, por outro lado, decisões completamente incoerentes na área ambiental inviabilizando atividades que sempre existiram. Ainda sobre políticas públicas, há muitas lacunas. Os governos não estão avançando na questão e, se existe um senso de urgência no rumo da sustentabilidade, esta transformação não virá via melhoria contínua, e sim via ruptura planejada. Esta estratégia está baseada no conceito de destruição criativa de Joseph Schumpeter, descrito no capítulo 5 do meu livro "Os desafios da sustentabilidade".

$\mathrm{Eu}$, quando fui presidente da Fundação Estadual de Engenharia do Meio Ambiente (FEEMA), criei o primeiro parque marinho do Estado do Rio de Janeiro, na llha Grande, localizada no sul do Estado. Em terra já existia essa reserva biológica e eu a criei no mar. Essa criação eu nunca proibi, até porque tem gente morando lá, eu nunca propus a proibição da pesca e do acesso. Muito pelo contrário. Eu acho que as pessoas devem ver um ambiente absolutamente 
intacto para saber qual é a importância daquilo, porque lá tem manguezal, tem todas as condições intactas. Então, ali foi um projeto interessante que o governador na época adotou, funcionou muito bem e hoje continua funcionando muito bem. Tem limites de uso, mas tem também condições que limitam os limites, ou seja, aquela região não foi transformada em algo intocável eternamente, o que, na minha maneira de ver, não seria sustentável. Lá existe uma população de 90 pessoas que vivem mais do turismo sustentável que da pesca.

2. Como as organizações, especialmente as do Terceiro setor, têm possibilidade de contribuir para reduzir os impactos sociais e ambientais e diminuir os problemas de preservação do planeta?

Eu vivi isso a vida inteira. Sustentabilidade não existe sem as três dimensões (ambiental, social e econômica) e não existe sem os três atores (sociedade civil, governo e empresas). E a eficácia e a eficiência no caminho da sobrevivência dependem do entendimento dos três setores. Essa é uma questão fundamental. No caso do setor empresarial, tirando exemplos que não confirmam a regra, a preocupação em $99 \%$ dos casos é basicamente gerar renda e recurso, ter o faturamento mais alto possível. Participei de vários conselhos consultivos de empresas e, no geral, não existe um envolvimento diferente desse.

Participei da criação do Conselho Empresarial Brasileiro para o Desenvolvimento Sustentável (CEBDS) em 1997 e saí de lá em 2010. O Conselho não era, na minha forma de ver, um instrumento de defesa do setor empresarial. Muito pelo contrário. Era uma alavanca para que eles se aproximassem o mais rápido possível do caminho da sobrevivência e da sustentabilidade, até para eles. Mas não acho que isso tenha avançado tanto assim. Hoje, o Conselho se tornou algo que defende as empresas. Eu nunca defendi empresa nenhuma, eu defendia esse caminho e, muitas vezes, tive embates duros lá. As empresas, na minha opinião, têm pouco envolvimento, até porque, em gral, conhecem pouco o tema. E os governos têm a função, desses três atores, de normatizar, dar estímulos e controlar.

O terceiro setor é um elo de ligação entre esses dois setores, mas ainda existe muita desconfiança entre empresas e governos. Não estou falando do caminho corrupto, que está muito prevalente atualmente, mas destacando que normalmente existe desconfiança. Um acha que o outro é capitalista selvagem, o outro acha que o um é burocrata, lento e ineficiente. Muitas vezes, o terceiro setor pode facilitar essa questão, ser um elo de ligação, um facilitador, inclusive na obtenção de recursos para a implementação de projetos na medida que hoje boa parte do terceiro setor tem a técnica. Muitas entidades têm a técnica.

O terceiro setor também é um garantidor, pode oferecer uma credibilidade que nem o governo tem, nem o setor empresarial tem. O terceiro setor também tem tudo para ser um bom operador de vários setores no caminho da sustentabilidade, como parques nacionais, reservas, reversão de pobreza, saúde e, especialmente, na educação, que é dificílimo. Sempre que se falar de operador, de eficiência e de conseguir mais com pouco recurso, existe um item fundamental que se chama métrica. Métrica. Tem que medir e essa medida tem que ser garantida por um conselho externo à entidade. $E$, junto com o terceiro 
setor, eu colocaria a academia, porque tive o privilégio de ter tido a experiência de academia durante muitos anos. Trabalhei no governo, trabalhei em empresas e no terceiro setor, no caso do CEBDS.

Me lembro que, quando eu estava no CEBDS, recebia por dia cinco ou seis relatórios de grandes empresas multinacionais do mundo inteiro e a primeira coisa que eu olhava nesses relatórios era o seguinte: existe algum grupo do terceiro setor, eventualmente do governo, da academia, que confirma se aquilo é verdade? A primeira coisa que eu ia olhar. Se não tinha, eu descartava. Mandava para a biblioteca. Perdia o interesse, porque eu não acredito que alguém possa falar de si mesmo com a credibilidade que o tema impõe. Agora, eu acredito no seguinte: se forem selecionadas pessoas respeitadas do terceiro setor ou até de empresas que sejam reconhecidamente sérias e militantes desse assunto, e chegar o dado dessa empresa, aí é completamente diferente. $\mathrm{Na}$ época a gente chamava de assurance committee, ou seja, aquele que dá a garantia da métrica.

\section{Na sua avaliação, a comunicação praticada pelas organizações tem contribuído para incentivar o debate sobre sustentabilidade e sensibilizar as pessoas para criarem ambientes mais sustentáveis?}

Na questão da comunicação, a primeira questão é a linguagem. Não adianta falar para quem já está convencido e é necessário ter casos exemplares. Sempre me perguntavam como se começa com sustentabilidade. Eu falava: para você convencer o seu superior e chegar até o seu presidente, comece com produção mais limpa, ecoeficiência. Primeiro porque é bom para a empresa, segundo porque é bom para a sociedade, e terceiro porque é bom para os ativos ambientais. Então é mais fácil e mais palatável. Agora, tem que ter casos exemplares com garantia, selo de alguma entidade ou conselho. Essa questão é fundamental.

Além disso, em termos comunicação e sustentabilidade, eu vejo também a necessidade de fundamento técnico, pois muitos jornalistas, até bemintencionados, às vezes falam bobagem. Por que? Não tiveram tempo nem paciência de estudar o assunto. Tem uma técnica relacionada a cada questão dessa. Eu cansei de ter debates, porque eu tinha que dizer o seguinte: "Olha, o que o senhor está falando não é assim, cientificamente é diferente". Eu fiz meu mestrado em Nova York, eu dou aula há 30 anos. Eu perguntava: "Qual é o livro técnico que o senhor me recomenda que dá garantia ao que o senhor está falando?". Então tem que ter a garantia de que está correto e tem que ter alguém que garanta.

Outro ponto é que, na comunicação, há uma questão fundamental que facilita quando se vai ao nível estratégico de tomada de decisão, no governo, nas empresas e no terceiro setor. Trata-se dos ativos intangíveis: marca e reputação. Possivelmente a marca Bayer, por exemplo, vale de $70 \%$ a $90 \%$ da empresa, ou seja, os ativos intangíveis valem muito mais do que os ativos tangíveis e sustentabilidade é um Headge, um seguro para que você não perca o seu valor nos ativos intangíveis. Isso em comunicação é fundamental. Eu cansei de convencer muitos CEOs e diretores de empresas com esse 
argumento. Um outro ponto é o marketing sustentável. Eu não tenho nada contra, eu acho que não há nenhum problema com o marketing sustentável. $A$ única questão que eu coloco é que ele seja ético. Não concordo com greenwashing porque a pior situação é aquela pincelada verde que acha que convence as pessoas. Isso tem um período muito curto de convencimento. Um exemplo interessante, que vem ganhando muito espaço mundial, nacional, regional e local, e que tem dado certo, é o dos produtos orgânicos. Esse é um setor que está conseguindo penetrar no mercado, inclusive com preço mais alto, mas com base na visão da melhoria da saúde das pessoas.

Outro item fundamental é a relação com stakeholders, ou grupos de interesse, em português. Para a implantação de uma nova usina, uma nova planta, de uma Dupont ou de uma Alcoa, por exemplo, ou de uma empresa de grande porte, e em geral essas empresas já são conscientes disso, é necessário construir uma relação com o entorno. Ou seja, o stakeholder é aquele que você influencia e por quem você é influenciado. É preciso selecionar um raio de cinco, dez quilômetros, e identificar os grupos de interesses mais significativos e as lideranças, para dialogar com eles para que a instituição seja feita ali. Essa é uma comunicação sofisticada, não é fácil, pois qualquer empresa dessa está sujeita a acidentes. Se existe uma relação forte, mecanismos com stakeholders, o acidente pode ser considerado um acidente. Se não existe, o acidente será considerado uma irresponsabilidade e isso inclui governo local, governo regional, às vezes até governo nacional, dependendo de onde a empresa estiver.

No meu livro "Desenvolvimento Sustentável 2012-2050: visão, rumos e contradições", selecionei vários autores, alguns de renome mundial, que eu considerava mais interessantes para aquele tema. No capítulo 5 desse livro, foi publicado o texto do jornalista Agostinho Vieira, que tinha acabado de chegar da Inglaterra, e havia se envolvido muito com essa questão. Ele era um jornalista sênior da Globo, e no livro há um capítulo bem interessante com a visão dele, não necessariamente igual à minha, mas é interessante a visão dele como jornalista.

Eu já fiz política profissional e já fui candidato, então sei o quanto é difícil acessar as pessoas em uma questão um pouco mais profunda. Se você disser que vai juntar trinta pessoas para falar sobre sustentabilidade, não vai ser fácil. Hoje, a comunicação é importante para acessar essas pessoas e a sociedade em geral. Não quem já está embarcado, porque esses não são a minha preocupação, mas aqueles que não têm nenhuma vinculação com o tema.

Uma das primeiras questões nesse sentido é a da linguagem, que não pode ser acadêmica, para não ficar restrita a poucas pessoas. Eu tive um programa chamado Viver Melhor, na rádio CBN, durante três anos, todos os dias da semana. O que eu fazia? Eu gravava o programa e, quando estava no táxi e aparecia a minha voz, eu perguntava ao motorista se ele estava entendendo o que estava sendo falado. Esse era um teste que eu fazia. O segundo teste era pedir para a minha empregada ouvir todo dia. Até o momento que ela começou a entender. $O$ significado era tentar envolver um maior número de pessoas 
nesse tema. Eu tinha que falar nessa linguagem. Utilizar a linguagem de professor da UFRJ, onde fui professor por 30 anos, era fácil.

Então, acho que os governos, e cansei de falar isso em reuniões com eles, precisam tratar o tema de forma muito mais palatável à população em geral para ter mais adeptos ao tema. Não vejo que isso tenha surtido tanto efeito. Eles falam em uma linguagem tão sofisticada que a impressão que dá é que eles estão com medo que as pessoas entendam e depois venham cobrar o erro deles. Essa é a impressão que eu tenho.

Então, além de fazer cumprir os acordos, que têm força de lei, também existe a responsabilidade dos governos comunicarem adequadamente o tema. É muito difícil um ministro do Meio Ambiente, ou um ministro dessa área, pressionar um presidente para assinar qualquer acordo. Mas as entidades, na sua base, com o corpo técnico, têm o conhecimento, porque trabalham com isso. Então a pressão ao próprio governo é um fator fundamental para que esse sistema avance.

4. Qual é a importância do Terceiro setor para liderar pessoas e organizar movimentos e ações para promover a melhoria da sustentabilidade em termos locais, regionais, nacionais e globais?

Liderança é tudo. No meu livro "Os desafios da sustentabilidade", apresento uma expressão que criei: a do estadista corporativo. Seja aonde for, na USP, na Natura, no Ministério do Meio Ambiente, não importa, o ideal é que houvessem milhões de estadistas corporativos liderando processos. $\mathrm{O}$ terceiro setor ganha muita importância nessa área de liderança, mas ele atua mais local e, talvez, regionalmente. Nacional e globalmente talvez esteja ainda muito lento. Algumas entidades mundiais, como as preservacionistas, talvez tenham recursos e capacidade de atuar globalmente, mas vou apresentar um dado. Eu fazia um trabalho muito grande junto com o World Business Council for Sustainable Development, o Conselho Empresarial Mundial para o Desenvolvimento Sustentável (WBCSD). Esta é a entidade mundial que congrega todos os CEBDS nacionais e trabalha com produtos, relatórios e ideias fascinantes, porque eles têm muito recurso financeiro. O grupo dos associados dessa entidade tem um PIB só menor que o do Japão. Então eles têm esse poder de transformação caso queiram.

Mas, quando eu conversava, eu observava que, naquele grupo enorme de empresas, mais de 100, apenas 10\% realmente estavam liderando aquela entidade. As demais estavam lá porque não queria perder o conhecimento ou queriam estar atentas às novas informações. As outras associações empresariais, em geral, em vez de serem um vetor de mudança, estão muito mais na defesa. Eu não vou nem citar nenhuma, mas no CEBDS eu tentava fazer completamente diferente. Era um instrumento de pressão e não um instrumento de defesa pura e simplesmente. Óbvio que, em algumas situações, eu as defendia de absurdos do governo, do Congresso, mas, em geral, as entidades são instrumentos de defesa e isso não é o melhor papel.

Acredito também que as ONGs, em geral, têm alguns desafios, porque elas tendem a ser muito mais voltadas para o verde, ligadas à preservação e podem entrar em discussões mais complexas para a sociedade, como o saneamento, 
por exemplo. O Brasil tem péssimas referências de saneamento, péssimos resultados. Outro tema mais recente, e que envolve a todos, é a segurança. Quem vive no Rio de Janeiro e São Paulo sabe bem o que é isso.

\section{Além dos recursos de comunicação, que outras iniciativas são estratégicas para ampliar o debate sobre sustentabilidade e contribuir para uma nova consciência social sobre esta temática?}

Em termos de recursos e estratégias, não se consegue isso se não houver sensibilização, se não houver uma liderança dentro da premissa do estadista corporativo. Seja aonde for. Acho que pode ser interessante analisar o trabalho da Fundação Avina, que trabalhava exatamente com terceiro setor. Ela não criava líderes, mas mapeava líderes na sociedade nos mais diversos campos e subvencionava projetos a partir de líderes consagrados. Isso está muito dentro da discussão da comunicação estratégica e da sustentabilidade.

A outra questão que pode ser um vetor na criação de mecanismos que gerem resultados concretos na área de sustentabilidade é a relação biunívoca entre sociedade e empresas durante a implantação de uma usina, por exemplo. Eles se tornam mais sensíveis a uma série de pleitos da sociedade, como, por exemplo, demandas ligadas à saúde e necessidades na educação. Em projetos assim, há exemplos de reconstituição de patrimônio de casas e apoio às pessoas em regiões mais desassistidas de saneamento. Esse é o momento em que se sai do plano teórico e se consegue beneficiar um grupo de pessoas e, também, o próprio sistema ambiental.

Agora, não acho que o senso de urgência tenha perpassado a sociedade. Passa longe disso. Nós não estamos evoluindo de forma absolutamente tranquila e garantida nesse tema da sobrevivência. No livro "Os desafios da sustentabilidade", estão algumas tabelas na página 20 do trabalho mais importante que eu participei na minha vida, chamado "Millennium ecosystem assessment", ou "Avaliação ecossistêmica do milênio". A USP participou também. Eu era diretor desse projeto mundial da ONU que reuniu acadêmicos do mundo inteiro para avaliar as condições dos ecossistemas no mundo. Essa tabela é uma referência direta que mostra que a pesca, por exemplo, está condenada a desaparecer possivelmente nos próximos 30 ou 40 anos. Os alimentos silvestres estão decaindo. Combustível de madeira está decaindo. Ou seja, a virada do milênio já foi há algum tempo e realmente não acredito que houve uma mudança nesse cenário claramente apresentado.

Se nós à época tivéssemos o padrão de terrorismo internacional e o padrão de violência nacional atual, nem sei como essa tabela seria colocada, porque essas são duas novas variáveis que, decididamente, só trazem complicação.

Então, ainda tratando de comunicação, não vejo um Nelson Mandela da sustentabilidade nem um Martin Luther King da mudança do clima. Não vejo qualquer grande líder que esteja puxando a sustentabilidade, essa visão da sobrevivência, ou mesmo alguns dos temas, como biodiversidade, por exemplo. Como sustentabilidade tem uma dimensão muito política, eu vejo alguns sinais extremamente preocupantes. Quando existe de um lado do planeta o Donald Trump que se elege do jeito que se elegeu, que fica sozinho no G20 e, mesmo assim, descarta considerações sobre a mudança do clima, e o Vladimir Putin do 
outro lado do mundo, que nem comenta o assunto, nós estamos em uma situação bem complexa, muito difícil. Mas, eu sou um otimista. Se não fosse, não estaria aqui conversando com você. 


\section{Leonardo Boff}

Atuacão profissional: Teólogo e escritor membro da Iniciativa Internacional da Carta da Terra

Breve currículo: Leonardo Boff doutorou-se em teologia pela Universidade de Munique. Foi professor de teologia sistemática e ecumênica com os franciscanos em Petrópolis e professor de ética, filosofia da religião e de ecologia filosófica na Universidade do Estado do Rio de Janeiro (UERJ). É um dos iniciadores da teologia da libertação. É assessor de movimentos populares. Conhecido como professor e conferencista no País e no exterior nas áreas de teologia, filosofia, ética, espiritualidade e ecologia. Em 1985 foi condenado a um ano de silêncio obsequioso pelo ex-Santo Ofício. A partir da década de 1980 começou a aprofundar a questão ecológica como prolongamento da teologia da libertação, pois não somente se deve ouvir o grito do oprimido, mas também o grito da Terra porque ambos devem ser libertados. Em razão deste compromisso participou da redação da Carta da Terra junto com M. Gorbachev, S. Rockfeller e outros. Escreveu vários livros e foi agraciado com vários prêmios. Junto com Mark Hathaway escreveu nos Estados Unidos The tao of liberation: exploring the ecogoy of transformation com prefácio de Fritjof Capra, ganhando a medalha de ouro da instituição Nautilus para criatividade intelectual e o primeiro lugar do livro religioso do ano. Recebeu os títulos de Doutor Honoris Causa em política pela Universidade de Turim (Itália), Doutor Honoris Causa em teologia pela Universidade de Lund (Suécia), Doutor Honoris Causa em teologia, ecumenismo, direitos humanos, ecologia e entendimento entre os povos pelas Faculdades EST de São Leopoldo e Doutor Honoris Causa pela Cátedra del Água da Universidade de Rosário na Argentina. Em 2008 pela Universidade de São Carlos em Guatemala e pela Universidade de Cuenca no Equador, recebeu o título de Professor Honorário. Foi assessor da Presidência da Assembleia da ONU ao tempo da administração de Miguel d'Escoto Brockmann (2008-2009) e participa atualmente do grupo de reforma da ONU, especialmente quanto à Declaração Universal do Bem Comum da Terra e da Humanidade.

\section{Qual é o papel dos governos e dos grupos intergovernamentais para o cumprimento dos acordos firmados em conferências sobre o clima no âmbito internacional?}

Enquanto os acordos não forem vinculantes e realmente assumidos obrigatoriamente pelos estados, há pouco campo de ação efetiva dos movimentos de obrigarem a aceitação dos acordos de Paris. As grandes corporações mandam na globalização e são mais fortes que a maioria dos estados e dos governos. Elas vêm os acordos como algo antissistêmico, quer dizer, algo que vem prejudicar seus negócios e os níveis de sua acumulação. Esta é cada vez mais concentrada. Estes são inimigos da ecologia. Não creem no aquecimento global ou se creem relegam para os anos vindouros a tomada de decisões efetivas. Mas vale sempre pressionar e apelar pelo valor ético das decisões tomadas e dos apelos por mudanças que elas implicam.

2. Como as organizações, especialmente as do Terceiro setor, têm possibilidade de contribuir para reduzir os impactos sociais e ambientais e diminuir os problemas de preservação do planeta? 
Não podemos esperar que as soluções venham de cima. O sistema capitalista e o neoliberalismo são tão consolidados que dificilmente se movem na direção de uma mudança no modo de produção, de relação para com a natureza e as formas do consumo. Este sistema é antivida e possui uma tendência suicida, como o Papa na sua encíclica sobre a ecologia o afirma. Tudo deverá vir de baixo, com pressões, com boicotes dos produtos das grandes empresas, com desestímulo de aplicação de ativos financeiros nestas corporações e na denúncia permanente de que elas, por sua irresponsabilidade, estão pondo o sistema-terra e o sistema-vida em alto risco. Sou da opinião que todos mudarão quando a grande crise chegar, alguma tragédia ecológico-social ou mesmo uma guerra nuclear de baixa intensidade (a de alta destruiria toda a vida no planeta), aí a humanidade vai despertar e dizer: ou mudamos ou morremos. Então poderá surgir uma governança global com poderes plurais, para debelar os problemas globais.

3. Na sua avaliação, a comunicação praticada pelas organizações tem contribuído para incentivar o debate sobre sustentabilidade e sensibilizar as pessoas para criarem ambientes mais sustentáveis?

Grande parte do debate é feito para ocultar a crise ecológica, seja da escassez dos bens e serviços, seja das ameaças que pesam sobre o nosso futuro. O uso do termo "sustentável" geralmente é apenas marketing, sem corresponder à realidade dos produtos. A sustentabilidade tem a função de um novo paradigma. Ela obriga a uma outra relação com a natureza, não mais de exploração, mas de sinergia. Temos que produzir para atender as demandas humanas, mas dentro dos limites impostos pela Terra que é um planeta velho e com bens e serviços escassos. Um planeta finito não suporta um projeto de crescimento infinito. Ele sucumbe à voracidade humana. Ou então o sistema-terra criará uma situação em que fará desaparecer esse câncer maligno, capaz de afetar a totalidade do planeta. O antropoceno parte desta constatação, quer dizer, entramos numa nova era geológica onde o meteoro rasante ameaçador não vem de fora, mas é o próprio ser humano que criou o princípio de autodestruição. Ele pode ser o satã da Terra quando é chamado a ser só seu anjo bom e protetor.

4. Qual é a importância do Terceiro setor para liderar pessoas e organizar movimentos e ações para promover a melhoria da sustentabilidade em termos locais, regionais, nacionais e globais?

É possível a sustentabilidade dentro do biorregionalismo. Toma-se a região com seus recursos, sua população, sua cultura e sua tecnologia e aí organizar um modo de produção, distribuição e consumo que seja suportável pelos recursos da região, com a capacidade de ser reproduzir e manter a sustentabilidade. Hoje em muitas partes do mundo se fazem experiências nesta área, onde se pode mostrar que é possível as regiões (geralmente definidas pelas bacias hidrográficas) realizar um desenvolvimento humano sustentável. Aqui as comunidades são importantes até no sentido de impedirem grandes conglomerações de riqueza ou de processos produtivos que desequilibram a região. A solução passa pela articulação de todos no terceiro setor que vão assumindo a hegemonia ideológica e prática para essa forma nova de estar sobre a Terra junto com a comunidade de vida. 


\begin{tabular}{l} 
5. Além dos recursos de comunicação, que outras iniciativas são \\
estratégicas para ampliar o debate sobre sustentabilidade e contribuir \\
para uma nova consciência social sobre esta temática? \\
\hline O problema ecológico é tão grave que devemos usar todos os recursos e meios \\
para despertar a consciência da gravidade da situação em que nos \\
encontramos. Isso vai desde a educação na família. A escola deve incorporar a \\
ética da convivência, do cuidado, e da sinergia com a natureza. Fundamental é \\
mudar a mente e o coração. A mente: possuir outra visão do universo e da Terra, \\
esta não como um baú de recursos infindáveis, mas como um super Ente vivo \\
que deve ser cuidado. Um coração: não basta a razão científico-analítica. \\
Precisamos da razão sensível e cordial que nos anime a defender a vida e a ter \\
compaixão por todos os seres que sofrem e principalmente nos leva a respeitar \\
a cada ser porque possui um valor intrínseco, independentemente do uso \\
humano que fazemos dele. Sem essa revolução da mente e do coração \\
dificilmente superaremos o atual drama que pode se transformar numa tragédia. \\
Temos que mudar e habitar de forma diferente a Casa Comum se quisermos \\
sobreviver e continuar nosso ensaio civilizatório. Caso contrário chegou o tempo \\
da tribulação da desolação, falando em termos bíblicos, quer dizer, chegou o \\
fim de nossa espécie humana.
\end{tabular}




\section{Oded Grajew (Instituto Ethos e Oxfam Brasil)}

Atuacão profissional: Presidente emérito do Instituto Ethos e presidente do Conselho da Oxfam Brasil.

Breve currículo: Empresário israelense, naturalizado brasileiro, com importante atuação no terceiro setor. Defende a responsabilidade social da empresa e a maior interação entre as empresas e o movimento social. Formouse em engenharia elétrica pela Escola Politécnica da Universidade de São Paulo (USP) fez pós-graduação em administração pela Fundação Getúlio Vargas (FGV). Em 1972 fundou a Grow Jogos e Brinquedos, dedicada a desenvolver jogos inteligentes para adultos e adolescentes. De 1990 a 1992 presidiu a Federação Latino-Americana de Fabricantes de Brinquedos. Permaneceu na Grow até 1993, quando decidiu trilhar outros caminhos. Em 1989, participou do grupo fundador e foi o primeiro coordenador-geral do Pensamento Nacional das Bases Empresariais (PNBE). Entre 1986 e 1992 foi presidente da Associação Brasileira dos Fabricantes de Brinquedos (Abrinq), quando criou, em 1990, a Fundação Abrinq pelos Direitos da Criança e do Adolescente. Entre 1996 e 2000 foi membro do Comitê Internacional do Conselho Norte-Americano das Fundações (Council of Foundation). Em 1998, participou da fundação do Instituto Ethos de Empresas e Responsabilidade Social, do qual é presidente emérito. Em 2001 idealizou o Fórum Social Mundial. Foi também um dos criadores do Movimento Nossa São Paulo para mobilizar empresas, sociedade e governo em torno da elaboração de um conjunto de metas que possam reverter os graves problemas sociais da capital. É membro do Conselho Consultivo do Global Compact, programa da Organização das Nações Unidas (ONU) que procura mobilizar a comunidade empresarial internacional na promoção de valores fundamentais nas áreas de direitos humanos, relações de trabalho e meio ambiente. Entre janeiro e novembro de 2003 foi assessor especial do Presidente da República, Luiz Inácio Lula da Silva. É membro do Conselho de Desenvolvimento Econômico e Social. Atualmente, é presidente do Conselho da Oxfam Brasil.

\section{Qual é o papel dos governos e dos grupos intergovernamentais para o cumprimento dos acordos firmados em conferências sobre o clima no âmbito internacional?}

O papel dos governos é fazer cumprir. Quer dizer, este é o compromisso do governo que assume. Então eles são os responsáveis, têm a responsabilidade de cumprir os acordos porque são eles que assinam. Os acordos são assinados pelos governos, então eles têm que estabelecer um caminho para o acordo ser cumprido porque eles geralmente preveem prazos. Cabe aos governos estabelecer os prazos e identificar o que é necessário para fazer cumprir os acordos. Geralmente, demanda uma articulação do governo como um todo porque os acordos geralmente abrangem vários ministérios, e isso demanda muitas vezes a participação e a cooperação de outras instâncias do governo, que podem ser estaduais, municipais ou regionais, depende do país. Existe todo um trabalho de articulação com essas outras instâncias porque isso depende, quase sempre, da participação do governo em outras instâncias. Se o governo for realmente sério no cumprimento dos acordos, é preciso formar uma instância de acompanhamento em que haja também a participação da sociedade civil para garantir o cumprimento, a qualidade, e o cumprimento dos acordos. Isso 
quando o governo quer levar a sério esses compromissos, esses acordos, que têm força de lei. Além disso, o governo muitas vezes tem que adequar os acordos internacionais para a legislação local. Então, por exemplo, no caso do Acordo de Paris, o governo brasileiro, além de assumir o compromisso internacionalmente, tem que adequar nacionalmente para fazer uma legislação, ou às vezes um decreto, para a legislação local e nacional.

O fato de existirem alguns acordos que são voluntários, de assinatura voluntária, não necessariamente pode ter alguma influência negativa para esse cumprimento. Se o governo assina um compromisso, ele já deixa de ser voluntário. O que pode ser voluntário é a extensão do compromisso ou, às vezes, o prazo do compromisso. Mas aí que tem que entrar o papel da sociedade, ou seja, fazer pressão para que o acordo deixe ser voluntário e seja um compromisso mandatório. Além disso, pré-estabelecer o prazo e a qualidade do acordo. É aí entra que entra o papel da sociedade civil para pressionar para que o acordo não seja apenas voluntário, mas que seja realmente cumprido.

2. Como as organizações, especialmente as do Terceiro setor, têm possibilidade de contribuir para reduzir os impactos sociais e ambientais e diminuir os problemas de preservação do planeta?

Elas são fundamentais, como nós temos visto. A lógica dos governos é a lógica do poder, e o poder se disputa a cada dois ou a cada quatro anos. Se você assistir alguma reunião de qualquer partido político, e eu não estou falando só do Brasil, mas do mundo, a discussão é sempre como é que se chega no poder e, se já está no poder, como é que se permanece no poder. Essa equação se resolve geralmente a cada dois ou a cada quatro anos, depende da legislação eleitoral de cada país, o que na realidade é um prazo curto quando nos referimos à questão da sustentabilidade. Quando falamos em sustentabilidade, temos que pensar sempre no médio e longo prazo, com projetos, políticas ou mudanças que geralmente tenham uma maturação maior que esses quatro anos. Isso geralmente não entra na perspectiva dos governos porque eles têm essa visão de curto prazo. Se você quer mudar a matriz energética, por exemplo, é necessário fazer investimentos que vão resultar em mudanças em cinco, seis, sete, oito, nove, dez anos, com resultados em dez ou doze anos. Ou, por exemplo, no caso dos Objetivos de Desenvolvimento Sustentável (ODS), que são metas até 2030, mas os governos estão pensando na próxima eleição. Essa é uma enorme dificuldade. Da mesma forma, existem dificuldades no caso das empresas porque os presidentes dessas companhias estão muito pressionados atualmente pelos resultados trimestrais. Se o presidente de uma empresa não apresentar lucro em um trimestre, ou nos dois trimestres seguidos, já é cogitada a demissão dele. É aí que entra a sociedade civil, que tem outra perspectiva, outro horizonte, outro calendário e outro prazo. Porque, na realidade, a sociedade civil tem força tanto como grupo de eleitores, quanto enquanto consumidores. Na realidade, o poder está na mão da sociedade porque são os eleitores que decidem qual é o governo que teremos, e são os consumidores que dizem se vão comprar ou não os produtos daquela empresa. A pressão da sociedade nesse sentido é boa, e colocar uma política que aponte para melhorias ambientais e a preservação do planeta é fundamental. Essa percepção é muito importante. 


\section{Na sua avaliação, a comunicação praticada pelas organizações tem contribuído para incentivar o debate sobre sustentabilidade e sensibilizar as pessoas para criarem ambientes mais sustentáveis?}

Isso tem sido feito. A pergunta é se isso é o suficiente. Há alguns anos, isso não era assunto, não estava na agenda, não se entendia do que realmente se tratava e hoje, pelo menos, está na agenda. Agora, entre estar na agenda e ser implementado é uma outra questão. Na realidade a comunicação tem ajudado, isso foi conseguido, isso foi feito de uma forma satisfatória, agora o desafio é avançar da agenda, da primeira etapa. Essa discussão não estava na agenda porque se falava do desenvolvimento de qualquer maneira, construir túneis fazer estradas. Agora está na agenda, está no discurso.

O grande desafio da comunicação é se isso está sendo realmente levado a sério, se está sendo implementado e, ao mesmo tempo, mostrar casos exemplares, casos de sucesso, mostrar que é possível. A comunicação é muito forte quando se faz um discurso e mostra que esse discurso é factível, que não se está sonhando. Então é importante compartilhar se existe uma cidade que reduziu uma determinada quantia do consumo de água, diminuiu o desperdício na rede de distribuição, ou se existe uma cidade que eliminou o combustível fóssil no transporte coletivo. Se você mostra quem já fez, aí você constrange quem não faz, porque essas pessoas não vão poder dizer que é um sonho, que é irreal. É importante denunciar os governos que não fazem ações nesse sentido, denunciar na época pré-eleitoral para mostrar ao político que a eleição dele, o poder que ele quer depende disso. Então agora temos que pensar em uma outra etapa, porque a discussão já está na agenda, já está no discurso. A própria ONU já estabeleceu os Objetivos de Desenvolvimento Sustentável para toda a humanidade, para todos os países. Isso está no discurso dos políticos, no discurso das empresas, na mídia. Agora é a hora da implementação e a comunicação tem que se concentrar nisso. Isso está muito ligado à questão de transparência, de ética, de fazer circular essas informações. Compartilhar iniciativas de quem faz, para valorizar, e informar à população quem não faz.

Agora não é mais possível ter só o discurso de que é importante tratar do meio ambiente porque o futuro da humanidade depende disso, que o aquecimento global é um risco para a humanidade e vai acabar com a natureza e que estamos gastando mais do que o planeta é capaz de repor. Isso foi comunicado, já chegou em todos. Agora, a comunicação, do meu ponto de vista, tem que ser sobre o que tem que ser feito, o que está sendo feito e o que não está sendo feito.

4. Qual é a importância do Terceiro setor para liderar pessoas e organizar movimentos e ações para promover a melhoria da sustentabilidade em termos locais, regionais, nacionais e globais?

Há muitos exemplos ao longo da história de mobilizações locais e nacionais, como o impeachment do Fernando Collor, as manifestações no Brasil, os direitos civis nos Estados Unidos. Mas o desafio para a ampliação da mobilização, da pressão, é a sociedade civil conseguir se juntar e atuar em rede. O desafio é a sociedade civil não assumir, nas organizações sociais, a cultura da empresa, que é a cultura da competição. A sociedade civil tem que ter uma 
cultura da cooperação. Cada organização, individualmente, é muito frágil diante do desafio, mas quando elas se juntam, quando atuam em rede, o impacto é muito maior. Então depende muito da capacidade, da visão e da disponibilidade das lideranças das organizações em não competirem entre si, mas de atuarem conjuntamente em rede cooperando para que o impacto possa ser não só local, não só nacional, não só continental, mas sim global.

Sobre a necessidade de implementação e controle de políticas públicas, também pode existir a contribuição do terceiro setor nesse sentido. Atualmente, com a maior capacidade de comunicação, o amplo acesso à informação, no caso do Brasil por exemplo tem a Lei de Acesso à Informação, a informação é a ferramenta mais importante nas mãos da sociedade civil. Qualquer ditadura, quando se implementa, a primeira coisa que se faz é cortar a informação porque quer a sociedade longe do controle social. E a informação baseada em indicadores, o que na realidade é a hora da verdade, ela é muito poderosa. Tanto é assim que os governos tentam esconder os indicadores porque o indicador é a hora da verdade. O governo pode dizer que privilegia os pobres, por exemplo, mas quando você analisa os indicadores para checar quanto do orçamento vai para classe rica e quanto do orçamento vai para classe a pobre, aí é a hora da verdade.

A verificação do discurso, a hora da verdade do discurso, se ele é verdadeiro ou não, ocorre quando se revelam os indicadores, que é o resultado concreto. Se o governo divulga que está cuidando da saúde da população, e você analisa o indicador e percebe que a mortalidade infantil aumentou, a mortalidade materna aumentou, o tempo de atendimento no posto de saúde aumentou, então não há discurso que resista a isso. O discurso sempre pode ser checado por meio de indicadores.

5. Além dos recursos de comunicação, que outras iniciativas são estratégicas para ampliar o debate sobre sustentabilidade e contribuir para uma nova consciência social sobre esta temática?

São importantes as manifestações que possam sensibilizar ou constranger os governos, mas também as iniciativas de mobilização. Tudo isso está ligado à comunicação, porque são ações que têm que estar conectadas com a comunicação, que têm que ter visibilidade, porque com a comunicação se ganha e se amplia o alcance. Assim, se produzem os resultados, mas a comunicação tem que ser uma comunicação conectada e relacionada com fatos concretos.

Só para fazer um parêntese, qualquer transformação na sociedade, para o bem ou para o mau, ela se faz por meio de políticas públicas. Isso precisa ficar bem claro. Não é um projeto aqui e outro lá que vai mudar a educação, a saúde, a relação com o meio ambiente as políticas energéticas, as políticas sociais. $O$ que tem poder de transformação pela escala são as políticas públicas. Isso precisa ficar bem claro. Os projetos localizados são bons porque produzem referências, mas o impacto realmente vai ser atingido no momento em que isso ganha escala por meio de políticas públicas. Então, a grande pressão, do meu ponto de vista, deve ser sobre os governos, porque as mudanças vêm com políticas públicas. As empresas já sabem disso e elas aprenderam a usar as políticas públicas a favor delas para que as ações tenham realmente impacto. 
E aí são várias as estratégias de levantamento de dados, de apurar informações, cobrar promessas, alertar o eleitor, participar das políticas públicas, se envolver com questões de sustentabilidade, participar da vida pública do país, se filiar a partidos, se candidatar, estar ativo nas políticas públicas de dentro e de fora.

O alvo são as políticas públicas e a comunicação é fundamental porque é ela que forma a cultura, mobiliza as ações e exerce a pressão. E a comunicação é uma ferramenta, tanto que o Donald Trump, por exemplo, usa bastante a comunicação porque sabe que o poder dele depende disso. Então, pensar na comunicação sob todas as suas formas é fundamental para quem quer defender uma causa, porque na realidade o terceiro setor é formado por pessoas e organizações que defendem causas. Isso depende de se ter adesão dos outros, formar uma cultura e produzir efeitos. Assim, tem que ser uma comunicação qualificada, baseada em indicadores, dados e informações detalhadas. Não pode ser uma comunicação sem credibilidade ou muito superficial. 


\section{Pedro Jacobi (USP)}

Atuação profissional: Professor Titular da Universidade de São Paulo Breve currículo: Possui graduação em Ciências Sociais (1973) e em Economia (1972) pela Universidade de São Paulo. Mestrado em Planejamento Urbano e Regional pela Graduate School of Design - Harvard University (1976), Doutorado em Sociologia pela Universidade de São Paulo (1986). Livre Docente em Educação (USP). Professor Titular da Faculdade de Educação e do Programa de Pós-Graduação em Ciência Ambiental (PROCAM/IEE/USP) da Universidade de São Paulo. Chefe da Divisão Científica de Gestão, Ciência e Tecnologia Ambiental do Instituto de Energia e Ambiente/USP. Presidente da Comissão de Pós-Graduação e Coordenador do PROCAM/USP 1998-2000 e 2010-2012). Coordenador do Grupo de Acompanhamento e Estudos de Govenança Ambiental - GovAmb/IEE. Coordenador do Laboratório de Pesquisa e Práticas em Educação e Sustentabilidade/IEE. Membro do Conselho e Pesquisador do Núcleo de Pesquisa INCLINE (Interdisciplinary Climate Investigation Center) da USP. Coordenador do grupo de Estudos de Meio Ambiente e Sociedade do Instituto de Estudos Avançados da USP. Coordenador da equipe brasileira do Projeto Bluegrass - FAPESP/ANR (20142017). Pesquisador Produtividade CNPq. Foi Coordenador de Projeto Alfa da Comunidade Europeia sobre Governança da Água na América Latina e Europa (2005-2009). Membro da Rede Waterlat. Presidente do Conselho do ICLEIBrasil. Membro do Conselho Diretor de Greenpeace Brasil desde 2014. Editor da revista Ambiente e Sociedade (ANPPAS). Membro do conselho editorial das revistas EURE (Santiago) (0250-7161), International Journal of Urban Sustainable Development, Organizações e Sociedade, Pesquisa em Educação Ambiental, Environmental Sociology. Foi presidente da ANPPAS (período 20002004). Foi membro do Conselho do Comitê de Meio Ambiente e Sociedade da International Sociological Association (ISA) de 2010 a 2014.

1. Qual é o papel dos governos e dos grupos intergovernamentais para o cumprimento dos acordos firmados em conferências sobre o clima no âmbito internacional?

É importante que ocorram esses avanços, o cumprimento de metas, mas os acordos internacionais podem fazer isso independentemente de decisões em nível nacional. Então, na medida em que prefeituras avançam em programas, na medida em que governos locais avançam na implementação de iniciativas, nós podemos concretamente ter resultados importantes, não necessariamente vinculados diretamente aos acordos internacionais. Então, grupos intergovernamentais é uma expressão um pouco genérica, mas se você estiver falando de agências intergovernamentais, fica mais completo e vejo relação com a mudança climática. A questão do cumprimento dos acordos é que eles são voluntários, então a questão é sempre a limitação em relação ao que significa um acordo voluntário e a escala desse acordo, a capacidade de realmente responder a esses acordos entre governos.

2. Como as organizações, especialmente as do Terceiro setor, têm possibilidade de contribuir para reduzir os impactos sociais e ambientais e diminuir os problemas de preservação do planeta? 
Eu sou membro do conselho nacional da maior organização mundial do Terceiro setor, que é o Greenpeace. O Greenpeace tem hoje mais de três milhões e duzentos mil doadores, então é atualmente, dentre as organizações planetárias, provavelmente a que tem maior potencial de adesão. Então, o que nós temos é um número muito grande e importante de organizações, com as melhores intenções, mas com uma capacidade muito pequena de poder envolver um número maior de pessoas. Então, hoje nós temos também uma questão que é o fato de que o setor privado cria muitas fundações e elas obviamente têm agendas que, às vezes, não são as agendas mais interessantes para a sociedade. Então nós temos uma questão altamente complicada de que a sociedade civil às vezes tem uma atuação ambígua, mas há um esforço sempre em manter as organizações. Agora, essas organizações dependem sempre de financiamento. No caso do Greenpeace, o melhor exemplo é justamente porque o financiamento é feito por meio de doadores e não de convênios, de contratos da dependência dos humores das empresas. São temas fundamentais. Se o Greenpeace, por exemplo, por alguma razão, por uma campanha equivocada, e isto despertasse o desinteresse dos doadores, acabaria o Greenpeace, ou perde o seu poder de atuação. Então, isso é importante destacar porque essas agendas surgem como iniciativas de resistência a determinadas formas de funcionamento do sistema capitalista ou não capitalista, mas pelo menos do sistema produtivo e da forma como ele acaba sendo um predador do ponto de vista dos órgãos e das instituições da sociedade civil. São ações que se organizam para reagir a partir de uma agenda que motive esses atores a questionar, por exemplo, a questionar a construção de mais hidrelétricas na Amazônia, a promover as energias alternativas, a questionar a caça da baleia, como foi no início do Greenpeace.

\section{Na sua avaliação, a comunicação praticada pelas organizações tem contribuído para incentivar o debate sobre sustentabilidade e sensibilizar as pessoas para criarem ambientes mais sustentáveis?}

A comunicação é fundamental! Ela é absolutamente fundamental! Ela é tão fundamental que é uma das grandes preocupações do Greenpeace. Já dizia o Chacrinha que quem não se comunica se trumbica. Então, nós temos aí uma questão muito concreta, ou seja, a comunicação que alimente, de alguma maneira, a identidade com uma causa. Então, o que você observa um pouco hoje em dia, é: Quantas organizações se comunicam? Como se comunicam? Quantos sites vinculados ao tema ambiental que haviam e que deixaram de existir? Um site por exemplo que eu lembro muito bem, chamado Mercado Ético, deixou de existir e era apoiado por empresas. Hoje, em termos ambientais, existem poucos sites realmente funcionando. Um deles é o Envolverde, que é um site que eu conheço muito bem os responsáveis, mas que também está sofrendo muito. Então, comunicação é absolutamente estratégico, mas a questão é que tipo de comunicação, como comunicar. O Greenpeace se mobiliza para se envolver em uma campanha, assim como os Médicos sem Fronteiras se comunicam o tempo inteiro porque precisam das doações para desenvolverem campanhas. Eu, por exemplo, no dia de hoje, apesar de ser do Greenpeace do Brasil, eu recebo o tempo inteiro, todos os dias, mensagens do Greenpeace internacional, e principalmente do Greenpeace americano, para apoiar as iniciativas do Greenpeace dos Estados Unidos preocupadíssimos com 
a chegada do Donald Trump ao poder. Então, existe um trabalho permanente de comunicação, até exaustivo. Mas esse é um dos grandes desafios e eu acho que, sem dúvida, a comunicação e a capacidade de uma comunicação que te envolva, que te motive a apoiar, e até de indagar. Indagar é mais difícil porque existe um corpo de pessoas envolvidas profissionalmente, antes o Greenpeace dependia mais de voluntários e hoje não é bem uma coisa de voluntários, hoje tem o compromisso com uma gestão que é quase como uma gestão empresarial, porém orientada para uma ação da sociedade. Porque tem metas, tem que cumprir metas. O Greenpeace hoje tem no Brasil 61 mil apoiadores e a meta é, nos próximos dois anos, de chegar a 150 mil. Isso é uma meta empresarial, literalmente uma meta empresarial. $\mathrm{E}$ uma meta empresarial porque o Greenpeace no Brasil é um dos ecossistemas mais importantes para a atuação do Greenpeace, mas o Brasil depende ainda bastante, para a realização da sua agenda, de recursos do Greenpeace internacional, mas cada vez menos. Ele já dependeu de $70 \%$ a $80 \%$, depois dependeu $50 \%$, hoje depende $30 \%$ de recursos internacionais. $E$ a ideia é que ele não tenha mais nenhum tipo de dependência, então isso significa que você tem que ter apoiadores. Como mobilizar esses apoiadores? A partir de telemarketing, a partir de todas formas de comunicação.

4. Qual é a importância do Terceiro setor para liderar pessoas e organizar movimentos e ações para promover a melhoria da sustentabilidade em termos locais, regionais, nacionais e globais?

Muitas vezes as ações das empresas são oportunistas, associadas a uma visão de marketing, e menos efetivamente preocupadas em se comprometerem com uma agenda de questionamento mais estrutural, da forma como funciona o sistema produtivo e como funcionam os governos. Do ponto de vista mais histórico, de uma análise da evolução dessas organizações do Terceiro setor no mundo, não vinculadas a empresas, eu acho que você elas vêm crescendo em importância e o poder de atuarem pela sustentabilidade. Agora, no Brasil, por exemplo, o Terceiro setor não vinculado às empresas, sofre altos e baixos. Isso é muito claro justamente pela falta de recursos para poderem viabilizar campanhas, então eu acho que o grande problema está justamente na incapacidade de garantir um número maior de apoiadores e doadores. 0 Greenpeace é isso, é apoiar uma causa. Quando a Natura tem uma atividade, ela tem uma causa, mas é a causa da empresa e de seus acionistas, que é diferente do Greenpeace. Mas eu acho que, agora, estamos vivendo um momento no qual a sobrevivência de muitas organizações está extremamente fragilizada. Eu mesmo participo de uma organização que, de fato, não tem tido condições de sobreviver. É uma pequena organização totalmente autônoma, que tem um histórico, porque começou em 1997, mas que não tem tido condições de sobreviver e, então existe um componente problemático da própria sociedade brasileira que não se envolve muito em causas comunitárias, em causas mais coletivas.

5. Além dos recursos de comunicação, que outras iniciativas são estratégicas para ampliar o debate sobre sustentabilidade e contribuir para uma nova consciência social sobre esta temática?

A educomunicação é uma forma de se adaptar. Na verdade, não é que seja algo tão diferente. Eu acompanho os trabalhos de educomunicação há mais de vinte anos. Não é que isso seja tão diferente, só que é uma forma mais focada em 
uma atuação educativa, com foco educativo, no sentido de ser essencialmente baseado em práticas educativas. Eu, por exemplo, trabalho muito com a visão de aprendizagem social. Nós fizemos uma publicação na forma de um manual, intitulada 'Temas atuais em mudanças climáticas'. Esta publicação é um material pedagógico, disponível digitalmente para professores e alunos trabalharem com os temas atuais de mudanças climáticas, conceitos elaborados por professores da USP. Nós reeditamos o material dentro de uma perspectiva educativa. Então, tudo isso são formas de trabalhar com a educomunicação. Essa é uma maneira talvez mais estática por ser um manual, mas aí vai depender muito da dinâmica de como trabalhar. Eu estou totalmente aberto para isso. Para mim, a principal questão é que a educomunicação, assim como outras iniciativas, não tem a receita pronta. Para mim esse é o ponto fundamental. Eu tenho essa visão das coisas. O que eu quero dizer é que ninguém está inventando a roda, mas eu acho que a importância da educomunicação está em sair um pouco do lugar de que, digamos, muitas vezes as iniciativas vêm com receitas prontas e que o trabalho das empresas já vem com uma ajuda muito fechada para responder aos interesses das empresas. Nesse sentido, eu acho que é importante todo tipo de iniciativa, mas tem que ampliar muito mais o trabalho com fóruns, com dinâmicas cada vez mais participativas, envolventes, e obviamente buscando uma forma de se comunicar com as gerações mais novas que, hoje, estão todas associadas a iniciativas digitais. 